Rev. 0

\title{
200 North Aggregate Area Source AAMS Report
}

Date Published

June 1993

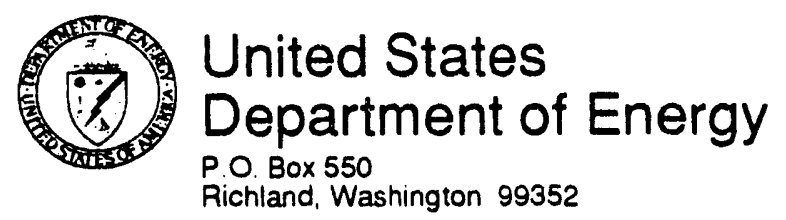

Approved for Public Release MASTER 


\section{NORTH AGGREGATE AREA SOURCE AAMS EXECUTIVE SUMMARY}

This report presents the results of an aggregate area management study (AAMS) for the 200 North Aggregate Area in the 200 Areas of the U.S. Department of Energy (DOE) Hanford Site in Washington State. This scoping level study provides the basis for initiating Remedial Investigation/Feasibility Study (RI/FS) activities under the Comprehensive Environmental Response, Compensation, and Liability Act of 1980 (CERCLA) or Resource Conservation and Recovery Act (RCRA) Facility Investigations (RFI) and Corrective Measures Studies (CMS) under RCRA. This report also integrates select RCRA treatment, storage, or disposal (TSD) closure activities with CERCLA and RCRA past practice investigations.

Through the experience gained to date on developing work plans, closure plans, and permit applications at the Hanford Site, the parties to the Hanford Federal Facility Agreement and Consent Order (Tri-Party Agreement) have recognized that all past practice investigations must be managed and implemented under one characterization and remediation strategy, regardless of the regulatory agency lead (as defined in the Tri-Party Agreement). In particular, the parties have identified a need for greater efficiency over the existing RI/FS and RFI/CMS investigative approaches, and have determined that, to expedite the ultimate goal of cleanup, much more emphasis needs to be placed on initiating and completing waste site cleanup through interim measures.

This streamlined approach is described and justified in The Hanford Federal Facility Agreement and Consent Order Change Package, dated May 16, 1991 (Ecology et al. 1991). To implement this approach, the three parties have developed the Hanford Site Past-Practice Strategy (DOE/RL 1992a) for streamlining the past practice remedial action process. This strategy provides new concepts for:

- $\quad$ Accelerating decision-making by maximizing the use of existing data consistent with data quality objectives (DQOs)

- Undertaking expedited response actions (ERAs) and/or interim remedial measures (IRMs), as appropriate, to either remove threats to human health and welfare and the environment, or to reduce risk by reducing toxicity, mobility, or volume of contaminants.

The Hanford Site Past-Practice Strategy (DOE/RL 1992a) describes the concepts and rramework for the RI/FS (or RFI/CMS) process in a manner that has a bias-for-action through optimizing the use of interim remedial actions, culminating with decisions on final remedies on both an operable-unit and aggregate-area scale. The strategy focuses on reaching early decisions to initiate and complete cleanup projects, maximizing the use of existing data, coupled with focused short time-frame investigations, where necessary. As more data become available on contamination problems and associated risks, the details of the longer term investigations and studies will be better defined. 
The strategy includes three paths for interim decision-making and a final remedyselection process for the operable unit that incorporates the three paths and integrates sites not addressed in those paths. The three paths for interim decision-making include the ERA, IRIM, and limited field investigation (LFI) paths. The strategy requires that aggregate area management study reports (AAMSRs) be prepared to provide an evaluation of existing site data to support initial path decisions. This AAMSR is one of ten reports that will be prepared for each of the ten aggregate areas defined in the 200 Areas.

The near-term past practice strategy for the 200 Areas provides for ERAs, IRMs, and LFIs for individual waste management units, waste management unit groups and groundwater plumes, and recommends separate source and groundwater operable units. Initial sitespecific recommendations for each of the waste management units within the 200 North Aggregate Area are provided in the report. Work plans will initially focus on limited intrusive investigations at the highest priority waste management units or waste management unit groups as established in the AAMSR. The goal of this initial focus is to establish whether IRMs are justified. Waste management units identified as candidate ERAs in Section 9.0 of the AAMS will be further evaluated following the Site Selection Process for Expedited Response Actions at the Hanford Site (Gustafson 1991).

While these elements may mitigate specific contamination problems through interim actions, the process of final remedy selection must be completed for the operable unit or aggregate area to rearh closure. The aggregation of information obtained from the LFIs and interim actions may be sufficient to perform the cumulative risk assessment and to define the final remedy for the operable unit or aggregate area. If the data are not sufficient, additional investigations and studies will be performed to the extent necessary to support final remedy selection. These investigations would be performed within the framework and process defined for RI/FS programs.

Several integration issues exist that are generic to the overall past practice process for the 200 Areas and include the following:

Future Work Plan Scope. Although the current practice for implementing RI/FS (RFI/CMS) activities is through operable unit based work plans, individual LFI/IRMs may be more efficiently implemented using LFI/IRM-specific work plans.

Groundwater Operable Units. A general strategy recommended for the 200 Areas is to define separate operable units for groundwater affected by 200 Areas source terms. This requires that groundwater be removed from the scope of existing source operable units and new groundwater-specific operable units be established. Recommendations for groundwater operable units will be developed in the groundwater AAMSRs.

Work Plan Prioritization. Although priorities are established in the AAMSR for operable units within the aggregate area, priorities between aggregate areas have yet to be established. The integration of priorities at the 200 Areas level is considered a prerequisite for establishing a schedule for past practice activities in the 200 Areas. 
It is intended that these integration issues be resolved following the completion of all ten AAMSRs (Draft A) scheduled for September 1992. Resolution of these issues will be based on a decisions/consensus process among the U.S. Environmental Protection Agency (EPA), Washington State Department of Ecology (Ecology), and DOE. Following resolution of these issues a schedule for past practice activities in the 200 Areas will be prepared.

Background, environmental setting, and known contamination data are provided in Sections 2.0, 3.0, and 4.1. This information provides the basis for development of the preliminary conceptual model in Section 4.2 and for assessing health and environmental concerns in Section 5.0. Preliminary applicable or relevant and appropriate requirements (ARARs) (Section 6.0) and preliminary remedial action technologies (Section 7.0) are also developed based on this data. Section 8.0 provides a discussion of the DQOs. Data needs identified in Section 8.0 are based on data gaps determined during the development of the conceptual model, human health and environmental concerns, ARARs, and remedial action technologies. Recommendations in Section 9.0 are developed using all the information provided in the sections which precede it.

The Hanford Site, operated by the DOE, occupies about $1,450 \mathrm{~km}^{2}\left(560 \mathrm{mi}^{2}\right)$ of the southeastern part of Washington north of the confluence of the Yakima and Columbia Rivers. The Hanford Site was established in 1943 to produce plutonium for nuclear weapons using production reactors and chemical processing plants. The 200 North Aggregate Area is located northwest of the 200 East Area, near the middle of the Hanford Site. There is one operable unit within the 200 North Aggregate Area.

Between 1944 and 1952, irradiated fuel elements produced by the plutonivm reactors in the 100 Areas were stored in three water-filled basins in the 200 North Aggregate Area. Storage of fuel elements was found to be unnecessary when it was determined that adequate storage time could be accomplished at the reactor facilities, and was discontinued in 1952. Contaminated water and sludges from the storage basins was disposed of to ponds and ditches in the 200 North Aggregate Area.

In 1972, one of the three deactivated storage facilities was converted to serve as a storage facility for contaminated plutonium fuel-handling equipment. In 1982, the other two deactivated storage facilities were converted to provide a facility for performing maintenance on PCB-contaminated transformers and on radiologically contaminated railroad equipment. The PCB-related activities are still active. 
The 200 North Aggregate Area coritains a variety of waste disposal and storage facilities. Low-level wastes such as cooling water were allowed to infiltrate into the ground through trenches and open ponds. Based on construction, purpose, or origin, the 200 North Aggregate Area waste management units fall into one of ten subgroups as follows:

- 1 (No. of waste management units) Plants, Buildings, and Storage Areas

- 1 Tanks and Vaults

- 0 Cribs and Drains

- 0 Reverse Wells

- 7 Ponds, Ditches, and Trenches

- 3 Septic Tanks and Associated Drain Fields

- 3 Transfer Facilities, Diversion Boxes, and Pipelines

- 0 Basins

- 1 Burial Site

- 2 Unplanned Releases.

Detailed descriptions of these waste management units are provided in Section 2.3.

There are several ongoing programs that affect buildings and waste management units in the 200 North Aggregate Area (Section 2.7). These programs include the Hanford Decommissioning and RCRA Closure Program and the Radiation Area Remedial Action (RARA) Program. Two units are operated by the Office of Support Services and, therefore, recommendations on these units will be made by that group rather than in this AAMS. The Radiation Area Remedial Action (RARA) Program regularly surveys the area and the three 200 North Aggregate Area Storage Facilities fall under the Decommissioning and RCRA Closure Program.

Discussions of surface hydrology and geology are provided on a regional, Hanford Site, and aggregate area basis in Section 3.0. The interpretation is based on a limited number of wells, and this limitation does not support a detailed delineation of waste management unit-specific features. The section also describes the flora and fauna, land use, water use, and human resources of the 200 North Aggregate Area and vicinity. Groundwater of the 200 North Aggregnte Area is described in detail in a separate 200 East Groundwater AAMSR. 
A preliminary site conceptual model is presented in Section 4.0. Section 4.1 presents the chemical and radiological data that are available for the different media types (including surface soil, vadose zone soil, air, surface water, and biota) and site-specific data for each waste management unit and unplanned release.

A preliminary assessment of potential impacts to human health and the environment is presented in Section 4.2. This assessment includes a discussion of release mechanisms, potential transport pathways, and a preliminary conceptual model of human and ecological exposure based on these pathways. Pisysical, radiological, and toxicological characteristics of the known and suspected contaminants at the aggregate area are also discussed.

Health and environmental concerns are presented in Section 5.0. The preliminary qualitative evaluation of potential human health concerns is intended to provide input to the waste management unit recommendation process. The evaluation includes (1) an identification of contaminants of potential concern for each exposure pathway that is likely to occur within the 200 North Aggregate Area, (2) identification of exposure pathways applicable to individual waste management units, and (3) estimates of relative hazard based on four available indicators of risk; the CERCLA Hazard Ranking System (HRS) and modified HRS (mHRS), surface radiation survey data, and Westinghouse Environmental Protection Group site scoring.

Potential ARARs to be used in developing and assessing various remedial action alternatives at the 200 North Aggregate Area are discussed in Section 6.0. Specific potential requirements pertaining to hazardous and radiological waste management, remediation of contaminated soils, surface water protection, and air quality are discussed.

Preliminary remedial action technologies are presented in Section 7.0. The process includes identification of remedial action objectives (RAOs), determination of general response actions, and identification of specific process options associated with each option type. The process options are screened based on their effectiveness, implementability and cost. The screened process options are combined into alternatives and the alternatives are described.

Data quality is addressed in Section 8.0. Identification of chemical and radiological constituents associated with the units and their concentrations, with a view to determine the contaminants of concern and their action levels, is a major requirement to execute the Hanford Site Past-Practice Strategy. There was found to be a limited amount of data in this regard. The section provides a summary of data needs identified for each of the waste management units in the 200 North Aggregate Area. The data needs provide the basis for development of detailed DQOs in subsequent work plans.

Section 9.0 provides management recommendations for the 200 North Aggregate Area based on the Hanford Site Past-Practice Strategy. Criteria for selecting appropriate Hanford Site Past-Practice Strategy paths (ERA, IRM, and final remedy selection) for individual waste management units and unplanned releases in the 200 North Aggregate Area are 
developed in Section 9.1. As a result of the data evaluation process, eight units were recommended for LFIs which could lead to IRMs and eight units were recommended for final remedy selection. A discussion of the data evaluation process is provided in Section 9.2. Table ES-1 provides a summary of the results of the data evaluation assessment of each unit. Table ES-2 provides the decision matrix patterns each unit followed in reaching the recommendation. Recommendations for redefining operable unit boundaries and prioritizing operable units for work plan development are provided in Section 9.3. All recommendations for future characterization needs will be more fully developed and implemented through work plans. Sections 9.4 and 9.5 provide recommendations for focused feasibility and treatability studies, respectively. 
DOE/RL-92-17, Rev. 0

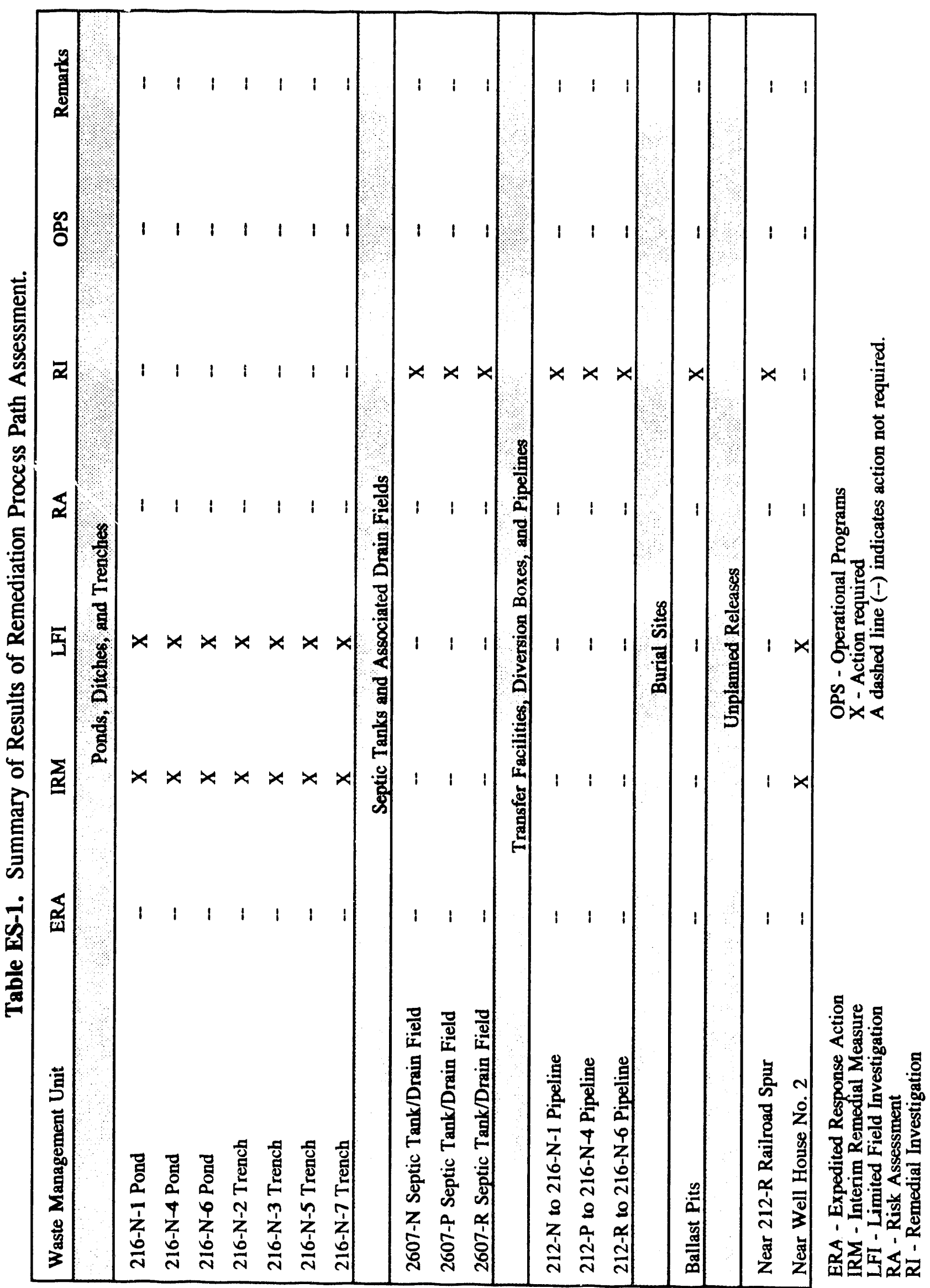

ES-7 
DOE/RL-92-17, Rev. 0

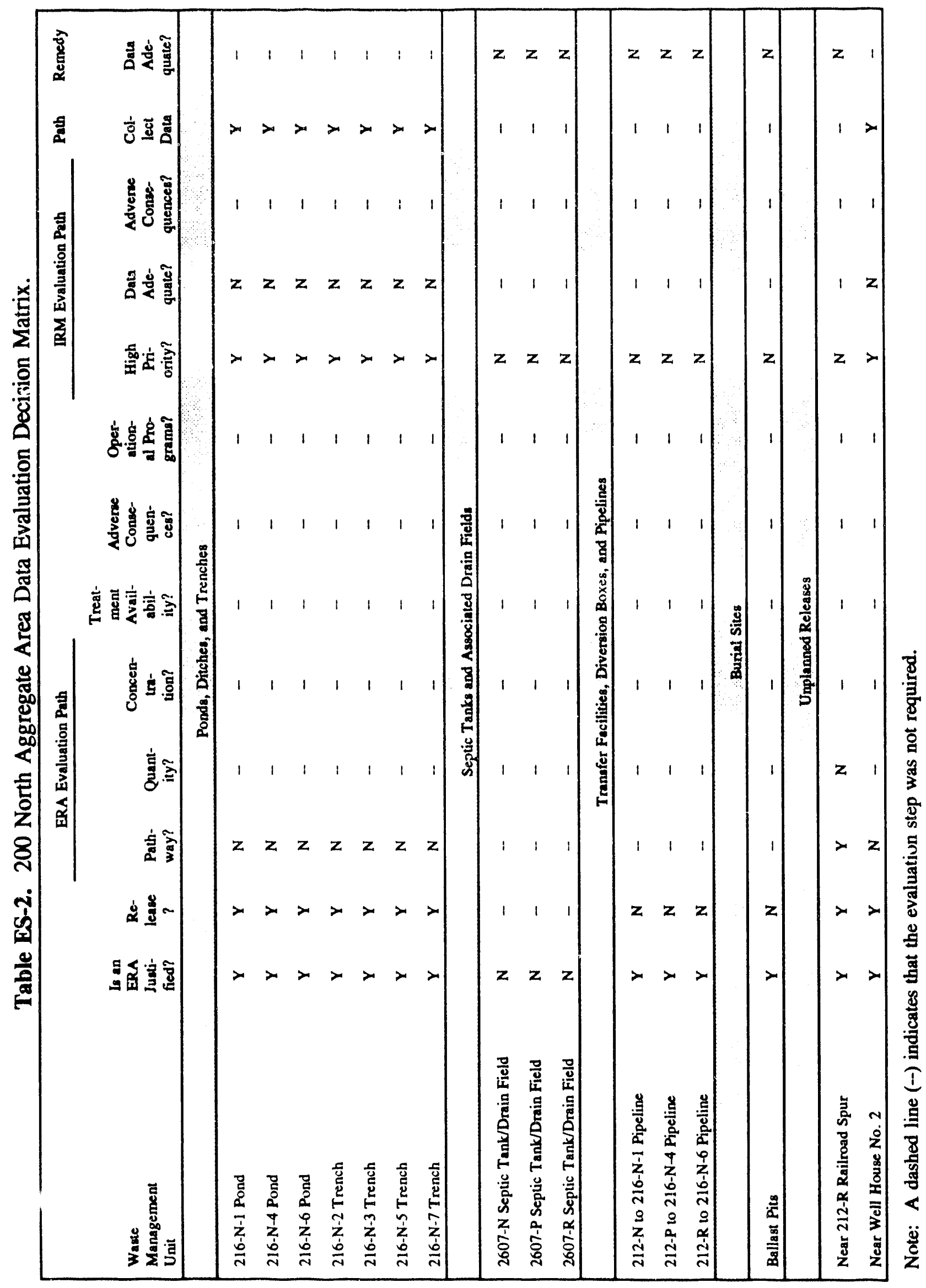


DOE/RL-92-17, Rev. 0

Table ES-3. Waste Management Units and Unplanned Releases to be Addressed by Other Programs.

\begin{tabular}{|c|c|c|c|c|}
\hline $\begin{array}{c}\text { Waste } \\
\text { Management } \\
\text { Unit }\end{array}$ & $\begin{array}{c}\text { Site } \\
\text { Type }\end{array}$ & Program & $\begin{array}{l}\text { Acitve/ } \\
\text { Inactive }\end{array}$ & $\begin{array}{c}\text { Operable } \\
\text { Unit }\end{array}$ \\
\hline \multicolumn{5}{|c|}{ Plants, Buildings, and Storage Areas } \\
\hline 212-P HWSA & Hazardous Waste Staging Area & DWMP & A & 200-NO-1 \\
\hline \multicolumn{5}{|c|}{ Tanks and Vaults } \\
\hline 212-P Transformer & Tank & DWMP & A & $200-\mathrm{NO}-1$ \\
\hline
\end{tabular}

DWMP - Defense Waste Management Program

HSFP - Hanford Surplus Facilities Program 


\section{ACRONYMS AND ABBREVIATIONS}

$\begin{array}{ll}\text { AAMS } & \text { aggregate area management study } \\ \text { AAMSR } & \text { aggregate area management study report } \\ \text { AEA } & \text { Atomic Energy Act } \\ \text { AKART } & \text { all known, available, and reasonable treatment technologies } \\ \text { ARARs } & \text { applicable or relevant and appropriate requirements } \\ \text { ASIL } & \text { acceptable source impact level } \\ \text { BAT } & \text { best available technology } \\ \text { BDAT } & \text { best demonstrated available treatment technologies } \\ \text { BWIP } & \text { Basalt Waste Isolation Project } \\ \text { CERCLA } & \text { Comprehensive Environmental Response, Compensation, } \\ & \text { and Liability Act of 1980 } \\ \text { CFR } & \text { Code of Federal Regulations } \\ \text { CLP } & \text { Contract Laboratory Program } \\ \text { CMS } & \text { Corrective Measures Studies } \\ \text { DCG } & \text { Derived Concentration Guide } \\ \text { DOE } & \text { U.S. Department of Energy } \\ \text { DOE/RL } & \text { U.S. Department of Energy, Richland Field Office } \\ \text { DQO } & \text { data quality objective } \\ \text { ECOlogy } & \text { Washington State Department of Ecology } \\ \text { EDMC } & \text { Environmental Data Management Center } \\ \text { EII } & \text { Environmental Investigations Instructions } \\ \text { EIMP } & \text { Environmental Information Management Plan } \\ \text { EPA } & \text { U.S. Environmental Protection Agency } \\ \text { ERA } & \text { expedited response actions } \\ \text { ERRA } & \text { Environmental Restoration Remedial Action } \\ \text { FFS } & \text { focused feasibility study } \\ \text { FOMP } & \text { Field Office Management Plan } \\ \text { FS } & \text { feasibility study } \\ \text { FWQC } & \text { Federal Water Quality Criteria } \\ \text { GTF } & \text { Grout Treatment Facility } \\ \text { Health } & \text { Washington State Department of Health } \\ \text { HEPA } & \text { high efficiency particulate air } \\ \text { HISS } & \text { Hanford Inactive Site Survey } \\ \text { HMS } & \text { Hanford Meteorological Station } \\ \text { HRS } & \text { Hazard Ranking System } \\ \text { HWOP } & \text { Hazardous Waste Operations Permit } \\ \text { HWSA } & \text { Hazardous Waste Staging Area } \\ \text { ICRP } & \text { International Commission on Radiological Protection } \\ \text { IMO } & \text { Information Management Overview } \\ \text { IRM } & \text { interim remedial measure } \\ \text { JSA } & \text { job safety analysis } \\ \text { LDR } & \text { land disposal restriction }\end{array}$


DOE/RL-92-17, Rev. 0

\section{ACRONYMS AND ABBREVIATIONS (cont.)}

\begin{tabular}{ll} 
LFI & limited field investigation \\
MCL & maximum contaminant levels \\
mHRS & modified Hazard Ranking System \\
MRP & management requirements and procedures \\
MTCA & Model Toxics Control Act \\
NAAQS & National Ambient Air Quality Standards \\
NCP & National Contingency Plan \\
NCRP & National Council on Radiation Protection \\
NEPA & National Environmental Policy Act \\
NESHAPs & National Emission Standards for Hazardous Air Pollutants \\
NPDES & National Pollutant Discharge Elimination System \\
NPL & Natiorial Priorities List \\
NSPS & New Source Performance Standards \\
OSHA & Occupational Safety and Health Administration \\
OSM & Office of Sample Management \\
PARCC & precision, accuracy, representativeness, completeness, comparability \\
PA & preliminary assessment \\
PCB & polychlorinated biphenyl \\
PMP & Project Management Plan \\
PNL & Pacific Northwest Laboratory \\
PRTR & Plutonium Recycle Test Reactor \\
PSPL & Puget Sound Power and Light Company \\
QA & quality assurance \\
QAPP & Quality Assurance Project Plan \\
QC & quality control \\
RA & risk assessment \\
RAO & remedial action objective \\
RARA & Radiation Area Remedial Action \\
RCRA & Resource Conservation and Recovery Act \\
RCW & Revised Code of Washington \\
RI & remedial investigation \\
RFI & RCRA Facility Investigations \\
RLS & Radionuclide Logging System \\
ROD & record of decision \\
RWP & radiation work permit \\
SARA & Superfund Amendments and Reauthorization Act \\
SDWA & Safe Drinking Water Act \\
SI & site inspection \\
SWP & special work permit \\
TAP & Toxic Air Pollutant \\
T-BACT & best available control technology for toxics \\
TBC & to-be-considered \\
& \\
\hline
\end{tabular}


DOE/RL-92-17, Rev. 0

ACRONYMS AND ABBREVIATIONS (cont.)

TCLP toxicity characteristic leaching procedure

TLD thermoluminescent dosimeter

Tri-Party Agreement TRU

TSCA

TSD

USC

USGS

VOC

WAC

WIDS

WIPP

Hrnford Federal Facility Agreement and Consent Order transuranic

Toxic Substance Control Act treatment, storage or disposal

United States Code

United States Geological Survey

volatile organic compound

Washington Administrative Code

Waste Information Data System

Waste Isolation Pilot Plant

WPCA

WPPSS

Washington State Water Pollution Control Act

Washington Public Power Supply System 


\section{CONTENTS}

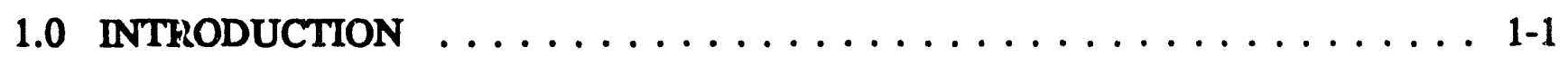

1.1 OVERVIEW .....................

1.1.1 Tri-Party Agreement . . . . . . . . . . . . . 1-2

1.1.2 Hanford Site Past-Practice Strategy . . . . . . . . . . . 1-2

1.2200 NPL SITE AGGREGATE AREA MANAGEMENT STUDY

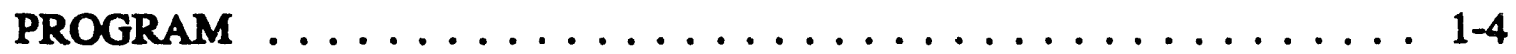

1.2.1 Overall Approach $\ldots \ldots \ldots \ldots \ldots \ldots \ldots \ldots \ldots \ldots \ldots$

1.2.2 Process Overview . . . . . . . . . . . . . 1-5

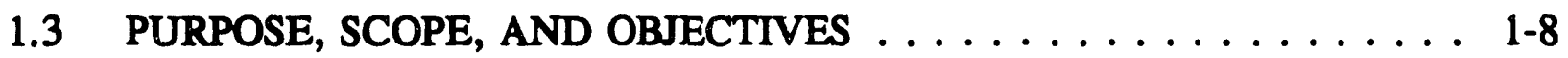

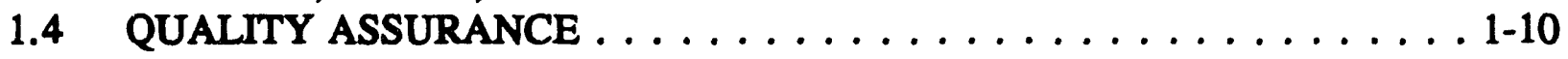

1.5 ORGANIZATION OF REPORT $\ldots \ldots \ldots \ldots \ldots \ldots \ldots \ldots \ldots \ldots$

2.0 FACILITY, PROCESS, AND OPERATIONAL HISTORY DESCRIPTIONS . . . 2-1

2.1 LOCATION . . . . . . . . . . . . . . . . 2-1

2.2 HISTORY OF OPERATIONS $\ldots \ldots \ldots \ldots \ldots \ldots \ldots \ldots \ldots \ldots$ 2-1

2.3 FACILITIES, BUILDINGS, AND STRUCTURES $\ldots \ldots \ldots \ldots \ldots .2-3$

2.3.1 Plants, Buildings, and Storage Areas . . . . . . . . . . 2-5

2.3.2 Tanks and Vaults . . . . . . . . . . . . . . . 2-9

2.3.3 Cribs and Drains . . . . . . . . . . . . . . . 2-9

2.3.4 Reverse Wells . . . . . . . . . . . . . . . . . 2-9

2.3.5 Ponds, Ditches, and Trenches . . . . . . . . . . . 2-10

2.3.6 Septic Tanks and Associated Drain Fields . . . . . . . . 2-12

2.3.7 Transfer Facilities, Diversion Boxes, and Pipelines . . . . . . 2-13

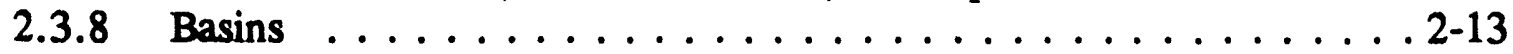

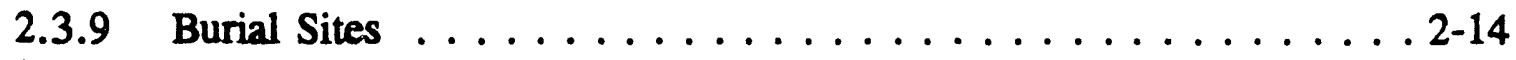

2.3.10 Unplanned Releases . . . . . . . . . . . . . . 2-14

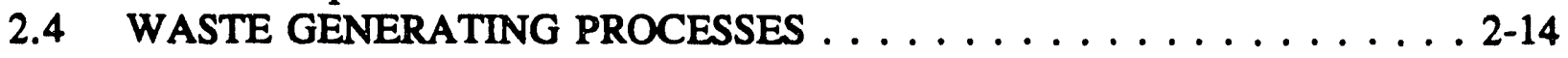

2.4.1 Irradiated Fuel Storage Operations $\ldots \ldots \ldots \ldots \ldots \ldots \ldots . \ldots \ldots$

2.4.2 Electrical Maintenance Activities . . . . . . . . . 2-16

2.4.3 Railroad Car Maintenance Activities . . . . . . . . . . . 2-17

2.5 INTERACTIONS WITH OTHER AGGREGATE AREAS OR

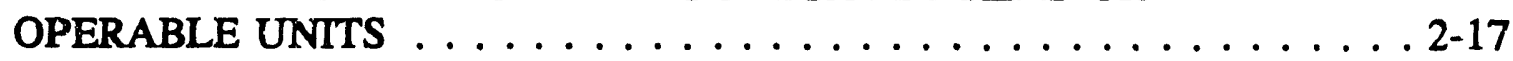

2.6 INTERACTION WITH RESOURCE CONSERVATION AND

RECOVERY ACT PROGRAM . . . . . . . . . . . . . . 2-17

2.7 INTERACTIONS WITH OTHER HANFORD PROGRAMS $\ldots \ldots \ldots .2-18$

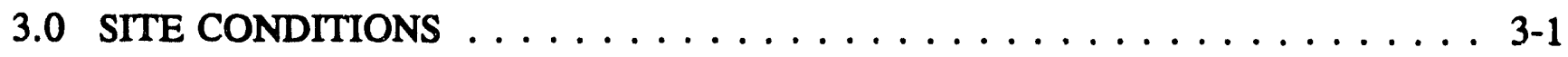

3.1 PHYSIOGRAPHY AND TOPOGRAPHY $\ldots \ldots \ldots \ldots \ldots \ldots$ 3-1

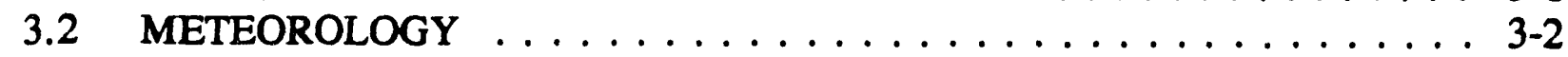

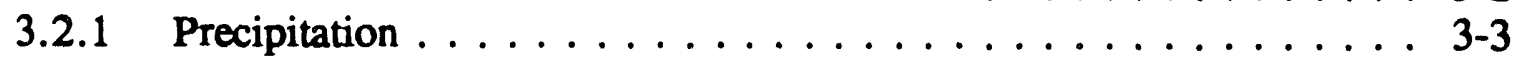

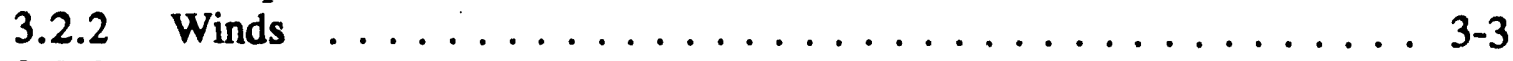

3.2.3 Temperature $\ldots \ldots \ldots \ldots \ldots \ldots \ldots \ldots \ldots \ldots \ldots$ 3-3 
3.3 SURFACE HYDROLOGY $\ldots \ldots \ldots \ldots \ldots \ldots \ldots \ldots \ldots \ldots$ 3-3

3.3.1 Regional Surface Hydrology . . . . . . . . . . . . . . 3-4

3.3.2 Surface Hydrology of the Hanford Site . . . . . . . . . . 3-4

3.3.3 200 North Aggregate Area Surface Hydrology . . . . . . . . . 3-5

3.4 GEOLOGY . . . . . . . . . . . . . . . . . 3-6

3.4.1 Regional Tectonic Framework . . . . . . . . . . . 3-6

3.4.2 Regional Stratigraphy . . . . . . . . . . . . . . 3-8

3.4.3 200 North Aggregate Area Geology . . . . . . . . . . . . 3-14

3.5 HYDROGEOLOGY $\ldots \ldots \ldots \ldots \ldots \ldots \ldots \ldots \ldots \ldots \ldots \ldots \ldots \ldots \ldots .17$

3.5.1 Regional Hydrogeology . . . . . . . . . . . . . . . . . . 3-17

3.5.2 Hanford Site Hydrogeology . . . . . . . . . . . . . . 3-19

3.5.3 200 North Aggregate Area Hydrogeology . . . . . . . . . . . 3-26

3.6 ENVIRONMENTAL RESOURCES . . . . . . . . . . . . . 3-29

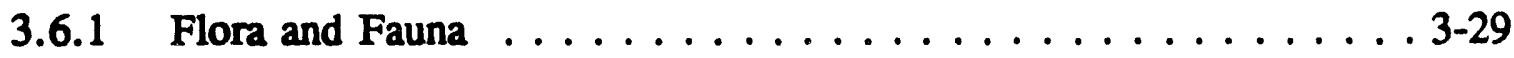

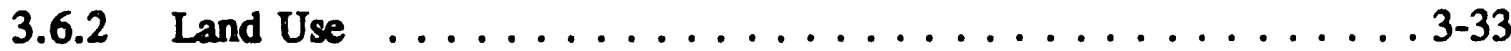

3.6.3 Water Use . . . . . . . . . . . . . . . . 3-34

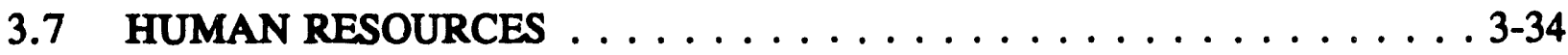

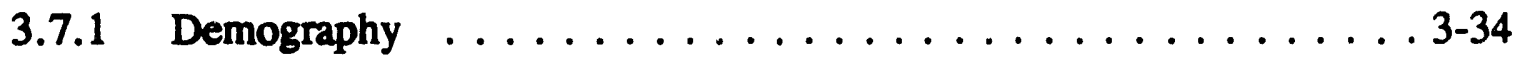

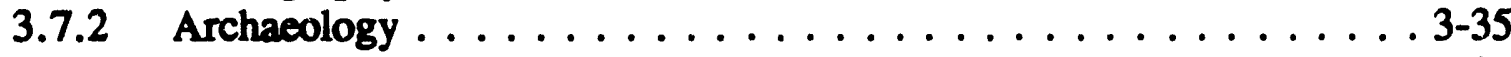

3.7.3 Historical Resources . . . . . . . . . . . . . . 3-35

3.7.4 Community Involvement $\ldots \ldots \ldots \ldots \ldots \ldots \ldots \ldots$ 3-35

4.0 PRELIMINARY CONCEPTUAL SITE MODEL . . . . . . . . . . . . 4-1

4.1 KNOWN AND SUSPECTED CONTAMINATION . . . . . . . . . 4 4-1

4.1.1 Affected Media . . . . . . . . . . . . . . . 4-3

4.1.2 Site Specific Data . . . . . . . . . . . . . . . . . . 4-6

4.2 POTENTIAL IMPACTS TO HUMAN HEALTH AND THE

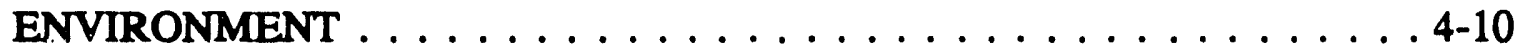

4.2.1 Release Mechanisms . . . . . . . . . . . . . . . 4-11

4.2.2 Transport Pathways . . . . . . . . . . . . . 4-12

4.2.3 Conceptual Model . . . . . . . . . . . . . . . . 4-18

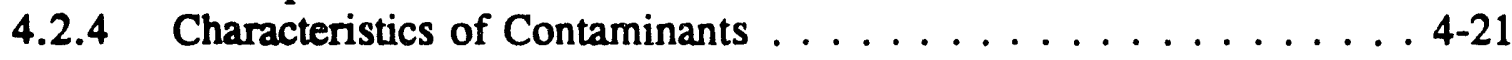

5.0 HEALTH AND ENVIRONMENTAL CONCERNS . . . . . . . . . . . 5-1

5.1 CONCEPTUAL FRAMEWORK FOR RISK-BASED SCREENING . . . . . 5-2

5.2 POTENTIAL EXPOSURE SCENARIOS AND HUMAN HEALTH

CONCERNS . . . . . . . . . . . . . . . . 5-3

5.2 .1 External Exposure . . . . . . . . . . . . . . 5-4

5.2.2 Ingestion of Soil or Inhalation of Fugitive Dust $\ldots \ldots \ldots \ldots \ldots$. . . .

5.2 .3 Inhalation of Volatiles . . . . . . . . . . . 5-5

5.2 .4 Migration to Groundwater $\ldots \ldots \ldots \ldots \ldots \ldots \ldots \ldots$ 5-5 
CONTENTS (cont.)

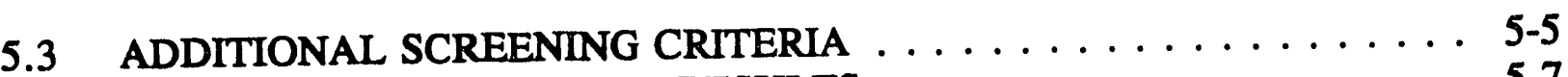

5.4 SUMMARY OF SCREENING RESULTS $\ldots \ldots \ldots \ldots \ldots \ldots \ldots \ldots$ 5-7

6.0 POTENTIALLY APPLICABLE OR RELEVANT AND APPROPRIATE

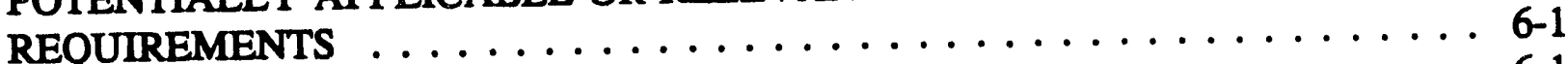

6.1 INTRODUCTION ...................6-1

6.2 CONTAMINANT-SPECIFIC REQUIREMENTS $\ldots \ldots \ldots \ldots \ldots$. . . .

6.2 .1 Federal Requirements . . . . . . . . . . . . 6-3

6.2.2 State of Washington Requirements . . . . . . . . . . 6-5

6.3 LOCATION-SPECIFIC REQUIREMENTS . . . . . . . . . . . . 6- 6-9

6.4 ACTION-SPECIFIC REQUIREMENTS . . . . . . . . . . . 6-9

6.4 .1 Federal Requirements . . . . . . . . . . . . . . . . 6-10

6.4.2 State of Washington Requirements . . . . . . . . . 6-13

6.5 OTHER CRITERIA AND GUIDANCE TO BE CONSIDERED . . . . . 6-15

6.5.1 Health Advisories .................6-16

6.5.2 International Commission on Radiation Protection/

National Council on Radiation Protection . . . . . . . . . . 6-16

6.5.3 Environmental Protection Agency Proposed Corrective

Actions for Solid Waste Management Units . . . . . . . . . 6-16

6.5.4 U.S. Department of Energy Standards for

Radiation Protection . . . . . . . . . . . . . . 6-16

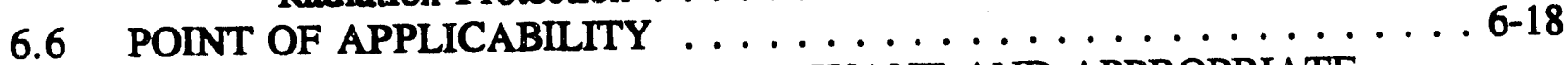

6.7 POTENTIAL APPLICABLE OR RELEVANT AND APPROPRIATE

REQUIREMENTS EVALUATION . . . . . . . . . . . . 6-19

7.0 PRELIMINARY REMEDIAL ACTION TECHNOLOGIES $\ldots \ldots \ldots \ldots$ 7-1

7.1 PRELIMINARY REMEDIAL ACTION OBJECTIVES . . . . . . . . 7 7-2

7.2 PRELIMINARY GENERAL RESPONSE ACTIONS $\ldots \ldots \ldots \ldots \ldots 7-3$

7.3 TECHNOLOGY SCREENING $\ldots \ldots \ldots \ldots \ldots \ldots \ldots \ldots$

7.4 PRELIMINARY REMEDIAL ACTION ALTERNATIVES . . . . . . . 7-7

7.4.1 Development of Remedial Alternatives . . . . . . . . . 7-7

7.4.2 Alternative 1--Engineered Multimedia Cover $\ldots \ldots \ldots$. . . . . . . with or without Vertical Barriers . . . . . . . . . . . . 7-10

7.4.3 Alternative 2-In-Situ Grouting or Stabilization $\ldots \ldots \ldots 7-10$

7.4.4 Alternative 3--Excavation, Soil Treatment, and Disposal . . . . . . . . . . . . . . . . . 7-11

7.4.5 Alternative 4--In-Situ Vitrification of Soil . . . . . . . . 7-12

7.4.6 Alternative 5--Excavation, Above-Ground Treatment, and Geologic Disposal of Soil with TRU Radionuclides . . . . . 7-13

7.4.7 Alternative 6-In-Situ Soil Vapor Extraction for VOCs . . . . . . . 7-13 
CONTENTS (cont.)

7.5 PRELIMINARY REMEDIAL ACTION ALTERNATIVES APPLICABLE TO WASTE MANAGEMENT UNITS AND UNPLANNED RELEASE SITES

8.0 DATA QUALITY OBIECTIVES . . . . . . . . . . . . . 8-1

8.1 DECISION TYPES (STAGE 1 OF THE DQO PROCESS) $\ldots \ldots \ldots . .88-1$

8.1.1 Data Users $\ldots \ldots \ldots \ldots \ldots \ldots \ldots \ldots \ldots \ldots$ 8-2

8.1 .2 Available Information $\ldots \ldots \ldots \ldots \ldots \ldots \ldots \ldots \ldots \ldots \ldots \ldots$

8.1.3 Evaluation of Available Data $\ldots \ldots \ldots \ldots \ldots \ldots \ldots \ldots$ 8-8

8.1 .4 Conceptual Model . . . . . . . . . . . . . . . . 8-10

8.1.5 Aggregate Area Management Study Objectives and Decisions . . . . . . . . . . . . . . . . 8-11

8.2 DATA USES AND NEEDS (STAGE 2 OF THE DQO PROCESS) $\ldots \ldots 8-13$

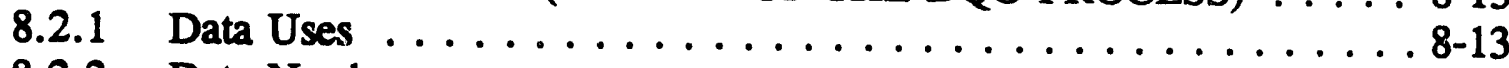

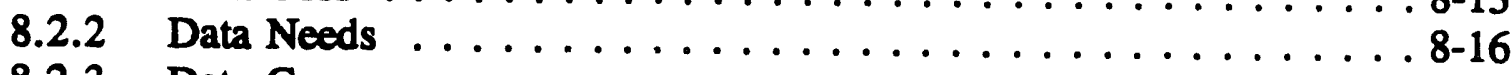

8.2.3 Data Gaps . . . . . . . . . . . . . . . . 8-19

8.3 DATA COLLECTION PROGRAM (STAGE 3 OF THE

DQO PROCESS) . . . . . . . . . . . . . . . . . . 8-20

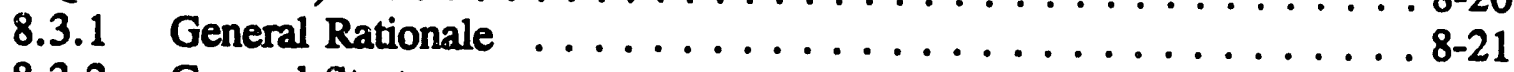

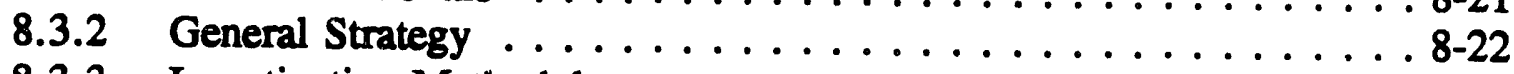

8.3.3 Investigation Methodology $\ldots \ldots \ldots \ldots \ldots \ldots \ldots \ldots \ldots . . \ldots \ldots$ 8-22

8.3.4 Data Evaluation and Decision Making $\ldots \ldots \ldots \ldots \ldots \ldots \ldots . . \ldots \ldots$

9.0 RECOMMENDATIONS .................... 9-1

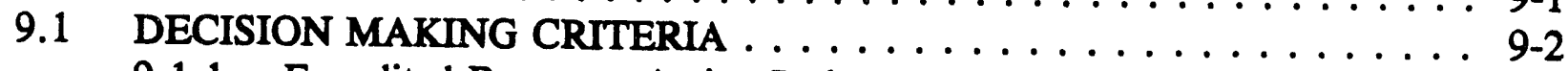

9.1 .1 Expedited Response Action Path $\ldots \ldots \ldots \ldots \ldots \ldots \ldots . \ldots \ldots$

9.1.2 Limited Field Investigation and Interim

Remedial Measure Path . . . . . . . . . . . . . . . . . 9 9-6

9.1.3 Final Remedy Selection Path . . . . . . . . . . . . 9-7

9.2 PATH RECOMMENDATIONS $\ldots \ldots \ldots \ldots \ldots \ldots \ldots \ldots \ldots \ldots \ldots \ldots . . \ldots \ldots$

9.2.1 Proposed Sites for Expedited Response Actions . . . . . . . . 9.8

9.2.2 Proposed Sites for Interim Remedial Measures . . . . . . . . . . . . 9-9

9.2.3 Proposed Sites for Limited Field Investigation Activities . . . . . . . . . . . . . . . . 9-9

9.2.4 Proposed Sites for Final Remedy Selection $\ldots \ldots \ldots \ldots \ldots \ldots . \ldots .12$

9.3 SOURCE OPERABLE UNIT REDEFINITION AND

PRIORITIZATION . . . . . . . . . . . . . . . . . 9-13

9.3.1 Units Addressed by Other Aggregate Areas or Programs . . . . . . 9-14

9.3.2 200 North Aggregate Area Operable Unit Redefinition . . . . . . . . 9-14

9.3.3 Investigation Prioritization $\ldots \ldots \ldots \ldots \ldots \ldots \ldots \ldots \ldots \ldots .14$

9.3.4 RCRA Facility Interface $\ldots \ldots \ldots \ldots \ldots \ldots \ldots \ldots \ldots \ldots \ldots \ldots$ 
DOE/RL-92-17, Rev. 0

\title{
CONTENTS (cont.)
}

9.4 FEASIBILITY STUDY $\ldots \ldots \ldots \ldots \ldots \ldots \ldots \ldots \ldots \ldots \ldots \ldots$

9.4.1 -Focused Feasibility Study $\ldots \ldots \ldots \ldots \ldots \ldots \ldots \ldots . \ldots \ldots$

9.4.2 Final Feasibility Study $\ldots \ldots \ldots \ldots \ldots \ldots \ldots \ldots \ldots$ 9-16

9.5 TREATABILITY STUDIES $\ldots \ldots \ldots \ldots \ldots \ldots \ldots \ldots \ldots \ldots \ldots . \ldots \ldots$

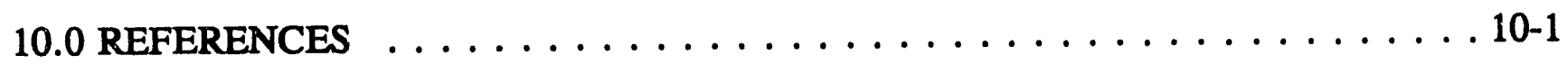

\begin{abstract}
APPENDIX A SAMPLE DATA
APPENDIX B HEALTH AND SAFETY PLAN

APPENDIX C PROJECT MANAGEMENT PLAN

APPENDIX D INFORMATION MANAGEMENT OVERVIEW
\end{abstract}

PLATES:

Plate 1 Facilities, Sites, Unplanned Releases, Topography, and Monitor Wells 


\section{CONTENTS (cont.)}

\section{FIGURES:}

1-1 Hanford Site Map . . . . . . . . . . . . . . . . . . . . . . . . 1F-1

1-2 Hanford Past Practice Strategy Flow Chart . . . . . . . . . . . . . . . . 1F-2

1-3 200 East Aggregate Areas . . . . . . . . . . . . . . . . . . . . . . . 1F-3

1-4 200 West Aggregate Areas . . . . . . . . . . . . . . . . . . . . . . . $1 F-4$

1-5 200 NPL Site Isolated Operable Units $\ldots \ldots \ldots \ldots \ldots \ldots \ldots \ldots \ldots \ldots$

2-1 Location of Plants, Buildings, and Storage Units . . . . . . . . . . . . . . . . 2F-1

2-2 Location of Tank and Vaults . . . . . . . . . . . . . . . . . . 2F-2

2-3 Location of Ponds, Ditches, and Trenches . . . . . . . . . . . . . . . . . . . . . . . . . . . . . . . . . . . . . . . .

2-4 Location of Septic Tanks and Associated Drain Fields . . . . . . . . . . . . . . . . . . 2F-4

2-5 Location of Transfer Facilities, Diversion Boxes, and Pipelines . . . . . . . . . . . 2F-5

2-6 Location of Burial Sites . . . . . . . . . . . . . . . . . . . . . 2F-6

2-7 Location of Unplanned Releases . . . . . . . . . . . . . . . . . . . . 2F-7

2-8 Process History of 200 North Aggregate Area . . . . . . . . . . . . . . . . . 2F-8

2-9 Waste Management Unit Operational History . . . . . . . . . . . . . . . . . . . . 2F-9

2-10 Typical Configuration of Disposal Trenches . . . . . . . . . . . . . . . . . . . 2F-10

2-11 General Arrangement of Storage Facility Building . . . . . . . . . . . . . . 2F-11

3-1 Topography and Location Map for the Hanford Site . . . . . . . . . . . . . . . . . 3F-1

3-2 Divisions of the Columbia Intermontane Province and Adjacent Snake

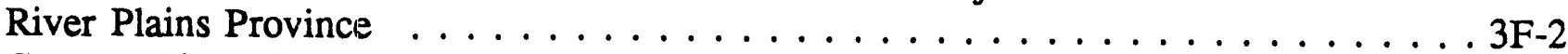

3-3 Geomorphic Units Within the Central Highlands and Columbia Basin

Subprovinces that Contain the Columbia River Basalt Group . . . . . . . . . . . . . 3F-3

3-4 Landforms of the Pasco Basin and the Hanford Site . . . . . . . . . . . . . . . . . . . . . . . . . . . . . . . .

3-5 Geomorphic Features Surrounding the 200 Areas . . . . . . . . . . . . . . . . . . . . . . . . . . . . . . . . .

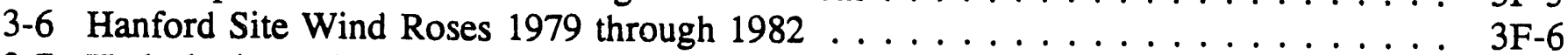

3-7 Hydrologic Basins Designated for the Washington State Portion of

the Columbia Plateau . . . . . . . . . . . . . . . . . . . . . . . . . . . .

3-8 Columbia Plateau and Surrounding Structural Provinces . . . . . . . . . . . . . 3F-8

3-9 Structural Subprovinces of the Columbia Plateau . . . . . . . . . . . . . . . . . . . . . . . . . . . . . . . . . . . . . .

3-10 Structural Elements of the Yakima Fold Belt Subprovince . . . . . . . . . . . . 3F-10

3-11 Geologic Structures of the Pasco Basin and the Hanford Site . . . . . . . . . . . . . 3F-11

3-12 Generalized Stratigraphy of the Hanford Site . . . . . . . . . . . . . . . . . 3F-12

3-13 Generalized Stratigraphy of the Suprabasalt Sediments Beneath

the Hanford Site . . . . . . . . . . . . . . . . . . . . . . . . . . . . . . . . . . . . . . . .

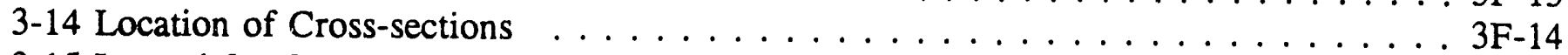

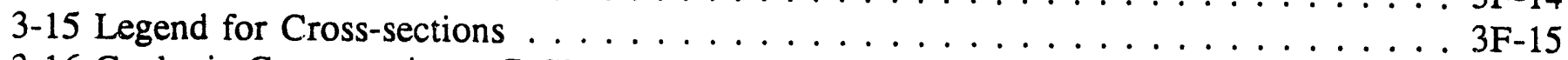

3-16 Geologic Cross-section - C-C' . . . . . . . . . . . . . . . . . . . 3F-16

3-17 Geologic Cross-section - E-E' . . . . . . . . . . . . . . . 3F-17 
CONTENTS (cont.)

\section{FIGURES (cont.):}

3-18 Geologic Cross-section - G-G' . . . . . . . . . . . . . . . . . 3F-18

3-19 Structure Contour Map of Surface of the Top of Basalt . . . . . . . . . . . . . . . 3F-19

3-20 Isopach Map of the Ringold Gravel Unit A . . . . . . . . . . . . . . . . . 3F-20

3-21 Structure Map of the Formation Top of the Ringold Gravel Unit A . . . . . . . 3F-21

3-22 Isopach Map of the Lower Mud Sequence, Ringold Formation . . . . . . . . . . . . 3F-22

3-23 Structure Map of the Lower Mud Sequence, Ringold Formation . . . . . . . . . 3F-23

3-24 Isopach Map of the Gravel Unit E, Ringold Formation . . . . . . . . . . . . . . . . 3F-24

3-25 Structure Map of the Gravel Unit E, Ringold Formation . . . . . . . . . . . . . . . . 3F-25

3-26 Structure Map of the Ringold Formation . . . . . . . . . . . . . . . . . . 3F-26

3-27 Isopach Map of the Lower Gravel Sequence, Hanford Formation . . . . . . . . . . 3F-27

3-28 Structure Map of the Lower Gravel Sequence, Hanford Formation . . . . . . . . . 3F-28

3-29 Isopach Map of the Sandy Sequence, Hanford Formation . . . . . . . . . . . . . . . 3F-29

3-30 Structure Map of the Sandy Sequence, Hanford Formation . . . . . . . . . . . . . . 3F-30

3-31 Isopach Map of the Upper Gravel Sequence, Hanford Formation . . . . . . . . . 3F-31

3-32 Isopach Map of the Entire Hanford Formation . . . . . . . . . . . . . 3F-32

3-33 Conceptual Hydrogeologic Column for the Hanford Site . . . . . . . . . . . . 3F-33

3-34 Wetting and Drying Curves for Well 299-W18-21 . . . . . . . . . . . . . . 3F-34

3-35 Particle Size Distribution and Water Retention Characteristics of Soil

from Hanford Site Lysimeters . . . . . . . . . . . . . . . . . . . . . . . . . . . . . . . . .

3-36 200 Areas Water Table Map, June $1990 \ldots \ldots$. . . . . . . . . . . . . . . . 3F-36

3-37 Conceptual Hydrogeologic Column for the PUREX Plant Aggregate Area . . . . . 3F-37

4-1 Gamma Isoradiation Contour Map of the 200 North Area . . . . . . . . . . . . . . . . 4F-1

4-2 Surface, Underground and Migrating Map of the 200 North Area . . . . . . . . . . 4F-2

4-3 Conceptual Model of the 200 North Aggregate Area . . . . . . . . . . . . . . . 4F-3

4-4 Physical Conceptual Model of Contaminant Distribution . . . . . . . . . . . . . 4F-4

7-1 Development of Candidate Remedial Alternatives for 200 North

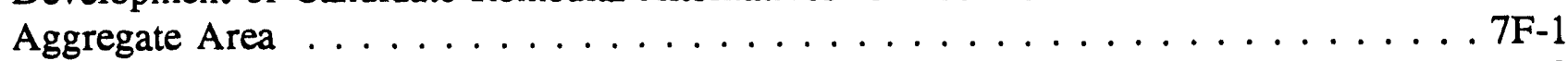

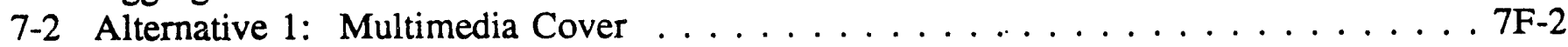

7-3 Alternative 2: In Situ Grouting of Soil . . . . . . . . . . . . . . 7F-3

7-4 Alternative 3: Excavation, Treatment and Disposal . . . . . . . . . . . . 7F-4

7-5 Alternative 4: In Situ Vitrification of Soil ................ 7 F-5

7-6 Alternative 5: Excavation, Vitrification, and Geologic Disposal of Soil with TRU Radionuclides . . . . . . . . . . . . . . . . . . . . . 7F-6

7-7 Alternative 6: Soil Vapor Extraction for VOCs . . . . . . . . . . . . . . . 7F-7

9-1 200 Aggregate Area Management Studies Decision Making Flowchart . . . . . . . . 9F-1 


\section{CONTENTS (cont.)}

\section{TABLES:}

1-1 Overall Aggregate Area Management Study (AAMS) Schedule for the 200 NPL Site . . . . . . . . . . . . . . . . . . . . . . . . 1T-1

2-1 Summary of 200 North Aggregate Area Waste Management Units . . . . . . . . . 2T-1

2-2 Radionuclide Waste Inventory Summary . . . . . . . . . . . . . . . 2T-2

2-3 Summary of Unplanned Releases . . . . . . . . . . . . . . . . . . 2T-3

2-4 Summary of Waste Producing Processes in the 200 North Aggregate Area . . . . . 2T 2T-4

2-5 Radionuclides and Chemicals Disposed of 200 North Aggregate Area Waste Management Units . . . . . . . . . . . . . . . . . . . 2T -5

3-1 Hydraulic Parameters for Various Areas and Geologic Units at the Hanford Site . . 3T-1

3-2 Summary of Reported Hydraulic Conductivity Values for Hanford Site Vadose Zone Sediments . . . . . . . . . . . . . . . . . . . . . . . . . . 3T-2

3-3 Endangered, Threatened, and Sensitive Plant Species Reported On or Near the Hanford Site . . . . . . . . . . . . . . . . . . . . . . 3T-3

3-4 Federal and State Classifications of Animals that Could Occur on the 200 Areas Plateau . . . . . . . . . . . . . . . . . . . . . 3T-4

4-1 Summary of Radionuclide Contamination in Various Affected Media for 200 North Aggregate Area Waste Management Units . . . . . . . . . . . . . . . . 4T-1

4-2 Types of Data Available for Each Waste Management Unit . . . . . . . . . . . . 4T-2

4-3 Results of External Monitoring, 1985 through 1989: TLDs (mrem/yr) . . . . . . . 4T-3

4-4 Results of External Radiation Monitoring for 1990 and 1991: TLDs (mrem/yr) . . . 4T-4

4-5 Results of External Radiation Surveys . . . . . . . . . . . . . . . . . 4T-5

4-6 Summary of Grid Soil Sampling Results $(\mathrm{pCi} / \mathrm{g}) \quad \ldots \ldots \ldots \ldots \ldots$. . . . . . . . 4T-6

4-7 Summary of Vegetation Sampling Results $(\mathrm{pCi} / \mathrm{g}) \ldots \ldots \ldots \ldots$. . . . . . . . 4T-7

4-8 Summary of Air Monitoring Results, 1985-1989: $\left(\mathrm{pCi} / \mathrm{m}^{3}\right) \ldots \ldots \ldots \ldots \ldots$. . . . . . . . .

4-9 Summary of Air Monitoring Results, $1990 \ldots \ldots$. . . . . . . . . . . . . . 4T 4T-9

4-10 Evaluation of Potential Groundwater Contamination . . . . . . . . . . . . . . 4T-10

4-11 Candidate Contaminants of Potential Concern for the 200 North Aggregate Area . 4T-11

4-12 Summary of Known and Suspected Contamination at 200 North Aggregate Area . 4T-12

4-13 Contaminants of Potential Concern for the 200 North Aggregate Area . . . . . . . . 4T-13

4-14 Soil-Water Distribution Coefficient $\mathrm{K}_{\mathrm{d}}$ for Radionuclides and Inorganics of

Concern at 200 North Waste Management Units . . . . . . . . . . . . . . 4T-14

4-15 Mobility of Inorganic Species in Soil . . . . . . . . . . . . . . . . . . 4T-15

4-16 Physical/Chemical Properties of Organic Contaminants of Concern for 200 North Aggregate Area Waste Management Units . . . . . . . . . . . . . . . . . 4 $4^{\prime} \mathrm{T}-16$

4-17 Radiological Properties of Potential Radionuclides of Concern in 200 North Aggregate Area Waste Management Units 
CONTENTS (cont.)

TABLES (cont.):

4-18 Comparison of Radionuclide Relative Risks or Radionuclides of Concern at the 200 North Aggregate Area . . . . . . . . . . . . . . . . . 4T-18

4-19 Potential Chronic Health Effects of Chemicals Detected or Disposed of at the 200 North Aggregate Area . . . . . . . . . . . . . . . . . . . . 4T-19

5-1 Hazard Ranking Scores for 200 North Aggregate Are . . . . . . . . . . . . . . 5T-1

6-1 Potential Contaminant-Specific ARARs and TBCs for Preliminary Inorganic and Organic Contaminants of Concern . . . . . . . . . . . . . 6T-1

6-2 Potential Location-Specific ARARs . . . . . . . . . . . . . . . . . 6T-2

7-1 Preliminary Remedial Action Objectives and General Response Actions . . . . . . . . . . . . . . . . . . 7T-1

7-2 Preliminary Remedial Action Technologies . . . . . . . . . . . . TT-2

$7-3$ Screening of Process Options . . . . . . . . . . . . . . . . . 7T-3

7-4 Preliminary Remedial Action Alternatives Applicable to Waste Management Units and Unplanned Release Sites . . . . . . . . . . . . . . . . 7T-4

8-1 Uses of Existing Data for 200 North Aggregate Area Waste Management Units $.8 \mathrm{~T}-1$

8-2 Data Needs for Preliminary Remedial Action Alternatives 200 North Aggregate Area . . . . . . . . . . . . . . . . . . . . 8 8T-2

8-3 Analytical Levels for the 200 North Aggregate Area . . . . . . . . . . . . . . 8T-3

8-4 Data Quality Objective Parameters for Chemical/Radiochemical Analyses . . . . . . 8T-4

8-5 Data Gaps by Site Category . . . . . . . . . . . . . . . . . . . . 8T-5

8-6 Applicable Characterization Methods at 200 North Aggregate Area Waste Management Units . . . . . . . . . . . . . . . . . . . 8T-6

9-1 Summary of the Results of Remediation Process Path Assessment 200 North Aggregate Area . . . . . . . . . . . . . . . . . . . . . 9T-1

9-2 200 North Aggregate Area Data Evaluation Decision Matrix . . . . . . . . . . . . 9T-2

9-3 Waste Management Units and Unplanned Releases to be Addressed by Other Programs 


\subsection{INTRODUCTION}

The U.S. Department of Energy (DOE) Hanford Site in Washington State is organized into numerically designated operational areas including the $100,200,300,400,600$, and 1100 Areas (Figure 1-1). The U.S. Environmental Protection Agency (EPA), in November 1989, included the 200 Areas of the Hanford Site on the National Priorities List (NPI) under the Comprehensive Environmental Response, Compensation and Liability Act (CERCLA) of 1980. Inclusion on the NPL initiates the Remedial Investigation (RI) and Feasibility Study (FS) process for characterizing the nature and extent of contamination, assessing risks to human health and the environment, and selection of remedial actions.

This report presents the results of an aggregate area management study (AAMS) for the 200 North Aggregate Area located in the 200 Areas. The study provides the basis for initiating RI/FS under CERCLA or under the Resource Conservation and Recovery Act (RCRA) Facility Investigations (RFI) and Corrective Measures Studies (CMS). This report also integrates RCRA treatment, storage, or disposal (TSD) closure activities with CERCLA and RCRA past practice investigations.

This chapter describes the overall AAMS approach for the 200 Areas, defines the purpose, objectives and scope of the AAMS, and summarizes the quality assurance (QA) program and contents of the report.

\subsection{OVERVIEW}

The 200 Areas, located near the center of the Hanford Site, encompasses the 200 West, East, and North Areas which contain reactor fuel processing and waste management facilities.

Under the Hanford Federal Facility Agreement and Consent Order (Tri-Party Agreement), signed by the Washington State Department of Ecology (Ecology), DOE, and EPA (Ecology et al. 1990), the 200 NPL Site encompasses the 200 Areas and selected portions of the 600 Area. The 200 NPL Site is divided into 8 waste area groups largely corresponding to the major processing plants (e.g., B Plant and T Plant), and a number of isolated operable units located in the surrounding 600 Area. Each waste area group is further subdivided into one or more operable units based on waste disposal information, location, facility type, and other site characteristics. The 200 NPL site includes a total of 44 operable units including 20 in the 200 East Area, 17 in the 200 West Area, 1 in the 200 North Area, and 6 isolated operable units. The intent of defining operable units was to group associated waste management units together, so that they could be effectively characterized and remediated under one work plan.

The Tri-Party Agreement also defines approximately 25 RCRA TSD groups within the 200 Areas which will be closed or permitted (for operation or postclosure care) in 
accordance with the Washington State Dangerous Waste Regulations (Washington Administrative Code [WAC] 173-303). The TSD facilities are often associated with an operable unit and are required to be addressed concurrently with past-practice activities under the Tri-Party Agreement.

This AAMS is one of ten studies that will provide the basis for past practice activities for operable units in the 200 Areas. In addition, the AAMS will be collectively used in the initial development of an area-wide groundwater model, and conduct of an initial site-wide risk assessment. Recent changes to the Tri-Party Agreement (Ecology et al. 1991), and the Hanford Site Past-Practice Strategy document (DOE/RL 1992a) establish the need and provide the framework for conducting AAMS in the 200 Areas.

\subsubsection{Tri-Party Agreement}

The Tri-Party Agreement was developed and signed by representatives from the EPA, Ecology, and DOE in May 1989, and revised in 1990 and 1991. The scope of the agreement covers all CERCLA past practice, RCRA past practice, and RCRA TSD activities on the Hanford Site. The purpose of the Tri-Party Agreement is to ensure that the environmental impacts of past and present activities are investigated and appropriately remediated to protect human health and the environment. To accomplish this, the Tri-Party Agreement provides a framework and schedule for developing, prioritizing, implementing, and monitoring appropriate response actions.

The 1991 revision to the Tri-Party Agreement requires that an aggregate area approach be implemented in the 200 Areas based on the Hanford Site Past-Practice Strategy (DOE/RL 1992a). This strategy requires the conduct of AAMS which are similar in nature to an RI/FS scoping study. The Tri-Party Agreement change package (Ecology et al. 1991) specifies that 10 Aggregate Area Management Study Reports (AAMSR) (major milestone M-27-00) are to be prepared for the 200 Areas. Further definition of aggregate areas and the AAMS approach is provided in Sections 1.2 and 1.3.

\subsubsection{Hanford Site Past-Practice Strategy}

The Hanford Site Past-Practice Strategy was developed between Ecology, EPA, and DOE to streamline the existing RI/FS and RFI/CMS processes. A primary objective of this strategy is to develop a process to meet the statutory requirements and integrate CERCLA RI/FS and RCRA Past Practice RFI/CMS guidance into a singular process for the Hanford Site that ensures protection of human health and welfare and the environment. The strategy refines the existing past practice decision-making process as defined in the Tri-Party Agreement. The fundamental principle of the strategy is a bias-for-action by optimizing the use of existing data, integrating past practice with RCRA TSD closure investigations, focusing the RI/FS process, conducting interim remedial actions, and reaching early decisions to initiate and complete cleanup projects on both operable-unit and aggregate-area 
scale. The ultimate goal is the comprehensive cleanup or closure of all contaminated areas at the Hanford Site at the earliest possible date in the most effective manner.

The process under this strategy is a continuum of activities wher zby the effort is refined based upon knowledge gained as work progresses. Whereas the strategy is intended to streamline investigations and documentation to promote the use of interim actions to accelerate cleanup, it is consistent with RI/FS and RFI/CMS processes. An important element of this strategy is the application of the observational approach, in which characterization data are collected concurrently with cleanup.

For the 200 Areas the first step in the strategy is the evaluation of existing information presented in AAMSR. Based on this information, decisions are made regarding which strategy path(s) to pursue for further actions in the aggregate area. The strategy includes three paths for interim decision making and a final remedy-selection process that incorporates the three paths and integrates sites not addressed in those paths. As shown on Figure 1-2, the three paths for decision making are the following:

- Expedited response action (ERA) path, where an existing or near-term unacceptable health or environmental risk from a site is determined or suspected, and a rapid response is necessary to mitigate the problem

- Interim remedial measure (IRM) path, where existing data are sufficient to indicate that the site poses a risk through one or more pathways and additional investigations are not needed to screen the likely range of remedial alternatives for interim actions; if a determination is made that an IRM is justified, the process proceeds to select an IRM remedy and a focused feasibility study (FFS), if needed, to select a remedy

- $\quad$ Limited field investigation (LFI) path, where minimum site data are needed to support IRM or other decisions, and are obtained in a less formal manner than that needed to support a final Record of Decision (ROD). Data generated from a LFI may be sufficient to directly support an interim ROD. Regardless of the scope of the LFI, it is a part of the RI process, and not a substitute for it.

The process of final remedy selection must be completed for the aggregate area to reach closure. The aggregation of information obtained from LFI and interim actions may be sufficient to perform the cumulative risk assessment and to define the final remedy for the aggregate area or associated operable units. If the data are not sufficient, additional investigations and studies will be performed to the extent necessary to support final remedy selection. These investigations would be performed within the framework and process defined for RI/FS or RFI/CMS programs. 


\subsection{NPL SITE AGGREGATE AREA MANAGEMENT STUDY PROGRAM}

The overall approach and scope of the 200 Areas AAMS program is based on the TriParty Agreement and the Hanford Site Past-Practice Strategy.

\subsubsection{Overall Approach}

As defined in the 1991 revision to the Tri-Party Agreement, the AAMS program for the 200 Areas consists of conducting a series of ten AAMS for eight source (Figures 1-3, 14, and 1-5) and two groundwater aggregate areas delineated in the 200 East, West, and North Areas. Table 1-1 lists the aggregate areas, the type of study, and associated operable units. With tie exception of 200-IU-6, isolated operable units associated with the 200 NPL site (Figure 1-5) are not included in the AAMS program. Generally, the quantity of existing information associated with isolated operable units is not considered sufficient to require study on an aggregate area basis prior to work plan development. Operable unit 200-IU-6 is addressed as part of the B Plant AAMS because of similarities in waste management units (i.e., ponds).

The eight source AAMS are designed to evaluate source terms on a plant-wide scale. Source AAMS are conducted for the following aggregate areas (waste area groups) which largely correspond to the major processing plants including the following:

- U Plant

- Z Plant

- S Plant

- T Plant

- PUREX

- B Plant

- Semi-Works

- 200 North.

The groundwater beneath the 200 Areas is investigated under two groundwater AAMS on an area-wide scale (i.e., 200 West and 200 East Areas). Groundwater aggregate areas were delineated to encompass the geography necessary to define and understand the local hydrologic regime, and the distribution, migration and interaction of contaminants emanating from source terms. The groundwater aggregate areas are considered an appropriate scale for developing conceptual and numerical groundwater models. 
The U.S. Department of Energy, Richland Field Office (DOE/RL) functions as the "lead agency" for the 200 AAMS program. Depending on the specific AAMS, EPA and/or Ecology function as the "Lead Regulatory Agency" (Table 1-1). Through periodic (monthly) meetings information is transferred and regulators are informed of the progress of the AAMS such that decisions established under the Hanford Site Past-Practice Strategy (e.g., is an ERA justified?) (Figure 1-2) can be quickly and collectively made between the three parties. These meetings will continually refine the scope of AAMS as new information is evaluated, decisions are made and actions taken. Completion milestones for AAMS are defined in Ecology et al. (1991) and duplicated in Table 1-1. All AAMSR are submitted as Secondary Documents which are defined in the Tri-Party Agreement as informational documents.

\subsubsection{Process Overview}

Each AAMS consists of three steps: (1) the analysis of existing data and formulation of a preliminary conceptual model, (2) identification of data needs and evaluation of remedial technologies, and (3) conduct of limited field characterization activities. Steps 1 and 2 are components of an AAMSR. Step 3 is a parallel effort for which separate reports will be produced.

The first and primary task of the AAMS investigation process involves the search, compilation and evaluation of existing data. Information collected for these purposes includes the following:

- Facility and process descriptions and operational histories for waste sources

- Waste disposal records defining dates of disposal, waste types, and waste quantities

- Sampling events of waste effluents and affected media

- Site conditions including the site physiography, geology, hydrology, meteorology, ecology, demography, and archaeology

- Environmental monitoring data for affected media including air, surface water, sediment, soil, groundwater and biota.

Collectively this information is used to identify cuntaminants of concern, to determine the scope of future characterization efforts, and to develop a preliminary conceptual model of the aggregate area. Although data collection objectives are similar, the types of information collected depend on whether the study is a source or groundwater AAMS. The data collection step serves to avoid duplication of previous efforts and facilitates a more focused investigation by the identification of data gaps. 
Topical reports referred to as Technical Baseline Reports are initially prepared to summarize facility information. These reports describe individual waste management units and unplanned releases contained in the aggregate area as identified in the Waste Information Data System (WIDS) (WHC 1991a). The reports are based on review of current and historical Hanford Site reports, engineering drawings and photographs and are supplemented with site inspections and employee interviews. Information contained in the reports is summiarized in the AAMSR. Other topical reports are used as sources of information in the AAMSR. These reports are as follows:

- U Plant Geologic and Geophysics Data Package

- Z Plant Geologic and Geophysics Data Package

- S Plant Geologic and Geophysics Data Package

- T Plant Geologic and Geophysics Data Package

- PUREX Geologic and Geophysics Data Package

- B Plant Geologic and Geophysics Data Package

- 200 N Geologic and Geophysics Data Package

- Semiworks Geologic and Geophysics Data Package

- Hydrologic Model for the 200 West Groundwater Aggregate Area

- Hydrologic Model for the 200 East Groundwater Aggregate Area

- Unconfined Aquifer Hydrologic Test Data Package for the 200 West Groundwater Aggregate Area

- Unconfined Aquifer Hydrologic Test Data Package for the 200 East Groundwater Aggregate Area

- Confined Aquifer Hydrologic Test Data Package for the 200 Groundwater Aggregate Area Management Studies

- Groundwater Field Characterization Report

- 200 West Area Borehole Geophysics Field Characterization

- 200 East Area Borehole Geophysics Field Characterization 
The general scope of the topical reports related to this AAMSR is described in Section 8.0.

Information on waste sources, pathways, and receptors is used to develop a preliminary conceptual model of the aggregate area. In the preliminary conceptual model, the release mechanisms and transport pathways are identified. If the conceptual understanding of the site is considered inadequate, limited field characterization activities can be undertaken as part of the study. Field characterization activities occurring in parallel with and as part of the AAMS process include the following:

- Expanded groundwater monitoring programs (non Contract Laboratory Program[CLP]) at approximately 80 select existing wells to identify contaminants of concern and refine groundwater plume maps

- In situ assaying of gamma-emitting radionuclides at approximately 10 selected existing boreholes per aggregate area to develop radioelement concentration profiles in the vadose zone.

Wells, boreholes, and analytes are selected based on a review of existing environmental data which is undertaken early in the AAMS process. Field characterization results will be presented later in topical reports.

After the preliminary conceptual model is developed, health and environmental concerns are identified. The purpose of this determination is to provide one basis for determining recommendations and prioritization for subsequent actions at waste management units. Potential applicable or relevant and appropriate requirements (ARARs) and potential remedial technologies are identified. In cases where the existing information is sufficient, the Hanford Site Past-Practice Strategy allows for a FS or CMS to be initiated prior to the completion of the study.

Data needs are identified by evaluating the sufficiency of existing data and by determining what additional data are necessary to adequately characterize the aggregate area, refine the preliminary conceptual model and potential ARARs, and/or narrow the range of remedial alternatives. Determinations are made regarding the level of uncertainty associated with existing data and the need to verify or supplement the data. If additional data are needed, the intended data uses are identified, data quality objectives (DQO) established and data priorities set.

Each AAMSR results in management recommendations for the aggregate area including the following:

- The need for ERA, IRM, and LFI or whether to remain in the final remedy selection path

- Definition and prioritization of operable units 
- Prioritization of work plan activities

- Integration of RCRA TSD closure activities

- The conduct of field characterization activities

- The need for treatability studies

- Identification of waste management units addressed entirely under other operational programs.

The waste management units recommended for ERA, IRM, or LFI actions are considered higher priority units. Lower priority waste management units will generally follow the conventional process for RI/FS. In spite of this distinction in the priority of sites, RI/FS activities will be conducted for all the waste management units. In the case of the higher priority waste management units, rapid response operations will be followed by conventional RI/FS activities, although these activities may be modified because of knowledge gained through the remediation activities. In the case of the lower priority waste management units, an area-wide RI/FS will be prepared which encompasses these units.

Based on the AAMSR, a decision is made on whether the study has provided sufficient information to forego further field investigations and prepare a FS. An RI/FS work plan (which may be limited to LFI activities) will be developed and executed. The background information normally required to support the preparation of a work plan (e.g., site description, conceptual model, DQO, etc.) is developed in the AAMSR. The future work plans will reference information from the AAMSR. They will also include the rationale for sampling and analysis, will present detailed, unit-specific DQO, and will further develop physical site models as the data allows. In some cases, there may be insufficient data to support any further analysis than is provided in the AAMSR, so an added level of detail in the work plan may not be feasible.

All ten AAMS are scheduled to be cornpleted by September 1992. This will facilitate a coordinated approach to prioritizing and implementing future past practice activities for the entire 200 Areas.

\subsection{PURPOSE, SCOPE, AND OBJECTIVES}

The purpose of conducting an AAMS is to compile and evaluate the existing body of knowledge and conduct limited field characterization work to support the Hanford Site Past-Practice Strategy decision-making process for an aggregate area. The AAMS process is similar in nature to the RI/FS scoping process prior to work plan development and is intended to maximize the use of existing data to allow a more focused RI/FS. Deliverables for an AAMS consist of the AAMSR and Health and Safety, Project Management, and Information Management Overview (IMO) Plans. 
DOE/RL-92-17, Rev. 0

Specific objectives of the AAMS include the following:

- Assemble and interpret existing data ircluding operational and environmental data

- Describe site conditions

- Conduct limited new site characterization work if data or interpretation uncertainty could be reduced by the work (results from this work may not be available for the AAMSR, but will be included in subsequent topical reports).

- Develop a preliminary conceptual model

- Identify contaminants of concern, and their distribution

- Identify potential ARARs

- Define preliminary remedial action objectives, screen potential remedial technologies, and if possible provide recommendations for FFS

- Recommend treatability studies to support the evaluation of remedial action alternatives

- Define data needs, establish general DQOs and set data priorities

- Provide recommendations for ERA, IRM, LFI or other actions

- Redefine and prioritize, if necessary, operable unit boundaries

- Define and prioritize, as data allow, work plan and other past practice activities with emphasis on supporting early cleanup actions and records of decisions

- Integrate RCRA TSD closure activities with past practice activities.

Information on single-shell and double-shell tanks is presented in Sections 2.0 and 4.0 of selected AAMSRs. The AAMSR is not intended to address remediation related to the tanks. Nonetheless, the tank information is presented because known and suspected releases from the tanks may influence the interpretation of contamination data at nearby waste management units. Information on other facilities and buildings is also presented for this same reason. However, because these structures are addressed by other programs, the AAMSR does not include recommendations for further action at these structures.

Depending on whether an aggregate area is a source or groundwater aggregate area, the scope of the AAMS varies. Source AAMS focus on source terms, and the environmental media of interest include air, biota, surface water, surface soil, and the unsaturated subsurface soil. Accordingly, detailed descriptions of facilities and operational information 
are provided in the source AAMSR. In contrast, groundwater AAMS focus on the saturated subsurface and on groundwater contamination data. Descriptions of facilities in the groundwater AAMSR are limited to liquid disposal facilities and reference is made to source AAMSR for detailed descriptions. The description of site conditions in source AAMSR concentrate on site physiography, meteorology, surface water hydrology, vadose zone geology, ecology, and demography. Groundwater AAMSR summarize regional geohydrologic conditions and contain detailed information regarding the local geohydrology on an area-wide scale. Correspondingly, other sections of the AAMSR vary depending on the environmental media of concern.

\subsection{QUALITY ASSURANCE}

A limited amount of field characterization work is performed in parallel with preparation of the AAMSR. To help ensure that data collected are of sufficient quality to support decisions, all work will be performed in compliance with Quality Assurance, DOE Order 5700.6C (DOE 1991), as well as Westinghouse Hanford's existing QA manual WHCCM-4-2 (WHC 1988a), and with procedures outlined in the QA program plan WHC-EP-0383 (WHC 1990a), specific to CERCLA RI/FS activities. This QA program plan describes the various plans, procedures, and instructions that will be used by Westinghouse Hanford to implement the QA requirements. Standard EPA guidance documents such as the USEPA Contract Laboratory Program Statement of Work for Organic Analysis (EPA 1988a) will also be followed.

\subsection{ORGANIZATION OF REPORT}

In addition to this introduction, the AAMSR consists of the following nine sections and appendices:

- Section 2.0, Facility, Process and Operational History Descriptions, describes the major facilities, waste management units and unplanned releases within the aggregate area. A chronology of waste disposal activities is established and waste generating processes are summarized.

- Section 3.0, Site Conditions, describes the physical, environmental, and sociological setting including, geology, hydrology, ecology, meteorology, and demography.

- Section 4.0, Preliminary Conceptual Site Model, summarizes the conceptual understanding of the aggregate area with respect to types and extent of contamination, exposure pathways and receptors.

- Section 5.0, Health and Environmental Concerns, identifies chemicals used or disposed within the aggregate area that could be of concern regarding public 
health and/or the environment and describes and applies the screening process for determining the relative priority of follow-up action at each waste management unit.

- Section 6.0, Potentially Applicable or Relevant and Appropriate Requirements, identifies federal and state standards, requirements, criteria, or limitations that may be considered relevant to the aggregate area.

- Section 7.0, Preliminary Remedial Action Technologies, identifies and screens potential remedial technologies and establishes remedial action objectives for environmental media.

- Section 8.0, Data Quality Objectives, reviews QA criteria on existing data, identifies data gaps or deficiencies, and identifies broad data needs for field characterization and risk assessment. The DQO and data priorities are established.

- Section 9.0, Recommendations, provides guidance for future past practice activities based on the results of the AAMS. Recommendations are provided for ERA at problem sites, IRM, LFI, refining operable unit boundaries, prioritizing work plans, and conducting field investigations and treatability studies.

- Section 10.0, References, list reports and documents cited in the AAMSR.

- Appendix A, Supplemental Data, provides supplemental data supporting the AAMSR.

The following plans are included and will be used to support past practice activities in the aggregate area:

- Appendix B: Health and Safety Plan

- Appendix C: Project Management Plan

- Appendix D: Information Management Overview

Community relations requirements for the 200 North Aggregate Area can be found in the Community Relations Plan for the Hanford Federal Facility Agreement and Consent Order (Ecology et al. 1989). 
Figure 1-1. Hanford Site Map.

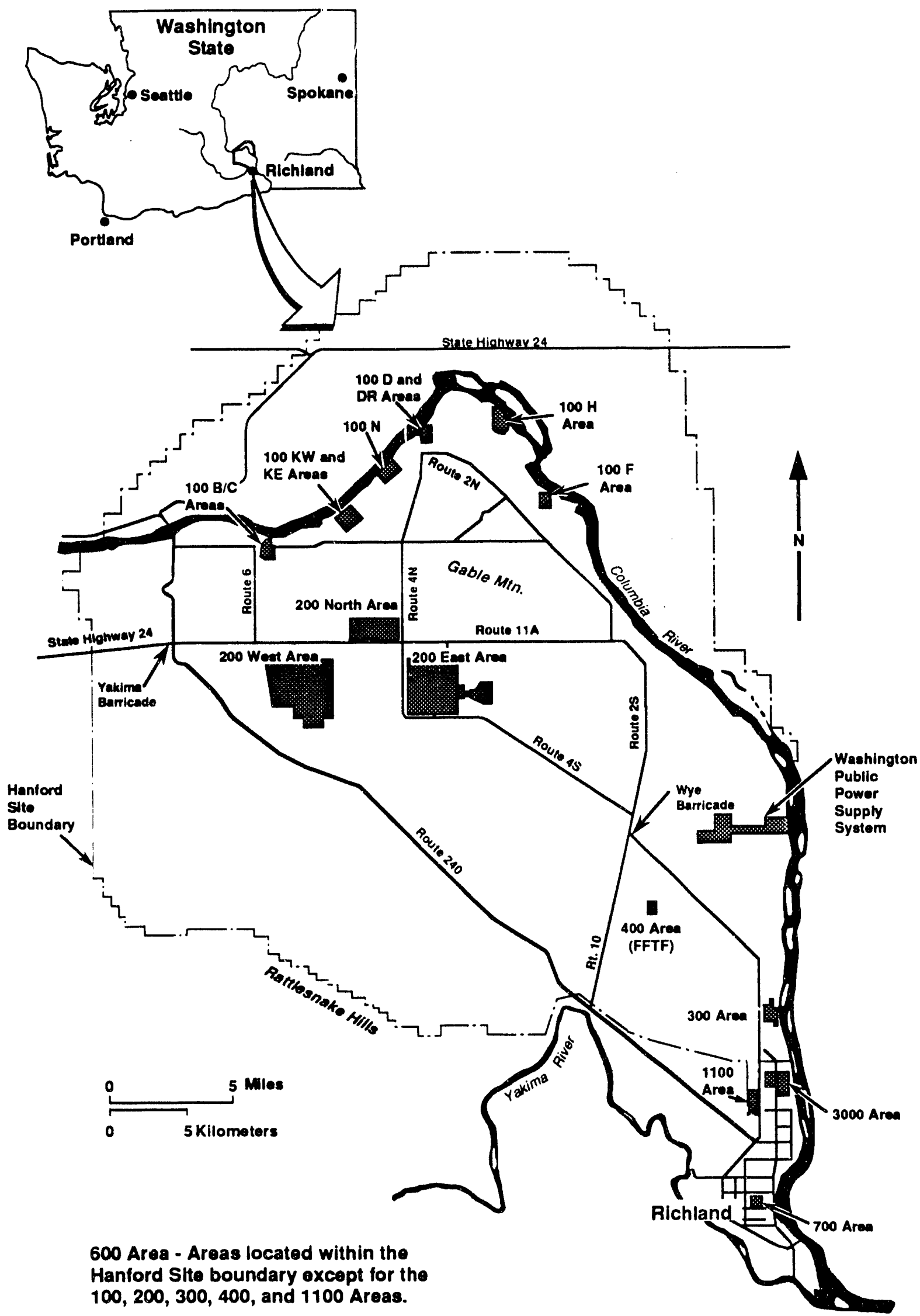


DOE/RL-92-17, Rev. 0

Figure 1-2. Hanford Past Practice Strategy Flow Chart.

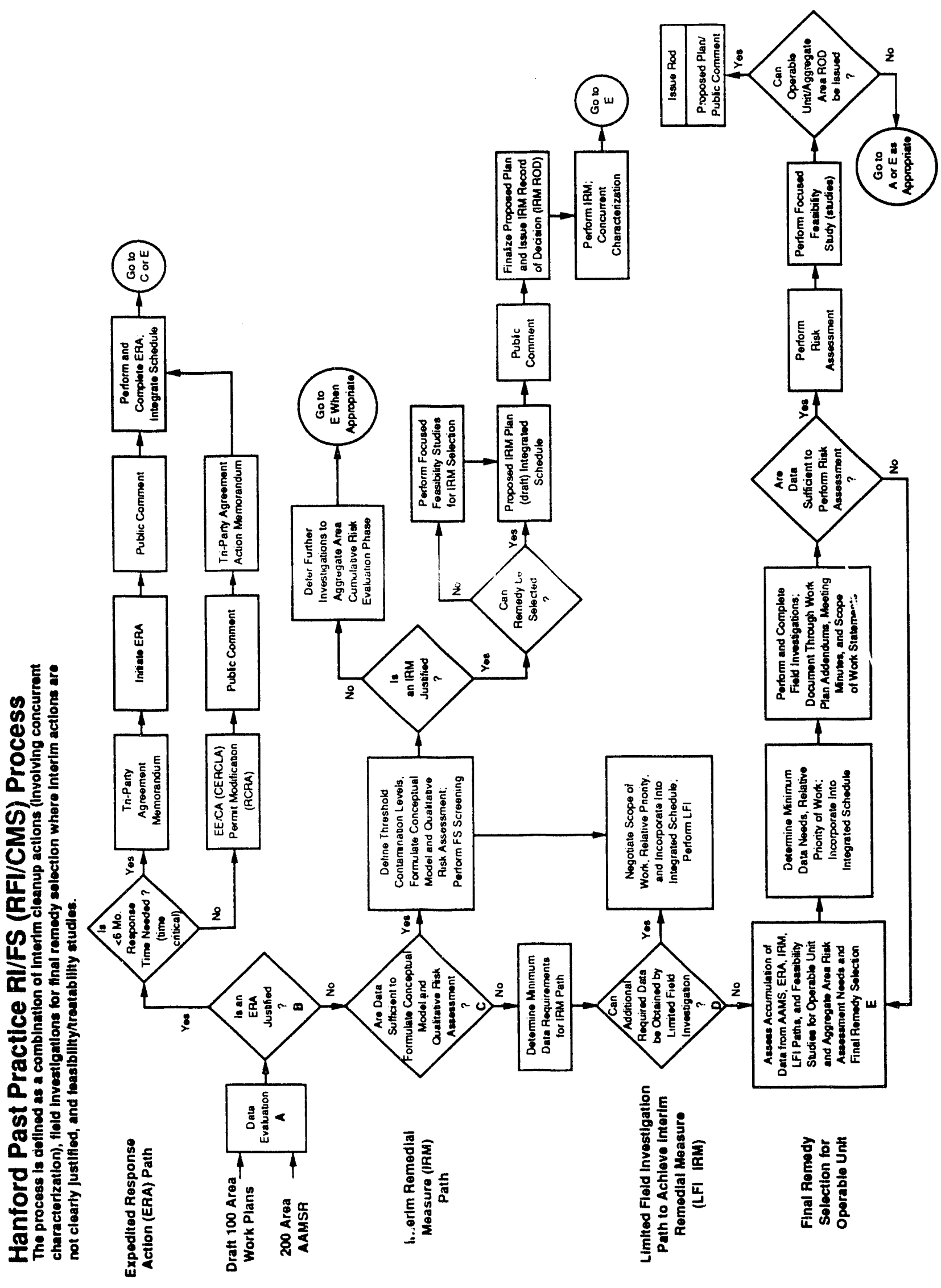


DOE/RL-92-17, Rev. 0

Figure 1-3. 200 East Aggregate Areas.

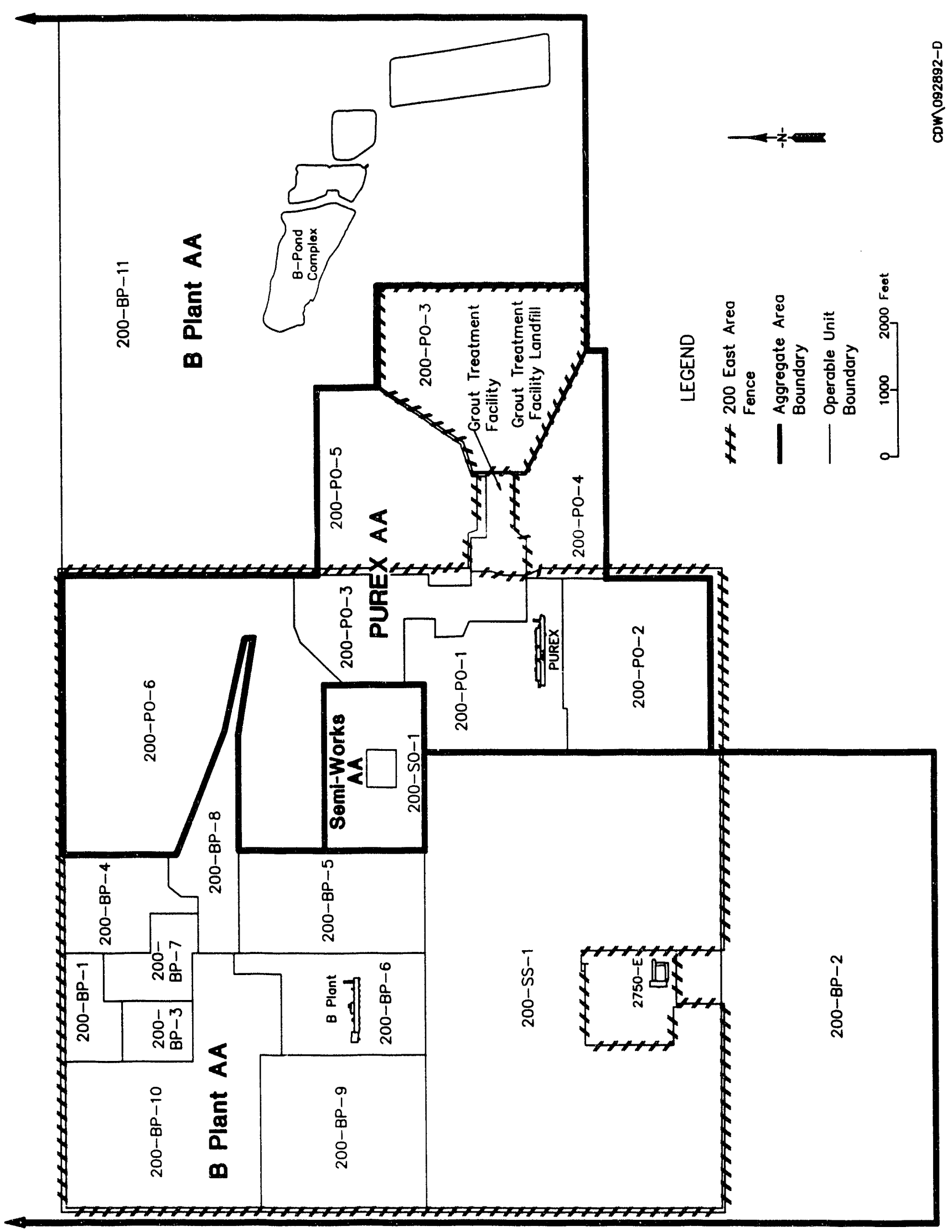


DOE/RL-92-17, Rev. 0

Figure 1-4. 200 West Aggregate Areas.

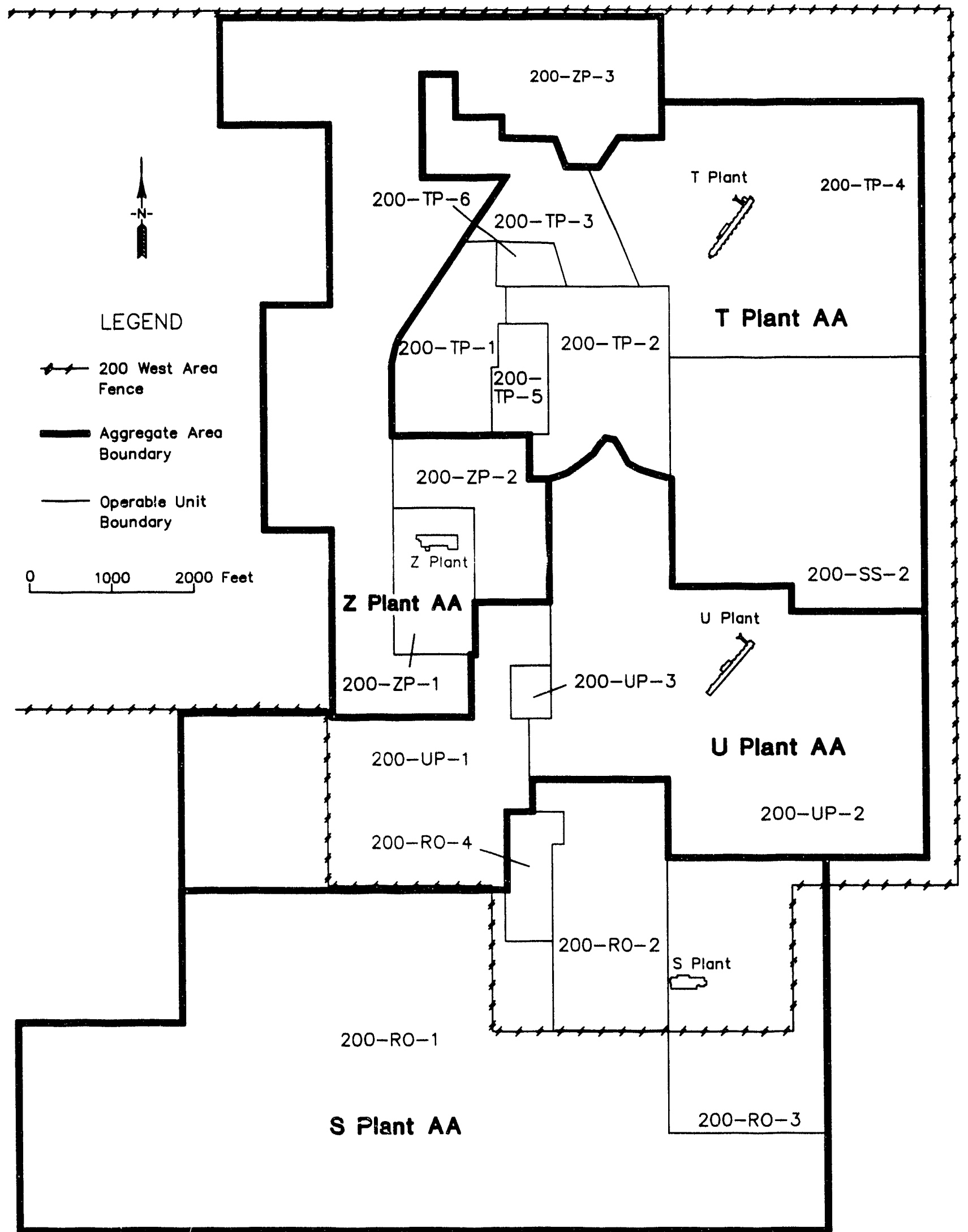

comos2892-E 
Figure 1-5. 200 NPL Site Isolated Operable Units

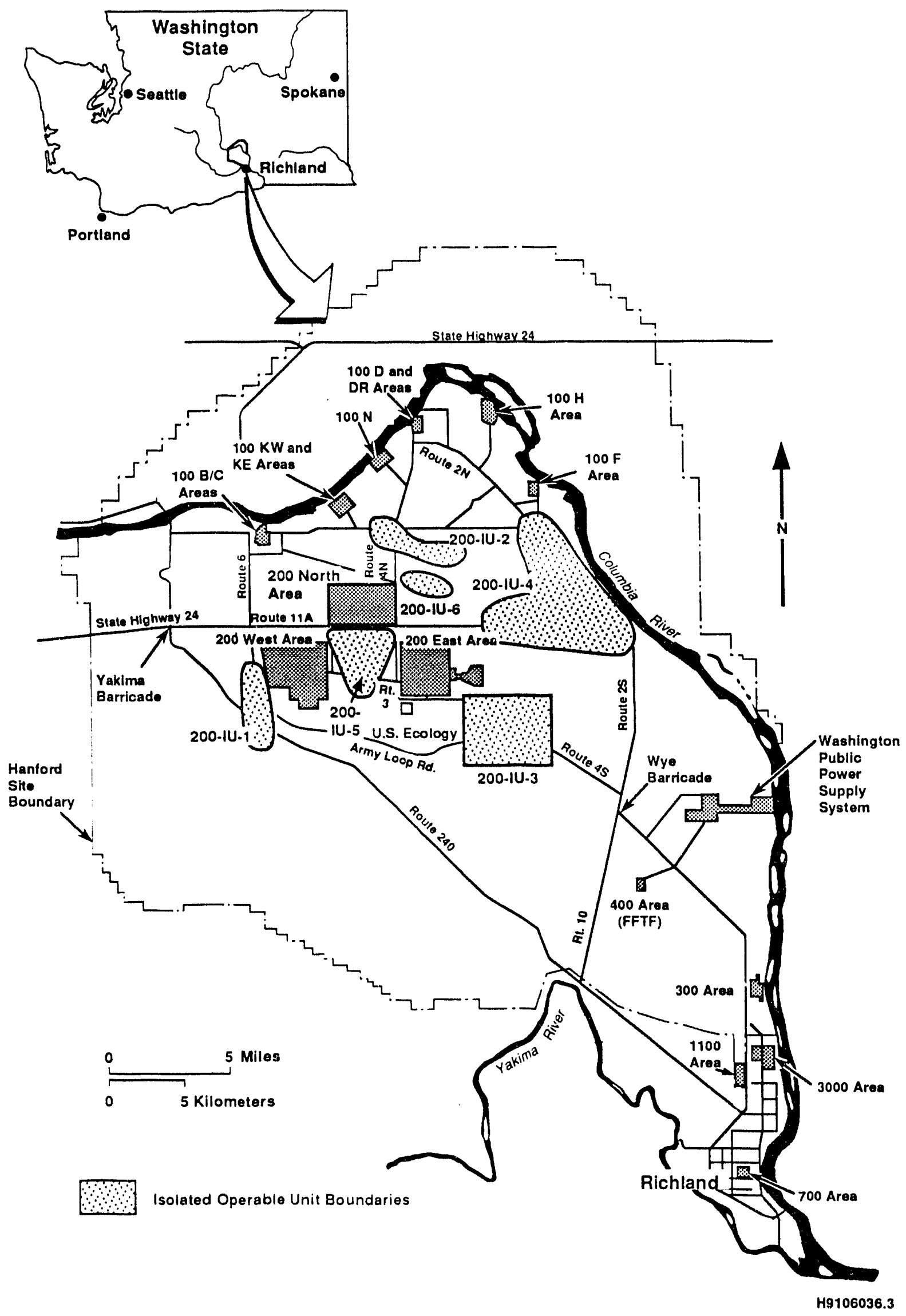


Table 1-1. Overall Aggregate Area Management Study (AAMS) Schedule for the 200 NPL Site.

\begin{tabular}{|c|c|c|c|c|}
\hline AAMS Title & $\begin{array}{c}\text { Operable } \\
\text { Units }\end{array}$ & AAMS Type & $\begin{array}{c}\text { Lead } \\
\text { Regulatory } \\
\text { Agency }\end{array}$ & $\begin{array}{l}\text { M-27-00 Interim } \\
\text { Milestones }\end{array}$ \\
\hline U Plant & $\begin{array}{l}\text { 200-UP-1 } \\
200 \text {-UP-2 } \\
\text { 200-UP-3 }\end{array}$ & Source & Ecology & M-27-02, January 1992 \\
\hline Z Plant & $\begin{array}{l}200-Z P-1 \\
200-Z P-2 \\
200-Z P-3 \\
\end{array}$ & Source & EPA & M-27-03, February 1992 \\
\hline S Plant & $\begin{array}{l}200-R O-1 \\
200-R O-2 \\
200-R O-3 \\
200-R O-4 \\
\end{array}$ & Source & Ecology & M-27-04, March 1992 \\
\hline T Plant & $\begin{array}{l}200 \text {-TP-1 } \\
200 \text {-TP-2 } \\
200 \text {-TP-3 } \\
200 \text {-TP-4 } \\
200 \text {-TP-5 } \\
200 \text {-TP-6 } \\
\text { S00-SS-2 } \\
\end{array}$ & Source & EPA & M-27-05, April 1992 \\
\hline PUREX & $\begin{array}{l}200-P O-1 \\
200-P O-2 \\
200-P O-3 \\
200-P O-4 \\
200-P O-5 \\
200-P O-6 \\
\end{array}$ & Source & Ecology & M-27-06, May 1992 \\
\hline B Plant & $\begin{array}{l}200-B P-1 \\
200-B P-2 \\
200-B P-3 \\
200-B P-4 \\
200-B P-5 \\
200-B P-6 \\
200-B P-7 \\
200-B P-8 \\
200-B P-9 \\
200-B P-10 \\
200-B P-11 \\
200-\text { IU-6 } \\
200-S S-1 \\
\end{array}$ & Source & EPA & M-27-07, June 1992 \\
\hline Semi-Works & 200-SO-1 & Source & Ecology & M-27-08, July 1992 \\
\hline 200 North & 200-NO-1 & Source & EPA & M-27-09, August 1992 \\
\hline 200 West & NA & Groundwater & EPA/Ecology & M-27-10, September 1992 \\
\hline 200 East & NA & Groundwater & EPA/Ecology & M-27-11, September 1992 \\
\hline
\end{tabular}




\subsection{FACILITY, PROCESS, AND OPERATIONAL HISTORY DESCRIPTIONS}

Section 2.0 of the aggregate area management study (AAMS) presents historical data on the $\mathbf{2 0 0}$ North Aggregate Area and detailed physical descriptions of the individual waste management units and unplanned releases. These descriptions include historical data on waste sources and disposal practices and are based on a review of current and historical Hanford Site reports, engineering drawings, site inspections, and employee interviews. Section 3.0 describes the environmental setting of the waste management units. The waste types and volumes are qualitatively and quantitatively assessed at each waste management unit in Section 4.0. Data from these three sections are used to identify contaminants and sites of concern (Section 5.0), potential applicable or relevant and appropriate requirements (ARARs) (Section 6.0), and current data gaps (Section 8.0).

This section describes the location of the 200 North Aggregate Area (Section 2.1), summarizes the history of operations (Section 2.2), describes facilities, buildings, and structures of the 200 North Aggregate Area (Section 2.3), and describes 200 North Aggregate Area waste generating processes (Section 2.4). Section 2.5 discusses interactions with the other aggregate areas or operable units. Sections 2.6 and 2.7 discuss interactions with the Resource Conservation and Recovery Act (RCRA) program and other Hanford programs.

\subsection{LOCATION}

The Hanford Site, operated by the U.S. Department of Energy (DOE), occupies about $1,450 \mathrm{~km}^{2}\left(560 \mathrm{mi}^{2}\right)$ of the southeastern part of Washington State north of the confluence of the Yakima and Columbia Rivers (Figure 1-1). The 200 North Aggregate Area is an uncontrolled area of approximately $3.5 \mathrm{~km}^{2}\left(1.5 \mathrm{mi}^{2}\right)$ near the middle of the Hanford Site. It is about $7 \mathrm{~km} \mathrm{(4} \mathrm{mi)} \mathrm{from} \mathrm{the} \mathrm{Columbia} \mathrm{River} \mathrm{and} 16 \mathrm{~km}(10 \mathrm{mi})$ from the nearest Hanford boundary. It consists of one operable unit, 200-NO-1. The 200 North Aggregate Area lies immediately northwest of the intersection of Routes $4 \mathrm{~N}$ and $11 \mathrm{~A}$, just $2 \mathrm{~km}(1.2 \mathrm{mi})$ northwest of the 200 East Area and $2 \mathrm{~km}(1.2 \mathrm{mi})$ northeast of the 200 West Area (Figure 1-4). The locations of the buildings and waste management units as well as the topography of the 200 North Aggregate Area are shown on Plate 1.

\subsection{HISTORY OF OPERATIONS}

The Hanford Site, established in 1943, was originally designed, built, and operated to produce plutonium for nuclear weapons using production reactors and chemical reprocessing plants. In March 1943, construction began on three reactor facilities (B, D, and F Reactors) and three chemical processing facilities (B, T, and U Plants). After World War II, six more reactors were built (H, DR, C, KW, KE, and N Reactors). Beginning in the 1950's energy research and development, isotope use, and other activities were added to the Hanford 
operation. In early 1964, a presidential decision was made to begin shut down of the reactors. Eight of the reactors were shut down by 1971. The $\mathbf{N}$ Reactor operated through 1987; and was placed on cold standby status in October 1989. Westinghouse Hanford was notified September 20, 1991 that they should cease preservation and proceed with activities leading to a decision on ultimate decommissioning of the reactor. These activities are scoped within a N Reactor shutdown program which is scheduled to be completed in 1999.

Operations in the 200 North Aggregate Area were mainly related to irradiated nuclear fuel storage. Many short-lived radioisotopes will decay to negligible levels in a relatively short period of time after being discharged from a reactor. The irradiated fuel produced in the 100 Area plutonium reacturs was stored for a length of time sufficient to allow this decay to occur.

Iodine-131 controlled the length of the storage period. This element has a half-life of about 8 days and was allowed to decay in storage for a number of half-lives before being released for presessing in the separations plants. Iodine-131 contained within a fuel element was released as a gas at the fuel separations plants (B Plant and T Plant) when the fuel elements were dissolved in nitric acid during the initial processing steps. To prevent the release of large quantities of iodine-131 at the separations plants, the fuel elements were kept in storage until iodine-131 had decayed to the concentration needed to meet the release criteria for the particular batch of irradiated fuel elements. The usual storage period for the fuel elements was approximately 40-60 days (Ballinger and Hall 1989) This storage period would reduce the quantity of an isotope such as iodine-131 to less than 1/1000 of the amount which was originally present.

Another important transmutation which occurred during the siorage pe-iod was the decay of neptunium-239 to the desired plutonium-239. The half-life of neptunium-239 was only 2.33 day:; therefore 40-60 cays of storage were normally used so that the gamma radiations from the principal activity was only a minor radiation hazard (General Electric 1956). Other radioisotopes that were present in the irradiated fuel elements generally had shorter half-lives than iodine-131; therefore, a storage time long enough to allow the decay of iodine-131 was more than sufficient to allow the decay of other isotopes.

The purpose of the 200 North Aggregate Area facilities was to provide a storage site for the fuel while the radioisotope decay processes were occurring. Geographically, the area is conveniently located, being approximately 7 to $12 \mathrm{~km}$ (4 to $7.5 \mathrm{mi}$ ) south of the reactor area (100 Area) and immediately north of the two fuel separations areas, 200 East and 200 West. The fuel elements were transported to and from the three storage facilities in the 200 North Aggregate Area by railcar.

The 200 North Aggregate Area provided this storage function from startup in 1944 until the spring of 1952 . During these early years of reactor operation in the 100 Area, it was found that the additional storage time in the 200 North Aggregate Area storage facilities was not really needed and they ivere used relatively infrequently. After 1952, the irradiated 
fuel was stored exclusively in the storage basins near the reactors in the 100 Area and the 200 North Aggregate Area storage facilities were shut down.

After a period of years of disuse, the three storage facility buildings of the 200 North Aggregate Area were used for other functions. The 212-N Building is used for contaminated equipment storage (1970 to present), the 212-P Building is used as a work area for electrical maintenance/hazardous waste storage (1982 to present), and the 212-R Building was used as a maintenance shop for radiologically contaminated railroad equipment (1982 to 1986).

\subsection{FACILITIES, BUILDINGS, AND S:RUCTURES}

The 200 North Aggregate Area contains a variety of waste disposal and storage facilities that were associated with 200 North Aggregate Area missions. Radiologically contaminated processing wastes were discharged to the soil column through trenches. Wastes which were not normally contaminated, but have the potential to contain radionuclides, such as cooling water, were allowed to infiltrate into the ground through ponds. Radiologically contaminated waste types are defined in DOE Order 5820.2A (DOE 1988a):

- High-level waste is defined as: highly radioactive material that results from the reprocessing of spent nuclear fuel, including liquid waste produced directly in reprocessing and any solid waste derived from the liquid, that contains a combination of TRU waste and fission products in concertrations as to require permanent isolation.

- TRU waste is defined as: without regard to source or form, waste that at the end of institutional control periods is contaminated with alpha-emitting transuranium radionuclides with half-lives greater than 20 years and concentrations greater than $100 \mathrm{nCi} / \mathrm{g}$. Heads of Field Elements can determine that other alpha contaminated wastes peculiar to a specific site, must be managed as TRU waste.

- Low-I e.al Waste is defined as: radioactive waste not classified as high-level w:ste, TRU waste, spent nucicar fuel, or IIe(2) byproduct material as defined by unis Order. Test specimens of fissionable material irradiated for research and development only, and not for the production of power or plutonium, may be classified as low-level waste, provided the concentration of TRU waste is less than $100 \mathrm{nCi} / \mathrm{g}$.

- Byproduct Material is defined as: (a) Any radioactive material (except special nuclear material) yielded in, or made radioactive by, exposure to the radiation incident or to the process of producing or utilizing special nuclear material. For purposes of determining the applicability of RCRA to any radioactive waste, the term "any radioactive material" refers only to the actual radionuclides dispersed or suspended in the waste substance. The nonradioactive hazardous waste 
component of the waste substance will be subject to regulation under RCRA.

(b) The tailings or waste produced by the extraction or concentration of uranium or thorium from any ore processed primarily for its source material content. Ore bodies depleted by uranium solution extraction operations and which remain underground do not constitute "byproduct material."

Based on construction, purpose, or origin, the 200 North Aggregate Area waste management units fall into one of the ten subgroups as follows:

- $\quad$ Plants, Buildings, and Storage Areas (Section 2.3.1)

- Tanks and Vaults (Section 2.3.2)

- Cribs and Drains (Section 2.3.3)

- $\quad$ Reverse Wells (Section 2.3.4)

- $\quad$ Ponds, Ditches, and Trenches (Section 2.3.5)

- $\quad$ Septic Tanks and Associated Drain Fields (Section 2.3.6)

- Transfer Facilities, Diversion Boxes, and Pipelines (Section 2.3.7)

- Basins (Section 2.3.8)

- $\quad$ Burial Sites (Section 2.3.9)

- Unplanned Releases (Section 2.3.10).

Table 2-1 presents a list of the waste management units within the 200 North Aggregate Area. In addition, the area contains two unplanned release sites. The locations of waste management units are shown on separate figures for each waste management group and on Plate 1. Tables 2-2 and 2-3 summarize data available regarding the quantity and types of radiological wastes disposed to the waste management units. These data have been compiled from the Waste Information Data System (WIDS) inventory sheets (WHC 1991a) and from the Hanford Inactive Site Survey (HISS) database, and other sources found during research. These inventories include all of the contaminants reported in the databases, but do not necessarily include all of the contaminants disposed of at each waste management unit. In the following sections each waste management unit is described within the context of one of the waste management unit types. 


\subsubsection{Plants, Buildings, and Storage Areas}

Plants and buildings are not generally identified as past practice waste management units according to the Hanford Federal Facility Agreement and Consent Order (Tri-Party Agreement), and will generally be addressed under the Decommissioning and RCRA Closure Program. The program is responsible for the surveillance, maintenance, and decommissioning of surplus facilities within the Environmental Restoration Programs. Section 2.7 details the interaction of the Hanford programs. In the 200 North Aggregate Area, the 212-N, 212-P, and 212-R Storage Facilities were the primary generators of waste disposed of within the 200 North Aggregate Area. These facilities are discussed together as a group in Section 2.3.1.1. Features which are unique to each building and descriptions of the current function of each individual facility are provided in Sections 2.3.1.2, 2.3.1.3, and 2.3.1.4. The locations of these buildings and storage areas in the 200 North Aggregate Area are shown on Figure 2-1.

Other buildings and structures located within the aggregate area are not in this document because they are not thought to have released contaminants and may be closed through a separate decontamination and decommissioning process. The decontamination and decommissioning program addresses both contaminated and uncontaminated structures and is described in the Hanford Surplus Facilities Program Plan (Hughes et al. 1990). These structures include:

- 2743-N Gate House and Guard Tower

- 2743-P Gate House and Guard Tower

- 2743-R Gate House and Guard Tower

- 2705-N Guard Towers

- 2705-P Guard Towers

- 2705-R Guard Towers

- 251-N Primary Electrical Substation

- 251-P Primary Electrical Substation

- 251-R Primary Electrical Substation

All of the above listed structures currently exist only as concrete foundations. 


\subsubsection{Process Facilities}

2.3.1.1.1 212-N, 212-P, and 212-R Buildings. The 212-N, 212-P, and 212-R Buildings were constructed in 1944 to store irradiated fuel from the plutonium reactors in the 100 Area. These buildings were constructed identically, and are composed of two main sections and a heater room. Each section of each building has a concrete slab roof and walls constructed of concrete and concrete block. The total area of each building is $555 \mathrm{~m}^{2}$ $\left(5,970 \mathrm{ft}^{2}\right)$. Figure 2-11 shows the arrangement of these buildings.

The high bay section, or transfer section, is $7.3 \times 22.6 \mathrm{~m}(24 \times 74 \mathrm{ft})$ with a $9 \mathrm{~m}$ (30 ft) high ceiling. It was used to load and off-load fuel elements to and from rail cars. The high ceiling was necessary to provide clearance for operation of a 30 ton crane. It has a $4.6 \times 5.5 \mathrm{~m}(15 \times 18 \mathrm{ft})$ opening for railroad access, and the rails extend $16.5 \mathrm{~m}(54 \mathrm{ft})$ into the building. The original 30 ton crane and associated motors have been removed, but the crane rails are still in place over the railroad unloading area. The interior height at this

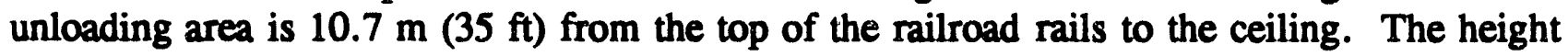

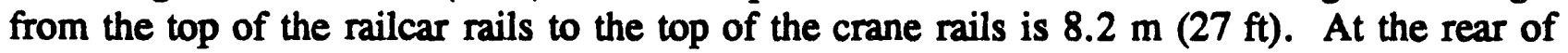
the railroad cut, are two transfer pits approximately $9 \mathrm{~m}(30 \mathrm{ft})$ deep. There are walkways on each side of the unloading area which provided access to the railcars during loading and unloading. The height from the walkways to the ceiling is $8.5 \mathrm{~m}(28 \mathrm{ft})$.

The low roof section of each building was used as a storage basin for the irradiated

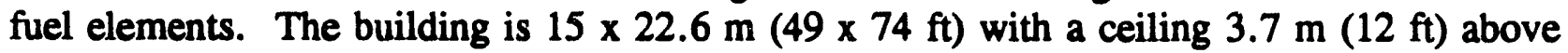
grade. The bottom of the basin extends $5.5 \mathrm{~m}(18 \mathrm{ft})$ below grade. It has a $5 \mathrm{~cm}(2 \mathrm{in}$.) wood plank floor, level with the walkways in the high roof section. This floor is $6 \mathrm{~m}(20 \mathrm{ft})$

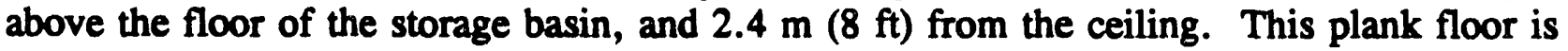

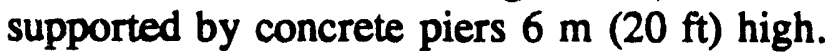

The heater room is adjacent to the low roof section and centered in relation to it. It is

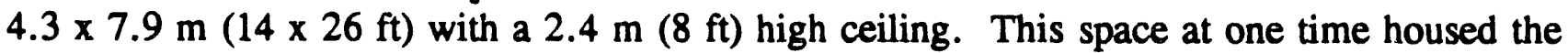
heaters and controls for preventing the water from freezing during winter months.

These buildings were constructed for the purpose of storing irradiated fuel from the reactors. Fuel elements were received from the 100 Area in buckets that held approximately 105 fuel elements, weighing about $383 \mathrm{~kg}(845 \mathrm{lb})$. These buckets were shielded in lead casks weighing about 17 tons. The buckets were loaded into casks, and three casks were carried by each well car. The casks were covered with water, and vented with pipes through which the water flowed. This prevented the irradiated fuel elements from heating to a point where the jackets would be damaged.

Once at the 212 Buildings, irradiated fuel elements were stored in the basins for about 40 to 60 days (Ballinger and Hall 1989). Water continuously flowed through the basin to prevent localized hot spots. The cooling time was used to reduce the radioactivity of gaseous fission products (primarily iodine) by allowing for radioactive decay of short-lived radionuclides before the fuel was sent to the reprocessing plants in the 200 Areas. 
Storage in these interim facilities was found to be an unnecessary operation, and after 1952, the buildings were no longer used to store irradiated fuel. The irradiated fuel elements were stored in the reactor basins for the specified cooling time, and then transported by rail directly to the separations areas. All of the electrical service to the 212 Buildings has been discontinued, and all of the equipment has been removed. Figure 2-11 shows the general arrangement of the storage facility buildings.

2.3.1.1.2 212-N Building. The 212-N Building, also known as the 212-N Storage Facility, was operational from 1944 to 1952 . During this time, the building provided underwater storage of irradiated fuel rods. Overflow water from the storage basin flowed to the 216-N-1 Pond. Cleanout waste from the storage basin was disposed of in the 216-N-2 and 216-N-3 Trenches. Electrical service was discontinued and the railroad tracks and equipment at the 212-N Building were removed when the facility was shut down in June, 1952.

Beginning in 1970, the 212-N and 212-R Buildings were used to store several wooden boxes containing hoods and equipment used for the fabrication of fuels for the Plutonium Recycle Test Reactor (PRTR). The boxes were stored from 1970 until 1972, at which time some were transferred to other Hanford sites and the rest were moved to their present storage location in the 212-N Building. The remaining boxes are contaminated with an estimated $40 \mathrm{~g}$ of plutonium. The total waste volume is $2,332 \mathrm{~m}^{3}\left(7,651 \mathrm{ft}^{3}\right)$. Currently the $212-\mathrm{N}$ Building contains 15 boxes which are stored in the high bay portion. They have been completely covered by a mound of vermiculite. The high bay section has been sealed shut by removing the wooden doors and welding steel plates to the metal door frames. The remainder of the building is unused.

2.3.1.1.3 212-P Building. The 212-P Building, also known as the 212-P Storage Facility, was operational from 1944 to 1952 . During this time, the building provided underwater storage of irradiated fuel rods. Overflow water from the storage basin flowed to the 216-N-4 Pond. Cleanout waste from the storage basin was disposed of in the 216-N-5 Trench. Electrical service was discontinued and the railroad tracks and equipment at the 212-P Building were removed when the facility was shut down in June 1952.

Since 1982, the 212-P Building has been used by Hanford electricians for transformer maintenance and as a polychlorinated biphenyl (PCB) temporary storage area. The WIDS reports that this unit has held nonradioactive PCBs and PCB-contaminated waste in temporary storage for up to 9 months. Radioactively contaminated PCBs, which were stored in this building, were moved to the central waste complex and are no longer present. Waste types include $854 \mathrm{~kg}$ of oil with less than $50 \mathrm{ppm}$ of PCB contamination; 1,348 $\mathrm{kg}$ of oil with greater than 50 ppm PCBs; 703 of PCB-contaminated lighting ballasts, overpacked; $1,159 \mathrm{~kg}$ of oil with greater than $500 \mathrm{ppm}$ PCBs; 7 sealed transformers with less than 30 ppm PCB-contaminated oil; 2 electron microscope power supplies with greater than 50 ppm PCB-contaminated oil; and $42 \mathrm{~kg}$ of regulated solvents with concentrations of more 
than 500 ppm PCB. Drained items, as allowed under the Toxic Substance Control Act (TSCA), are occasionally stored on a Waste Staging Containment Area located at the southwest corner of the building.

2.3.1.1.4 212-R Building. The 212-R Building, also known as the 212-R Storage Facility, was operational from 1944 to 1952 . During this time, the building provided underwater storage of irradiated fuel rods. Overflow water from the storage basin flowed to the 216-N-6 Pond. Cleanout waste from the storage basin was disposed of in the 216-N-7 Trench. The fuel storage operation was shut down in June, 1952 and put into laid away status. Currently, because the $212-\mathrm{R}$ Building is in laid-away status, it could theoretically be reactivated for its original purpose within six months. The six-month reactivation period is no longer possible, however, because of regulatory permitting and notification requirements which must be met prior to restart. These requirements were not anticipated in the original six-month restart period and would significantly increase the restart period beyond the originally-planned time period.

Beginning in 1970, the 212-R Building was used to store several wooden boxes containing hoods and equipment used for the fabrication of fuels for the Plutonium Recycle Test Reactor (PRTR). The boxes were stored from 1970 until 1972, at which time some were transferred to other Hanford sites and the rest were moved to their present storage location in the 212-N Building. From the summer of 1982 to the fall of 1986 , the $212-\mathrm{R}$ Building was used for the maintenance, decontamination, and repair of radiologically contaminated railroad equipment. Two contaminated railroad cask cars and two contaminated locomotives are stored immediately south of the building in a surface contamination radiation zone. Two well pump houses are located about $25 \mathrm{~m}(82 \mathrm{ft})$ east of the building.

2.3.1.1.5 Well House No. 1. Two well pump houses are located approximately $25 \mathrm{~m}$ (82 ft) east of the 212-R Building. Well House No. 1 is the southernmost of the two. It is approximately $4.3 \times 3.5 \mathrm{~m}(14 \times 11 \mathrm{ft})$ in size. The electrical connections and equipment have been removed. The well in Well House No. 1 (6-55-60A) was completed in December

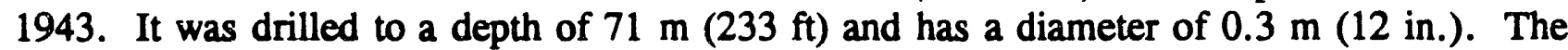
screened interval is from 58 to $70 \mathrm{~m}$ (190 to $230 \mathrm{ft}$ ) (McGhan 1989). Abandonment of this well will consist of backfilling with concrete, grout, puddled-clay, or bentonite in compliance with Washington Administrative Code (WAC) 173-160. The geology of the area around the well is described in Section 3.0.

2.3.1.1.6 Well House No. 2. Well House No. 2 is the northernmost well pump house east of the 212-R Building. It was constructed identically to Well House No. 1 and is approximately $4.3 \times 3.5 \mathrm{~m}(14 \times 11 \mathrm{ft})$ in size. The electrical connections and equipment have been removed. The well in Well House No. 2 (6-55-60B) was completed in July 1944. It was drilled to a depth of $88 \mathrm{~m}(288 \mathrm{ft})$ and has a diameter of $0.66 \mathrm{~m}(24 \mathrm{in}$.). The screened interval is from 70 to $87 \mathrm{~m} \mathrm{(230} \mathrm{to} 285 \mathrm{ft}$ ) (McGhan 1989). Abandonment of this well will consist of backfilling with concrete, grout, puddled-clay, or bentonite in compliance with WAC 173-160. The geology of the area around the well is described in Section 3.0. 
An area approximately $3 \times 3 \mathrm{~m}(10 \times 10 \mathrm{ft})$ west of the well house is delimited by a light weight chain barrier and marked as a zone of underground radioactive materials. Twis valve boxes associated with the well house are within the chained area.

\subsubsection{Waste Management Unit Buildings}

2.3.1.2.1 212-P Hazardous Waste Staging Area. A Hazardous Waste Staging Area for PCB-contaminated transformer oil is located at the southeast corner of the 212-P Building. The site, which began operation in 1982, consists of several concrete pads with a combined size of approximately $24 \times 6 \mathrm{~m}(80 \times 20 \mathrm{ft})$. The staging area is used for the temporary storage of drums containing transformer oil with PCB concentrations of less than $50 \mathrm{ppm}$. It is also used for storage of drums resulting from pump-flush operations. A $1515 \mathrm{~L}$ (400 gal) above-ground tank used to store transformer oil is located at the east end of the hazardous waste staging area and sits on a support structure approximately $2 \mathrm{~m}(6.5 \mathrm{ft})$ above the ground.

\subsubsection{Tanks and Vaults}

There is one tank present in the 200 North Aggregate Area. It is an unnumbered tank and will be referred to as the 212-P Transformer Oil Tank. The location of the tank is shown on Figure 2-2.

2.3.2.1 212-P Transformer Oil Tank. The 212-P Transformer Oil Tank is an aboveground welded steel tank located southeast of the 212-P Building in the hazardous

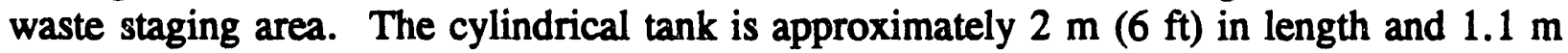
$(3.5 \mathrm{ft})$ in diameter and holds about $1515 \mathrm{~L} \mathrm{(400} \mathrm{gal).} \mathrm{A} \mathrm{covered} \mathrm{access} \mathrm{hole} \mathrm{is} \mathrm{located} \mathrm{at}$ the top of the tank and is $0.45 \mathrm{~m}$ (18 in.) in diameter. The tank sits on a support structure and is approximately $2 \mathrm{~m}(6.5 \mathrm{ft})$ above ground level. Currently the tank is used for the temporary storage of transformer oils containing PCBs. The tank was brought to the Hanford Site for this purpose and has no prior Hanford history.

\subsubsection{Cribs and Drains}

Cribs and drains are waste management units that were designed to percolate wastewater into the ground without exposing it to the open air. There are no cribs or drains within the 200 North Aggregate Area.

\subsubsection{Reverse Wells}

Reverse wells are injection wells drilled to a depth somewhat abuve the water table. They were used to dispose of liquid wastes in the early years of Hanford operations. There are no reverse wells within the 200 North Aggregate Area. 


\subsubsection{Ponds, Ditches, and Trenches}

The ponds and trenches in the 200 North Aggregate Area were designed to percolate liquid waste into the ground. The ponds in the 200 North Aggregate Area include the 216- $\mathrm{N}-1$ Pond, the 216-N-4 Pond, and the 216-N-6 Pond. Each pond is associated with one of the three storage facilities. Four trenches are contained within the 200 North Aggregate Area. Two trenches are associated with the 212-N Building, one trench is associated with the 212-P Building, and one trench is associated with the 212-R Building. The trenches were excavations that were opened for a short time (started-up, filled in, and deactivated in less than a two-month period of time) to dispose of the liquid waste and sludge produced in each representative building. Ditches are usually open excavations that convey liquid effluent between facilities and waste management units. There are no ditches contained within the 200 North Aggregate Area. The locations of the ponds and trenches in the 200 North Aggregate Area are shown on Figure 2-3. Figure 2-10 shows the configuration of a typical disposal trench.

2.3.5.1 216-N-1 Pond. The 216-N-1 Pond is an inactive liquid waste management unit located approximately $274 \mathrm{~m}(900 \mathrm{ft})$ south of the $212-\mathrm{N}$ Storage Facility. It received $946,000,000 \mathrm{~L}(250,000,000 \mathrm{gal})$ of low activity basin overflow water from the $212-\mathrm{N}$ Storage Facility between 1944 and 1952.

The pond was approximately $152 \times 30 \times 1 \mathrm{~m}$ deep $(500 \times 100 \times 3 \mathrm{ft})$. It was deactivated in June 1952 and backfilled with 0.6 to $1.8 \mathrm{~m} \mathrm{(2} \mathrm{to} 6 \mathrm{ft}$ ) of clean soil. It cannot be documented if inlet valving to the 212-N Storage Basin was locked when the 216-N-1 Pond was deactivated, but it is likely that this was done based on typical practices at similar waste management units. Currently, no chains or barriers are present at this site and it is not marked as a radiation zone. It is possible that underground contamination exists at this site based on its similar operational history to the 216-N-4 and 216-N-6 Ponds which are known to be contaminated. A permanent concrete monument marks the north end of the pond site.

2.3.5.2 216- $\mathrm{N}-4$ Pond. The 216-N-4 Pond is an inactive liquid waste management unit located approximately $274 \mathrm{~m}$ (900 ft) south of the 212-P Storage Facility. It received $946,000,000 \mathrm{~L}(250,000,000 \mathrm{gal})$ of low activity basin overflow water from the 212-P Storage Facility between 1944 and 1952.

The pond was approximately $152 \times 60 \times 1 \mathrm{~m}$ deep ( $500 \times 200 \times 3 \mathrm{ft})$. It was deactivated in June 1952 by closing and locking the inlet valving to the 212-P Basin. The unit was backfilled with 0.6 to $1.8 \mathrm{~m}$ ( 2 to $6 \mathrm{ft}$ ) of clean soil. The site is marked by underground radioactive material warning signs, but no chains or barriers are present. A permanent concrete monument marks the north end of the pond site. 
2.3.5.3 216-N-6 Pond. The 216-N-6 Pond is an inactive liquid waste management unit located approximately $274 \mathrm{~m}(900 \mathrm{ft})$ south of the 212-R Storage Facility. It received $946,000,000 \mathrm{~L}(250,000,000 \mathrm{gal})$ of low activity basin overflow water from the $212-\mathrm{R}$ Storage Facility between 1944 and 1952.

The pond was approximately $152 \times 46 \times 1 \mathrm{~m}$ deep $(500 \times 150 \times 3 \mathrm{ft})$. It was deactivated in June 1952 by closing and locking the inlet valving to the $212-\mathrm{R}$ Basin. The unit was backfilled with 0.6 to $1.8 \mathrm{~m}(2$ to $6 \mathrm{ft})$ of clean soil. The site is marked by underground radioactive material warning signs, but no chains or barriers are present. A permanent concrete monument marks the north end of the pond site.

2.3.5.4 216-N-2 Trench. The 216-N-2 Trench is an inactive waste management unit located approximately 15 to $30 \mathrm{~m}(50$ to $100 \mathrm{ft}$ ) northwest of the $212-\mathrm{N}$ Building. It received 7,500,000 $\mathrm{L}(1,980,000 \mathrm{gal})$ of low activity water and sludge when the 212-N basin was drained to be used for special tests in March 1947. There is no known documentation for these special tests.

The trench was approximately $15 \times 3 \times 2 \mathrm{~m}$ deep $(50 \times 10 \times 7 \mathrm{ft})$. It was deactivated in April 1947 by backfilling and removing the aboveground piping. Based on typical practices, the piping was probably placed into the trench before it was backfilled.

The waste management unit is surrounded by a light weight chain barrier and underground radioactive material warning signs. This trench is beside and parallel to the 216-N-3 Trench and the single barrier encloses both trenches. A permanent concrete monument identifies the unit.

2.3.5.5 216-N-3 Trench. The 216-N-3 Trench is an inactive waste management unit located approximately 15 to $30 \mathrm{~m}(50$ to $100 \mathrm{ft}$ ) northwest of the $212-\mathrm{N}$ Building. It received $7,600,000 \mathrm{~L}(2,000,000 \mathrm{gal})$ of low activity water and sludge when the $212-\mathrm{N}$ basin was deactivated and drained in 1952.

The trench was about $15 \times 6 \times 3 \mathrm{~m}$ deep $(50 \times 20 \times 6 \mathrm{ft})$. It was deactivated in June 1952 by backfilling and removing the above-ground piping. Based on typical practices, the piping was probably placed into the trench before it was backfilled.

The waste management unit is surrounded by a light weight chain barrier and underground radioactive material warning signs. This trench is beside and parallel to the 216-N-2 Trench and the single barrier encloses both trenches. A permanent concrete monument identifies the unit.

2.3.5.6 216-N-5 Trench. The 216-N-5 Trench is an inactive waste management unit located approximately $30 \mathrm{~m}(100 \mathrm{ft})$ northwest of the 212-P Building. It received $7,600,000 \mathrm{~L}(2,000,000 \mathrm{gal})$ of low activity water and sludge when the 212-P Basin was deactivated and drained in 1952. 
The trench was about $24 \times 4.5 \times 2 \mathrm{~m}$ deep $(80 \times 15 \times 6 \mathrm{ft})$. It was deactivated in June 1952 by backfilling and removing the above-ground piping. Based on typical practices, the piping was probably placed into the trench before it was backfilled.

The waste management unit is surrounded by a light weight chain barrier and underground radioactive material warning signs. A permanent concrete monument identifies the unit.

2.3.5.7 216-N-7 Trench. The 216-N-7 Trench is an inactive waste management unit located approximately $30 \mathrm{~m}(100 \mathrm{ft})$ northwest of the $212-\mathrm{R}$ Building. It received $7,600,000 \mathrm{~L}(2,000,000 \mathrm{gal})$ of low activity water and sludge when the 212-R Basin was deactivated and drained in 1952.

The trench was about $24 \times 4.5 \times 2 \mathrm{~m}$ deep $(80 \times 15 \times 6 \mathrm{ft})$. It was deactivated in June 1952 by backfilling and removing the above ground piping. Based on typical practices, the piping was probably placed into the trench before it was backfilled.

The waste management unit is surrounded by a light weight chain barrier and underground radioactive material warning signs. A permanent concrete monument identifies the unit.

\subsubsection{Septic Tanks and Associated Drain Fields}

The 212 Buildings were once the center of a security area which included security fences, guard towers and a gate house. Each gate house had a septic tank and drain field. Each tank appears to have been filled with soil. The locations of the septic tanks and drain fields in the 200 North Aggregate Area are shown on Figure 2-4.

2.3.6.1 2607-N Septic Tank and Drain Field. The 2607-N Septic Tank was located $6 \mathrm{~m}$ (20 ft) south of the 2743-N Guard House at the $212-\mathrm{N}$ Building. It was a $908 \mathrm{~L}$ (240 gal) tank and was abandoned in 1952. The drain field is approximately $365 \mathrm{~m}^{2}\left(1,200 \mathrm{ft}^{2}\right)$ in area and lies south of the septic tank system.

2.3.6.2 2607-P Septic Tank and Drain Field. The 2607-P Septic Tank was located $6 \mathrm{~m}$ (20 ft) south of the 2743-P Guard House at the 212-P Building. It was a $908 \mathrm{~L}$ (240 gal) tank and was abandoned in 1952. The drain field is approximately $365 \mathrm{~m}^{2}\left(1,200 \mathrm{ft}^{2}\right)$ in area and lies south of the septic tank system.

2.3.6.3 2607-R Septic Tank and Drain Field. The 2607-R Septic Tank was located $6 \mathrm{~m}$ (20 ft) south of the 2743-R Guard House at the 212-R Building. It was a $908 \mathrm{~L}$ (240 gal) tank and was abandoned in 1952 . The drain field is approximately $365 \mathrm{~m}^{2}\left(1,200 \mathrm{ft}^{2}\right)$ in area and lies south of the septic tank system. 


\subsubsection{Transfer Facilities, Diversion Boxes, and Pipelines}

Transfer facilities connect major processing facilities with each other and with the various waste disposal and storage facilities. Diversion boxes are concrete boxes with transfer lines leading into, and out of, the sides. They contain jumpers which allow different lines to be connected, changing the routing of wastes. Pipelines connect waste generating facilities with waste management units. In the 200 North Aggregate Area there are no diversion boxes; however, there are three main pipelines which carried waste to the ponds from each of the irradiated fuel storage basins. The location of the pipelines is shown on Figure 2-5.

2.3.7.1 212-N to 216-N-1 Pipeline. The 212-N Building was connected to the 216-N-1 Pond by an underground $0.46 \mathrm{~m}$ (18 in.) vitrified clay pipe. There are two access manholes along the line. The first is located approximately $3 \mathrm{~m}(10 \mathrm{ft})$ south of the $212-\mathrm{N}$ Building. A second manhole is located about halfway between the 212-N Building and the 216-N-1 Pond. Each manhole is delimited by a light weight chain barrier and underground radioactive material warning signs. The pipeline right-of-way is not posted as a zone of underground radioactive material.

2.3.7.2 212-P to 216-N-4 Pipeline. The 212-P Building was connected to the 216-N-4 Pond by an underground $0.46 \mathrm{~m}$ (18 in.) vitrified clay pipe. There are two access manholes

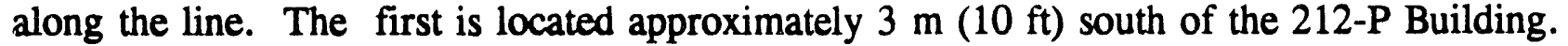
A second manhole is located about halfway between the 212-P Building and the 216-N-4 Pond. Each manhole is delimited by a light weight chain barrier and underground radioactive material warning signs. The pipeline right-of-way is not posted as a zone of underground radioactive material.

2.3.7.3 212-R to 216-N-6 Pipeline. The 212-R Building was connected to the $216-\mathrm{N}-6$ Pond by an underground $0.46 \mathrm{~m}$ (18 in.) vitrified clay pipe. There are two access manholes along the line. The first is located approximately $3 \mathrm{~m}(10 \mathrm{ft})$ south of the 212-R Building. A second manhole is located about halfway between the 212-R Building and the 216-N-6 Pond. Each manhole is delimited by a light weight chain barrier and underground radioactive material warning signs. The pipeline right-of-way is not posted as a zone of underground radioactive material.

\subsubsection{Basins}

Retention basins are concrete-lined settling ponds that receive liquids before they overflow into ditches. There are no retention basins within the 200 North Aggregate Area. 


\subsubsection{Burial Sites}

Several pits approximately $12 \mathrm{~m} \mathrm{(40} \mathrm{ft)} \mathrm{in} \mathrm{diameter} \mathrm{have} \mathrm{been} \mathrm{observed} \mathrm{on} \mathrm{the} \mathrm{site.}$ They are located approximately 60 to $90 \mathrm{~m}$ (200 to $300 \mathrm{ft}$ ) southwest of the 212-P Building. Although no formal burial sites are present in the 200 North Aggregate Area, it appears that these pits were used to dispose of electrical conduit and mechanical waste which was visible during a site visit in May 1992. A general outline of the location of the pits is shown on Figure 2-6.

\subsubsection{Unplanned Releases}

There are two unplanned release sites in the 200 North Aggregate Area that contain radiation warning signs, but are not associated with any waste management units. Although these sites are unnumbered, they will be referred to in this AAMS as unplanned releases. Figure 2-7 shows the location of the unplanned releases. A brief discussion of each site's history is included in Table 2-3.

2.3.10.1 Unplanned Release near 212-R Railroad Spur. Immediately south of the 212-R

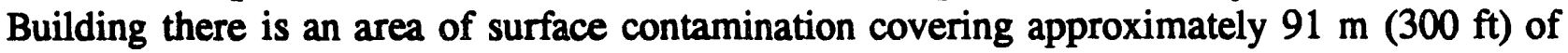
the railroad track extending from the building. Two contaminated railroad cask cars and two contaminated locomotives are located on the track. A light chain barrier surrounds the area and surface contamination signs are present.

2.3.10.2 Unplanned Release near Well Pump House No. 2. There is a contaminated area adjacent to the northern well pump house (Well House No. 2) located east of the 212-R

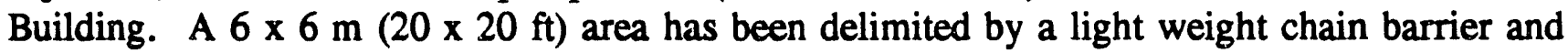
underground radioactive material warning signs. Two valve boxes associated with the well water supply system are located within the barrier.

\subsection{WASTE GENERATING PROCESSES}

The facilities of the 200 North Aggregate Area were built to provide temporary storage of irradiated fuel elements produced in the plutonium reactors in the 100 Area. There was relatively little waste generation that occurred, hence the small number of waste management units. However, the water used to store, shield, and cool the fuel was discharged into the ground via ponds. In addition, sediment which collected in the bottom of the storage basins was discharged to trenches following the shutdown of the storage facilities. Figure 2-8 shows the historical timelines for the waste generating processes. Table 2-4 summarizes the available information about the waste streams produced within the aggregate area. Table 2-5 lists radionuclides, organic and inorganic chemicals that may have been disposed of at the 200 North Aggregate Area waste management units. 


\subsubsection{Irradiated Fuel Storage Operations}

Three 200 North Aggregate Area buildings, the 212-N, 212-P, and 212-R Storage Facilities, contained storage basins and transfer facilities for moving buckets of irradiated fuel elements from the 100 Area into and out of the lead casks which were transported in railroad wellcars to the 200 North Aggregate Area. The fuel elements were irradiated in the reactors in the 100 Area and discharged from the reactors directly into water filled basins adjacent to the reactors. The fuel elements were then placed into special "buckets" which were in turn hoisted into the lead casks. Approximately 105 fuel elements, weighing about $384 \mathrm{~kg}(845 \mathrm{lb})$, were placed into each bucket. The buckets were loaded into the leadshielded casks, which weighed about $15,400 \mathrm{~kg}$ (17 tons) and three casks were loaded onto each railroad wellcar for transport to the 200 North Aggregate Area storage facilities. The casks were filled with water and cooled with pipes through which water flowed to prevent overheating and localized hot spots in the buckets.

At the 212 Buildings, the casks were lifted out of the wellcars by crane and lowered into a water-filled transfer pit. As the cask was lowered its cover was removed by a ledge at the top of the pit. The cover was moved aside and a yoke was lowered from the overhead crane to pick up each bucket for transfer to the storage basin. When the irradiated fuel was ready to be transferred to the separations processing areas, the transfer procedure was reversed to get the buckets back into the casks and onto the wellcars. The wellcars were transferred to the separations plants by rail where they were again unloaded.

Irradiated fuel elements were stored in the basins for about 40 to 60 days in the early years. Water continuously flowed through the basins to prevent localized hot spots. Two wells, located just east of the 212-R Storage Facility, supplied the water to the storage basins. This water was unfiltered which meant that dissolved and suspended solids in the water had the potential to be exposed to radiation from the fuel elements. Table 2-5 provides a list of radionuclides that this water could have been exposed to. Each storage facility had heating equipment to keep the basin water from freezing. Water overflow from the storage basin in each of the storage facilities basin was transported by an underground pipeline to its associated pond located about $275 \mathrm{~m}(900 \mathrm{ft})$ south of the storage facility.

Each of the three ponds consisted of depressions existing in the natural terrain. Except for an occasional berm no excavation or other effort was made to define or enhance the pond formation. The discharged water dispersed by evaporation and percolation into the soil.

Cooling time, or the time between the discharge of an irradiated fuel element and its processing, was used primarily to reduce the radioactivity of gaseous fission products (primarily iodine) by allowing the radioactive decay of the short-lived radionuclides before the dissolution of the fuel in the separation plants.

The storage of the irradiated fuel elements in the storage facilities in the 200 North Aggregate Area was eventually found to be unnecessary since adequate storage times could be accomplished at the reactor facilities. By 1952, there was no longer a need for the excess 
fuel storage facilities in the 200 North Aggregate Area and the 212-N, 212-P, and 212-R facilities were shut down in June 1952.

The water which flowed through the storage basins in the 200 North Aggregate Area storage basins had the potential to become contaminated through exposure to radiation from the fuel eiements, through particulate contamination from the surface of the fuel elements, and/or by leakage through the aluminum cladding which enclosed the irradiated fuel elez_ents. The radionuclide portion of Table $2-5$ provides a list of those potential contaminants.

Leakage through the aluminum cladding surrounding the fuel element was less likely prior to 1952, before, reactor power levels werc stepped-up to increase production. The most likely means for a cladding failed fuel element to reach the 200 North Aggregate Area may have been through mechanical shock caused by handling.

All the 212 Storage Facilities were shut down in June 1952. As part of the shutdown procedure, the fuel storage basins were drained and cleaned. The water and sediment which was in the storage basins was disposed by pumping to shallow (approximately $2 \mathrm{~m}, 6 \mathrm{ft}$ ) trenches located about $30 \mathrm{~m}(100 \mathrm{ft})$ northwest of wach storage building. The trenches were immediately backfilled after disposal. The basin in the 212-N Building was first drained and cleaned in 1947 , or a special test that is not dicumented (Baldridge 1959). The water and basin sediments frut.1 this first cleanout were placed in the $216-\mathrm{N}-2$ Trench. The $212-\mathrm{N}$ storage basin was drained and cleaned for the shutdown in 1952 and the cleanout wastes were placed in the 216-1 J-3 Trench. The storage basins in the 212-P and 212-R Buildings were cleaned only once, in 1952, and the wastes were placed in the $216-\mathrm{N}-5$ and $216-\mathrm{N}-7$ Trenches, respectively.

Each of the three 200 North Aggregate Area storage facilities was surrounded with a

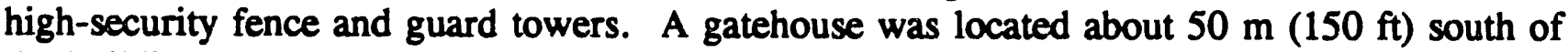
the building. Each gatehouse had a septic tank and drain field south of its location. The fences, guard towers, and gatehouses have been partially removed so that only concrete foundations remain.

\subsubsection{Electrical Maintenance Activities}

Since 1982 the 212-P Storage Facility has been used as an electrical maintenance facility by Hanford electricians and as a temporary storage area for PCBs. Transformers and capacitors requiring servicing have been worked on at this facility. Drained items have been occasionally stored on an asphalt pad at the site. The PCB-contaminated oils are temporarily stored in a small aboveground tank. Other PCB-contaminated wastes are stored in drums in a s.orage facility adjacent to the 212-P Building and inside the 212-P Building. 


\subsubsection{Railroad Car Maintenance Activities}

From the spring of 1982 until the fall of 1986 the 212-R Storage Facility was used as a railroad car maintenance site. Railcars needing brake or wheel bearing maintenance were brought to the site, decontaminated, and repaired. The decontamination was done by wiping the surfaces of the equipment with swabs wetted with a liquid solvent. The decontamination wastes were placei is: bags and transported to solid waste burial sites outside of the 200 North Aggregate Area. Although no longer used as a maintenance site, two locomotive engines and two wellcars (one without wheels) were on the rail spur in front of the 212-R Building in May 1992. They are surrounded by chain and marked as a surface contamination site.

\subsection{INTERACTIONS WITH OTHER AGGREGATE AREAS OR OPERABLE UNITS}

The 200 North Aggregate Area consists of the 200-NO-1 Operable Unit. This aggregate area is isolated from any other aggregate area or operable unit. It is located $2 \mathrm{~km}$ $(1.2 \mathrm{mi})$ northwest of the 200 East separations area and a similar distance northeast of the 200 West separations area.

From 1944 until 1952 the three Storage Facilities provided water-cooled storage for irradiated fuel elements from the 100 Area reactors to the north. After typically 40 to 60 days storage the fuel elements were moved to eithe: or the separations areas.

Transportation was provided by special railroad flatcars called wellcars which kept the fuel elements continually suspended in water. Rail connections were the only mission link to other areas.

Other than providing this service there are no other documented interactions with other specific areas of the Hanford Site. The water for the storage basins came from two wells located within the 200-NO-1 Operable Unit and all waste disposal occurred within the operable unit.

\subsection{INTERACTION WITH RESOURCE CONSERVATION AND RECOVERY ACT PROGRAM}

Appendices B and C of the Tri-Party Agreement (Ecology et al. 1990) list RCRA TSD facilities on the Hanford Site that have entered interim status and, thus, will require final permitting or closure. Within the geographical extent of the 200 North Aggregate Area there are no facilities that fall within this program.

The 212-P Storage Building is currently being used as a hazardous waste storage area for collection of PCB contaminated oil from transformers and capacitors. As a temporary hazardous waste accumulator, this building is not required to have a RCRA Part B permit. 
Waste handling activities at this site are regulated by the TSCA. Waste shipments are made quarterly or as necessary to comply with the TSCA nine-month storage limitation.

\subsection{INTERACTIONS WITH OTHER HANFORD PROGRAMS}

There are several other ongoing programs that may affect buildings and waste management units in the 200 North Aggregate Area. These programs are the Environmental Restoration Program, the Waste Management Program, the Radiation Area Remedial Action (RARA) Program, and the Single-Shell Tank Closure Program. The Environmental Restoration Program is responsible for the Decommissioning and RCRA Closure Program.

The Decommissioning and RCRA Closure Program is responsible for the safe and costeffective surveillance, maintenance, and decommissioning of surplus facilities at the Hanford Site. The three 200 North Aggregate Area Storage Facilities, 212-N, 212-P, and 212-R, fall within this category. The $212-\mathrm{R}$ facility was placed on laid-away status in 1952 with the potetntial that it could be reactivated for its original purpose within six months. The sixmonth reactivation period is no longer possible because of regulatory permitting and notification requirements which must be met prior to restart. These requirements were not anticipated in the original six-month restart period and would significantly increase the restart period beyond the originally planned time period.

The RARA Program is conducted as part of the Environmental Restoration Program. The RARA is responsible for the surveillance, maintenance, decontamination, and/or interim stabilization of inactive waste management units at the Hanford Site. A major concern associated with these requirements is the management and control of surface soil contamination.

This program surveys the $216-\mathrm{N}-2,216-\mathrm{N}-3,216-\mathrm{N}-5$, and $216-\mathrm{N}-7$ Trenches and the 216-N-1, 216-N-4 and 216-N-6 Ponds on a semiannual basis. No recent surface contamination has been detected at these sites. One controlled access surface radiation zone in the 200 North Aggregate Area is covered by this program. The controlled area is the surface contamination zone around the engines and railcars on the south side of the 212-R Storage Building. Currently, responsibility for this surface contamination zone has not been determined. It is recommended that this site be evaluated according to the criteria given in Westinghouse Hanford management requirements and procedures (MRP) Section 5.10 (WHC 1991b) to assign responsibility for this site. This procedure is used to determine if the site belongs under the RARA program or another site program. The RARA program also surveys the 216-N-2, 216-N-3, 216-N-5, and 216-N-7 Trenches and the 216-N-4 and 216-N-6 Ponds on a quarterly basis. No recent surface contamination has been detected at these sites. 
DOE/RL-92-17, Rev. 0

The Office of Support Services is responsible for the operation of the 212-P Storage Facility. Since 1982 this unit has stored transformer and capacitor oil with PCB contamination. This facility meets all the TSCA requirements for temporary storage of PCBs. 
DOE/RL-92-17, Rev. 0

Figure 2-1. Location of Plants, Buildings, and Storage Units.

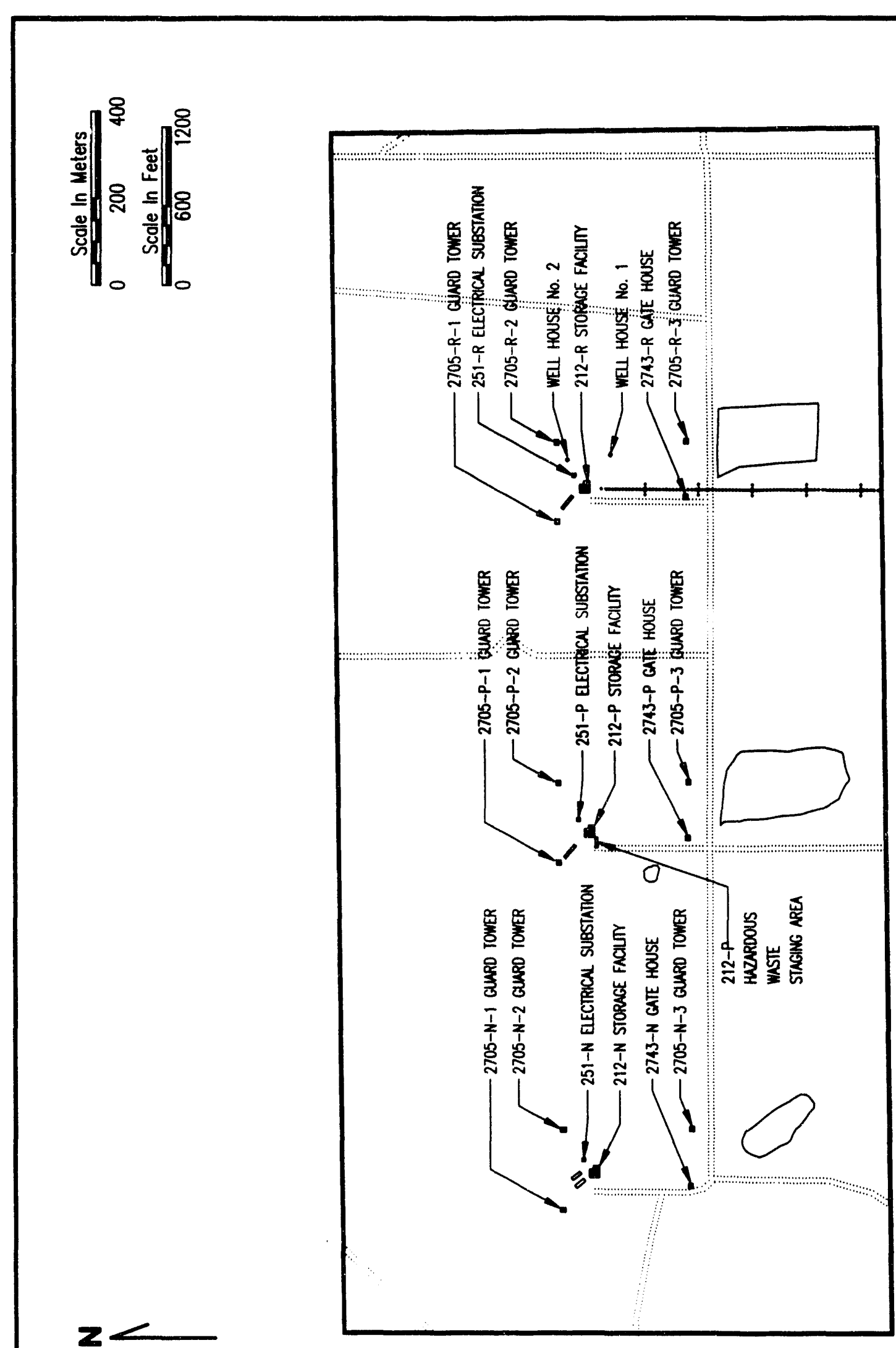


DOE/RL-92-17, Rev. 0

Figure 2-2. Location of Tank and Vaults.

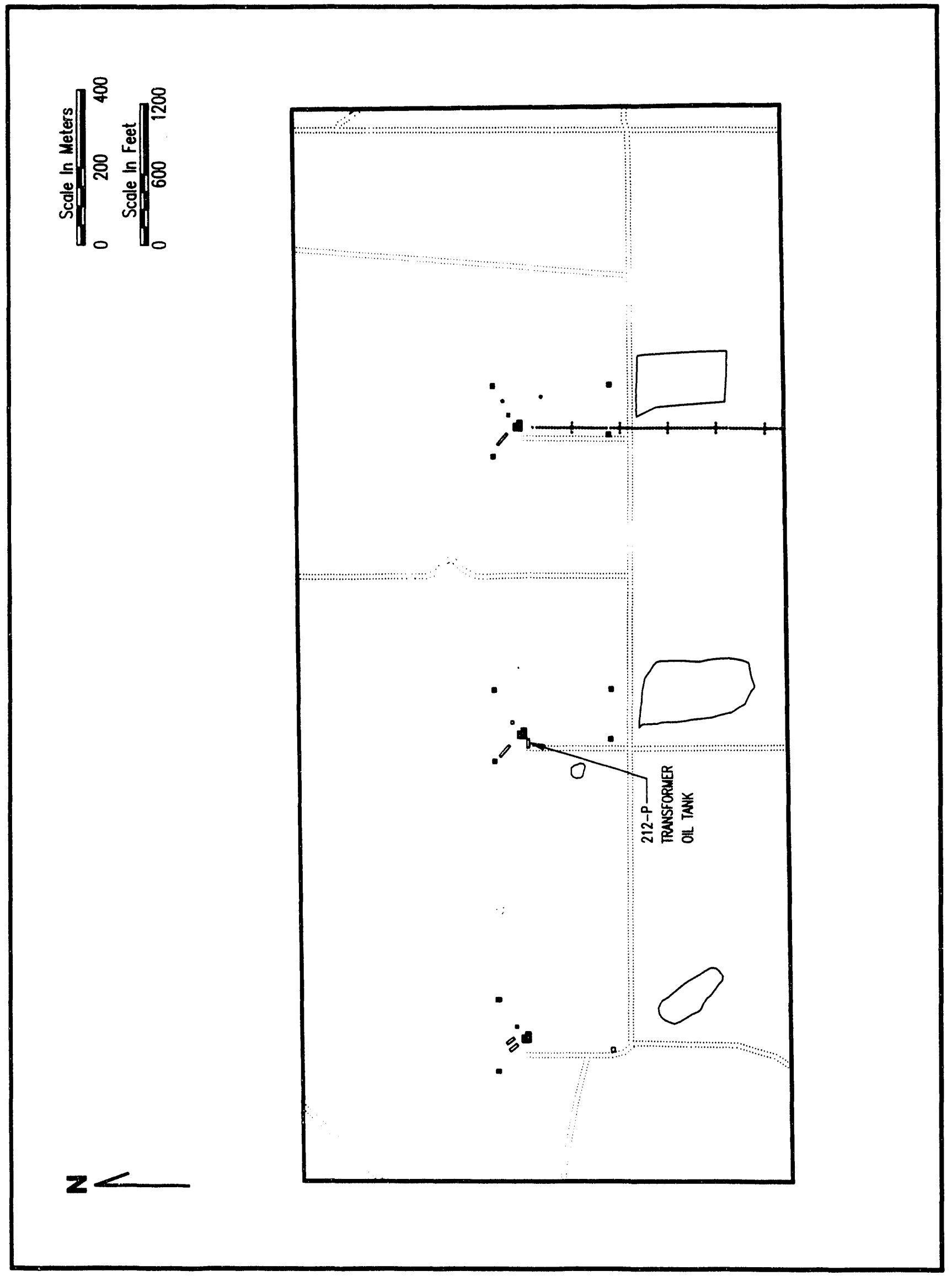


DOE/RL-92-17, Rev. 0

Figure 2-3. Location of Ponds, Ditches, and Trenches.

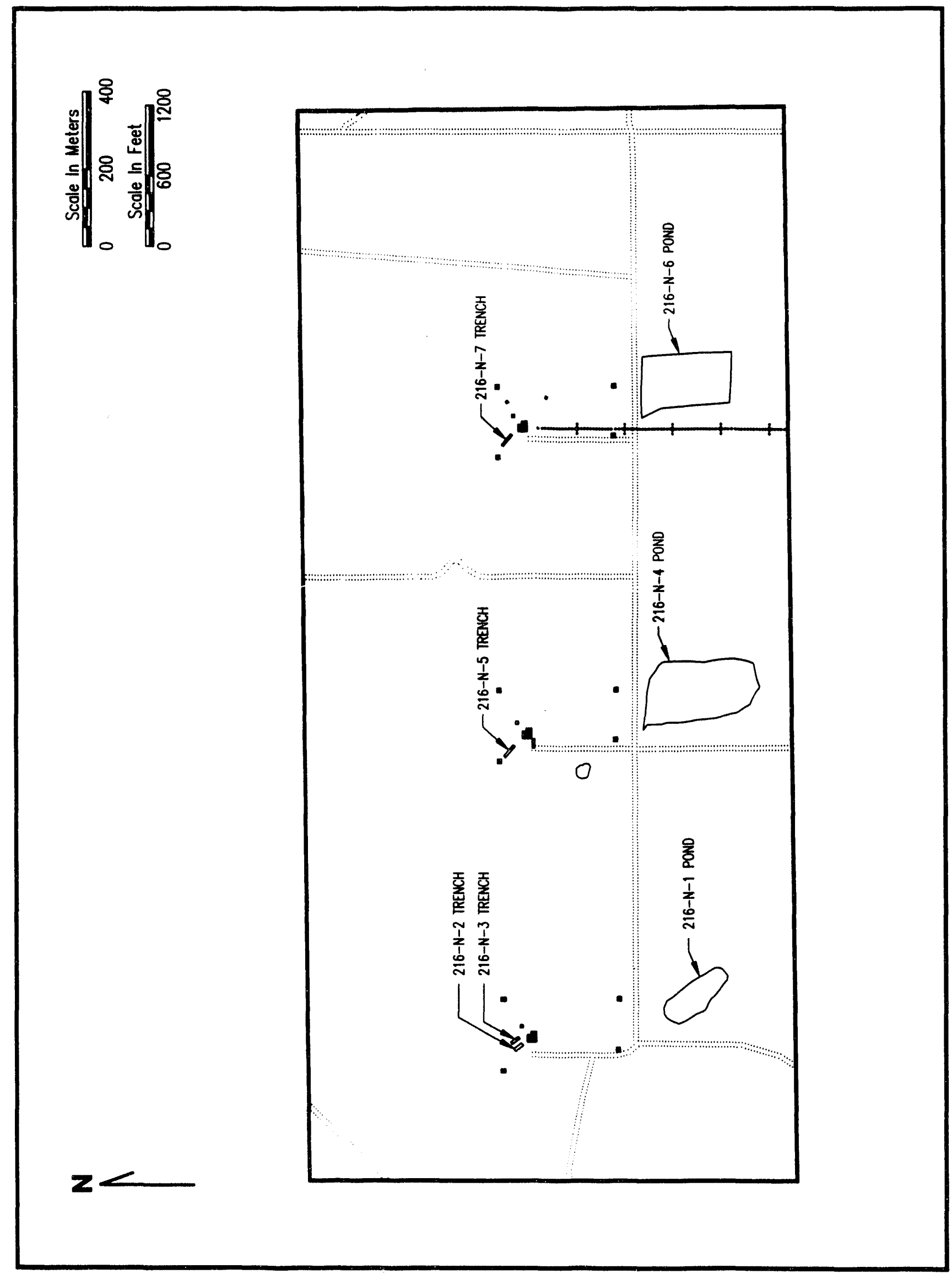


DOE/RL-92-17, Rev. 0

Figure 2-4. Location of Septic Tanks and Associated Drain Fields.

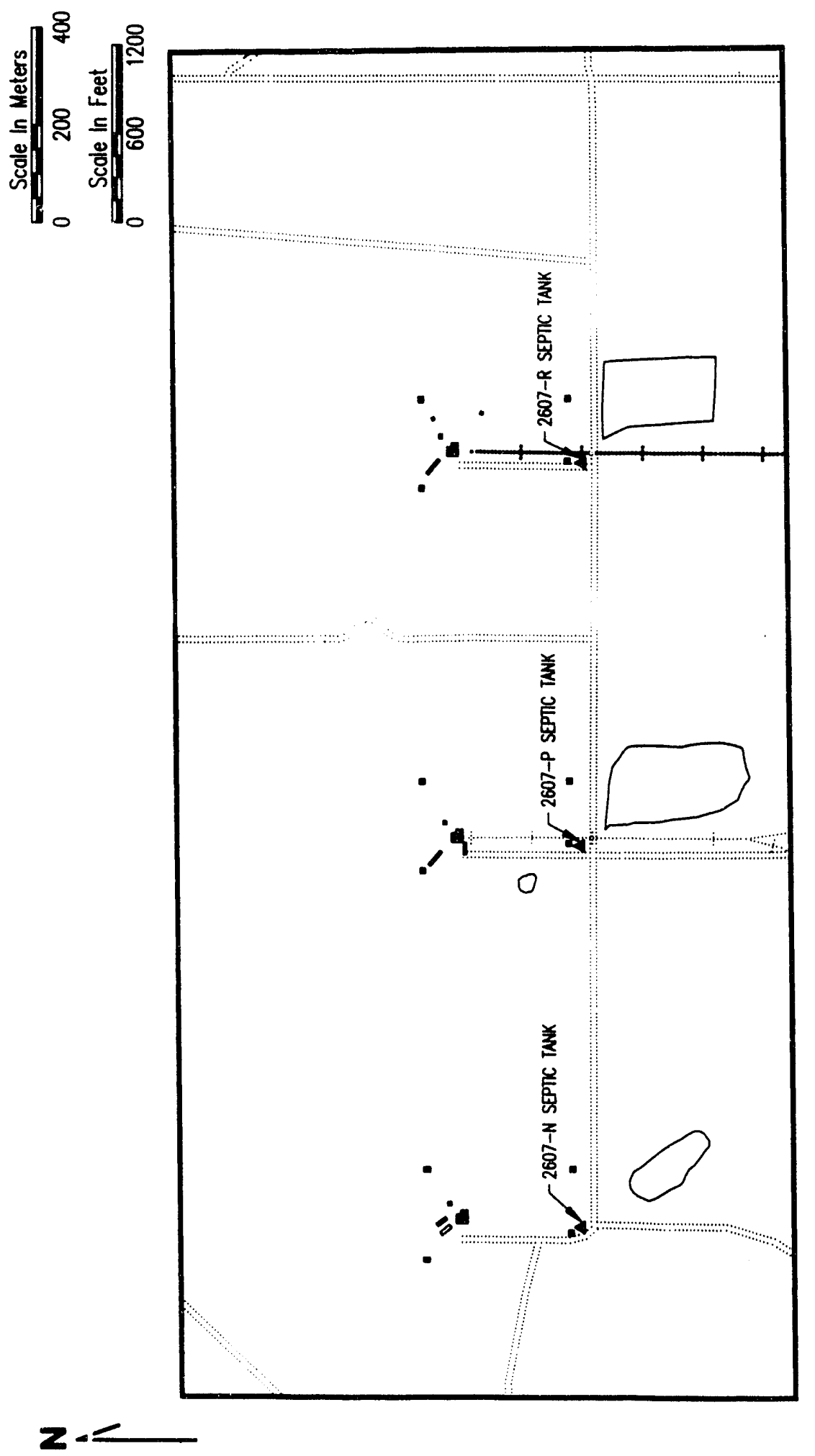


DOE/RL-92-17, Rev. 0

Figure 2-5. Location of Transfer Facilities, Diversion Boxes, and Pipelines.
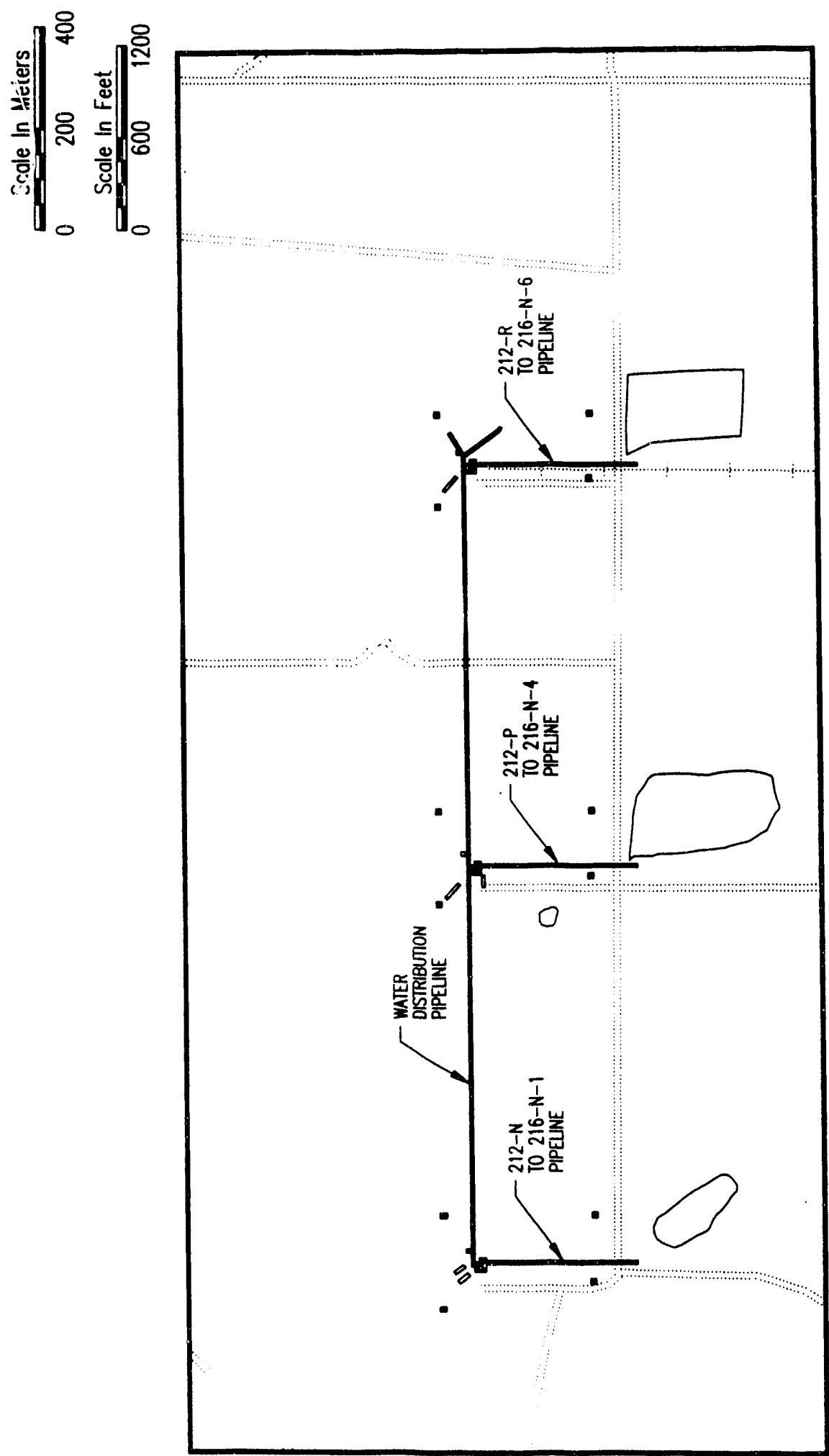
DOE/RL-92-17, Rev. 0

Figure 2-6. Location of Burial Sites.

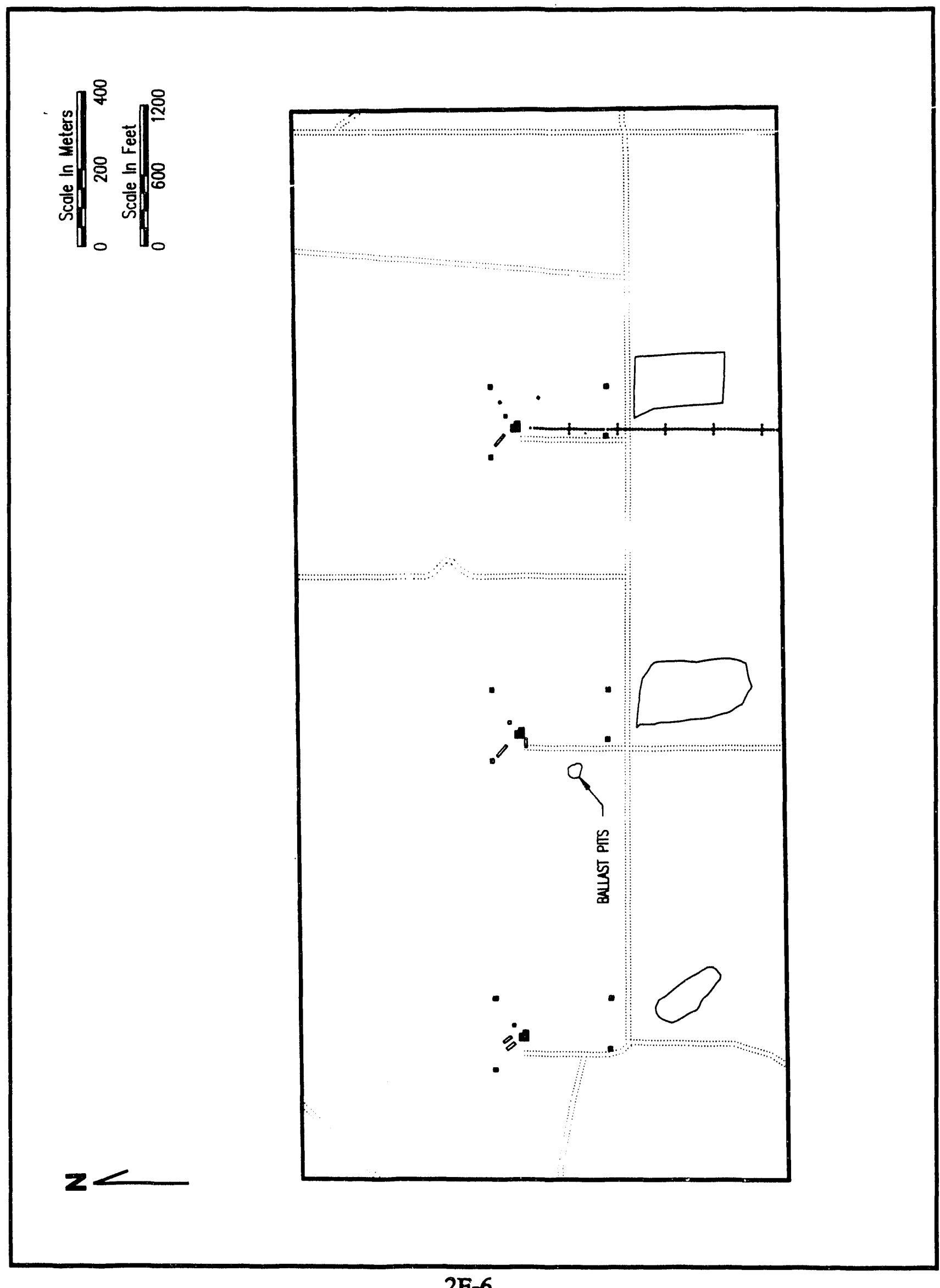


DOE/RL-92-17, Rev. 0

Figure 2-7. Location of Unplanned Releases.
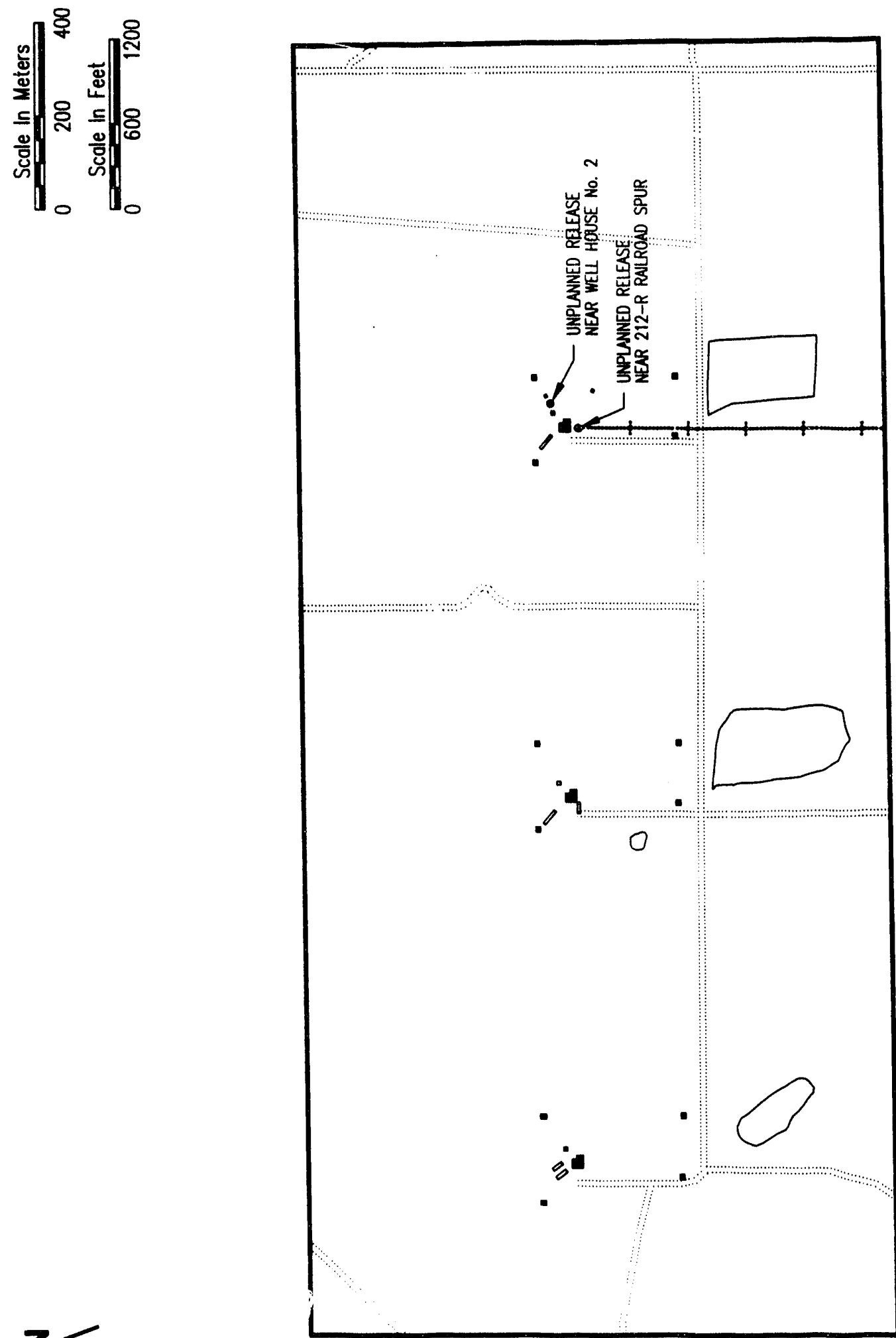
DOE/RL-92-17, Rev. 0

Figure 2-8. Process History of 200 North Aggregate Area.

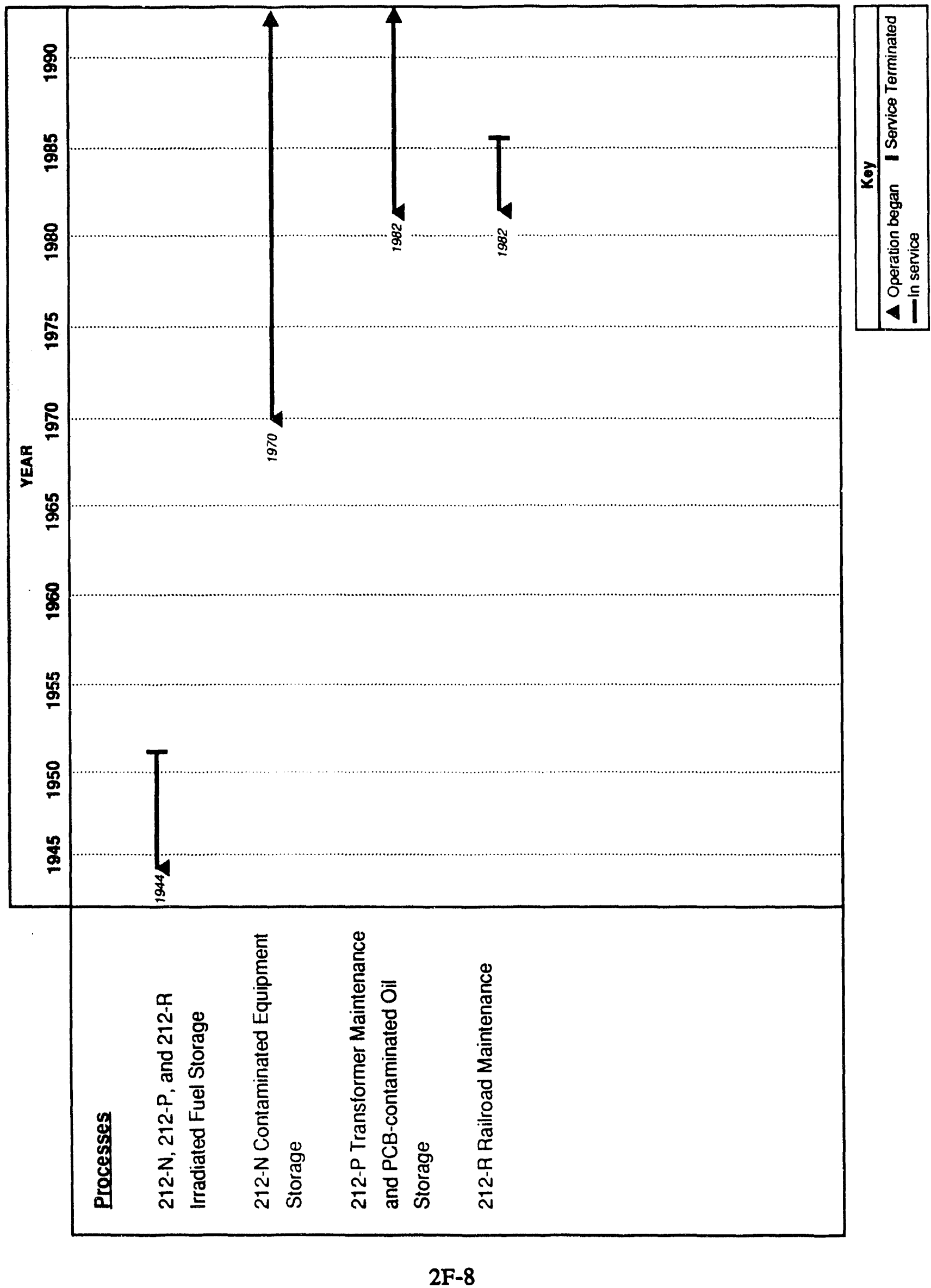


DOE/RL-92-17, Rev. 0

Figure 2-9. Waste Management Unit Operational History. (Page 1 of 2)

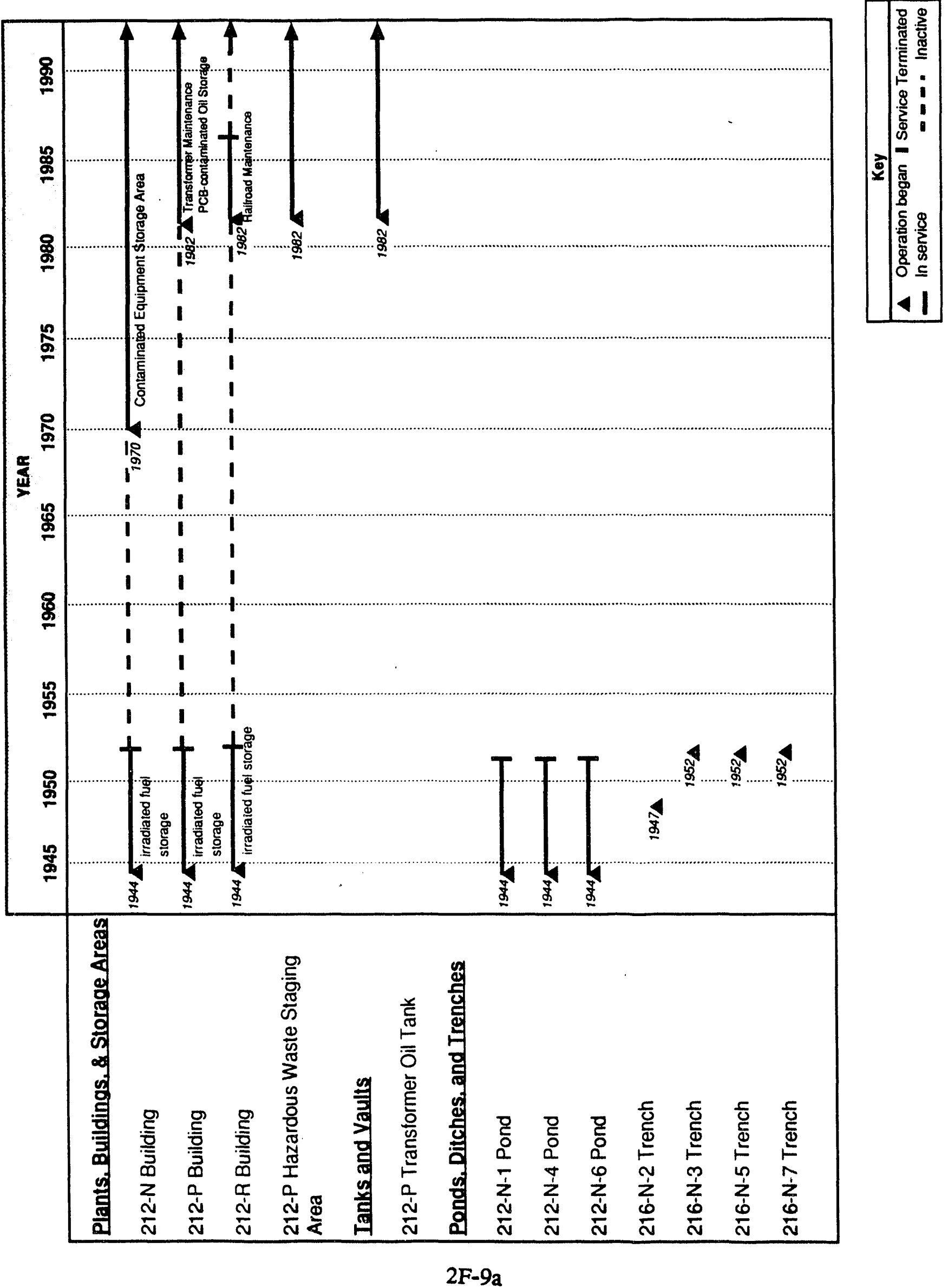


DOE/RL-92-17, Rev. 0

Figure 2-9. Waste Management Unit Operational History. (Page 2 of 2)

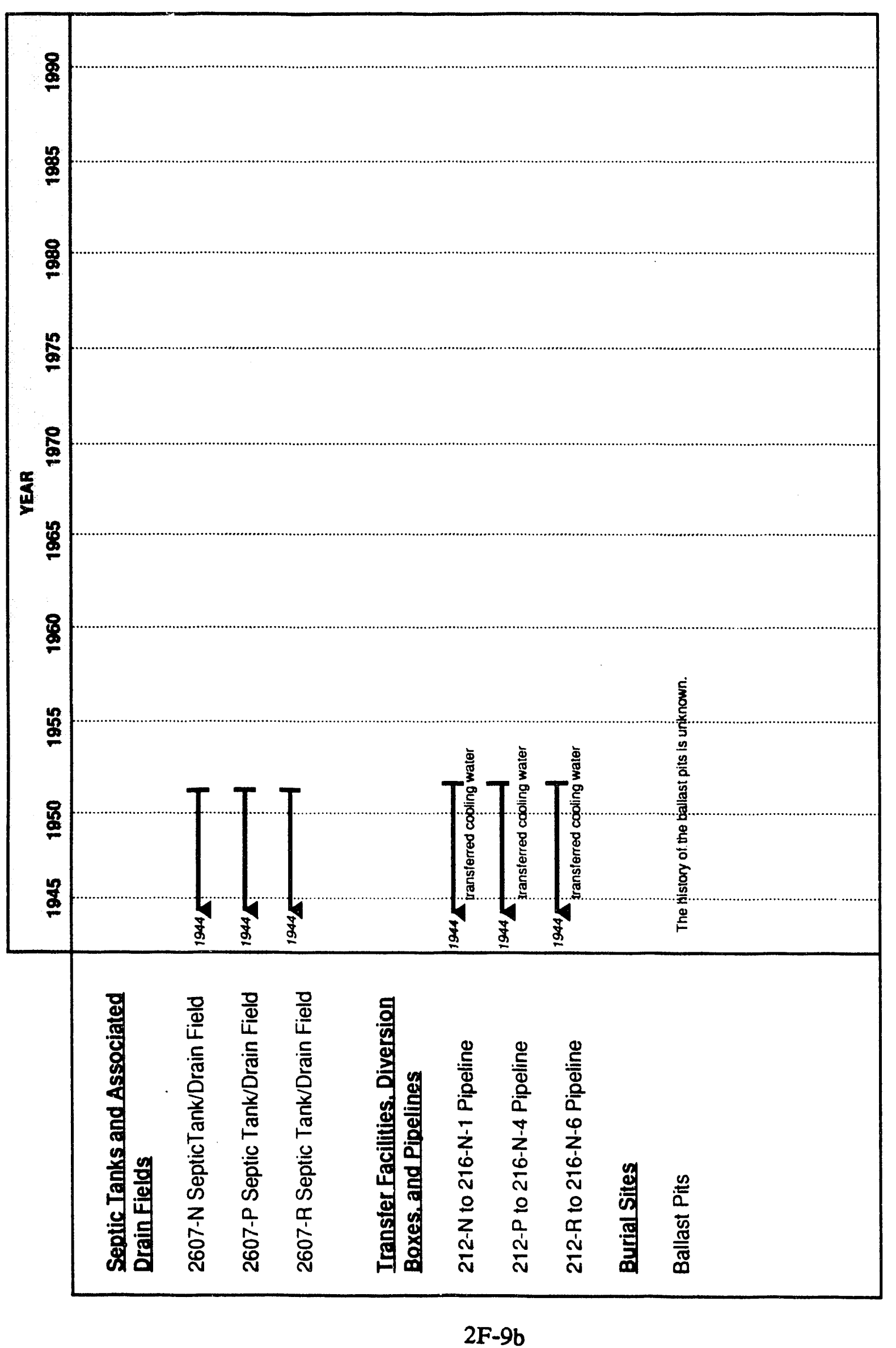


DOE/RL-92-17, Rev. 0

Figure 2-10. Typical Configuration of Disposal Trenches.

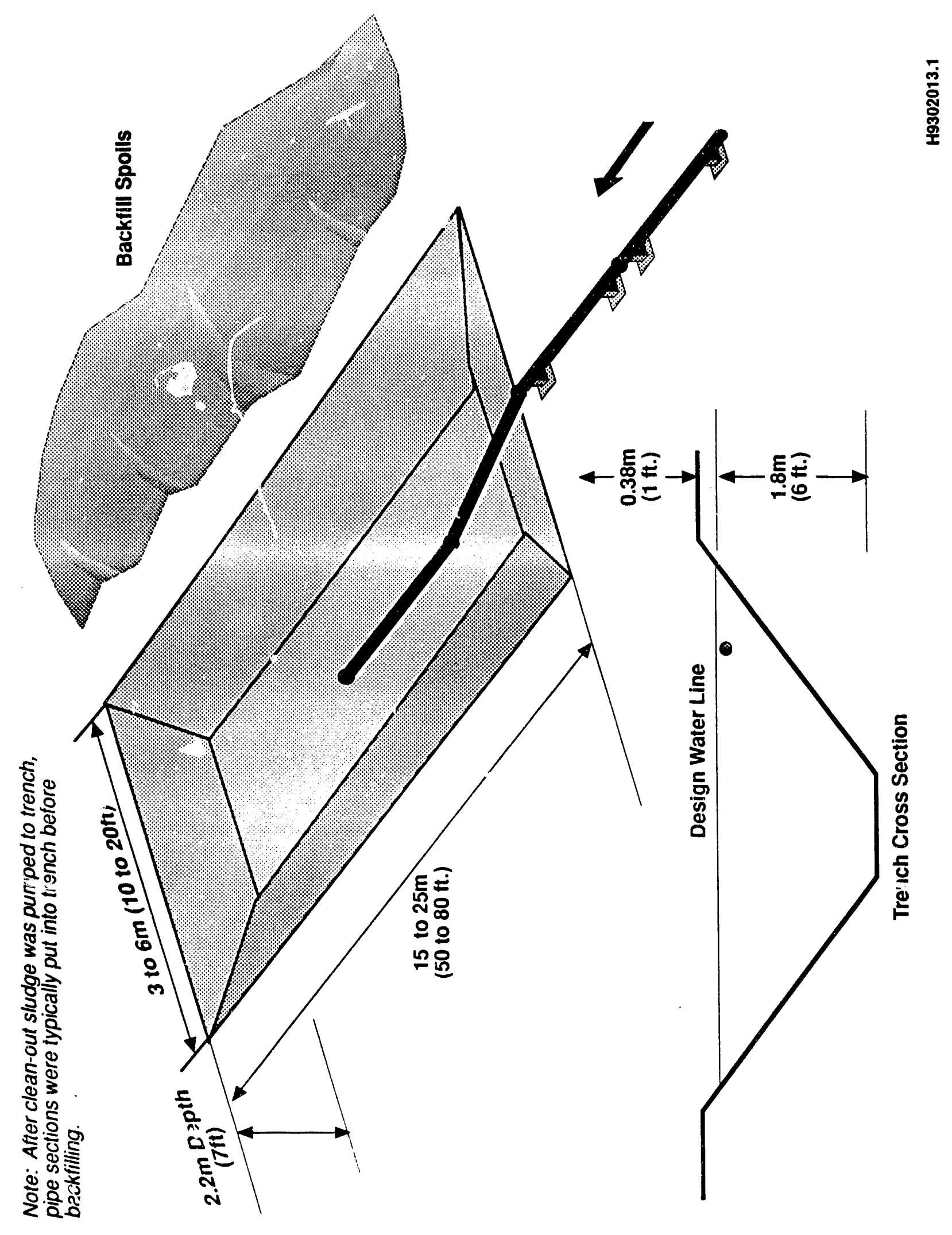


DOE/RL-92-17, Rev. 0

Figure 2-11. General Arrangement of Storage Facility Building.

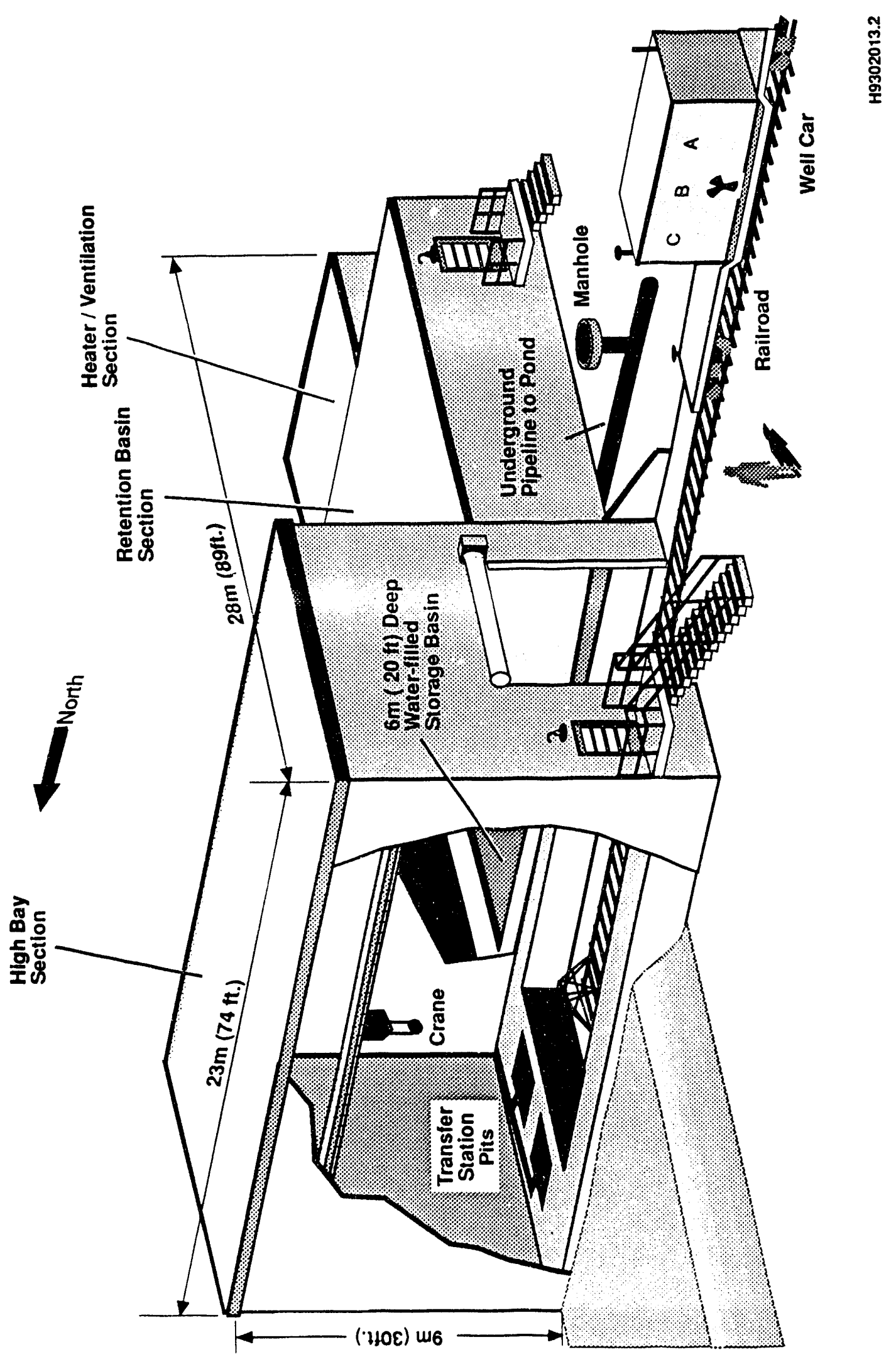


DOE/RL-92-17, Rev. 0

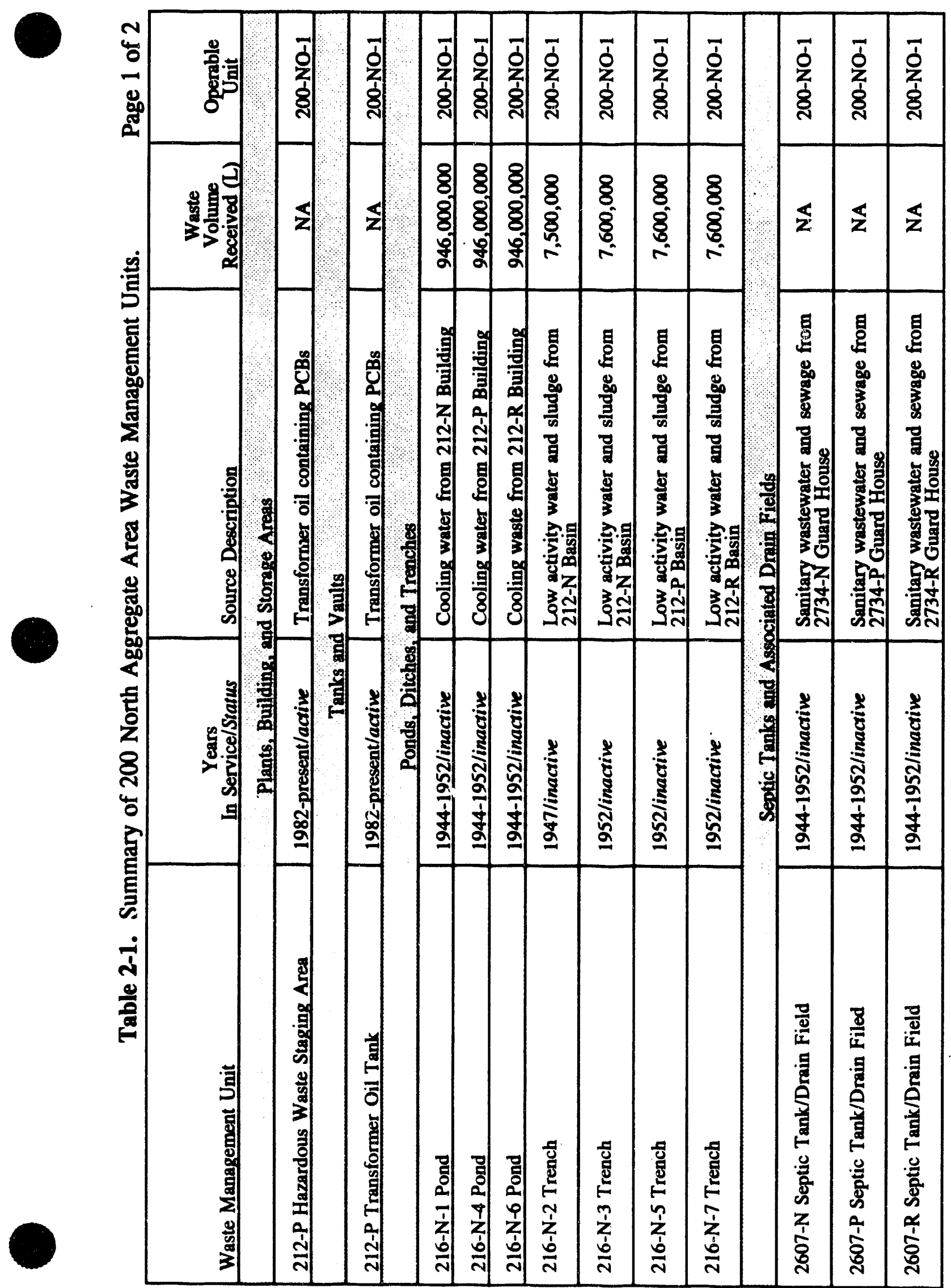


DOE/RL-92-17, Rev. 0

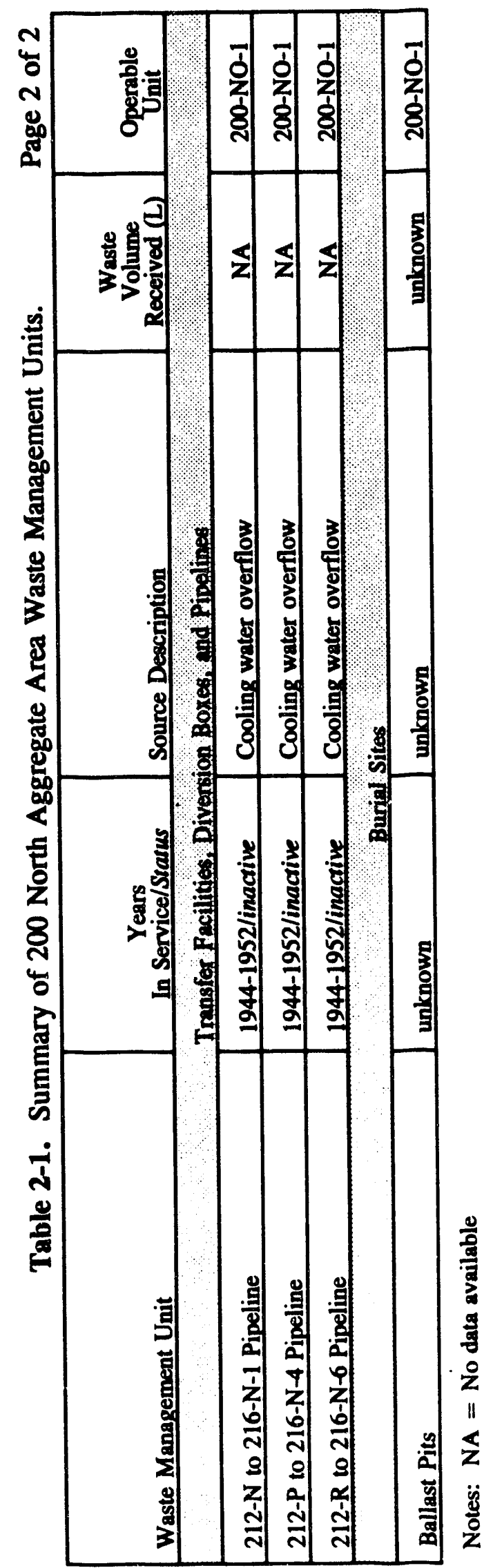


DOE/RL-92-17, Rev. 0

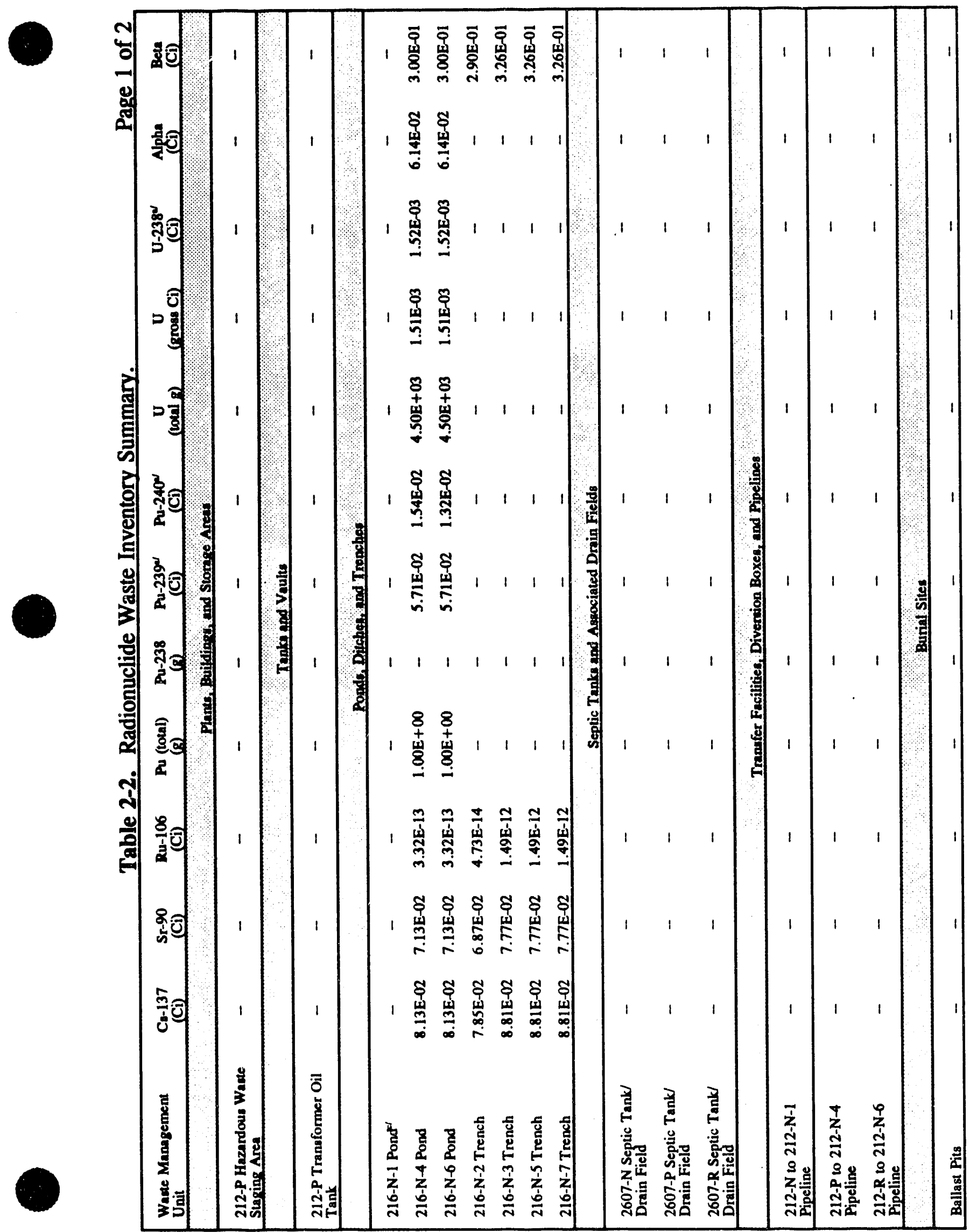


DOE/RL-92-17, Rev. 0

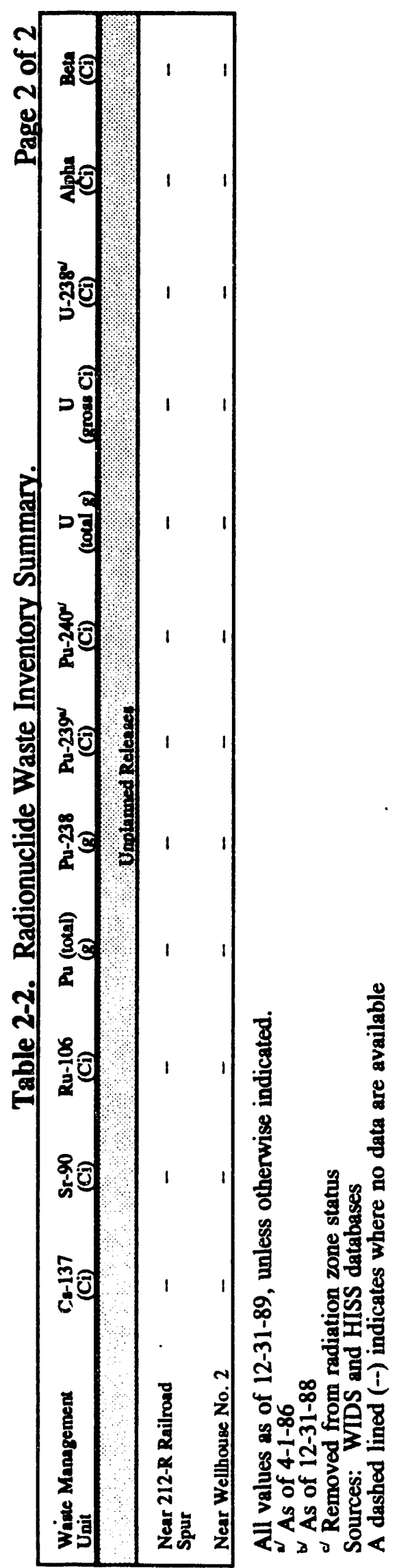


DOE/RL-92-17, Rev. 0

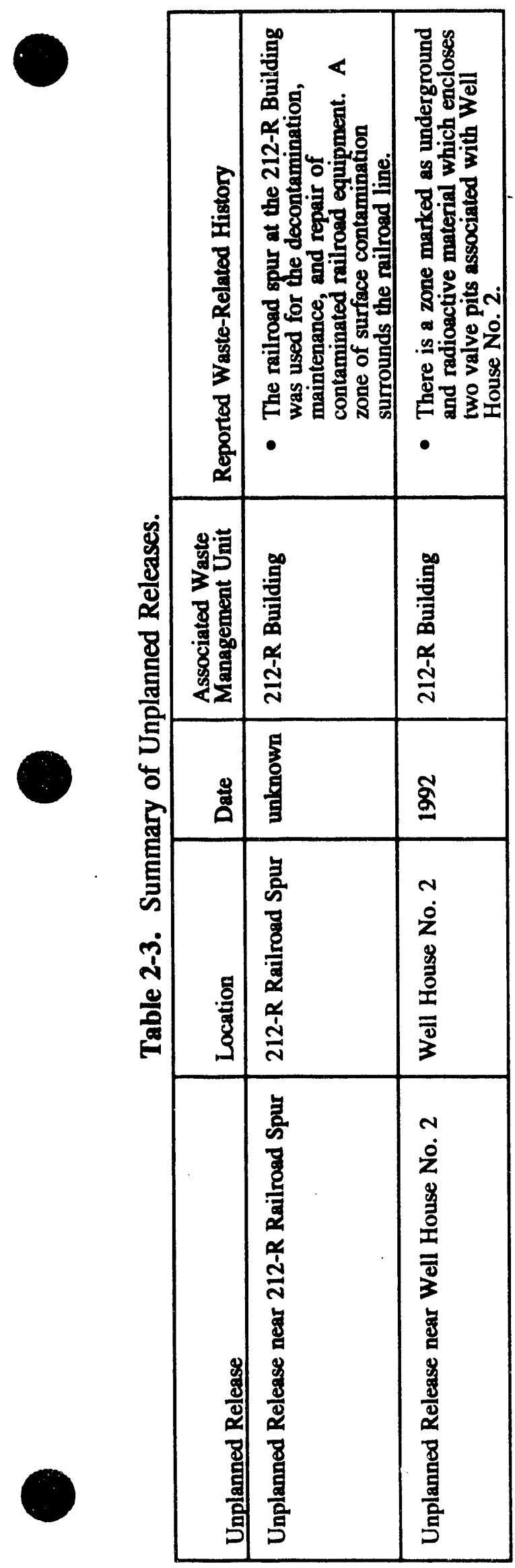


DOE/RL-92-17, Rev. 0

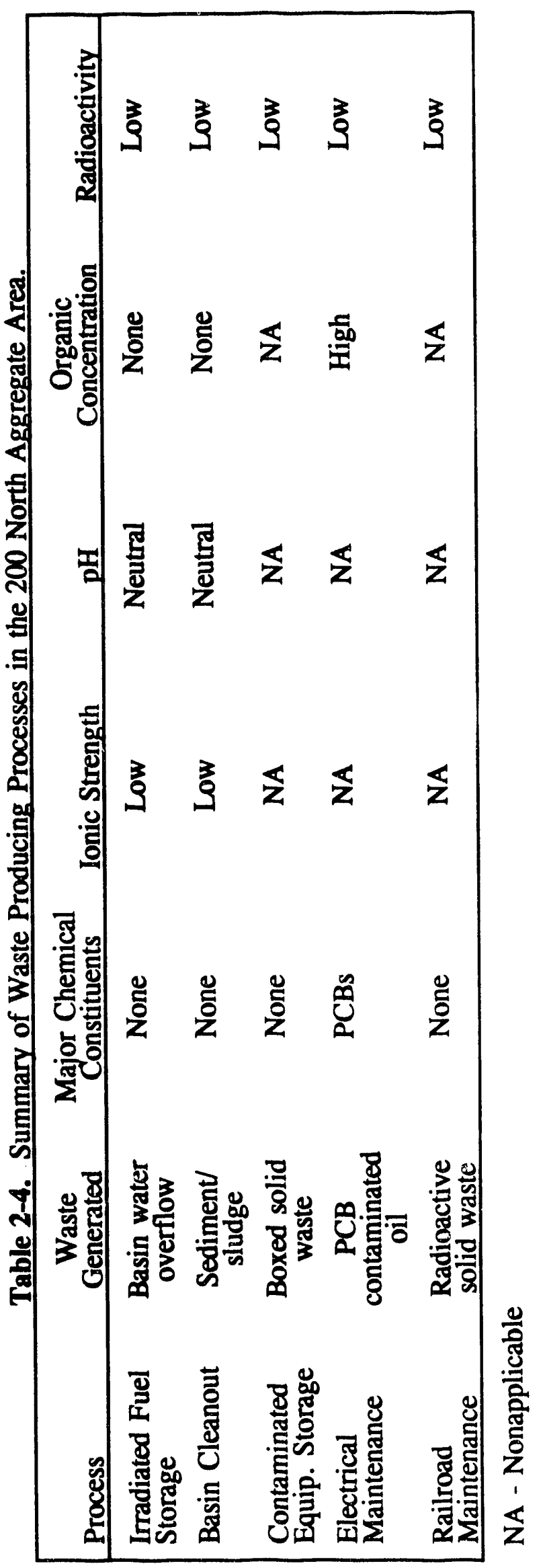


Table 2-5. Radionuclides and Chemicals Disposed of 200 North Aggregate Area Waste Management Units.

\section{RADIONUCLIDES}

Actinium-225

Actinium-227

Americium-241

Americium-242

Americium-242m

Americium-243

Antimony-126

Antimony-126m

Astitine-217

Barium-135m

Barium-137m

Barium-140

Bismuth-210

Bismuth-211

Bismuth-213

Bismuth-214

Carbon-14

Cerium-141

Cerium-144

Cesium-134

Cesium-135

Cesium-137

Cobalt-57

Cobalt-58

Cobalt- 60

Curium-242

Curium-244

Curium-245

Europium-152

Europium-154

Europium-155

Francium-221

Francium-223

Iodine-129, 131

Iron-59

Lanthanum-140
Lead-209

Lead-210

Lead-211

Lead-212

Lead-214

Manganese-54

Neptunium-237

Neptunium-239

Nickel-59

Nickel-63

Niobium-93m

Niobium-95

Palladium-107

Plutonium-238

Plutonium-239/240

Plutonium-241

Polonium-210

Polonium-213

Polonium-214

Polonium-215

Polonium-218

Potassium-40

Praeseodymium-144

Promethium-147

Protactinium-231

Protactinium-233

Protactinium-234m

Radium-223

Radium-225

Radium-226

Rhodium-103

Rhodium-106

Ruthenium-103

Ruthenium-106

Samarium-151

Selenium-79
Silver-110m

Sodium-22

Strontium-85

Strontium-89

Strontium-90

Technetium-99

Tellurium-129

Thallium-207

Thorium-227

Thorium-229

Thorium-230

Thorium-231

Thorium-233

Thorium-234

Tin-126

Tritium

Uranium-233

Uranium-234

Uranium-235

Uranium-238

Yttrium-90

Yttrium-91

Zinc-65

Zirconium-93

Zirconium-95

METALS

Aluminum

VOLATILE ORGANICS

Acetone

Trichloroethylene

SEMHVOLATHEORGANHES

POLYCHLORINATED

BIPHENYLS

Note: Not all analytes are reported in waste inventories. 


\subsection{SITE CONDITIONS}

The following sections describe the physical nature and setting of the Hanford Site and the $\mathbf{2 0 0}$ North Aggregate Area. The site conditions are presented in the following sections:

- Physiography and Topography (Section 3.1)

- $\quad$ Meteorology (Section 3.2)

- $\quad$ Surface Hydrology (Section 3.3)

- $\quad$ Geology (Section 3.4)

- Hydrogeology (Section 3.5)

- $\quad$ Environmental Resources (Section 3.6)

- Human Resources (Section 3.7).

Sections describing topography, geology, and hydrogeology have been taken from standardized texts provided by Westinghouse Hanford (Delaney et al. 1991; Lindsey et al. 1991; and Lindsey et al. 1992) for that purpose.

\subsection{PHYSIOGRAPHY AND TOPOGRAPHY}

The Hanford Site (Figure 3-1) is situated within the Pasco Basin of southcentral Washington. The Pasco Basin is one of a number of topographic depressions located within the Columbia Basin Subprovince of the Columbia Intermontane Province (Figure 3-2), a broad basin located between the Cascade Range and the Rocky Mountains. The Columbia Intermontane Province is the product of Miocene continental flood basalt volcanism and regional deformation that occurred over the past 17 million years. The Pasco Basin is bounded on the north by the Saddle Mountains, on the west by Umtanum Ridge, Yakima Ridge, and the Rattlesnake Hills, on the south by Rattlesnake Mountain and the Rattlesnake Hills, and on the east by the Palouse slope (Figure 3-1).

The physiography of the Hanford Site is dominated by the low-relief plains of the Central Plains physiographic region and anticlinal ridges of the Yakima Folds physiographic region (Figure 3-3). Surface topography seen at the Hanford Site is the result of (1) uplift of anticlinal ridges, (2) Pleistocene cataclysmic flooding, and (3) Holocene eolian activity (DOE 1988b). Uplift of the ridges began in the Miocene epoch and continues to the present. Cataclysmic flooding occurred when ice dams in western Montana and northern Idaho were breached, allowing large volumes of water to spill across eastern and central Washington. The last major flood occurred abojt 13,000 years ago, during the late Pleistocene Epoch. 
Anastomosing flood channels, giant current ripples, bergmounds, and giant flood bars are among the landforms created by the floods. Since the end of the Pleistocene Epoch, winds have locally reworked the flood sediments, depositing dune sands in the lower elevations and loess (windblown silt) around the margins of the Pasco Basin. Generally, sand dunes have been stabilized by anchoring vegetation except where they have been reactivated where vegetation is disturbed (Figure 3-4).

A series of operational areas have been delineated at the Hanford Site. The 100 Areas are situated in the northern part of the Hanford Site adjacent to the Columbia River in an area cominonly called the "Horn." The elevation of the "Horn" is between 119 and $143 \mathrm{~m}$ (390 and $470 \mathrm{ft}$ ) above mean sea level (msl) with a slight increase in elevation away from the river. The 200 Areas are situated on a broad flat area called the 200 Areas Plateau. The 200 Areas Plateau is near the center of the Hanford Site at an elevation of approximately 198 to $229 \mathrm{~m}$ (650 to $750 \mathrm{ft}$ ) above msl. The plateau decreases in elevation to the north, northwest, and east toward the Columbia River, and plateau escarpments have elevation changes of between 15 to $30 \mathrm{~m}(50$ to $100 \mathrm{ft})$.

The 200 North Aggregate Area is situated on the 200 Areas Plateau north of a relatively flat prominent terrace (Cold Creek Bar), on a flood channel formed during the late Pleistocene flooding (Figure 3-5). The 200 North Aggregate Area gently slopes to the south, with a maximum elevation change of approximately $12 \mathrm{~m}(40 \mathrm{ft})$.

The topography of the 200 North Aggregate Area slopes gently to the south and east (Figure 3-1). The elevation in the vicinity of the 200 North Aggregate Area ranges from

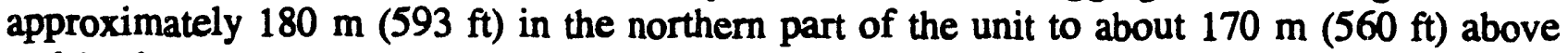
$\mathrm{msl}$ in the southern part. A detailed topographic map of the area is provided as Plate 1. There are no natural surface drainage channels within the aggregate area.

\subsection{METEOROLOGY}

The following sections provide information on Hanford Site meteorology including precipitation (Section 3.2.1), wind conditions (Section 3.2.2), and temperature variability (Section 3.2.3).

The Hanford Site lies east of the Cascade Mountains and has a semiarid climate because of the rainshadow effect of the mountains. The weather is monitored at the Hanford Meteorology Station, located between the 200 East and 200 West Areas, and at other points situated through the reservation. The following sections summarize the Hanford Site meteorology. 


\subsubsection{Precipitation}

The Hanford Site receives an annual average of $16 \mathrm{~cm}(6.3$ in.) of precipitation. Precipitation falls mainly in the winter, with about half of the annual precipitation occurring between November and February. The maximum $25 \mathrm{yr} / 24 \mathrm{~h}$ storm event has been calculated at $3.8 \mathrm{~cm}(1.5 \mathrm{in}$.) (Stone et al. 1983). The maximum $100 \mathrm{yr} / 24 \mathrm{~h}$ storm event is approximately $5 \mathrm{~cm}(2 \mathrm{in}$.$) . Average winter snowfall ranges from 13 \mathrm{~cm}(5.3 \mathrm{in}$.) in January to $0.8 \mathrm{~cm}(0.31 \mathrm{in}$.) in March. The record snowfall of $62 \mathrm{~cm}(24.4 \mathrm{in}$.) occurred in February 1916 (Stone et al. 1983). During December through February, snowfall accounts for about $38 \%$ of all precipitation in those months.

The average yearly relative humidity at the Hanford Site for 1946 to 1980 was $54.4 \%$. Humidity is higher in winter than in summer. The monthly averages for the same period range from $32.2 \%$ for July to $80 \%$ in December. Atmospheric pressure averages are higher in the winter months and record absolute highs and lows also occur in the winter.

\subsubsection{Winds}

The Cascade Mountains have considerable effect on the wind regime at the Hanford Site by serving as a source of cold air drainage. This gravity drainage results in a northwest to west-northwest prevailing wind direction. The average mean monthly speed for 1945 to 1980 is $3.4 \mathrm{~m} / \mathrm{s}(7.7 \mathrm{mph})$. Peak gust speeds range from 28 to $36 \mathrm{~m} / \mathrm{s}(63$ to $80 \mathrm{mph})$ and are generally southwest or west-southwest winds (Stone et al. 1983).

Figure 3-6 shows wind roses for the Hanford Telemetry Network (Stone et al. 1983). The gravity drainage from the Cascades produces a prevailing west-northwest wind in the 200 North Aggregate Area. In July, hourly average wind speeds range from a low of $2.3 \mathrm{~m} / \mathrm{s}(5.2 \mathrm{mph})$ from 9 to 10 a.m. to a high of $6 \mathrm{~m} / \mathrm{s}(13.0 \mathrm{mph})$ from 9 to $10 \mathrm{p} . \mathrm{m}$.

\subsubsection{Temperature}

Based on data from 1914 to 1980 , minimum winter temperatures vary from -33 to $-6^{\circ} \mathrm{C}\left(-27\right.$ to $\left.+22{ }^{\circ} \mathrm{F}\right)$ and maximum summer temperatures vary from 38 to $46^{\circ} \mathrm{C}$ (100 to $\left.115^{\circ} \mathrm{F}\right)$. Between 1914 and 1980 , a total of 16 days with temperatures $-29^{\circ} \mathrm{C}\left(-20^{\circ} \mathrm{F}\right)$ or below are recorded. There are 10 days of record when the maximum temperature failed to go above $-18{ }^{\circ} \mathrm{C}\left(0^{\circ} \mathrm{F}\right)$. Prior to 1980 there were three summers on record when the temperatures were $38^{\circ} \mathrm{C}\left(100^{\circ} \mathrm{F}\right)$ or above for 11 consecutive days (Stone et al. 1983). 
DOE/RL-92-17, Rev. 0

\subsection{SURFACE HYDROLOGY}

The following subsections provide information on regional (Section 3.3.1), Hanford Site (Section 3.3.2), and 200 North Aggregate Area (Section 3.3.3) surface hydrology including surface water features and their relationship to Hanford areas.

\subsubsection{Regional Surface Hydrology}

Surface drainage enters the Pasco Basin from several other basins, which include the Yakima River Basin, Walla Walla River Basin, Palouse/Snake Basin, and Big Bend Basin (Figure 3-7). Within the Pasco Basin, the Columbia River is joined by major tributaries including the Yakima, Snake, and Walla Walla Rivers. No perennial streams originate within the Pasco Basin. Columbia River inflow to the Pasco Basin is recorded at the United States Geological Survey (USGS) gage below Priest Rapids Dam, and outflow is recorded below McNary Dam. Average annual flow at these recording stations is approximately $1.1 \times 10^{11} \mathrm{~m}^{3}\left(8.7 \times 10^{7}\right.$ acre- $\left.\mathrm{ft}\right)$ at the USGS gage and $1.6 \times 10^{11} \mathrm{~m}^{3}\left(1.3 \times 10^{8}\right.$ acre-ft) at the McNary Dam gage (DOE 1988b).

Total estimated precipitation over the basin averages less than $15.8 \mathrm{~cm} / \mathrm{yr}(6.2 \mathrm{in} . / \mathrm{yr})$. Mean annual runoff from the basin is estimated to be less than $3.1 \times 10^{7} \mathrm{~m}^{3} / \mathrm{yr}\left(2.5 \times 10^{4}\right.$ acre-ft/yr), or approximately $3 \%$ of the total precipitation. The remaining precipitation is assumed to be lost through evapotranspiration with a small component (perhaps less than 1\%) recharging the groundwater system (DOE 1988b).

\subsubsection{Surface Hydrology of the Hanford Site}

Primary surface water features associated with the Hanford Site, located near the center of the Pasco Basin, are the Columbia and Yakima Rivers and their major tributaries, the Snake and Walla Walla Rivers. West Lake, about 4 hectares (10 acres) in size and less than

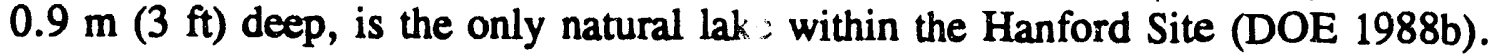
Wastewater ponds, cribs, and ditches associated with nuclear fuel reprocessing and waste disposal activities are also present on the Hanford Site.

The Columbia River flows through the northern part and along the eastern border of the Hanford Site. This section of the river, the Hanford Reach, extends from Priest Rapids Dam to the headwaters of Lake Wallula (the reservoir behind McNary Dam). Flow along the Hanford Reach is controlled by Priest Rapids Dam. Several drains and intakes are also present along this reach, including irrigation outfalls from the Columbia Basin Irrigation Project, the Washington Public Power Supply System (WPPSS) Nuclear Project 2, and Hanford Site intakes for onsite water use. Much of the northern and eastern parts of the Hanford Site are drained by the Columbia River. 
Routine water quality monitoring of the Columbia River is conducted by the U.S. Department of Energy (DOE) for both radiological and nonradiological parameters and has been reported by Pacific Northwest Laboratory (PNL) since 1973. Washington State Department of Ecology (Ecology) has issued a Class A (excellent) quality designation for Columbia River water along the Hanford Reach from Grand Coulee Dam, through the Pasco Basin, to McNary Dam. This designation requires that all industrial uses of this water be compatible with other uses including drinking, wildlife habitat, and recreation. In general, the Columbia River water is characterized by a very low suspended load, a low nutrient content, and an absence of microbial contaminants (DOE 1988b).

Approximately one-third of the Hanford Site is drained by the Yakima River system. Cold Creek and its tributary, Dry Creek, are ephemeral streams on the Hanford Site that are within the Yakima River drainage system. Both streams drain areas along the western part of the Hanford Site and cross the southwestern part of the Hanford Site toward the Yakima River. Surface flow, which may occur during spring runoff or after heavier-than-normal precipitation, infiltrates and disappears into the surface sediments. Rattlesnake Springs, located on the western part of the Hanford Site, forms a small surface stream that flows for about $2.9 \mathrm{~km}(1.8 \mathrm{mi})$ before infiltrating into the ground.

\subsubsection{North Aggregate Area Surface Hydrology}

No natural surface water bodies exist in the 200 North Aggregate Area, although 216-N-8 Pond (West Lake) is located $0.8 \mathrm{~km}(0.5 \mathrm{mi})$ east of the area. Figure 3-5 shows the location of West Lake, Gable Mountain Pond, and B Ponds, relative to the 200 North Aggregate Area. Prior to the filling of Gable Mountain Pond, West Lake was an intermittent seasonal pond located in a natural basin at the base of Gable Mountain. The introduction of large quantities of water to Gable Mountain Pond and the 216-B Pond from 200 East and West Area separations activities, raised the water table in the area sufficiently to provide year-round water to the West Lake.

The former artificial surface water bodies in the 200 North Aggregate Area are the former 216-N-1 Pond, 216-N-4 Pond, and the 216-N-6 Pond, each located approximately $274 \mathrm{~m}(900 \mathrm{ft})$ south of $212-\mathrm{N}, 212-\mathrm{P}$, and 212-R Buildings, respectively. Each pond was dedicated to a building, from which it received overflow from the cooling basins in the buildings. The ponds were designed to disperse displaced cooling water by percolation and evaporation. The ponds were made by constructing low berms and using natural depressions on the gently sloping ground south of the buildings.

The 200 North Aggregate Area is not in a designated flood plain. Calculations of probable maximum floods for the Columbia River and the Cold Creek Watershed indicate that the aggregate area is not expected to be inundated under maximum flood conditions (DOE/RL 1991a). 


\subsection{GEOLOGY}

The following sections provide information pertaining to geologic characteristics of southcentral Washington, the Hanford Site, the 200 East Area (which is close by and has well characterized geology), and the 200 North Aggregate Area. Topics included are the regional tectonic framework (Section 3.4.1), regional stratigraphy (Section 3.4.2), and 200 North Aggregate Area geology (Section 3.4.3).

The geologic characterization of the Hanford Site, including the 200 East Area and 200 North Aggregate Area is the result of many previous site investigation activities at Hanford. These activities include the siting of nuclear reactors, characterization activities for the Basalt Waste Isolatio is Project (BWIP), waste management activities, and related geologic studies supporting these efforts. Geologic investigations have included regional and Hanford Site surface mapping, borehole/well sediment logging, field and laboratory sediment classification, and in situ and laboratory hydrogeologic properties testing.

\subsubsection{Regional Tectonic Framework}

The following sections provide information on regional (southcentral Washington) geolugic structure, structural geology of the Pasco Basin and the Hanford Site, and regional and Hanford Site seismology.

3.4.1.1 Regional Geologir Structure. The Columbia Plateau is a part of the North American continental plai and lies in a back-arc setting east of the Cascade Range. It is bounded on the north by the Okanogan Highlands, on the east by the Northern Rocky Mountains and Idaho Batholith, and on the south by the High Lava Plains and Snake River Plain (Figure 3-8).

The Columbia Plateau can be divided into three informal structural subprovinces (Figure 3-9): Blue Mountains, Palouse, and Yakima Fold Belt (Tolan and Reidel 1989). These structural subprovinces are delincated on the basis of their structural fabric, unlike the physiographic provinces that are defined on the basis of landforms. The Hanford Site is located in the Yakima Fold Belt Subprovince near its junction with the Palouse Subprovince.

The principal characteristics of the Yakima Fold Belt (Figure 3-10) are a series of segmented, narrow, asymmetric anticlines that have wavelengths between 5 and $32 \mathrm{~km}$ (3 and $19 \mathrm{mi}$ ) and amplitudes commonly less than $1 \mathrm{~km}(0.6 \mathrm{mi})$ (Reidel 1984; Reid $\mathrm{ll}$ et al. 1989a). The northern limbs of the anticlines generally dip steeply to the north, ars vertical, or even overturned. The southern limbs generally dip at relatively shallow angles to the south. Thrust or high-angle reverse faults with fault planes that strike parallel or subparallel to the axial trends are principally found on the north sides of these anticlines. The amount of vertical stratigraphic offset associated with these faults varies but commonly exceeds hundreds of meters. These anticlinal ridges are separated by broad synclines or basins that, 
in many cases, contain thick accumulations of Tertiary- to Quaternary-age sediments. The Pasco Basin is one of the larger structural basins in the Yakima Fold Belt Subprovince.

Deformation of the Yakima folds occurred under a north-south compression and was contemporaneous with the eruption of the basalt flows (Reidel 1984; Reidel et al. 1989a). Deformation occurred during the eruption of the Columbia River Basalt Group and continued through the Pliocene epoch, into the Pleistocene epoch, and perhaps to the present.

3.4.1.2 Pasco Basin and Hanford Site Structural Geology. The Pasco Basin, in which the Hanford Site is located, is a structural depression bounded on the north by the Saddle Mountains anticline, on the east by the Palouse Slope, on the west by the Umtanum Ridge, Yakima Ridge, and Rattlesnake Hills anticlines, and on the south by the Rattlesnake Mountain anticline (Figure 3-11). The Pasco Basin is divided by the Gable Mountain anticline, the easternmost extension of the Umtanum Ridge anticline, into the Wahluke syncline in the north, and the Cold Creek syncline in the south. Both the Cold Creek and Wahluke synclines are asymmetric and relatively flat-bottomed structures. The north limbs of both synclines dip gently (approximately $5^{\circ}$ ) to the south and the south limbs dip steeply to the north. The deepest parts of the Cold Creek syncline, the Wye Barricade depression, and the Cold Creek depression are approximately $12 \mathrm{~km}(7.5 \mathrm{mi})$ southeast of the Hanford Site 200 Areas, and just to the west-southwest of the 200 West Area, respectively. The deepest part of the Wahluke syncline lies just north of Gable Gap.

The 200 North Aggregate Area is situated on the crest of a secondary fold superimposed on the southern side of the Umtanum Ridge-Gable Mountain anticline (Ault 1981). This location is also part of the southward dipping north limb of the Cold Creek syncline, approximately $3 \mathrm{~km}(5 \mathrm{mi})$ north of the syncline axis. The axis of the Gable Mountain-Gable Butte segment of the Umtanum Ridge anticline lies approximately $1.5 \mathrm{~km}$ $(1 \mathrm{mi})$ north of the 200 North Aggregate Area. The axes of the anticline and syncline are separated by a distance of 9 to $10 \mathrm{~km}(5.6$ to $6.2 \mathrm{mi})$ and the crest of the anticline (as now exposed) is over $200 \mathrm{~m}$ (656 ft) higher than the uppermost basalt layer in the syncline axis. As a result, the overall dip of the basalts and overlying sediments is to the south and southwest beneath the 200 North and East Areas.

3.4.1.3 Regional and Hanford Site Seismology. Eastern Washington, especially the Columbia Plateau region, is a seismically inactive area when compared to the rest of the western United States (DOE 1988b). The historic seismic record for eastern Washington began in approximately 1850 , and no earthquakes large enough to be felt had epicenters on the Hanford Site. The closest regions of historic moderate-to-large earthquake generation are in western Washington and Oregon and western Montana and eastern Idaho. The most significant event relative to the Hanford Site is the 1936 Milton-Freewater, Oregon, earthquake that had a magnitude of 5.75 and that occurred more than $90 \mathrm{~km}$ (54 mi) away. The largest Modified Mercalli Intensity for this event was felt about $105 \mathrm{~km}$ (63 mi) from the Hanford site at Walla Walla, Washington, and was VII. 
Geologic evidence of past moderate or possibly large earthquake activity is shown by the anticlinal folds and faulting associated with Rattlesnake Mountain, Saddle Mountain, and Gable Mountain. Currently, micro-size earthquakes occur on the flanks of the Saddle Mountain Uplift, but not on the folds or their related faults (DOE 1988b). The suggested recurrence rates of moderate and larger-size earthquakes on and near the Hanford Site are measured in geologic time (tens of thousands of years).

\subsubsection{Regional Stratigraphy}

The following sections summarize regional stratigraphic characteristics of the Columbia River Basalt and Suprabasalt sediments. Specific references to the Hanford Site and 200 North Aggregate Area are made where applicable to describe the general occurrence of these units within the Pasco Basin.

The principal geologic units within the Pasco Basin include the Miocene age basalt of the Columbia River Basalt Group, and overlying late Miocene to Pleistocene suprabasalt sediments (Figure 3-12). Older Cenozoic sedimentary and volcaniclastic rocks underlying the basalts are not exposed at the surface near the Hanford Site. The basalts and sediments thicken into the Pasco Basin and generally reach maximum thicknesses in the Cold Creek syncline. The suprabasalt sedimentary sequence at the Hanford Site pinches out against the anticlinal structures of Saddle Mountains, Gable Mountain/Umtanum Ridge, Yakima Ridge, and Rattlesnake Hills.

The suprabasalt sediment-sequence is up to approximately $230 \mathrm{~m}$ (750 ft) thick and dominated by laterally extensive deposits assigned to the late Miocene- to Pliocene-age Ringold Formation and the Pleistocene-age Hanford formation (Figure 3-13). Locally occurring stanta informally referred to as the pre-Missoula gravels, the Plio-Pleistocene unit, and the eariy "Palouse" soil comprise the remainder of the sedimentary sequence. The preMissoula gravels underlie the Hanford formation in the east-central Cold Creek syncline and at the east end of Gable Mountain anticline east and south of the 200 Areas. The preMissoula gravels have not been identified in the 200 West Area. The nature of the contact between the pre-Missoula gravels and the overlying Hanford formation has not been completely delineated. In addition, it is unclear whether the pre-Missoula gravels overlie or interfinger with the early "Palouse" soil and Plio-Pleistocene unit. Magnetic polarity data indicate the unit is no younger than early Pleistocene in age $(>1 \mathrm{Ma}$ [million years before present]) as reported in Baker et al. (1991).

Relatively thin surficial deposits of eolian sand, loess, alluvium, and colluvium discontinuously overlie the Hanford formation.

3.4.2.1 Columbia River Basalt Group. The Columbia River Basalt Group (Figure 3-12) comprises an assemblage of tholeiitic, continental flood basalts of Miocene age. These flows cover an area of more $163,700 \mathrm{~km}^{2}\left(63,000 \mathrm{mi}^{2}\right)$ in Washington, Oregon, and Idaho and have an estimated volume of about $174,356 \mathrm{~km}^{3}\left(40,800 \mathrm{mi}^{3}\right)$ (Tolan et al. 1989). Isotopic 
age determinations indicate that basalt flows were erupted approximately 17 to $6 \mathrm{Ma}$ with more than $98 \%$ by volume being erupted in a 2.5 million year period (17 to $14.5 \mathrm{Ma}$ ) (Reidel et al. 1989b).

Columbia River basalt flows were erupted from north-northwest-trending fissures of linear vent systems in north-central and northeastern Oregon, eastern Washington, and western Idaho (Swanson et al. 1979). The Columbia River Basalt Group is formally divided into five formations (from oldest to youngest): Imnaha Basalt, Picture Gorge Basalt, Grande Ronde Basalt, Wanapum Basalt, and Saddle Mountains Basalt. Of these, only the Picture Gorge Basalt is not known to be present in the Pasco Basin. The Saddle Mountains Basalt, divided into the Ice Harbor, Elephant Mountain, Pomona, Esquatzel, Asotin, Wilbur Creek and Umatilla Members (Figure 3-12), forms the uppermost basalt unit throughout most of the Pasco Basin. The Elephant Mountain Member is the uppermost unit beneath most of the Hanford Site except near the 300 Area where the Ice Harbor Member is found and north of the 200 Areas where the Saddle Mountains Basalt has been eroded down to the Umatilla Member locally. On anticlinal ridges bounding the Pasco Basin, the Saddle Mountain Basalt is locally absent, exposing the Wanapum and Grande Ronde Basalts.

3.4.2.2 Ellensburg Formation. The Ellensburg Formation consists of all sedimentary units that occur between the basalt flows of the Columbia River Basalt Group in the central Columbia Basin. The Ellensburg Formation generally displays two main lithologies: volcaniclastics (Reidel and Fecht 1981; Smith et al. 1989), and siliciclastics (DOE 1988b). The volcaniclastics consist mainly of primary pyroclastic air fall deposits and reworked epiclastics derived from volcanic terrains west of the Columbia Plateau. Siliciclastic strata in the Ellensburg Formation consists of reworked clastic, plutonic, and metamorphic detritus derived from the Rocky Mountain terrain. These two lithologies occur as both distinct and mixed in the Pasco Basin. A detailed discussion of the Ellensburg Formation in the Hanford Site is given by Reidel and Fecht (1981). Smith et al. (1989) provide a discussion of age equivalent units adjacent to the Columbia Plateau.

The stratigraphic names for individual units of the Ellensburg Formation are given in Figure 3-12. The nomenclature for these units is based on the upper- and lower-bounding basalt flows and thus the names are valid only for those areas where the bounding basalt flows occur. Because the Pasco Basin is an area where most bounding flows occur, the names given in Figure 3-12 are applicable to the Hanford Site. At the Hanford Site the three uppermost units of the Ellensburg Formation are the Selah interbed, the Rattlesnake Ridge interbed, and the Levey interbed.

3.4.2.2.1 Selah Interbed. The Selah interbed is bounded on the top by the Pomona Member and on the bottom by the Esquatzel Member. The interbed is a variable mixture of silty to sandy vitric tuff, arkosic sands, tuffaceous clays, and locally thin stringers of predominantly basaltic gravels. The Selah interbed is found beneath most of the Hanford Site. 
3.4.2.2.2 Rattlesnake Ridge Interbed. The Rattlesnake Ridge interbed is bounded on the top by the Elephant Mountain Member and on the bottom by the Pomona Member. The

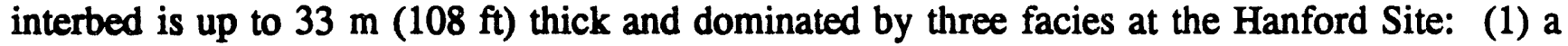
lower clay or tuffaceous sandstone, (2) a middle, micaceous-arkosic and/or tuffaceous sandstone, and (3) an upper, tuffaceous siltstone to sandstone. The unit is found beneath most of the Hanford Site.

3.4.2.2.3 Levey Interbed. The Levey interbed is the uppermost unit of the Ellensburg Formation and occurs between the Ice Harbor Member and the Elephant Mountain Member. It is confined to the vicinity of the 300 Area. The Levey interbed is a tuffaceous sandstone along its northern edge and a fine-grained tuffaceous siltstone to sandstone along its western and southern margins.

3.4.2.3 Ringold Formation. The Ringold Formation at the Hanford Site is up to $185 \mathrm{~m}$ (607 ft) thick in the deepest part of the Cold Creek syncline south of the 200 West Area and $170 \mathrm{~m}(558 \mathrm{ft})$ thick in the western Wahluke syncline near the 100-B Area. The Ringold Formation pinches out against the Gable Mountain, Yakima Ridge, Saddle Mountains, and Rattlesnake Mountain anticlines. It is largely absent in the northern and northeastern parts of the 200 East Area and adjacent areas to the north in the vicinity of West Lake. The Ringold Formation is assigned a late Miocene to Pliocene age (Fecht 1987; DOE 1988b) and was deposited in alluvial and lacustrine environments (Bjornstad 1985; Fecht 1987; Lindsey 1991).

Recent studies of the Ringold Formation (Lindsey and Gaylord 1989; Lindsey et al. 1992) indicate that it is best described and divided on the basis of sediment facies associations and their distribution. Facies associations in the Ringold Formation (defined on the basis of lithology, petrology, stratification, and pedogenic alteration) include fluvial gravel, fluvial sand, overbank deposits, lacustrine deposits, and alluvial fan. The facies associations are summarized as follows:

- Fluvial gravel--Clast-supported granule to cobble gravel with a sandy matrix dominates the association. Intercalated sands and muds also are found. Clast composition is very variable, with common types being basalt, quartzite, porphyritic volcanics, and greenstones. Silicic plutonic rocks, gneisses, and volcanic breccias also are found. Sands in this association are generally quartzofeldspathic, with basalt contents generally in the range of 5 to $25 \%$. Low angle to planar stratification, massive channels, wide, shallow channels, and large-scale cross-bedding are found in outcrops. The association was deposited in a gravelly fluvial system characterized by wide, shallow shifting channels.

- Fluvial sand--Quartzo-feldspathic sands displaying cross-bedding and crosslamination in outcrop dominate this association. These sands usually contain less than $15 \%$ basalt lithic fragments, although basalt contents as high as $50 \%$ may be encountered. Intercalated strata consist of lenticular silty sands and clays up to $3 \mathrm{~m}$ (10 ft) thick and thin $(<0.5 \mathrm{~m})$ gravels. Fining upwards sequences less than 
$1 \mathrm{~m}(3.3 \mathrm{ft})$ to several meters thick are common in the association. Strata comprising the association were deposited in wide, shallow channels.

- Overbank deposits--This association dominantly consists of laminated to massive silt, silty fine-gained sand, and paleosols containing variable amounts of pedogenic calciurn carbonate. Overbank deposits occur as thin lenticular interbeds $(<0.5 \mathrm{~m}$ to $2 \mathrm{~m},<1.6 \mathrm{ft}$ to $6 \mathrm{ft}$ ) in the fluvial gravel and fluvial sand associations and as thick (up to $10 \mathrm{~m}, 33 \mathrm{ft}$ ) laterally continuous sequences. These sediments record deposition in a floodplain under proximal levee to more distal floodplain conditions.

- Lacustrine deposits--Plane laminated to massive clay with thin silt and silty sand interbeds displaying some soft-sediment deformation characterize this association. Coarsening upwards packages less than $1 \mathrm{~m}(3.3 \mathrm{ft})$ to $10 \mathrm{~m}(33 \mathrm{ft})$ thick are common in the association. Strata comprising the association were deposited in a lake under standing water to deltaic conditions.

- Alluvial fan--Massive to crudely stratified, weathered to unweathered basaltic detritus dominates this association. These basaltic deposits generally are found around the periphery of the basin. This association was deposited largely by debris flows in alluvial fan settings.

The lower half of the Ringold Formation contains five separate stratigraphic intervals dominated by fluvial gravels. These gravels, designated units, A, B, C, D, and E (also called FSA, FSB, FSC, FSD and FSE [Lindsey and Gaylord 1989; Lindsey et al. 1991]) (Figure 3-13), are separated by intervals containing deposits typical of the overbank and lacustrine facies associations. The lowermost of the fine-grained sequences, overlying unit $\mathrm{A}$, is designated the lower mud sequence. The uppermost gravel unit, unit $\mathrm{E}$, grades upwards into interbedded fluvial sand and overbank deposits. These sands and overbank deposits are overlain by lacustrine-dominated strata.

Fluvial gravel units A and E correspond to the lower basal and middle Ringold units respectively as defined by DOE (1988b). Gravel units B, C, and D do not correlate to any previously defined units (Lindsey et al. 1991). The lower mud sequence corresponds to the upper basal and lower units as defined by DOE (1988b). The upper basal and lower units are not differentiated. The sequence of fluvial sands, overbank deposits, and lacustrine sediments overlying unit E corresponds to the upper unit as seen along the White Bluffs in the eastern Pasco Basin. This essentially is the same usage as originally proposed by Newcomb (1958) and Myers et al. (1979).

3.4.2.4 Plio-Pleistocene Unit. Unconformably overlying the Ringold Formation in the western Cold Creek syncline in the vicinity of 200 West Area (Figures 3-11, 3-12, and 3-13) is the laterally discontinuous Plio-Pleistocene unit (DOE 1988b). The unit is up to $25 \mathrm{~m}$ $(82 \mathrm{ft})$ thick and divided into two facies: (1) sidestream alluvium and (2) calcic paleosol (Stage III and Stage IV) (DOE 1988b). The calic paleosol facies consist of massive calcium 
carbonate-cemented silt, sand, gravel, (caliche) to interbedded caliche-rich and caliche-poor silts and sands. The basaltic detritus facies consists of weathered and unweathered basaltic gravels deposited as locally derived slope wash, colluvium, and sidestream alluvium. Where the unit occurs, it unconformably overlies the Ringold Formation. The Plio-Pleistocene unit appears to be correlative to other sidestream alluvial and pedogenic deposits found near the base of the ridges bounding the Pasco Basin on the north, west, and south. These sidestream alluvial and pedogenic deposits are inferred to have a late Pliocene to early Pleistocene age on the basis of stratigraphic position and magnetic polarity of interfingering loess units.

\subsubsection{Pre-Miscoula Gravels. Quartzose to gneissic clast-supported pebble to cobble} gravel with a quartzo-feldspathic sand matrix underlies the Hanford formation in the eastcentral Cold Creek syncline and at the east end of Gable Mountain anticline east and south of the 200 East Area (Figures 3-11, 3-12, and 3-13). These gravels, called the pre-Missoula gravels (PSPL 1982), are up to $25 \mathrm{~m}$ (82 ft) thick, contain less basalt than underlying Ringold gravels and overlying Hanford deposits, have a distinctive white or bleached color, and sharply truncate underlying strata. The nature of the contact between the pre-Missoula gravels and the overlying Hanford formation is not clear. In addition, it is unclear whether the pre-Missoula gravels overlie or interfinger with the early "Palouse" soil and PlioPleistocene unit. Magnetic polarity data indicates the unit is no younger than early Pleistocene in age ( $>1 \mathrm{Ma}$ ) (Baker et al. 1991).

3.4.2.6 Early "Palouse" Soil. The early "Palouse" soil consists of up to $20 \mathrm{~m}(66 \mathrm{ft})$ of massive, brown yellow, and compact, loess-like silt and minor fine-grained sand (Tallman et al. 1979, 1981; DOE 1988b). These deposits overlie the Plio-Pleistocene unit in the western Cold Creek syncline around the 200 West Area (Figures 3-11, 3-12, and 3-13). The unit is differentiated from overlying graded rhythmites (Hanford formation) by greater calcium carbonate content, massive structure in core, and high natural gamma response in geophysical logs (DOE 1988b). This natural gamma response is due to the inherent stratigraphic properties of this unit, rather than from effects of radionuclide contamination. The upper contact of the unit is poorly defined, and it may grade up-section into the lower part of the Hanford formation. Based on a predominantly reversed polarity the unit is inferred to be early Pleistocene in age (Baker et al. 1991).

3.4.2.7 Hanford Formation. The Hanford formation consists of pebble to boulder gravel, fine- to coarse-grained sand, and silt (Baker et al. 1991). These deposits are divided into three facies: (1) gravel-dominated, (2) sand-dominated, and (3) silt-dominated. These facies are, referred to as coarse-grained deposits, plane-laminated sand facies, and rhythmite faces, respectively in Baker et al. (1991). The silt-dominated deposits also are referred to as the "Touchet Beds" or slackwater deposits, while the gravel-dominated facies are generally referred to as the Pasco Gravels. The Hanford formation is thickest in the Cold Creek bar in the vicinity of 200 West and 200 East Areas where it is up to $65 \mathrm{~m}(213 \mathrm{ft})$ thick (Figures 3-26 through 3-30). The Hanford formation was deposited by cataclysmic flood waters that drained out of glacial Lake Missoula (Fecht et al. 1987; DOE 1988b; and Baker et al. 1991). Hanford deposits are absent on ridges above approximately $385 \mathrm{~m}$ $(1,263 \mathrm{ft})$ above sea level. The following sections describe the three Hanford formation facies. 
In addition to the three Hanford formation facies, clastic dikes (Black 1980) also are commonly found in the Hanford formation. These dikes, while common in the Hanford formation, also are found locally in other sedimentary units in the Pasco Basin. Clastic dikes, whether in the Hanford formation or other sedimentary units, are structures that generally cross-cut bedding, although they do locally parallel bedding. The dikes generally consist of alternating vertical to subvertical layers (millimeters to centimeters thick) of silt, sand, and granules. Where the dikes intersect the ground surface, a feature known as patterned ground can be observed (Lindsey et al. 1992).

3.4.2.7.1 Pasco Gravels. The Pasco Gravels consist of two facies, a graveldominated and sand dominated facies. The gravel-dominated facies is dominated by coarsegrained basaltic sand and granule to boulder gravel. These deposits display massive bedding, plane to low-angle bedding, and large-scale planar cross-bedding in outcrop, while the gravels generally are matrix-poor and display an open-framework texture. Lenticular sand and silt beds are intercalated throughout the facies. Gravel clasts in the facies generally are dominated by basalt (50 to $80 \%)$. Other clast types include Ringold and Plio-Pleistocene ripups, granite, quartzite, and gneiss. The relative proportion of gniessic and granitic clasts in Hanford gravels versus Ringold gravels generally is higher (up to $20 \%$ as compared to less than $5 \%$ ). Sands in this facies usually are very basaltic (up to $90 \%$ ), especially in the granule size range. Locally Ringold and Plio-Pleistocene rip-up clasts dominate the facies comprising up to $75 \%$ of the deposit. The gravel facies dominates the Hanford formation in the 100 Areas north of Gable Mountain, the northern part of 200 East Area, and the eastern part of the Hanford Site including the 300 Area. The gravel-dominated facies was deposited by high-energy flood waters in or immediately adjacent to the main cataclysmic flood channelways.

The sand-dominated facies consists of fine-grained to coarse-grained sand and granular sand displaying plane lamination and bedding and less commonly plane cross-bedding in outcrop. These sands may contain small pebbles and rip-up clasts in addition to pebblegravel interbeds and silty interbeds less thiari $\mathrm{I} \mathrm{m}(3.3 \mathrm{ft})$ thick. The silt content of these sands is variable, but where it is low, an open framework texture is common. These sands are typically very basaltic, commonly being referred to as black or gray or salt and pepper sands. This facies is most common in the central Cold Creek syncline, in the central to southern parts of the 200 East and 200 West Areas, and in the vicinity of the WPPSS facilities. The sand dominant facies was deposited in channelways as flow power waned and adjacent to main flood channelways as water in the channelways spilled out of them, losing their competence. The facies is transitional between gravel-dominated facies and siltdominated facies.

3.4.2.7.2 Touchet Beds. The Touchet Beds consists of a silt-dominated facies. The silt-dominated facies consists of thiniy bedded, plane laminated and ripple cross-laminated silt and fine- to coarse-grained sand that commonly display normally graded rhythmites similar to Bouma sequences, a few centimeters to several tens of centimeters thick in outcrop (Myers et al. 1979, DOE 1988b; Baker et al. 1991). This facies dominates the Hanford formation throughout the central, southern, and western Cold Creek syncline within and south of 200 
East and West Areas. These sediments were deposited under silt-dominated conditions and in backflooded areas (DOE 1988b).

3.4.2.8 Surficial Deposits. Surficial deposits consist of silt, sand, and gravel that form a thin $(<10 \mathrm{~m}, 33 \mathrm{ft}$ ) veneer across much of the Hanford Site. These sediments were deposited by a mix of eolian and alluvial processes.

\subsubsection{North Aggregate Area Geology}

The following sections describe the occurrence and variation of suprabasalt sediments in the 200 North Aggregate Area. The sections discuss notable stratigraphic characteristics, sediment thickness variations, dip trends, and other features such as areas where sediments are known or suspected to be absent. Also, stratigraphic variations pertinent to the 200 North Aggregate Area are identified where applicable, and are presented in the overall context of stratigraphic trends throughout the 200 North Aggregate Area. The following sections are based on Lindsey et al. (1992).

Geologic cross-sections depicting the distribution of basalt and sedimentary units within and near the 200 North Aggregate Area are presented on Figures 3-14 through 3-18. Figure 3-14 illustrates the cross-sections locations. A legend for symbols used on the crosssections is provided on Figure 3-15. The cross-sections are based on geologic information from wells shown on Figure 3-14, as interpreted in Lindsey et al. (1992). Logs for the few wells in the 200 North Aggregate Area were reviewed, but considered too generalized and inadequate to supply detail for the unconsolidated units, and therefore would not add significant value to the cross sections. Figures 3-19 through 3-31 present structure maps of the top of the sedimentary units, and isopach maps illustrating the thickness of each unit in the 200 East Area and 200 North Aggregate Area. The structure and isopach maps are included from Lindsey et al. (1992). Plate 1 should be consulted to identify locations of 200 North Aggregate Area buildings and waste management units referenced in the text.

3.4.3.1 Elephant Mountain Member. The uppermost basalt unit beneath most of the 200 East Aggregate Area is the Elephant Mountain Member of the Saddle Mountains Basalt Formation. At one location just east of the 200 North Aggregate Area, a channel has been eroded through the Elephant Mountain Member, into the underlying Rattlesnake Ridge Interbed (Figure 3-17). Boring logs show that the top of basalt dips under the 200 North Aggregate Area, suggesting that additional erosional channels may exist. If so, then Hanford formation sediments may overlie the Rattlesnake Ridge Interbed or the Pomona Member. The Pomona Member underlies the Rattlesnake Ridge Interbed.

\subsubsection{Ellensburg Formation. The Rattlesnake Ridge Interbed of the Ellensburg} Formation is found beneath the entire 200 East Area (Reidel and Fecht 1981) and presumably the 200 North Aggregate Area. It is in contact with Hanford formation sediments in a channel eroded through the Elephant Mountain Member just east of 200 North Aggregate Area. 
3.4.3.3 Ringold Formation. Near the 200 North Aggregate Area, the Ringold Formation includes the fluvial gravels of unit $A$, the paleosol and lacustrine muds of the lower mud sequence, the fluvial gravels of unit $\mathrm{E}$, and the sand and minor muds of the upper unit. Ringold units B, C, and D are not found in the immediate vicinity of the 200 North Aggregate Area. The other Ringold strata are found throughout the southern two-thirds of the 200 East Area. In the 200 North Aggregate Area itself, only the uppermost Ringold unit $\mathrm{E}$ has been identified in the western part (Figures 3-19 through 3-25).

The Ringold unit E in the 200 North Aggregate Area is up to $5 \mathrm{~m}(16 \mathrm{ft})$ thick in the southwest corner and occurs in a thin lobe that trends to the northeast, pinching out just west of the middle of the aggregate area. Within this lobe the surface dives to the southeast.

3.4.3.4 Plio-Pleistocene Unit and Early "Palouse" Soil. The Plio-Pleistocene unit and the early "Palouse" soil are not found within or near the 200 North Aggregate Area. They are encountered only near the eastern boundary of the 200 West Area approximately $5 \mathrm{~km} \mathrm{(3 \textrm {mi } )}$ from the 200 North Aggregate Area.

3.4.3.5 Hanford Formation. As discussed in the regional geology section, the cataclysmic flood deposits of the Hanford formation are divided into three facies: (1) gravel-dominated, (2) sand-dominated, and (3) the silt-dominated facies. Typical lithologic successions consist of fining upwards packages, major fine-grained intervals, and laterally persistent coarsegrained sequences. Studying the distribution of these facies types and identifying similarities in lithologic succession from borehole to borehole across the 200 East Area indicates the Hanford formation can be divided into three stratigraphic sequences. However, because of the variability of Hanford deposits, indentification of these sequences is difficult and contacts between them can be very gradational. Where these sequences cannot be identified, the Hanford depsoits are referred to as "undifferentiated Hanford."

The sequences are composed mostly of the gravel-dominated and sand-dominated facies. Silt-dominated facies are relatively rare except in the southern part of the 200 East Area. Two of the sequences are dominated by deposits typical of the gravel-dominated facies and they are designated the upper and lower gravel sequences. The third sequence consists of deposits of the sand-dominated facies with minor intercalated occurrences from both the gravel-dominated and silt-dominated facies. This sequence, designated the sandy sequence, generally is situated between the upper and lower gravel sequences.

The lower gravel sequence is dominated by deposits typical of the gravel-dominated facies. Local intercalated intervals of the sand-dominated facies are also found. The lower gravel sequence ranges up to $23 \mathrm{~m}(75 \mathrm{ft})$ thick and is found only in a paleochannel just east of the 200 North Aggregate Area. Because of the absence of the sandy sequence that separates the lower from the upper gravelly iequences it is impossible to determine the true extent of the lower gravelly sequence. The contact between the lower gravelly sequence and the overlying sandy sequence is placed at the top of the first thick ( $>6 \mathrm{~m},>20 \mathrm{ft}$ ) gravel interval encountered below the sand-dominated strata of the sandy sequence. 
The sandy sequence consists of a heterogenous mix of sands typical of the sanddominated facies. The sandy sequence ranges from 0 to $92 \mathrm{~m}(0$ to $280 \mathrm{ft})$ thick. This sequence is dominated by the sand-dominated facies in the north, and the silt-dominated facies towards the south. Gravels, occurring as single clasts and as interbeds, are common in the sandy sequence, especially towards the north. The sandy sequence probably contains the greatest concentration of clastic dikes and it is laterally equivalent with lower fine sequence in the 200 West Area (Lindsey et al. 1991). Where the sandy sequence pinches out it commonly interfingers with gravels of the overlying and underlying gravel sequences. Where this occurs the contact separating the sandy sequence from the other intervals is arbitrary. The sandy sequence is differentiated from the gravelly strata of the upper and lower gravel sequences on the basis of sand content. The base of the sandy sequence is placed at the top of the highest gravelly interval and underlies sand-dominated strata. The top of the sequence is placed at the top of the highest thick, sand-dominated interval. The unit ranges up to $15 \mathrm{~m}(50 \mathrm{ft})$ thick in the paleochannel east of the 200 North Aggregate Area, and up to $8 \mathrm{~m}(25 \mathrm{ft})$ in the eastern extreme of the area.

The third unit of the Hanford formation stratigraphic sequence consists of graveldominated strata referred to as the upper gravel sequence. This sequence is dominated by deposits typical of the gravel-dominated facies. The sequence thins from as much as $70 \mathrm{~m}$ $(230 \mathrm{ft})$ in the north to zero near the southern border of the 200 East Area. It is thickest over the paleochannel east of the 200 North Aggregate Area, but spreads farther from the channel than underlying units.

Subsurface data show the 200 North Aggregate Area to be underlain primarily by undifferentiated Hanford (figures 3-26 and 3-27). Undifferentiated Hanford extends to the north and south of the aggregate area (figure 3-31). In the extreme eastern portion of the aggregate area, however, the sandy sequence is present and thickens from zero to $10 \mathrm{~m}$ $(33 \mathrm{ft})$ to the east. The presence of the sandy sequence in this portion of the aggregate area permits differentiation of the upper gravel sequence from the lower gravel sequence. Where the sandy sequence is present, the lower gravel sequence is apparently absent (Figure 3-26). The sandy sequence is overlain by sediments of the upper gravel sequence and which reach a maximum thickness of $70 \mathrm{~m} \mathrm{(230} \mathrm{ft)} \mathrm{(Figures} \mathrm{3-26} \mathrm{and} \mathrm{3-27).} \mathrm{Farther} \mathrm{east} \mathrm{of} \mathrm{the} \mathrm{aggregate}$ area, the sandy and upper gravel sequences occur primarily as channel-silting sediments in a south-trending channel eroded through the Elephant Mountain Member (Figures 3-17, 3-28, and 3-29).

In Figures 3-26 through 3-30, many isopach contours terminate against the 0 thickness contour at high angle, without intervening contours of progressively less thickness. Relations like this can be indicative of fault truncation, but the Hanford formation is not faulted and the disposition of the contours is caused by the depositionai environment of the Hanford formation, stratigraphic differentiation, and the fact that each figure represents a subset of the Hanford formation. 
The Hanford formation was deposited in cataclysmic flood events, which scoured channels through the uppermost basalt unit, and then filled those channels. This created steep-walled channels, where infilling sediments can thin extremely across very little distance, causing abrupt contour contacts, especially along the banks of the channel.

The dominant causes of the unusual contour patterns, however, are caused by the systematics by which Lindsey et al. (1992) generated them. Figures 3-26 through 3-30 illustrate different subdivisions of the Hanford formation, which in older boreholes is prevented from subdivision due to the generalized boring logs completed when they were drilled. In the cross sections, Lindsey et al. (1992) distinguish various subdivisions of the Hanford formation from Hanford-Undifferentiated, and communicate the difference in the contour maps by abruptly terminating a Hanford formation subdivision, no matter how thick it is, when it can no longer be differentiated. Comparing Figure 3-16 to Figures 3-26 through 3-30 illustrates this well. Figure 3-31 shows the entire Hanford formation with a regular thinning and thickening, without breaks or abrupt contacts that appear in contour maps of the Hanford formation subdivisions.

3.4.3.6 Holocene Surficial Deposits. Holocene-age surficial deposits in the 200 North Aggregate Area are dominated by very fine- to medium-grained to occasionally silty eolian sands. These deposits have been removed from much of the area by construction activities. Where the eolian sands are found they tend to consist of thin $(<3 \mathrm{~m}, 10 \mathrm{ft})$ sheets that cover the ground. Dunes are not generally well developed within the 200 North Aggregate Area. The Holocene surficial deposits are not differentiated on cross-sections and maps because they are relatively thin and because of the lack of definition on so many of the borehole geologic logs available for the 200 North Aggregate Area.

\subsection{HYDROGEOLOGY}

Regional hydrogeology and hydrogeology of the 200 North Area are summarized in the following sections. Where sufficient data exists, interpretations of the hydrogeology beneath the 200 North Aggregate Area are presented. The information presented in these sections is principally taken from the standardized text (Delaney et al. 1991) provided by Westinghouse Hanford for this purpose.

\subsubsection{Regional Hydrogeology}

The hydrogeology of the Pasco Basin is characterized by a multiaquifer system that consists of four hydrogeological units tha: correspond to the upper three formations of the Columbia River Basalt Group (Grande Ronde Basalt, Wanapum Basalt, and Saddle Mountains Basalt) and the suprabasalt sediments. The basalt aquifers consist of the tholeiitic flood basalts of the Columbia River Basalt Group and relatively minor amounts of intercalated fluvial and volcaniclastic sediments of the Eliensburg Formation. Confined zones in the basalt aquifers are present in the sedimentary interbeds and/or interflow zones 
that occur between dense basalt flows. The main water-bearing portions of the interflow zones are networks of interconnecting vesicles and fractures of the flow tops and flow bottoms (DOE 1988b). The suprabasalt sediment or uppermost aquifer system consists of fluvial, lacustrine, and glaciofluvial sediments. This aquifer is regionally unconfined and is contained largely within the Ringold Formation and Hanford formation. The position of the water table in the southwest Pasco Basin is generally within the Ringold fluvial gravels of unit E. In the northern and eastern Pasco Basin the water table is generally within the Hanford formation. Table 3-1 presents hydraulic parameters for various water-bearing geologic units at the Hanford Site.

Local recharge to the shallow basalt aquifers results from infiltration of precipitation and runoff along the margins of the Pasco Basin, and in areas of artificial recharge where a downward gradient from the unconfined aquifer systems to the uppermost confined basalt aquifer may occur. Regional recharge of the deep basalt aquifers is inferred to result from interbasin groundwater movement originating northeast and northwest of the Pasco Basin in areas where the Wanapum and Grande Ronde Basalts crop out extensively (DOE 1988b). Groundwater discharge from shallow basalt aquifers is probably to the overlying aquifers and to the Columbia River. The discharge area(s) for the deeper groundwater system is uncertain, but flow is inferred to be generally southeastward with discharge thought to be south of the Hanford Site (DOE 1988b).

Erosional "windows" through dense basalt flows allows direct interconnection between the uppermost aquifer systems and underlying confined basalt aquifers. Graham et al. (1984) reported that some contamination was present in the uppermost confined aquifer (Rattlesnake Ridge interbed) south and east of Gable Mountain Pond. Graham et al. (1984) evaluated the hydrologic relationships between the Rattlesnake Ridge Interbed aquifer and the unconfined aquifer in this area and delineated a potential area of intercommunication beneath the northeast portion of the 200 East Area.

The base of the uppermost aquifer system is defined as the top of the uppermost basalt flow. However, fine-grained overbank and lacustrine deposits in the Ringold Formation locally form confining layers for Ringold fluvial gravels underlying unit E. The uppermost aquifer system is bounded laterally by anticlinal basalt ridges and is approximately $152 \mathrm{~m}$ $(500 \mathrm{ft})$ thick near the center of the Pasco Basin.

Sources of natural recharge to the uppermost aquifer system are rainfall and runoff from the higher bordering elevations, water infiltrating from small ephemeral streams, and river water along influent reaches of the Yakima and Columbia Rivers. The movement of precipitation through the unsaturated (vadose) zone has been studied at several locations on the Hanford Site (Gee 1987; Routson and Johnson 1990; Rockhold et al. 1990). Conclusions from these studies vary. Gee (1987) and Routson and Johnson (1990) conclude that no downward percolation of precipitation occurs on the 200 Areas Plateau where the sediments are layered and vary in texture, and that all moisture penetrating the soil is remnyed uy evapotranspiration. These two studies analyzed data collected over a period of 12 and 14 years, respectively, and do not specifically address short-term seasonal fiuctuations. 
Rockhold et al. (1990) suggest that downward water movement below the root zone is common in the 300 Area, where soils are coarse-textured and precipitation is above normal.

\subsubsection{Hanford Site Hydrogeology}

This section describes the hydrogeology of the Hanford Site with specific reference to the 200 Areas.

3.5.2.1 Hydrostratigraphy. The hydrostratigraphic units of concern in the 200 Areas are (1) the Rattlesnake Ridge interbed (confined water-bearing zone), (2) the Elephant Mountain Member (confining horizon), (3) the Ringold Formation (unconfined and confined waterbearing zones and lower part of the vadose zone), (4) the Plio-Pleistocene unit and early "Palouse" soil (primary vadose zone perching horizons and/or perched groundwater zones) and (5) the Hanford formation (vadose zone) (Figure 3-32). The Plio-Pleistocene unit and early "Palouse" soil are only encountered in the 200 West Area. Strata below the Rattlesnake Ridge interbed are not discussed because the more significant water-bearing intervals, relating to environmental issues, are primarily closer to ground surface. The hydrogeologic designations for the 200 Areas were determined by examination of borehole logs and integration of these data with stratigraphic correlations from existing reports.

3.5.2.1.1 Vadose Zone. The vadose zone beneath the 200 Areas ranges from approximately $55 \mathrm{~m}(180 \mathrm{ft})$ beneath the former $U$ Pond to approximately $104 \mathrm{~m} \mathrm{(340} \mathrm{ft)}$ west of the 200 East Area (Last et al. 1989). Sediments in the vadose zone consist of the (1) fluvial gravel of Ringold unit E, (2) the upper unit of the Ringold Formation, (3) PlioPleistocene unit, (4) early "Palouse" soil, and (5) Hanford formation. Only the Hanford formation is continuous throughout the vadose zone in the 200 Areas. The upper unit of the Ringold Formation, the Plio-Pleistocene unit, and the early "Palouse" soil only occur in the 200 West Area. The unconfined aquifer water table (discussed in Section 3.5.2.1.3) lies within the Ringold unit $\mathrm{E}$ and the Hanford formation.

The transport of water through the vadose zone depends in complex ways on several factors, including most significantly the moisture content of the soils and their hydraulic properties. Darcy's law, although originally conceived for saturated flow only, was extended by Richards to unsaturated flow, with the provisions that the soil hydraulic conductivity becomes a function of the water content of the soil and the driving force is predominantly differences in moisture level. The moisture flux, $\mathrm{q}$, in $\mathrm{cm} / \mathrm{s}$ in one direction is then described by a modified form of Darcy's law commonly referred to as Richards' Equation (Hillel 1971) as follows:

$$
\mathrm{q}=\mathrm{K}(\theta) \times \partial \varphi / \partial \theta \times \partial \theta / \partial \times \text { (Richards' Equation) }
$$

where

- $\mathbf{K}(\theta)$ is the water-content-dependent unsaturated hydraulic conductivity in $\mathrm{cm} / \mathrm{s}$ 
Once the relationship between unsaturated hydraulic conductivity and moisture content is known for a paricular lithologic unit, travel time can also be estimated for a steady-state flux passing through each layer by assuming a unit hydraulic gradient. Under the unit gradient condition, only the force of gravity is acting on water and all other forces are considered negligible. These assumptions may be met for flows due to natural recharge since moisture differences become smoothed out after sufficient time. Travel time for each lithologic unit of a set thickness and calculated for any given recharge rate and the total travel time is equivalent to the sum of the travel times for each individual lithologic unit. To calculate the travel time for any particular waste management unit the detailed layering of the lithologic units should be considered. For waste management units with artificial recharge (e.g., cribs and trenches) more complicated analyses would be required to account for the efffects of saturation.

Several other investigators have measured vadose zone soil hydraulic conductivities and moisture retention characteristics at the Hanford Site both in situ (i.e., in lysimeters) and in specially prepared laboratory test columns. Table 3-2 summarizes data identified for this study by stratigraphic unit. Rockhold et al. (1988) presents a number of moisture retention characteristic curves and plots of hydraulic conductivity versus moisture content for various Hanford soils. For the Hanford formation, vadose zone hydraulic conductivity values at saturation range from $10^{-4}$ to $10^{-2} \mathrm{~cm} / \mathrm{s}$. 'These saturated hydraulic conductivity values were measured at volumetric water contents of 40 to $50 \%$. Hydraulic conductivity values corresponding to volumetric water contents, ranging from 2 to $10 \%$, ranged from $2 \times 10^{-11}$ to $7 \times 10^{-7} \mathrm{~cm} / \mathrm{s}$.

An example of the potential use of this vadose zone hydraulic parameter information is presented by Smoot et al. (1989) in which precipitation infiltration and subsequent contaminant plume movement near a prototype single-shell tank was evaluated using a numerical computer code. Smoot et al. (1989) used the UNSAT-H one-dimensional finitedifference unsaturated zone water flow computer code to predict the precipitation infiltration for several different soil horizon combinations and characteristics. The researchers used statistically generated precipitation values that were based on actual daily precipitation values recorded at the Hanford Site between 1947 and 1989 to simulate precipitation infiltration from January 1947 to December 2020 . The same authors also used the PORFLO-3 computer code to simulate ${ }^{106} \mathrm{Ru}$ and ${ }^{137} \mathrm{Cs}$ movement through the unsaturated zone.

Smoot et al. (1989) concluded that 68 to $86 \%$ of the annual precipitation infiltrated into a gravel-capped soil column while less than $1 \%$ of the annual precipitation infiltrated into a silt loam-capped soil column. For the gravel-capped soil column, the simulations showed the ${ }^{106} \mathrm{Ru}$ plume approaching the water table after 10 years of simulated precipitation infiltration. The simulated ${ }^{137} \mathrm{Cs}$ plume migrated a substantially shorter distance due to greater adsorption on soil particles. In both cases, the simulated plume migration scenarios are considered to be conservative due to the relatively large soil absorption coefficients used.

Graham et al. (1981) estimated that historical artificial recharge from liquid waste disposal in the 200 (Separations) Areas exceeded all natural recharge by a factor of ten. In 
the absence of ongoing artificial recharge, i.e., liquid waste disposal to the soil column, natural recharge could potentially be a driving force for mobilizing contaminants in the subsurface. Natural sources of recharge to the vadose zone and the underlying water table aquifer are discussed in Section 3.5.2.2. Additional discussion of the potential for natural and artificial recharge to mobilize subsurface contaminants is presented in Section 4.2.

Another facet of moistuze migration in the vadose zone is moisture retention above the water table. Largely because of capillary forces, some portion of the moisture percolating down from the ground surface to the unconfined aquifer will be held against gravity in soil pore space. Finer-grained soils retain more water (against the force of gravity) on a volumetric basis than coarse-grained soils (Hillel 1971). Because unsaturated hydraulic conductivity increases with increasing moisture content, finer-grained soils may be more permeable than coarse-grained soils at the same water content. Also, because the moisture retention curve for coarse-grained soils is generally quite steep (Smoot et al. 1989), the permeability contrast between fine-grained and coarse-grained soils at the same water content can be substantial. The occurrence of interbedded fine-grained and coarse-grained soils may result in the formation of "capillary barriers" and can in turn lead to the formation of perched water zones. General conditions leading to the formation of perched water zones at the Hanford Site are discussed in Section 3.5.2.1.2. The potential for perched water zones in the 200 North Aggregate Area is discussed in Section 3.5.3.1.2.

3.5.2.1.2 Perched Water Zones. Moisture moving downward through the vadose zone may accumulate on top of highly cemented horizons and may accumulate above the contact between a fine-grained horizon and an underlying coarse-grained horizon as a result of the "capillary barrier" effect. If sufficient moisture accumulates, the soil pore space in these perching zones may become saturated. In this case, the capillary pressure within the horizon may locally exceed atmospheric pressure, i.e., saturated conditions may develop. Additional input of downward percolating moisture to this horizon may lead to a hydraulic head buildup above the top of the horizon. Consequently, a monitoring well screened within or above this horizon would be observed to contain free water.

The lateral extent and composition of the Plio-Pleistocene and early "Palouse" soil units may provide conditions amenable to the formation of perched water zones in the vadose zone above the unconfined aquifer. The calcrete facies of the Plio-Pleistocene unit, consisting of calcium-carbonate-cemented silt, sand, and gravel, is a potential perching horizon due to its likely low hydraulic conductivity. However, the Plio-Pleistocene unit is typically fractured and may have erosional scours in some areas, potentially allowing deeper infiltration of groundwater, a factor which may limit the lateral extent of accumulated perched groundwater. The early "Palouse" soil horizon, consisting of compact, loess-like silt and minor fine-grained sand, is also a likely candidate for accumulating moisture percolating downward through the sand and gravel-dominated Hanford formation. As discussed earlier, the Plio-Pleistocene unit and the early "Palouse" soil do not occur in the 200 East Area. Fine grained layers in the Hanford and Ringold Formations may, however, act as local perching zones. 
3.5.2.1.3 Unconfined Aquifer. The uppermost aquifer system in the 200 Areas is an unconfined aquifer and occurs primarily within the sediments of the Ringold Formation and Hanford formation. In the 200 West Area the upper aquifer is contained within the Ringold Formation and displays unconfined to locally confined or semiconfined conditions. In the 200 North Aggregate Area the upper aquifer occurs in the Hanford formation. The depth to groundwater in the upper aquifer underlying the 200 Areas ranges from approximately $60 \mathrm{~m}$ (197 ft) beneath the former 216-U-10 Pond in the 200 West Area to approximately $105 \mathrm{~m}$

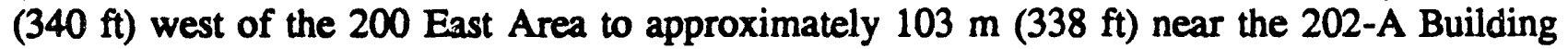
in the 200 Easi Area. In the 200 North Aggregate Area depth to groundwater ranges from 44 to $49 \mathrm{~m}$ (143 to $160 \mathrm{ft}$ ). The unconfined aquifer thins out near Gable Butte, where basalt is higher than the water table (Figure 3-34). The saturated thickness of the unconfined aquifer ranges from approximately 67 to $112 \mathrm{~m} \mathrm{(220} \mathrm{to} 368 \mathrm{ft})$ in the 200 West Area and approximately $61 \mathrm{~m}(200 \mathrm{ft})$ in the southern 200 East Area to nearly absent in the northeastern 200 East Area and northern 200 North Aggregate Area where the aquifer thins out and terminates against the basalt located above the water table in that area. The saturated thickness in the 200 North Aggregate Area reaches $52 \mathrm{~m}(170 \mathrm{ft})$ in the east.

The upper part of the uppermost aquifer in the 200 East Area and the 200 North Aggregate Area consists of generally unconfined groundwater withifi ine Ringold unit E. In the northern and eastern part of the 200 North Aggregate Area, the Ringold Formation is absent and the water table is located within the Hanford formation.

Due to its importance with respect to contaminant transport, the unconfined aquifer is generally the most characterized hydrologic unit beneath the Hanford Site. A number of observation wells have been installed and monitored in the unconfined aquifer. Additionally, in situ aquifer tests have been conducted in a number of the unconfined aquifer monitoring wells. Results of these in situ tests vary greatly depending on the following:

- Horizontal position/location between areas across the Hanford Site and even smaller areas (such as across portions of the 200 Areas)

- Depth, even within a single hydrostratigraphic unit

- Analytical methods for estimating hydraulic conductivity.

Details regarding this aquifer system will be discussed in the 200 East Groundwater Aggregate Area Management Study Report (AAMSR).

3.5.2.2 Natural Groundwater Recharge. Sources of natural recharge to groundwater at the Hanford Site include precipitation infiltration, runoff from higher bordering elevations and subsequent infiltration within the Hanford Site boundaries, water infiltrating from small ephemeral streams, and river water infiltrating along influent reaches of the Yakima and Columbia Rivers (Graham et al. 1981). The principal source of naiural recharge is believed to be precipitation and runoff infiltration along the periphery of the Pasco Basin. Small streams such as Cold Creek and Dry Creek, west of the 200 West Area, also lose water to 
the ground as they spread out on the valley plain. Considerable debate exists as to whether any recharge to groundwater occurs from precipitation falling on broad areas of the 200 Areas Plateau.

Natural precipitation infiltration at or near waste management units or unplanned releases may provide a driving force for the mobilization of contaminants previously introduced to surface or subsurface soils. For this reason, determination of precipitation recharge rates at the Hanford Site has been the focus of many previous investigations. Previous field programs have been designed to assess precipitation, infiltration, water storage changes, and evaporation to evaluate the natural water balance during the recharge process. Precipitation recharge values ranging from 0 to $10 \mathrm{~cm} / \mathrm{yr}(0$ to $4 \mathrm{in} / \mathrm{yr})$ have been estimated from various siudies.

The primary factors affecting precipitation recharge appear to be surface soil type, vegetation type, topography, and year-to-year variations in seasonal precipitation. A modeling analysis (Smoot et al. 1989) indicated that 68 to $86 \%$ of the precipitation falling on a gravel-covered site might infiltrate to a depth greater than $2 \mathrm{~m}(6 \mathrm{ft})$. As discussed below, various field studies suggest that less than $25 \%$ of the precipitation falling on typical Hanford Site soils actually infiltrates to any depth.

Examples of precipitation recharge studies include:

- A study by Gee and Heller (1985) described various models used to estimate natural recharge rates. Many of the models use a water retention relationship for the soil. This relates the suction required to remove (or move) water to its dryness (saturation or volumetric moisture content). Two of these have been developed by Gee and Heller (1985) for soils in lysimeters on the Hanford Site. As an example of available data, the particle size distribution and the water retention curves of these two soils are shown in Figure 3-34. Additional data and information about possible models for unsaturated flow may be found in Brownell et al. (1975), and Rockhold et al. (1990).

- Moisture contents have been obtained from a number of core-barrel samples in the 200 Areas (East and West) and varied from 1 to $18 \%$, with most in the range of 2 to $6 \%$ (Last et al. 1989). The data appear to indicate zones of increased moisture content that could be interpreted as signs of moisture transport.

- A lysimeter study reported by Routson and Johnson (1990) was conducted at a location $1.6 \mathrm{~km}$ south of the 200 East Area. During much of the lysimeters' 13year study period between 1972 and 1985, the surface of the lysimeters were maintained unvegetated with herbicides. No information regarding the soil types in the lysimeters was found. To a precision of $+/-0.2 \mathrm{~cm}$, no downward moisture movement was observed in the instruments during periodic neutronmoisture measurements or as a conclusion of a final soil sample collection and moisture content analysis episode. 
- An assessment of precipitation recharge involving the redistribution of ${ }^{137} \mathrm{Cs}$ in vadose zone soil also reported by Routson and Johnson (1990). In this study, split-spoon soil simples were collected beneath a solid waste burial trench in the T Plant Aggregace Area. The trench, located just south and west of the 218-W3AE Burial Ground, approximately $6 \mathrm{~km}(3.7 \mathrm{mi})$ west of the 200 East Area, received soil containing ${ }^{137} \mathrm{Cs}$ from an unspecified spill. Cesium-137 was not detected below the bottom of the burial trench. However, increased ${ }^{137} \mathrm{Cs}$ activity was observed above the top of the waste fill which Routson and Johnson concluded indicated that net negative recharge (loss of soil moisture to evapotranspiration) had occurred during the 10-year burial period.

Sparse Russian thistle was observed at the burial trench area in 1980. Rockhold et al. (1990) noted that ${ }^{137} \mathrm{Cs}$ appears to absorb strongly to Hanford Site soils indicating that the absence of the radionuclide at depth below the burial trench may not support the conclusion that no downward moisture movement occurred.

- A weighing lysimeter study reported by Rockhold et al. (1990) was conducted at a grassy plot approximately $5 \mathrm{~km}(3 \mathrm{mi})$ northwest of the 300 Area. The grass test site was located in a broad, shallow topographic depression approximately $900 \mathrm{~m}(2,953 \mathrm{ft})$ wide, several hundred meters long, trending southwest. The area is covered with annual grasses (cheatgrass and bluegrass). The upper $3.5 \mathrm{~m}$ $(11.5 \mathrm{ft})$ of the soil profile consists of slightly silty to silty sand (sandy loam) with an estimated saturated hydraulic conductivity of $9 \times 10^{-3} \mathrm{~cm} / \mathrm{s}$. Rockhold et al. (1990) estimated that approximately $0.8 \mathrm{~cm}(0.3 \mathrm{in}$.$) of downward moisture$ movement occurred between July 1987 and June 1988. This represents approximately $7 \%$ of the total precipitation recorded in that area during that time period.

- A gravel-covered lysimeter study discussed by Rockhold et al. (1990) was conducted at the 200 East Area lysimeter site, approximately $1 \mathrm{~km}(1.6 \mathrm{mi})$ south

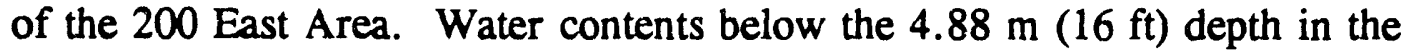
closed-bottom lysimeter have not changed reasonably between 1972 and 1988, implying that significant recharge has not occurred. Data are insufficient to conclude whether the presence of a plant community on the lysimeter is the reason for the lack of water increase.

The drainage (downward moisture movement) observed in these studies may represent potential recharge to deeper vadose zone soils and/or the underlying water table.

3.5.2.3 Groundwater Flow. Groundwater flow north of Gable Mountain currently trends in a northeasterly direction as a result of mounding near reactors and flow through Gable Gap. South of Gable Mountain, flnw is interrupted locally by the groundwater mounds in the 200 Areas. There is also a component of groundwater flow to the north between Gable Mountain and Gable Butte from the 200 Areas. In the 200 East Area, groundwater 
elevations in June 1990 (Figure 3-34) for the unconfined aquifer showed little variation and were generally around $133 \mathrm{~m}$ (405 ft) (Kasza et al. 1990).

Temporary reversal of groundwater flow entering the Columbia River may occur during transient, high-river stages. This occurrence is known as bank storage. Correlations were made between groundwater level and river-stage fluctuations along a $81 \mathrm{~km}(50 \mathrm{mi})$ reach of the Columbia River adjacent to the Hanford Site by Newcomb and Brown (1961). They concluded that a $260 \mathrm{~km}^{2}\left(100 \mathrm{mi}^{2}\right)$ area within the Hanford Site was affected by bank storage. During a 45 day rise in river stage, it was estimated that water infiltrated at an average rate of $4,500,000 \mathrm{~m}^{3} /$ day $\left(3,700\right.$ acre-ft/day) versus $1,233,000 \mathrm{~m}^{3} /$ day $(1,000$ acre$\mathrm{ft} /$ day) during the 165 day recession period. Since this study was conducted, dam control on the Columbia River has reduced the magnitude of bank storage on the groundwater system.

Natural groundwater inflow to the unconfined aquifer primarily occurs along the western boundary of the Hanford Site. Historically, much greater recharge occurred from a number of waste management units in the 200 Areas. Manmade recharge probably substantially exceeded natural precipitation recharge in these areas. The unconfined aquifer ultimately discharges to the Columbia River, either near the 100 Areas, north of the 200 Areas through Gable Gap, or between the 100 Areas and the 300 Area, east of the 200 Areas. The precise path is strongly dependent on the hydrologic conditions in the 200 East Area (Delaney et al. 1991). If recharge in the 200 East Area is large, more of the recharge from the 200 West Area is diverted north through Gable Gap toward the 100 Areas.

Generally, however, the easterly route appears to be more likely for recharge from the 200 West Area.

3.5.2.4 Historical Effects of Operations. Historical effluent disposal at the Hanford Site altered previously prevailing groundwater hydraulic gradients and flow directions. Before operations at the Hanford Site began in 1944, groundwater flow was generally toward the east, and the groundwater hydraulic gradient in the 200 East Area was on the order of 0.0003 (Delaney et al. 1991). Prior to disposing liquid waste to the soil column in the 200 (Separations) Areas, groundwater elevations in the 200 East Area may have been as much as $18 \mathrm{~m}$ (55 ft) lower in 1944 than at present. As seen in Figure 3-34, a distinct groundwater mound is still apparent east of the 200 East Area near the 216-B-3 Pond. The 216-B-3 Pond has caused the groundwater flow direction to change to a northwest-southeast flow pattern. Before its stabilization, water routed to the Gable Mountain Pond created a mound, blocking the eastward flow of groundwater and forcing it north, through Gable Gap.

\subsubsection{North Aggregate Area Hydrogeology}

This section presents additional hydrogeologic information identified with specific application to the 200 North Aggregate Area.

3.5.3.1 Hydrostratigraphy. As shown on Figure 3-36, the hydrostratigraphic units of concern beneath the 200 North Aggregate Area are (1) the Rattlesnake Ridge interbed, (2) 
the Elephant Mountain Basalt member, (3) the Ringold Formation E, and (4) the Hanford formation. The hydrogeologic designations for the 200 North Aggregate Area were determined by examination of borehole logs from Lindsey et al. (1992) and integration of these data with stratigraphic correlations from existing reports. For the purposes of the 200 North AAMSR, this discussion will be limited to the vadose zone and possible perching horizons with the vadose zone underlying the aggregate area. Additional information on the aquifer systems will be discussed in the 200 East Groundwater AAMSR.

3.5.3.1.1 Vadose Zone. Based on the June 1990 groundwater elevation data (Kasza et al. 1990), the vadose zone beneath the 200 North Aggregate Area ranges in thickness from about $49 \mathrm{~m}(160 \mathrm{ft})$ along the western part of the aggregate area to $50 \mathrm{~m}(165 \mathrm{ft})$ in the east (Figure 3-35). The observed variation in vadose zone thickness is the result of variable surface topography and the variable elevation of the water table in the underlying unconfined aquifer.

During the 1985 Grout Treatment Facility (GTF) baseline and site characterization study, several groundwater monitor wells were drilled (Swanson et al. 1988). The data collected from the drilling of these wells (299-E25-25, 299-E25-26, 299-E25-27 and 299-E25-28) provided information pertaining to the vadose zone east of the 200 North Aggregate Area, in Hanford formation. Similar data were collected, to the west from groundwater monitor wells adjacent to the 216-U-12 Crib and at the southwest border of the U Plant Aggregate Area (Goodwin 1990). Analysis of the borehole samples collected from the GTF and U Plant indicate that soil moisture is normally between $<1 \%$ to $27 \%$ by weight. Of 105 samples analyzed for moisture content from the U Plant Aggregate Area, $86 \%$ were between $1 \%$ and $10 \%$ by weight; gravelly sands averaged $1.4 \%$ by weight. At the GTF, 126 samples were collected for soil moisture and $89 \%$ were between $1 \%$ and $10 \%$ by weight. The gravelly samples from the GTF had an average moisture content of $2.6 \%$. It should be noted however, that both investizations are in the vicinity of previously active cribs and/or ditches, and that there is some impact by the disposal of liquid waste on these moisture contents. Also, since the 200 North Aggregate Area is underlain by more gravelly Hanford units, the lower averages are probably more representative.

3.5.3.1.2 Perched Water Zones. Unlike other areas on the Hanford Site, the likelihood of perched water occurring in the 200 North Aggregate Area is low. In the 200 West Area perched water is found predominantly in the Plio-Pleistocene and the early "Palouse" soil. Those stratigraphic units are not present in the 200 East Area. However, because of the large quantity of liquid waste disposed of and variabiloity of the grain size/stratigraphy and occurrence of intercalated lenses, perched groundwater is possible.

3.5.3.2 Natural Groundwater Recharge. As discussed in Section 3.3.3, only one natural surface water body exists near the 200 North Aggregate Area near Gable Mountain. Other than in this one location, the potential for natural groundwater recharge within the 200 North Aggregate Area is limited to precipitation infiltration. No precipitation infiltration data were identified with specific reference to the 200 North Aggregate Area. However, the amount of 
precipitation infiltration is likely comparable to the range of values identified for various Hanford test sites, i.e., 0 to $10 \mathrm{~cm} / \mathrm{yr}$.

As suggested in Section 3.5.2.2, precipitation infiltration rates probably vary with respect to location within the $\mathbf{2 0 0}$ North Aggregate Area. Higher infiltration rates are expected in unvegetated areas or areas with shallow rooting plants in areas with gravelly soils exposed at the surface, and in areas where the topography is flat.

3.5.3.3 Groundwater Flow Beneath the 200 North Aggregate Area. Within the 200 North Aggregate Area, groundwater flow is generally toward the east, based on December 1990 Hanford wells groundwater elevation data (DOE/RL 1991a) (Figure 3-35). A review of groundwater maps of the unconfined aquifer (Kasza et al. 1990) indicates a fairly even gradient east to the West Lake Area, where the gradient becomes nearly flat. From this area, groundwater could flow north through Gable Gap, or southeast skirting Gable Mountain.

Graham et al. (1984) and Lindsey et al. (1992) show that in the Gable Mountain area, erosional windows in the Elephant Mountain Basalt are adjacent to the unconfined aquifer and the unconfined Rattlesnake Ridge interbed. This has the effect of bringing the confined Rattlesnake Ridge interbed aquifer in contact with the unconfined aquifer. Graham et al. (1984) detected tritium and iodine contamination in the Rattlesnake Ridge interbed, showing that hydraulic communication exists. The Rattlesnake Ridge aquifer eventually discharges back into the unconfined aquifer (through the erosional window) near West Lake; consequently both aquifers under the $\mathbf{2 0 0}$ North Aggregate Area may contain contamination from Gable Mountain Pond.

3.5.3.4 Historical Effects of Operations. Artificial recharge from waste management facilities within the 200 North Area probably caused minor changes to the water levels of the unconfined aquifer between 1944 and the end of the plant facilities in 1952. Given the time since the end of recharge and the general eastward gradient under most of the 200 North Aggregate Area, the effects of operations have probably dissipated. However, in the eastern part of the 200 North Aggregate Area, and in the vicinity east of the aggregate area, Hanford operations have had a substantial effect.

Historically, the majority (greater than $90 \%$ ) of wastewater discharged from the 200 East Area has been routed to the B or Gable Mountain Ponds (Zimmerman et al. 1986). Between 1943 and 1980 approximately $3.433 \times 10^{11} \mathrm{~L}\left(9.07 \times 10^{10} \mathrm{gal}\right)$ of wastewater had been discharged to these ponds. In 1957 the Gable Mountain Pond began receiving wastewater, and recharge was enough to raise the local unconfined aquifer sufficiently to block the former eastward flow and force groundwater to flow north through Gable Gap. During this time groundwater elevations in the unconfined aquifer and the topmost interbeds in the underlying basalt were identical and in apparent equilibrium, suggesting hydraulic communication between Gable Mountain Pond and underlying "confined" aquifers. The existence of erosional windows that are adjacent to the Hanford formation and the 
Rattlesnake Ridge Interbed directly (Lindsey et al. 1992; Graham et al. 1984) shows that hydraulic communication between aquifers exists.

Between 1950 and 1955 small groundwater elevation increases occurred south of Gable Mountain in response to wastewater discharges from B Plant. The existence of nitrate, cyanide, and total beta plumes north of 200 East (ascribed to discharges from the cribs in 200-BP-1) may be a result of this mounding (DOE/RL 1991b). Nitrate extends across the eastern part of the 200 North Aggregate Area, through Gable Gap, while total beta and cyanide plumes skirt the eastern edge of the aggregate area (DOE/RL 1991b).

\subsection{ENVIRONMENTAL RESOURCES}

The Hanford Site is characterized as a cool desert or a shrub-steppe and supports a biological community typical of this environment.

\subsubsection{Flora and Fauna}

The 200 Areas Plateau is represented by a number of plant, mammal, bird, reptile, amphibian, and insect species as discussed below.

3.6.1.1 Vegetation of the 200 Areas Plateau. The vegetation of the 200 Areas Plateau is characterized by native shrub steppe interspersed with large areas of disturbed ground with a dominant annual grass component. The native stands are classified as an Artemisia tridentatalPoa sandbergii - Bromuś tectorum community (Rogers and Rickard 1977) meaning that the dominant shrub is big sagebrush (Artemisia tridentata) and the understory is dominated by the native Sandberg's bluegrass (Poa sandbergii) and the introduced annual cheatgrass (Bromus tectorum). Other shrubs that are typically present include gray rabbitbrush (Chrysothamnus nauseosus), green rabbitbrush (C. viscidiflorus), spiny hopsage (Grayia spinosa), and occasionally antelope bitterbrush (Pursia tridentata). Other native bunchgrasses that are typically present include bottlebrush squirreltail (Sitanion hystrix), Indian ricegrass (Oryzopsis hymeitoides), needle-and-thread (Stipa commode), and prairie junegrass (Koleria cristata). Common and important herbaceous species include turpentine cymopteris (Cymopteris terebinthinus), globemallow (Spheracea munroana), balsamroot (Basamorhiza careyana), several milk vetch species (Astragalus caricinus, A. sclerocarpus, A. succumbens), long-leaf phlox (Phlox longifolia), the common yarrow (Achillea millifolium), pale evening-primrose (Oenothera pallida), thread-leaf phacelia (Phacelia linearis), and several daisy/fleabane species (Erigeron poliospermus, E. Filifolius, and E. pumilus). In all, well over 100 plant species have been documented to occur in native stands on the 200 Areas Plateau.

Disturbed communities on the 200 Areas Plateau are primarily the result of either mechanical disturbance or range fires. Mechanical disturbance, including construction activities, soli borrow areas, road clearings, and fire breaks, results in drastic changes to the 
plant community. This type of disturbance usually entails a complete loss of soil structure and total disruption of nutrient cycling. The principle colonizers of mechanically disturbed areas are the annual weeds Russian thistle (Salsola kali), Jim Hill mustard (Sisymbrium altissimum), and bur-ragweed (Ambrosia acanthicarpa). If no further disturbance occurs, the areas will eventually become dominated by cheatgrass. All of these annual weeds are occasionally found in native stands, but only at relatively low frequencies.

Range fires also have dramatic effects on the overall ecosystem, the most obvious being the complete removal of Sagebrush from the community, and the rapid increase in cheatgrass coverage. Unlike the native grasses, the other important shrubs, and many of the perennial herbaceous species, Sagebrush is unable to resprout from rootstocks after being burned. Therefore, there is no dominant shrub component in burned areas until Sagebrush is able to become re-established from seed. Burning also opens the community to the invasion by cheatgrass, which is capable of quickly utilizing the nutrients that are released through burning. The extensive cover of cheatgrass may then prevent the re-establishment of many of the native species, including Sagebrush. The species richness in formerly burned areas is usually much lower than in native stands, often consisting of only cheatgrass, Sandberg's bluegrass, Russian thistle, and Jim Hill mustard, with very few other species.

The vegetation in and around the ponds and ditches on the 200 Areas Plateau is significantly different from that of the surrounding dryland areas. Several tree species are present, especially cottonwood (Populus trichocarpa) and willows (Salix spp.). A number of wetland species area also present including several sedges (Carex spp.), bulrushes (Scirpus spp.), cattails (Typha latifolia and T. angustifolia), and pond-weeds (Potamogeton spp.).

\subsubsection{Plant Species of Concern. The Washington State Department of Natural} Resources, Natural Heritage Program classifies rare plants in the State of Washington in three different categories, depending on the overall distribution of the taxon and the state of its natural habitat. These categories are: Endangered, which is a "vascular plant taxon in danger of becoming extinct or extirpated in Washington within the near future if factors contributing to its decline continue. Populations of these taxa are at critically low levels or their habitats have been degraded or depleted to a significant degree"; Threatened, which is a "vascular plant taxon likely to become endangered within the near future in Washington if factors contributing to its population decline or habitat degradation or loss continue"; and Sensitive, which is a taxon that is "vulnerable or declining, and could become endangered or threatened in the state without active management or removal of threats" (definitions taken from the Washington Natural Heritage Program [1990]). Of concern to the Hanford Site, there are two Endangered taxa, two Threatened taxa, and at least eleven Sensitive taxa; these are listed in Table 3-3. All four of the Threatened and Endangered taxa are presently candidates for the Federal Endangered Species List.

Of the two Endangered taxa, Fersistantsepal Yellowcress is well documented along the banks of the Columbia River throughout the 100 Areas, it is unlikely to occur in the 200 Areas. The northern wormiwood (Artemisia campestris spp. borealis) is known in the State of Washington by only two populations, one across from The Dalles, Oregon, and the other 
near Beverly, Washington, just north of the Hanford Site. This taxon has not been found on the Hanford Site, but would probably occur only on rocky areas immediately adjacent to the Columbia River if it were present. Neither of the Threatened taxa listed in Table 3-2 has been observed on the Hanford Site. The Columbia milk vetch (Astragalus columbionus) is known to be relatively common on the Yakima Firing Range, and has been documented to occur within 1.6 to $3.2 \mathrm{~km}$ (1 to $2 \mathrm{mi}$ ) to the west of the Hanford Site on both sides of Umptanum Ridge. This species could occur on the 200 Areas Plateau. Hoover's desert parsley (Lomatium tuberosum) inhabits the steep talus slopes near Priest Rapids Dam. Potentially, it could be found on similar slopes on Gable Mountain and Gable Butte, but has yet to be documented in these areas.

Of the Sensitive species, five are inhabitants of aquatic or moist habitats and the other six are inhabitants of dry upland habitats. Dense sedge (Carex densa), shining flatsedge (Cyperus rivularis), southern mudwort (Limosella acoulis) and false-pimpernel (Lindernia anagallidea) are all known to occur in the 100 Areas, especially near the $100 \mathrm{~B}-\mathrm{C}$ Area, in or near the Columbia River. Some of these species could be present in or near ponds and ditches in the 200 Areas. The few-flowered collinsia (Collinsia sparsiflora var. bruciae) may also occur in these habitats. The gray cryptantha (Cryptantha leucophaca) occurs on open dunes throughout the Hanford Site. Piper's daisy (Erigeron piperianus) is fairly common on Umptanum Ridge and Rattlesnake Ridge, but has also been documented in the vicinity of B Pond, the A-24 Crib, and 100-H Area. Bristly cryptantha (Cryptantha interrupta), dwarf evening-primrose (Oenothera pygmaea) have been found at the south end of the White Bluffs, approximately $3.2 \mathrm{~km}(2 \mathrm{mi})$ upstream from the 300 Area. The Palouse milk vetch (Astragalus arrectus) and coyote tobacco (Nicotiana attenuata) are not as well documented but are known to inhabit dry sandy areas such as the 200 Areas Plateau.

In addition to the three classifications for species of concern listed above, the Natural Heritage Program also maintains a "Monitor" list, which is divided into three groups. Group 1 consists of taxa in need of further field work before a formal status can be assigned. The tooth-sepal Dodder (Cuscuta denticulata), which has been found in the State of Washington only on the Hanford Site is the only taxon in this group that is of concern to Hanford operations. This parasitic species has been found in the area west of McGee Ranch. Group 2 of the Monitor list includes species with unresolved taxonomic questions. Thompson's sandwort (Arenaria franklinii var. thompsonil) is of concern to Hanford operations. However, the representatives of this species in the State of Washington are now believed to all be variety franklinii which is not considered particularly rare. Group 3 of the Monitor list includes taxa that are either more abundant or less threatened than previously believed. There are approximately 15 taxa on the Hanford Site that are included on this list

3.6.1.3 Fauna of the 200 Areas Plateau. The mammals, birds, reptiles, amphibians inhabiting the 200 Areas Plateau are discussed below.

3.6.1.3.1 Mammals. The largest mammal occurring on the 200 Areas Plateau is the mule deer (Odocoileus hemionus). Although mule deer are much more common to riparian sites along the Columbia River they are frequently observed foraging throughout the 200 
Areas. Elk (Cervus elaphus) also occur at Hanford but they have only been observed at the Arid Lands Ecology Reserve. Other mammal species common to the 200 Areas include badgers (Taxidea taxus), coyotes (Canis latrans), blacktail jackrabbits (Lepus californicus), Townsend ground squirrels (Spermophilus townsendii), Great Basin pocket mice (Perognathus parvus), pocket gophers (Thomomys talpoides), and deer mice (Peromyscus maniculatus). Badgers are known for their digging capability and have been implicated several times for encroaching into inactive burial grounds throughout the 200 Areas. The majority of the badger excavations in the 200 Areas are a result of badgers searching for prey (mice and ground squirrels). Coyotes are the principal predators, consuming such prey as rodents, insects, rabbits, birds, snakes and lizards. The Great Basin pocket mouse is the most abundant small mammal, which thrives in sandy soils and lives entirely on seeds from native and revegetated plant species. Townsend ground squirrels are not abundant in the 200 Areas but they have been seen at several different sites. Other small mammals that occur in low numbers include the Western harvest mouse (Reithrodontomys megalotis) and the Grasshopper mouse (Onychomys leucogaster). Mammals associated more closely with buildings and facilities include Nuttall's cottontails (Sylvilagus nuttallii), house mice (Mus musculus), Norway rats (Ruttus norvegicus), and some bat species. Bats probably play a minor role in the 200 Areas' ecosystem but no documentation is available on bat populations at Hanford. Mammals such as skunks (Mephitis mephitis), raccoons (Procyon lotor), weasels (Mustela spp.), porcupines (Erethizon dorsatum), and bobcats (Lynx rufus) have only been observed on very few occasions.

3.6.1.3.2 Birds. Over 235 species of birds have been documented to occur at the Hanford Site (Landeen et al. 1991). At least 100 of these species have been observed in the 200 Areas. The most common passerine birds include starlings (Sturnus vulgaris), horned larks (Ermophila alpestris), meadowlarks (Sturnella neglecta), Western kingbirds (Tyranus virticalis), rock doves (Columba livia), barn swallows (Hirundo rustica), cliff swallows (Hirundo pyrrhonota), black-billed magpies (Pica pica) and ravens (Corvus corax). Co.nmon raptors include the Northern harrier (Circus cyaneus), American kestrel (Falco sparvarius), and Red tailed hawk (Buteo jamaicensis). Swainson's hawks (Buteo swainsoni) sometimes nest in the trees located at some of the army bunker sites that were used in the 1940's. Golden eagles (Aquila chrysaetos) are observed infrequently. Burrowing owls (Athene cunicularia) nest at several locations throughout the 200 Areas. The most common upland game birds found in the 200 Areas are California quail (Callipepla californica) and chukar partridge (Alectoris chukar), however, ring-necked pheasants (Phasianus colchicus) and gray partridge (Perdix perdix) may be found in limited numbers. The only native game bird common to the 200 Areas Plateau is the mourning dove (Zenaida macronra) which migrates south each fall. Other species of note which nest in undisturbed sagebrush habitats in the 200 Areas include Sage sparrows (Amphispiza belli), and loggerhead shrikes (Lanius ludovicianus). Long-billed curlews (Numenius americanus) also use the sagebrush areas and revegetated burial grounds for nesting and foraging.

Waterfowl and aquatic birds inhabit 216-B-3 Pond and other areas where there is running or standing water. Waterfowl and other birds are not present in great numbers near West Lake because of the high alkali and phosphate content of the water, the elevated $\mathrm{pH}$, 
and sparse vegetation (Meinhardt and Frostenson 1979). Aquatic birds and waterfowl observed at West Lake include Canada geese (Branta canadensis), American coot (Fulica americana), mallard (Anas platyrhynchos), ruddy duck (Oxyura jamaicensis), redhead (Aythya americana), bufflehead (Bucephala albeola), black-crowned night heron (Nycticorax nycticorax), American widgeon (Mareca Americana), ringneck duck (Aythya collaris), and goldeneye (Bucephala clangula) (Fitzner and Rickard 1975).

3.6.1.3.3 Reptiles and Amphibians. Common reptiles include gopher snakes (Pituophis melanoleucus) and sideblotched lizards (Uta stansburiana). Other reptiles and amphibians that are infrequently observed include sagebrush lizards (Sceloporus graciosus), horned toads (Phryosoma douglassii), western spadefoot toads (Scaphiopus intermontana), jellow-bellied racer (Coluber constrictor), Pacific rattlesnake (Crotalus viridis), and striped whipsnake (Masticophis taeniatus). Both lizards and snakes are prey items of mammalian and avian predators.

3.6.1.3.4 Insects. There are hundreds of insect species which inhabit the 200 Areas. Two of the most common groups of insects include several species of darkling beetles and grasshoppers. Harvester ants are also common and have been implicated in the uptake of radionuclides from some of the burial grounds in the 200 East Area. Harvester ants can excavate and bring up material from as far down as 5 to $6 \mathrm{~m}$ (15 to $20 \mathrm{ft}$ ). Other major groups of insects include bees, tutterflies and scarab beetles. Insects impact the surrounding plant community as well as serving as the prey base for many species of birds, reptiles and mammals.

3.6.1.4 Wildife Species of Concern. Some animals that inhabit the Hanford Site have been give special status designations by the state and federal government. Some of these designations include state and federal threatened and endangered species, federal candidate, state munitor, state sensitive, and state candidate species. Species listed in Table 3-3 as state andor federal threatened and endangered such as the bald eagle (Haliaeetus leucocephalus), peregrine faicon (Falco peregrinus), American white pelican (Pelecanus erythroryhnchos), ferruginous hawk (Buteo regalis), and sandhill crane (Grus canadensis) do not inhabit the 200 Areas. The bald eagle and American white pelican utilize the Columbia River and associated habitats for roosting and feeding. Peregrine falcons and sandhill cranes fly over the Hanford Site during migration. Ferruginous hawks nest on the Hanford Site but nesting has not been documented for this species on the 200 Areas Plateau. Other species listed in Table 3-4 as state and/or federal candidates and state monitor species such as burrowing owls, great blue herons, prairie falcons (Falco mexicanus), Sage sparrows, and loggerhead shrikes are not uncornmon to the 200 Areas Plateau.

\subsubsection{Land Use}

The 200 North Aggregate Area is the location of the 212-N, -P, -R Buildings and its attendant facilities and structures. Past activities at the these buildings were the cooling of fuel rods and later the storage of polychlorinated biphenyl (PCB)-contaminated electrical 
equipment and alpha-contaminated equipment. Waste management units that remain active are noted in Figure 2-1, Operational and Waste-Related History. Access to the entire Hanford Site is aclministratively controlled to ensure public health and safety and for reasons of national security.

\subsubsection{Water Use}

There is no consumptive use of groundwater within the 200 North Aggregate Area. Water for drinking and emergency use, and facilities process water is drawn from the Columbia River, treated, and imported to the 200 East and West Areas. The nearest wells used to supply drinking water are located at the Yakima Barricade (Well 699-40-100-C) about $12 \mathrm{~km}(7 \mathrm{mi})$ west of the 200 North Aggregate Area; at the Hanford Safety Patrol Training Academy (Well 699-528-E0) about $47 \mathrm{~km}(28 \mathrm{mi})$ to the southeast; at the PNL Observatory (Well 6652-C); and near the Fast Flux Test Facility in the 400 Area (Well 699S1-8J) about $38 \mathrm{~km}(23 \mathrm{mi})$ to the southeast. The nearest water supply wells located offsite are about $9 \mathrm{~km}(5.4 \mathrm{mi})$ to the northwest (upgradient). These wells obtain their water from the basalt and the basalt interbeds (the Berkshire Well and Chateau Ste. Michelle No. 1 and No. 2). The latter wells are reportedly used for irrigation although they may also be used to supply drinking water. Three wells for emergency cooling water supply are located in the 200 East Area near B Plant (2 wells), approximately $5.6 \mathrm{~km}(3.5 \mathrm{mi})$ to the southeast, and 1 near the 241-N Tank Farms, approximately $6.6 \mathrm{~km}(4.1 \mathrm{mi})$ to the southeast.

\subsection{HUMAN RESOURCES}

The environmental conditions at the 200 North Aggregate Area must be evaluated in relationship to the surrounding population centers and other human resources. A very brief summary of demography, archaeology, historical resources, and community involvement is given below.

\subsubsection{Demography}

There are no residences on the Hanford Site. The nearest inhabited residences are farm homes on land located approximately $18 \mathrm{~km}(11 \mathrm{mi})$ north of the 200 North Aggregate Area. There are approximately 411,000 (1990 census) people living within a $80 \mathrm{~km}$ (50 mi) radius of the 200 Areas Plateau. The primary population centers are the cities of Richland, Kennewick, and Pasco, located southeast of the Hanford Site, Prosser to the south, Sunnyside to the southwest, and Benton City. to the southeast. 


\subsubsection{Archaeology}

An archaeologic survey has been conducted of undeveloped portions of the 200 East Area by the Hanford Cultural Resources Laboratory. Isolated artifacts and sites of interest were identified in the 200 West Area but not within the 200 North Aggregate Area. The closest site of interest is the remains of the White Bluffs Road, located approximately $15 \mathrm{~km}$ $(9 \mathrm{mi})$ northwest of the aggregate area, which was previously an Indian trail. More informationj is available in Rice (1980) and Chatters (1984).

\subsubsection{Historical Resources}

The only historic site near the 200 North Aggregate Area is the old White Bluffs freight road which crosses diagonally through the 200 West Area. This site is not considered to be eligible for the National Register.

\subsubsection{Community Involvement}

A Community Relations Plan (Ecology et al. 1989) has been developed for the Hanford Site Environmental Restoration Program that includes any potentially affected community with respect to the 200 North AAMSR. The Community Relations Plan includes a discussion on analysis of key community concerns and perceptions regarding the project, along with a list of all interested parties. 
Figure 3-1. Topography and Location Map for the Hanford Site.

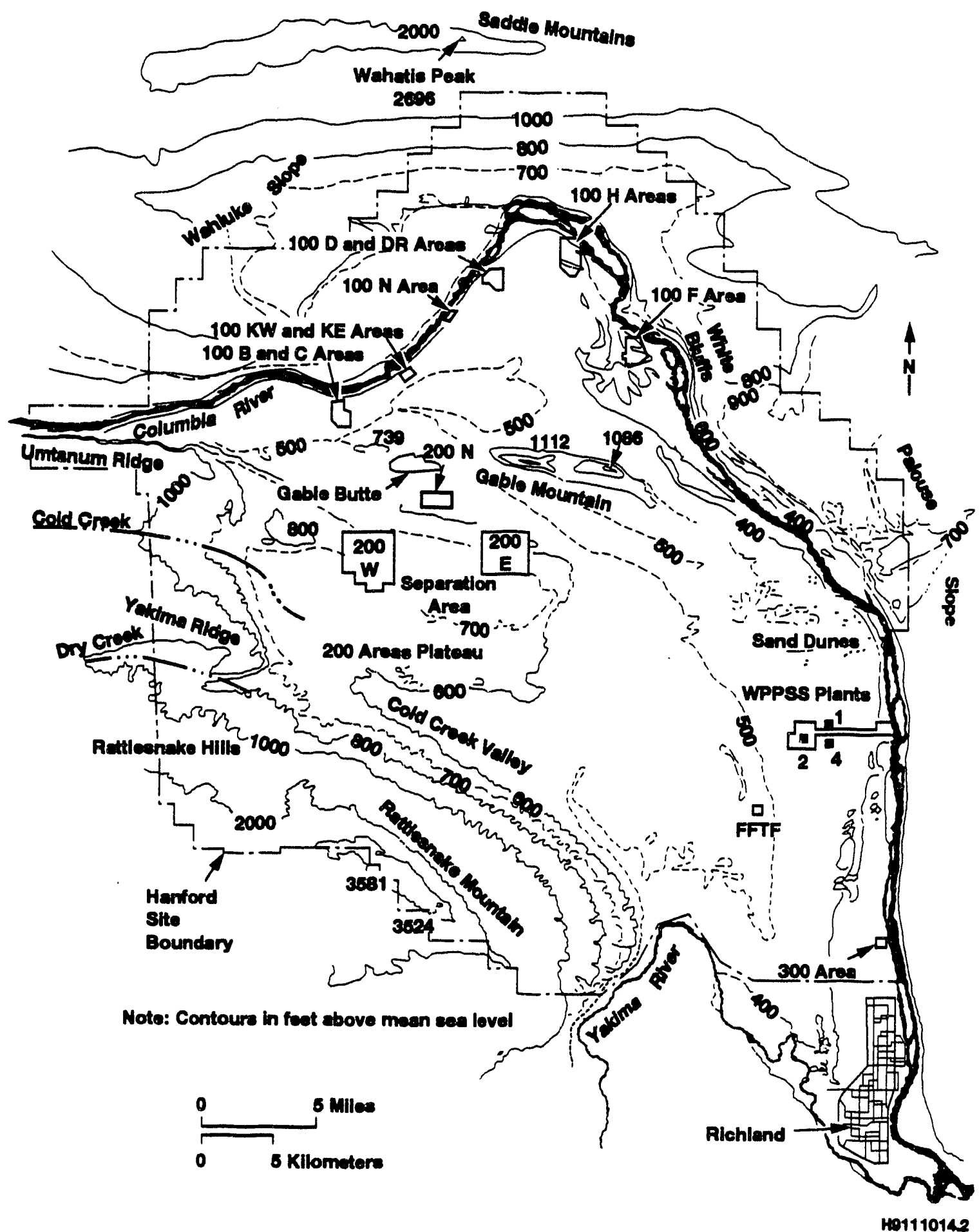


Figure 3-2. Divisions of the Columbia Intermontane Province and Adjacent Snake River Plains Province.

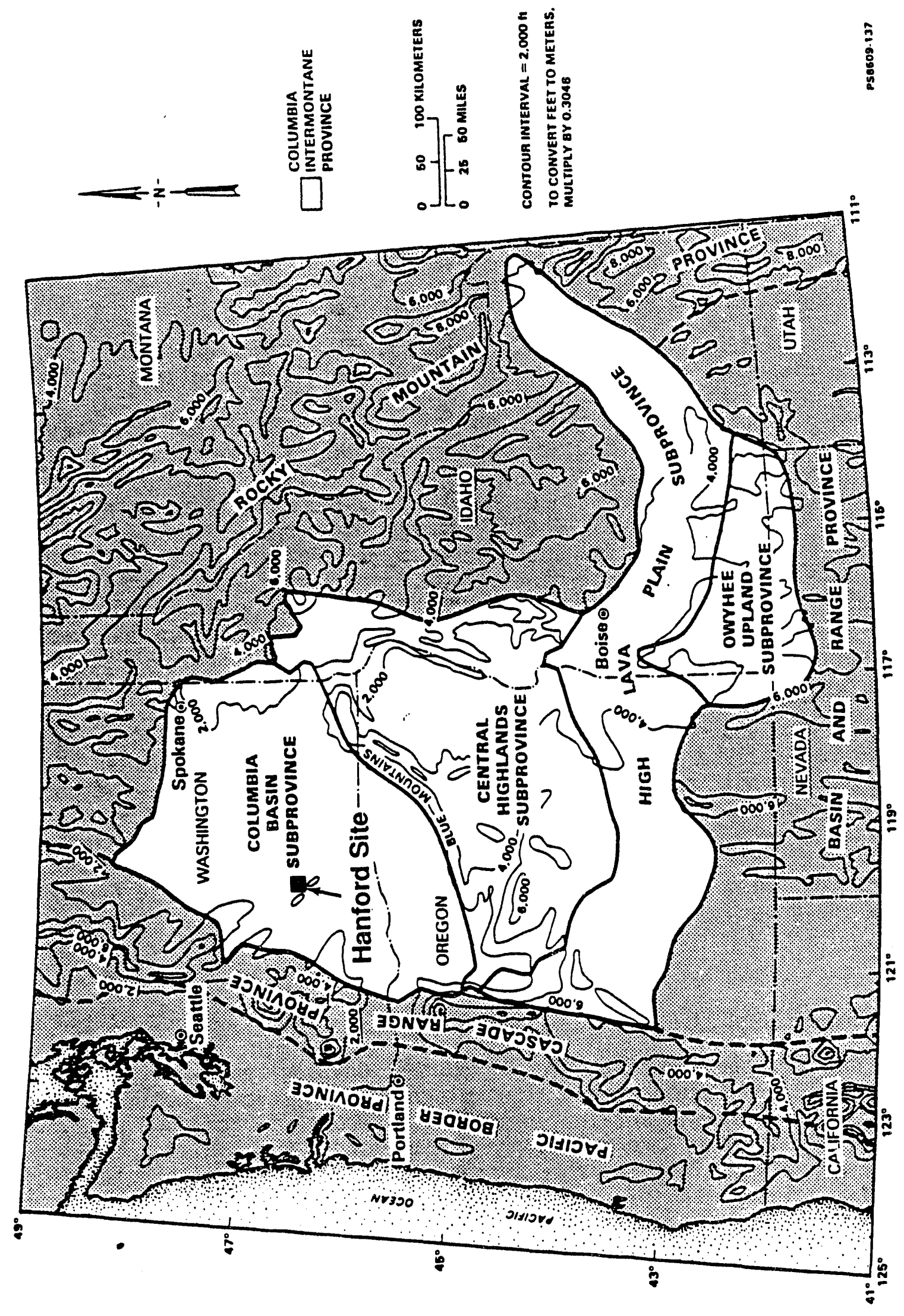


Figure 3-3. Geomorphic Units Within the Central Highlands and Columbia Basin Subprovinces that Contain the Columbia River Basalt Group.

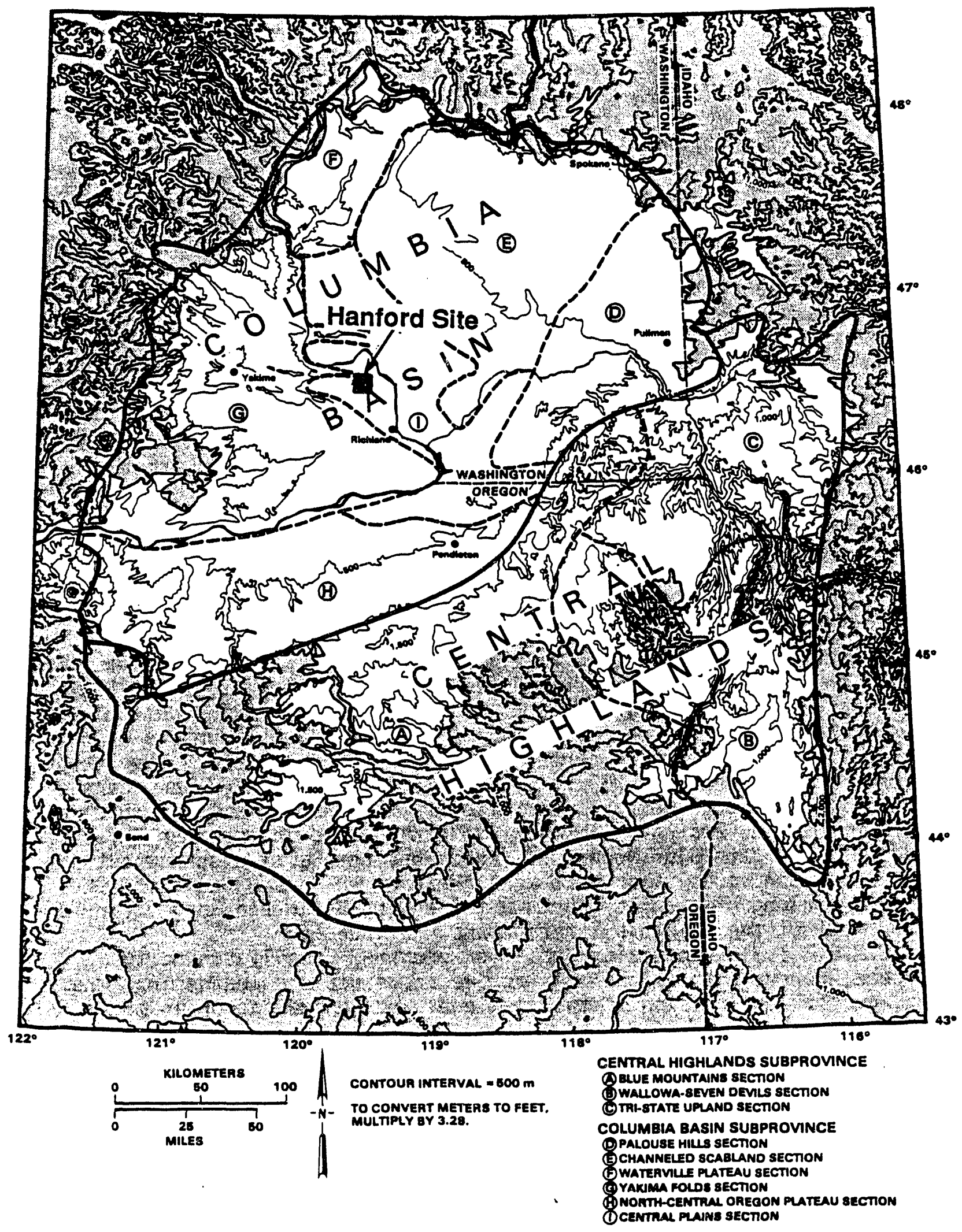


Figure 3-4. Landforms of the Pasco Basin and the Hanford Site.

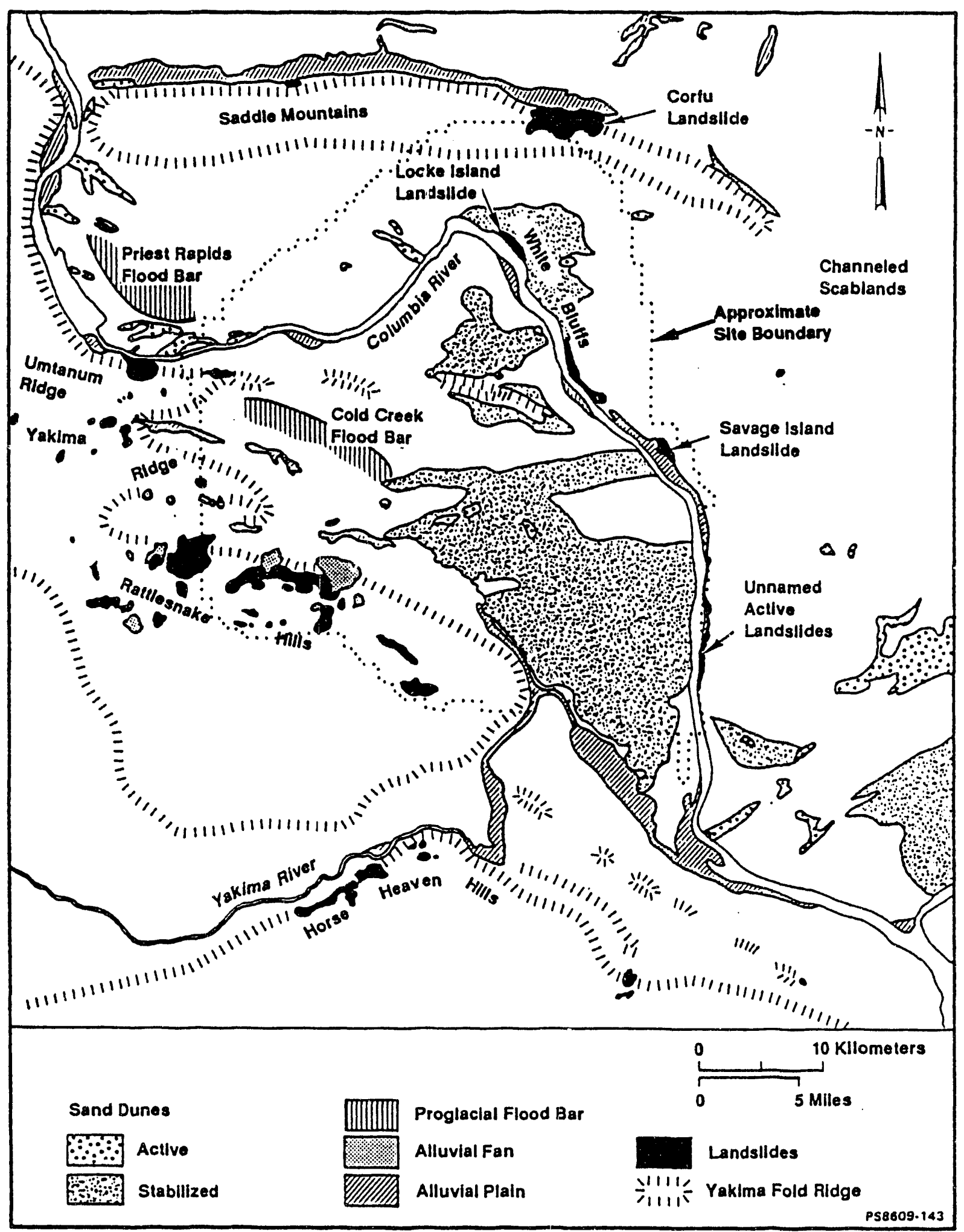

PS-90-246 
DOE/RL-92-17, Rev. 0

Figure 3-5. Geomorphic Features Surrounding the 200 Areas.

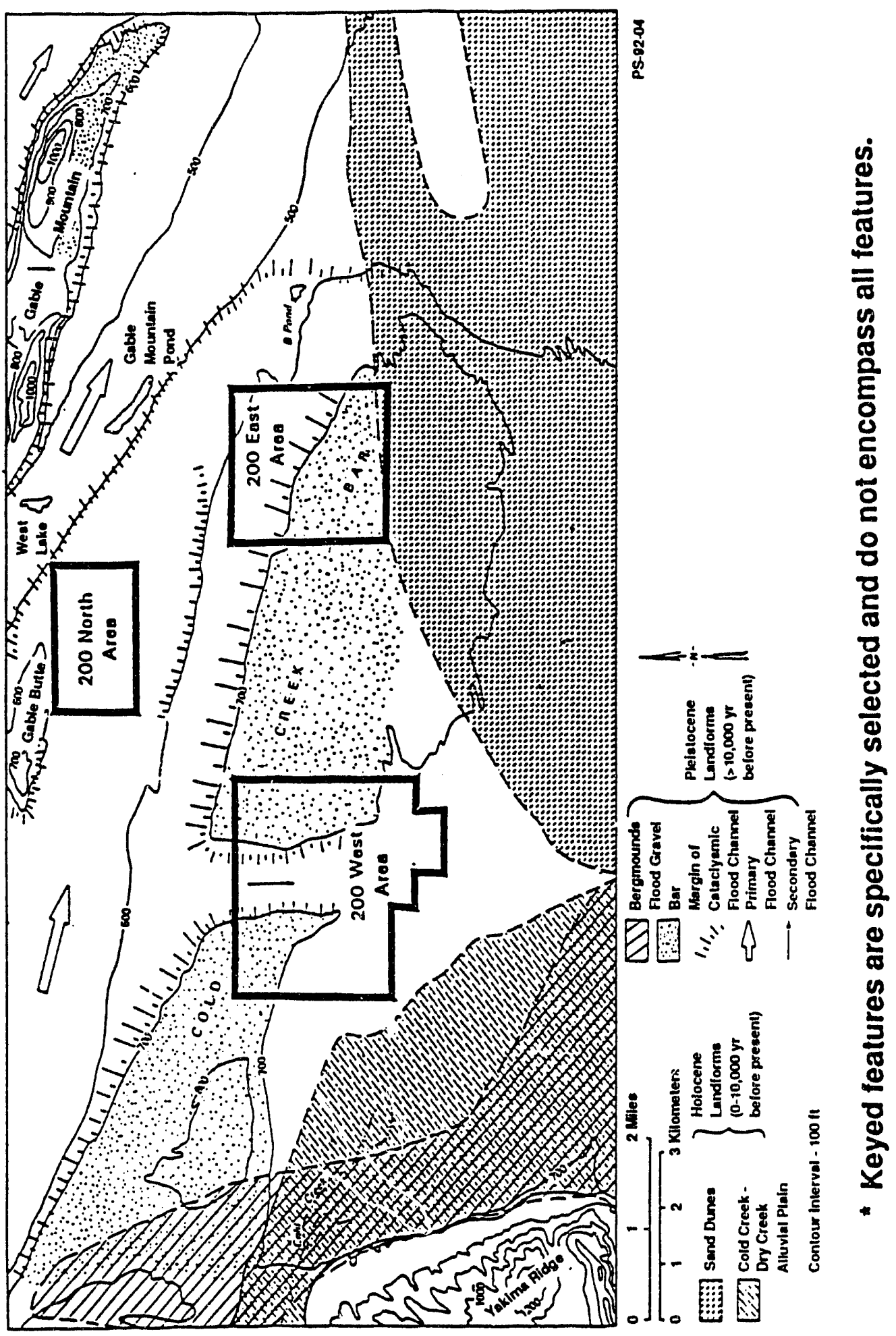


Figure 3-6. Hanforid Site Wind Roses 1979 through 1982 (Stone et al. 1983).

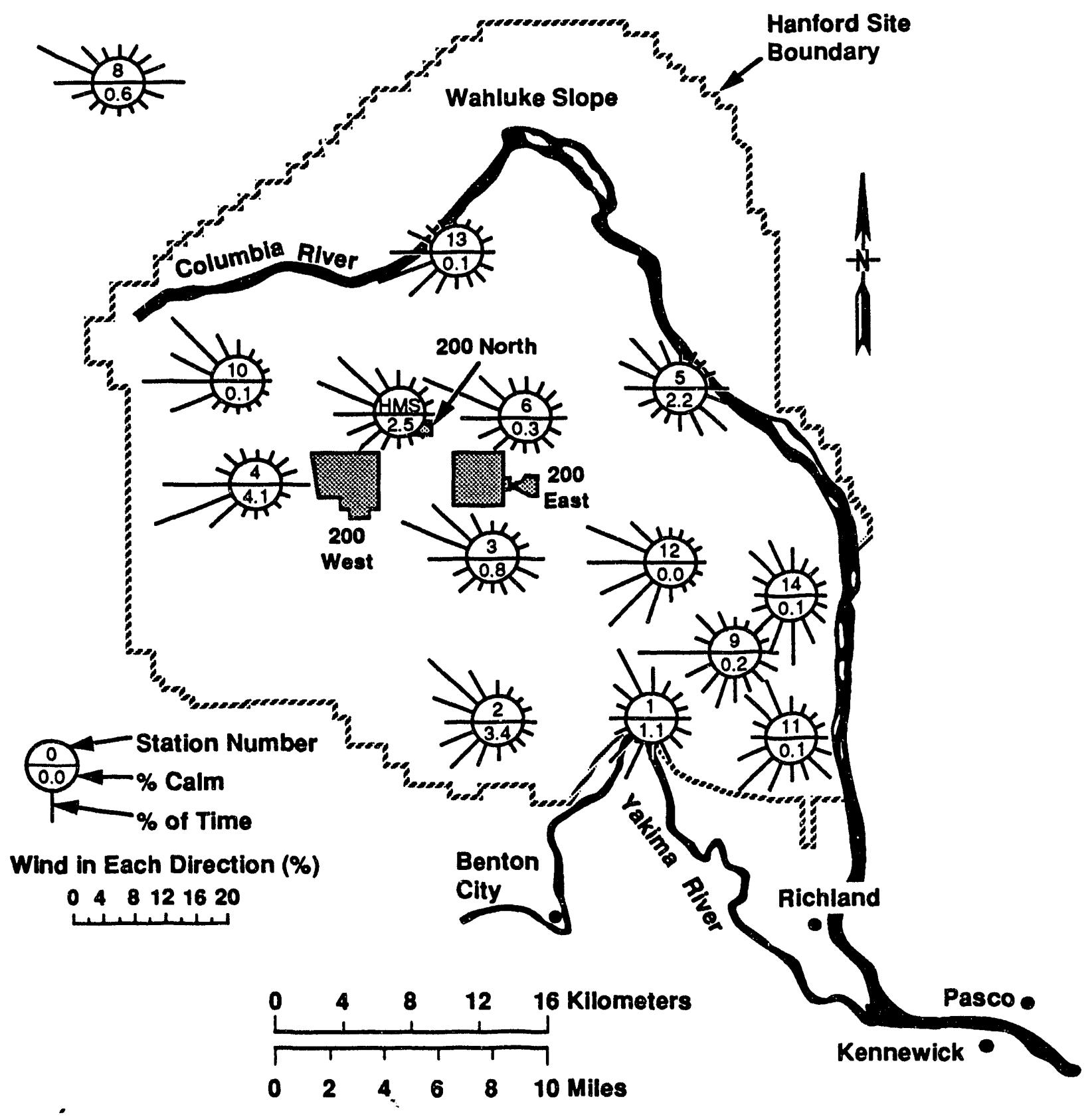

HMS = Hanford Meteorological Station 
Figure 3-7. Hydrologic Basins Designated for the Washington State Portion of the Columbia Plateau.

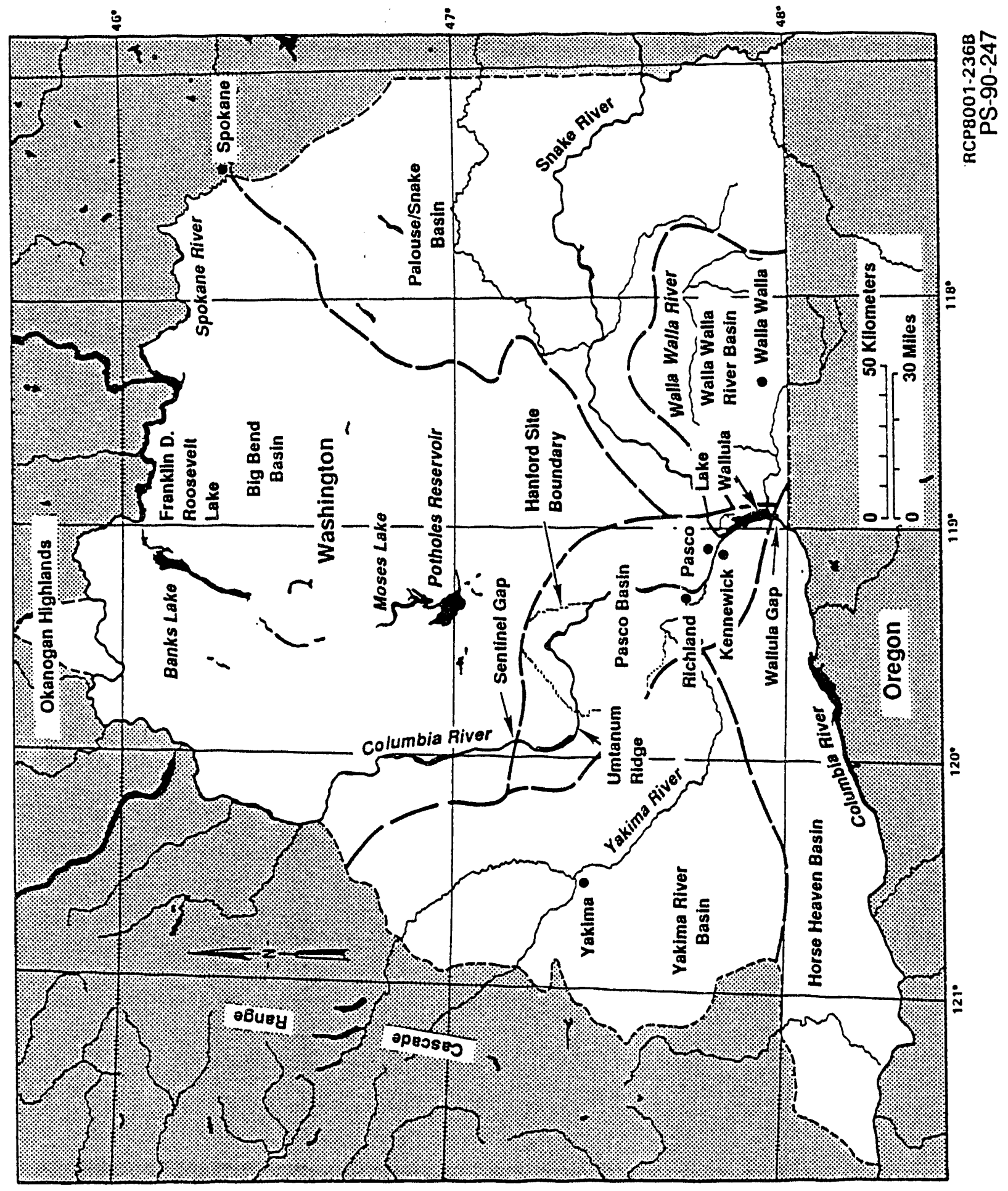


DOE/RL-92-17, Rev. 0

Figure 3-8. Columbia Plateau and Surroundrig Structural Provinces.

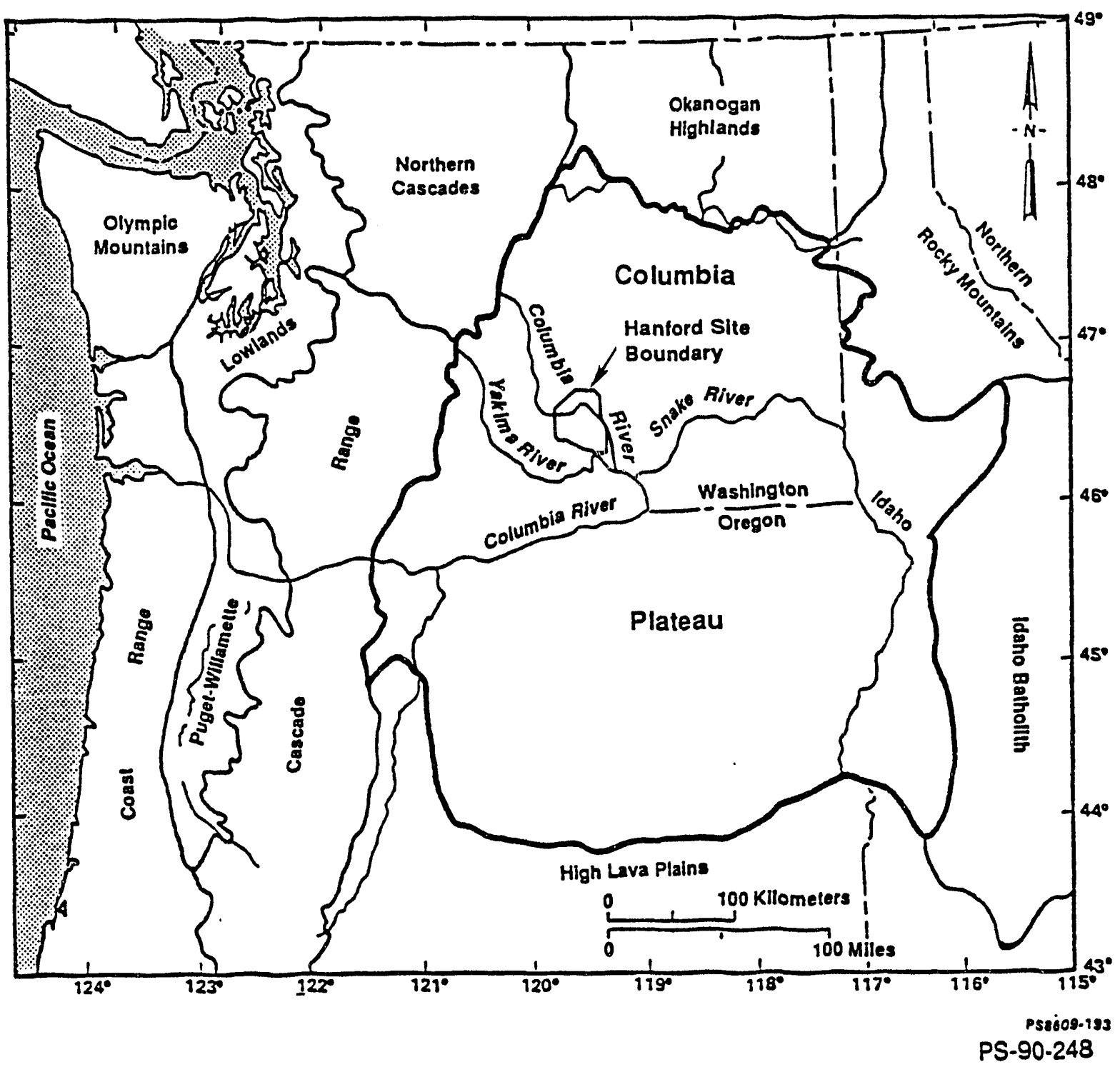


Figure 3-9. Structural Subprovinces of the Columbia Plateau.

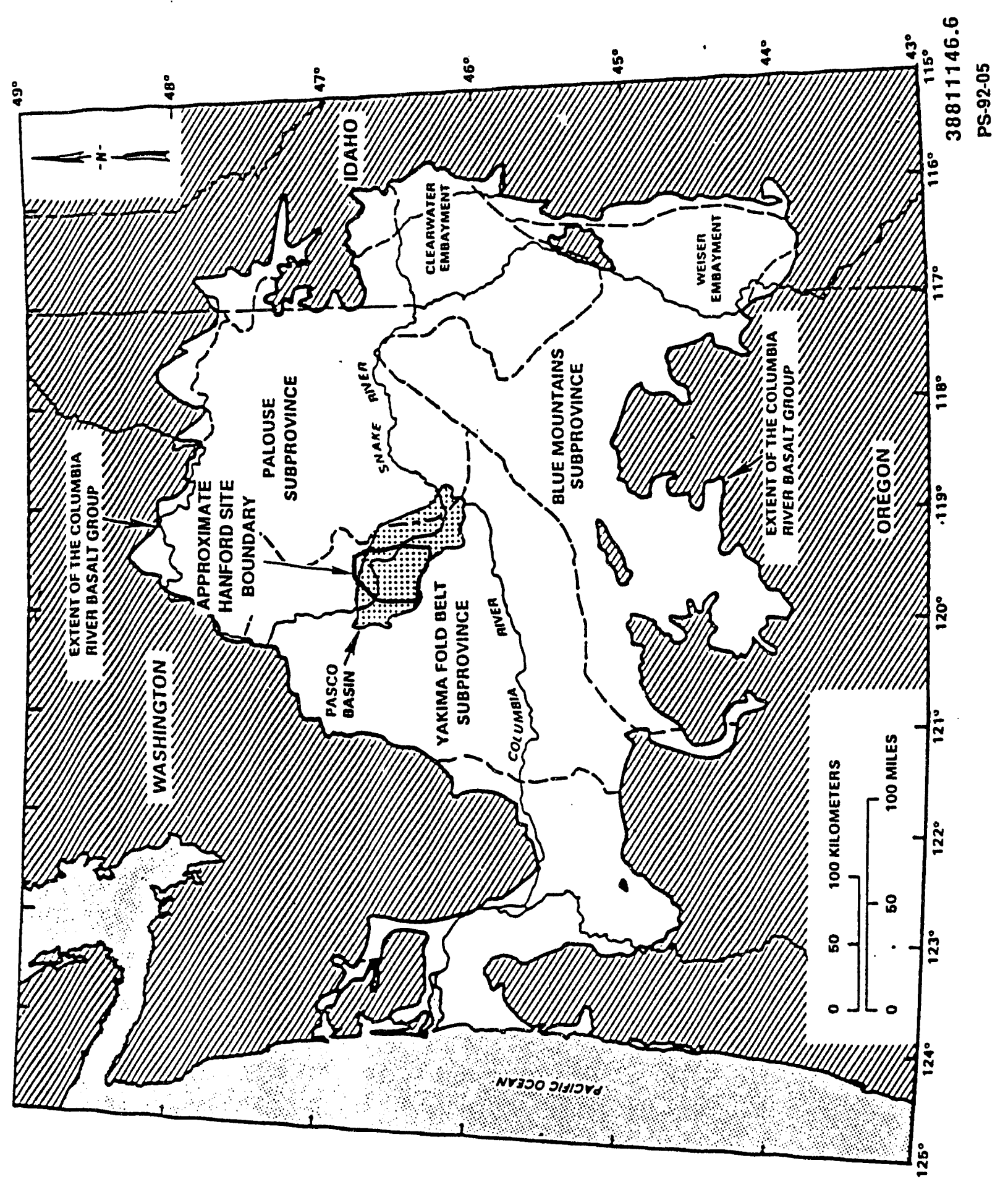


DOE/RL-92-17, Rev. 0

Figure 3-10. Structural Elements of the Yakima Fold Belt Subprovince.

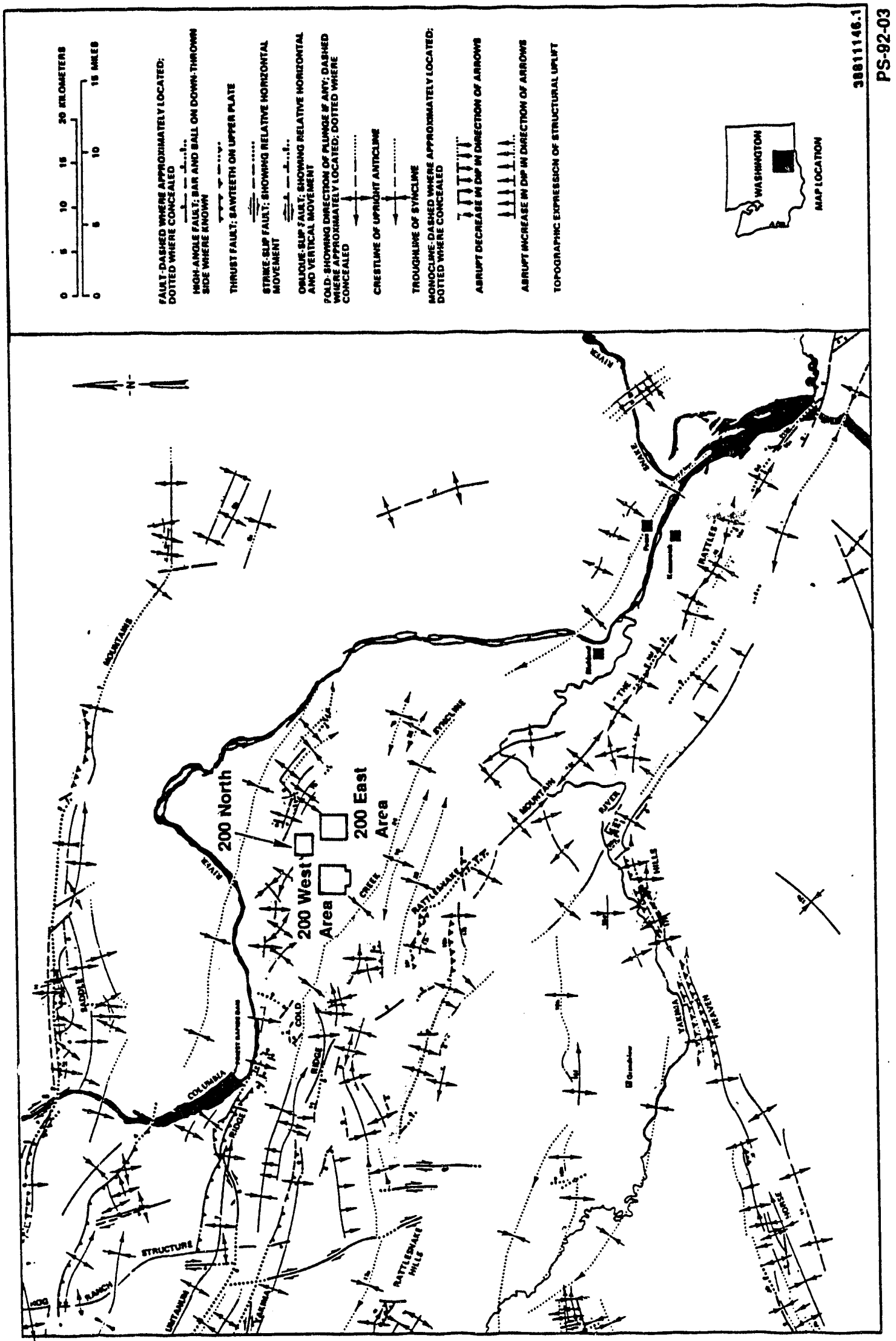


Figure 3-11. Geologic Structures of the Pasco Basin and the Hanford Site.

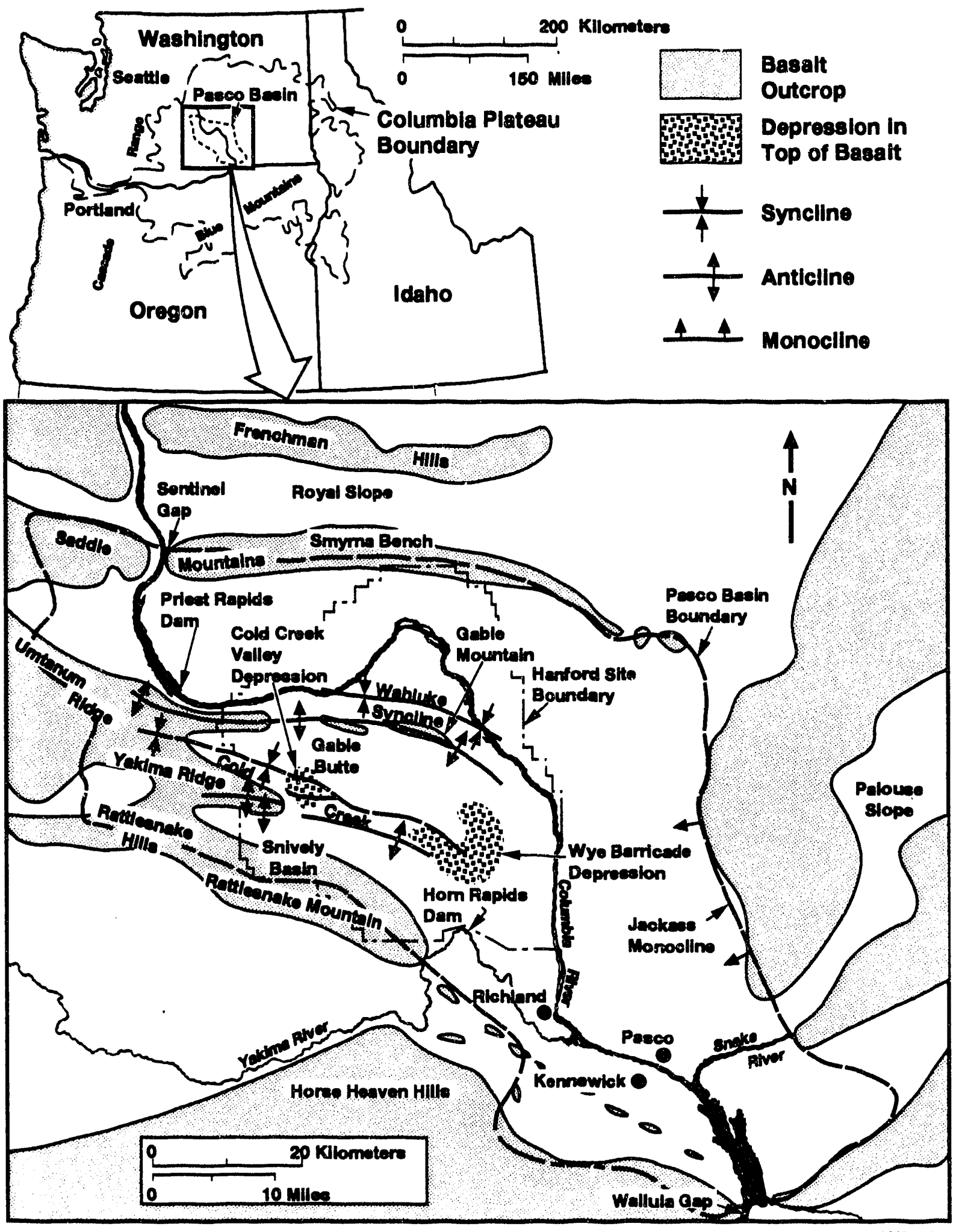


Figure 3-12. Generalized Stratigraphy of the Hanford Site.

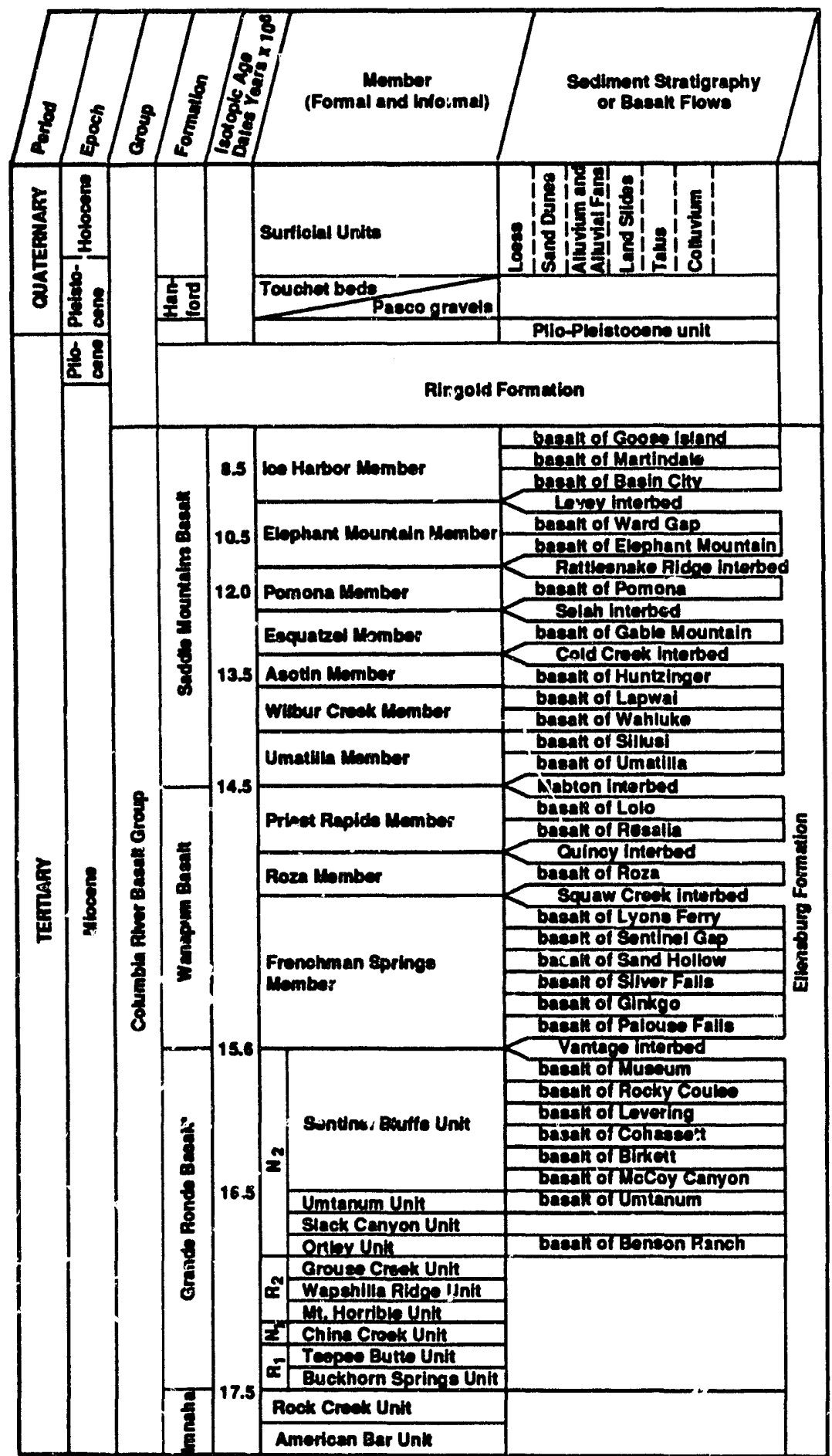

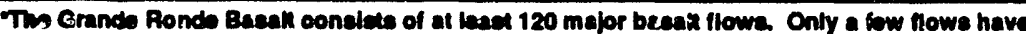
been nawed $M_{2}, R_{2}, M_{1}$ and $R_{1}$ are magnelestretioraphis unite.

Ho100029.6. 
Figure 3-13. Generalized Stratigraphy of the Suprabasalt Sediments Beneath the Hanford Site.

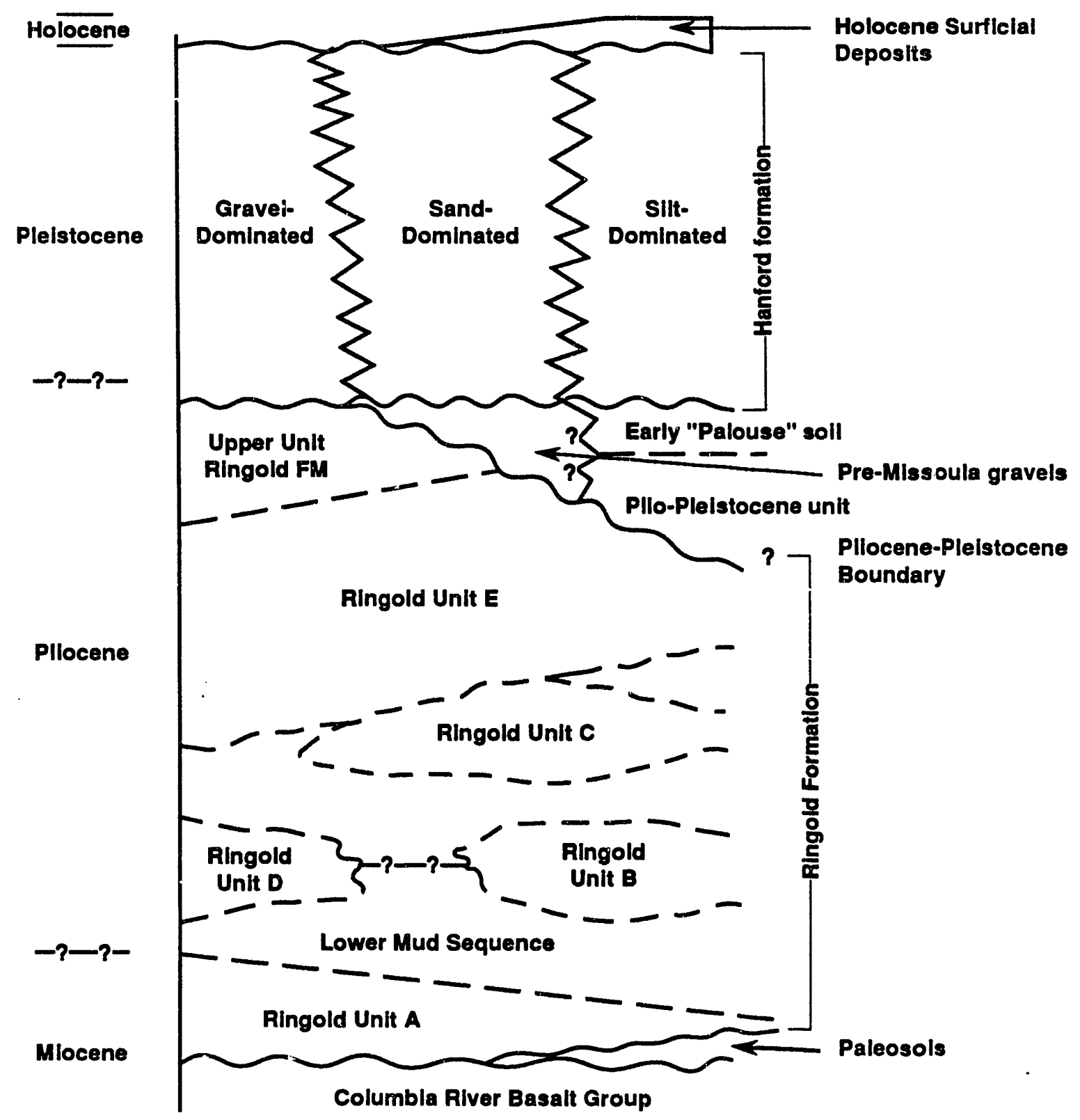

H9210018.1a 
DOE/RL-92-17, Rev. 0

Figure 3-14. Location of Cross-sections.

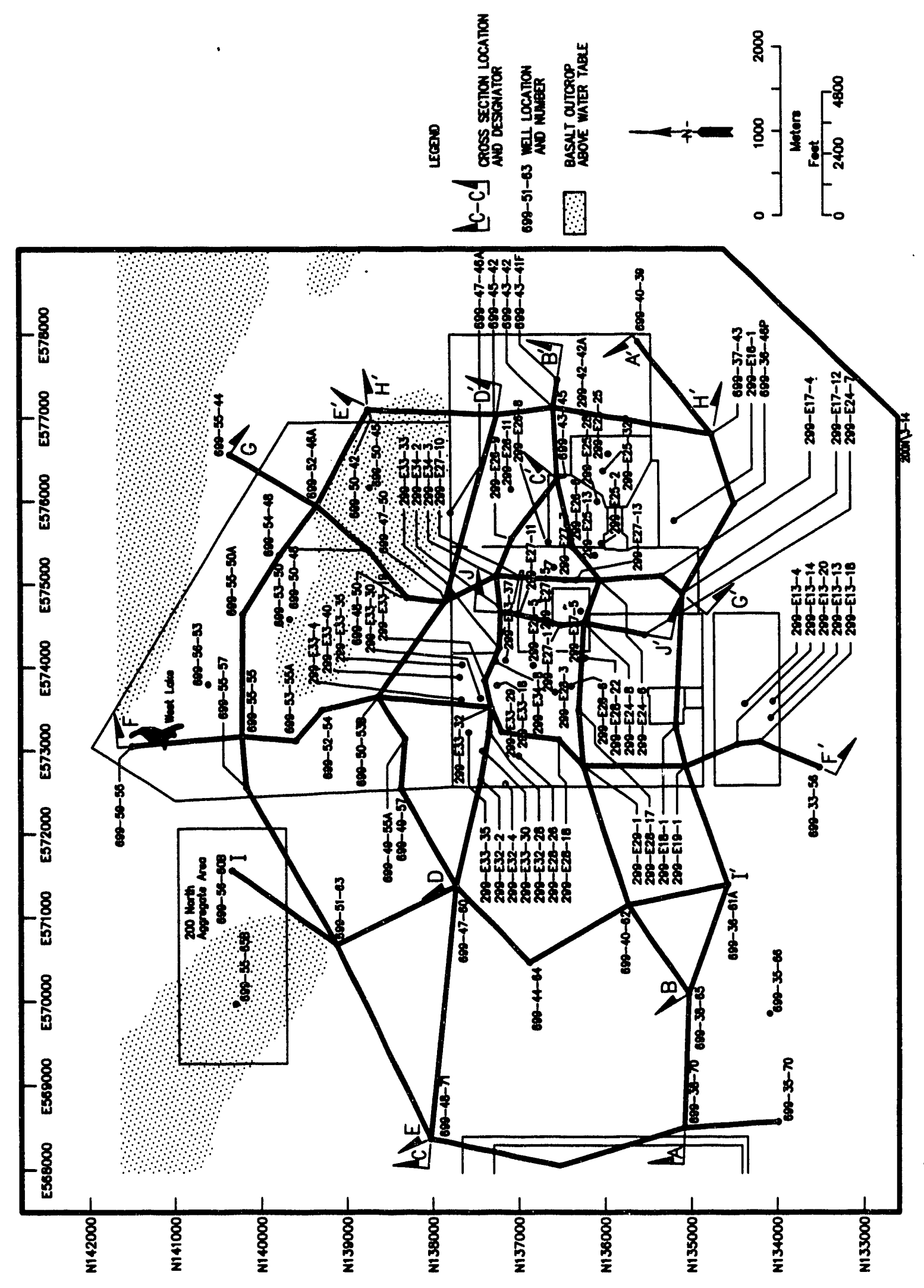


Figure 3-15. Legend for Cross-sections.

\section{Explanation}

Additional Lithologic Symbols,

Includes Subordinate Lithologies

- Clay rich

$\sim \sim$ Silt rich

Scales

$\because \because$ Sandy

$\vdots \vdots:$ Pebbly to cobbly

$\because \because$ Bouldery

Calcium carbonote present

$x^{x} x^{x}$ Paleosol

Itzasalt

IIII Cemented

$100 \mathrm{ft}$

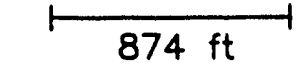

Vertical

Exaggeration

$8.7 x$

Blank portions of the cross section well logs represent sediments (dominantly sand) do not fit into sediment categories depicted by symbols listed above.

\section{Other Symbols}

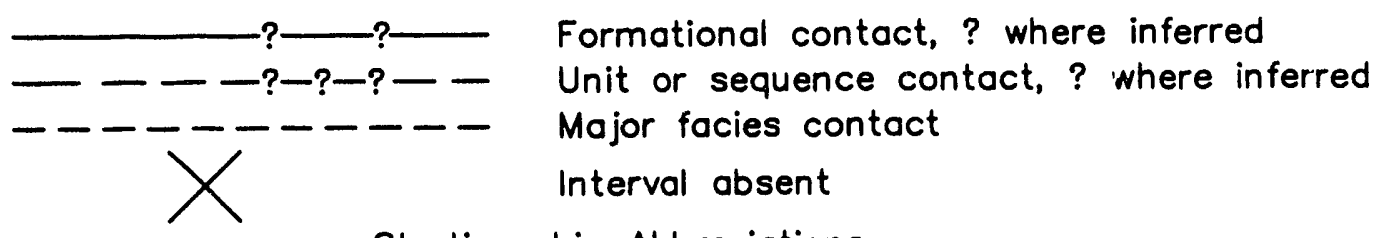

Stratigraphic Abbreviations

Eo - Eolian (Holocene) deposits

Hug - Upper gravel sequence, Hanford formation

Hs - Sandy Sequence, Hanford formation

Hig - Lower grovel sequence, Hanford formation

$\frac{H}{R}$ - Hanford/Ringold contact

$E$ - Gravel Unit E, Ringold Formation

LM - Lower mud sequence, Ringold Formation

A - Gravel unit A, Ringold Formation

EM - Elephant Mountain Basalt Member, Saddle Mountains Basalt 

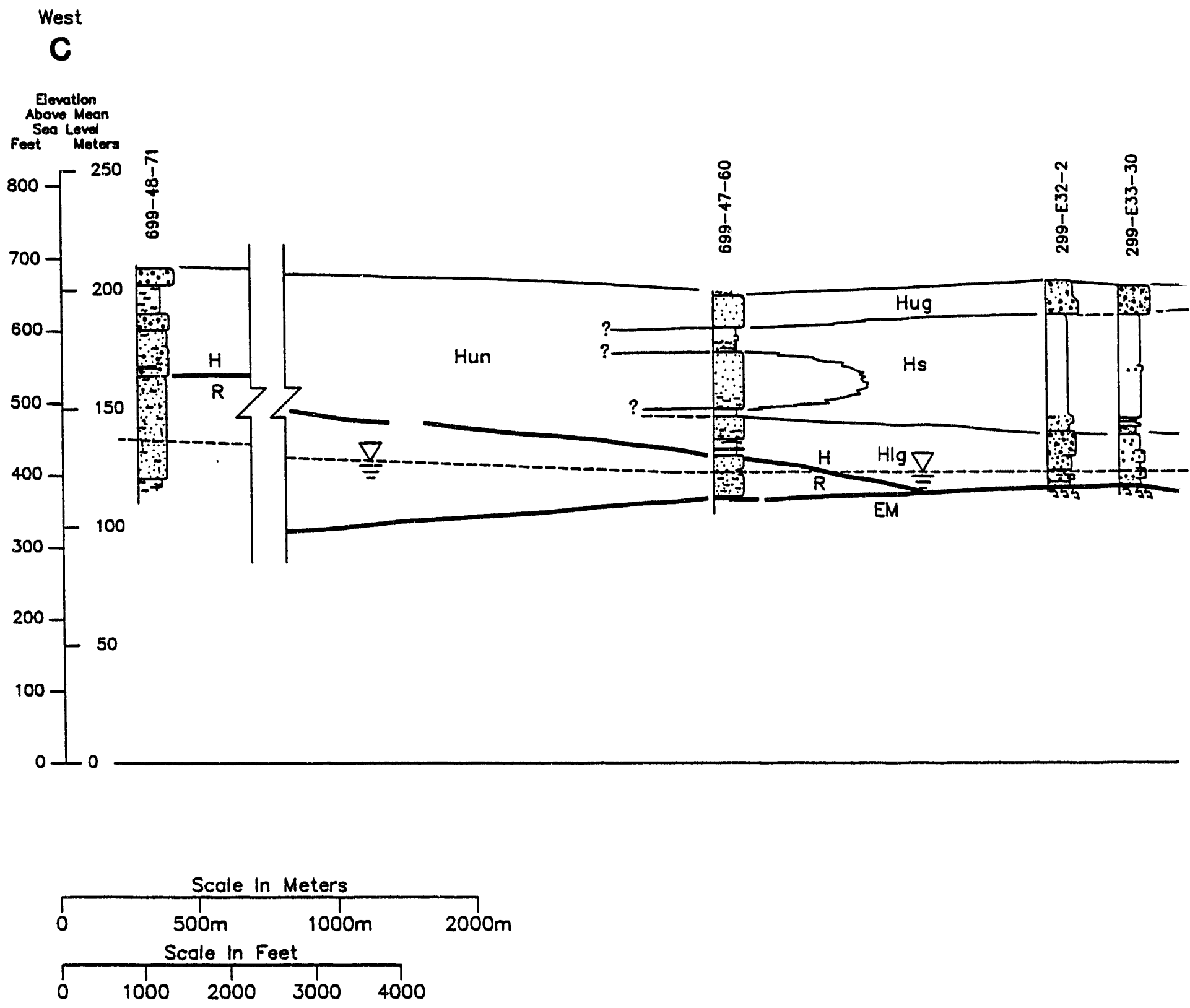


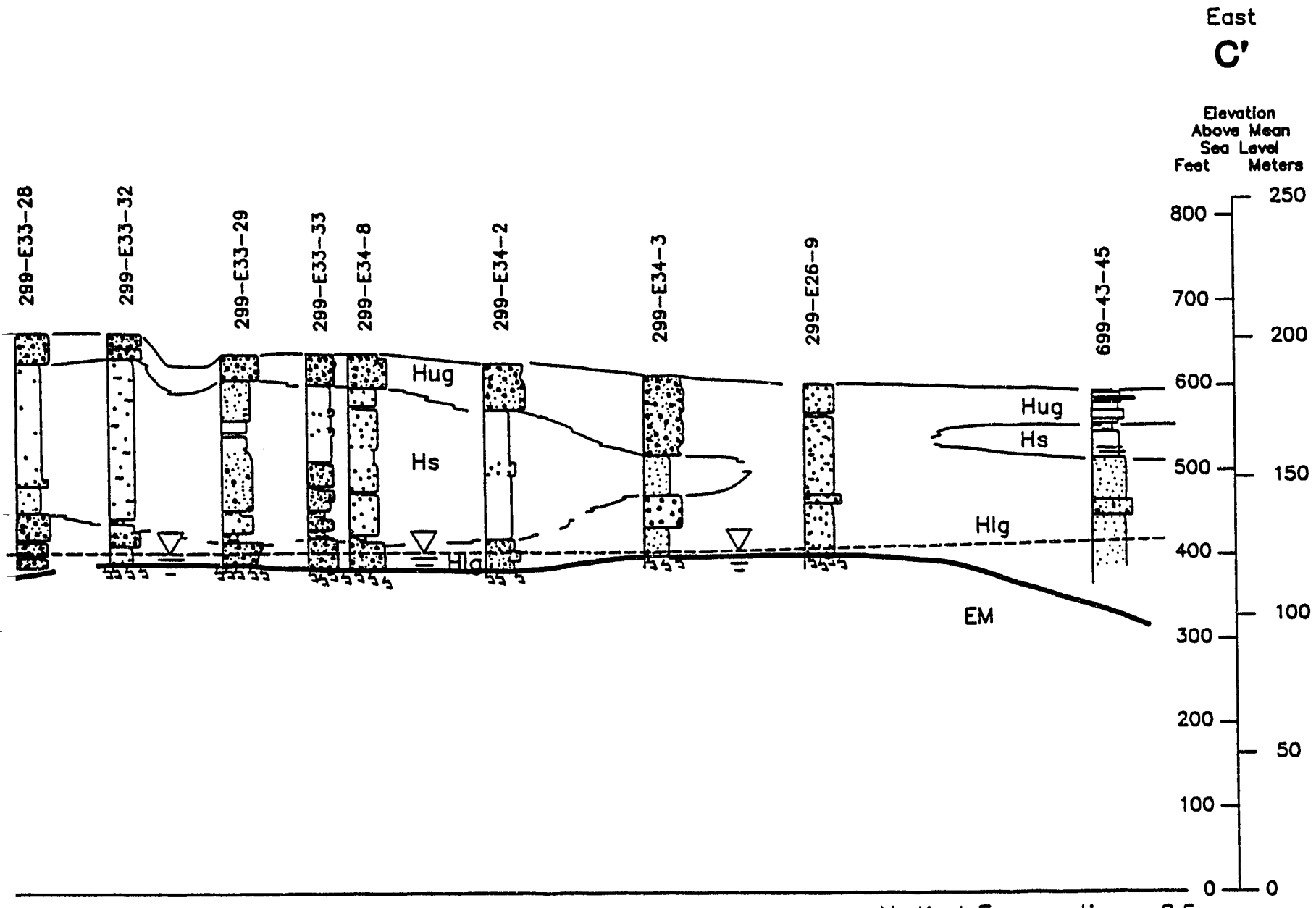

Vertical Exaggeration $\times 8.5$

NoT:

Blank area in lithologic column indicates that

interval is composed only of grain size indicated

at bottom of column; no other grain sizes present.

Figure 3-16. Geologic Cross-section - C-C'. 


\section{West \\ E}
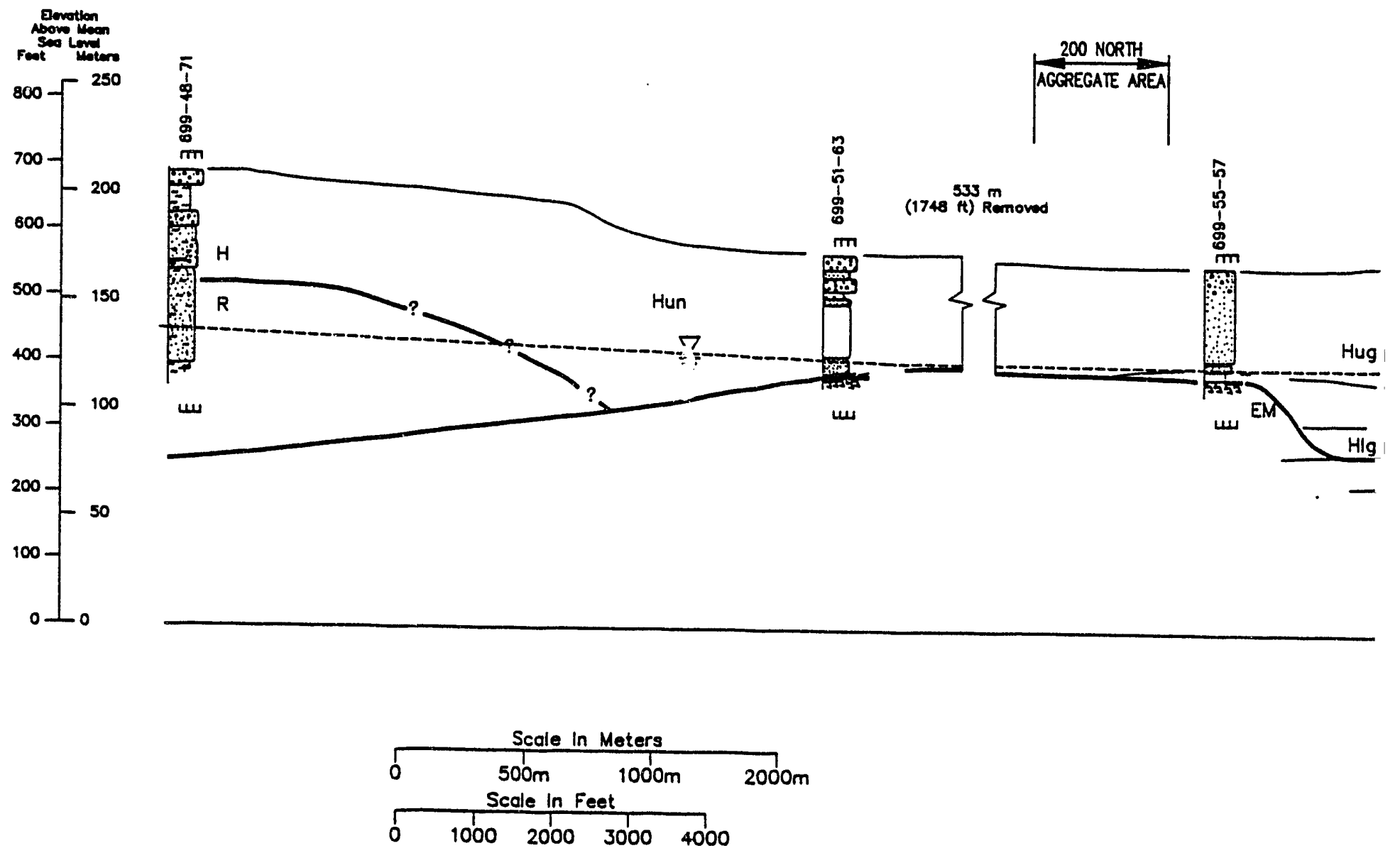
DOE/RL-92-17, Rev. 0

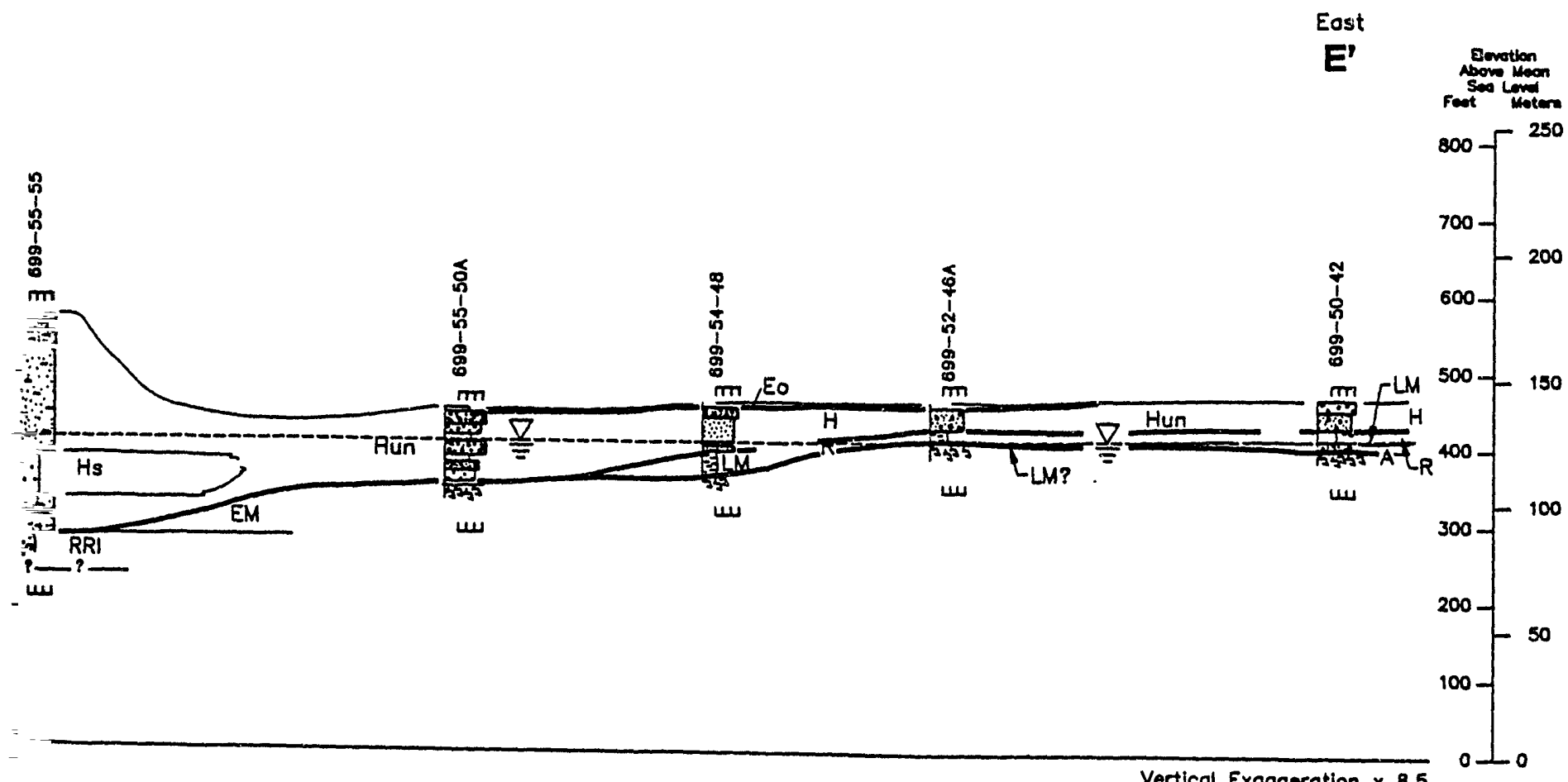

Vertical Exaggeration $\times 8.5$

NOT:

Blank area in lithologle column indleates that

Interval is composed only of groin size indicated

at bottom of column; no other groin sizes present.

Figure 3-17. Geologic Cross-section - E-E'. 

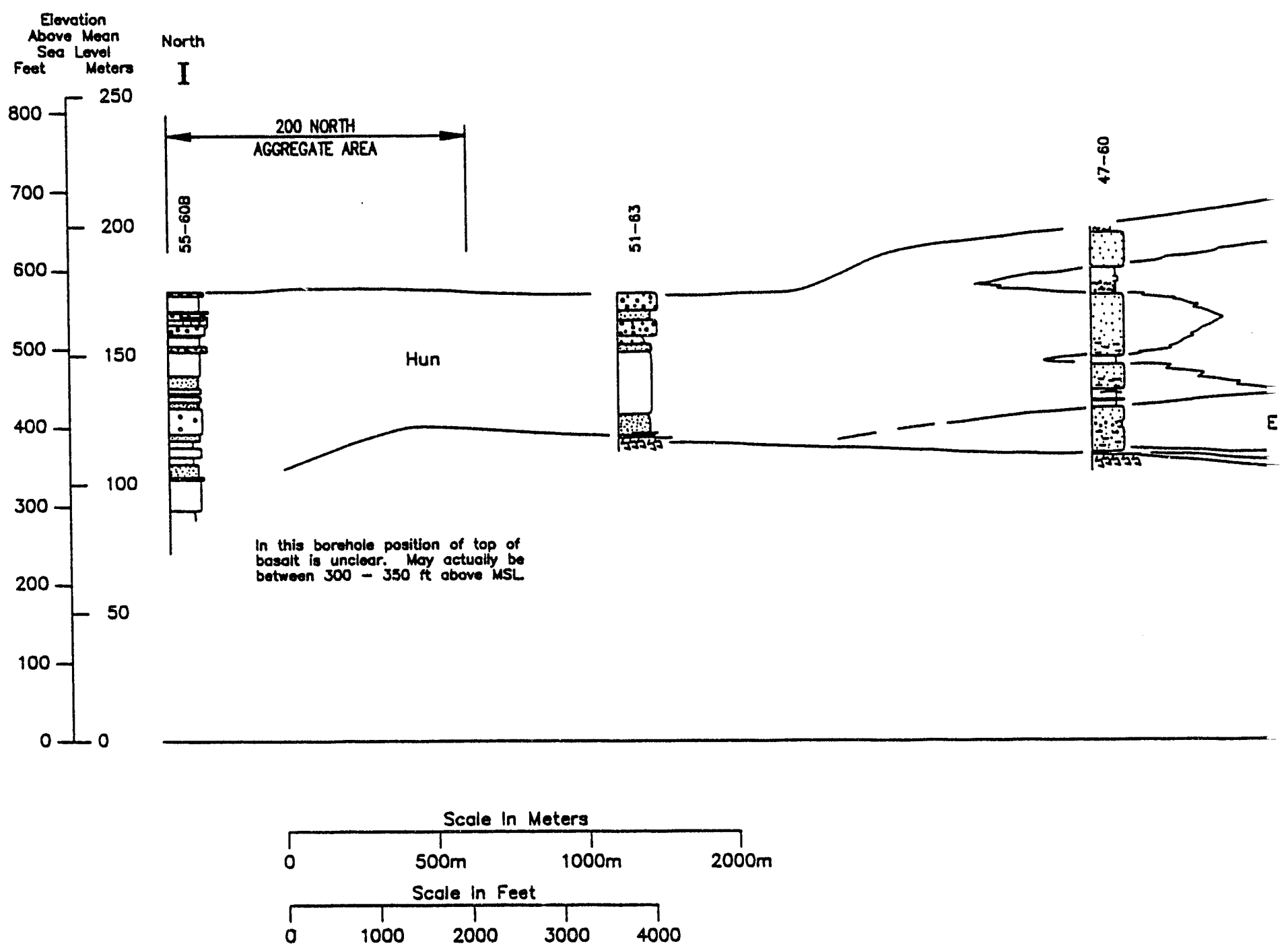
DOE/RL-92-17, Rev. 0

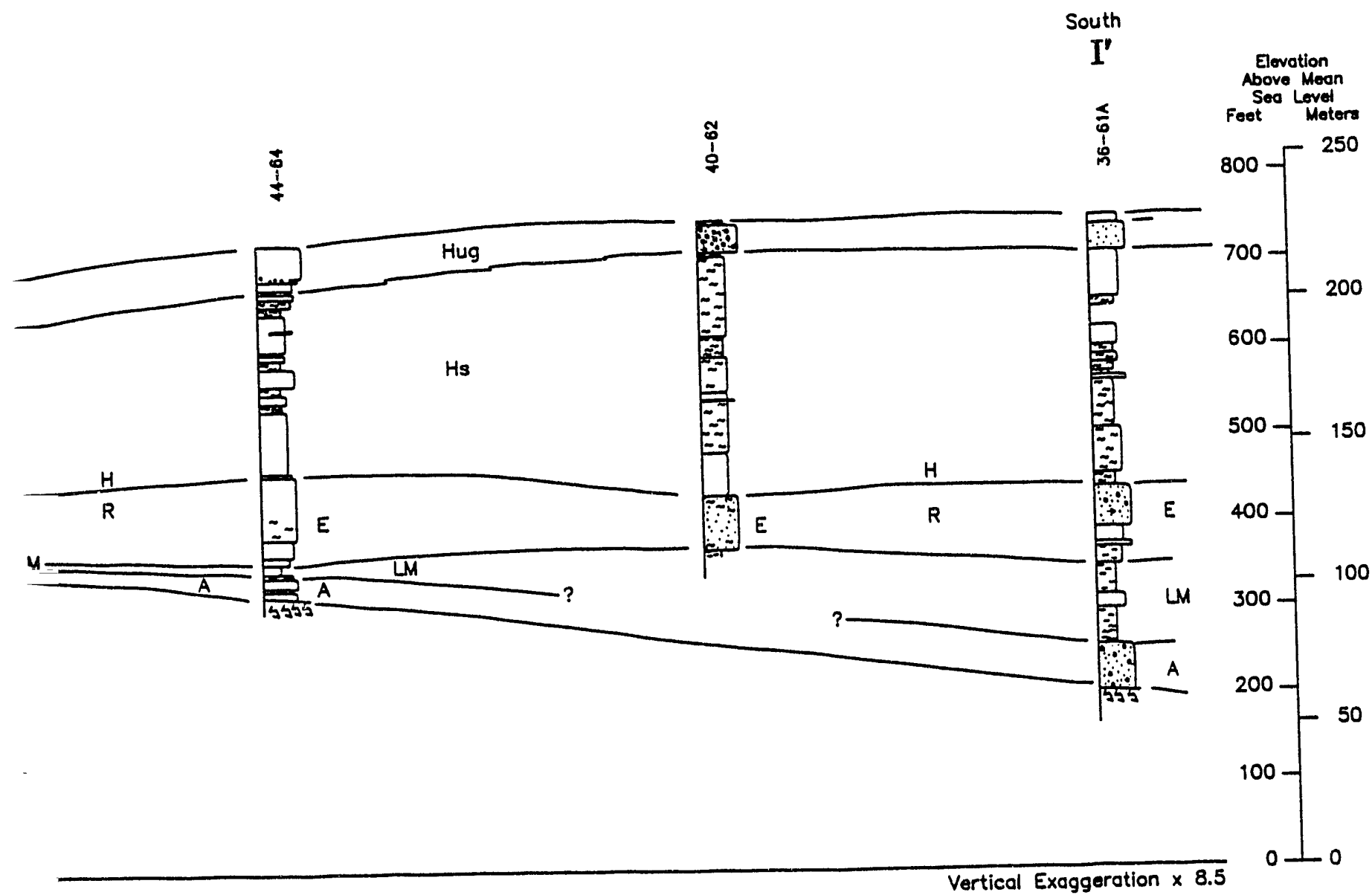

NOTE:

Blank area in lithologic column indicates that interval is composed only of grain size indicated at bottom of column; no other grain sizes present.

Figure 3-18. Geologic Cross-section - G-G'. 
DOE/RL-92-17, Rev. 0

Figure 3-19. Structure Contour Map of Surface of the Top of Basalt.
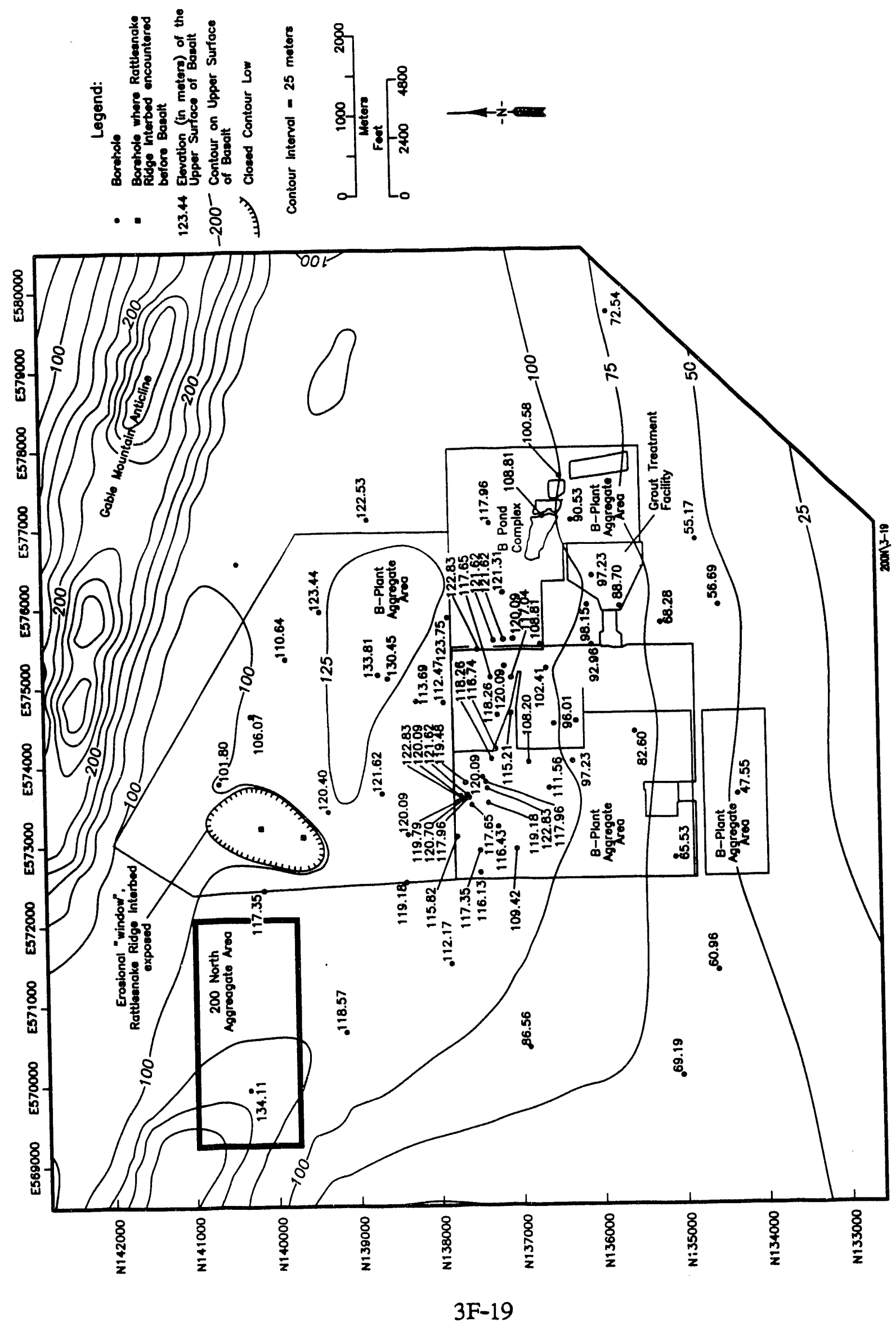
DOE/RL-92-17, Rev. 0

Figure 3-20. Isopach Map of the Ringold Gravel Unit A.
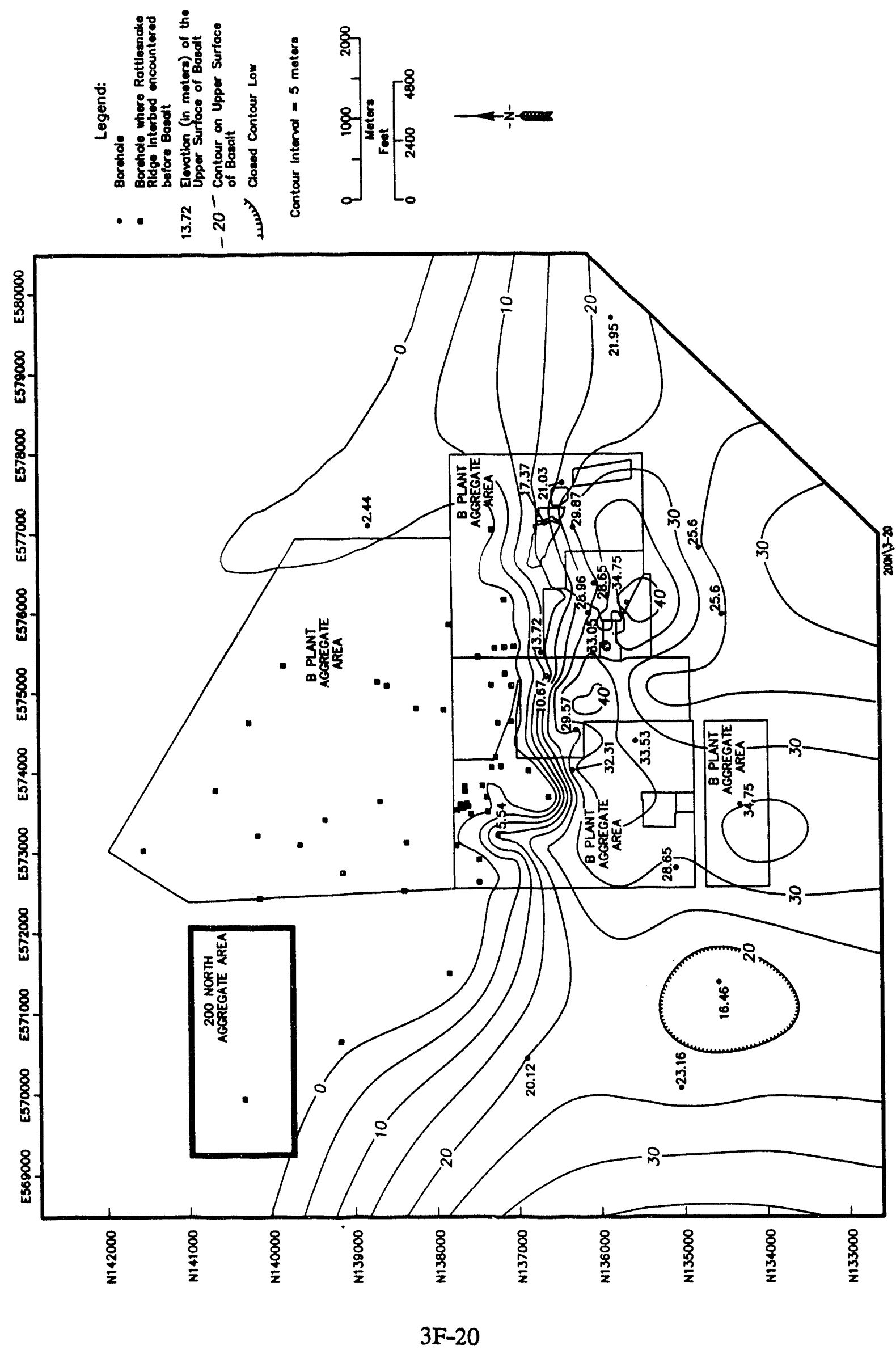
DOE/RL-92-17, Rev. 0

Figure 3-21. Structure Map of the Formation Top of the Ringold Gravel Unit A.
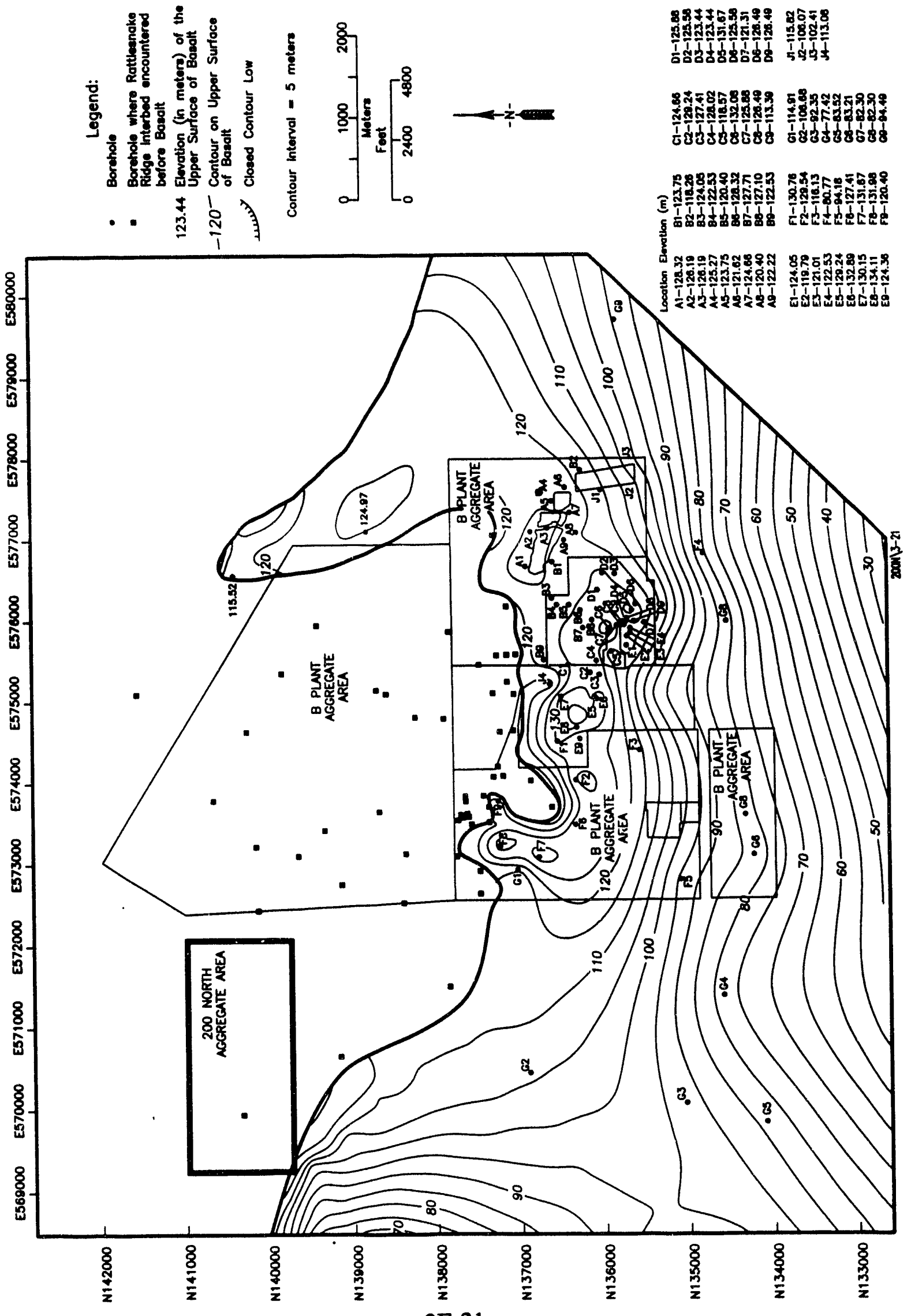
DOE/RL-92-17, Rev. 0

Figure 3-22. Isopach Map of the Lower Mud Sequence, Ringold Formation.
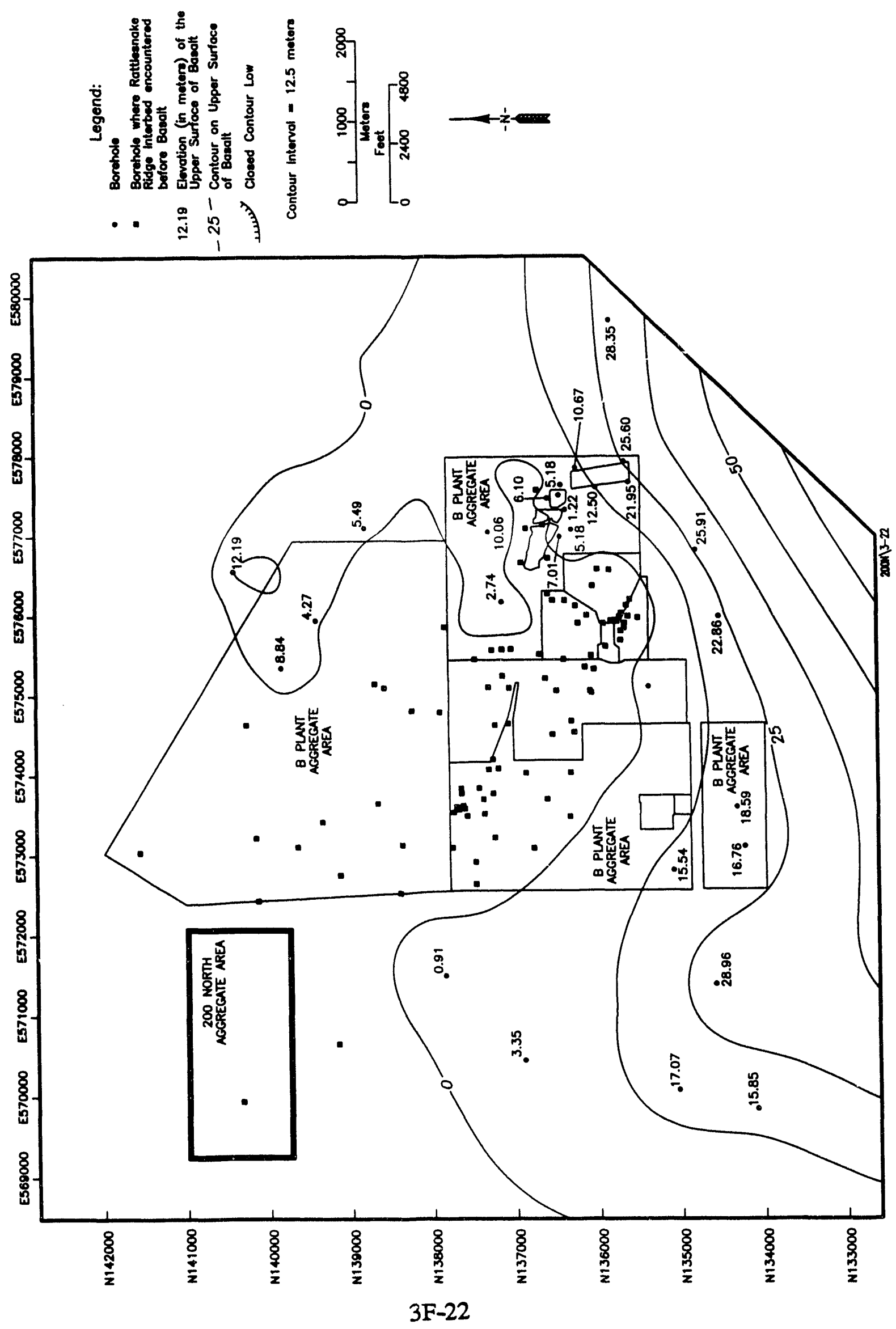
Figure 3-23. Structure Map of the Lower Mud Sequence, Ringold Formation.
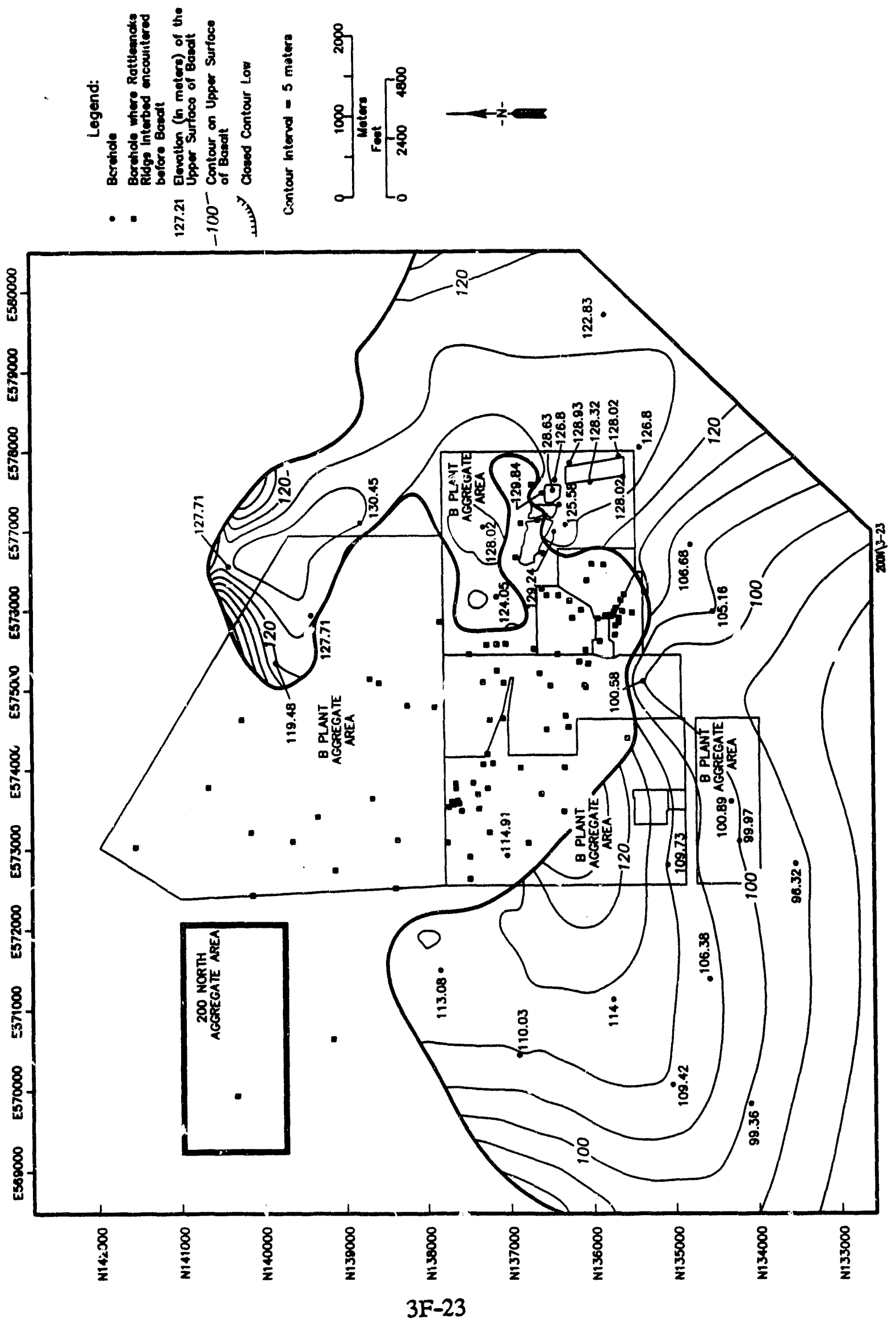
DOE/RL-92-17, Rev. 0

Figure 3-24. Isopach Map of the Gravel Unit E,

Ringold Formation.
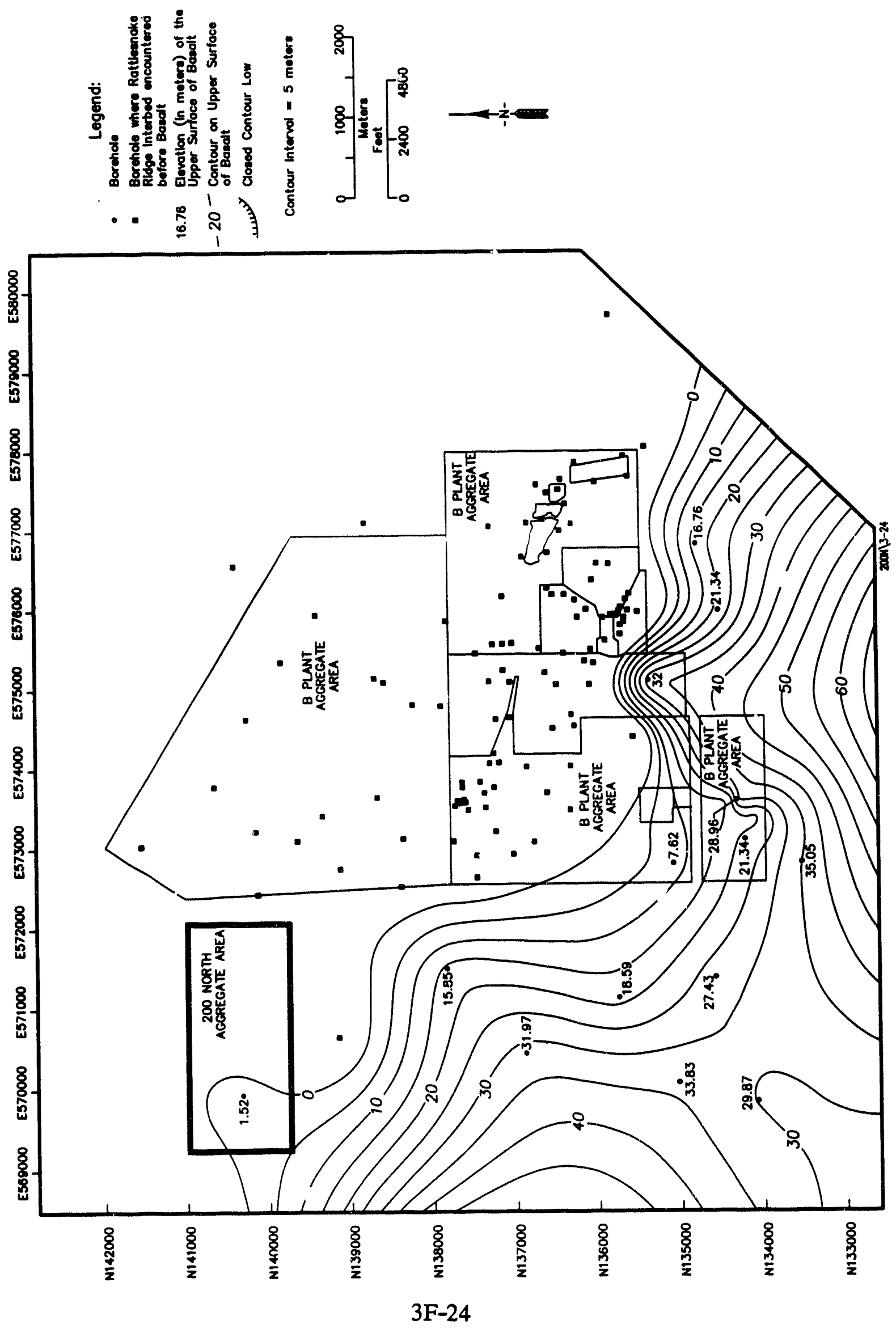
DOE/RL-92-17, Rev. 0

Figure 3-25. Structure Map of the Gravel Unit E, Ringold Formation.
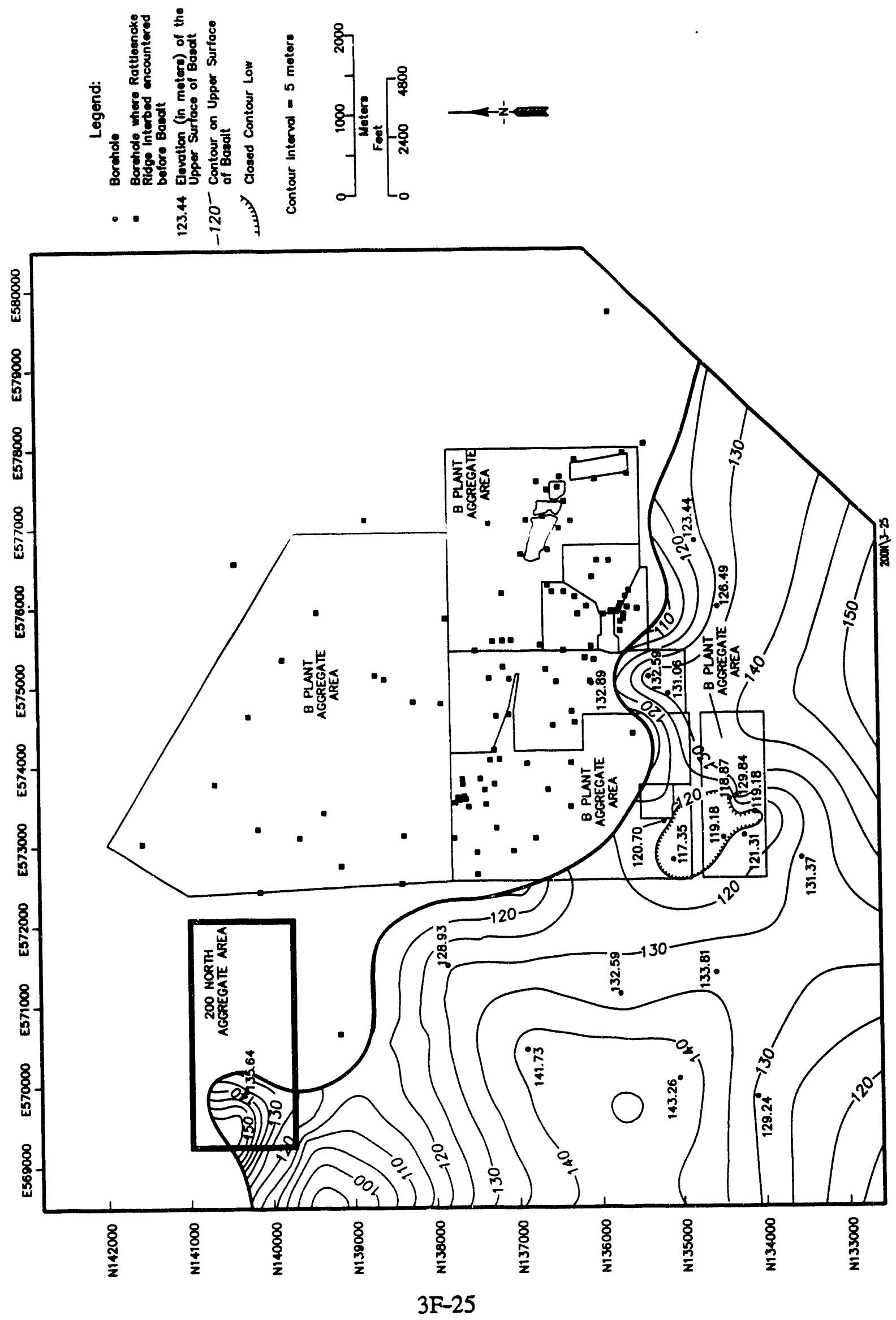
Figure 3-26. Structure Map of the Ringold Formation.
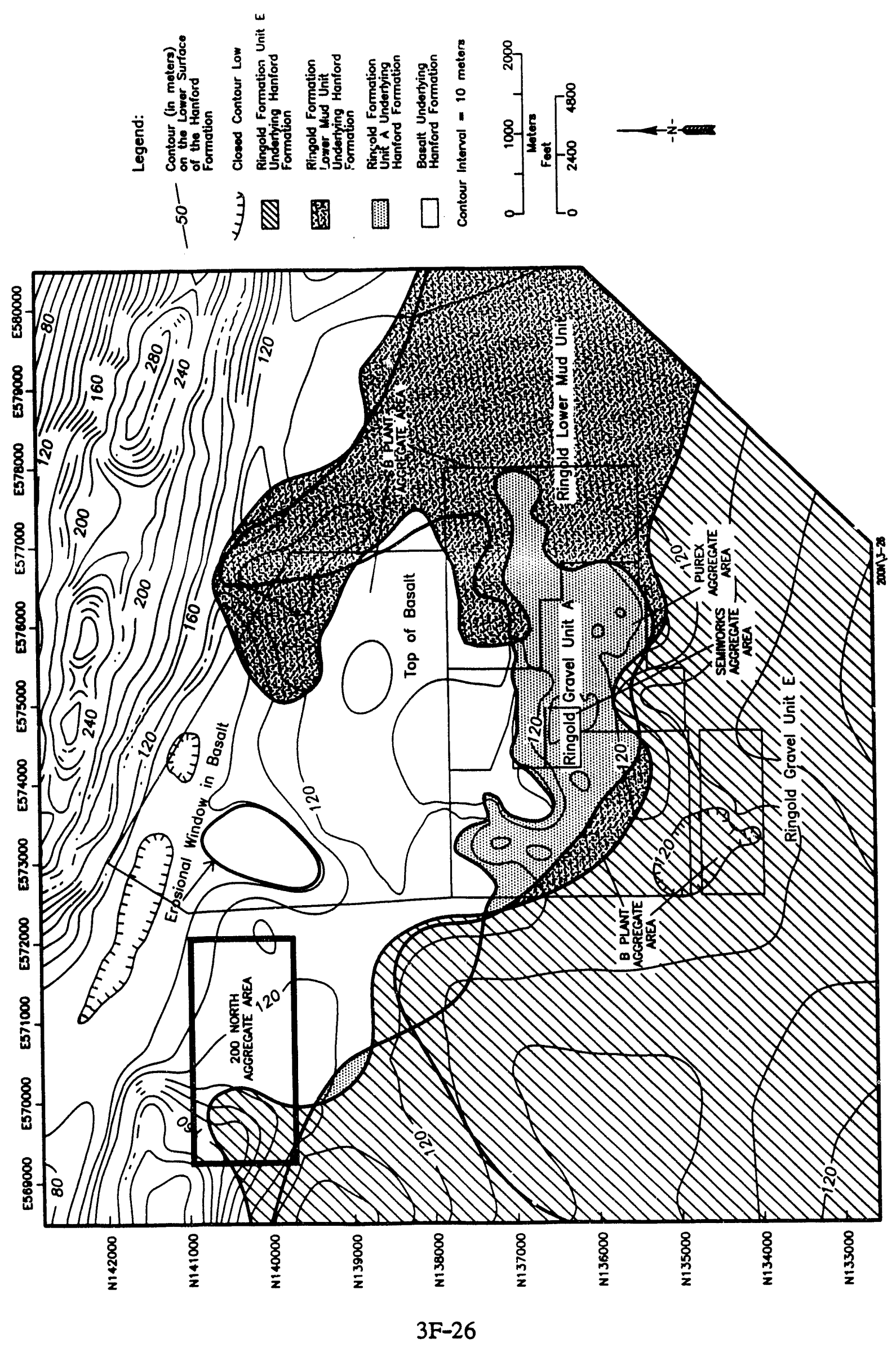
Figure 3-27. Isopach Map of the Lower Gravel Sequence, Hanford Formation.
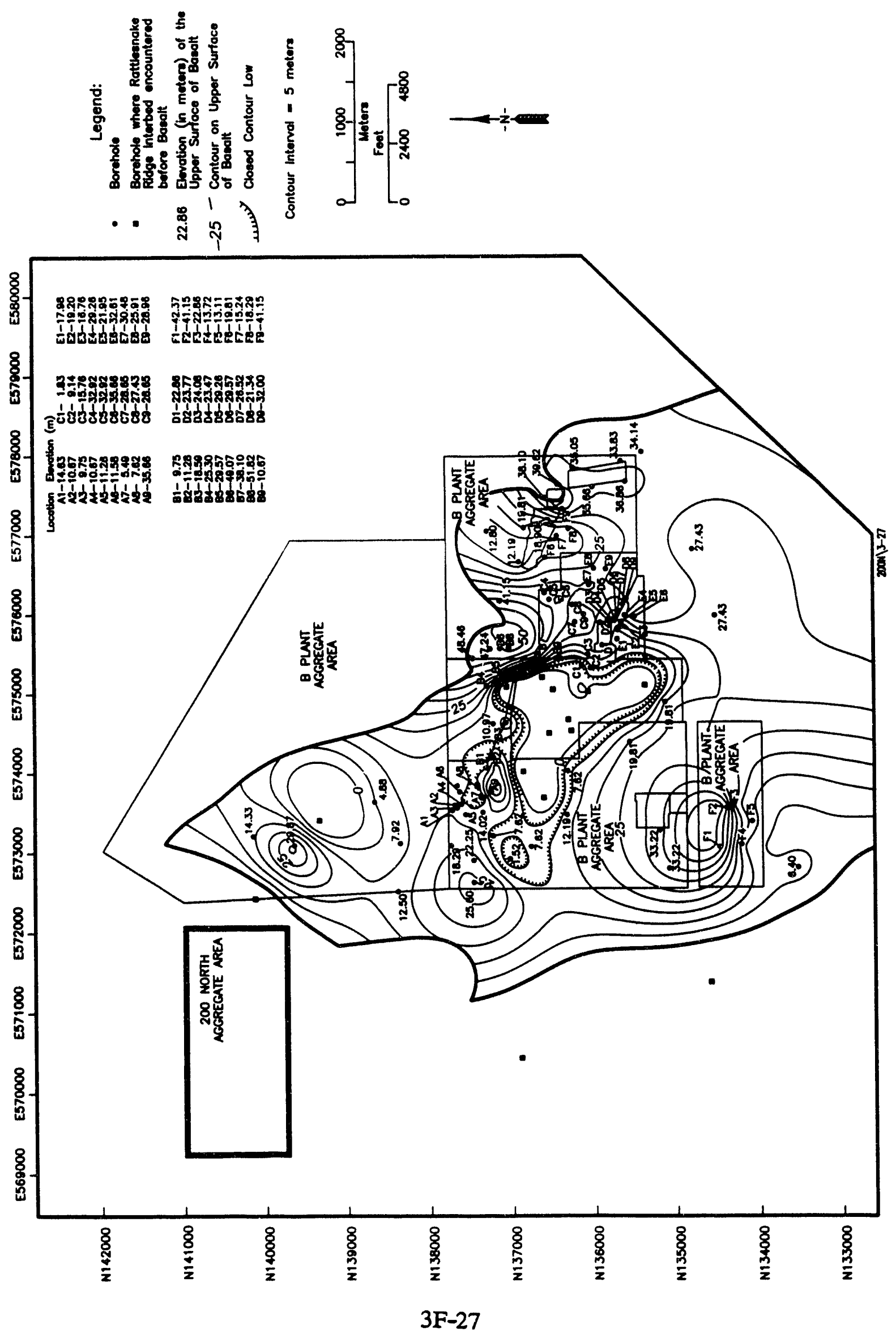
Figure 3-28. Structure Map of the Lower Gravel Sequence, Hanford Formation.
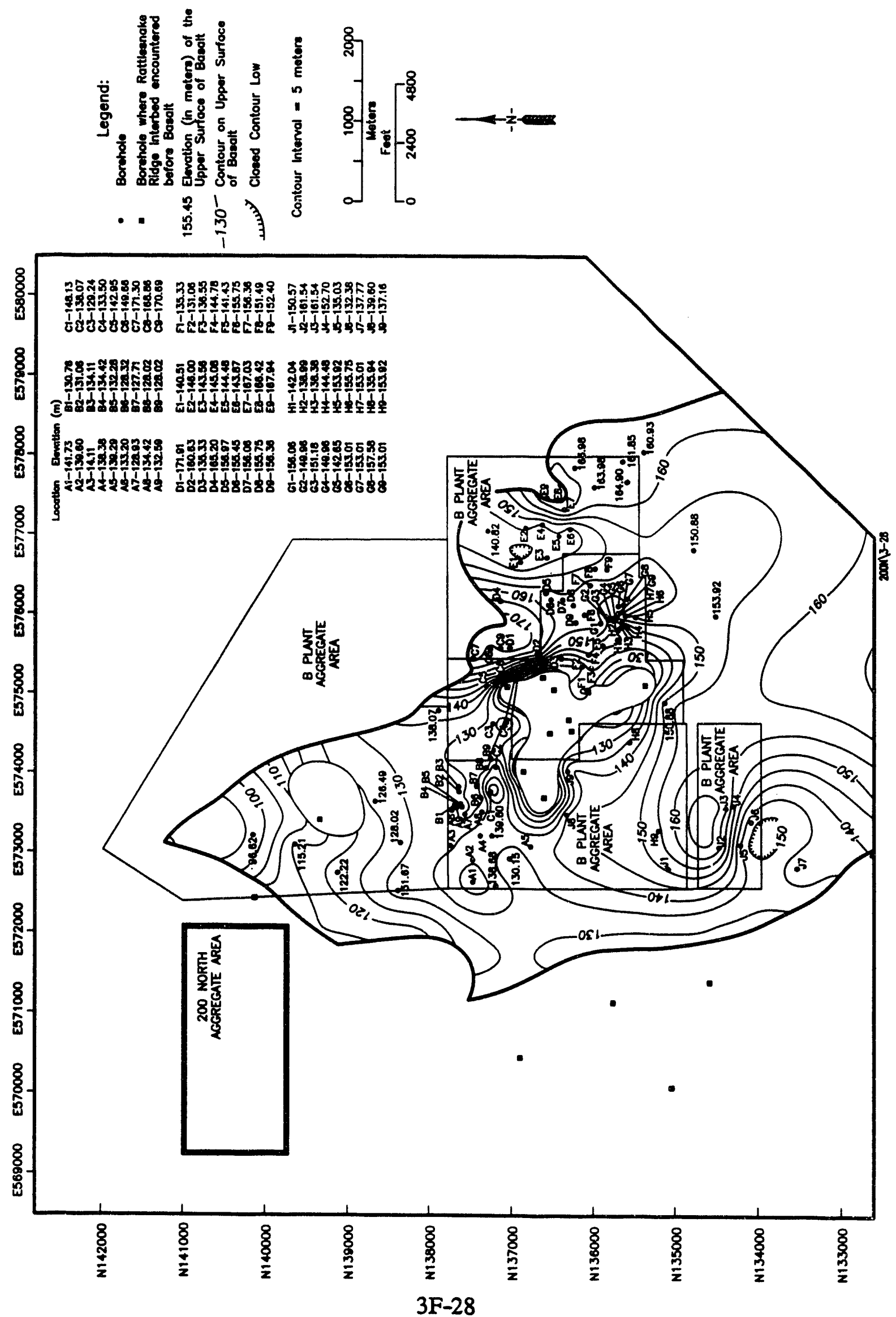
Figure 3-29. Isopach Map of the Sandy Sequence, Hanford Formation.
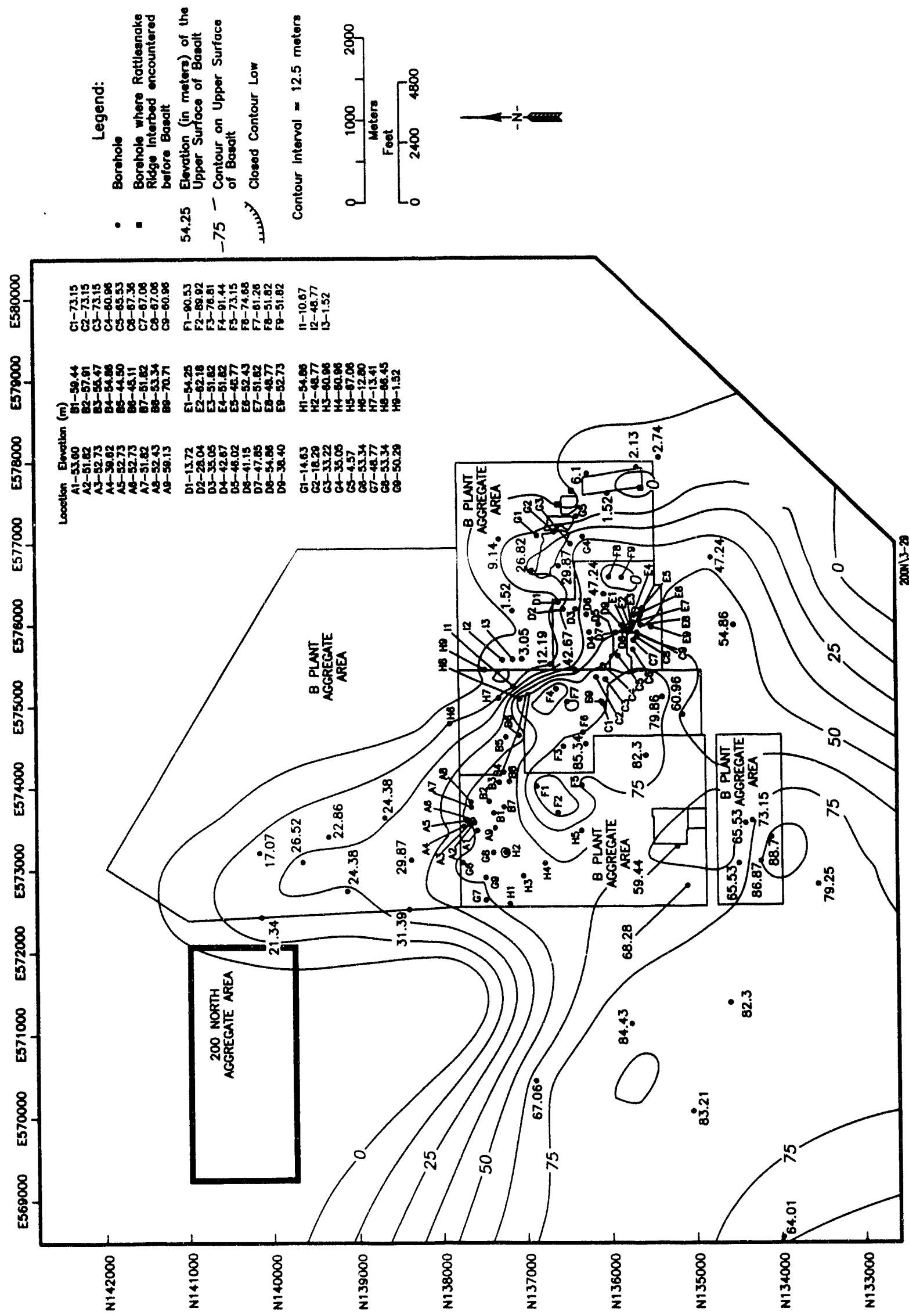
Figure 3-30. Structure Map of the Sandy Sequence, Hanford Formation.
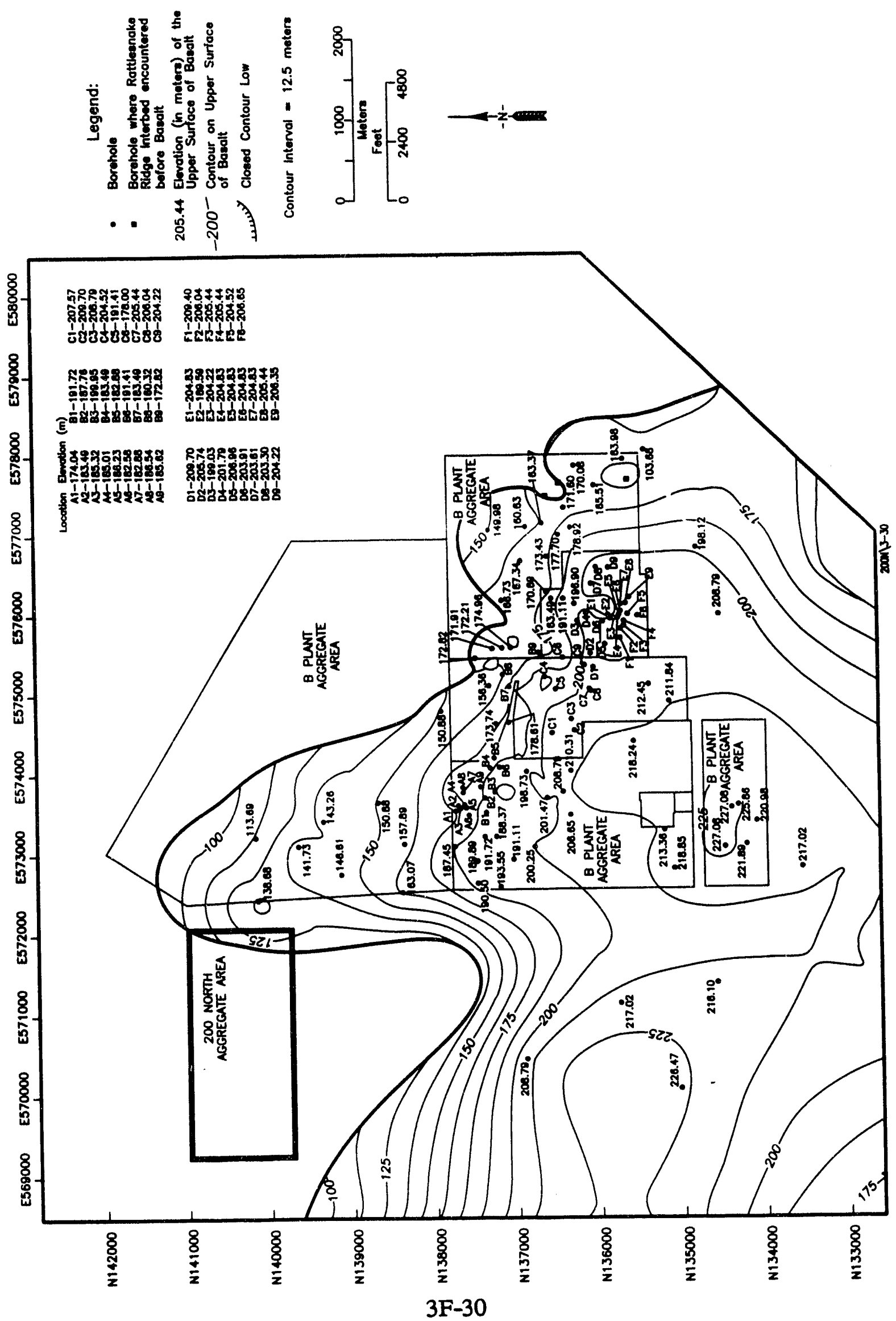
Figure 3-31. Isopach Map of the Upper Gravel Sequence, Hanford Formation.

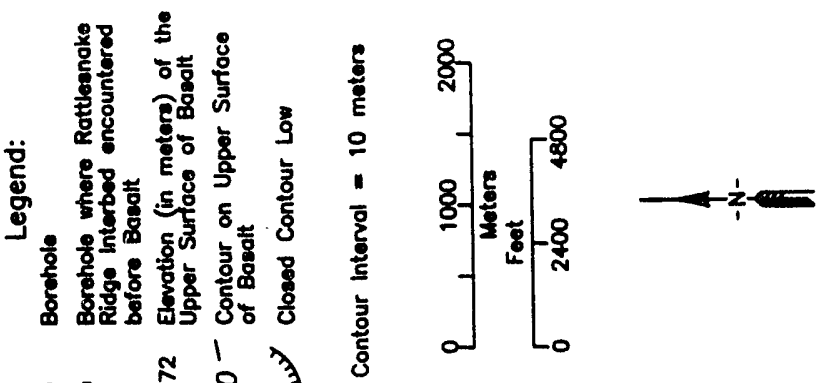

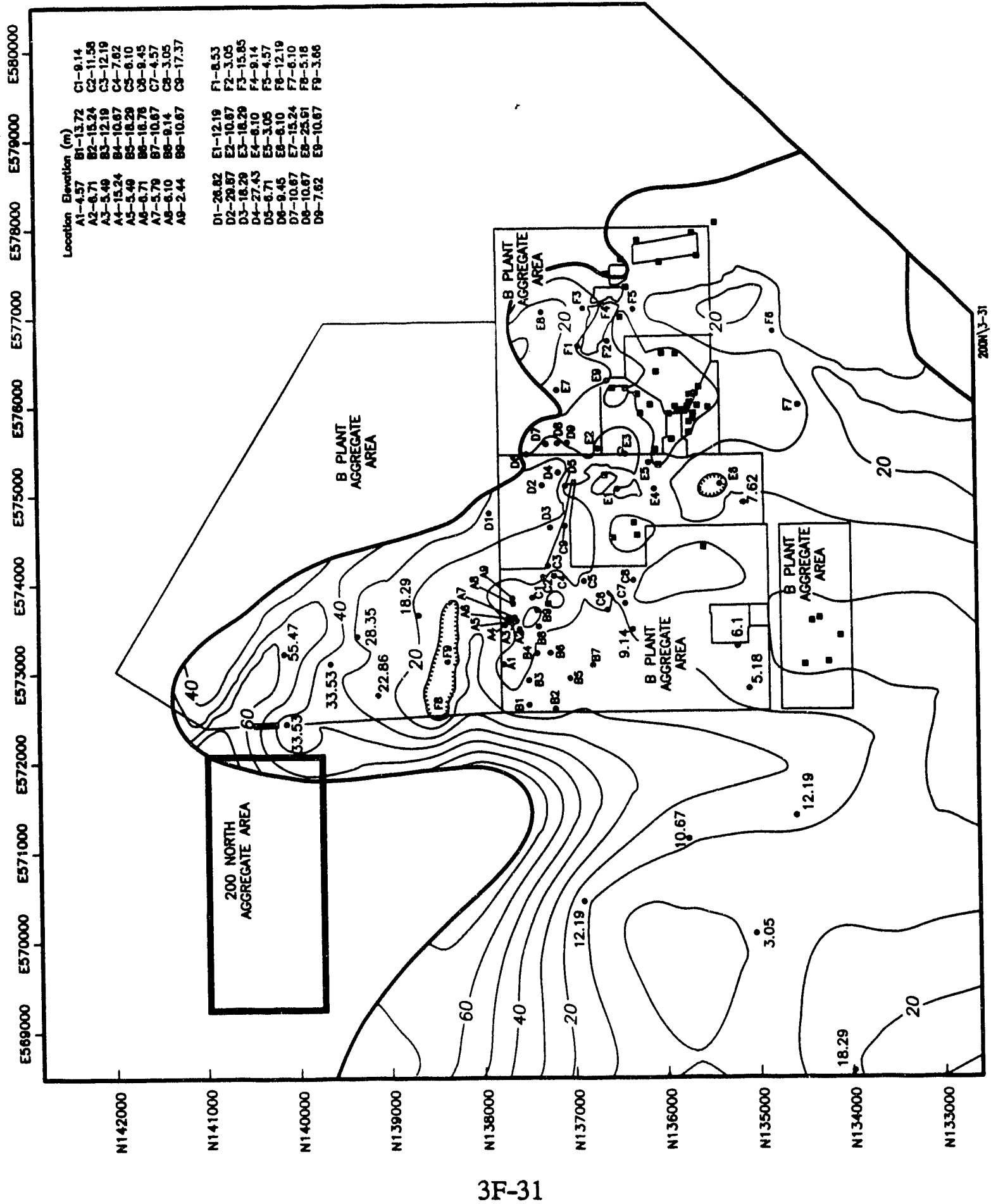


Figure 3-32. Isopach Map of the Entire Hanford Formation.

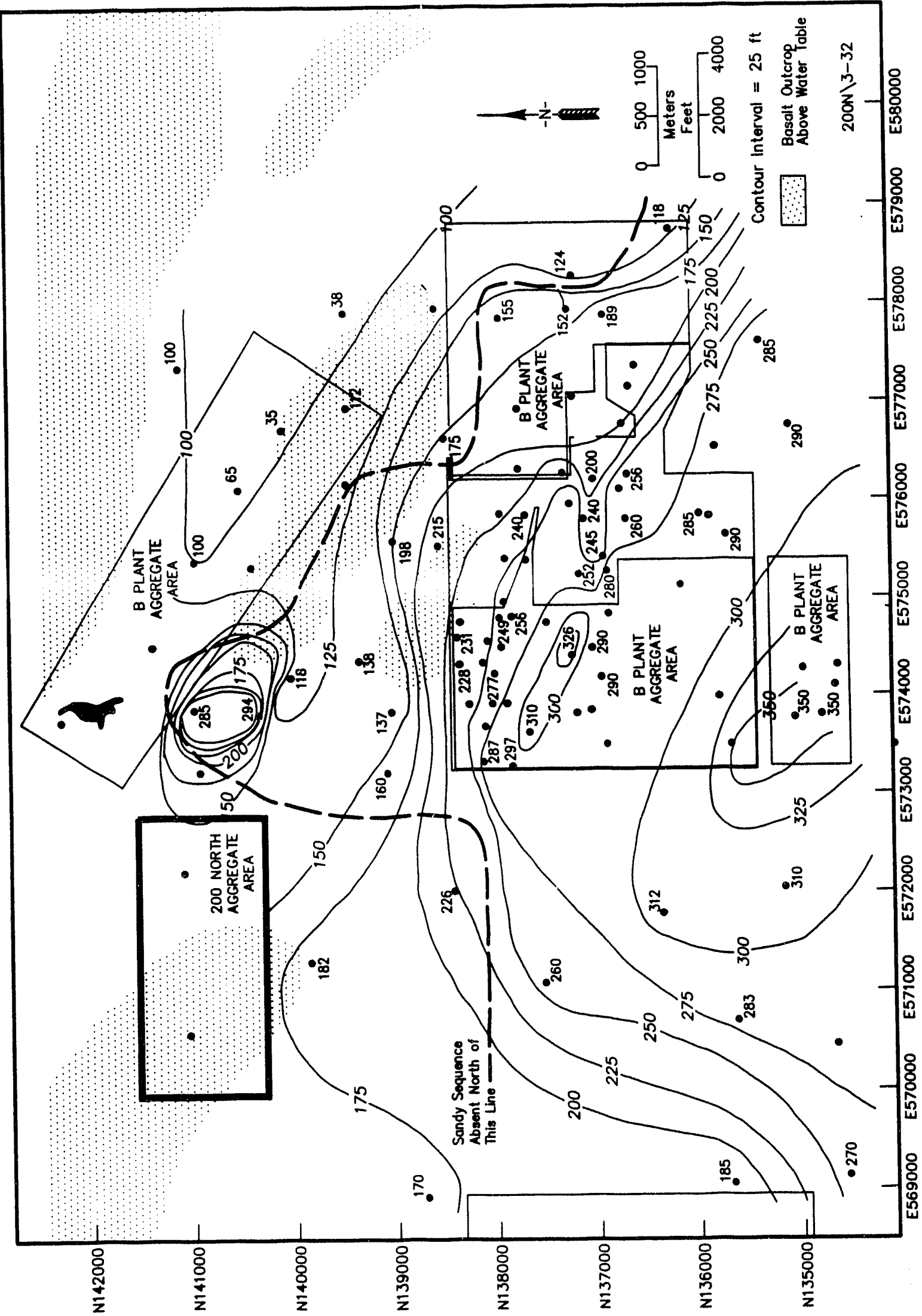


Figure 3-33. Conceptual Hydrogeologic Column for the Hanford Site.

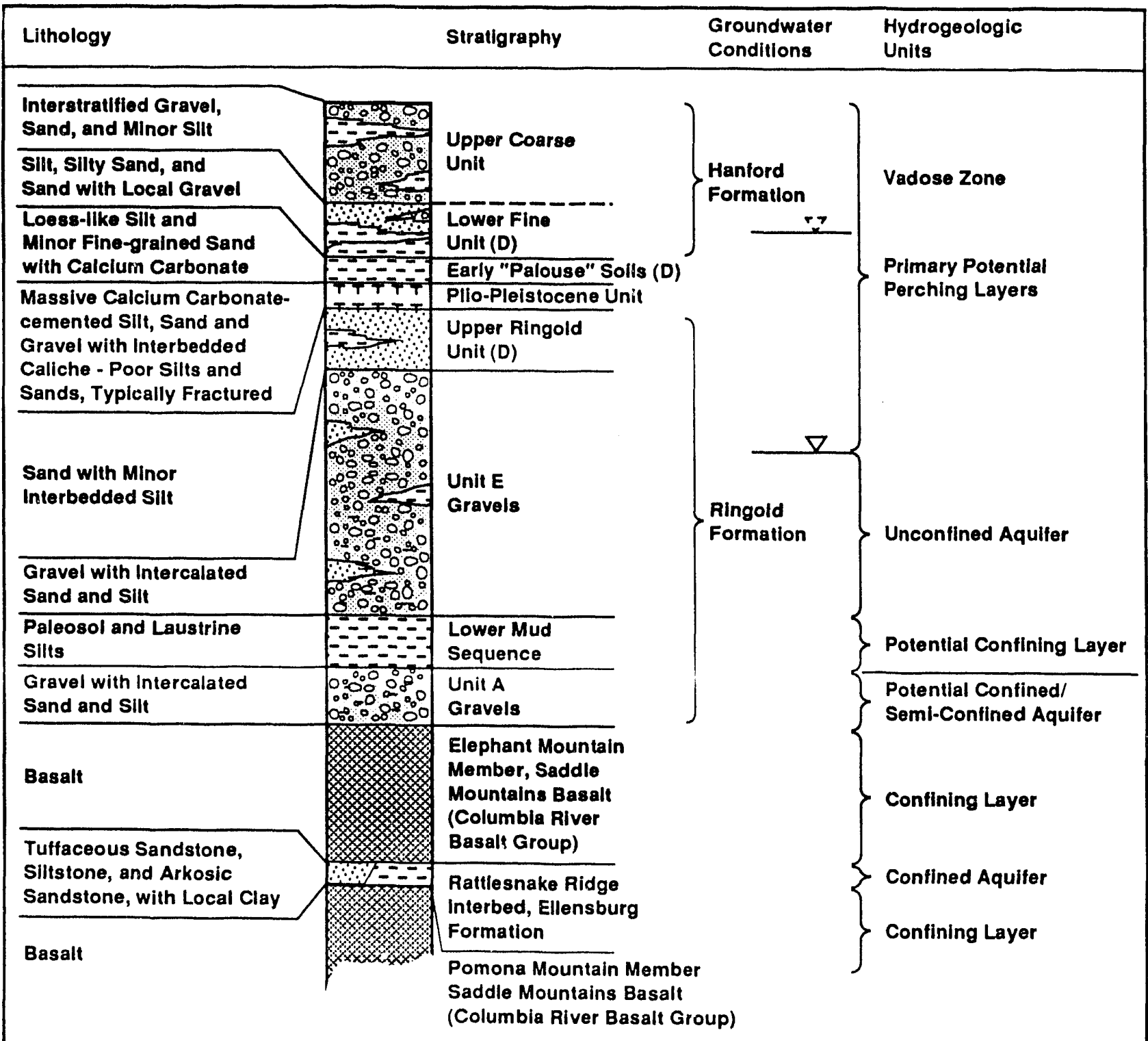

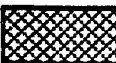

$\because$

$=-\overline{-}=-7$ sil

$00000^{\circ}$

$0.808: 0$

TTTTT

TTTTT
Basalt

Sand

Gravel

Cemented Calcium Carbonate (Caliche)

\section{$\nabla \quad$ Groundwater Table}

$\because \quad$ Potential Perching Layers (localized, potential perched groundwater may also be associated with fine-grained sediments of Hanford formation and Upper Ringold Unit)

(D) Unit Not Continuous Over Z Plant Aggregate Area

Lithology, stratigraphy, and groundwater conditions based on data from Lindsey et al. (1991), and Delaney ot al. (1991). 
DOE/RL-92-17, Rev. 0

Figure 3-34. Wetting and Drying Curves for Well 299-W18-21.
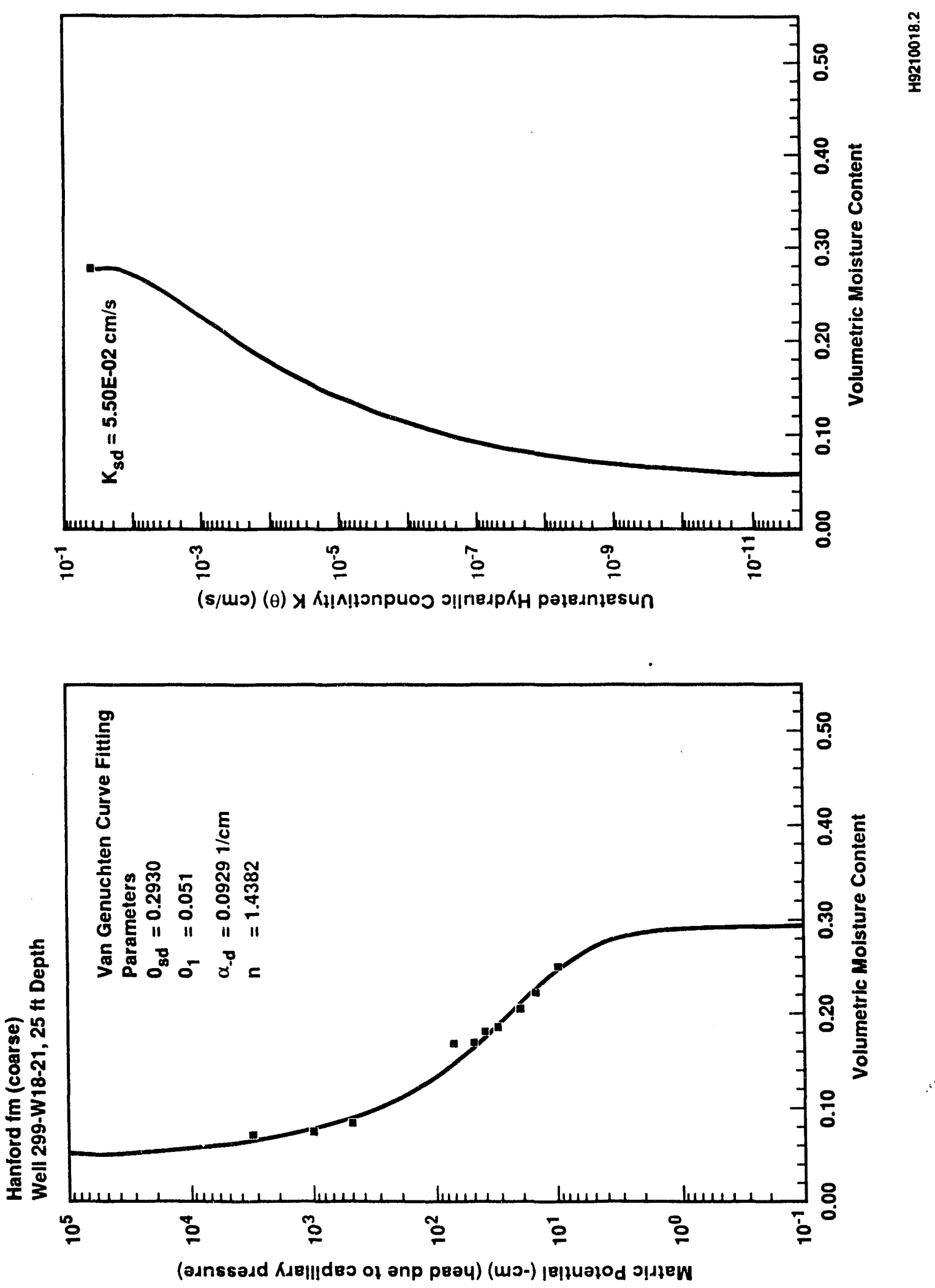
Figure 3-35. Particle Size Distribution and Water Retention Characteristics of Soil from Hanford Site Lysimeters.

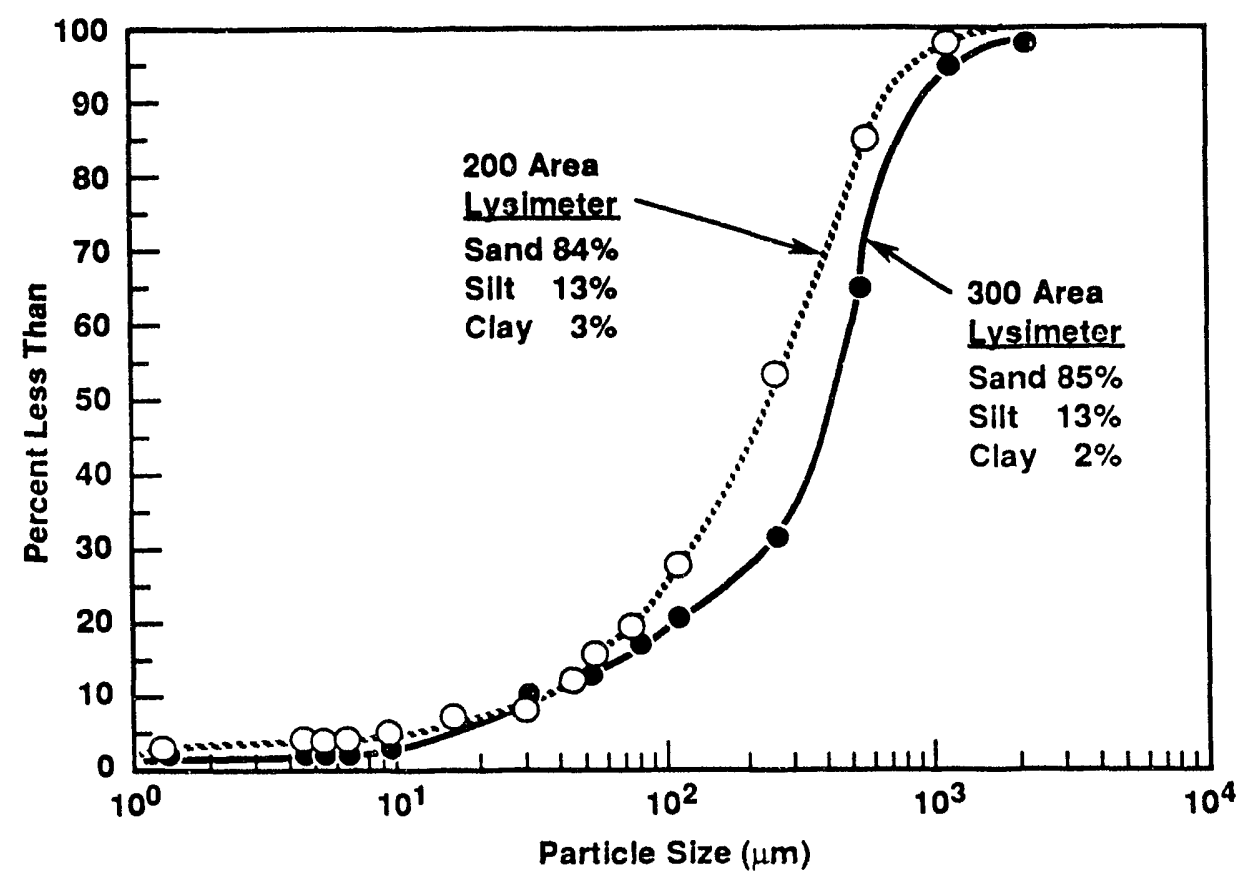

a. Particle Size Distribution

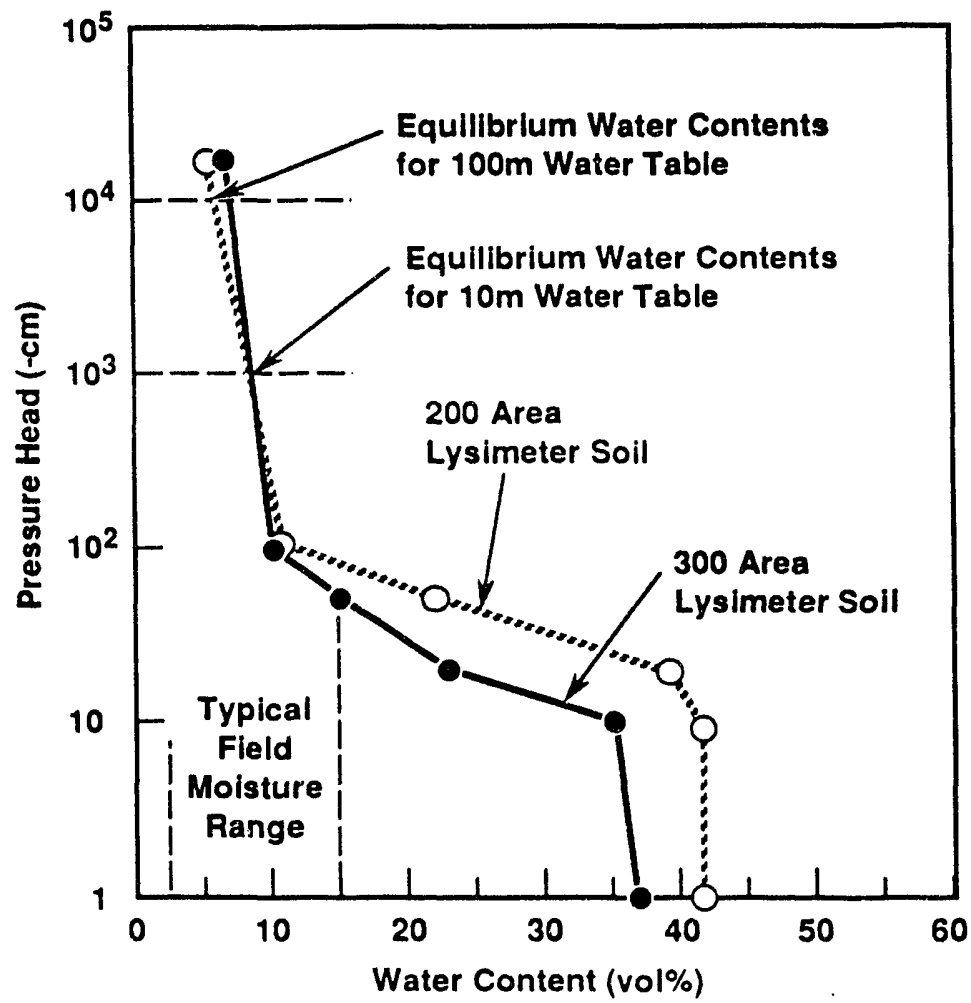

b. Water Retention Characteristics 


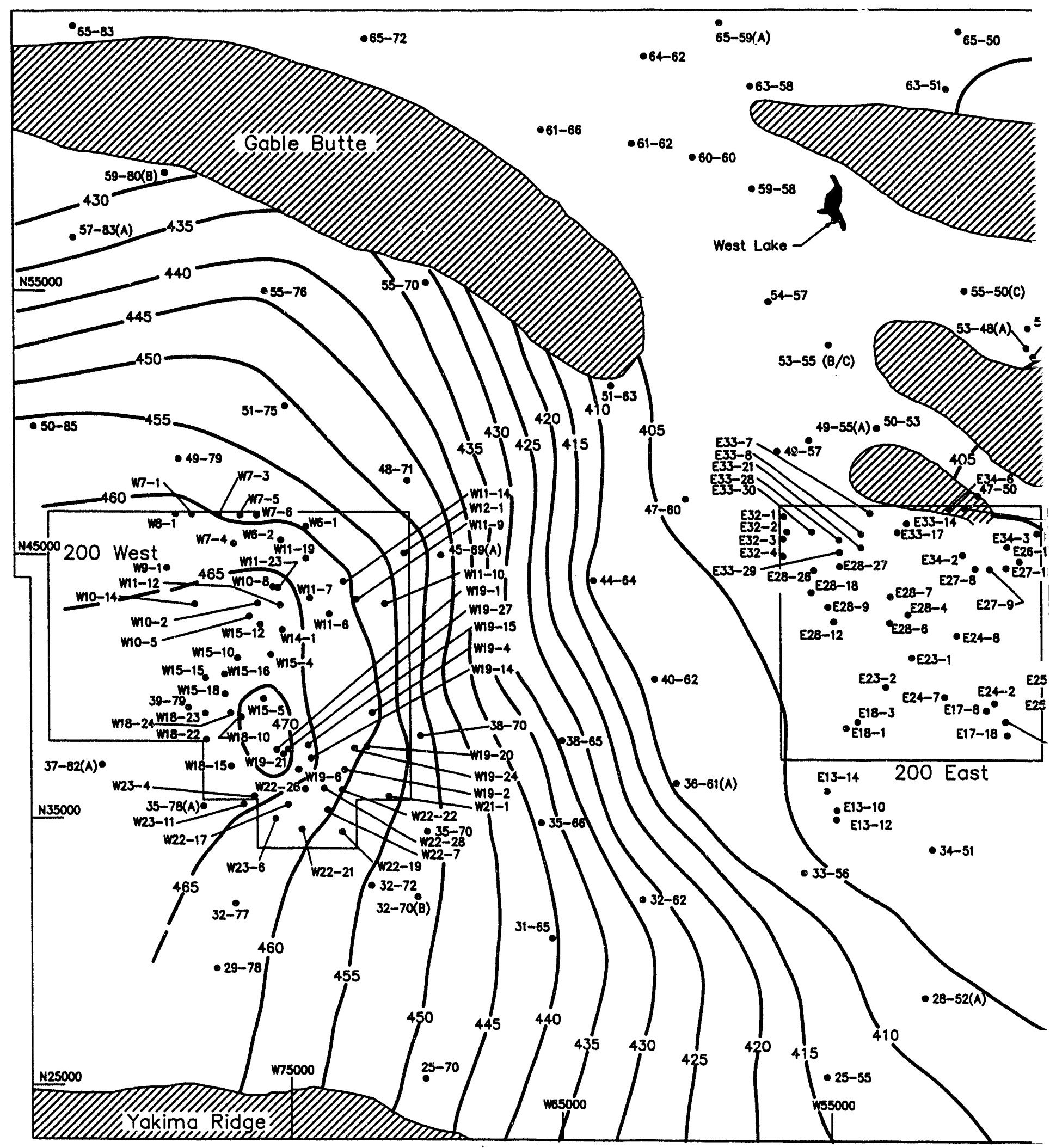


DOE/RL-92-17, Rev. 0

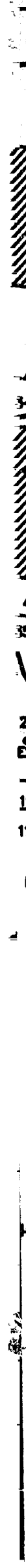

\section{Areas Water Table Map June 1.990}

\footnotetext{
Woter toble contours in feet above mean sea level

W22-26
$\square$

Data points used to prepare map

Ponds

Areas where the bosalt surface is generally above the water table
}

Gable Mountain

The 200 Areas water tabls map has been prepared by the Geosciences Group. Environmental Division, of Westinghouse Hanford Company.

Note: To convert to metric, multiply elevation (it) by 0.3048 to obtain elevation (m).
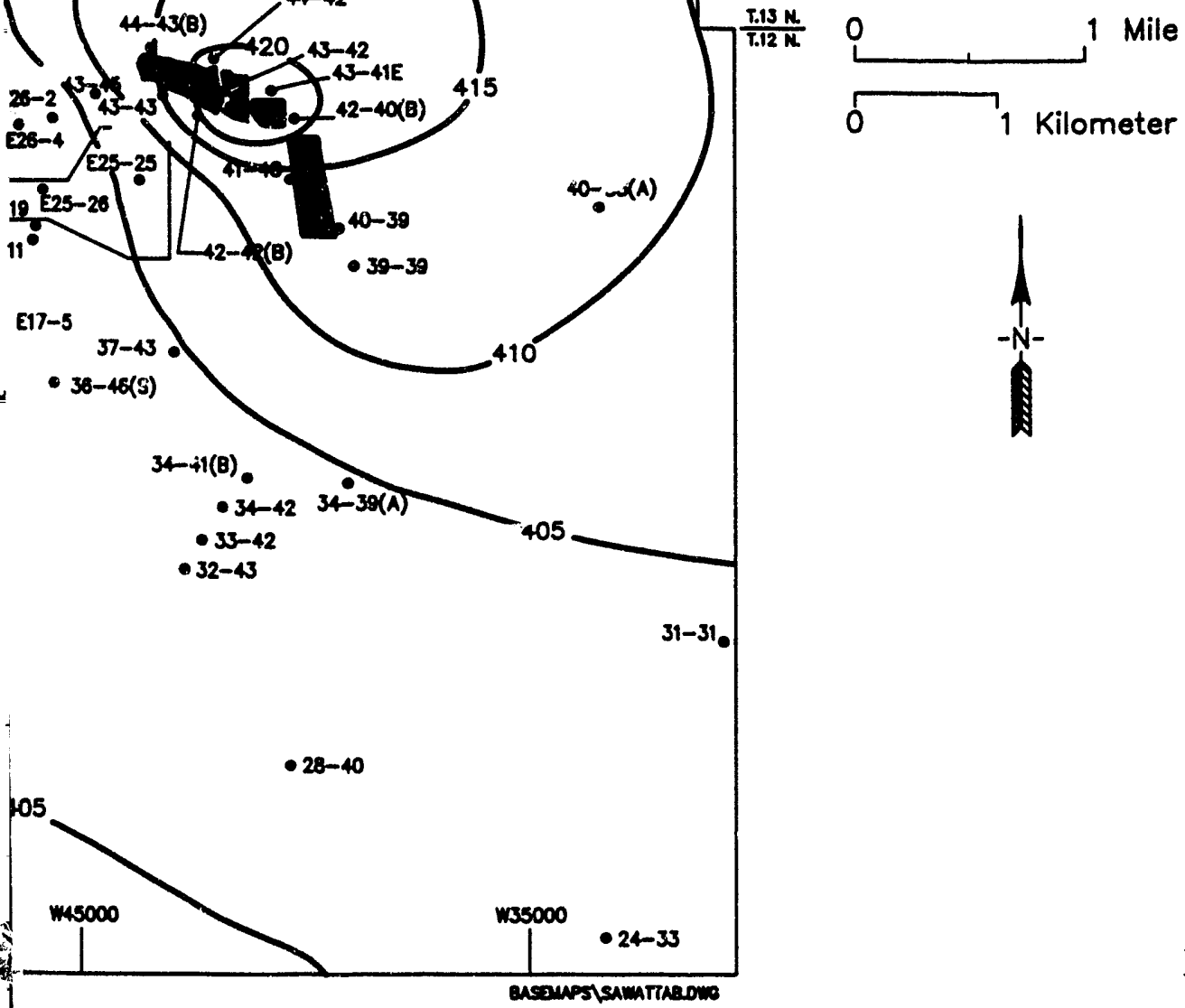

Figure 3-36. 
Figure 3-37. Conceptual Hydrogeologic Column for the PUREX Plant Aggregate Area.

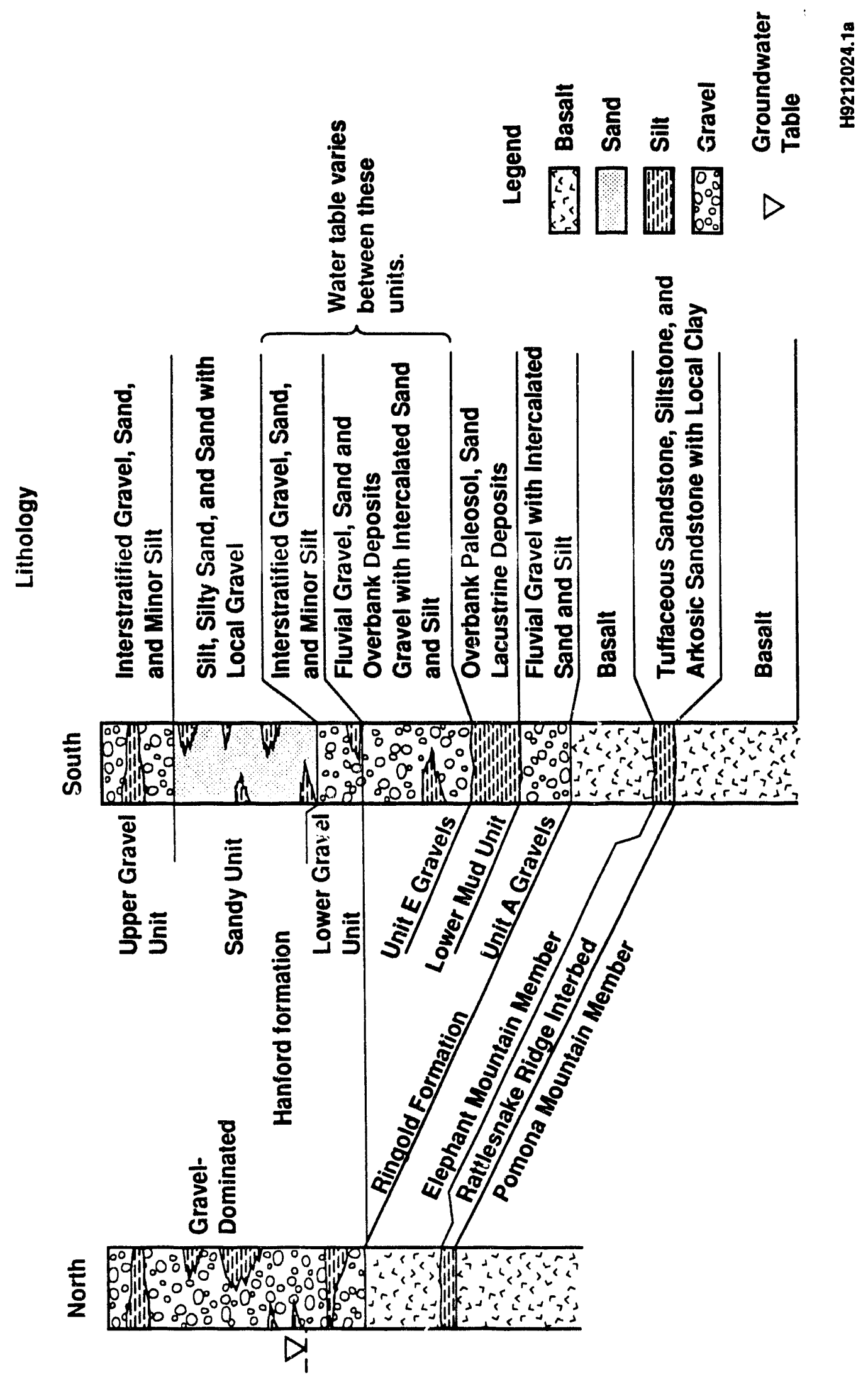


Table 3-1. Hydraulic Parameters for Various Areas and Geologic Units at the Hanford Site.

\begin{tabular}{|c|c|c|}
\hline Location & Interval tested & Hydraulic conductivity (m/day) \\
\hline Pasco Basin & $\begin{array}{l}\text { Hanford formation } \\
\text { Ringold Formation } \\
\text { Unit E } \\
\text { Ringold Formation } \\
\text { Unit A }\end{array}$ & $\begin{array}{c}150-6,200 \\
6-180 \\
0.03-3\end{array}$ \\
\hline 100 Area & Ringold Formation Unit E & $9-395$ \\
\hline 200 Areas & $\begin{array}{l}\text { Hanford formation } \\
\text { Ringold Formation } \\
\text { Unit E } \\
\text { Ringold Formation } \\
\text { Unit A }\end{array}$ & $\begin{array}{c}610-3,050 \\
2.7-70 \\
0.3-3.6\end{array}$ \\
\hline 200 West Area & $\begin{array}{l}\text { Ringold Formation } \\
\text { Unit E } \\
\text { Ringold Formation } \\
\text { Unit A } \\
\text { Lower Ringold }\end{array}$ & $\begin{array}{c}0.02-61 \\
0.5-1.2 \\
9 \times 10^{-6}-2.4 \times 10^{-5 v}\end{array}$ \\
\hline Slug Tests at U-12 Crib & Upper Ringold & $2.4-13$ \\
\hline 300 Area & Hanford Formation & $3,350-15,250$ \\
\hline 300 Area & Ringold Formation & $0.58-3,050$ \\
\hline 1100 Area & $\begin{array}{l}\text { Ringold Formation } \\
\text { Units C/B }\end{array}$ & $0.09-1.5$ \\
\hline 1100 Area & $\begin{array}{l}\text { Ringold Formation } \\
\text { Overbank Deposits }\end{array}$ & $\begin{array}{c}2.4 \times 10^{-4} \\
0.03\end{array}$ \\
\hline
\end{tabular}

Source: Bjornstad 1990; Connely of al. 1992; and Rockhold et al. 1988.

vaboratory tests rather than in-situ tests. 
Table 3-2. Summary of Reported Hydraulic Conductivity Values for Hanford Site Vadose Zone Sediments.

Page 1 of 2

\begin{tabular}{|c|c|c|c|c|}
\hline $\begin{array}{l}\text { Reported Hydraulic } \\
\text { Conductivity Value } \\
\text { or Range of } \\
\text { Values in } \mathrm{cm} / \mathrm{s}\end{array}$ & $\begin{array}{l}\text { Water Content } \\
\text { Volume Percent }\end{array}$ & $\begin{array}{c}\text { Reported Geologic } \\
\text { Unit or } \\
\text { Sediment Type } \\
\end{array}$ & $\begin{array}{l}\text { Test Area or } \\
\text { Sampling } \\
\text { Location }\end{array}$ & $\begin{array}{c}\text { Measurement } \\
\text { Method or Basis } \\
\text { for Reported Value }\end{array}$ \\
\hline $6.7 \times 10^{-7}$ & 10 & Sand & 200 Area & $\begin{array}{l}\text { Lysimeter Soil } \\
\text { Experiments }\end{array}$ \\
\hline $1.7 \times 10^{-8}$ & 7 & - & -- & - \\
\hline $1.7 \times 10^{-9}$ & 5.5 & - & - & - \\
\hline $1.7 \times 10^{-10}$ & 5 & - & - & - \\
\hline $1.3 \times 10^{-11}$ & 4.3 & - & - & - \\
\hline $\begin{array}{l}2.6 \times 10^{-3} \\
5.7 \times 10^{-4}(\mathrm{sat})\end{array}$ & $\begin{array}{l}31 \\
56\end{array}$ & $\begin{array}{l}\text { Sandy soil reported } \\
\text { as "typical or many } \\
\text { surface materials at } \\
\text { the Hanford Site." }\end{array}$ & - & $\begin{array}{l}\text { Unsaturated } \\
\text { column studies. }\end{array}$ \\
\hline $\begin{array}{l}6.3 \times 10^{-11} \\
2.2 \times 10^{-11}\end{array}$ & $\begin{array}{l}2.9 \\
2.8\end{array}$ & $\begin{array}{c}\text { Near-surface soils } \\
-\end{array}$ & $\begin{array}{l}\text { 2-km south of } \\
200 \text { East Area }\end{array}$ & $\begin{array}{l}\text { K estimates by Gee } \\
1987 \text { using water } \\
\text { retention curve data } \\
\text { from Figure } 7 \text { in } \\
\text { Hsieh, et al., } 1973 .\end{array}$ \\
\hline $\begin{array}{l}5.40 \times 10^{8} \\
9.78 \times 10^{-3} \text { (sat) } \\
8.4 \times 10^{-3} \text { (sat, } \\
\text { arithmetic mean of } \\
\text { four measurements) }\end{array}$ & $\begin{array}{l}8.3 \\
42.2 \\
\mathrm{na}\end{array}$ & $\begin{array}{l}\text { Sandy fill excavated } \\
\text { from near-surface } \\
\text { soil (Hanford } \\
\text { formation) with 1.27- } \\
\text { cm particle size } \\
\text { fraction screened out. }\end{array}$ & $\begin{array}{l}\text { Buried Waste } \\
\text { Test Facility } \\
\text { (BWTF): } 300 \\
\text { North Area } \\
\text { Burial Grounds }\end{array}$ & $\begin{array}{l}\text { Laboratory steady- } \\
\text { state flux } \\
\text { measurements. }\end{array}$ \\
\hline $\begin{array}{l}8 \times 10^{-8} \\
4 \times 10^{-3} \text { (Southeast } \\
\text { Caisson } \\
1 \times 10^{-8} \\
1 \times 10^{-2} \text { (North } \\
\text { Caisson) }\end{array}$ & $\begin{array}{l}11 \\
26 \\
10 \\
29\end{array}$ & $\begin{array}{l}\text { NA } \\
\text { NA } \\
\text { NA } \\
\text { NA }\end{array}$ & $\begin{array}{l}\text { BWTF: } \\
\text { Southeast } \\
\text { Caisson, and } \\
\text { North Caisson }\end{array}$ & $\begin{array}{l}\text { Unsteady drainage- } \\
\text { flux field } \\
\text { measurements. }\end{array}$ \\
\hline $\begin{array}{l}4.5 \times 10^{-3} \text { (arithmetic } \\
\text { mean of } 15 \\
\text { measurements) }\end{array}$ & Field Saturation & NA & $\begin{array}{l}\text { BWTF North } \\
\text { Caisson and } \\
\text { area north of } \\
\text { caisson }\end{array}$ & $\begin{array}{l}\text { Guelph } \\
\text { permeameter field } \\
\text { measurements }\end{array}$ \\
\hline
\end{tabular}


Table 3-2. Summary of Reported Hydraulic Conductivity Values for Hanford Site Vadose Zone Sediments.

Page 2 of 2

\begin{tabular}{|c|c|c|c|c|}
\hline $\begin{array}{l}\text { Reported Hydraulic } \\
\text { Conductivity Value } \\
\text { or Range of } \\
\text { Values in } \mathrm{cm} / \mathrm{s}\end{array}$ & $\begin{array}{l}\text { Water Content } \\
\text { Volume Percent }\end{array}$ & $\begin{array}{c}\text { Reported Geologic } \\
\text { Unit or } \\
\text { Sediment Type }\end{array}$ & $\begin{array}{l}\text { Test Area or } \\
\text { Sampling } \\
\text { Location }\end{array}$ & $\begin{array}{c}\text { Measurement } \\
\text { Method or Basis } \\
\text { for Reported Value }\end{array}$ \\
\hline $\begin{array}{l}1 \times 10^{-3} \text { (Upper Soil, } \\
\text { arithmetic mean of } 7 \\
\text { measurements) } \\
9.2 \times 10^{-3} \text { (Lower } \\
\text { Soil, arithmetic mean } \\
\text { of } 4 \text { measurements) }\end{array}$ & $\begin{array}{l}\text { Field Saturation } \\
\text { Field Saturation }\end{array}$ & $\begin{array}{l}\text { Loam sand over sand } \\
\text { NA }\end{array}$ & $\begin{array}{l}\text { Grass Site; } 3 \\
\mathbf{k m} \text { of BWTF }\end{array}$ & $\begin{array}{l}\text { Guelph } \\
\text { permeameter field } \\
\text { measurements }\end{array}$ \\
\hline $\begin{array}{l}8 \times 10^{-7} \\
9 \times 10^{-4}\end{array}$ & $\begin{array}{l}16 \\
40\end{array}$ & Loam to sandy loam & $\begin{array}{l}\text { McGee } \\
\text { Ranch:NW of } \\
200 \text { West Area } \\
\text { on State Rt. } \\
240\end{array}$ & $\begin{array}{l}\text { Unsteady drainage- } \\
\text { flux field } \\
\text { measurements. }\end{array}$ \\
\hline $\begin{array}{l}9 \times 10^{-4} \text { (arithmetic } \\
\text { mean of } 9 \\
\text { measurements }\end{array}$ & Field Saturation & NA & - & $\begin{array}{l}\text { Guelph } \\
\text { permeameter field } \\
\text { measurements. }\end{array}$ \\
\hline $\begin{array}{l}5 \times 10^{-3} \text { (sat) } \\
1 \times 10^{-3} \text { (sat) } \\
5 \times 10^{-4} \text { (sat) } \\
1 \times 10^{-4} \text { (sat) } \\
5 \times 10^{-5} \text { (sat) }\end{array}$ & $\begin{array}{l}50 \\
50 \\
40 \\
40 \\
40\end{array}$ & $\begin{array}{l}\text { Sand, Gravel } \\
\text { Coarse Sand } \\
\text { Fine Sand } \\
\text { Sand, Silt } \\
\text { Caliche }\end{array}$ & $\begin{array}{l}\text { Sediment types } \\
\text { are idealized to } \\
\text { represent } \\
\text { stratigraphic } \\
\text { layers } \\
\text { commonly } \\
\text { encountered } \\
\text { below } 200 \\
\text { Areas liquid } \\
\text { disposal sites. }\end{array}$ & $\begin{array}{l}\mathbf{K}_{\text {wet }} \text { values derived } \\
\text { from idealized } \\
\text { moisture content } \\
\text { curves on Figure } \\
\text { B-1. }\end{array}$ \\
\hline $\begin{array}{l}1.2 \times 10^{-5} \text { (sat) } \\
6.7 \times 10^{-6} \text { to } 2.8 \times \\
10^{-1} \text { (sat) } \\
1.10 \times 10^{-3} \text { (sat) } \\
1.80 \times 10^{-4} \text { to } 3.00 \times \\
10^{-4} \text { (sat) }\end{array}$ & $\begin{array}{l}19.6 \text { to } 18.9 \\
37.6 \text { to } 41.4\end{array}$ & $\begin{array}{l}\text { Hanford formation } \\
\text { Early "Palouse" Soils } \\
\text { Upper Ringold } \\
\text { Middle Ringold }\end{array}$ & $\begin{array}{l}\text { Well 299-W7- } \\
9,218-W-5 \\
\text { Burial Ground }\end{array}$ & $\begin{array}{l}\text { van Genuchten } \\
\text { equation fitted to } \\
\text { moisture } \\
\text { characteristic } \\
\text { curves for Well } \\
299-W 7-9 \text { soil } \\
\text { samples }\end{array}$ \\
\hline
\end{tabular}

Notes:

NA - Not identified in source.

sat - Value for saturated soil.

field saturation - Equilibrium water content after several days of gravity drainage.

Source: Bjornstad 1990; Connely et al. 1992; and Rockhold et al. 1988. 
Table 3-3. Endangered, Threatened, and Sensitive Plant Species Reported On or Near the Hanford Site.

\begin{tabular}{|c|c|c|c|}
\hline Scientific Name & Common Name & Family & $\begin{array}{l}\text { Washington } \\
\text { State Status }\end{array}$ \\
\hline $\begin{array}{l}\text { Rorippa columbiae }{ }^{a /} \text { Suksd. } \\
\text { ex Howell }\end{array}$ & $\begin{array}{l}\text { Persistantsepal } \\
\text { Yellowcress }\end{array}$ & Brassicaceae & Endangered \\
\hline $\begin{array}{l}\text { Artemesia campestris L ssp. } \\
\text { borealis (Pall.) Hall \& Clem. } \\
\text { var. wormskioldii }{ }^{\alpha} \text { (Bess.) } \\
\text { Cronq. }\end{array}$ & $\begin{array}{l}\text { Northern } \\
\text { Wormwood }\end{array}$ & Asteraceae & Endangered \\
\hline $\begin{array}{l}\text { Astragulus columbianus" } \\
\text { Barneby }\end{array}$ & $\begin{array}{l}\text { Columbia Milk } \\
\text { Vetch }\end{array}$ & Fabaceae & Threatened \\
\hline $\begin{array}{l}\text { Lomatium tuberosum } \\
\text { Hoover }\end{array}$ & $\begin{array}{l}\text { Hoover's Desert- } \\
\text { Parsley }\end{array}$ & Apiaceae & Threatened \\
\hline Astragalus arrectus Gray & Palouse Milk Vetch & Fabaceae & Sensitive \\
\hline $\begin{array}{l}\text { Collinsia sparsiflora } \\
\text { Fisch.\&Mey. var bruciae } \\
\text { (Jones) Newsom }\end{array}$ & $\begin{array}{l}\text { Few-Flowered } \\
\text { Collinsia }\end{array}$ & Scrophulariaceae & Sensitive \\
\hline $\begin{array}{l}\text { Cryptantha interrupta } \\
\text { (Greene)Pays. }\end{array}$ & Bristly Cryptantha & Boraginaceae & Sensitive \\
\hline $\begin{array}{l}\text { Cryptantha leucophaea } \\
\text { Dougl. Pays }\end{array}$ & Gray Cryptantha & Boraginaceae & Sensitive \\
\hline Erigeron piperianus Cronq. & Piper's Daisy & Asteraceae & Sensitive \\
\hline Carex densa L.H. Bailey & Dense Sedge & Cyperaceae & Sensitive \\
\hline Cyperus rivularis Kunth & Shining Flatsedge & Cyperaceae & Sensitive \\
\hline $\begin{array}{l}\text { Limosella acaulis } \\
\text { Ses.\&Moc. }\end{array}$ & Southern Mudwort & Scrophulariaceae & Sensitive \\
\hline $\begin{array}{l}\text { Lindernia anagallidea } \\
\text { (Michx.)Pennell }\end{array}$ & False-pimpernel & Scrophulariaceae & Sensitive \\
\hline Nicotiana attenuata Torr. & Coyote Tobacco & Solanaceae & Sensitive \\
\hline Oenothera pygmaea Dougl. & $\begin{array}{l}\text { Dwarf Evening- } \\
\text { Primrose }\end{array}$ & Onagraceae & Sensitive \\
\hline
\end{tabular}

a/ Indicates candidates on the 1991 Federal Register, Notice of Review. 
Table 3-4. Federal and State Classifications of Animals that Could Occur on the 200 Areas Plateau.

\begin{tabular}{|lcc|}
\hline Common Name & Status Federal & State \\
\hline Peregrine Falcon (Falco peregrinus) & FE & SE \\
Sandhill Crane (Grus canadensis) & - & SE \\
Bald Eagle (Haliaeetus leucocephalus) & FT & ST \\
Ferruginous Hawk (Buteo regalis) & FC2 & ST \\
Swainson's Hawk (Buteo swainsoni) & FC2 & SC \\
Golden Eagle (Aquila chrysaetos) & - & SC \\
Burrowing Owl (Athene cuniculuria) & -- & SC \\
Loggerhead Shrike (Lanius & -- & SC \\
lucovicianus) & & \\
Sage Sparrow (Amphispiza belli) & - & SC \\
Great Blue Heron (Casmerodius & -- & SM \\
albus) & & SM \\
Merlin (Falco columbarius) & - & SM \\
Prairie Falcon (Falco mexicanus) & - & SM \\
Long-billed Curlew (Numenius & -- & SC \\
americanus) & & \\
Striped Whipsnake (Masticophis \\
taeniatus
\end{tabular}

FE - Federal Endangered

FT - Federal Threatened

FC2 - Federal Candidate

SE - State Endangered

ST - State Threatened

SC - State Candidate

SM - State Monitor

Above information taken from Washington Department of Wildlife June 1991. Species of Concern in Washington.

"-" = No Federal status. 


\subsection{PRELIMINARY CONCEPTUAL SITE MODEL}

Section 4.1 presents the chemical and radiological data available for each waste management unit. These chemical data, along with physical descriptions of the waste management units (Section 2.0) and descriptions of the surrounding environment (Section 3.0) are evaluated in Section 4.2 and 5.0 in order to qualitatively assess the potential impacts of the contamination to human health and to the environment. The quality and sufficiency of the existing data are assessed in Section 8.0. This information is also used to identify potential applicable or relevant and appropriate requirements (ARARs) (Section 6.0). Contaminant information is assessed in Section 7.0 to provide a basis for selecting technologies which can be implemented at the waste management units and unplanned release sites.

Contaminants released into the environment at a waste management unit or unplanned release site may migrate from the point of release into other types of media. The potentially affected media in the 200 North Aggregate Area include surface soil, surface water, vadose zone soil and perched groundwater, air, and biota. The media that are affected at a specific site will depend upon the quantities, chemical and physical properties of the material released, and the subsequent history. The potentially affected media at each waste management unit or unplanned release site are listed in Table 4-1.

\subsection{KNOWN AND SUSPECTED CONTAMINATION}

There is one area of radiological data available for the 200 North Aggregate Area: site-specific data that are applicable to individual waste management units and unplanned releases. The nearest area-wide environmental data useful in characterizing regional contamination trends are those of the 200 East and 200 West Areas.

Some waste management units and unplanned releases have been the subject of radiological studies in the past. However, most of these studies were limited in scope and did not provide a comprehensive analysis of the character and distribution of the contamination at each unit. The types of unit-specific data that are available for some waste management units include inventory information, soil and biota sampling, and surface radiological contamination surveys. The nearest external radiation dose rate monitoring, borehole geophysics, and groundwater sampling are for areas in the B Plant Aggregate Area of 200 East and the T Plant Aggregate Area of 200 West approximately $1.2 \mathrm{~km}$ (1 mile) southeast and southwest, respectively, of 200 North Aggregate Area.

Table 4-2 summarizes the types of site-specific data available for each of the waste management units. It should be emphasized that the table only summarizes what types of data are available; it does not indicate the sufficiency of the data, either in terms of quality or quantity. These concerns are addressed in Section 8.0. The unit-specific information is presented for each waste management unit in Section 4.1.2. 
Although groundwater issues are considered outside the scope of this study, some groundwater data have been included. Groundwater contaminant plumes that are known to have originated from specific waste management units are described because they offer insight into the distribution of contaminants within the vadose zone (Table 4-10). The 200 East Groundwater Aggregate Area Management Study Report (AAMSR) includes the 200 North Aggregate Area.

There are no area-iwide data directly applicable to any waste management unit within the 200 North Aggregate Area. The most applicable sources of general environmental data are quarterly and annual environmental surveillance reports published by Westinghouse Hanford for the 200 East and 200 West areas. Likewise, limited, area-wide geophysical data are available that include gravity, magnetic, magnetotelluric, seismic refraction, and seismic reflection surveys (DOE 1988b). However, these studies are not useful for characterizing the extent of chemical and radionuclide contamination and are not presented in Section 4.0. As noted, these data are applicable only on a broad 200 Area-scale. These data are discussed in more detail in Section 8.1.2.

The most recent environmental monitoring of the Hanford Site was conducted by the Pacific Northwest Laboratory (PNL) (Eberhardt et al. 1989) and Westinghouse Hanford. However, most of the data applicable to the 200 North Aggregate Area have been published by Westinghouse Hanford. The latest Quarterly Environmental Radiological Survey Summary Reports were reviewed during the current study, as well as the last six annually published environmental surveillance reports (Elder et al. 1986, 1987, 1988, 1989; Schmidt et al. 1990, 1991, 1992). The quarterly reports only contain surface radiological contamination survey results. The annual reports describe several different sampling and survey programs including surface soil sampling, external radiation measurements, biota sampling, air sampling, surface water sampling, groundwater sampling, and radiological surveys.

Section 4.1 describes available data regarding known and suspected contamination in the 200 North Aggregate Area on a media-specific basis (air, surface soil, surface water, biota, and vadose zone soil). The text summarizes sources of radiological sampling information. Section 4.1.1 presents data on a media-specific basis. Section 4.1.1.1 present comments about air quality sampling data. Surface soil data are described in Section 4.1.1.2. Comments about surface water sampling are presented in Section 4.1.1.3. Comments about vegetation and other biota sample analyses are presented in Section 4.1.1.4. Vadose zone sampling information is presented in Section 4.1.1.5. An assessment of the nature and extent of groundwater contamination is presented in the 200 East Groundwater AAMSR.

To supplement available radiological data, historical waste inventory information for the 200 North Aggregate Area waste management units was also included in the evaluation of known and suspected contaminants. Historical waste inventory data are detailed in Section 2.0 of this report (Tables 2-1 and 2-2). As discussed in Section 2.0, the compilation 
is based on supporting data from the Waste Inventory Data System (WIDS) (WHC 1991a) and the Hanford Inactive Site Survey (HISS) Database (DOE 1986).

\subsection{Affected Media}

4.1.1.1 Air. There are no high volume samplers stationed within or adjacent to the 200 North Aggregate Area. The nearest air sampling takes place in the 200 West area about $1.2 \mathrm{~km}(1 \mathrm{mi})$ southwest of 200 North Aggregate Area and in the 200 East Area just north of the B-Tank Farms, about $1.8 \mathrm{~km}(1.5 \mathrm{mi})$ southeast of the 200 North Aggreagate Area. Data from these two nearest sampling points, and a remote point located at the Yakima Barricade, are presented in Tables 4-8 and 4-9.

Samplers contain filters that collect airborne particulates. Air samples are collected by drawing air at a flowrate of $2 \mathrm{ft}^{3} / \mathrm{min}$ through a $47 \mathrm{~mm}$ diameter open face filter positioned

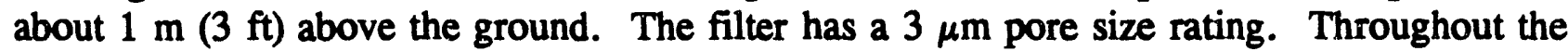
200 Areas air samplers are operated on a continuous basis. Sample filters are exchanged weekly, held one week to allow for decay of short-lived natural radioactivity (Radon-222 daughter products), and sent for initial laboratory analyses of gross alpha and beta activity. After the initial analysis, the filters are stored until the end of the calendar quarter, at which time they are composited by sample location (or as deemed appropriate according to data need) and sent for laboratory analyses of specific radionuclides. Compositing of the filters by sample location provides a larger sample size, and thus, a more sensitive measurement of the concentration of airborne radionuclides resulting from operations in the 200 Areas.

The filters are analyzed quarterly for ${ }^{90} \mathrm{Sr},{ }^{137} \mathrm{Cs},{ }^{239} \mathrm{Pu}$, and total $\mathrm{U}$. The results have shown a steady decline in the concentration of these radionuclides from 1985 to 1987 , a slight increase in 1988, and then a decline again in 1989 throughout the 200 areas (Schmidt et al. 1990). The increased radionuclide concentrations in 1988 were on the average greater than 1987 concentrations; however, they were still lower than the first samples taken in 1985 . This increase can be attributed to variability in naturally occurring concentrations and statistical uncertainty in conducting measurements (PNL 1989).

4.1.1.2 Surface Soil. There are several sources of data available for characterizing surface soil contamination. These include aerial and ground radiological surveys, and surface soil sampling. These data will be presented in the following sections. In addition, there is a limited amount of site-specific radiological and soil sampling data that will be presented in the appropriate sections of Section 4.1.2.

4.1.1.2.1 Radiological Surveys. Radiological survey results may be influenced by buried or airborne radionuclide contamination but are generally indicative of surface and shallow soil contamination. Depending upon instrumentation and survey techniques used, results may be reported in $\mathrm{ct} / \mathrm{min}$, dis $/ \mathrm{min}, \mathrm{mR} / \mathrm{hr}$, or mrem/yr. Typical natural background levels for these measurements are approximately: $50 \mathrm{ct} / \mathrm{min}, 2000 \mathrm{dis} / \mathrm{min}$ (for a $\mathrm{NaI}$ detector), $0.047 \mathrm{mR} / \mathrm{hr}$, and $84 \mathrm{mrem} / \mathrm{yr}$ (Woodruff et al. 1991). An aerial gamma-ray 
radiation survey was performed over all the 200 Areas (North, West, and East) in July and August of 1988 (Reiman and Dahlstrom 1988). The survey lines were flown with a $122 \mathrm{~m}$

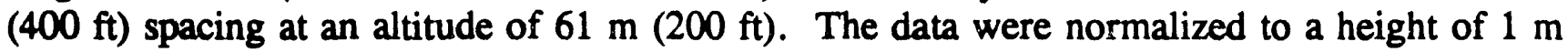
$(3 \mathrm{ft}$ ) above the ground surface. Figure 4-1 presents the gross count data from this survey (ct/s) on an isoradiation contour map that covers the western two-thirds portion of the 200 North Aggregate Area. The remaining portion of the 200 North Aggregate Area was not covered by the survey. Only the 212-N and 212-P Storage Facilities can be seen in Figure 4-1. In this figure, background activity has been subtracted from the data. Background was determined onsite by suppressing specie-specific, naturally occuring activity and confirming with additional background measurements south and east of the Hanford site. No radiation above background (700 ct/s, see Figure 4-1) was detected in the portion of the 200 North Aggregate Area that was surveyed.

Figure 4-2 conceptually shows areas of surface contamination and underground contamination identified from surface surveys. The primary areas of underground contamination that are depicted for the 200 North Aggregate Area are the 216-N-4 and 216-N-6 pond areas. No surface contamination or contaminant migration areas are identified on Figure 4-2.

Table 4-5 summarizes the radiological survey results for each waste management unit and unplanned release. One known area of surface contamination (212-R railroad spur) will be discussed in more detail in the section dealing with the individual waste management units and unplanned releases (Section 4.1.2). Surface radiological surveys are done quarterly at the 4 trench and 3 pond waste management units. The other waste management units are not surveyed because they are non-radiation areas (i.e. the 212-P Hazardous Waste Staging area and transformer oil tank, and the septic tanks and drain fields), or limited knowledge of their existance has precluded a survey (in the case of the ballast pits, a survey of disposed materials would have been performed prior to disposal, but documentation of this is not known to exist).

4.1.1.2.2 External Radiation Dose Rate Measurements. Dose rates from penetrating radiation have not been measured within the 200 North Aggregate Area. This type of measurement is usually taken with thermoluminescent dosimeters (TLDs) and is reported in mrem/yr. The TLDs measure dose rates resulting from all types of external penetrating radiation sources including cosmic radiation, naturally occurring radioactivity, fallout from nuclear weapons testing, and contributions from other Hanford Site activities.

The nearest external dose rate measurements have been taken at West Lake in the 200-IU-6 Operable Unit which is about $2 \mathrm{~km}(1 \mathrm{mi})$ east of the 200 North Aggregate Area. These data, presented in Tables 4-3 and 4-4, indicate an average dose of $96 \mathrm{mrem} / \mathrm{yr}$ with a maximum of $128 \mathrm{mrem} / \mathrm{yr}$ and a minimum of $64 \mathrm{mrem} / \mathrm{yr}$ (for the years 1989 and 1990). These data are very similar to the average of sites in the B Plant Aggregate Area in the 200 East Area and the U Plant Aggregate Area in the 200 West area. Refer to the AAMSRs for these aggregate areas for specific dose rate measurments as well as Schmidt et al. 1990, 
1991, 1992, and Edler et al. 1986, 1987, 1988, and 1989. It is expected that dose rate measurements taken within the 200 North Aggregate Area would be similar to those reported in Tables 4-3 and 4-4.

4.1.1.2.3 Surface Soil Sampling. In 1990, soil samples were taken for the first time at two sampling sites within the 200 North Aggregate-Area. The data from the analysis of the samples for 1990 and 1991 is presented in Table 4-6. Site 83 is located at the 216-N-1 Pond and site 84 is located at the 216-N-6 Pond. The results of the analysis of the samples indicates that the concentrations of the detectable radionuclides are comparable to results from background samples collected at locations off of the Hanford Site (PNL 1989, PNL 1990).

4.1.1.3 Surface Water. No natural surface water exists in the 200 North Aggregate Area. The man-made ponds existed only temporarily due to the storage basin overflow. There is no source of water in the area since the wells are no longer functioning and all pumps have been removed.

4.1.1.4 Biota. Westinghouse Hanford and PNL have conducted various biota sampling activities beginning in 1971 through 1988 inside and outside the Hanford Site. No upward trends in radionuclide concentrations were detected for any of the wildlife species examined. A significant downward trend was noted in many sample analytes, particularly ${ }^{137} \mathrm{Cs}$.

Three factors are believed to have contributed to the decline in concentration of these radionuclides: the cessation of atmospheric testing, the 1971 shutdown of the last Hanford reactor ( $\mathbf{N}$ reactor) that discharged once-through cooling water to the river, and the reduction of environmental radionuclide contamination associated with some Hanford facilities and operations.

Biota samples were collected beginning in 1990 from site 83 located at 216-N-1 Pond within the 200 North Aggregate Area. In 1991, biota samples were collected from site 83 as well as site 84 located at 216-N-6 Pond. Table 4-7 presents the sample analysis results of the vegetation sampling for 1990 and 1991 . With the exception of ${ }^{239 / 240} \mathrm{Pu}$ and ${ }^{137} \mathrm{Cs}$, the results of the analysis of the samples indicates that the concentrations of the detectable radionuclides are comparable to results from background samples collected at locations off of the Hanford Site (PNL 1990). The slightly elevated ${ }^{239 / 240} \mathrm{Pu}$ and ${ }^{137} \mathrm{Cs}$ results may be due to biological uptake from below-ground contamination.

4.1.1.5 Vadose Zone. The extent of contamination in the vadose zone is usually studied by geophysical borehole logging. No geophysical borehole logging has been conducted in the 200 North Aggregate Area. Records indicate that four boreholes were dug in the aggregate area in 1944 (see Plate 1) as part of a geotechnical soil investigation carried out at the site prior to construction of the structures. These boreholes were filled in after the construction was completed in 1945 and they are not available for borehole logging. There are still two wells in existance used to supply cooling water to the storage basins (699-55-60A and 699-55-60B). These wells have not been used for geophysical logging purposes since they 
are currently outside of the geophysical logging scope for Hanford site waste management units. Thier feasibility for future geophysically logging as part of any LFIs will be examined during those investigations.

Waste management units that have received large volumes of liquid are more likely to cause subsurface contaminant migration. The potential for liquid wastes to migrate through the vadose zone to the groundwater can be conservatively estimated by comparing the volume of waste discharged at each waste management unit to the estimated pore volume in the vadose zone soil column below the waste management unit. If the volume of liquid discharged to the ground is larger than the total soil column pore volume, then it is likely that wastewater would reach the groundwater.

Calculations comparing pore volume to effluent volume were completed for the seven waste management units for which waste effluent volume data were available. These calculations are summarized in Table 4-10. They are based upon several conservative assumptions: (1) the discharged water does not spread out laterally from the point of discharge (i.e., the volume of affected vadose zone is equal to the depth to groundwater times the plan-view area of the base of the waste management unit); (2) there is no significant change in liquid volume being introduced to the soil column due to evapotranspiration or precipitation; and (3) the average pore volume of the soil column is between 0.1 and 0.3 (the lower and upper pore volume estimates shown in Table 4-10). The calculations indicate that, using the 0.1 pore volume estimate, all seven waste management units $(216-\mathrm{N}-1,216-\mathrm{N}-4,216-\mathrm{N}-6,216-\mathrm{N}-2,216-\mathrm{N}-3,216-\mathrm{N}-5$, and $216-\mathrm{N}-7)$ have the potential for migration of liquid discharges to the unconfined aquifer.

In 1973, shallow trenches were cut near the head end of each of the 200 North Aggregate Area pond locations and the soil in the trenches was surveyed for radiological contamination. No radiation was measured in the trench at the $216-\mathrm{N}-1$ Pond site and the site was released from radiation zone status. Dose rates up to $500 \mathrm{mrem} / \mathrm{hr}$ were measured at the $216-\mathrm{N}-4$ and $216-\mathrm{N}-6$ pond sites.

\subsubsection{Site Specific Data}

This section presents the site-specific data that are available for each waste management unit and unplanned release. The units are discussed in the same groups as were presented in Section 2.0.

4.1.2.1 Plants, Buildings, and Storage Areas. No site-specific data were compiled for any of the buildings in the 200 North Aggregate Area. However, there is one waste storage area that is an active waste management unit. Waste staging areas provide temporary storage for hazardous chemicals until arrangements can be made for their removal to an offsite facility.

The 212-P Waste Staging Area is made up of several concrete pads. Drums marked with polychlorinated biphenyl (PCB) labels are stored on the westernmost pad. The drums 
are typically filled with PCB wastes prior to shipment offsite. No chains surround the site, although there is a sign stating LESS THAN 50 PPM PCB STORAGE ONLY. Another sign present on the next concrete pad says, PUMP-FLUSH OPERATIONS STORAGE ONLY. At the eastern end of the staging area is a transformer oil storage tank with a capacity of approximately $1515 \mathrm{~L}$ (400 gal). NO SMOKING signs are present.

4.1.2.2 Tanks and Vaults. No inventory data are available for the transformer oil storage tank at the east end of the 212-P Waste Staging Area. The tank is an active waste management unit and the inventory varies. The tank is used to accumulate transformer oil, some of which may be PCB-contaminated, prior to shipment offsite.

4.1.2.3 Cribs and Drain Fields. No cribs or drains are located within the 200 North Aggregate Area.

4.1.2.4 Reverse Wells. No reverse wells are located within the 200 North Aggregate Area.

4.1.2.5 Ponds, Ditches, and Trenches. Three ponds and four trenches are included in the 200 North Aggregate Area. The 216-N-1 Pond, 216-N-2 Trench, and 216-N-3 Trench received wastewater and cleanout sludges from the 212-N Building. The 216-N-4 Pond and 216-N-5 Trench received similar waste from the 212-P Building and the 216-N-6 Pond and 216-N-7 Trench received waste from the 212-R Building.

4.1 2.5.1 216-N-1 Pond. The 216-N-1 Pond is an inactive waste management unit that received storage basin overflow water from the 212-N Building while it was in operation between 1944 to 1952 . A survey conducted sometime prior to 1953 detected radiological contamination at this site with a dose rate up to $500 \mathrm{mrem} / \mathrm{hr}$. The area was backfilled in

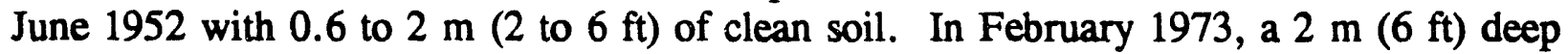
trench was cut near the head end of the pond site and a radiological survey was made of soils exposed within the trench. No radiological contamination was detected and the site was subsequently removed from radiation zone status (WHC 1991a). No chains or barriers are present and a permanent concrete monument marks the north end of the pond site.

Radiological surveillance of the site is done semiannually. The October 1991 survey detected no contamination.

4.1.2.5.2 216-N-4 Pond. The 216-N-4 Pond, an inactive waste management unit, is posted as a zone of underground radioactive materials. A survey conducted sometime prior to 1953 detected surface radiological contamination with a dose rate up to $500 \mathrm{mrem} / \mathrm{hr}$. The area was backfilled in June 1952 with 0.6 to $2 \mathrm{~m} \mathrm{(2} \mathrm{to} 6 \mathrm{ft})$ of clean soil. In

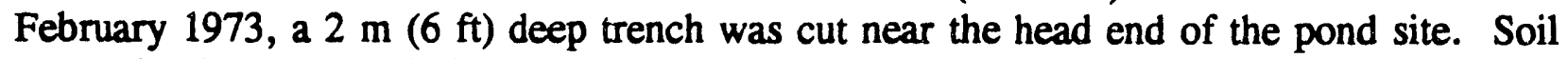
contamination up to $1,000 \mathrm{ct} / \mathrm{min}$ was detected near the bottom (WHC 1991a).

Radiological surveillance is done semiannually. The October 1991 survey detected no surface contamination. Current inventory data are summarized in Table 2-2. 
4.1.2.5.3 216-N-6 Pond. The 216-N-6 Pond, an inactive waste management unit, is posted as a zone of underground radioactive materials. A survey conducted sometime prior to 1953 detecter surface radiological contarnination with a dose rate up to $500 \mathrm{mrem} / \mathrm{hr}$. The area was backfilled in June 1952 with 0.6 to $2 \mathrm{~m}(2$ to $6 \mathrm{ft})$ of clean soil. In February 1973, a $2 \mathrm{~m}(6 \mathrm{ft})$ deep trench vas cut near the head end of the pond site. Soil contamination up to $4,000 \mathrm{c} / \mathrm{min}$ was detected near the bottom (WHC 1991a).

The 216-N-6 Pond is surveyed semiannually for rad'ological contamination. The October 1991 survey detected no surface contamination. Current inventory data are summarized in Table 2-2.

4.1.2.5.4 216-N-2 Trench. The 216-N-2 Trench, used from March to April 1947, is posted as a zone of undergrovid radioactive materials. Surveillance is done semiannually. The October 1991 survev detzcted no surface contamination. Current inventory data are summarized in Table 2 :

4.1.2.5.5 216-N-3 Tren:h. The 216-N-3 Trench, used from May to June 1952, is posted as a zone of undergroun 1 radioactive materials. Surveillance is done semiannually. The October 1991 survey detectisd no surface contamination. Current inventory data are summarized in Table 2-2.

4.1.2.5.6 216-N-5 Trench. The 216-N-5 Trench, used from May to June 1952, is posted as a zone of underground radioactive materials. Surveillance is done semiannually. The October 1991 survey detected no surface contamination. Current inventory data are summarized in Table 2-2.

4.1.2.5.7 216-N-7 Trench. The 216-N-7 Trench, used from May to June 1952, is posted as a zone of underground radioactive materials. Surveillance is done semiannually. The October 1991 survey detected no surface contamination. Current inventory data are summarized in " able 2-2.

4.1.2.6 Sept ic Tanks and Associated Drain Fields. The septic lanks in the 200 North Aggregate Area are not thought to have received any hazardous or radiological waste; consequently there are no inventories available for them. These sites are not surveyed for surface radiological contamination.

4.1.2.6.1 2607-N Septic Tank and Drain Field. This septic tank was in service from 1944 to 1952, and received sanitary wastewater and sewage from the 2743-N Guard House. It is not thought to have received any hazardous or radiological waste. No radiological or cher ical inventories are provided in the WIDS data sheets.

4.1.2.6.2 2607-P Septic Tank and Drain Field. This septic tank was in service from 1944 to 1952, and received sanitary wastewater and sewage from the 2743-P Guard House. It is not thought to have received any hazardous or radiological waste. No radiological or chemical inventories are provided in the WIDS data sheets. 
4.1.2.6.3 2607-R Septic Tank and Drain Field. This septic tank was in service from 1944 to 1952, and received sanitary wastewater and sewage from the 2743-R Guard House. It is not thought to have received any hazardous or radiological waste. No radiological or chemical inventories are provided in the WIDS data sheets.

4.1.2.7 Transfer Facilities, Diversion Boxes, and Pipelines. Transfer facilities connect major processing facilities with each other and with various waste disposal and storage facilities. In the 200 North Aggregate Area they include three pipelines which carried cooling water overflow to the ponds from the storage basins in each of the 212 Buildings and a water distribution pipeline which carried water from the well houses at the $212-R$ facility to the storage basins at $212-\mathrm{N}, 212-\mathrm{P}$, and $212-\mathrm{R}$. No radiological inventories are available for the pipelines.

4.1.2.7.1 212-N to 216-N-1 Pipeline. This vitrified clay pipeline carried approximately $946,000,000 \mathrm{~L}(250,000,000 \mathrm{gal})$ of low activity cooling water to the 216-N-1 Pond. It is not known to have leaked, and no radiological inventories are provided in the WIDS data sheets.

Two access manholes, located along the pipeline, are surrounded by light weight chain barriers and underground radioactive material signs.

4.1.2.7.2 212-P to 216-N-4 Pipeline. This vitrified clay pipeline carried approximately $946,000,000 \mathrm{~L}(250,000,000 \mathrm{gal})$ of low activity cooling water to the 216-N-4 Pond. It is not known to have leaked, and no radiological inventories are provided in the WIDS data sheets.

Two access manholes, located along the pipeline, are surrounded by light weight chain barriers and underground radioactive material signs.

4.1.2.7.3 212-R to 216-N-6 Pipeline. This vitrified clay pipeline carried approximately $946,000,000 \mathrm{~L}(250,000,000 \mathrm{gal})$ of low activity cooling water to the 216-N-6 Pond. It is not known to have leaked, and no radiological inventories are provided in the WIDS data sheets.

Two access manholes, located along the pipeline, are surrounded by light weight chain barriers and underground radioactive material signs.

4.1.2.8 Basins. No basins are located within the 200 North Aggregate Area. The tasins contained within the 212-N, 212-P, and 212-R Buildings are considered to be part of the building and did not function as waste management units. It is possible that leakage from these basins may have contaminated the soil beneath or surrounding the basins but this cannot be confirmed.

4.1.2.9 Burial Sites. No sites are within the 200 North Aggregate Area which were intended to be used as bur al sites. Several pits, believed to be excavated for ballast for 
railroads, are located in the 200 North Aggregate Area southwest of the 212-P storage facility. Electrical conduit, fittings and mechanical waste are observed in the bottom of one of the ballast pits and the vegetation and soil at the bottom of the pits appears to be slightly different in color and appearance than the surrounding areas.

4.1.2.10 Unplanned Releases. Two sites in the 200 North Aggregate Area, not associated with any other waste management unit, are within light chain barriers and posted as contaminated areas. Limited information is available on these unplanned release sites.

4.1.2.10.1 Unplanned Release near 212-R Railroad Spur. This unplanned release site, located south of the 212-R Building, is surrounded by a light chain barrier and posted as a zone of surface contamination. The surface soils in this area are discolored and spotted with what appears to be sandblasting wastes. The site is not routinely surveyed for surface contamination and no radiological surveillance data are available. The basis for posting the site is not known.

4.1.2.10.2 Unplanned Release near Well House No. 2. An area immediately west of Well House No. 2 and east of the 212-R Building is within a light chain barrier and posted as a zone of underground radioactive materials. Two valve boxes associated with the well pump house are contained within this barrier. The valves were used to control water flow on the water distribution pipeline to the $212-\mathrm{N}, 212-\mathrm{P}$, and $212-\mathrm{R}$ storage facilities. No radiological surveillance data are available for this site.

One explanation for the underground radioactive contamination present at this site is that contaminated water from the basins in the 212-N, 212-P, and 212-R storage facilities could have flowed in the reverse direction from the basin to the well in the well house. This might have occurred if inadequate backflow prevention devices were installed to prevent water from siphoning out of the basin and into the well. The driving force for the siphoning

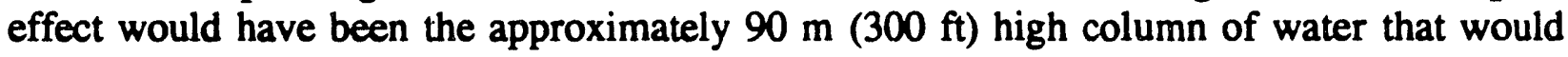
have existed in the well during operation. This water column could have pulled basin water into the well when the pump was shut down, if backflow prevention devices were malfunctioning or not present. If back-siphoning did occur, it is possible that contaminants from the storage basins may have been introduced into the groundwater through the water supply well in either or both of the well houses.

\subsection{POTENTIAL IMPACTS TO HUMAN HEALTH AND THE ENVIRONMENT}

This preliminary assessment is intended to provide a qualitative evaluation of potential human health and environmental hazards associated with the known and suspected contaminants at the 200 North Aggregate Area. The assessment includes a discussion of release mechanisms, potential transport pathways, develops a conceptual model of human and environmental exposure based on these pathways, and presents the physical, radiological, and toxicological characteristics of the known or suspected contaminants. 
In developing the conceptual model, potential exposures to groundwater have not been addressed in detail. Since migration to groundwater is the primary route for potential future exposures to many of the chemicals disposed of at the site, this pathway (i.e., travel time, receptors) will be addressed in the 200 West and 200 East Groundwater AAMSR.

It is important to note that these evaluations do not attempt to quantify potential human health or environmental risks associated with exposure to 200 North Aggregate Area waste management unit contaminants. Such risk assessments cannot be performed until additional waste unit characterization data are acquired. Risk assessment activities will be performed in accordance with the Hanford Site Baseline Risk Assessment Methodology document (DOE/RL 1992b), prepared in response to the Tri-Party Agreement M-29 milestone. This methodology incorporates the requirements established in the Risk Assessment Guidance for Superfund (EPA 1989a) and the EPA Region 10 Supplemental Risk Assessment Guidance for Superfund (EPA 1991a).

The ability of this qualitative assessment to address potential environmental and ecological risks is severely constrained by the relative lack of data regarding potentially exposed biotic populations and exposure pathways. As discussed in Section 3.6, past studies of biota have been mostly conducted on a site-wide basis and do not provide useful data to evaluate the potential impacts of the 200 North Aggregate Area. The extent of 200 North Aggregate Area biota sampling has been limited to vegetation sampling (Section 4.1.1.4). The role of biota in transporting contaminants through the environment is discussed in the sections that follow, and biota are included as receptors in the conceptual model. However, the assessment of potential ecological risks associated with biota exposure to 200 North Aggregate Area contaminants is currently constrained by the lack of data. This data gap is addressed in Section 5.0, and is discussed further in Section 8.2.3.

\subsubsection{Release Mechanisms}

The 200 North Aggregate Area waste management units can be divided into two general categories based on the nature of the waste release: (1) units where waste was discharged directly to the environment; and (2) units where waste was disposed of inside a containment structure and bypassed an engineered barrier to reach the environment.

In the first group are those waste management units where release of wastes to the soil column was an integral part of the waste disposal strategy. Included in this group are septic system drain fields, ponds, and disposal trenches. Also in this group are unplanned releases that involved waste material released to the soil. For this group of waste management units, if discharges to the unit contained contaminants of concern, it can be assumed that soils underlying the waste management unit are contaminated. The first task in developing a conceptual model for these units is to determine whether contaminants of concern are retained in soil near the waste management unit, or are likely to migrate to the underlying aquifer and then to receptor points such as drinking water wells or surface water bodies. 
Factors affecting migration of contaminants away from the point of release will be discussed in the following section.

In the second group are waste management units that were intended to act as a barrier to environmental releases. Included in this group are tanks, waste staging facilities, and transfer pipe lines. Waste management units that received only dry waste could also be included in this category, since the potential for wastes to migrate to soils outside of the unit is low due to the negligible natural recharge rate at the Hanford Site. For these waste management units, the first consideration to be addressed in developing a conceptual model is the integrity of the containment structure.

The ability of this report to evaluate the efficacy of engineered barriers is limited by the lack of vadose zone soil sampling data and air sampling data for many waste management units. Available sampling information for the waste management units and unplanned releases has been summarized in Section 4.1. The efficacy and integrity of concrete liners and steel tanks have not been determined. For those units that received only dry wastes, such as gloves, pumps, contaminated dirt, and process equipment, the potential for release is expected to be low.

In addition to evaluating releases to the subsurface, the conceptual model must address the potential for releases to air and, for radionuclides, the potential for direct irradiation. Most units have some type of barrier to releases to the surface; however, barriers can fail over time or may not be designed to prevent migration by certain transport pathways (e.g., volatilization).

\subsubsection{Transport Pathways}

Transport pathways expected within the 200 North Aggregate Area are summarized in this section, including:

- Drainage and leaching from soil to groundwater

- Volatilization from wastes, surface water, and shallow soils

- Wind erosion of contaminated surface soils

- Deposition of fugitive dust on soils, plants, and surface water

- Uptake from soils by vegetation

- Uptake by animals via direct contact with soils or surface waters, or ingestion of soils, vegetation, and other animals

- Direct radiation. 
In addition, transport within the saturated zone and subsequent release to groundwater wells or to surface water (i.e., the Columbia River) is of potential concern, but will not be addressed in this document, since this topic will be the focus of the 200 East Groundwater AAMSR.

Following transport, exposure may occur through the following pathways:

- Inhalation of volatilized contaminants or suspended particulates

- Ingestion of contaminants in soils, vegetation, or animals

- Direct dermal contact with contaminants in soils

- Direct exposure to radiation.

4.2.2.1 Transport from Soils to Groundwater. Soil is the initial receiving medium for waste discharges in the 200 North Aggregate Area, whether the release is directly to soil or through failure of a containment system. Several factors determine whether contaminants that are introduced into the vadose zone will reach the unconfined aquifer, which lies at a

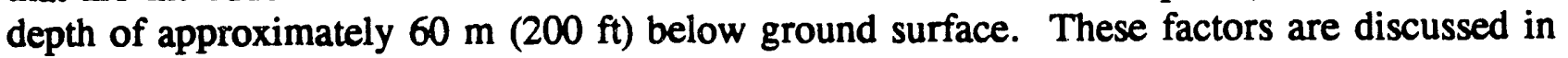
the following sections.

4.2.2.1.1 Depth of Release. As a general rule, for a given volume, waste management units that released wastes at a greater depth below the surface have a higher potential to contaminate groundwater than waste management units where the release was shallow. Other factors, however, such as rate of discharge, underlying geology, and many others will all significantly impact contaminant movement. Within the 200 North Aggregate Area, all discharges were at or very near to the surface which indicates that the potential for groundwater contamination is lower than if the discharge had been farther below the surface.

4.2.2.1.2 Liquid Volume or Recharge Rate. For waste constituents to migrate to the underlying water table, some source of recharge must be present. In the 200 North Aggregate Area, the primary source of moisture for mobilizing contaminants are waste management units that discharge liquid waste to the soil column and precipitation recharge. As discussed in Section 3.5.2, a number of studies have estimated natural precipitation recharge in a range from 0 to $10 \mathrm{~cm} / \mathrm{yr}(0$ to $4 \mathrm{in} . / \mathrm{yr}$ ), primarily depending on surface soil type, vegetation, and topography. The upper value in the range was a computer model generated estimate rather than actual measurement. The actual natural precipitation recharge for the 200 North Aggregate Area is likely to fall at the lower end of this range for sites like the three ponds, since the naturally coarse soils have been covered with a fine-grained backfill upon deactivation. Gravelly surface soils with no or minor shallow rooted vegetation appear to facilitate precipitation recharge. The trench sites which have not been backfilled and have gravelly surface soils with shallow rooted vegetation are likely to have higher recharge rates than the pond sites. One modelling study (Smoot et al. 1989) indicated that some radionuclide $\left({ }^{137} \mathrm{Cs}\right.$ and $\left.{ }^{106} \mathrm{Ru}\right)$ transport could occur with as little as $5 \mathrm{~cm} / \mathrm{yr}(2 \mathrm{in} . / \mathrm{yr})$ 
of natural recharge. However, other researchers (Routson and Johnson 1990) have concluded that no net precipitation recharge occurs in the 200 Areas, particularly at waste management units that are capped with fine-grained soils or impermeable covers.

With respect to artificial recharge, the $216-\mathrm{N}-1,-4$, and -6 Ponds, and the 216-N-2, -3 , -5 , and -7 Trenches received volumes of liquid waste that substantially exceeded the total estimated soil pore volume present below the footprint of those units. In this case, the moisture content of soil below the waste management units likely approached saturation during the periods of use of these facilities. Because vadose zone hydraulic conductivities are maximized at water contents near saturation, the volume of liquid wastewater historically discharged to the waste management units probably enhanced fluid migration in the vadose zone beneath these units.

Long-term gavity drainage is also a potential mechanism of contaminant migration. It is unknown how long after shutdown of a site, that the soil under such a unit will continue to drain and to transport contamination to the groundwater.

Contaminants that are not initially transported to the water table by drainage may be mobilized at a later date if a large volume of liquid is added to the unit. In addition, liquids discharged to one unit could mobilize wastes discharged to an adjacent unit if lateral migration takes place within the vadose zone.

4.2.2.1.3 Soil Moisture Transport Properties. The moisture flux in the vadose zone is dependent on hydraulic conductivity as well as gradients of moisture content or matrix suction. Higher unsaturated hydraulic conductivities are associated with higher moisture contents. However, higher unsaturated hydraulic conductivities may be associated with finegrained soils compared to coarse-grained soils at low moisture contents. Because of the stratified nature of the Hanford Site vadose zone soils and the moisture content dependence of unsaturated hydraulic conductivity, vertical anisotrophy is expected, i.e., vadose zone soils are likely to be more permeable in the horizontal direction than in the vertical. This vertical anisotrophy may reduce the potential for sontaminant migration to the unconfined aquifer.

4.2.2.1.4 Retardation. The rate at which contaminants will migrate out of a complex waste mixture and be transported through unsaturated soils depends on a number of characteristics of the chemical, the waste, and the soil matrix. In general, chemicals that have low solubilities in the leaching fluid or are strongly adsorbed to soils will be retarded in their migration velocity compared to the movement of soil pore water. Studies have been conducted of soil parameters affecting waste migration at the Hanford Site to attempt to identify the factors that control migration of radionuclides and other chemicals. Recent studies of soil sorption are summarized in Serne and Wood (1990). Some of the processes that have been shown to control the rate of transport are as follows:

- Adsorption to Soils. Most contaminants are chemically attracted to some degree to the solid components of the soil matrix. For organic compounds, the adsorption is generally to the organic fraction of the soil, although in extremely 
low-organic soils, adsorption to inorganic components may be of greater importance. Soil components contributing to adsorption of inorganic compounds include clays, organic matter, and iron and aluminum oxyhydroxides. In general, Hanford surface soils are characterized as sandy or gravelly with very low organic content $(<0.1 \%)$ and low clay content $(<12 \%)$ (Tallman et al. 1981). Thus, site-specific adsorption factors are likely to be lower, and rate of transport higher, than the average for soils nationwide.

- Filtration. Filtration of suspended particulates by fine-grained sediments has been suggested as a mechanism for concentration of radionuclides in certain sedimentary layers. This finding suggests that migration of suspended particulates may be an important mechanism of transport for poorly soluble contaminants.

- Solubility. The rate of release of some chemicals is controlled by the rate of dissolution of the chemical from a solid form. The concentration of these chemicals in the pore water will be extremely low, even if they are poorly sorbed. An example cited by Serne and Wood (1990) is the solubility of plutonium oxide, which appears to be the limiting factor controlling the release of plutonium from waste materials at neutral and basic $\mathrm{pH}$.

- Ionic Strength of Waste. For some inorganics, the dominant mechanism leading to desorption from the soil matrix is ion exchange. Leachate having high ionic strength (high salt content) can bias the sorption equilibrium toward desorption, leading to higher concentrations of the contaminant in the soil pore water.

- Waste pH. The pH of a leachant has a strong effect on inorganic contaminant transport. Acidic leachates tend to increase migration both by increasing the solubility of precipitates and by changing the distribution of charged species in solution. The exact impact of acidic or basic wastes will depend on whether the chemical is normally in cationic, anionic, or neutral form, and the form that it takes at the new pH. Cationic species tend to be more strongly adsorbed to soils than neutral or anionic species. The extent to which addition of acidic leachate will cause a contaminant to migrate will also depend on the buffering or neutralizing capacity of the soil, which is correlated with the calcium carbonate $\left(\mathrm{CaCO}_{3}\right)$ content of the soil. The soils in the Hanford formation beneath the 200 North Aggregate Area generally have carbonate contents in the range of 0.1 to $5 \%$. Higher carbonate contents (20 to $30 \%$ ) are observed within the PlioPleistocene caliche layer. 
Once the leaching solution has been neutralized, the dissolved constituents may re-precipitate or become reabsorbed to the soil. Observations of $\mathrm{pH}$ impacts on waste transport elsewhere at the Hanford Site include:

- The remobilization of uranium beneath the 216-U-1 and 216-U-2 Cribs is believed to have occurred in part because of this introduction of low $\mathrm{pH}$ solutions.

- $\quad$ Leaching of americium from the Z Plant Aggregate Area 216-Z-9 Trench sediments was found to be solubility controlled and correlated to solution $\mathrm{pH}$.

4.2.2.1.5 Contaminant Loss Mechanisms. Processes that can lead to loss of contaminants from soils, and thus decrease the amount of contaminant available for leaching to groundwater, include:

- Radioactive Decay. Radioactivity decays over time, generally decreasing the quantities and concentrations of radioactive isotopes.

- Biotransformation. Microorganisms in the soil may degrade organic contaminants such as acetone, and inorganic chemicals such as nitrate. They may also affect the mobility of metals through redox chemistry and complexation with metabolic products.

- Chemical Transformation. Hydrolysis, oxidation, reduction, radiolytic degradation and other chemical reactions are possible degradation mechanisms for contaminants.

- Vegetative Uptake. Vegetation may remove contaminants from the soil, bring them to the surface, and introduce them to the food web.

- Volatilization. Organic chemicals and volatile radionuclides can be transported in the vapor phase through open pores in soil either to adjacent soil or to the atmosphere. These volatilized compounds could include acetone, radon (a decay product of uranium), and tritium (HTO in tritiated water). Some elements (mainly fission products such as iodine, ruthenium, cerium, and antimony) are referred to as "semivolatiles" because they have a lesser tendency to volatilize.

4.2.2.2 Transport from Soils to Air. Transport of contaminants from waste management units to the atmosphere can occur by means of vapor transport or by fugitive dust emissions.

Vapor transport may occur from waste management units where volatile organics (e.g., acetone) or volatile radionuclides $\left({ }^{14} \mathrm{C},{ }^{14} \mathrm{CO}_{2},{ }^{129} \mathrm{I}\right.$, or $\left.{ }^{3} \mathrm{H}\right)$ have been released. Transport mechanisms include evaporation/volatilization, and diffusion down a concentration gradient 
and gas-driven flow. Situations where the latter process may occur include production of methane gas from degradation of organic compounds in soil, or production of hydrogen and oxygen gases by radiolytic hydrolysis of water.

In order for fugitive dust emissions to occur, contaminants must be exposed at the surface of the waste management unit. A number of mechanisms could lead to exposure of contaminants in soil-covered waste management units. These mechanisms include uptake by vegetation, transport by animals, disruption of the waste management unit (e.g., cave-ins at cribs), and wind erosion. Wind erosion can strip off surface soil and uncover waste materials. This mechanism has been identified as an ongoing problem in some of the waste management unit areas. The processes by which biota may expose contaminated soils are discussed in Section 4.2.2.4.

The contribution of the 200 North Aggregate Area to the overall fugitive dust emissions at the Hanford Site boundary is expected to be relatively minor based on the presence of clean cover soil over potentially contaminated areas (i.e. $216-\mathrm{N}-1,-4,-6$ Ponds) with 0.6 to $1.8 \mathrm{~m}(2$ to $6 \mathrm{ft})$ of clean soil. These 3 ponds, with a combined surface area of roughly $20,910 \mathrm{~m}^{2}$ (5.2 acres) represent the greatest majority of potentially contaminated surface soils.

4.2.2.3 Transport from Soils to Surface Water. The 200 North Aggregate Area ponds and trenches are all deactivated, and the ponds have been backfilled with 0.6 to $1.8 \mathrm{~m}(2$ to $6 \mathrm{ft}$ ) of clean soil. The ponds and trenches have been marked with concrete monuments, and with the exception of $216-\mathrm{N}-1$ pond, are posted for underground radioactive material. The trenches are surrounded by light weight chain barriers.

Transport of contaminants to surface water bodies outside of the 200 North Aggregate Area via groundwater discharge and deposition of fugitive dust on water bodies are the primary pathways of potential concern for surface water effects. Groundwater discharge will be addressed in the 200 West and 200 East Groundwater AAMSR.

4.2.2.4 Transport from Soils to Biota. Biota, plants and animals have the potential for taking up (bio-uptake), concentrating (bioaccumulating), transporting, and depositing contamination beyond its original extent. Transfer from one species to another in the food chain is also possible because of predation. The possibility of these processes contributing significantly to the transport of contamination from 200 North Aggregate Area waste management units, or to result in damage to affected ecosystems, is unclear. The currently available data, as described in Sections 3.6 and 4.1, are too general and do not adequately evaluate biotic transport or ecological risk. This data gap is discussed further in Sections 5.0 and 8.0. The future acquisition of additional data will be guided by the requirements for human health and ecological risk assessments in the Hanford Baseline Risk Assessment Methodology (DOE/RL 1992b), which has been prepared in response to the M-29 milestone.

4.2.2.4.1 Uptake by Vegetation. Release of radioactivity to the surface by growth of vegetation is potential problem at 200 North Aggregate Area waste management units. Roots 
of sagebrush and other native species can take up radionuclides from soils below the surface and transport these chemicals to the foliage. Wind dispersal of portions of the contaminated vegetation, or entire plants (tumbleweeds) can lead to transport of contaminants outside of the unit. Westinghouse Hanford has an ongoing vegetation control (herbicide application, reseeding with shallow-rooted vegetation, and mechanical removal) and radiological survey program to prevent radioactivity from being transported by this mechanism. However, the program does not ensure complete removal of vegetation, and incidents of detection of contaminated vegetation are reported occasionally in the radiological surveys.

4.2.2.4.2 Transport by Animals. Disturbance of waste management unit barriers by animals occasionally leads to release of contaminants to the surface. Subsurface soils can be transported to the surface by burrowing animals, thus exposing contaminants for release to the air. Additionally, animals that become contaminated by direct contact with subsurface waste or through ingestion of subsurface contaminants (e.g., chemical salts) and contaminated vegetation, water, or other animals can spread contamination in their feces on the surface and outside of the waste management unit. Burrowing rodents and harvester ants can trasport near-surface contaminants to the surface. Rabbits were noted as causing the greatest spread of contamination in separations areas in 1985 (Elder et. al. 1986).

\subsubsection{Conceptual Model}

Figure 4-3 presents a graphical summary of the physical characteristics and mechanisms at the site which could potentially affect the generation, transport, and impact of contamination in the 200 North Aggregate Area on humans and biota (conceptual model).

The sources of contamination include overflow water from irradiated fuel cooling basins in the 212 buildings; cleanout waste associated with the basins; PCB contaminated waste oil from electrical transformer maintenance operations in the 212-P building; sanitary wastes; and contaminated equipment or waste material that was spilled during transit.

Contaminants from these sources have been disposed of at the waste management units that are under investigation. These include the $216-\mathrm{N}-1,-4$, and -6 ponds, trenches, septic tanks and drain fields, tanks, and the various unplanned releases that have occurred on the site. These releases and disposal activities are described in Sections 2.0 and 4.1.

From these waste management units, various release mechanisms may have transported contamination to the potentially affected media. Volatilization could release chemicals from surface waters into the atmosphere. Materials in the trenches and ponds may have seeped into the vadose zone, or deposited into the sediments. Biota may have taken up contaminants from the surface water and near-surface contaminated soils (via deep roots or burrowing animals).

Many waste management units discharge their waste effluents directly to the near surface (vadose zone) soils. The trenches and ponds are potential release points via leaching 
or drainage of the liquid portion of the disposed materials. The unplanned releases have mainly impacted surface soils although some contamination may have also taken place on building surfaces. Fugitive dust from sediment and surface soils has also been released or resuspended due to wind effects or surface disturbances, and some surface soils have been buried or removed to offsite disposal.

The primary mechanism of vertical contaminant migration is the downward movement of water from the surface through the vadose zone to the unconfined aquifer. The contaminants generally move as a dissolved phase in the water and their rate of migration is controlled both by groundwater movement rates and by adsorption and desorption reactions involving the surrounding sediments. Some contaminants are strongly sorbed on sediments and their downward movement through the stratigraphic column is greatly retarded.

Significant lateral migration of contaminants is restricted to perched water zones and to the unconfined aquifer, where water is moving laterally. Again adsorption and desorption reactions may greatly retard lateral contaminant migration. Contaminants that were introduced to the soil column outside of the aggregate area may migrate into the area along with perched or aquifer water.

Figure 4-4 is a schematic diagram illustrating these processes and describing probable contaminant distributions in the vadose zone. For liquid waste management units, the point of release shown on this figure may be in the subsurface, such as at cribs, drains, and reverse wells, or it may be exposed to the surface, such as at ponds, ditches, trenches, or at most unplanned releases. Small-scale contaminant releases are much less likely to impact the lower vadose zone or groundwater than large scale releases. Liquid disposal units in the 200 North Aggregate Area are dominated by ponds and trenches. Table 4-10 identifies those units that had liquid discharges large enough to reach the unconfined aquifer.

Contaminant distributions near any burial ground type units in the 200 North Aggregate Area are likely significantly different from those associated with the liquid waste management units. Because burial grounds received only dry waste, the burial grounds are unlikely to release contaminants to the vadose zone. As a result, only surface contaminant releases have been identified at burial grounds. In this case, wind and near surface biological activity are the dominant processes for transporting and redistributing contaminants.

Contaminant distribution at most unplanned releases is expected to be at or just below the surface. These sites generally received little, if any, liquid, therefore, migration into the lower vadose zone is not expected. The primary process for transporting and redistributing contaminants in this case is wind and near surface biological activity.

The schematic diagram is based on the stratigraphy underlying the 200 North Aggregate Area, the chemical characteristics of the primary suspected contaminants in the area, and known vadose zone contaminant distributions identified from previous studies. The subsurface geology of the aggregate area is presented in Sections 3.4 and 3.5, and the chemical characteris" $"$ s of various contaminants are detailed in Section 4.2.4. 
In the past, drilling and sampling programs have been conducted at the 216-Z-1A Tile Field (Price et al. 1979), the 216-Z-9 Trench (Smith 1973), the 216-Z-12 Crib (Kasper 1981), the 200-BP-1 Operable Unit cribs (the BY Cribs) (Buckmaster and Kaczor 1992, Appendix A), the 216-U-10 Pond (Last and Duncan 1980), and the 216-Z-19 Ditch (Last and Duncan 1980). These studies, in conjunction with geophysical well logging data, have been used to estimate the expected contaminant distributions beneath comparable waste management units in the 200 North Aggregate Area.

Some of the general conclusions that may be drawn from these previous studies are:

(1) Maximum radionuclide contaminant concentrations should be expected directly beneath the main discharge points of the units with the exception of highly mobile contaminants such as tritium.

(2) Radionuclide contamination is not expected to spread laterally more than 15 to $30 \mathrm{~m}$ ( 50 to $100 \mathrm{ft}$ ) beyond the point of discharge and should be at much lower concentrations than those noted beneath the center of the discharge point; a possible exception being areas of perched water.

(3) Radionuclide contamination decreases rapidly with depth. The highest concentrations should occur within 2 or $3 \mathrm{~m}$ (6 to $10 \mathrm{ft}$ ) of the bottom of the discharge point and

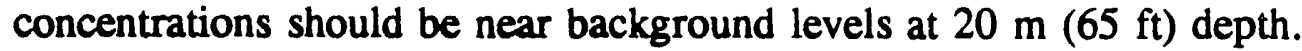

(4) The maximum lateral radionuclide contaminant movement tends to occur along relatively impermeable horizons.

(5) Radionuclide contaminants should be concentrated in fine-grained horizons compared to surrounding coarse-grained horizons and when found in coarse-grained horizons they are associated with the fine-grained particles.

(6) Most chemical contaminants of concern have distributions that tend to mimic radionuclide contaminant distributions in the vadose zone.

There are four exposure routes by which humans (offsite and onsite) and other biota (plants and animals) can be exposed to these possible contaminants:

- Inhalation of airborne volatiles or fugitive dusts with adsorbed contamination

- Ingestion of surface water, fugitive dust, surface soils, biota (either directly or through the food chain), or groundwater 
- Direct contact with the waste materials (such as those exhumed by burrowing animals), contaminated surface soils, buildings, or plants, and

- Direct radiation from waste materials, surface soils, building surfaces, pipelines and other facilities, or fugitive dusts.

\subsubsection{Characteristics of Contaminants}

Table 4-11 is a list of radioactive and nonradioactive chemical substances that represent candidate contaminants of potential concern for this study based on their known presence in wastes, usage, disposal in waste management units, historical association, or detection in environmental media at the 200 North Aggregate Area. Table 4-12 summarizes the types of known or suspected contamination thought to exist at the individual waste sites. Known contaminants have been proven to exist from sampling and inventory data (Tables 2-1 and 2-2). Suspected contaminants are those which could occur at a site based upon historical practices or chemical associations. Given the large number of contaminants known or suspected to be present, it is appropriate to focus this assessment on those contaminants that have been detected through sampling efforts and which pose the greatest risk to human health or the environment.

The EPA Region 10 guidance on risk-based contaminant screening (EPA 1991a), as summarized in the Hanford Baseline Risk Assessment Methodology (DOE/RL 1992b), was consulted to establish the 200 North Aggregate Area contaminants of potential concern. The risk-based contaminant screening mostly involves comparing maximum contaminant concentrations to risk-based benchmark concentrations. However, for the 200 North Aggregate Area, direct risk-based screening could not be performed. To ensure that the intent of the EPA Region 10 approach could be achieved an alternative and more conservative approach was developed. This requires 200 North Aggregate Area contaminants with potential risks to be included in the list of contaminants of potential concern. The alternative approach retains any contaminant that is known or suspected of being carcinogenic or toxic, regardless of quantity or concentration.

Table 4-13 lists the contaminants of potential concern for the 200 North Aggregate Area. This list was developed from Table 4-11 and includes only those contaminants which meet the following criteria:

- Radionuclides that have a half-life of greater than one year. Radionuclides with half-lives less than one year will not persist in the environment at concentrations sufficient to contribute to overall risks.

- Radionuclides with a half-life of less than one year and are part of long-lived decay chains that result in the buildup of the short-lived radionuclide activity to a level of $1 \%$ or greater of the parent radionuclide's activity within the time period of interest. Although daughter radionuclides are adequately identified during 
normal parent radionuclide investigations, they are also identified as contaminants of concern through this criterion. This provides an additional level of assurance that all primary contaminants will be addressed.

- Contaminants that are known or suspected carcinogens or have a U.S. EPA noncarcinogenic toxicity factor. In addition, any chemicals with known toxic effects but no toxicity factors are included. Several chemicals have known toxic effects but no toxicity criteria are presently available. In some instances the criteria may have been withdrawn by EPA pending review of the toxicological data and will be reissued at a future date. It should be noted that PCBs were eliminated from the list of contaminants of potential concern because they are manageu as part of an active Toxic Substance Control Act regulated operation.

The following characteristics will be discussed for the contaminants listed in Table 4-13:

- Detection of contaminants in environmental media

- Historical association with plant activities

- Mobility

- Persistence

- Toxicity

- Bioaccumulation.

4.2.4.1 Detection of Contaminants in Environmental Media. The nature and extent of surface and subsurface soils, surface water, groundwater, air, and biota contamination have not yet been adequately characterized for the 200 North Aggregate Area. All recent environmental monitoring data were reviewed and summarized for each media in Section 4.1.

The most extensive monitoring data available has been for groundwater. Because groundwater will be evaluated in the 200 East Groundwater AAMSR, it will not be discussed further here. The only routine sarnpling data that correspond directly to waste management units are the external radiation surveys, which are performed on a regular basis. There is little soil or vegetation sampling data available for any of the units.

4.2.4.2 Historical Association with 200 North Aggregate Area Activities. Radionuclides that are known components of 200 North Aggregate Area waste streams are listed in Table 2-5. This list includes contaminants associated with the irradiated fuel elements that originated in the reactor areas (100 Areas) and were temporarily stored in the 200 North Aggregate Area facilities. 
Based on WHC (1991a), radionuclides that are known to have been disposed of to 200 North Aggregate Area waste management units in the greatest quantities are as follows:

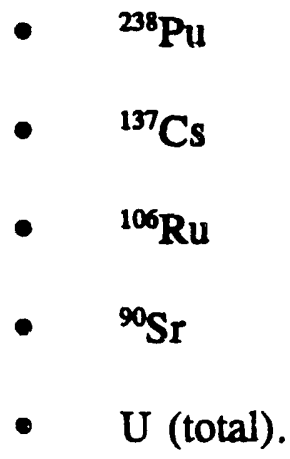

Since waste streams that came into contact with the irradiated fuel elements are known to have been disposed of directly to the soil column in some waste management units, it is probable that the chemicals on this list have affected environmental media.

Note that a complete radionuclide analysis of the 200 North Aggregate Area waste streams is not available. Thus, it is possible that additional radionuclides were disposed of to 200 North Aggregate Area waste management units that are not included in the waste inventories.

Nonradioactive chemicals reportedly released into 200 North Aggregate Area waste management units are limited to aluminum, acetone, and halogenated hydrocarbons.

4.2.4.3 Mobility. Since most wastes at the 200 North Aggregate Area were released directly to subsurface soils via infiltration, the mobility of the wastes in the subsurface will determine the potential for future exposures. The mobility of the contaminants listed in Table 4-13 varies widely and depends on site-specific factors as well as the intrinsic properties of the contaminant. These site-specific factors include site stratigraphy, hydraulic conductivity, porosity, and other factors. Much of the site-specific information needed to charar ,rize rnobility is not available and will need to be obtained during future field investigations. However, it is possible to make general statements about the relative mobility of the candidate contaminants of concern.

4.2.4.3.1 Transport to the Subsurface. The mobility of radionuclides and other inorganic elements in groundwater depends on the chemical form and charge of the element or molecule, which in turn depends on site-related factors such as the $\mathrm{pH}$, redox state, and ionic composition of the groundwater. Cationic species (e.g., $\left.\mathrm{Cd}^{2+}, \mathrm{Pu}^{4+}\right)$ generally are retarded in their migration relative to groundwater to a greater extent than anionic species such as nitrate $\left(\mathrm{NO}_{3}{ }^{-}\right)$. The presence in groundwater of complexing or chelating agents can increase the mobility of metals by forming neutral or negatively charged compounds. 
The chemical properties of radionuclides are essentially identical to the nonradioactive form of the element; thus, discussions of the chemical properties affecting the transport of contaminants can apply to both radionuclides and nonradioactive chemicals.

A soil-water distribution coefficient $\left(\mathrm{K}_{d}\right)$ can be used to predict mobility of inorganic chemicals in the subsurface. Table 4-14 presents a summary of soil-water distribution coefficients $\left(K_{d}\right)$ that have been developed for many of the inorganic contaminants of concern at the $\mathbf{2 0 0}$ North Aggregate Area. As discussed above, the $\mathrm{pH}$ and ionic strength of the leaching medium has an impact on the absorption of inorganics to soil; thus, the listed $\mathrm{K}_{\mathrm{d}}$ values are valid only for a limited range of $\mathrm{pH}$ and waste composition. In addition, soil sorption of inorganics is highly dependent on the mineral composition of the soil, the ionic composition of the soil pore water, and other site-specific factors. Thus, a high degree of uncertainty is involved with use of $K_{d}$ values that have not been verified by experimentation with site soils.

Serne and Wood (1990) recommended $\mathrm{K}_{d}$ values for use with Hanford waste assessments for a limited number of important radionuclides (americium, cesium, cobalt, copper, iodine, plutonium, ruthenium, strontium, and tritium) based on soil column or batch desorption studies, and have proposed conservative average values for a more extensive list of elements based on a review of the literature. An assumed retardation of $<1$ is recommended for americium, cesium, plutonium, and strontium under acidic conditions.

Strenge and Peterson (1989) developed default $\mathbf{K}_{\mathrm{d}}$ values for a large number of elements for use in the Multimedia Environmental Pollution Assessment System (MEPAS), a computerized waste management unit evaluation system. The $\mathrm{K}_{\mathbf{d}}$ values were based on findings in the scientific literature, and include non-site-specific as well as Hanford Site values. Values are provided for nine sets of environmental conditions: three ranges of waste $\mathrm{pH}$ and three ranges of soil adsorbent material (sum of percent clay, organic material, and metal hydrous oxides). The values presented in the fourth column of Table 4-14 are for conditions of neutral waste $\mathrm{pH}$ and less than $10 \%$ adsorbent material, which is likely to be most representative of Hanford Site soils.

The mobility of inorganic species in soil can be divided roughly into three classes using site-specific values (Serne and Wood 1990) where available and generic values otherwise: highly mobile $\left(K_{d}<5\right)$, moderately mobile $\left(5<K_{d}<100\right)$, and low mobility $\left(K_{d}>100\right)$. Table 4-15 lists the class ranking for each of the inorganic contaminants of concern. The ranking presented in this table indicates general mobility characteristics. Actual mobility of specific contaminants will be influenced by their valence state and ligands. Specific mobilities will be determined in future site investigations and will address these potential influences.

The tendency of organic compounds to adsorb to the organic fraction of soils is indicated by the soil organic matter partition coefficient, $K_{o c}$. Partition coefficients for the organic chemicals of concern at the 200 North Aggregate Area are listed in Table 4-16. Chemicals with low $\mathrm{K}_{\mathrm{oc}}$ values are weakly absorbed by soils and will tend to migrate in the 
subsurface, although their rate of travel will be retarded somewhat relative to the pore water or groundwater flow. Soils at the Hanford Site have very little organic carbon content and thus sorption to the inorganic fraction of soils may dominate over sorption to soil organic matter.

4.2.4.3.2 Transport to Air. Transport of contaminants from waste management units to the atmosphere between soils and air can occur by means of vapor transport or fugitive dust emissions. Contaminants subject to transport via airborne dust dispersion are those that are non-volatile and persistent on the soil surface, including most radionuclides and inorganics, and some organics such as creosote and coal tar.

Chemicals subject to volatilization are mostly organic compounds; however, some of the radionuclides detected at the site are subject to evaporation and could be lost from shallow soils to the ambient air. The most important species in this category are ${ }^{14} \mathrm{C},{ }^{3} \mathrm{H}$, and ${ }^{129} \mathrm{I}$.

The tendency of an organic compound to volatilize can be predicted from its Henry's Law Constant, $\mathbf{K}_{\mathrm{h}}$, a measured or calculated parameter with units of atmospheres per cubic meter per mole of chemical. Henry's Law Constants of the organic candidate contaminants of concern are presented in Table 4-16. Compounds with a $\mathrm{K}_{\mathrm{b}}$ greater than about $10^{-3}$ will be lost rapidly to the atmosphere from surface water and shallow soils. There are no 200 North Aggregate Area organic contaminants of concern that fall into this clidss.

4.2.4.4 Persistence. Once released to environmental media, the concentration of a contaminant may decrease because of biological or chemical transformation, radioactive decay, or the intermediate transfer processes discussed above that remove the chemical from the medium (e.g., volatilization to air). Radiological, chemical, and biological decay processes affecting the persistence of the 200 North Aggregate Area contaminants of concern are discussed below.

The persistence of radionuclides depends primarily on their half-lives. A comparison of the half-lives and specific activities for most radionuclide contaminants of concern for 200 North Aggregate Area is presented in Table 4-17. The specific activity is the decay rate per unit mass, and is inversely proportional to the half-life of the radionuclide. Half-lives for the radionuclides listed in Table 4-17 range from seconds to over one billion years. Also listed are the decay mechanisms of primary concern for the radionuclide. Note that radionuclides often undergo several decay steps in quick succession, (e.g., an alpha decay followed by release of one or more gamma rays). The daughter products of these decays are themselves often radioactive.

Decay will occur during transport (e.g., through the vadose zone to the aquifer, through the aquifer) and may lead to significant reductions in levels discharging to the Columbia River. For direct exposures (e.g., to surface soils or air), the half-life of the radionuclide is of less importance, unless the half-life is so short that the radionuclide undergoes substantial decay between the time of disposal and release to the environment. 
Nonradioactive inorganic chemicals detected at the site are generally persistent in the environment, although they may decline in concentration due to transport processes or change their chemical form due to chemical or biological reactions. Nitrate undergoes chemical and biological transformations that may lead to its loss to the atmosphere (as $\mathrm{N}_{2}$ ) or incorporation into living organisms, depending on the redox environment and microbiological communities present in the medium.

Biotransformation rates for organics vary widely and are highly dependent on sitespecific factors such as soil moisture, redox conditions, and the presence of nutrients and of organisms capable of degrading the compound. Ketones, such as acetone are easily degraded by microorganisms in soil and thus would tend not to persist. Chlorinated solvents (e.g. Methylene Chloride) may undergo slow biotransformation in the subsurface under anoxic conditions. Volatiel aromatics sucha s toluene, are generally intermediate in their biodegradability.

4.2.4.5 Toxicity. Contaminants may be of potential concern for impacts to human health if they are known or suspected to have carcinogenic properties, or if they have adverse noncarcinogenic human health effects. The toxicity characteristics of the chemicals detected at the operable unit are summarized below.

4.2.4.5.1 Radionuclides. All radionuclides are classified by EPA as known human carcinogens based on their property of emitting ionizing radiation and on the evidence provided by epidemiological studies of radiation-induced cancers in humans. Noncarcinogenic health effects associated with radiation exposure include genetic and teratogenic effects; however, these effects generally occur at higher exposure levels than those required to induce cancer. Thus, the carcinogenic effect of radionuclides is the primary identified health concern for these chemicals (EPA 1989b).

Risks associated with radionuclides differ for various routes of exposure depending on the type of ionizing radiation emitted. Nuclides that emit alpha or beta particles are hazardous primarily if the materials are inhaled or ingested, since these particles expend their energy within a short distance after penetrating body tissues. However, beta particles may pose a threat to the retina of the eyes since there is no tissue to absorb the beta energy. Protective eye wear in this case is recommended to minimize the possibility of damaging the eye. Gamma-emitting radioisotopes, which deposit energy over much larger distances, are of concern as both external and internal hazards. A fourth mode of radioactive decay, neutron emission, is generally not of major health concern, since this mode of decay is much less frequent than other decay processes. In addition to the mode of radioactive decay, the degree of hazard from a particular radionuclide depends on the rate at which particles or gamma radiation are released from the material.

Excess cancer risks for exposure to the primary radionuclide contaminants of concern by inhaling air, drinking water, ingesting soil, and by external irradiation are shown in Table 4-18. These values represent the increase in probability of cancer to an individual exposed for a lifetime to a radionuclide at a level of $1 \mathrm{pCi} / \mathrm{m}^{3}$ in air, $1 \mathrm{pCi} / \mathrm{L}$ in drinking 
water, $1 \mathrm{pCi} / \mathrm{g}$ in ingested soil, or to external radiation from soil having a radionuclide content of $1 \mathrm{pCi} / \mathrm{g}$ (EPA 1991a). These values are computed as the slope factor (risk per unit intake or exposure) multiplied by the inhalation or ingestion rate and the number of days in a 70 year lifetime (EPA 1991a).

For those radionuclides without EPA slope factors, the Hanford Baseline Risk Assessment Methodology (DOE/RL 1992b) will be consulted. This document proposes to consult the EPA Office of Radiation Programs to request the development of a slope factor or to use the dose conversion factors developed by the International Commission on Radiological Protection to calculate a risk value. Any Hanford site risk assessments be performed in accordance with the Hanford Baseline Risk Assessment Methodology document (DOE/RL 1992b) which includes the guidance established in the Risk Assessment Guidance for Superfund (EPA 1989a) and the EPA Region 10 Supplemental Risk Assessment Guidance for Superfund (EPA 1991a).

The unit risk factors for different radionuclides are roughly proportional to their specific activities, but also incorporate factors to account for distribution of each radionuclide within various body organs, the type of radiation emitted, and the length of time that the nuclide is retained in the organ of interest.

Based on the factors listed in Table 4-18, the highest risk for exposure to $1 \mathrm{pCi} / \mathrm{m}^{3}$ in air is from plutonium, americium and uranium isotopes, which are alpha emitters. Among the radionuclides contaminants of concern for the 200 North Aggregate Area, the highest risks from ingestion of soil at $1 \mathrm{pCi} / \mathrm{g}$ are for ${ }^{227} \mathrm{Ac},{ }^{241} \mathrm{Am},{ }^{243} \mathrm{Am},{ }^{238} \mathrm{Pu},{ }^{244} \mathrm{Cm},{ }^{134} \mathrm{Cs},{ }^{129} \mathrm{I}$, ${ }^{237} \mathrm{~Np},{ }^{231} \mathrm{~Pa}$, ${ }^{226} \mathrm{Ra}$, ${ }^{229} \mathrm{Th}$, and the uranium isotopes. The primary gamma-emitters are ${ }^{60} \mathrm{Co}$, ${ }^{134} \mathrm{Cs},{ }^{137} \mathrm{Cs}$ (because of its metastable decay product, ${ }^{177 m} \mathrm{Ba}$ ), ${ }^{152} \mathrm{Eu},{ }^{154} \mathrm{Eu},{ }^{239} \mathrm{~Np}$, and ${ }^{214} \mathrm{~Pb}$. It is important to note that this table only presents unit risk factors for the listed radionuclides and does not include potential contributions from daughter products.

The standard EPA risk assessment methodology assumes that the probability of a carcinogenic effect increases linearly with dose at low dose levels, i.e., there is no threshold for carcinogenic response. The EPA methodology also assumes that the combined effect of exposure to multiple carcinogens is additive without regard to target organ or cancer mechanism. However, the additive risk resulting for radionuclides and carcinogenic chemicals should be computed separately (EPA 1989b).

4.2.4.5.2 Hazardous Chemicals. Carcinogenic and non-carcinogenic health effects associated with chemicals anticipated at the aggregate area are summarized in Table 4-19. The basis for these potential health effects are described in the respective reference documents and may be associated with either human or animal data. Health effects were developed according to the hierarchy established in the Risk Assessment Guidance for Superfund (EPA 1989a). References were consulted in the following order: Integrated Risk Information System (EPA 1991b), Health Effects Assessment Summary Tables (EPA 1991a), and other toxicity articles and documents. As discussed in Section 4.2.3, the relative lack of 
data regarding potentially exposed biotic populations prevents the evaluation of ecological toxicity. This has been identified as a data gap and is discussed in Chapter 8.0 of this AAMSR.

4.2.4.6 Bioaccumulation potential. Contaminants may be of concern for exposure if they have a tendency to accumulate in plant or animal tissues at levels higher than those in the surrounding medium (bioaccumulation) or if their levels increase at higher trophic levels in the food chain (biomagnification). Contaminants may be bioaccumulated because of element-specific uptake mechanisms (e.g., incorporation of strontium into bone) or by passive partitioning into body tissues (e.g., concentration of organic chemicals in fatty tissues). 


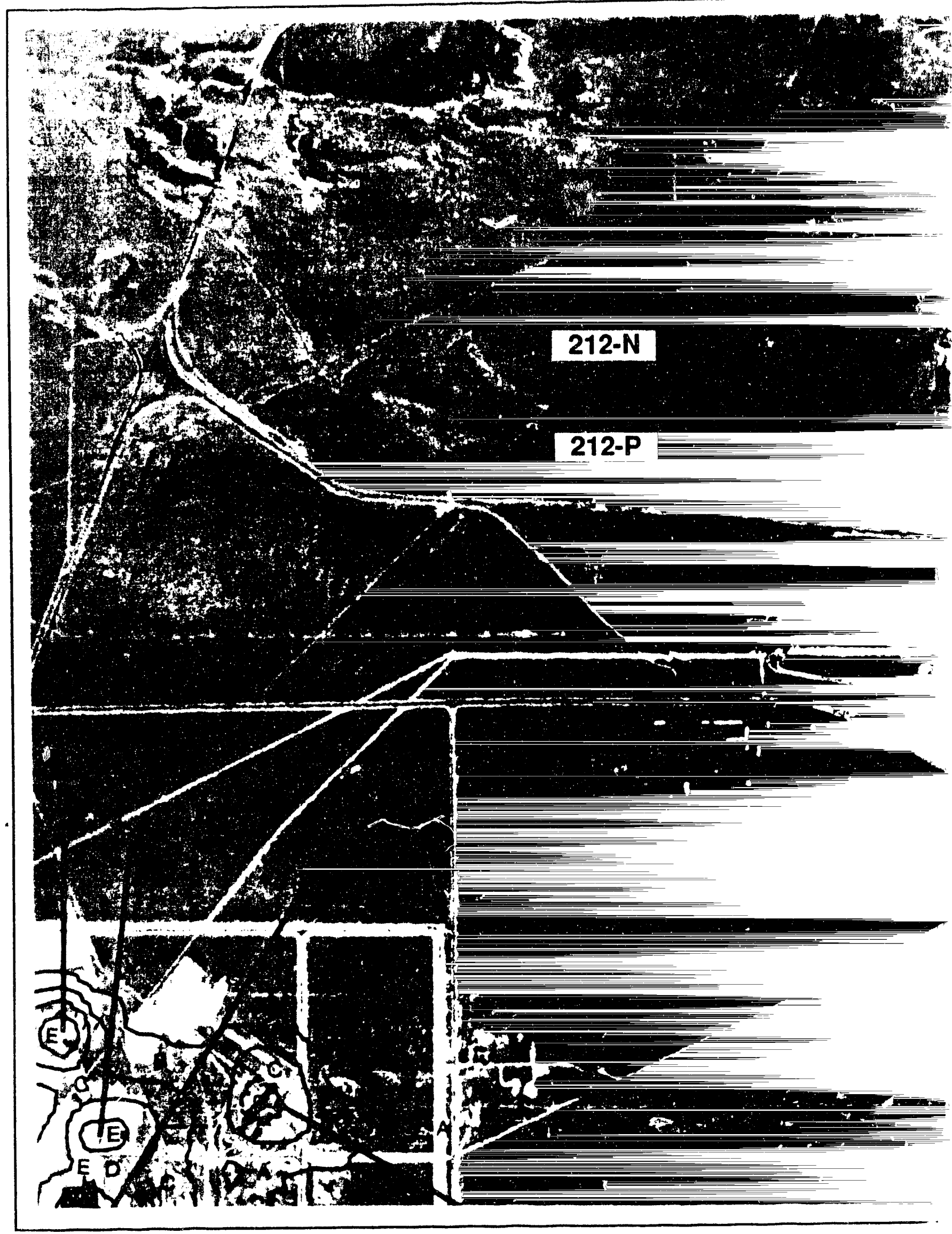




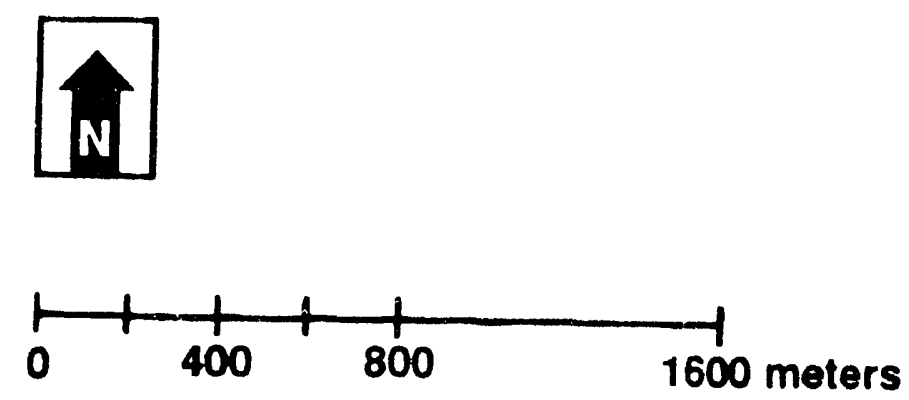

Zone $\mathrm{A}=<700 \mathrm{ct} / \mathrm{s}$

Zone $\mathrm{B}=700$ to $2,200 \mathrm{ct} / \mathrm{s}$

Zone $\mathrm{C}=2,200$ to $7,000 \mathrm{ct} / \mathrm{s}$

Zone $\mathrm{D}=7,000$ to $22,000 \mathrm{ct} / \mathrm{s}$

200 North Aggregate Area is outlin

The results are displayed as relative levels of man-made radionuclide activity.
Zone $\mathrm{E}=22,000$ to $70,000 \mathrm{ct} / \mathrm{s}$

Zone $\mathrm{F}=70,000$ to $220,000 \mathrm{ct} / \mathrm{s}$

Zone $\mathrm{G}=220,000$ to $700,000 \mathrm{ct} / \mathrm{s}$

Zone $\mathrm{H}=700,000$ to $2,200,000 \mathrm{ct} / \mathrm{s}$ 
DOE/RL-92-17, Rev. 0

Figure 4-2. Surface, Underground and Migrating Map of the 200 North Area.

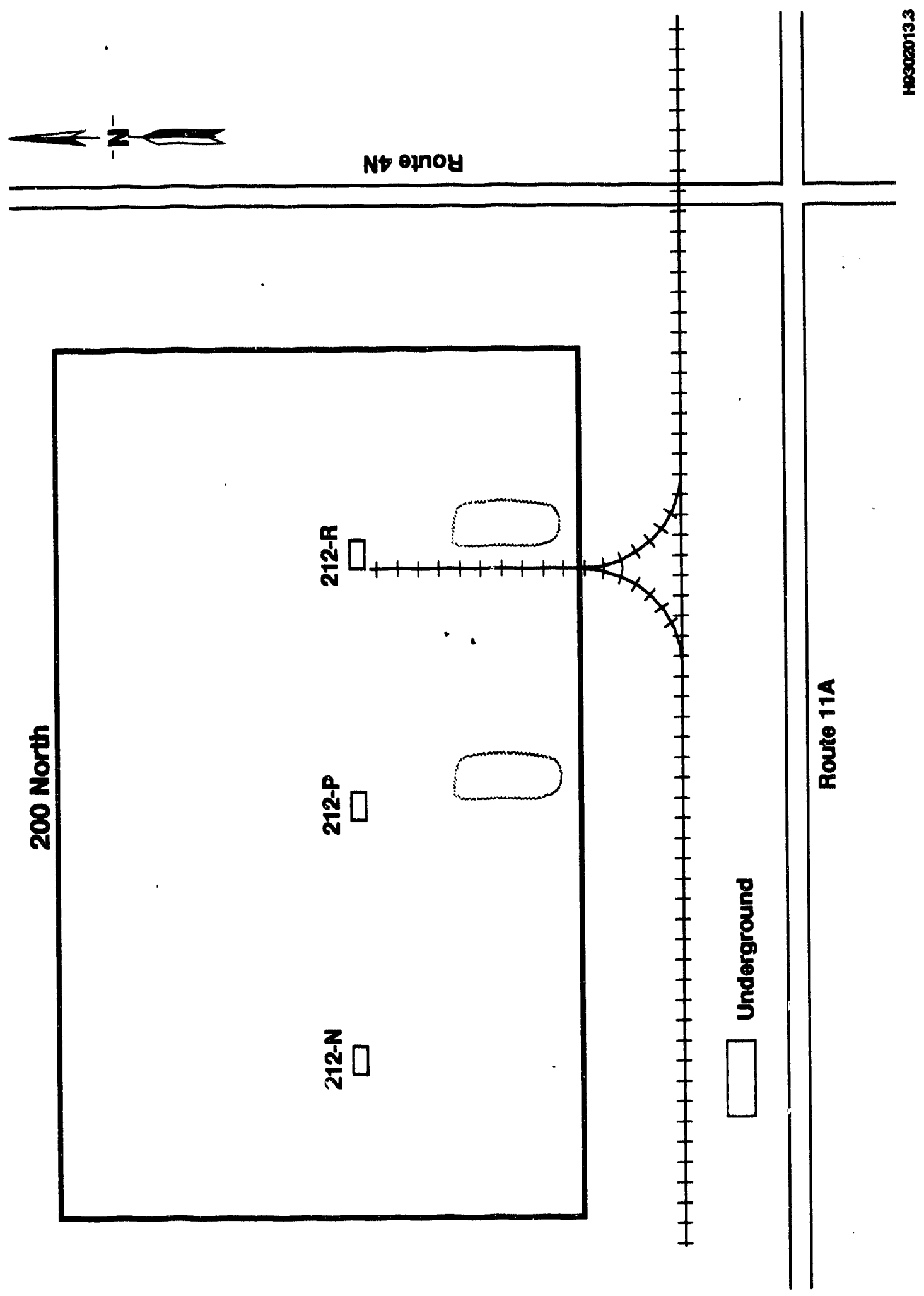


DOE/RL-92-17, Rev. 0

Figure 43. Conceptual Model of the 200 North Aggregate Area.

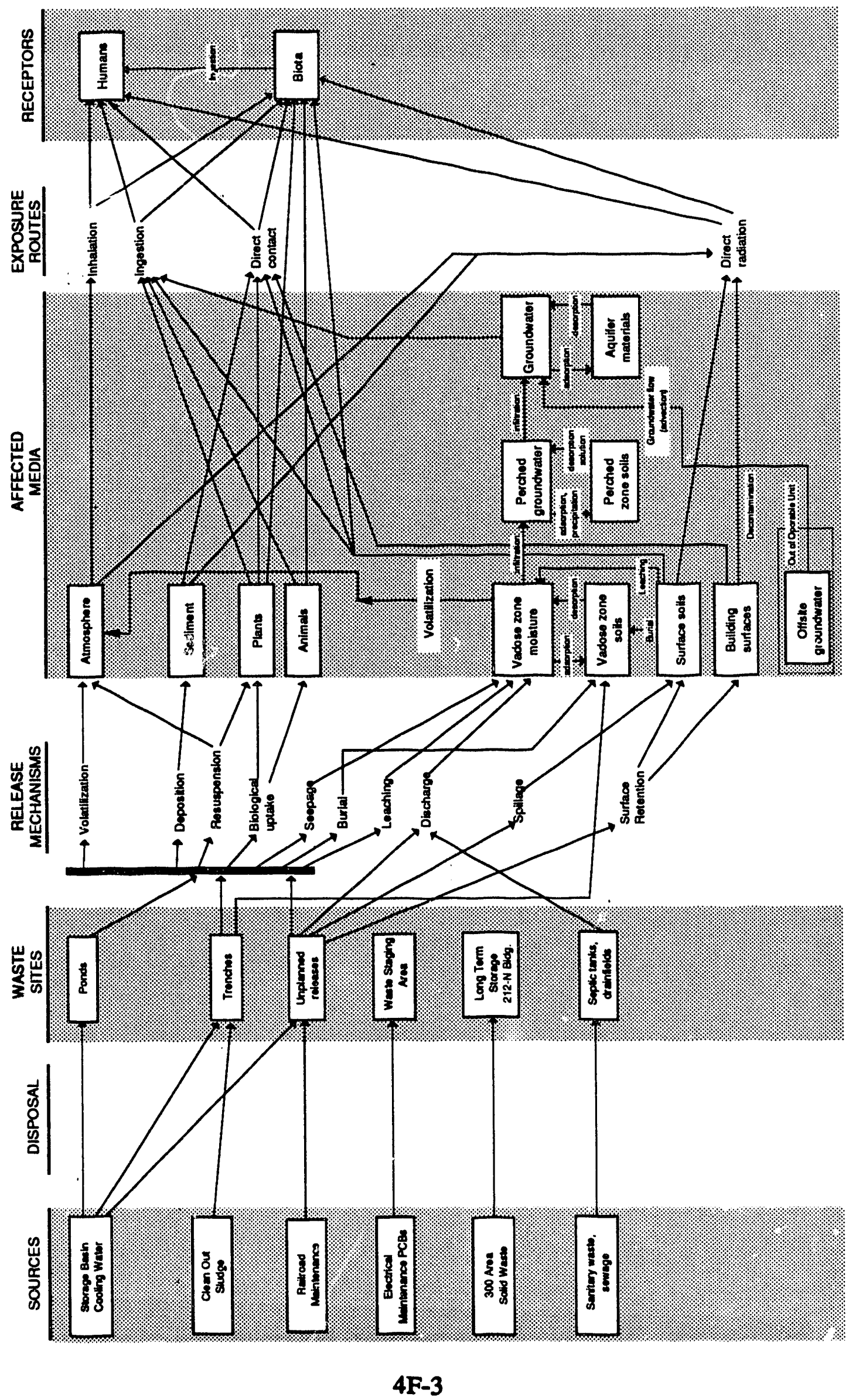


DOE/RL-92-17, Rev. 0

Figure 4-4. Physical Conceptual Model of Contaminant Disțribution.
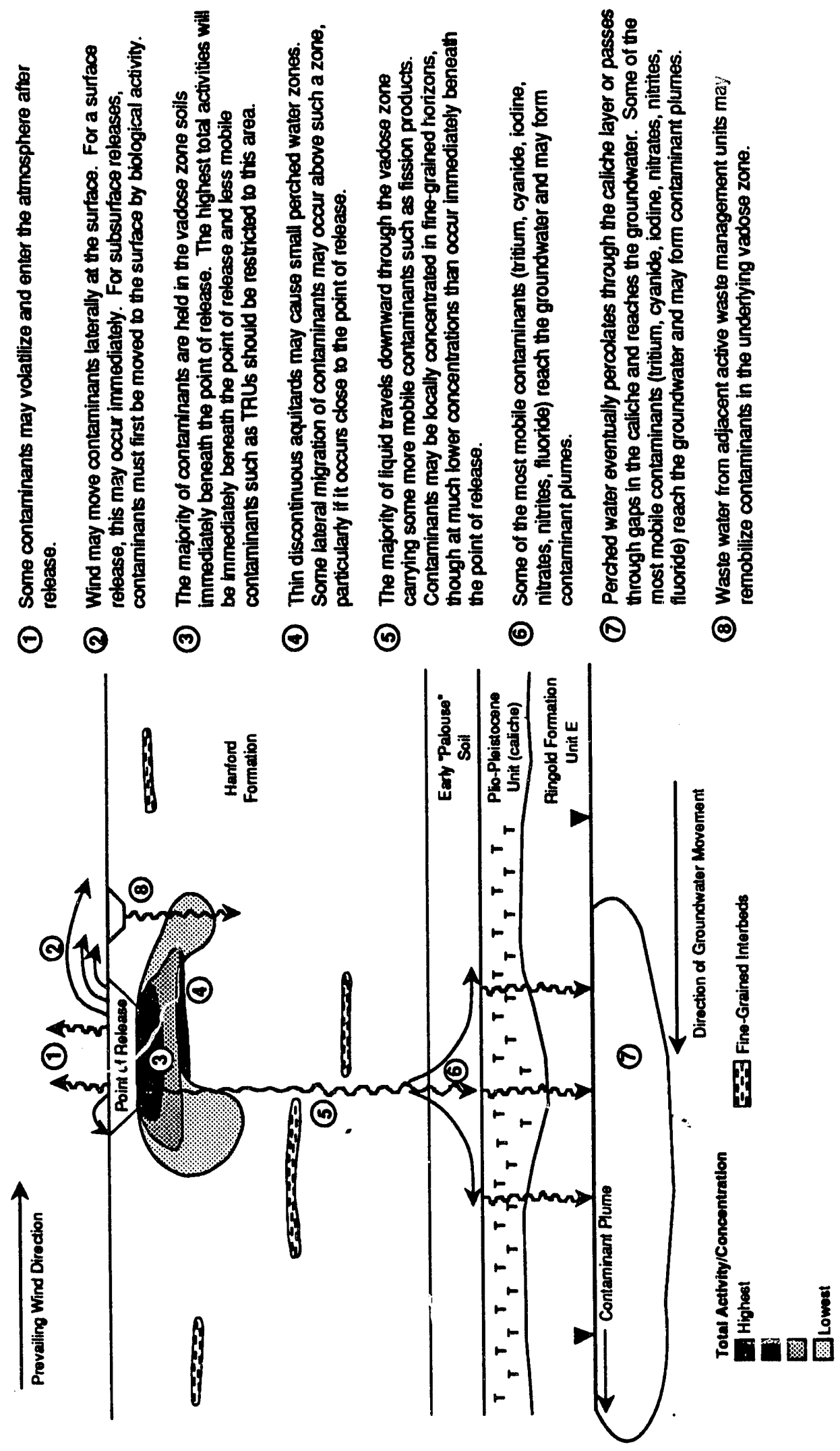
DOE/RL-92-17, Rev. 0

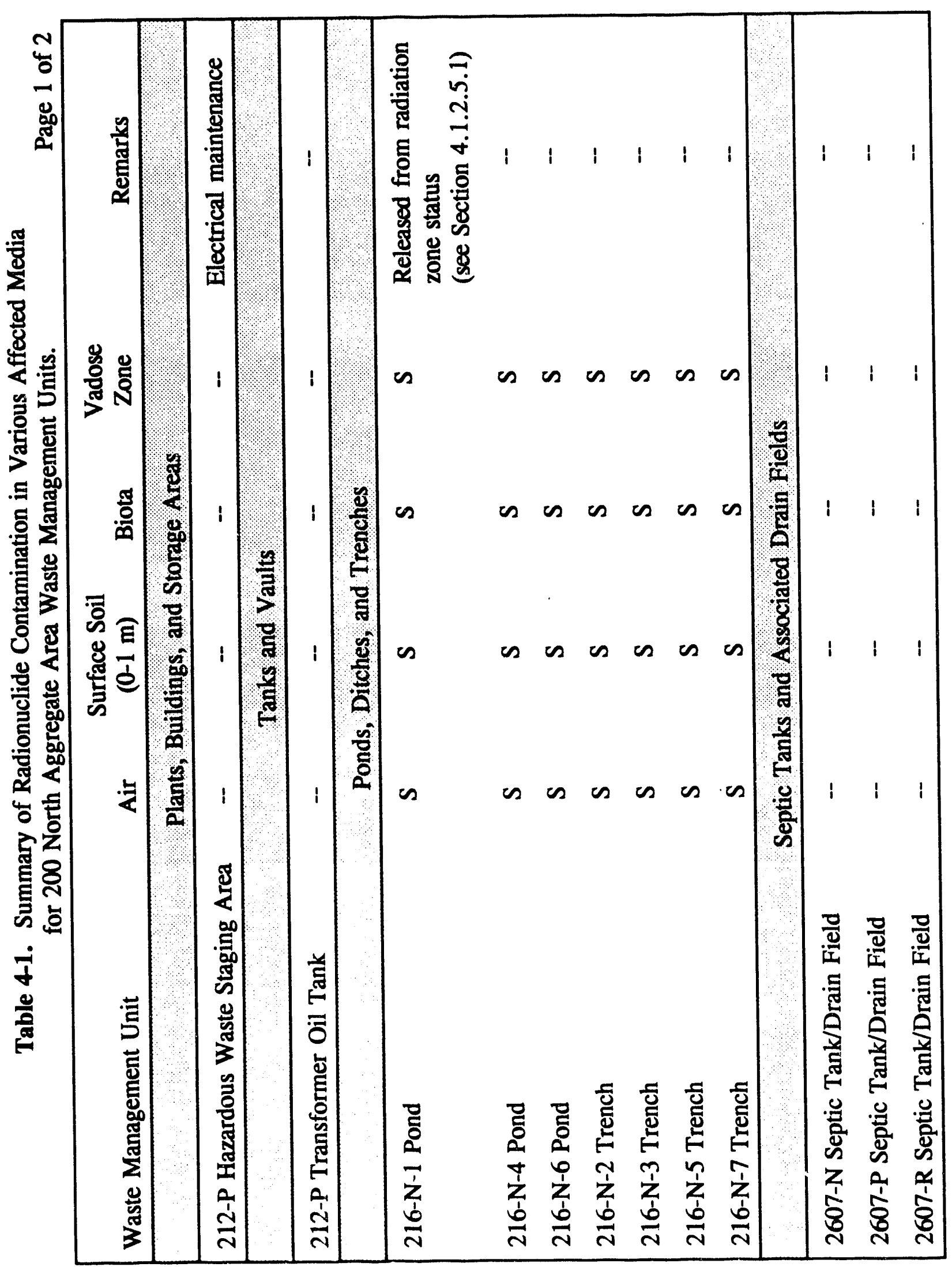


DOE/RL-92-17, Rev. 0

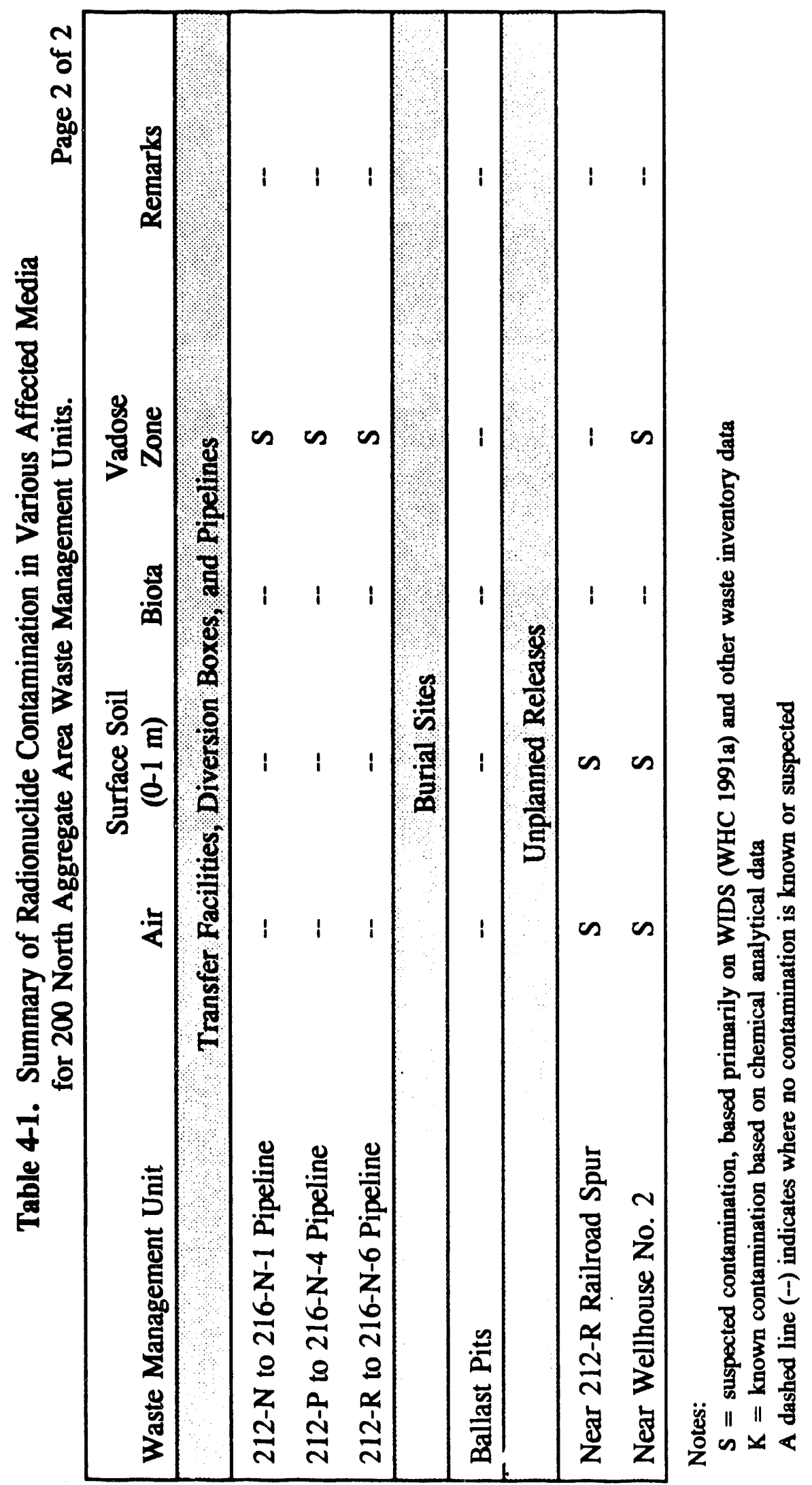


DOE/RL-92-17, Rev. 0

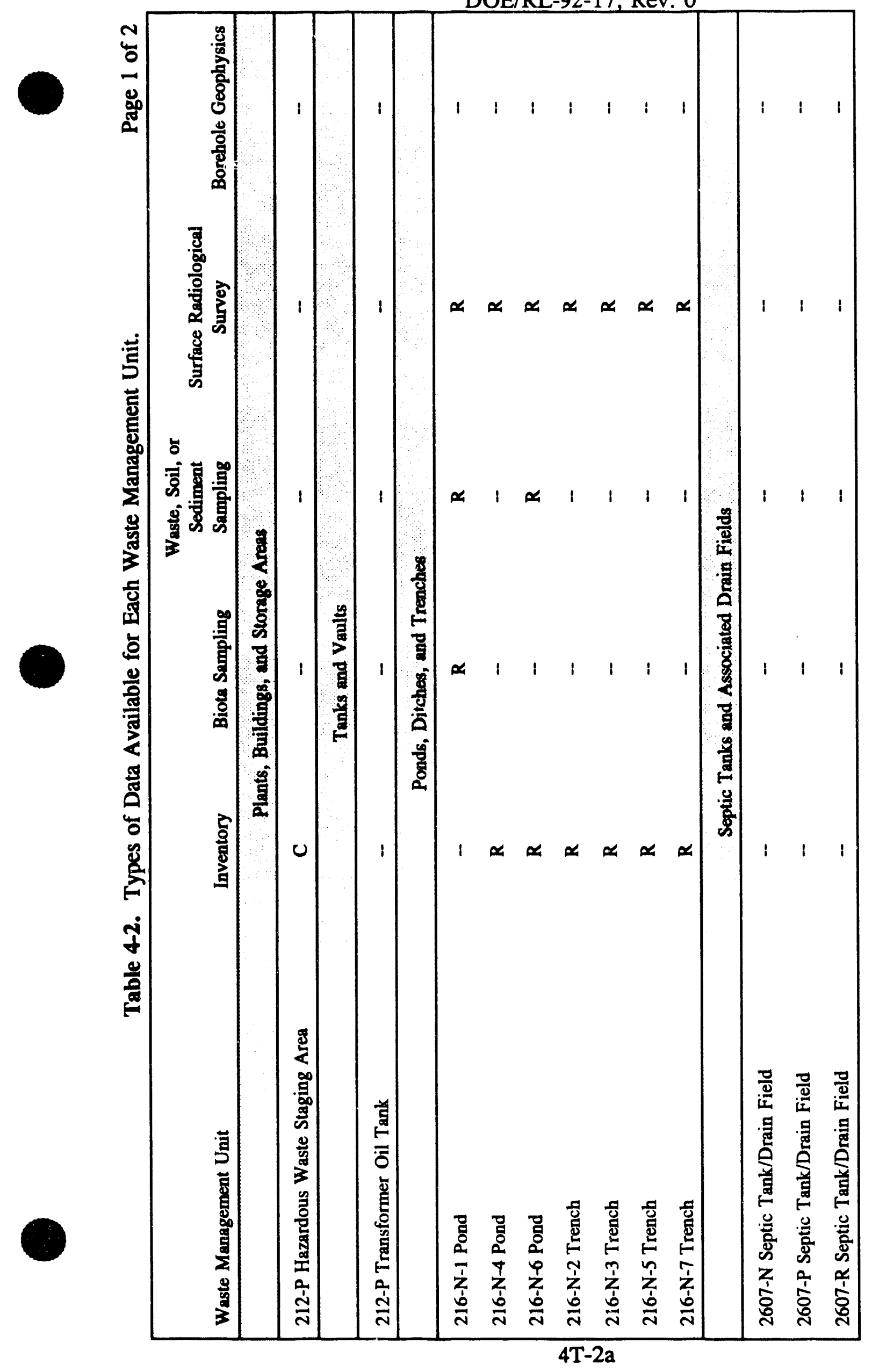




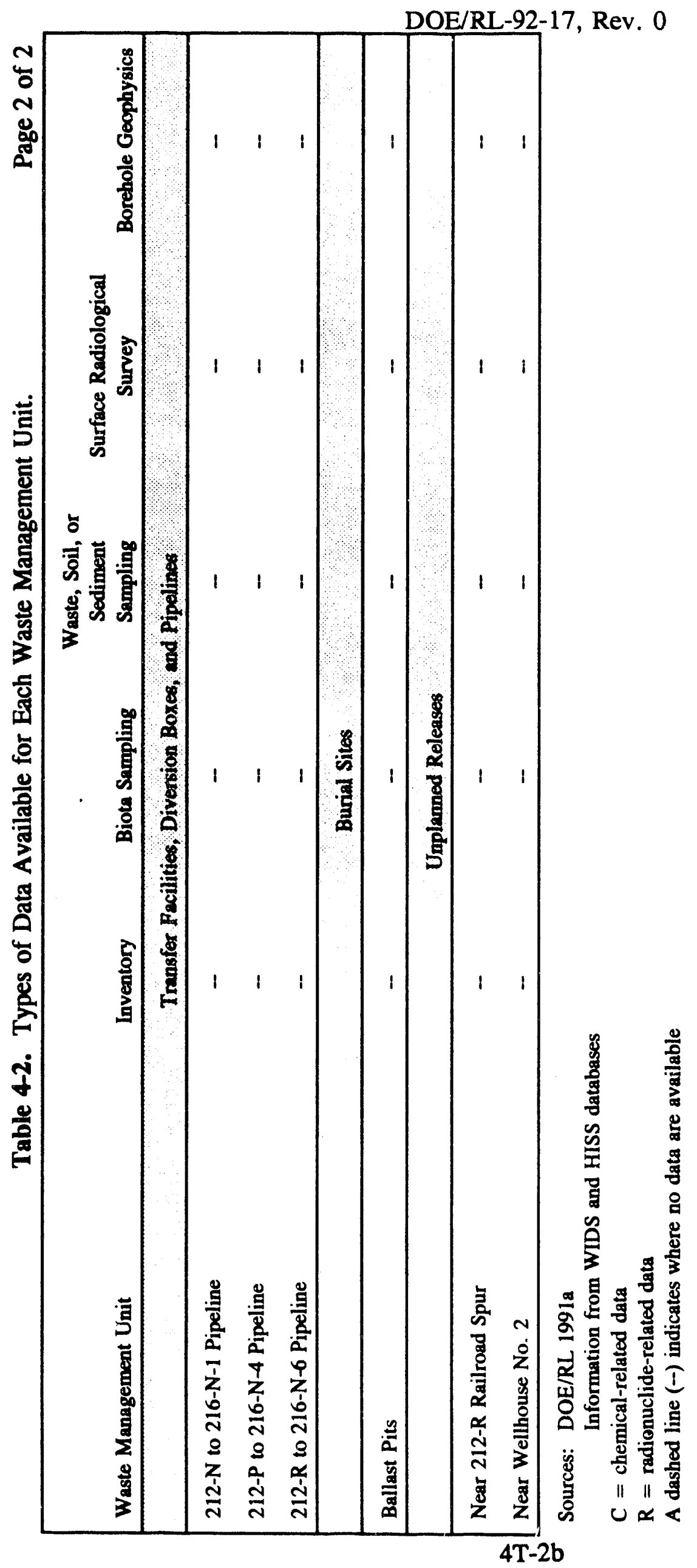


Table 43. Results of External Radiation Monitoring, 1985 through 1989: TLDs (mrem/yr).

\begin{tabular}{|lccccc|}
\hline Location & 1985 & 1986 & 1987 & 1988 & 1989 \\
\hline West Lake: & & & & & \\
Max & - & - & -- & - & 100 \\
Min & -- & - & -- & - & 64 \\
TotalAverage & - & - & -- & - & 85 \\
\hline
\end{tabular}

Source: Schmidt et al. 1990; Elder al. 1986, 1987, 1988, 1989.

A dashed line $(-)$ indicates where no data are available. 
DOE/RL-92-17, Rev. 0

Table 4-4. Results of External Radiation Monitoring for 1990 and 1991:

TLDs (mrem/yr).

\begin{tabular}{|lccc|}
\hline 228: West Lake & Maximum & Minimum & TotatAverage \\
\hline \multirow{2}{*}{1990} & 128 & 92 & 106 \\
1991 & 97 & 70 & 88 \\
\hline
\end{tabular}

Source: Schmidt et al. 1991, 1992. 
Table 4-5. Results of External Radiation Surveys.

\begin{tabular}{|c|c|c|c|c|c|}
\hline \multirow[b]{2}{*}{ Waste Management Unit } & \multicolumn{3}{|c|}{ Radiation Surveys } & \multirow{2}{*}{$\begin{array}{c}\text { Radiation } \\
\text { Survey } \\
\text { Date }\end{array}$} & \multirow[b]{2}{*}{$\begin{array}{c}\text { Radiation } \\
\text { Type }\end{array}$} \\
\hline & $\mathrm{ct} / \mathrm{min}$ & $\mathrm{dis} / \mathrm{min}$ & $\mathrm{mrem} / \mathbf{h}$ & & \\
\hline \multicolumn{6}{|c|}{ 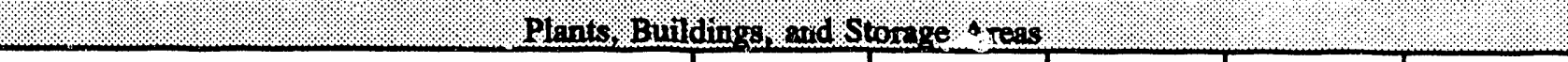 } \\
\hline 212-P Hazardous Waste Staging Are2 & NA & NA & $\mathbf{N A}$ & NA & $\mathbf{N A}$ \\
\hline \multicolumn{6}{|c|}{ Tantos and Toults } \\
\hline 212-P Transformer Oil Tank & NA & NA & NA & NA & NA \\
\hline \multicolumn{6}{|c|}{ pouds, pitches ond trienches } \\
\hline 216-N-1 Pond & $=-$ & - & $<0.1$ & $10 / 9 / 91$ & Beta \\
\hline 216-N-4 Pond & - & - & $<0.1$ & $10 / 9 / 91$ & Beta \\
\hline 216-N-6 Pond & - & - & $<0.1$ & $10 / 9 / 91$ & Beta \\
\hline 216-N-2 Trench & - & - & $<0.1$ & $10 / 9 / 91$ & Beta \\
\hline 216-N-3 Trench & - & - & $<0.1$ & $10 / 9 / 91$ & Beta \\
\hline 216-N-5 Trench & - & - & $<0.1$ & $10 / 9 / 91$ & Beta \\
\hline 216-N-7 Trench & - & - & $<0.1$ & $10 / 9 / 91$ & Beta \\
\hline \multicolumn{6}{|c|}{ 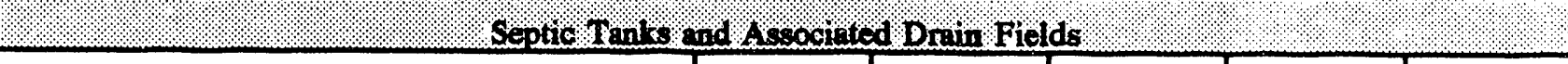 } \\
\hline 2607-N Septic Tank/Drain Field & $\mathbf{N A}$ & NA & $\mathbf{N A}$ & NA & NA \\
\hline 2607-P Septic Tank/Drain Field & NA & NA & NA & $\mathbf{N A}$ & NA \\
\hline 2607-R Septic Tank/Drain Field & NA & NA & NA & NA & $\mathbf{N A}$ \\
\hline \multicolumn{6}{|c|}{ Tirnosfer Facilities, Diversion Boxes, and Pipelines } \\
\hline 212-N to 216-N-1 Pipeline & $\begin{array}{c}\text { <Detec- } \\
\text { tion } 1\end{array}$ & - & - & $8 / 24 / 88$ & $\begin{array}{c}\text { Beta } \\
\text { Gamma } \\
\end{array}$ \\
\hline 212-P to 216-N-4 Pipeline & $\begin{array}{c}\text { <Detec- } \\
\text { tion }\end{array}$ & - & - & $8 / 24 / 88$ & $\begin{array}{c}\text { Beta } \\
\text { Gamma } \\
\end{array}$ \\
\hline 212-R to 216-N-6 Pipeline & $\begin{array}{c}\text { <Detec- } \\
\text { tion } 1\end{array}$ & - & - & $8 / 24 / 88$ & $\begin{array}{c}\text { Beta } \\
\text { Gamma } \\
\end{array}$ \\
\hline \multicolumn{6}{|c|}{ Bunialsites } \\
\hline Ballast Pits & NA & $\mathbf{N A}$ & NA & NA & NA \\
\hline \multicolumn{6}{|c|}{ Uaplanned Releases } \\
\hline Unplanned Release near 212-R Railroad Spur & NA & $\mathbf{N A}$ & NA & $\mathbf{N A}$ & NA \\
\hline Unplanned Release near Well House No. 2 & - & $\begin{array}{c}\text { < Detec- } \\
\text { tion }\end{array}$ & - & $3 / 20 / 92$ & Beta \\
\hline
\end{tabular}

Notes: NA $=$ No data available.

A dashed line (-) indicates where the data are not presented available in $\mathrm{ct} / \mathrm{min}$ or $\mathrm{dis} / \mathrm{min}$.

'The actual detection limit is not recorded on the radiation survey report. Normal background values for this area are in the $150-200 \mathrm{cpm}$ range. 
DOE/RL-92-17, Rev. 0

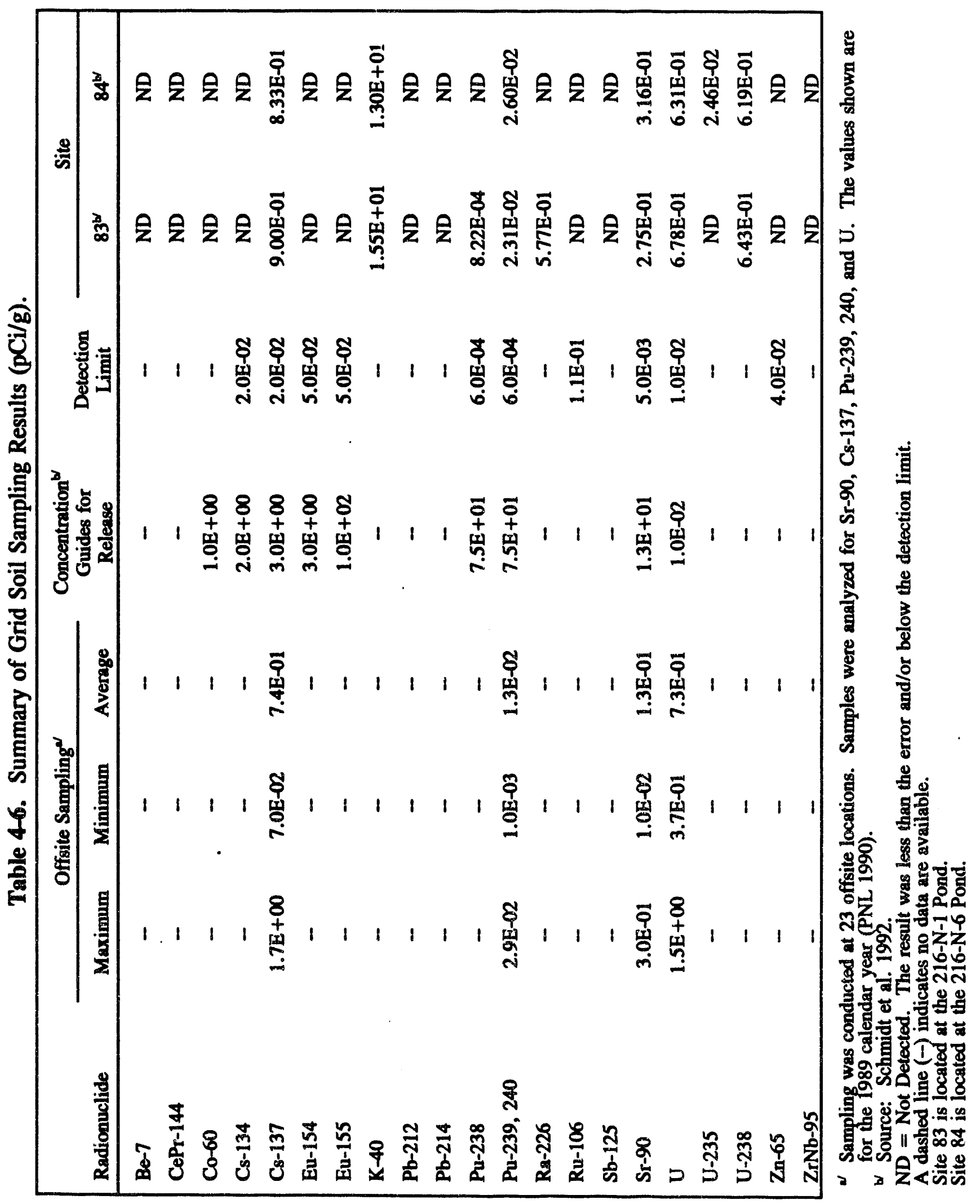


DOE/RL-92-17, Rev. 0

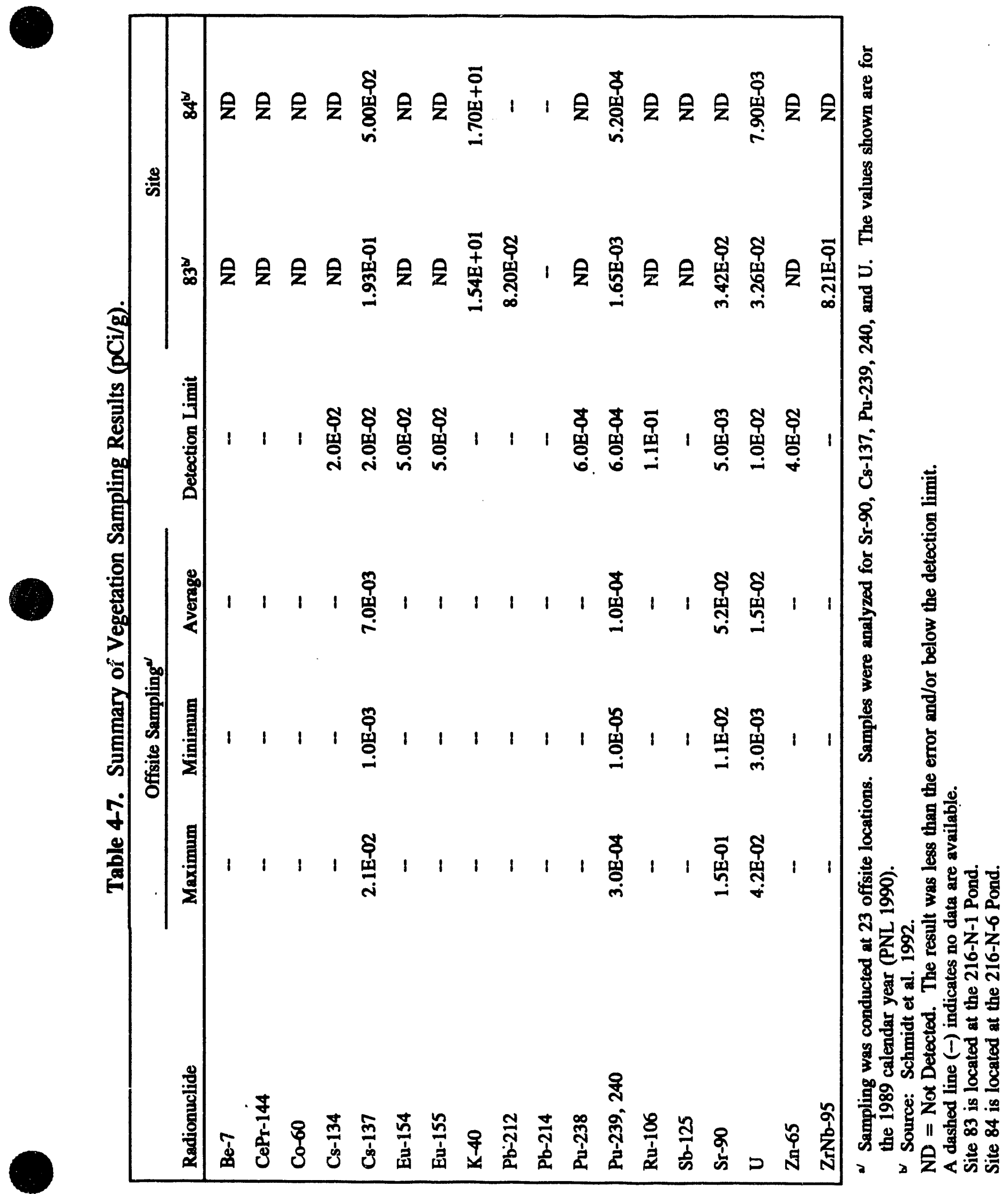


DOE/RL-92-17, Rev. 0

Table 4-8. Summary of Air Monitoring Results, 1985-1989: (pCi/m3).

\begin{tabular}{|lccc|}
\hline & \multicolumn{3}{c|}{ Site } \\
\cline { 2 - 4 } Radionuclide & N961 & N965 & N967\% \\
\hline Sr-90 & $1.21 \mathrm{E}-04$ & $1.08 \mathrm{E}-04$ & $1.30 \mathrm{E}-\mathrm{U} 4$ \\
Cs-137 & $1.65 \mathrm{E}-04$ & $4.31 \mathrm{E}-04$ & $8.63 \mathrm{E}-04$ \\
Pu-239 & $6.68 \mathrm{E}-05$ & $6.45 \mathrm{E}-06$ & $5.88 \mathrm{E}-06$ \\
U (Total) & $2.42 \mathrm{E}-05$ & $3.96 \mathrm{E}-05$ & $2.61 \mathrm{E}-05$ \\
\hline
\end{tabular}

Source: Schmidt et al. 1990; Elder et al. 1986, 1987, 1988, 1989.

- All values are averages for each year with detection from 1985-1989 (see Table A-3).

Site 961 is located at Yakima Barricade.

Site 965 is located at the NE comer of the 200 West Area.

Site 967 is located north of 241-B and -BY Tank Farms. 
DOE/RL-92-17, Rev. 0

Table 49. Summary of Air Monitoring Results, $199^{\circ}\left(\mathrm{pCi} / \mathrm{m}^{3}\right)$.

\begin{tabular}{|lccc|}
\hline & \multicolumn{3}{c|}{ Site } \\
\cline { 2 - 4 } Radionuclide & N961 & N965 & N967 $^{\nu}$ \\
\hline Sr-90 & $5.36 \mathrm{E}-05$ & $2.61 \mathrm{E}-05$ & $3.78 \mathrm{E}-905$ \\
Cs-137 & $1.96 \mathrm{E}-04$ & $-1.72 \mathrm{E}-04$ & $6.22 \mathrm{E}-04$ \\
Pu-239 & $4.44 \mathrm{E}-07$ & $5.09 \mathrm{E}-06$ & $2.31 \mathrm{E}-06$ \\
U (Total) & $2.77 \mathrm{E}-05$ & $2.34 \mathrm{E}-05$ & $2.50 \mathrm{E}-05$ \\
\hline
\end{tabular}

" Source: Schmidt et al. 1992.

Negative values indicate concentrations at or near instrument background levels of radioectivity.

Site 961 is located at Yakima Barricade.

Site 965 is located at the NE corner of the 200 West Area.

Site 967 is located north of 241-B and -BY Tank Farms. 
DOE/RL-92-17, Rev. 0

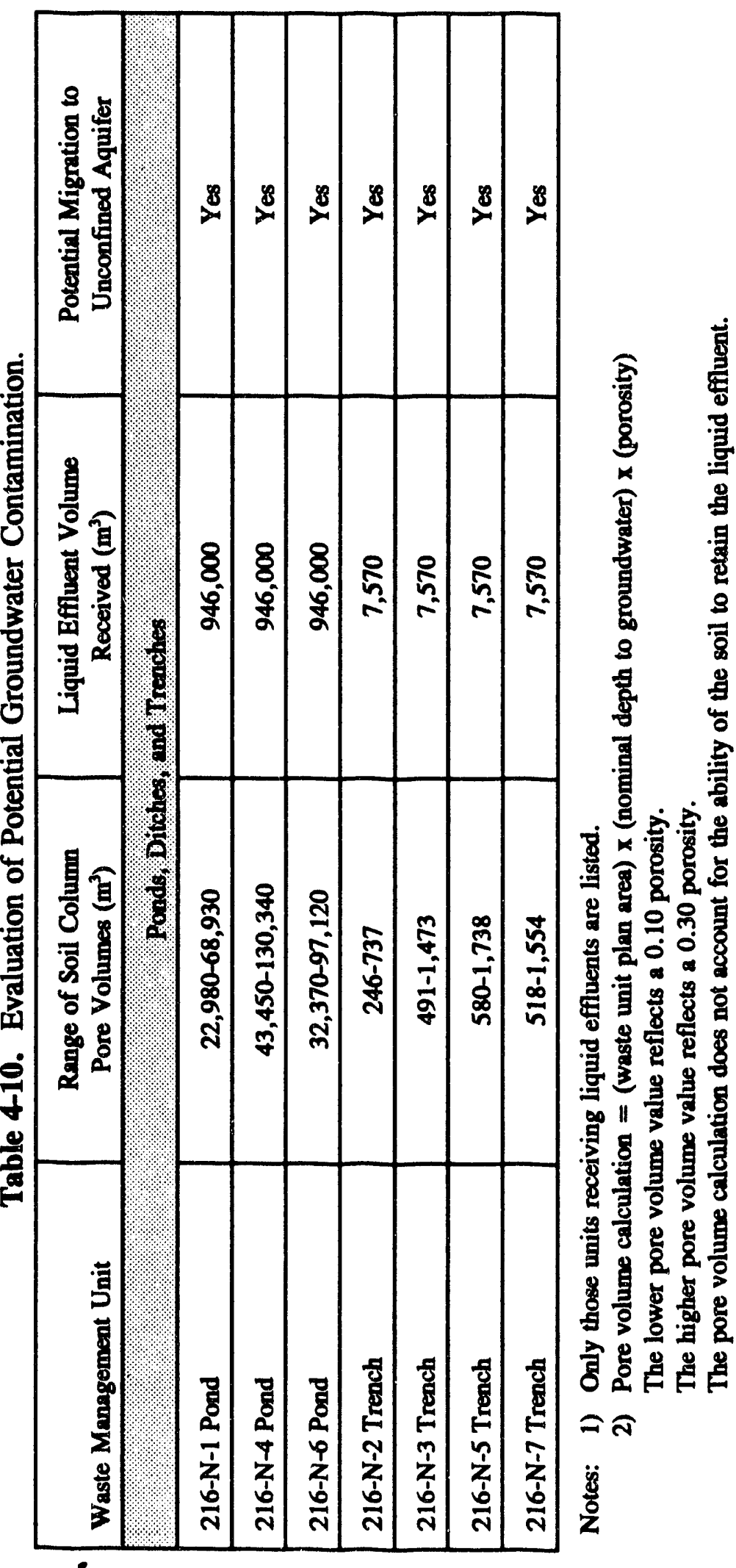


Table 4-11. Candidate Contaminants of Potential Concern for the 200 North Aggregate Area.

\section{TRANSURANICS}

Americium-241

Americium-242

Americium-242m

Americium-243

Curium-242

Curium-244

Curium-245

Neptunium-237

Neptunium-239

Plutonium-238

Plutonium-239/240

Plutonium-241

\section{URANIUM}

Uranium-233

Uranium-234

Uranium-235

Uranium-238

\section{FISSION PRODUCTS}

Actinium-225

Actinium-227

Antimony-126

Antimony-126m

Astitine-217"

Barium-135m ${ }^{2}$

Barium-137m

Barium-140

Bismuth-210

Bismuth-211

Bismuth-213

Bismuth-214

Carton-14

Cerium-141"

Cerium-144"

Cesium-134

\section{FISSION PRODUCTS (Cont.)}

Cesium-135

Cesium-137

Cobalt-57

Cobalt-58

Cobalt -60

Europium-152

Europium-154

Europium-155

Francium-221

Francium-223

Iodine-129

Iodine-131

Iron-59"

Lanthanum-140

Lead-209

Lead-210

Lead-211

Lead-212

Lead-214

Manganese-54"

Nickel-59

Nickel-63

Niobium-93m

Niobium-95

Palladium-107

Polonium-210

Polonium-213

Polonium-214

Polonium-215

Polonium-218

Potassium-40

Praeseodymium-144

Promethium-147

Protactinium-231

Protactinium-233

Protactinium-234m

Redium-223

Radium-225

Radium-226
FISSION PRODUCTS (Cont.)

Rhodium-103

Rhodium-106

Ruthenium-103/

Ruthenium-106

Samarium-151

Selenium-79

Silver-110m

Sodium-22

Strontium-85

Strontium-89

Strontium-90

Technetium-99

Tellurium-129

Thallium-207

Thorium-227

Thorium-229

Thorium-230

Thorium-231

Thorium-233"

Thorium-234

Tin-126"

Tritium

Yttrium-90

Yttrium-91

Zinc-65

Zirconium-93

Zirconium-95

METALS

Aluminum

VOLATILE ORGANICS

Acetone

Trichloroethylene

SEMIVOLATILE ORGANICS

Polychlorinated Biphenyls

- The radionuclide has a half-life of $<1$ year and if it is a daughter product, the parent has a half-life of $<1$ year, or the buildup of the short-lived daughter would result in an activity of $<1 \%$ of the parent radionuclide's initial activity. 
DOE/RL-92-17, Rev. 0

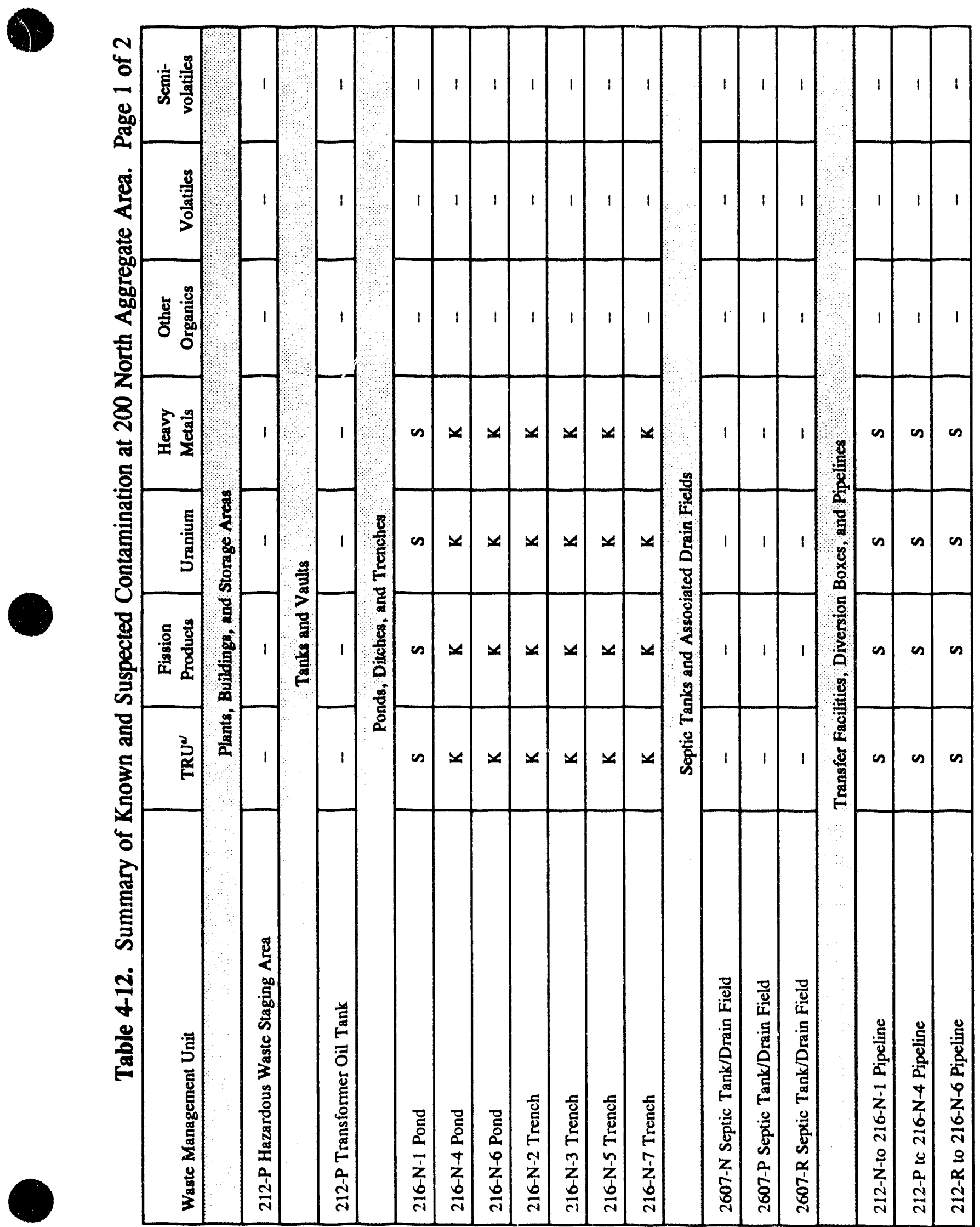


DOE/RL-92-17, Rev. 0

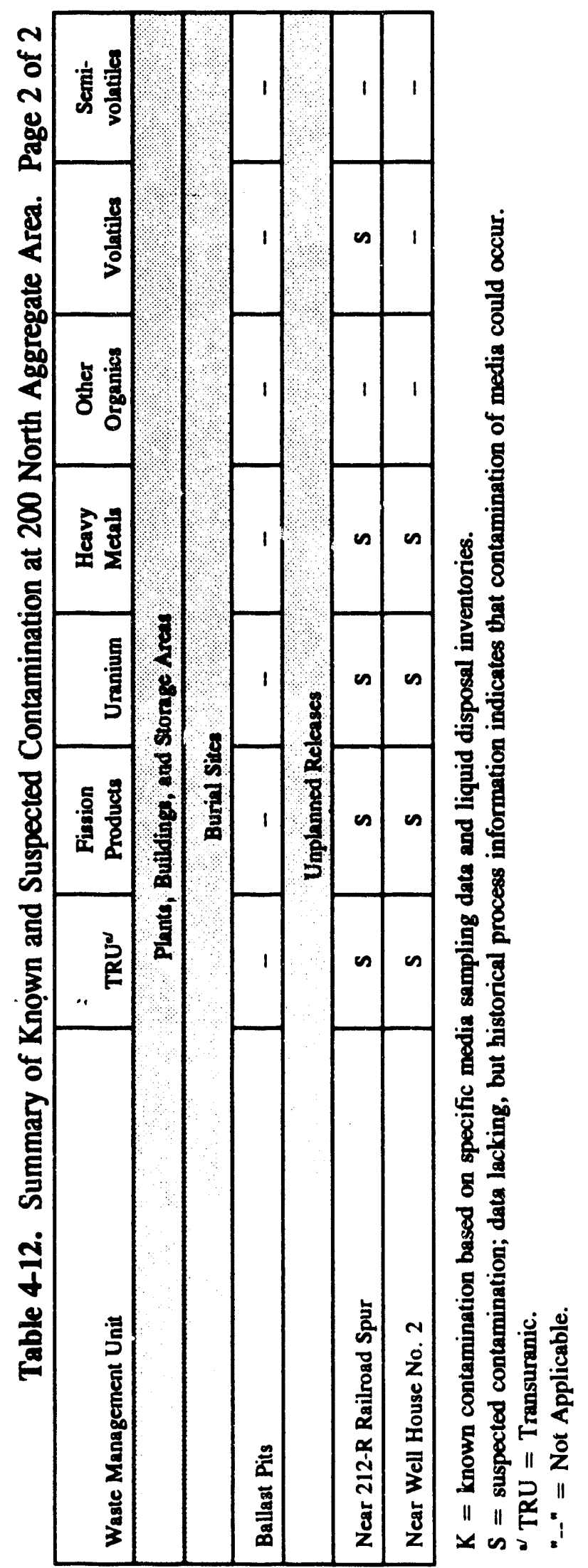


Table 413. Contaminants of Potential Concern for the 200 North Aggregate Area.

\begin{tabular}{|c|c|}
\hline RADIONUCIIDES & $\begin{array}{l}\text { FISSION PRODUCTS } \\
\text { (continued) }\end{array}$ \\
\hline $\begin{array}{l}\text { Gross alpha } \\
\text { Gross beta }\end{array}$ & $\begin{array}{l}\text { Iodine-129 } \\
\text { Lead-209 }\end{array}$ \\
\hline TRANSURANICS & $\begin{array}{l}\text { Lead-210 } \\
\text { Lead-211 }\end{array}$ \\
\hline Americium-241 & Lead-212 \\
\hline $\begin{array}{l}\text { Americium-242 } \\
\text { Americium-242m }\end{array}$ & $\begin{array}{l}\text { Lead-214 } \\
\text { Nickel-59 }\end{array}$ \\
\hline Americium-243 & Niobium-93m \\
\hline Curium-242 & Polonium-214 \\
\hline Curium-244 & Polonium-215 \\
\hline Curium-245 & Polonium-218 \\
\hline Neptunium-237 & Potassium-40 \\
\hline Neptunium-239 & Protactinium-231 \\
\hline $\begin{array}{l}\text { Plutonium-238 } \\
\text { Plutonium-239/240 }\end{array}$ & $\begin{array}{l}\text { Protactinium-234m } \\
\text { Radium-225 }\end{array}$ \\
\hline Plutonium-241 & $\begin{array}{l}\text { Radium-226 } \\
\text { Ruthenium-106 }\end{array}$ \\
\hline URANIUM & $\begin{array}{l}\text { Samarium-151 } \\
\text { Selenium-79 }\end{array}$ \\
\hline Uranium-233 & Sodium-22 \\
\hline Uranium-234 & Strontium-90 \\
\hline Uranium-235 & Technetium-99 \\
\hline Uranium-238 & Thallium-207 \\
\hline FISSION PRODUCTS & Thorium-229 \\
\hline & Thorium-230 \\
\hline Actinium-225 & Thorium-231 \\
\hline Actinium-227 & Tritium \\
\hline Antimony-126 & Yttrium-90 \\
\hline $\begin{array}{l}\text { Antimony-120m } \\
\text { Barium-137m }\end{array}$ & Zirconium-93 \\
\hline $\begin{array}{l}\text { Carbon-14 } \\
\text { Cesium-134 }\end{array}$ & VOLATILE ORGANICS \\
\hline $\begin{array}{l}\text { Cesium-134 } \\
\text { Cesium-135 }\end{array}$ & Acetone \\
\hline $\begin{array}{l}\text { Cesium-137 } \\
\text { Cobalt-60 }\end{array}$ & Trichloroethylene \\
\hline $\begin{array}{l}\text { Europium-152 } \\
\text { Europium-154 } \\
\text { Europium-155 } \\
\text { Francium-221 }\end{array}$ & $\begin{array}{l}\text { POLYCHLORINATED } \\
\text { BIPHENYLS }\end{array}$ \\
\hline
\end{tabular}


Table 4-14. Summary of Soil-Water Distribution Coefficient $K_{d}$ for Radionuclides and Inorganics of Concern at 200 North Waste Management Units. Page 1 of 2

\begin{tabular}{|c|c|c|c|}
\hline $\begin{array}{c}\text { Blement } \\
\text { or } \\
\text { Chemical }\end{array}$ & $\begin{array}{l}\text { Recommended K } \\
\text { for Hanford Site } \\
\text { (Serne and Wood 1990) } \\
\text { in mL/g }\end{array}$ & $\begin{array}{c}\text { Conservative } \\
\text { Default K/ } \\
\text { (Serne and Wood 1990) } \\
\text { in } \mathrm{mL} / \mathrm{g}\end{array}$ & $\begin{array}{c}\text { MEPAS Default } \mathbf{K}_{\text {. }} \\
\text { pH 6-9" } \\
\text { (Strenge and } \\
\text { Peterson 1989) } \\
\text { in } \mathrm{mL} / \mathrm{g}\end{array}$ \\
\hline Actinium & - & - & 228 \\
\hline Americium & $\begin{array}{c}2 \\
100-1000 \\
(<1 @ \text { pH } 1-3)\end{array}$ & 100 & 82 \\
\hline Antimony & - & - & 2 \\
\hline Berium & - & 50 & 530 \\
\hline Carbon $\left({ }^{14} \mathrm{C}\right)$ & - & - & 0 \\
\hline Cesium & $\begin{array}{c}200-1,000 \\
1-200 \text { (acidic warte) }\end{array}$ & 50 & 51 \\
\hline Cobalt & $500-2000$ & 10 & 1.9 \\
\hline Curium & $100->2,000$ & 100 & 82 \\
\hline Buropium & - & - & 228 \\
\hline Francium & - & - & - \\
\hline lodine & $<1$ & 0 & 0 \\
\hline Iron & - & 20 & 15 \\
\hline Lead & - & 30 & 234 \\
\hline Neptunium & $<1-5$ & 3 & 3 \\
\hline Nickel & - & 15 & 12.2 \\
\hline Niobium & - & - & 50 \\
\hline Plutonium & $\begin{array}{c}100-1,000 \\
<1 \text { at pH } 1-3\end{array}$ & 100 & 10 \\
\hline Polonium & - & - & 5.9 \\
\hline Protactinium & - & - & 0 \\
\hline Radium & - & 20 & 24.3 \\
\hline Ruthenium & $\begin{array}{c}20-700 \\
(<2 \text { at }>1 \mathrm{M} \text { nitrate })\end{array}$ & - & 274 \\
\hline Samarium & - & $\cdots$ & 228 \\
\hline Selenium & - & 0 & 5.91 \\
\hline Sodium & - & 3 & 0 \\
\hline
\end{tabular}


Table 4-14. Summary of Soil-Water Distribution Coefficient $K_{d}$ for Radionuclides and Inorganics of Concern at 200 North Waste Management Units. Page 2 of 2

\begin{tabular}{|c|c|c|c|}
\hline $\begin{array}{l}\text { Element } \\
\text { or } \\
\text { Chemical } \\
\end{array}$ & $\begin{array}{c}\text { Recommended K } \\
\text { for Hanford Site } \\
\text { (Serne and Wood 1990) } \\
\text { in mL/g }\end{array}$ & $\begin{array}{c}\text { Conservative } \\
\text { Default } K_{4}^{2} \\
\text { (Serne and Wood 1990) } \\
\text { in } \mathrm{mL} / \mathrm{g}\end{array}$ & $\begin{array}{c}\text { MEPAS Default K } \\
\text { pH 6-9 } \\
\text { (Strenge and } \\
\text { Peterson 1989) } \\
\text { in } \mathrm{mL} / \mathrm{g}\end{array}$ \\
\hline Strontium & $\begin{array}{c}5-100 \\
3-5 \text { (acidic conditions) } \\
200-500 \text { (w/phosphate } \\
\text { or oxalare) }\end{array}$ & 10 & 24.3 \\
\hline Technetium & $0-1$ & 0 & 3 \\
\hline Thallium & - & - & 0 \\
\hline Thorium & - & 50 & 100 \\
\hline Tritium & 0 & 0 & 0 \\
\hline Uranium & - & 0 & 0 \\
\hline Yutrium & - & - & 278 \\
\hline Zirconium & - & 30 & 50 \\
\hline
\end{tabular}

- Average $\mathrm{K}_{\mathrm{d}}$ values for low salt and organic solutions with neutral $\mathrm{pH}$.

Default values for pH 6-9 and soil content of [clay + organic matter + metal oxyhydroxides] $<10 \%$ (Strenge and Peterson 1989). 
Table 4-15. Mobility of Inorganic Species in Soil.

\begin{tabular}{|ll|}
\hline Highly mobile $\left(\mathrm{K}_{\mathbf{d}}<5\right)$ & \\
\hline Antimony & Silver \\
Carbon $\left(\right.$ as $\left.^{14} \mathrm{CO}_{2}\right)$ & Sodium \\
Iodine & Technetium \\
Neptunium & Thallium \\
Protactinium & Tritium \\
Selenium & Uranium \\
\hline Moderately mobile $\left(5<\mathrm{K}_{\mathbf{d}}<100\right)$ & \\
\hline Barium & Polonium \\
Bismuth & Radium \\
Cesium & Strontium \\
Lead & Thorium \\
Nickel & Zirconium \\
Niobium & \\
\hline Low mobility $\left(\mathrm{K}_{1}>100\right)$ & \\
\hline Actinium & \\
Americium & \\
Cesium & \\
Cobalt & \\
Curium & \\
Europium & \\
Plutonium & \\
Ruthenium & \\
Samarium & \\
Yttrium & \\
\hline
\end{tabular}


DOE/RL-92-17, Rev. 0

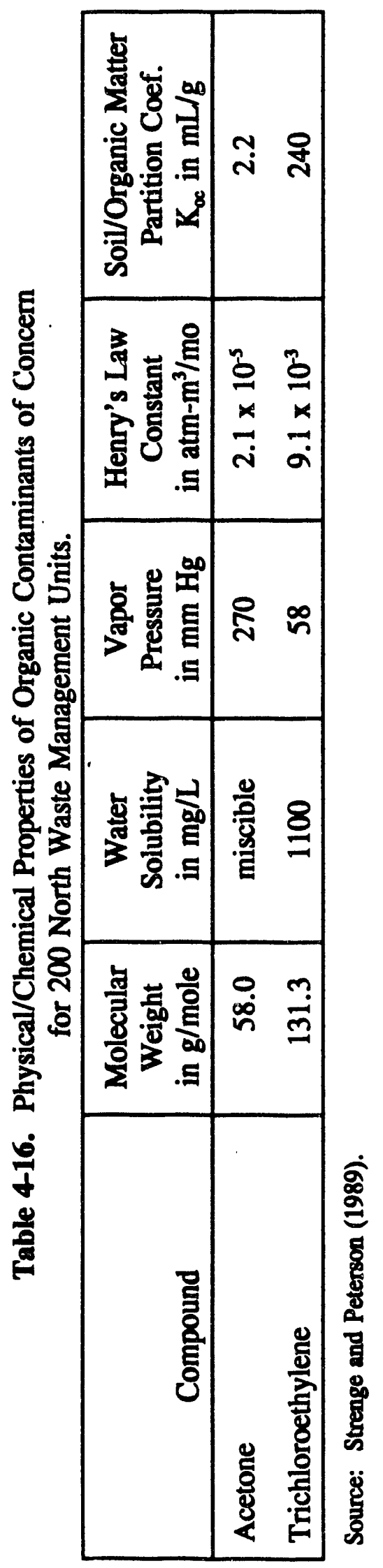


Table 4-17. Radiological Properties of Potential Radionuclides of Concern in 200 North Waste Management Units. Page 1 of 2

\begin{tabular}{|c|c|c|c|}
\hline Radionuclide & Half-Life & $\begin{array}{c}\text { Specific } \\
\text { Activity } \\
\text { in } \mathrm{Ci} / \mathrm{g}\end{array}$ & $\begin{array}{c}\text { Principal } \\
\text { Radiation of } \\
\text { Concern }^{\text {bi }} \\
\end{array}$ \\
\hline${ }^{225} \mathrm{Ac}$ & $10 \mathrm{~d}$ & $5.8 \times 10^{4}$ & $\alpha$ \\
\hline${ }^{227} \mathrm{Ac}$ & $21.8 \mathrm{yr}$ & $7.2 \times 10^{1}$ & $\beta, \alpha$ \\
\hline${ }^{241} \mathrm{Am}$ & $4323 \mathrm{yr}$ & $3.4 \times 10^{\circ}$ & $\alpha$ \\
\hline${ }^{242} \mathrm{Am}$ & $16 \mathrm{hr}$ & $8.1 \times 10^{5}$ & $\bar{\beta}$ \\
\hline${ }^{242 m} \mathrm{Am}$ & $152 \mathrm{yr}$ & $9.7 \times 10^{0}$ & $\alpha$ \\
\hline${ }^{243} \mathrm{Am}$ & $7,380 \mathrm{yr}$ & $2.0 \times 10^{-1}$ & $\alpha$ \\
\hline$\overline{137 m \mathrm{Ba}}$ & $2.6 \mathrm{~min}$ & $5.3 \times 10^{8}$ & $\gamma$ \\
\hline${ }^{14} \mathrm{C}$ & $5,730 \mathrm{yr}$ & $4.5 \times 10^{\circ}$ & $\beta$ \\
\hline${ }^{242} \mathrm{Cm}$ & $163.2 \mathrm{~d}$ & $3.3 \times 10^{3}$ & $\alpha$ \\
\hline $244 \mathrm{Cm}$ & $18.1 \mathrm{yr}$ & $8.1 \times 10^{1}$ & $\alpha$ \\
\hline${ }^{245} \mathrm{Cm}$ & $8,500 \mathrm{yr}$ & $1.7 \times 10^{-1}$ & $\alpha, \gamma$ \\
\hline${ }^{60} \mathrm{Co}$ & $5.3 \mathrm{yr}$ & $1.1 \times 10^{3}$ & $\gamma$ \\
\hline${ }^{134} \mathrm{Cs}$ & $2.06 \mathrm{yr}$ & $1.3 \times 10^{3}$ & $\gamma$ \\
\hline${ }^{135} \mathrm{Cs}$ & $3 \times 10^{6} \mathrm{yr}$ & $8.8 \times 10^{-4}$ & $\beta$ \\
\hline${ }^{137} \mathrm{Cs}$ & $30 \mathrm{yr}$ & $8.7 \times 10^{1}$ & $\gamma$ \\
\hline${ }^{152} \mathrm{Eu}$ & $13.3 \mathrm{yr}$ & $7.7 \times 10^{2}$ & $\beta, \gamma^{\mathrm{cl}}$ \\
\hline${ }^{154} \mathrm{Eu}$ & $8.8 \mathrm{yr}$ & $2.7 \times 10^{2}$ & $\beta, \gamma^{c l}$ \\
\hline${ }^{155} \mathrm{Eu}$ & $4.96 \mathrm{yr}$ & $4.6 \times 10^{2}$ & $\beta, \gamma$ \\
\hline${ }^{221} \mathrm{Fr}$ & $4.8 \mathrm{~min}$ & $1.8 \times 10^{8}$ & $\alpha, \gamma$ \\
\hline${ }^{3} \mathrm{H}$ & $12.3 \mathrm{yr}$ & $9.7 \times 10^{3}$ & $\beta$ \\
\hline${ }^{129} \mathrm{I}$ & $1.6 \times 10^{7} \mathrm{yr}$ & $1.7 \times 10^{-4}$ & $\beta$ \\
\hline$\overline{{ }^{40} \mathrm{~K}}$ & $1.3 \times 10^{9} \mathrm{yr}$ & $6.7 \times 10^{-6}$ & $\beta, \gamma^{c l}$ \\
\hline${ }^{59} \mathrm{~N}$ & $8 \times 10^{4} \mathrm{yr}$ & $7.6 \times 10^{-2}$ & $\gamma$ \\
\hline${ }^{22} \mathrm{Na}$ & $2.6 \mathrm{yr}$ & $6.3 \times 10^{3}$ & $\beta, \gamma$ \\
\hline $93 \mathrm{~m} \mathrm{Nb}$ & $14.6 \mathrm{yr}$ & $2.8 \times 10^{2}$ & $\gamma^{\mathrm{c} /}$ \\
\hline${ }^{237} \mathrm{~Np}$ & $2.14 \times 10^{6} \mathrm{yr}$ & $7.0 \times 10^{-4}$ & $\alpha, \gamma$ \\
\hline${ }^{239} \mathrm{~Np}$ & $2.35 \mathrm{~d}$ & $2.3 \times 10^{5}$ & $\beta$ \\
\hline${ }^{231} \mathrm{~Pa}$ & $32,800 \mathrm{yr}$ & $4.7 \times 10^{-2}$ & $\alpha$ \\
\hline${ }^{234 m} \mathrm{~Pa}$ & $1.2 \mathrm{~min}$ & $6.7 \times 10^{8}$ & $\beta, \gamma$ \\
\hline${ }^{209} \mathrm{~Pb}$ & $3.25 \mathrm{hr}$ & $4.5 \times 10^{6}$ & $\beta$ \\
\hline $210 \mathrm{~Pb}$ & $22.3 \mathrm{yr}$ & $7.6 \times 10^{1}$ & $\bar{\beta}$ \\
\hline${ }^{211} \mathrm{~Pb}$ & 36.1 $\mathrm{min}$ & $2.5 \times 10^{7}$ & $\beta$ \\
\hline${ }^{212} \mathrm{~Pb}$ & $10.6 \mathrm{hr}$ & $1.4 \times 10^{6}$ & $\beta, \gamma^{c l}$ \\
\hline${ }^{214} \mathrm{~Pb}$ & $26.8 \mathrm{~min}$ & $3.3 \times 10^{7}$ & $\beta, \gamma^{c \prime}$ \\
\hline${ }^{214} \mathrm{Po}$ & $6 \times 10^{-5} \mathrm{sec}$ & $8.8 \times 10^{14}$ & $\alpha$ \\
\hline${ }^{215} \mathrm{Po}$ & $7.8 \times 10^{-4} \mathrm{sec}$ & $2.9 \times 10^{13}$ & $\alpha$ \\
\hline
\end{tabular}


Table 417. Radiological Properties of Potential Radionuclides of Concern in 200 North Waste Management Units. Page 2 of 2

\begin{tabular}{|c|c|c|c|}
\hline Radionuclide & Half-Life & $\begin{array}{c}\text { Specific } \\
\text { Activity/ } \\
\text { in } \mathrm{Ci} / \mathrm{g}\end{array}$ & $\begin{array}{c}\text { Principal } \\
\text { Radiation of } \\
\text { Concern }^{\mathrm{b} /}\end{array}$ \\
\hline $218 \mathrm{Po}$ & $3.05 \mathrm{~min}$ & $2.8 \times 10^{8}$ & $\alpha$ \\
\hline${ }^{238} \mathrm{Pu}$ & $87.7 \mathrm{yr}$ & $1.7 \times 10^{1}$ & $\alpha$ \\
\hline${ }^{239} \mathrm{Pu}$ & $24,400 \mathrm{yr}$ & $6.2 \times 10^{-2}$ & $\alpha$ \\
\hline${ }^{240} \mathrm{Pu}$ & $6,560 \mathrm{yr}$ & $2.3 \times 10^{-1}$ & $\alpha$ \\
\hline${ }^{241} \mathrm{Pu}$ & $14.4 \mathrm{yr}$ & $1.0 \times 10^{2}$ & $\beta$ \\
\hline${ }^{225} \mathrm{Ra}$ & $14.8 \mathrm{~d}$ & $3.9 \times 10^{4}$ & $\beta$ \\
\hline${ }^{226} \mathrm{Ra}$ & $1,600 \mathrm{yr}$ & $9.9 \times 10^{-1}$ & $\alpha$ \\
\hline${ }^{100} \mathrm{Ru}$ & $1.0 \mathrm{yr}$ & $3.4 \times 10^{3}$ & $\beta, \gamma^{c \prime}$ \\
\hline${ }^{79} \mathrm{Se}$ & $<65,000 \mathrm{yr}$ & $7.0 \times 10^{-2}$ & $\beta$ \\
\hline${ }^{151} \mathrm{Sm}$ & $90 \mathrm{yr}$ & $2.6 \times 10^{1}$ & $\bar{\beta}$ \\
\hline${ }^{90} \mathrm{Sr}$ & $28.5 \mathrm{yr}$ & $1.4 \times 10^{2}$ & $\beta$ \\
\hline${ }^{99} \mathrm{Tc}$ & $213,000 \mathrm{yr}$ & $1.1 \times 10^{-2}$ & $\beta$ \\
\hline $227 \mathrm{Th}$ & $18.7 \mathrm{~d}$ & $3.1 \times 10^{4}$ & $\bar{\alpha}$ \\
\hline${ }^{229} \mathrm{Th}$ & $7,340 \mathrm{yr}$ & $2.1 \times 10^{-1}$ & $\alpha$ \\
\hline${ }^{230} \mathrm{Th}$ & $77,000 \mathrm{yr}$ & $2.1 \times 10^{-2}$ & $\alpha$ \\
\hline${ }^{231} \mathrm{Th}$ & $25.5 \mathrm{hr}$ & $5.3 \times 10^{5}$ & $\bar{\beta}$ \\
\hline${ }^{207} \mathrm{TI}$ & $4.8 \mathrm{~min}$ & $1.9 \times 10^{8}$ & $\beta, \gamma$ \\
\hline${ }^{233} \mathrm{U}$ & $159,000 \mathrm{yr}$ & $9.7 \times 10^{-3}$ & $\alpha$ \\
\hline${ }^{234} \mathrm{U}$ & $244,500 \mathrm{yr}$ & $6.2 \times 10^{-3}$ & $\bar{\alpha}$ \\
\hline${ }^{235} \mathrm{U}$ & $7.0 \times 10^{8} \mathrm{yr}$ & $2.2 \times 10^{-6}$ & $\alpha, \gamma$ \\
\hline${ }^{238} \mathrm{U}$ & $4.5 \times 10^{9} \mathrm{yr}$ & $3.4 \times 10^{-7}$ & $\alpha$ \\
\hline${ }^{90} \mathrm{Y}$ & $64.1 \mathrm{hr}$ & $5.4 \times 10^{5}$ & $\bar{\beta}$ \\
\hline${ }^{93} \mathrm{Zr}$ & $1.5 \times 10^{6} \mathrm{yr}$ & $2.6 \times 10^{-3}$ & $\beta$ \\
\hline
\end{tabular}

Calculated from half-life and atomic weight.

$\alpha$-alpha decay; $\beta$-negative beta decay; $\gamma$-release of gamma rays.

Daughter radiation. 
Table 4-18. Comparison of Radionuclide Relative Risks for Radionuclides of Concern at the 200 North Aggregate Area.

Page 1 of 3

\begin{tabular}{|c|c|c|c|c|c|}
\hline Radionuclide & Haif-Life & $\begin{array}{c}\text { Air } \\
\text { Unit Risk } \\
\text { in }\left(\mathrm{pCi} / \mathrm{m}^{3}\right)^{-1}\end{array}$ & $\begin{array}{l}\text { Drinking Water } \\
\text { Unit Risk }{ }^{d /} \text { in } \\
(\mathrm{pCi} / \mathrm{L})^{-1}\end{array}$ & $\begin{array}{c}\text { Soil } \\
\text { Ingestion } \\
\text { Unit Risk } \\
\text { in }\left(\mathrm{pCi} / \mathrm{g}^{-1}\right.\end{array}$ & $\begin{array}{l}\text { External } \\
\text { Exposure } \\
\text { Unit Risk } \\
\text { in }(\mathrm{pCi} / \mathrm{g})^{-1}\end{array}$ \\
\hline${ }^{225} \mathrm{Ac}$ & $10 \mathrm{~d}$ & $1.2 \times 10^{-3}$ & $8.7 \times 10^{-7}$ & $4.6 \times 10^{8}$ & $9.4 \times 10^{-6}$ \\
\hline${ }^{2 m} \mathrm{Ac}$ & $21.8 \mathrm{yr}$ & $4.2 \times 10^{-2}$ & $1.8 \times 10^{-5}$ & $9.5 \times 10^{7}$ & $1.3 \times 10^{-7}$ \\
\hline${ }^{201} \mathrm{Am}$ & $433 \mathrm{yr}$ & $2.1 \times 10^{-2}$ & $1.6 \times 10^{-5}$ & $8.4 \times 10^{7}$ & $1.6 \times 10^{-5}$ \\
\hline${ }^{212} \mathrm{Am}$ & $16 \mathrm{hr}$ & na & na & na & na \\
\hline${ }^{202 m} \mathrm{Am}$ & $152 \mathrm{yr}$ & na & na & na & na \\
\hline${ }^{213} \mathrm{Am}$ & $7,380 \mathrm{yr}$ & $2.1 \times 10^{-2}$ & $1.5 \times 10^{-5}$ & $8.1 \times 10^{7}$ & $3.6 \times 10^{-5}$ \\
\hline${ }^{14} \mathrm{C}$ & $5,730 \mathrm{yr}$ & $3.2 \times 10^{-9}$ & $4.7 \times 10^{-8}$ & $2.5 \times 10^{-9}$ & 0 \\
\hline${ }^{212} \mathrm{Cm}$ & $163.2 \mathrm{~d}$ & na & na & na & na \\
\hline${ }^{24} \mathrm{Cm}$ & $18.1 \mathrm{yr}$ & $1.4 \times 10^{-2}$ & $1.0 \times 10^{-5}$ & $5.4 \times 10^{7}$ & $5.9 \times 10^{-7}$ \\
\hline${ }^{215} \mathrm{Cm}$ & $8,500 \mathrm{yr}$ & na & na & na & na \\
\hline${ }^{80} \mathrm{Co}$ & $5.3 \mathrm{yr}$ & $8.1 \times 10^{-5}$ & $7.8 \times 10^{-7}$ & $4.1 \times 10^{-8}$ & $1.3 \times 10^{-3}$ \\
\hline${ }^{134} \mathrm{Cs}$ & $2.06 \mathrm{yr}$ & $1.4 \times 10^{-5}$ & $2.1 \times 10^{-6}$ & $1.1 \times 10^{-7}$ & $8.9 \times 10^{-4}$ \\
\hline${ }^{137} \mathrm{C}_{8}$ & $30 \mathrm{yr}$ & $9.6 \times 10^{-6}$ & $1.4 \times 10^{-6}$ & $7.6 \times 10^{-8}$ & $\begin{array}{c}0 \\
\left(3.4 \times 10^{-4}\right)^{f}\end{array}$ \\
\hline${ }^{152} \mathrm{Eu}$ & $13.3 \mathrm{yr}$ & $6.1 \times 10^{-3}$ & $1.1 \times 10^{-7}$ & $5.7 \times 10^{-9}$ & $6.3 \times 10^{-4}$ \\
\hline${ }^{154} \mathrm{Eu}$ & $8.8 \mathrm{yr}$ & $7.2 \times 10^{-5}$ & $1.5 \times 10^{-7}$ & $8.1 \times 10^{.9}$ & $6.8 \times 10^{-4}$ \\
\hline${ }^{155} \mathrm{Eu}$ & $4.96 \mathrm{yr}$ & na & na & na & \\
\hline${ }^{3} \mathrm{H}$ & $12.3 \mathrm{yr}$ & $4.0 \times 10^{-8}$ & $2.8 \times 10^{-9}$ & $1.5 \times 10^{-10}$ & 0 \\
\hline${ }^{129} \mathbf{I}$ & $1.6 \times 10^{7} \mathrm{yr}$ & $6.1 \times 10^{-5}$ & $9.6 \times 10^{-6}$ & $5.1 \times 10^{-7}$ & $1.5 \times 10^{-5}$ \\
\hline${ }^{40} \mathrm{~K}$ & $1.3 \times 10^{9} \mathrm{yr}$ & $4.0 \times 10^{-6}$ & $5.7 \times 10^{-7}$ & $3.0 \times 10^{8}$ & $7.8 \times 10^{-5}$ \\
\hline${ }^{2} \mathrm{Na}$ & $2.6 \mathrm{yr}$ & na & na & na & na \\
\hline${ }^{93 m} \mathrm{Nb}$ & $14.6 \mathrm{yr}$ & na & na & na & na \\
\hline${ }^{59} \mathrm{Ni}$ & $75,000 \mathrm{yr}$ & $3.5 \times 10^{-7}$ & $4.4 \times 10^{-9}$ & $2.3 \times 10^{-10}$ & $3.4 \times 10^{-7}$ \\
\hline${ }^{237} \mathrm{~Np}$ & $2.14 \times 10^{6} \mathrm{yr}$ & $1.8 \times 10^{-2}$ & $1.4 \times 10^{-5}$ & $7.3 \times 10^{-7}$ & $1.8 \times 10^{.5}$ \\
\hline${ }^{209} \mathrm{~Np}$ & $2.35 \mathrm{~d}$ & $7.7 \times 10^{-7}$ & $4.8 \times 10^{-8}$ & $2.5 \times 10^{-9}$ & $1.1 \times 10^{-4}$ \\
\hline${ }^{231} \mathrm{~Pa}$ & $32,800 \mathrm{yr}$ & $2.0 \times 10^{-2}$ & $9.7 \times 10^{-6}$ & $5.1 \times 10^{7}$ & $2.0 \times 10^{.5}$ \\
\hline${ }^{209} \mathrm{~Pb}$ & $3.25 \mathrm{hr}$ & $3.6 \times 10^{-8}$ & $4.3 \times 10^{-9}$ & $2.3 \times 10^{-10}$ & 0 \\
\hline${ }^{210} \mathrm{~Pb}$ & $22.3 \mathrm{yr}$ & $8.7 \times 10^{-4}$ & $3.4 \times 10^{-5}$ & $1.8 \times 10^{6}$ & $1.8 \times 10^{-6}$ \\
\hline${ }^{211} \mathrm{~Pb}$ & $36.1 \mathrm{~min}$ & $1.5 \times 10^{-6}$ & $9.2 \times 10^{-9}$ & $4.9 \times 10^{-10}$ & $2.9 \times 10^{-5}$ \\
\hline${ }^{212} \mathrm{~Pb}$ & $10.6 \mathrm{hr}$ & $2.4 \times 10^{.5}$ & $3.7 \times 10^{-7}$ & $1.9 \times 10^{8}$ & $9.2 \times 10^{-5}$ \\
\hline
\end{tabular}


Table 4-18. Comparison of Radionuclide Relative Risks for Radionuclides of Concern at the 200 North Aggregate Area.

Page 2 of 3

\begin{tabular}{|c|c|c|c|c|c|}
\hline Radionuclide & Half-Life & $\begin{array}{c}\text { Air } \\
\text { Unit Risk } \\
\text { in }\left(\mathrm{pCi} / \mathrm{m}^{3}\right)^{-1}\end{array}$ & $\begin{array}{l}\text { Drinking Water } \\
\text { Unit Risk }^{-/} \text {in } \\
(\mathrm{pCi} / \mathrm{L})^{-1}\end{array}$ & $\begin{array}{c}\text { Soil } \\
\text { Ingestion } \\
\text { Unit Risk } \\
\text { in }(\mathrm{pCi} / \mathrm{g})^{-1}\end{array}$ & $\begin{array}{l}\text { External } \\
\text { Exposure } \\
\text { Unit Riske } \\
\text { in }(\mathrm{pCi} / \mathrm{g})^{-1}\end{array}$ \\
\hline${ }^{214} \mathrm{~Pb}$ & $26.8 \mathrm{~min}$ & $1.5 \times 10^{-6}$ & $9.2 \times 10^{-9}$ & $4.9 \times 10^{-10}$ & $1.5 \times 10^{-4}$ \\
\hline${ }^{214} \mathrm{Po}$ & $6 \times 10^{-5} \mathrm{sec}$ & $1.4 \times 10^{.13}$ & $5.1 \times 10^{-16}$ & $2.7 \times 10^{-17}$ & $4.7 \times 10^{-8}$ \\
\hline${ }^{215} \mathrm{PO}_{0}$ & $7.8 \times 10^{-4} \mathrm{sec}$ & $2.9 \times 10^{-12}$ & $1.4 \times 10^{-14}$ & $7.6 \times 10^{-16}$ & $8.7 \times 10^{-8}$ \\
\hline${ }^{210} \mathrm{Po}$ & $3.05 \mathrm{~min}$ & $3.0 \times 10^{-7}$ & $1.4 \times 10^{-9}$ & $7.6 \times 10^{-11}$ & 0 \\
\hline${ }^{200} \mathrm{Pu}$ & $87.7 \mathrm{yr}$ & $2.1 \times 10^{-2}$ & $1.4 \times 10^{-5}$ & $7.6 \times 10^{-7}$ & $5.9 \times 10^{.7}$ \\
\hline${ }^{209} \mathrm{Pu}$ & $24,400 \mathrm{yr}$ & $2.6 \times 10^{-2}$ & $1.6 \times 10^{-5}$ & $8.4 \times 10^{8}$ & $2.6 \times 10^{-7}$ \\
\hline${ }^{20} \mathrm{Pu}$ oxide & $24,400 \mathrm{yr}$ & $2.6 \times 10^{-2}$ & $1.6 \times 10^{-6}$ & $8.4 \times 10^{8}$ & $2.6 \times 10^{-7}$ \\
\hline${ }^{200} \mathrm{Pu}$ & $6,560 \mathrm{yr}$ & $2.1 \times 10^{-2}$ & $1.6 \times 10^{-5}$ & $8.4 \times 10^{-8}$ & $5.9 \times 10^{-7}$ \\
\hline${ }^{200} \mathrm{Pu}$ oxide & $6,560 \mathrm{yr}$ & $2.1 \times 10^{-2}$ & $1.6 \times 10^{-6}$ & $8.4 \times 10^{8}$ & $5.9 \times 10^{-7}$ \\
\hline${ }^{201} \mathrm{Pu}$ & $14.4 \mathrm{yr}$ & $1.5 \times 10^{-4}$ & $2.5 \times 10^{-7}$ & $1.3 \times 10^{-8}$ & $\mathbf{0}$ \\
\hline${ }^{25} \mathbf{R a}$ & $14.8 \mathrm{~d}$ & $8.2 \times 10^{-4}$ & $3.4 \times 10^{-6}$ & $1.8 \times 10^{-7}$ & $8.0 \times 10^{-6}$ \\
\hline${ }^{20} \mathbf{R a}$ & $1,600 \mathrm{yr}$ & $1.5 \times 10^{-3}$ & $6.1 \times 10^{-6}$ & $3.2 \times 10^{7}$ & $4.1 \times 10^{-6}$ \\
\hline${ }^{2 m a}$ & $5.75 \mathrm{yr}$ & $3.4 \times 10^{-4}$ & $5.1 \times 10^{-6}$ & $2.7 \times 10^{7}$ & $5.6 \times 10^{-13}$ \\
\hline${ }^{106} \mathbf{R u}$ & $1.0 \mathrm{yr}$ & $2.3 \times 10^{-4}$ & $4.9 \times 10^{-7}$ & $2.6 \times 10^{8}$ & 0 \\
\hline mse & $<65,000 \mathrm{yr}$ & na & $\mathbf{n a}$ & na & na \\
\hline${ }^{151} \mathrm{Sm}$ & $90 \mathrm{yr}$ & na & na & na & na \\
\hline${ }^{20} \mathrm{Sr}$ & $28.5 \mathrm{yr}$ & $2.8 \times 10^{.5}$ & $1.7 \times 10^{-6}$ & $8.9 \times 10^{-8}$ & 0 \\
\hline${ }^{29} \mathrm{Tc}$ & $213,000 \mathrm{yr}$ & $4.2 \times 10^{-6}$ & $6.6 \times 10^{-8}$ & $3.5 \times 10^{-9}$ & $3.4 \times 10^{-10}$ \\
\hline${ }^{2 n} \mathrm{Th}$ & $18.72 \mathrm{~d}$ & $2.5 \times 10^{-3}$ & $2.5 \times 10^{-7}$ & $1.3 \times 10^{8}$ & $6.6 \times 10^{-6}$ \\
\hline${ }^{200} \mathrm{Th}$ & $7,340 \mathrm{yr}$ & $3.9 \times 10^{-2}$ & $2.0 \times 10^{-6}$ & $1.1 \times 10^{7}$ & $5.8 \times 10^{-5}$ \\
\hline${ }^{200} \mathrm{Th}$ & $77,000 \mathrm{yr}$ & $1.6 \times 10^{-2}$ & $1.2 \times 10^{-6}$ & $6.5 \times 10^{8}$ & $5.9 \times 10^{-7}$ \\
\hline${ }^{21} \mathrm{Th}$ & $25.5 \mathrm{hr}$ & $2.5 \times 10^{-7}$ & $2.0 \times 10^{-8}$ & $1.1 \times 10^{9}$ & $1.1 \times 10^{-5}$ \\
\hline${ }^{233} \mathrm{U}$ & $159,000 \mathrm{yr}$ & $1.4 \times 10^{-2}$ & $7.2 \times 10^{-6}$ & $3.8 \times 10^{-7}$ & $3.2 \times 10^{-7}$ \\
\hline${ }^{204} \mathrm{U}$ & $244,500 \mathrm{yr}$ & $1.4 \times 10^{-2}$ & $7.2 \times 10^{-6}$ & $3.8 \times 10^{-7}$ & $5.6 \times 10^{-7}$ \\
\hline${ }^{25} \mathrm{U}$ & $7.0 \times 10^{8} \mathrm{yr}$ & $1.3 \times 10^{2}$ & $6.6 \times 10^{-6}$ & $3.5 \times 10^{7}$ & $9.7 \times 10^{-5}$ \\
\hline
\end{tabular}


Table 4-18. Comparison of Radionuclide Relative Risks for Radionuclides of Concern at the 200 North Aggregate Area.

Page 3 of 3

\begin{tabular}{|c|c|c|c|c|c|}
\hline Radionuclide & Half-Life & $\begin{array}{c}\text { Air } \\
\text { Unit Risk } \\
\text { in }\left(\mathrm{pCi} / \mathrm{m}^{3}\right)^{-1}\end{array}$ & $\begin{array}{l}\text { Drinking Water } \\
\text { Unit Risk }{ }^{\alpha / 1} \text { in } \\
(\mathrm{pCi} / \mathrm{L})^{-1}\end{array}$ & $\begin{array}{c}\text { Soil } \\
\text { Ingestion } \\
\text { Unit Risk }^{\mathrm{d}} \\
\text { in (pCi/g) }\end{array}$ & $\begin{array}{l}\text { External } \\
\text { Exposure } \\
\text { Unit Risk } \\
\text { in }(\mathrm{pCi} / \mathrm{g})^{-1}\end{array}$ \\
\hline${ }^{200} \mathrm{U}$ & $4.5 \times 10^{8} \mathrm{yr}$ & $1.2 \times 10^{-2}$ & $6.6 \times 10^{-6}$ & $3.5 \times 10^{7}$ & $4.5 \times 10^{-7}$ \\
\hline${ }^{90} \mathrm{Y}$ & $64.1 \mathrm{hr}$ & $2.8 \times 10^{-6}$ & $1.6 \times 10^{-7}$ & $8.6 \times 10^{-9}$ & 0 \\
\hline
\end{tabular}

- Caleulated from half-life and atomic weight.

b Excess cancer risk associated with lifetime exposure to $1 \mathrm{pCi} / \mathrm{m}^{3}\left(10^{-12}\right.$ curies) per day in air (EPA 1991).

a Excess cancer risk associated with lifetime exposure to $1 \mathrm{pCi}$ (10 12 curies) per day in drinking water (EPA 1991).

d Excess cancer risk associated with lifetime exposure to $1 \mathrm{pCi} / \mathrm{g}\left(10^{-12} \mathrm{curies} / \mathrm{g}\right)$ per day in soil (EPA 1991).

a Excess cancer risk associated with lifetime exposure to surface soils containing $1 \mathrm{pCi} / \mathrm{g}$ of gammaemitting radionuclides (EPA 1991).

i External radiation risk from ${ }^{137 m} \mathrm{Ba}$, a short-lived decay product of ${ }^{137} \mathrm{Cs}$.

na No information available. 
Table 419. Potential Chronic Human Health Effects of Chemicals Detected or Disposed of at 200 North Aggregate Area.

\begin{tabular}{|l|c|c|c|}
\hline \multicolumn{1}{|c|}{ Chemical } & $\begin{array}{c}\text { Tumor Site } \\
\text { Inhalation Route; } \\
\text { Oral Route } \\
\text { [Weight of Evidence } \\
\text { Group'] }\end{array}$ & $\begin{array}{c}\text { Non-carcinogenic } \\
\text { Chronic Health Effects } \\
\text { Inhalation Route; Oral Route }\end{array}$ & Reference \\
\hline $\begin{array}{l}\text { Acetone } \\
\text { Trichloroethylene }\end{array}$ & NA; Lymphonia [B2] & NA; kidney and liver effects & EPA 1991a \\
\hline
\end{tabular}

- Weight of Evidence Groups for carcinogens: A - Human carcinogen (sufficient evidence of carcinogenicity in humans); B - Probable human carcinogen (B1 - Limited evidence of carcinogenicity in humans; B2 - Sufficient evidence of carcinogenicity in animals with inadequate or lack of data in humans); C - Possible human carcinogen (limited evidence of carcinogenicity in animals and inadequate or lack of human data); D - Not classifiable as to human carcinogenicity (inadequate or no evidence). 


\subsection{HEALTH AND ENVIRONMENTAL CONCERNS}

This preliminary qualitative evaluation of potential human health and environmental concerns is intended to provide input to the 200 North Aggregate Area waste management unit recommendation process (Section 9.0) This process requires consideration of immediate and long-term impacts to human health and the environment. As discussed in Section 4.2, existing 200 North Aggregate Area and waste management unit data are not adequate to support an evaluation of potential impacts on the environment. Although ecological impacts are an integral part of the complete assessment of aggregate area and waste unit potential risks, they cannot be evaluated further at this time. Ecological risk assessment is included in the listing of data needs presented in Section 8.0 with the associated data needs identified as a data gap to be addressed in future investigations. The approach that has been taken to identify potential concerns related to individual waste management units and unplanned releases is as follows:

- Contaminants of potential concern are identified for each exposure pathway that is likely to occur within the 200 North Aggregate Area. Selection of contaminants was discussed in Section 4.2. Contaminants of potential concern were selected from the list of candidate contaminants of potential concern presented in Table 4-13. This table includes contaminants that are likely to be present in the environment based on occurrence in the liquid process wastes that were discharged to soils, and also contaminants that have been detected in environmental samples within the aggregate area but have not been identified as components of 200 North waste streams.

- Exposure pathways potentially applicable to individual waste management units are identified based on the presence of the above contaminants of potential concern in wastes in the waste management units, consideration of known or suspected releases from those waste management units, and the physical and institutional controls affecting site access and use over the period of interest. The relationships between waste management units and exposure pathways are summarized in the conceptual model (Section 4.2).

- Estimates of relative hazard derived for the 200 North waste management units are identified using the Comprehensive Environmental Response, Compensation, and Liability Act (CERCLA) Hazard Ranking System (HRS), modified Hazard Ranking System (mHRS), surface radiation survey data, and by Westinghouse Hanford Environmental Protection Group scoring. Other indicators of relative hazard, such as rate of release of contaminants and irreversible results of continuing residence of contaminants, were not used because they generally require unit-specific data that are not available for most units. 
The human health concerns, and various hazard ranking scores listed above, are used to establish whether or not a site is considered a "high" priority. In the data evaluation process presented in Section 9.0, "high" priority sites are evaluated for the potential implementation of an interim remedial measure (IRM). "Low" priority sites are evaluated to determine what type of additional investigation is necessary to establish a final remedy. Further detail is presented in Section 9.0.

The data used for this evaluation are presented in the earlier sections of this report. The types of data that have been assessed include site histories and physical descriptions (Section 2.0), descriptions of the physical environment of the study area (Section 3.0) and a summary of the available chemical and radiological data for each waste management unit (Section 4.0).

The quality and sufficiency of these data are assessed in Section 8.0. This information is also used to identify applicable or relevant and appropriate requirements (ARARs) (Section 6.0).

\subsection{CONCEPTUAL FRAMEWORK FOR RISK-BASED SCREENING}

The range of potential human health and environmental exposure pathways at the 200 North Aggregate Area was summarized in Section 4.2. In Section 4.2 the role of biota in transporting contaminants through the environment is also discussed, and biota are included as receptors in the conceptual model. However, the assessment of potential ecological risks associated with biota exposure to 200 North Aggregate Area contaminants is currently constrained by the lack of data. This gap in the 200 North Aggregate Area data is discussed in Section 8.2.3. As a result, the risk-based screening of waste management unit priorities discussed in this section is by necessity limited to potential human health risks.

The U.S. Environmental Protection Agency (EPA 1989a) considers a human exposure pathway to consist of four elements: (1) a source and mechanism for contaminant release, (2) a retention or transport medium (or media), (3) a point of potential human contact, and (4) an exposure route (e.g., ingestion) at the contact point. The probability of the existence of a particular pathway is dependent upon the physical and institutional controls affecting site access and use. In the absence of site access controls and other land use restrictions, the identified potential exposure pathways could all occur. For example, it could be hypothesized that an individual could establish a residence within the boundaries of the 200 North Aggregate Area, disrupt the soil surface and contact buried contamination, and drill a well and withdraw contaminated groundwater for drinking water and crop irrigation. However, within the five- to ten-year period of interest associated with identification and prioritization of remedial actions within the 200 North Aggregate Area, unrestricted access and uncontrolled disruption of buried contaminants have a negligible probability of occurrence. 
The conceptual model presented in Section 4.2 was evaluated to identify an appropriate framework for screening waste management units and establishing their remediation priorities based on potential health hazards. Based on the five- to ten-year period of interest for waste unit prioritization, and the presence of site access controls during that period, a screening framework was developed encompassing the range of release mechanisms, affected media, and exposure routes associated with an onsite occupational receptor. While work activities are assumed to include occasional contact with surface soils, it is assumed that no contact with buried contaminants will take place without proper protective measures.

Workers may be exposed via the following routes at the 200 North Aggregate Area:

- Ingestion of surface soils

- Inhalation of volatilized contaminants and resuspended particles

- Direct dermal contact with surface soils

- Direct exposure to radiation from surface soils and airborne resuspended particles

Since evaluation of migration in the saturated zone is not within the scope of a source area aggregate area manageinent study (AAMS), ingestion or contact with groundwater was not evaluated as an exposure pathways. However, since migration of waste constituents within the saturated zone will be addressed in the 200 East Groundwater Aggregate Area Management Study Reporis (AAMSR), contaminants likely to migrate to the water table and waste management units that have a high potential to impact groundwater will be identified.

\subsection{POTENTIAL EXPCSURE SCENARIOS AND HUMAN HEALTH CONCERNS}

The routes by which a Hanford Site worker could potentially be exposed to contamination at the waste management units include ingestion, inhalation, direct contact with soils, and direct exposure to radiation. To evaluate the potential for exposure at individual waste management units, it is necessary to have data available for surface soils, air, and radiation le\%eis. Although samples have been collected from each of these media, only the surface radiation survey data (contamination levels and dose rate) are specific to individual waste management units. Therefore, only pathways associated with the surface radiological contamination and external dose rates can be evaluated with confidence at this time. Potential exposures by other pathways were evaluated based on available knowledge about contaminants disposed of to the waste management unit and the engineered barriers to releases. 


\subsubsection{External Exposure}

External dose rate surveys, which are performed on a waste management unit basis, were used as the measure of a unit's potential for impacting human health through direct external radiation exposure. The contaminants of potential concern for this pathway are the radionuclides that emit moderate to high energy penetrating gamma radiation. The measured dose rates at 200 North Aggregate Area waste management units are presented in Table 5-1 from the available survey data.

For nine of the sixteen 200 North Aggregate Area waste management units, no radiation survey data are available. For the seven units that do have radiation survey data of some type, the external exposure levels were reported as less than $0.1 \mathrm{mrem} / \mathrm{hr}$.

The Westinghouse Hanford manual WHC-CM-4-10, Section 7 (WHC 1988a) was used as the basis for setting one of the criteria that are used to identify waste management units that can be considered high priority sites. The manual indicates that with radiation levels of $2 \mathrm{mrem} / \mathrm{h}$ be posted with "Radiation Area" signs and undergo access controls for the purpose of personnel protection. With the same objective in mind, the level of $2 \mathrm{mrem} / \mathrm{h}$ is recommended as one of the criteria for distinguishing "high priority" from "low priority" waste management units.

High levels of radiation were reportedly associated with the ponds during their operation. However, those levels were observed in the early years of the Hariford Site. The ponds were reportedly remediated by covering the area with soil, and more recent survey data indicate much reduced levels. In any event, additional measurements are necessary to estabiish the current contaminant levels at these sites and are identified as a data gap in Section 8.0.

\subsubsection{Ingestion of Soil or Inhalation of Fugitive Dust}

Radionuclides and nonradioactive contaminants of concern for the soil ingestion and fugitive dust inhalation pathways (see Section 4.2.2.2) are those that are nonvolatile, and are persistent in surface soils and have appreciable carcinogenic or toxic effects by ingestion or inhalation. However, little information is available to evaluate the presence of specific radionuclides in surface soils. As indicated in Table 5-1, there are no current gross activity survey data for the 200 North Aggregate Area waste management units.

The Westinghouse Hanford Environmental Protection group policies state that the presence of any smearable alpha constitutes a potential threat to human health and qualifies a waste management unit for a high remediation priority (Huckfeldt 1991b). Waste management units that exhibit elevated alpha readings in radiological surveys can be presumed to have surface contamination, since alpha radiation cannot penetrate solids. 
The Westinghouse Hanford manual Radiation Protection (WHC 1988) was also used to set criteria for identifying waste management units that can be considered high remediation priority sites. The manual indicates that posting ("Surface Contamination Area") and access controls are to be implemented at a level of $100 \mathrm{ct} / \mathrm{min}$ above background beta/gamma, and/or $20 \mathrm{dis} / \mathrm{min}$ alpha, for the purpose of personnel protection. With the same objective in mind, the levels of $100 \mathrm{ct} / \mathrm{min}$ above background beta/gamma and $20 \mathrm{dis} / \mathrm{min}$ alpha are recommended as two of the criteria for identification of high priority waste management units.

It should be noted that these radiation readings may indicate transient conditions (e.g., presence of contaminated vegetation) and that routine stabilization of surface contamination is carried out under the auspices of the Westinghouse Hanford Radiation Area Remedial Action (RARA) program. For those beta/gamma survey readings that are in units of dis/min, a conversion was made to $\mathrm{ct} / \mathrm{min}$ assuming a survey detector efficiency of $10 \%$

As summarized in Section 4.1, the distribution of volatile orgaincs in soils is not well defined $\mathrm{n}$ the 200 North Aggregate Area. Although semivolatile compounds may have been used around the 200 North facilities, no information is avialable on whether these compounds are still present in the near surface soil column for transport to the soil surface.

\subsubsection{Inhalation of Volatiles}

The primary volatile radionuclide of concern is tritium. Exposure to tritium (as tritiated water vapor) and the potential for tritium release via radiolytic production of hydrogen from aqueous radioactive wastes is possible. The primary nonradioactive volatile contaminant of concern is acetone. As in the case of tritium, the available information is not sufficient to enable evaluation of this pathway.

\subsubsection{Migration to Groundwater}

Risks that could potentially occur due to migration of contaminants in groundwater to existing or potential receptors will be addressed in the 200 East and 200 West Groundwater AAMSR and thus, will not be discussed in the 200 North AAMS. However, the potential for individual units to impact groundwater has been discussed in Section 4.1.

\subsection{ADDITIONAL SCREENING CRITERIA}

In addition to determining human health concerns for a worker at each of the waste management units, previously developed site ranking criteria were investigated for the purpose of setting priorities for waste management units and unplanned releases. These criteria are the CERCLA HRS scores assigned during preliminary assessment/site inspection 
(PA/SI) activities performed for the Hanford Site (DOE/RL 1988), and the rankings assigned by the Westinghouse Hanford Environmental Protection Group to prioritize sites needing remedial actions for radiological control (Huckfeldt 1991).

Both of these ranking systems take into account some measure of hazard and environmental mobility, and are thus appropriate to consider for waste unit prioritization. The HRS ranking system evaluates sites based on their relative risk, taking into account the population at risk, the hazardous waste constituent toxicity and concentration at the facility, the potential for contamination of the environment, the potential risk of fire and explosion, and the potential for exposure associated with humans or animals that come into contact with the waste management unit inventory. The HRS is thus appropriate to consider for screening waste management units.

The PA/SI screening was performed using the U.S. Environmental Protection Agency (EPA's) HRS and mHRS. The HRS (40 CFR 300) is a site ranking methodology which was designed to determine whether sites should be placed on the CERCLA National Priorities List (NPL) based on chemical contamination history. The EPA has established the criteria for placement on the NPL to be a score of 28.5 or greater. The HRS criteria used in the PA/SI have been revised (December 14, 1990). The HRS scores are only used as available indicators of relative risk; therefore, the revision will not impact the evaluation process. The mHRS is a ranking system developed by the Pacific Northwest Laboratory (PNL) for the U.S. Department of Energy (DOE) that uses the basic methodology of the old (preDecember 1990) HRS; however, it more accurately predicts the impacts from radionuclides. The mHRS takes into account concentration, half-life, and other chemical-specific parameters that are not considered by the HRS. The mHRS has not been accepted by EPA as a ranking system.

Several of the 200 North Aggregate Area waste management units were ranked in the PA/SI using either the HRS and mHRS. For those waste management units that were not ranked in the PA/SI, unit type and discharge history were evaluated in comparison with ranked units for the purpose of setting priorities. If a waste management unit that has been ranked exhibits similar characteristics (e.g., construction, waste type, and volume), the value for the ranked unit was applied to the unit without an HRS or mHRS score. If no ranked waste management units exhibit similar characteristics, then the unit was not ranked; however, a high or low score was determined qualitatively through evaluation of unit configuration and contamination history.

Table 5-1 lists the HRS and mHRS rankings, as well as scores that were assigned for unranked waste management units, based on their similarity to ranked units in terms of type, construction, and quantity of waste disposed of. If no similar waste management units were available for comparison, the units were not ranked but were assigned a qualitative indicator of migration potential. Table 5-1 also lists the units scored by the Westinghouse Environmental Protection Group (Huckfeld 1991b). A score of 7 or greater results in the assignment of a "high" priority to the unit. A value of 7 was chosen to represent the approximate midpoint of the scoring range. 
For the HRS rating, six of the sixteen 200 North Aggregate Area waste management units were given a score of 28.5 or greater. For the mHRS ranking, none of the units were ranked. One unit received a qualitative "high" score and eight units received a qualitative "low" score. The unit that received a qualitative "high" HRS score was given such a rating based on its discharge history of large quantities of hazardous materials, which could potentially have been transported to the groundwater. It must be stressed that the high scoring of 200 North units is conservative and somewhat arbitrary in nature. A more definitive determination of actual hazards associated with these units requires the collection and analysis of additional characterization data that are not currently available. The units that received "low" scores were given such a ranking because there is no known history of liquid hazardous material disposal that could affect groundwater beneath the 200 North Aggregate Area.

\subsection{SUMMARY OF SCREENING RESULTS}

The screening process was used to sort sites as either high priority or low priority. Table 5-1 lists the 200 North Aggregate Area waste management units that exceeded one or more of the screening criteria identified in the preceding Sections. In total, eight units were identified as high priority.

Radiation survey results (dose rate and/or contamination) were available for seven of the sixteen waste management units. Of the seven units, none had survey results that exceeded one or more of the criteria $(2 \mathrm{mrem} / \mathrm{h}, 100 \mathrm{ct} / \mathrm{min}$ beta/gamma, and $20 \mathrm{ct} / \mathrm{min}$ alpha).

For the HRS scores, six waste management units were given scores of 28.5 or greater. One unit received a qualitative "high" score. 
DOE/RL-92-17, Rev. 0

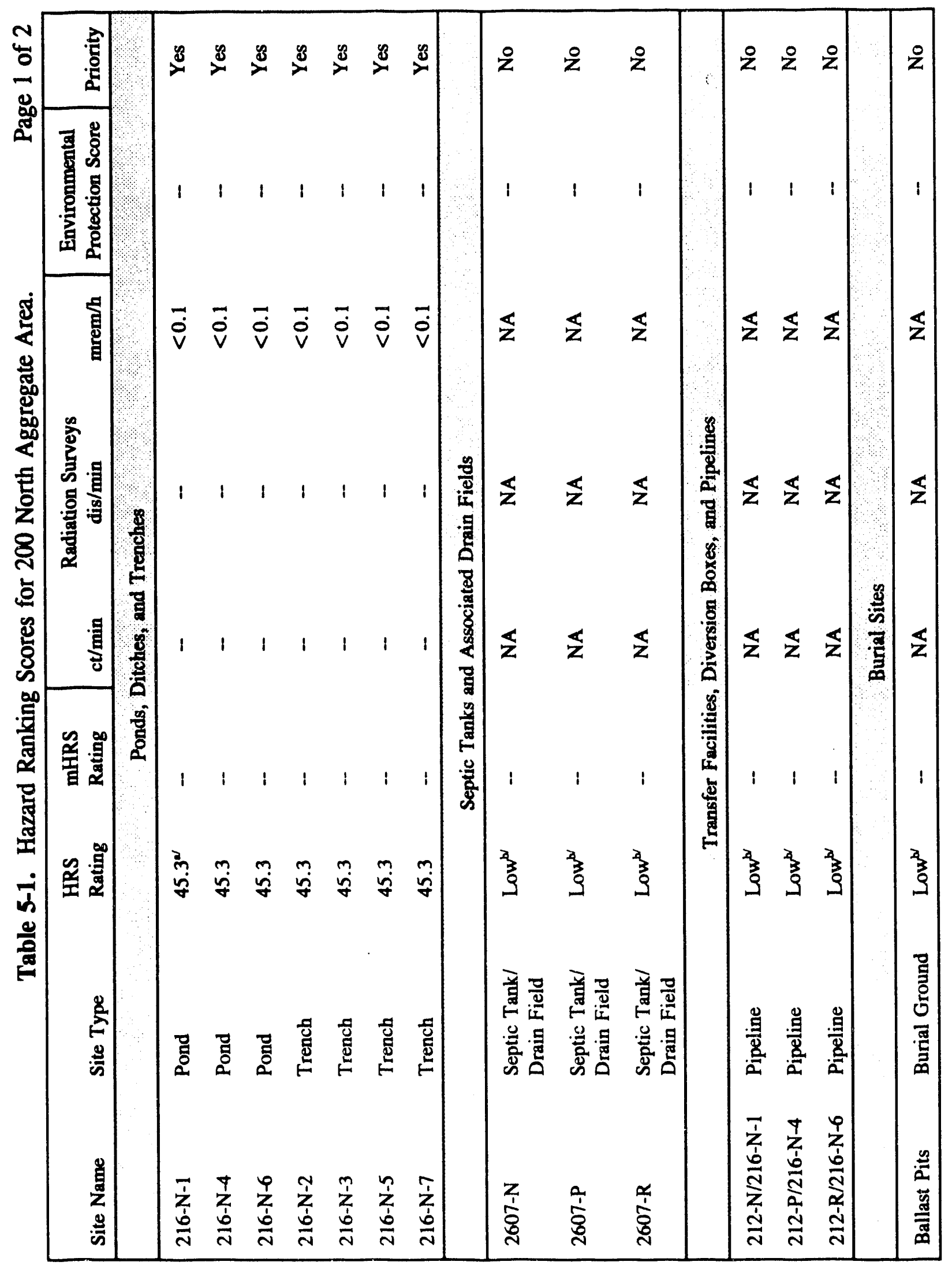


DOE/RL-92-17, Rev. 0

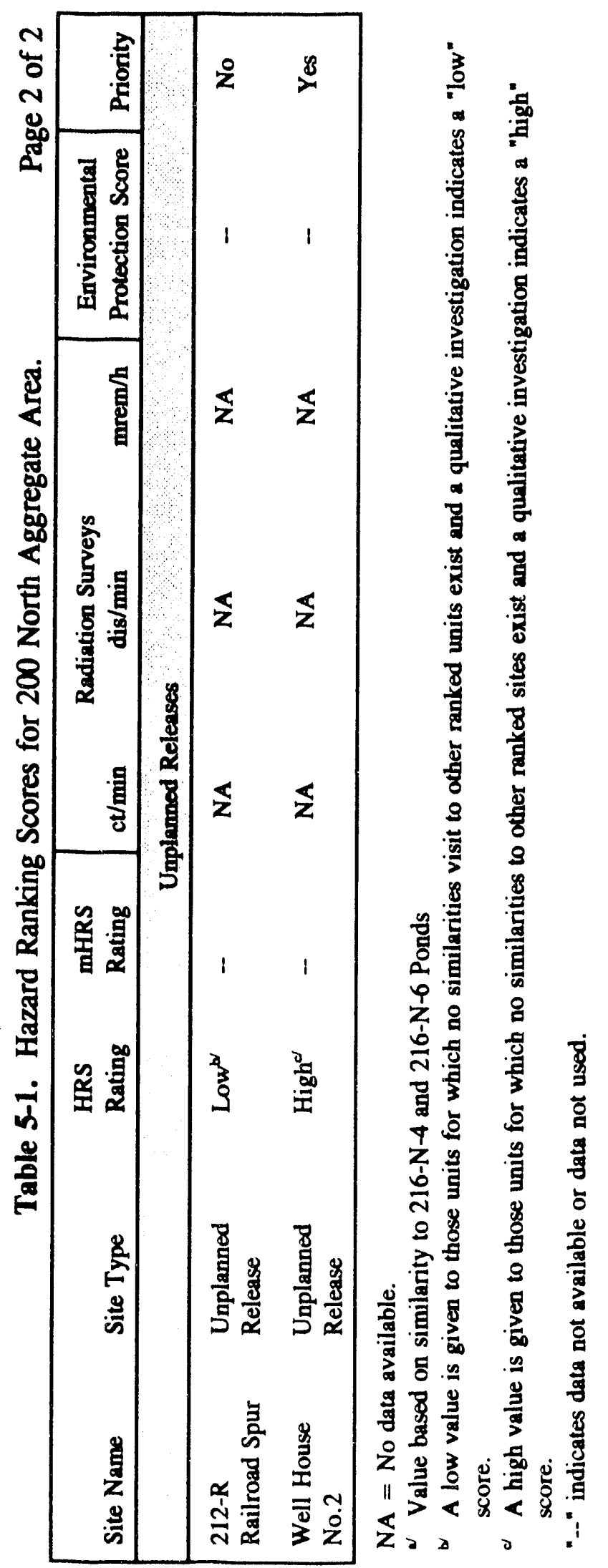


DOE/RL-92-17, Rev. 0

\subsection{POTENTIALLY' APPLICABLE OR RELEVANT AND APPROPRIATE REQUIREMENTS}

\subsection{INTRODUCTION}

The Superfund Amendments and Reauthorization Act (SARA) of 1986 amended the Comprehensive Environmental Response, Compensation, and Liability Act (CERCLA) to require that all applicable or relevant and appropriate requirements (ARARs) be employed during implementation of a hazardous waste site cleanup. "Applicable" requirements are defined by the U.S. Environmental Protection Agency (EPA) in "CERCLA Compliance with Other Laws Manual" (OSWER Directive 9234.1-01, August 8, 1988) as:

cleanup standards, standards of control, and other substantive environmental protection requirements, criteria, or limitations promulgated under federal or state law that specifically address a hazardous substance, pollutant, contaminant, remedial action, location, or other circumstance at a CERCLA site. include:

A separate set of "relevant and appropriate" requirements that must be evaluated

cleanup standards, standards of control, and other substantive environmental protection requirements, criteria, or limitations promulgated under federal or state law that while not "applicable" to a hazardous substance, pollutant, contaminant, remedial action, location, or other circumstance at a CERCLA site, address problems or situations sufficiently similar to those encountered at the CERCLA site that their use is well suited to the particular site.

"To-be-Considered Materials" (TBCs) are nonpromulgated advisories or guidance issued by federal or state governments that are not legally binding and do not have the status of potential ARARs. However, in many circumstances, TBCs will be considered along with potential ARARs and may be used in determining the necessary level of cleanup for protection of health or the environment.

The following sections identify potential ARARs to be used in developing and assessing various remedial action alternatives at the 200 North Aggregate Area. Specific requirements pertaining to hazardous and radiological waste management, remediation of contaminated soils, surface water protection, and air quality will be discussed. 
The potential ARARs focus on federal or state statutes, regulations, criteria, and guidelines. The specific types of potential ARARs evaluated include the following:

- Contaminant-specific

- Location-specific

- $\quad$ Action-specific.

Potential contaminant-specific ARARs are usually health or risk-based numerical values or methodologies that, when applied to site-specific conditions, result in the establishment of numerical contaminant values that are generally recognized by the regulatory agencies as allowable to protect human health and the environment. In the case of the 200 North Aggregate Area, potential contaminant-specific ARARs address chemical constituents and/or radionuclides. The potential contaminant-specific ARARs that were evaluated for the 200 North Aggregate Area are discussed in Section 6.2.

Potential location-specific ARARs are restrictions placed on the concentration of hazardcus substances, or the conduct of activities, solely because they occur in specific locations. The potential location-specific ARARs that were evaluated for the 200 North Aggregate Area are discussed in Section 6.3.

Potential action-specific ARARs apply to particular remediation methods and technologies, and are evaluated during the detailed screening and evaluation of remediation alternatives. The potential action-specific ARARs that were evaluated for the 200 North Aggregate Area are discussed in Section 6.4.

The TBC requirements are other federal and state criteria, advisories, and regulatory guidance that are not promulgated regulations, but are to be considered in evaluating altematives. Potential TBCs include U.S. Department of Energy (DOE) Orders that carry out authority granted under the Atomic Energy Act. All DOE Orders are potentially applicable to operations at the 200 North Aggregate Area. Specific TBC requirements are discussed in Section 6.5.

Potential contaminant- and location-specific ARARs will be refined during the aggregate area management study (AAMS) process. Potential action-specific ARARs are briefly discussed in this section, and will be further evaluated upon final selection of remedial alternatives. The points at which these ARARs must be achieved and the timing of the ARARs evaluations are discussed in Sections 6.6 and 6.7, respectively. 


\subsection{CONTAMINANT-SPECIFIC REQUIREMENTS}

A contaminant-specific requirement sets concentration limits in various environmental media for specific hazardous substances, pollutants, or contaminants. Based on available information, some of the currently known or suspected contaminants that may be present in the 200 North Aggregate Area are outlined in Table 4-13. The currently identified potential federal and state contaminant-specific ARARs are summarized below.

\subsubsection{Federal Requirements}

Federal contaminant-specific requirements are specified in several statutes, codified in the U.S. Code (USC), and promulgated in the Code of Federal Regulations (CFR), as follows:

- Clean Water Act (33 U.S.C. 1251). Federal Water Quality Criteria (FWQC) (40 CFR 131) are developed under the authority of the Clean Water Act (CWA) (33 USC 1251) to serve as guidelines to the states for determining receiving water quality standards. Different FWQC are derived for protection of human health and protection of aquatic life. The human health FWQC are further subdivided according to how people are expected to use the water (e.g., drinking the water versus consuming fish caught from the water). The SARA 121(d)(2) states that remedial actions shall attain FWQC where they are relevant and appropriate, taking into account the designated or potential use of the water, the media affected, the purpose of the criteria, and current information. Many more substances have FWQC than maximum contaminant levels (MCLs) issued under the Safe Drinking Water Act (SDWA, see discussion below); consequently, EPA and other state agencies rely on these criteria more than MCLs, even though these criteria can only be considered relevant and appropriate and not applicable.

The FWQC would not be considered at 200 North Aggregate Area, as no natural surface water bodies exist. The only man-made surface water bodies at the 200 North Aggregate Area were waste management units.

- Safe Drinking Water Act (42 U.S.C. 30.0(f)). Under the authority of the SDWA (42 USC 300 (f)), MCLs (40 CFR 141) apply when the water may be used for drinking. Currently, EPA and the State of Washington apply MCLs as the standards for groundwater contaminants at CERCLA sites that could be used as drinking water sources. Groundwater contamination and application of MCLs as potential ARARs are addressed under a separate AAMS specific to groundwater.

- Resource Conservation and Recovery Act (42 USC 6901, 40 CFR 260 to 271). The Resource Conservation and Recovery Act (RCRA) addresses the generation and transportation of hazardous waste, and waste management activities at 
facilities that treat, store, or dispose of hazardous wastes. Subtitle C (Hazardous Waste Management) mandates the creation of a cradle-to-grave management and permitting system for hazardous wastes. The RCRA defines hazardous wastes (40 CFR 261) as "solid wastes" (even though the waste is often liquid in physical form) that may cause or significantly contribute to an increase in mortality or serious illness, or that poses a substantial hazard to human health or the environment when improperly managed. In Washington State, RCRA is implemented by EPA and the authorized state agency, the Washington State Department of Ecology (Ecology).

The CERCLA Sections 121(d) and 121(e), respectively, require that CERCLA activities, including remedial actions, comply with substantive requirements and not administrative requirements such as permitting. Therefore, hazardous waste activities conducted onsite at the 200 North Aggregate Area will comply with the substantive requirements of RCRA, which are deemed to be potential ARARs.

Two key potential contaminant-specific ARARs have been adopted under the federal hazardous waste regulations: the Toxicity Characteristic Leaching Procedure (TCLP) designation limits promulgated under 40 CFR Part 261; and the hazardous waste land disposal restrictions (LDRs) for constituent concentrations promulgated under 40 CFR Part 268.

The TCLP designation limits define when a waste is hazardous, and are used to determine when more stringent management standards apply than would be applied to typical solid wastes. Thus, the TCLP potential contaminant-specific ARARs can be used to determine when RCRA waste management standards may be required. The TCLP limits are presented in Table 6-1.

The LDRs are numerical limits derived by EPA by reviewing available technologies for treating hazardous wastes. Until a prohibited waste can meet the numerical limits, it can be prohibited from land disposal. Two sets of limits have been promulgated: limits for constituent concentrations in waste extract, which uses the TCLP test to obtain a leached sample of the waste; and limits for constituent concentrations in waste, which addresses the total contaminant concentration in the waste. Applicability to CERCLA actions is based on determinations of waste "placement/disposal" during a remediation action. According to OSWER Directive 9347.3-05FS, EPA concludes that Congress did not intend in situ consolidation, remediations, or improvement of structural stability to constitute placement or disposal. The land disposal numerical limits can be used to determine if generated cleanup wastes can be redisposed of onsite without further treatment, or must be subject to certain treatment practices prior to land disposal. The LDR limits are presented in Table 6-1 (see Section 6.4.1 for a further discussion on applying the LDR limits). 
- Clean Air Act (42 USC 7401). The Clean Air Act (42 USC 7401) establishes National Primary and Secondary Ambient Air Quality Standards (NAAQS) (40 CFR Part 50), National Emission Standards for Hazardous Air Pollutants (NESHAPs)(40 CFR Part 61), and New Source Performance Standards (NSPS) (40 CFR Part 60).

In general, new and modified stationary sources of air emissions must undergo a preconstruction review to determine whether the construction or modification of any source, such as a CERCLA remedial program, will interfere with attainment or maintenance of NAAQS or fail to meet other new source review requirements including NESHAPs and NSPS. However, the process applies only to "major" sources of air emissions (defined as emissions of 250 tons per year). The 200 North Aggregate Area would not constitute a major source.

Section 112 of the Clean Air Act directs EPA to establish standards at the level that provides an ample margin of safety to protect the public health from hazardous air pollutants. The NESHAP standards for radionuclides are directly applicable to DOE facilities under Subpart $\mathrm{H}$ of Section 112 that establishes a $10 \mathrm{mrem} / \mathrm{yr}$ facility-wide standard for exposure to an offsite receptor. Further, if the maximum individual dose during remediation exceeds $1 \%$ of the NESHAP standard $(0.1 \mathrm{mrem} / \mathrm{yr})$, a report meeting the substantive requirements of an application for approval of construction must be prepared.

\subsubsection{State of Washington Requirements}

Potential state contaminant-specific requirements are specified in several statutes, codified in the Revised Code of Washington (RCW) and promulgated in the Washington Administrative Code (WAC).

- Model Toxics Control Act (RCW 70.105D, Chapter 173-340 WAC). The Model Toxics Control Act (MTCA) (RCW 70.105D) authorized Ecology to adopt cleanup standards for remedial actions at hazardous waste sites. These regulations are considered potential ARARs for soil, groundwater, and surface water cleanup actions. The processes for identifying, investigating, and cleaning up hazardous waste sites are defined and cleanup standards are set for groundwater, soil, surface water, and air in Chapter 173-340 WAC.

Under the MTCA regulations, cleanup standards may be established by one of three methods.

Method A may be used if a routine cleanup action, as defined in WAC 173-340-200, is being conducted at the site or relatively few hazardous substances are involved for which cleanup standards have been specified by Tables 1,2 , or 3 of WAC 173-340-720 through -745 . 
- Under Method B, a risk level of $10^{-6}$ is established and a risk calculation based on contaminants present is determined.

- $\quad$ Method C cleanup standards represent concentrations that are protective of human health and the environment for specified site uses. Method C cleanup standards may be established where it can be demonstrated that such standards comply with applicable state and federal laws, that all practical methods of treatment are used, that institutional controls are implemented, and that one of the following conditions exist: (1) Method A or B standards are below background concentrations; (2) Method A or Method B results in a significantly greater threat to human health or the environment; (3) Method A or Method B standards are below technically possible concentrations; or (4) the site is defined as an industrial site for purposes of soil remediation.

Table 1 of Method A addresses groundwater, so it is not considered to be an ARAR for the 200 North Aggregate Area (groundwater will be addressed in the 200 East and 200 West Groundwater Aggregate Area Management Study Reports, AAMSRs). Table 2 of Method A is intended for non-industrial site soil cleanups, and Table 3 is intended for industrial site soil cleanups. Method A industrial soil cleanup standards for preliminary contaminants of concern are provided as potential ARARs in Table 6-1.

In addition to Method A, Method B and Method C cleanup standards may also be considered potential ARARs for the 200 North Aggregate Area. Method B and Method C cleanup standards can be calculated on a case-by-case basis in concert with Ecology. Method B and Method C should be used where Method A standards do not exist or cannot be met, or where routine cleanup actions cannot be implemented at a specific waste management unit.

- State Hazardous Waste Management Act and Dangerous Waste Regulations (Chapter 173-303 WAC). The State of Washington is a RCRA-authorized state for hazardous waste management, and has developed state-specific hazardous waste regulations under the authority of the State Hazardous Waste Management Act. Generally, state hazardous waste regulations (WAC 173-303) parallel the federal regulations. The state definition of a hazardous waste incorporates the EPA designation of hazardous waste that is based on the compound being specifically listed as hazardous, or on the waste exhibiting the properties of reactivity, ignitability, corrosivity, or toxicity as determined by the TCLP.

In addition, Washington State identifies other waste as hazardous. Three unique criteria are established: toxic dangerous waste; persistent dangerous waste; and carcinogenic dangerous waste. These additional designation criteria may be imposed by Ecology as potential ARARs, for purposes of determining acceptable cleanup standards and appropriate waste management standards. 
- Ambient Air Quality Standards and Emission Limits for Radionuclides (Chapter 173-480 WAC). These Ecology ambient air quality standards specify maximum accumulated dose limits to members of the public. Other Air Quality Standards potentially applicable include carbon monoxide, ozone, and nitrogen dioxide (WAC 173-475) and volatile organic compounds (VOCs) (WAC 173-490). Although these standards may be potential ARARs, these standards are less restrictive than DOE public dose limits per DOE Order 5400.5, Radiation Protection of the Public and the Environment.

- Monitoring and Enforcement of Air Quality and Emission Standards for Radionuclides (Chapters 246-247 WAC). These standards by the Washington State Department of Health (Health) adopt the Ecology standards for maximum accumulated does limits to members of the public. These standards apply to DOE facilites as provided in WAC 246-247-010 (2).

- Controls for New Sources of Toxic Air Pollutants (Chapter 173-460 WAC). In accordance with regulations recently promulgated by Ecology in Chapter 173-460 WAC, any new emission source will be subject to Toxic Air Pollutant emission standards. The regulations establish acceptable source impact levels (ASILs) for hundreds of organic and inorganic compounds. Ecology's ASILs may constitute potential ARARs for cleanup activities that have a potential to affect air. The ASILs for preliminary contaminants of concern are outlined in Table 6-1.

- Water Quality Standards. Washington State has promulgated various numerical standards related to surface water and groundwater contaminants. These are included principally in the following regulations:

- Public Water Supplies (Chapter 248-54 WAC). This regulation establishes drinking water standards for public water supplies. The standards essentially parallel the federal drinking water standards (40 CFR Parts 141 and 143).

- Water Quality Standards for Ground Waters of the State of Washington (RCW 90.44, Chapter 173-200 WAC). This regulation establishes contaminant standards for protecting existing and future beneficial uses of groundwater through the reduction or elimination of the discharge of contaminants to the state's groundwater.

- Water Quality Standards for Surface Waters of the State of Washington (Chapter 173-201 WAC and Proposed Amendments to Chapters 173-203 and 173-201 WAC). Ecology has adopted numerical ambient water quality criteria for six conventional pollutant parameters for (WAC 173-201-045): (1) fecal coliform bacteria; (2) dissolved oxygen; (3) total dissolved gas; (4) temperature; (5) $\mathrm{pH}$; and (6) turbidity. In addition, toxic, radioactive, or 
deleterious material concentrations shall be below those of public health significance or which may cause acute or chronic toxic conditions to the aquatic environment or which may adversely affect any water use.

Numerical criteria currently exist for a limited number of toxic substances (WAC 173-201-047). Ecology has initiated rulemaking to modify and incorporate numerical criteria for toxic chemicals and to reclassify certain waters of the state to Class A or better.

Under the state Water Quality Standards, the criteria and classifications do not apply inside an authorized mixing zone surrounding a wastewater discharge. In defining mixing zones, Ecology generally follows guidelines contained in "Criteria for Sewage Works Design." Although water quality standars. can be exceeded inside the dilution zone, state regulations will not permit discharges that cause mortalities of fish or shellfish within the zone or that diminish aesthetic values.

These water quality standards constitute ARARs for purposes of establishing cleanup standards for the $\mathbf{2 0 0}$ North Aggregate Area. Because no surface water bodies exist within the 200 North Aggregate Area, however, there will be no need to achieve ambient water c'rality standards during remediation activities. Groundwater will be addressed in the 200 East Groundwater AAMSRs in which pertinent groundwater-related potential ARARs will be covered.

The numerical water quality standards cited above may become potential ARARs if selected remedial actions could result in discharges to groundwater or surface water (e.g., if treated wastewaters are discharged to the soil column or the Columbia River). Determining appropriate standards for such discharges will depend on the type of remediation performed and will have to be established on a case-by-case basis as remerliz: actions are defined.

- National Pollutant Discharge Elimination System and Water Quality Standards (RCW 90.48, WAC 173-220 and 40 CFR 122). National Pollutant Discharge Elimination System (NPDES) regulations govern point source discharges into navigable waters. Limits on the concentrations of contaminants and volumetric flowrates that may be discharged are determined on a case-by-case basis and permitted under this program. No point source discharges have been identified. The EPA implements this program in Washington State for federal facilities; however, assumption of the NPDES program by the state is likely within five years. 


\subsection{LOCATION-SPECIFIC REQUIREMENTS}

Potential location-specific ARARs are requirements placed on the concentration of hazardous substances or the conduct of activities solely because they are in specific locations. Some examples of special locations include floodplains, wetlands, historic places, and sensitive ecosystems or habitats.

Table 6-2 lists various location-specific standards and indicates which of these may be potential ARARs. Potential ARARs have been identified as follows:

- Floodplains. Requirements for protecting floodplains are not ARARs for activities conducted within the 200 North Aggregate Area as the aggregate area is not located in floodplain boundaries (see Section 3.1). However, remedial actions selected for cleanup may require projects in or near floodplains (e.g., construction of a treatment facility outfall at the Columbia River). In such cases, location-specific flood plain requirements may be potential ARARs.

- Wetlands, Shorelines, and Rivers and Streams. Requirements related to wetlands, shoreines, and rivers and streams are not ARARs for activities conducted within the 200 North Aggregate Area. However, remedial actions solected for cleanup may require projects on a shoreline or wetland, or discharges to wetlands (e.g., construction of a treatment facility outfall at the Columbia River). In such cases, location-specific shoreline and wetlands requirements may be potential ARARs.

- Threatened and Endangered Species Habitats. As discussed in Section 3.6, various threatened and endangered species inhabit portions of the Hanford Site and may occur in the 200 North Aggregate Area (American peregrine falcon, bald eagle, white pelican, and sandhill crane). Therefore, critical habitat protection for these species would constitute a potential ARAR.

- Wild an undergring study pursuant to the federal Wild and Scenic Rivers Act. Pending resul's of this study, actions that may impact the Hanford Reach may be restricted. This requirement wculd not be an ARAK for remedial activities within the 200 North Aggregate Area. However, Wild and Scenic Rivers Act requirements ray be potential ARARs for actions taken as a result of 200 North Aggregate Area cleanup efforts and that could affect the Hanford Reach.

\subsection{ACTION-SPECIFIC REQUIREMENTS}

Potential action-specific ARARs are requirements that are triggered by specific remedial actions at a site. These remedial actions will not be fully defined until a remedial approach has been selected. Yowever, the universe of action-specific ARARs defined by a 
preliminary screening of potential remedial action alternatives will help focus the selection process. Potential action-specific ARARs are outlined below. (Note that potential contaminant- and location-specific ARARs discussed above will also include provisions for potential action-specific ARARs to be applied once the remedial action is selected.)

\subsubsection{Federal Requirements}

- Comprehensive Environmental Response, Compensation, and Liability Act (42 USC 9601). The CERCLA and regulations adopted pursuant to CERCLA contained in the National Contingency Plan (40 CFR Part 300) include selection criteria for remedial actions. Under the criteria, excavation and offsite land disposal options are least favored when onsite treatment options are available. Emphasis is placed on alternatives that permanently treat or immobilize contamination. Selected alternatives must be protective of human health and the environment, which implies that federal and state ARARs be met. However, a remedy may be selected that does not meet all potential ARARs if the requirement is technically impractical, if its implementation would produce a greater risk to human health or the environment, if an equivalent level of protection can otherwise be provided, if state standards are inconsistently applied, or if the remedy is only part of a complete remedial action which attains ARARs.

The CERCLA gives state cleanup standards essentially equal importance as federal standards in guiding cleanup measures in cases where state standards are more stringent. State standards pertain only if they are generally applicable, were passed through formal means, were adopted on the basis of hydrologic, geologic, or other pertinent considerations, and do not preclude the option of land disposal by a state-wide ban. Most importantly, CERCLA provides that cleanup of a site must ensure that public health and the environment are protected. Selected remedies should meet all ARARs, but issues such as cost-effectiveness must be weighed in the selection process.

- Resource Conservation and Recovery Act (42 USC 6901, 40 CFR 260 to 271). The RCRA (42 USC 6901) and regulations adopted pursuant to RCRA describe numerous action-specific requirements that may be potential ARARs for cleanup activities. The primary regulations are promulgated under 40 CFR Parts 262 (standards for generators), 264, and 265 (standards for owners and operators of hazardous waste treatment, storage, and disposal facilities), and include such action-specific requirements as follows:

- Packaging, labeling, placarding, and manifesting of offsite waste shipments

- Inspecting waste management areas to ensure proper performance and safe conditions 
- Preparation of plans and procedures to train personnel and respond to emergencies

- Management standards for containers, tanks, incinerators, and treatment units

- Design and performance standards for land disposal facilities

- Groundwater monitoring system design and performance.

Many of these requirements will depend on the particular remediation activity undertaken, and will have to be identified as remediation proceeds.

One key potential area of action-specific RCRA ARARs is the 40 CFR Part 268 LDRs. In addition to the contaminant-specific constituent concentration limits established in the LDRs (as previously discussed in Section 6.2.1), EPA has identified best demonstrated available treatment technologies (BDATs) for various waste streams. The EPA could require the use of BDATs prior to allowing land disposal of wastes generated during remediation. The EPA's imposition of the LDRs and BDAT requirements will depend on various factors.

Applicability to CERCLA actions is based on determinations of waste "placement/disposal" during a remediation action. According to OSWER Directive 9347.3-05FS, EPA concludes that Congress did not intend in situ consolidation, remediations, or improvement of structural stability to constitute placement or disposal. Placement or disposal would be considered to occur if:

- Wastes from different units are consolidated into one unit (other than a land disposal unit within an area of contamination)

- Waste is removed and treated outside a unit and redeposited into the same or another unit (other than a land disposal unit within an area of contamination)

- Waste is picked up from a unit and treated within the area of contamination in an incinerator, surface impoundment, or tank and then redeposited into the unit (except for in situ treatment).

Consequently, the requirement to use BDAT would not apply under the LDR standards unless placement or disposal had occurred. However, remediation actions involving excavation and treatment could trigger the requirements to use BDAT for wastes subject to the LDR standards. In addition, the agencies could consider BDAT technologies to be relevant and appropriate; when developing and evaluating potential remediation technologies. 
Two additional components of the LDR program should be considered with regard to an excavate and treat remedial action. First, a national capacity variance was issued by EPA for contaminated soil and debris for a two-year period ending May 8, 1992 (54 FR 26640). Second, a series of variances and exemptions may be applied under an excavate and treat scenario. These include the following:

- A no-migration petition

- A case-by-case extension to an effective date

- A treatability variance

- Mixed waste provisions of a Federal Facilities Compliance Act.

The applicability and relevance of each of these options will vary based on the specific details of a 200 North Aggregate Area excavate and treat option. An analysis of these variances can be developed once engineering data on the option becomes available.

The effect of the LDR program on mixed waste management is significant. Currently, limited technologies are available for effective treatment of these waste streams and no commercially available treatment facilities exist except for liquid scintillation counting fluids used for laboratory analysis and testing. The EPA recognized that inadequate capacity exists and issued a national capacity variance until May 8, 1992 to allow for the development of such treatment capacity.

Lack of treatment and disposal capacity also presents implications for storage of these materials. Under 40 CFR 268.50, mixed wastes subject to LDRs may be stored for up to one year. Beyond one year, the owner/operator has the burden of proving such storage is for accumulating sufficient quantities for treatment. On August 29, 1991, EPA issued a mixed waste storage enforcement policy providing some relief from this provision for generators of small volumes of mixed wastes. However, the policy was limited to facilities generating less than $28 \mathrm{~m}^{3}\left(1,000 \mathrm{ft}^{3}\right)$ of land disposal-prohibited waste per year. Congress is considering amendments to RCRA postponing the storage prohibition for another five years; however, final action on these amendments has not occurred.

- Clean Water Act (33 USC 1251). Regulations adopted pursuant to the CWA (33 USC 1251) under the NPDES mandate use of best available treatment technologies (BAT) prior to discharging contaminants to surface waters. The NPDES requirements would not be ARARs for actions conducted only within the 200 North Aggregate Area. However, NPDES requirements could constitute potential ARARs for cleanup actions which would result in discharge of treated 
wastewaters to the Columbia River, and associated treatment systems could be required to utilize $\mathrm{BAT}$.

- Toxic Substances Control Act. The 212-P Storage Building is currently being used as a storage area for collection of polychlorinated biphenyl (PCB) contaminated oil from transformers and capacitors. Under the authority of the Toxic Substances Control Act, requirements for management of PCB material are found at 40 CFR Part 761. Those standards apply only to those PCBs with concentrations of $50 \mathrm{ppm}$ or greater. Generally, PCB storage requirements apply to PCBs and PCB items which have been removed from service and designated for disposal. However, PCB storage requirements also apply to any PCB liquids (50 ppm or greater) in PCB Containers which are being stored for authorized servicing of electrical equipment.

In accordance with the Part 761 standards, a PCB storage facility must meet the criteria listed under section 761.65(b) including specific standards for the roof, walls, and floors. PCB storage areas must be properly marked, recorded and inspected every 30 days. Containers used for the storage of PCBs must comply with Department of Transportation shipping container specifications under 49 CFR 178.80.

- Department of Transportation Standards (40 CFR 171 to 177). The Department of Transportation standards contained in 40 CFR 171 to 177 specify the requirements for packaging, labeling, and placarding for offsite transport of hazardous materials. These standards ensure that hazardous substances and wastes are safely transported using adequate means of transport and proper documentation.

- Ambient Air Quality Surveillance (40 CFR 58).

\subsubsection{State of Washington Requirements}

- Hazardous Waste Management (WAC 173-303). As discussed in Section 6.4.1, there are various requirements addressing the management of hazardous wastes that may be potential action-specific ARARs. Pertinent Washington regulations appear in Chapter 173-303 WAC (under the authority of RCW 70.105) and generally parallel federal management standards.

Determination of ARARs will be on a case-by-case basis as cleanup actions proceed. 
- Solid Waste Management (WAC 173-304). Washington State regulations describe management standards for solid waste in Chapter 173-304 WAC (under the authority of RCW 70.95). Some of these management standards may be potential ARARs for disposal of cleanup wastes within the 200 North Aggregate Area. Solid waste standards include such requirements as the following:

- Inspecting waste management areas to ensure proper performance and safe conditions

- Management standards for incinerators and treatment units

- Design and performance standards for landfills

- Groundwater monitoring system design and performance.

Many of these requirements will depend on the particular remediation activity undertaken, and will have to be identified as remediation proceeds.

- Water Quality Management. Chapter $90.48 \mathrm{RCW}$, the Washington State Water Pollution Control Act (WPCA), requires use of all known, available, and reasonable treatment technologies (AKART) for treating contaminants prior to discharge to waters of the state. Implementing regulations appear principally at Chapters 173-216, 173-220, and 173-240 WAC.

The WPCA requirements for groundwater could be potential ARARs for actions conducted within the 200 North Aggregate Area if such actions would result in discharge of liquid contaminants to the soil column. In this event, Ecology would require use of AKART to treat the liquid discharges prior to soil disposal.

The WPCA requirements for surface water would not be ARARs for actions conducted only within the 200 North Aggregate Area. However, these requirements could potentially constitute ARARs for cleanup actions that would result in discharge of treated wastewaters to the Columbia River and associated treatment systems could be required to demonstrate they meet AKART.

- Air Quality Management (RCW 70.94). Under the authority of the Washington Clean Air Act (RCW 70.94), the Toxic Air Pollutant regulations for new air emission sources, promulgated in Chapter 173-460 WAC, require use of best available control technology for air toxics (T-BACT). The Toxic Air Pollutant regulations may be potential ARARs for cleanup actions at the 200 North Aggregate Area that could result in emissions of toxic contaminants to the air. Ecology may require the use of T-BACT to treat such air emissions. 
- Water Well Construction (RCW 18.104). This regulation establishes authority for Ecology to require the licensing of water well contractors and operators and for the regulation of water well construction.

- Nuclear Energy and Radiation (RCW 70.98). Chapter 70.98 RCW establishes a program to establish procedures for assumption and performance of certain regulatory responsibilities with respect to byproduct, source, and special nuclear materials.

- Pollution Disclosure Act (RCW 90.52). Chapter 90.52 RCW describes the authority of the state to regulate reports for any commercial or industrial discharge, other than sanitary sewage, into waters of the state.

- Water Resources Act (RCW 90.54). Chapter 90.54 RCW gives the state authority to implement water related resources programs.

- Minimum Standards for Construction and Maintenance of Wells (Chapter 173-160 WAC). Well construction regulations establish minimum standards for water well construction and require the preparation of construction reports.

- Rules and Regulations Governing the Licensing of Well Contractors and Operators (Chapter 173-162 WAC). Chapter 173-162 WAC establishes requirements for licensing well drillers.

- State Waste Discharge Permit Program (Chapter 173-216 WAC). Chapters 173-216 WAC establishes a permit system for discharges of wastewater to groundwater and surface water via the municipal sewage system.

- Underground Injection Control Program (Chapter 173-218 WAC). Chapter 173-218 WAC pertains to the injection of wastes into aquifers that are used for drinking water.

- Incinerators (Chapter 173-303-670 WAC). If incinerators are used for a remedial technology this regulation would be applicable.

\subsection{OTHER CRITERIA AND GUIDANCE TO BE CONSIDERED}

In addition to the potential ARARs presented, other federal and state criteria, advisories, guidance, and similar materials are TBC in determining the appropriate degree of remediation for the 200 North Aggregate Area. A myriad of resources may be potentially evaluated. The following represents an initial assessment of TBC provisiors. 


\subsubsection{Health Advisories}

The EPA Office of Drinking Water publishes advisories identifying contaminants for which health advisories have been issued.

\subsubsection{International Commission on Radiation Protection/National Council on Radiation Protection}

The International Commission of Radiation Protection and the National Council on Radiation Protection have a guidance standard of $100 \mathrm{mrem} / \mathrm{yr}$ whole body dose of gamma radiation. These organizations also issue recommendations on other areas of interest regarding radiation protection.

\subsubsection{Environmental Protection Agency Proposed Corrective Actions for Solid Waste Management Units}

In the July 27, 1990, federal register (55 FR 30798), EPA published proposed regulations for performing corrective actions (cleanup activities) at solid waste management units associated with RCRA facilities. The proposed 40 CFR Part 264 Subpart S includes requirements that would be TBCs for determining an appropriate level of cleanup at the 200 North Aggregate Area. In particular, EPA included an appendix, "Appendix A - Examples of Concentrations Meeting Criteria for Action Levels," which presented recommended contaminant concentrations warranting corrective action. These contaminant-specific TBCs are included in Table 6-1 for the preliminary contaminants of concern.

\subsubsection{U.S. Department of Energy Standards for Radiation Protection}

A number of DOE Orders exist which could be TBCs. The DOE Orders that establish potential contaminant-specific or action-specific standards for the remediation of radioactive wastes and materials are discussed below.

- DOE Order 5400.5-DOE Standards for Radiation Protection of the Public and Environment. The DOE Order 5400.5 establishes the requirements for DOE facilities to protect the environment and human health from radiation including soil and air contamination. The purpose of the Order is to establish standards and requirements for operations of the DOE and DOE contractors with respect to protection of members of the public and the environment against undue risk from radiation.

The Order mandates that the exposure to members of the public from a radiation source as a consequence of routine activities shall not exceed 100 mrem from all exposure sources due to routine DOE activities. In accordance with the Clean 
Air Act, exposures resulting from airborne emissions shall not exceed 10 mrem to the maximally exposed individual at the facility boundary. The DOE Order 5400.5 provides Derived Concentration Guide (DCG) values for releases of radionuclides into the air or water. The DCG values are calculated so that, under conditions of continuous exposure, an individual would receive an effective dose equivalent of $100 \mathrm{mrem} / \mathrm{yr}$. Because dispersion in air or water is not accounted for in the DCG, actual exposures of maximally exposed individuals in unrestricted areas are considerably below the $100 \mathrm{mrem} / \mathrm{yr}$ level.

The DOE Order 5400.5 also provides for establishment of soil cleanup levels through a site-specific pathway analysis such as the allowable residual contamination level method. The calculation of allowable residual contamination level values for radionuclides is dependent on the physical characteristics of the site, the radiation dose limit determined to be acceptable, and the scenarios of human exposure judged to be possible and to result in the upper-bound exposure.

- DOE Order 5820.2A-Radioactive Waste Management. The DOE Order 5820.2A applies to all DOE contractors and subcontractors performing work that involves management of waste containing radioactivity. This Order requires that wastes be managed in a manner that ensures protection of the health and safety of the public, operating personnel, and the environment. The DOE Order 5820.2A establishes requirements for management of high-level, transuranic, and low-level wastes as well as wastes containing naturally occurring or accelerator produced radioactive material, and for decommissioning of facilities. The requirements applicable to the 200 North Aggregate Area remediation activities include those related to transuranic (TRU) waste and lowlevel radioactive waste. These are summarized below.

Management of Transuranic Waste. Transuranic (TRU) waste resulting from the 200 North Aggregate Area remedial action must be managed to protect the public and worker health and safety, and the environment, and performed in compliance with applicable radiation protection standards and environmental regulations. Practical and cost-effective methods must be used to reduce the volume and toxicity of TRU waste.

The TRU waste must be certified in compliance with the Waste Isolation Pilot Plant (WIPP) Acceptance Criteria, placed in interim storage, if required, and sent to the WIPP. Any TRU waste that the DOE has determined, with the concurrence of the EPA Administrator, does not need the degree of isolation provided by a geologic repository or TRU waste that cannot be certified or otherwise approved for acceptance at the WIPP must be disposed of by alternative methods. Alternative disposal methods must be approved by DOE Headquarters and comply with NEPA requirements and EPA/state regulations. 
- Management of Low-Level Radioactive Waste. The requirements for management of low-level radioactive waste presented in DOE Order 5820.2A are relevant to the remedial alternative of removal and disposal of 200 North Aggregate Area wastes. Performance objectives for this option shall ensure that external exposure to the radioactive material released into surface water, groundwater, soil, plants, and animals does not result in an effective dose greater than $25 \mathrm{mrem} / \mathrm{yr}$ to the public. Releases to the environment shall be at levels as low as reasonably achievable. An inadvertent intruder after the institutional control period of 100 years is not to exceed $100 \mathrm{mrem} / \mathrm{yr}$ for continuous exposure or $500 \mathrm{mrem}$ for a single acute exposure. A performance assessment is to be prepared to demonstrate compliance with the above performance objectives.

Other requirements under DOE Order 5820.2A which may affect remediation of the 200 North Aggregate Area include waste volume minimization, waste characterization, waste acceptance criteria, waste treatment, and shipment. The low-level radioactive waste may be stored by appropriate methods prior to disposal to achieve the performance objectives discussed above. Disposal site selection, closure/post-closure, and monitoring requirements are also discussed in this Order.

\subsection{POINT OF APPLICABILITY}

A significant factor in the evaluation of remedial alternatives for the 200 North Aggregate Area will be the determination of the point at which compliance with identified ARARs must be achieved (i.e., the point of a specific ARAR's applicability). These points of applicability are the boundaries at which the effectiveness of a particular remedial alternative will be assessed.

For most individual radioactive species transported by either water or air, Ecology and Health standards generally require compliance at the boundaries of the Hanford Site (e.g. Clean Air Act, Section 6.2.1). The assumed point of compliance for radioactive species is the point where a member of the public would have unrestricted access to live and conduct business, and, consequently, to be maximally exposed. Although Health is responsible for monitoring and enforcing the air standards promulgated by Ecology, and generally recognizes the site boundary as the point of applicability, Ecology has recently indicated that compliance may be required at the point of emission.

The point at which compliance with identified ARARs must be achieved will be a significant factor in evaluating appropriate remedial alternatives in the 200 North Aggregate Area. Applicability of ARARs at the point of discharge, at the boundary of the disposal unit, at the boundary of the AAMS, at the boundary of the Hanford Site, and/or at the point of maximum exposure will need to be determined. 


\subsection{POTENTIAL APPLICABLE OR RELEVANT AND APPROPRIATE REQUIREMENTS EVALUATION}

Evaluation of ARARs is an iterative process that will be conducted at multiple points throughout the remedial process:

- When the public health evaluation is conducted to assess risks at the 200 North Aggregate Area, the contaminant-specific ARARs and advisories and locationspecific ARARs will be identified more comprehensively and used to help determine the cleanup goals.

- During detailed analyses of alternatives, all the ARARs and advisories for each alternative will be examined to determine what is needed to comply with other laws and to be protective of public health and the environment.

Following completion of the investigation, the remedial alternative selected must be able to attain all ARARs unless one of the six statutory waivers provided in Section 121(d)(4)(A) through (f) of CERCLA is invoked. Finally, during remedial design, the technical specifications of construction must ensure attainment of ARARs. The six reasons ARARs can be waived are as follows:

- The remedial action is an interim measure, where the final remedy will attain ARARs upon completion.

- Compliance will result in greater risk to human health and the environment than will other options.

- Compliance is technically impracticable.

- An alternative remedial action will attain the equivalent performance of the ARAR.

- For state ARARs, the state has not consistently applied (or demonstrated the intention to consistently apply) the requirements in similar circumstances.

- For CERCLA-financed actions under Section 104, compliance with the ARAR will not provide a balance between the need for protecting public health, welfare, and the environment at the facility, and the need for fund money to respond to other sites (this waiver is not applicable at the Hanford Site).

Once investigations have been completed and final remedies have been selected, the ARARs that must be met will be formally identified in the Record of Decision (ROD). Compliance with those ARARs specified in the ROD will be achieved through the remedial action. The ARARs may need to be reevaluated if unanticipated circumstances are encountered during remediation which prevent the ability to satisfy the identified ARARs. 
Table 6-1. Potential Contaminant-Specific ARARs and TBCs for Preliminary Inorganic and Organic Contaminants of Concern.

\begin{tabular}{|c|c|c|c|c|c|c|c|}
\hline & \multirow{2}{*}{$\begin{array}{c}\text { RCRA } \\
\text { TCLP } \\
\text { Designation } \\
\text { Limits } \\
\text { in } \\
\mathrm{mg} / \mathrm{L}\end{array}$} & \multicolumn{2}{|c|}{$\begin{array}{c}\text { RCRA } \\
\text { Land Ban Limits }\end{array}$} & \multirow{2}{*}{$\begin{array}{c}\text { MTCA } \\
\text { Method A } \\
\text { Cleanup } \\
\text { Lovels } \\
\text { Industrial Soil } \\
\text { in } \\
\text { mg/kg }\end{array}$} & \multirow{2}{*}{$\begin{array}{c}\text { Toxic Air } \\
\text { Pollutants } \\
\text { (ASIL) } \\
\text { in } \\
\mu \mathrm{g} / \mathrm{m}^{3}\end{array}$} & \multicolumn{2}{|c|}{$\begin{array}{l}\text { RCRA Corrective } \\
\text { Action Levels } \\
\text { (Proposed)" }\end{array}$} \\
\hline & & $\begin{array}{r}\text { CCWE } \\
\text { in } \mathrm{mg} / \mathrm{L}\end{array}$ & $\begin{array}{l}\text { CCW in } \\
\text { mg/kg }\end{array}$ & & & $\begin{array}{l}\text { Air in } \\
\mu \mathrm{g} / \mathrm{m}^{3}\end{array}$ & $\begin{array}{l}\text { Soil in } \\
\text { mg/kg }\end{array}$ \\
\hline \multicolumn{8}{|l|}{$\begin{array}{l}\text { INORGANIC } \\
\text { CHEMICALS }\end{array}$} \\
\hline Barium & 100.0 & 100.0 & - & - & 1.70 & - & - \\
\hline Lead & 5.0 & 5.0 & - & $1,000.0$ & - & - & - \\
\hline Nickel & - & 134 & - & - & $3.3^{\mathrm{b}}$ & - & 2000.0 \\
\hline $\begin{array}{l}\text { Uranium } \\
\text { ORGANIC } \\
\text { CHEMICALS }\end{array}$ & - & - & - & - & 0.7 & - & - \\
\hline Acetone & - & - & 5.9 & - & $5927.4^{b /}$ & - & 8000.00 \\
\hline $\begin{array}{l}\text { Trichloro- } \\
\text { ethylene } \\
\text { SEMI- } \\
\text { VOLATILES }\end{array}$ & - & - & - & 0.5 & - & - & 60 \\
\hline PCB: & - & - & - & 10.0 & - & - & - \\
\hline
\end{tabular}

ASIL = Acceptable Source Impect Lovel

CCWE = Constituent Concentration in Waste Extract

$\mathrm{CCW}=$ Constituent Concentration in Waste

$\mathrm{mg} / \mathrm{L}=$ milligrams per liter

MTCA $=$ Washington State Model Toxics Control Act

$\mathrm{mg} / \mathrm{kg}=$ milligrams per kilogram

RCRA = Federal Resource Conservation and Recovery Act

TCLP = Toxic Characteristic Leaching Procedure

WAC = Washington Administrative Code

$\mu \mathrm{g} / \mathrm{m}^{3}=$ micrograms per cubic meter

- RCRA Corrective Action Levels are only proposed at this time (40 CFR Part 264 Subpart S), so are not ARARs yet; they are "To Be Considered."

b 24-hour average

- Annual average

"-" = Not applicable 
DOE/RL-92-17, Rev. 0

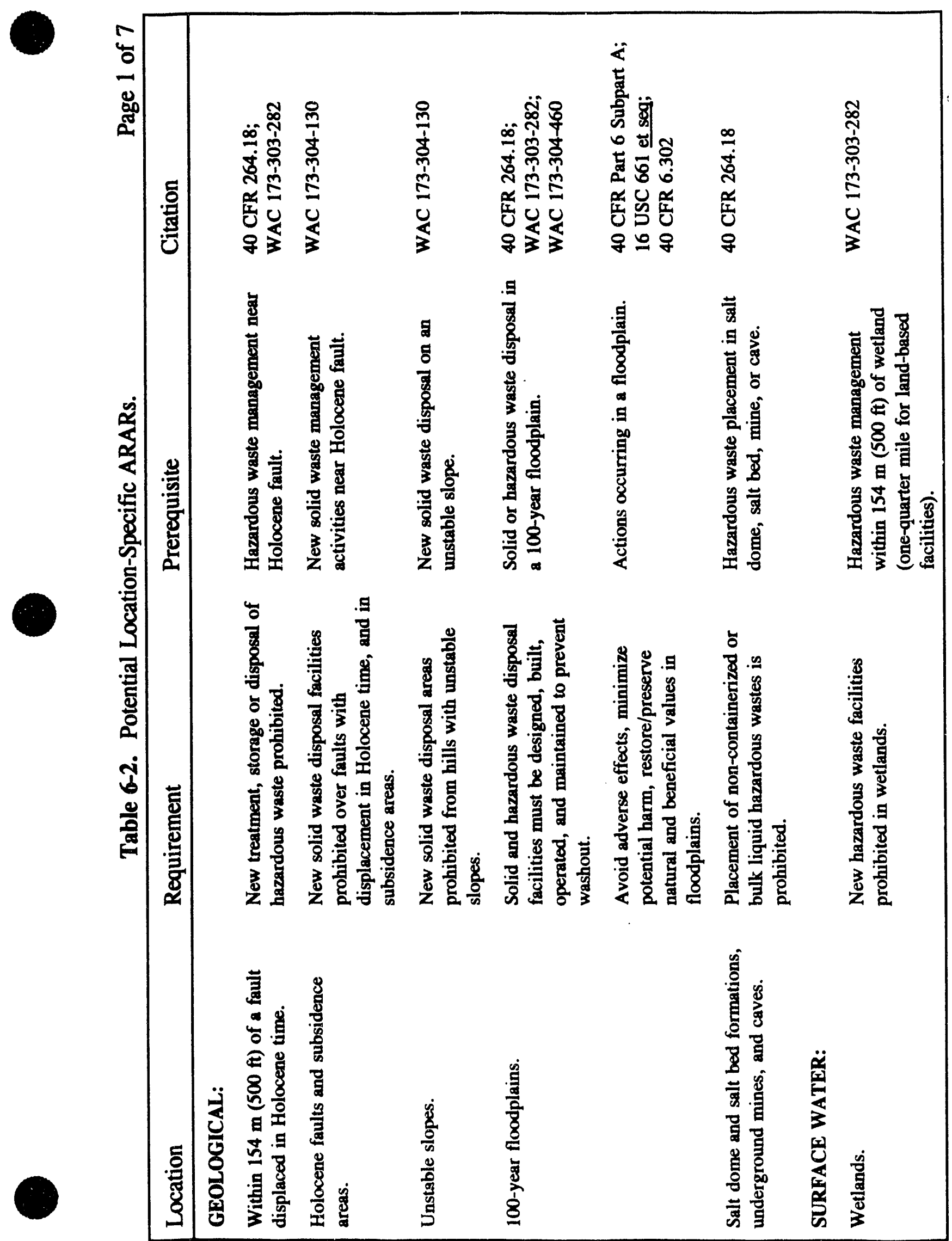


DOE/RL-92-17, Rev. 0

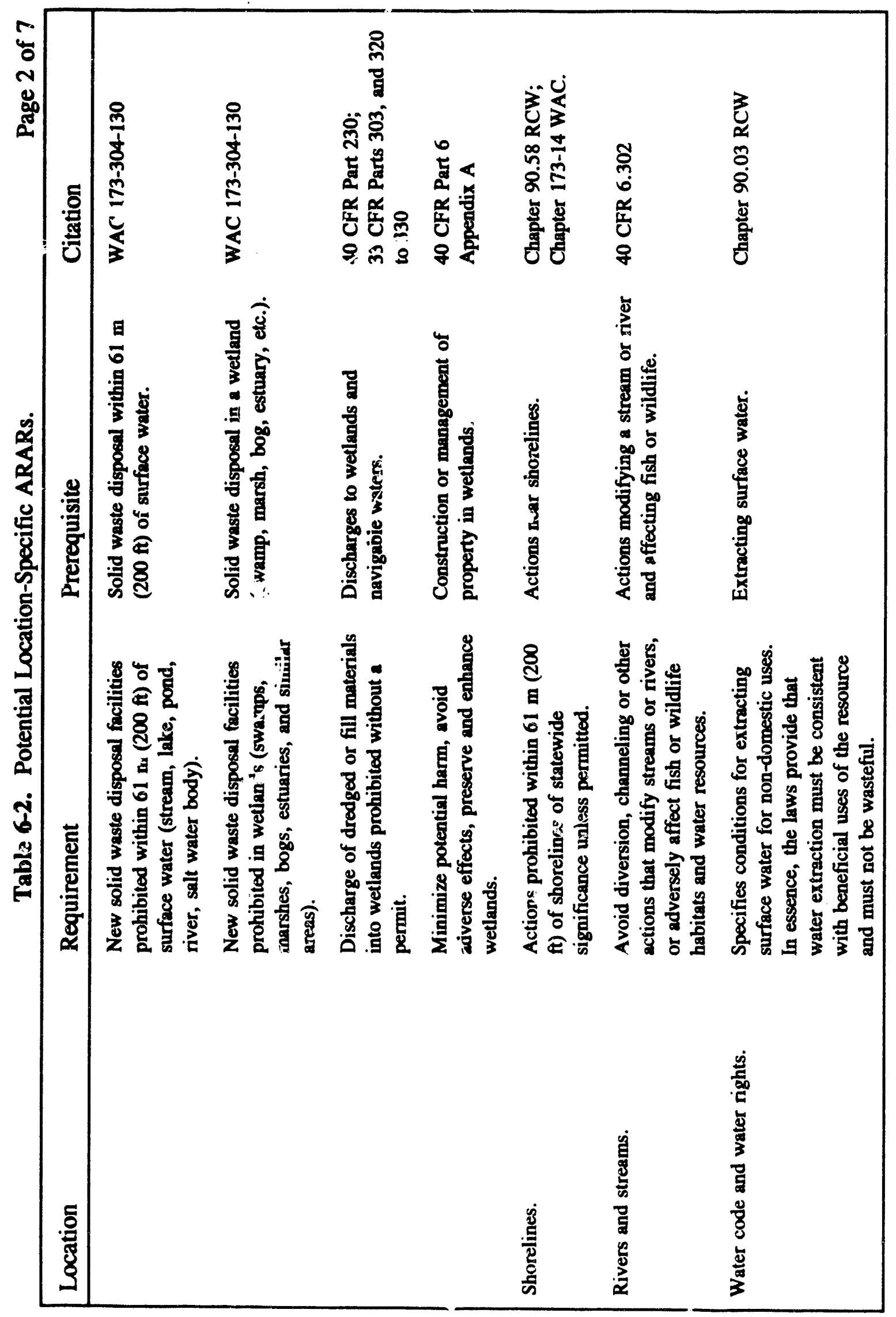


DOE/RL-92-17, Rev. 0

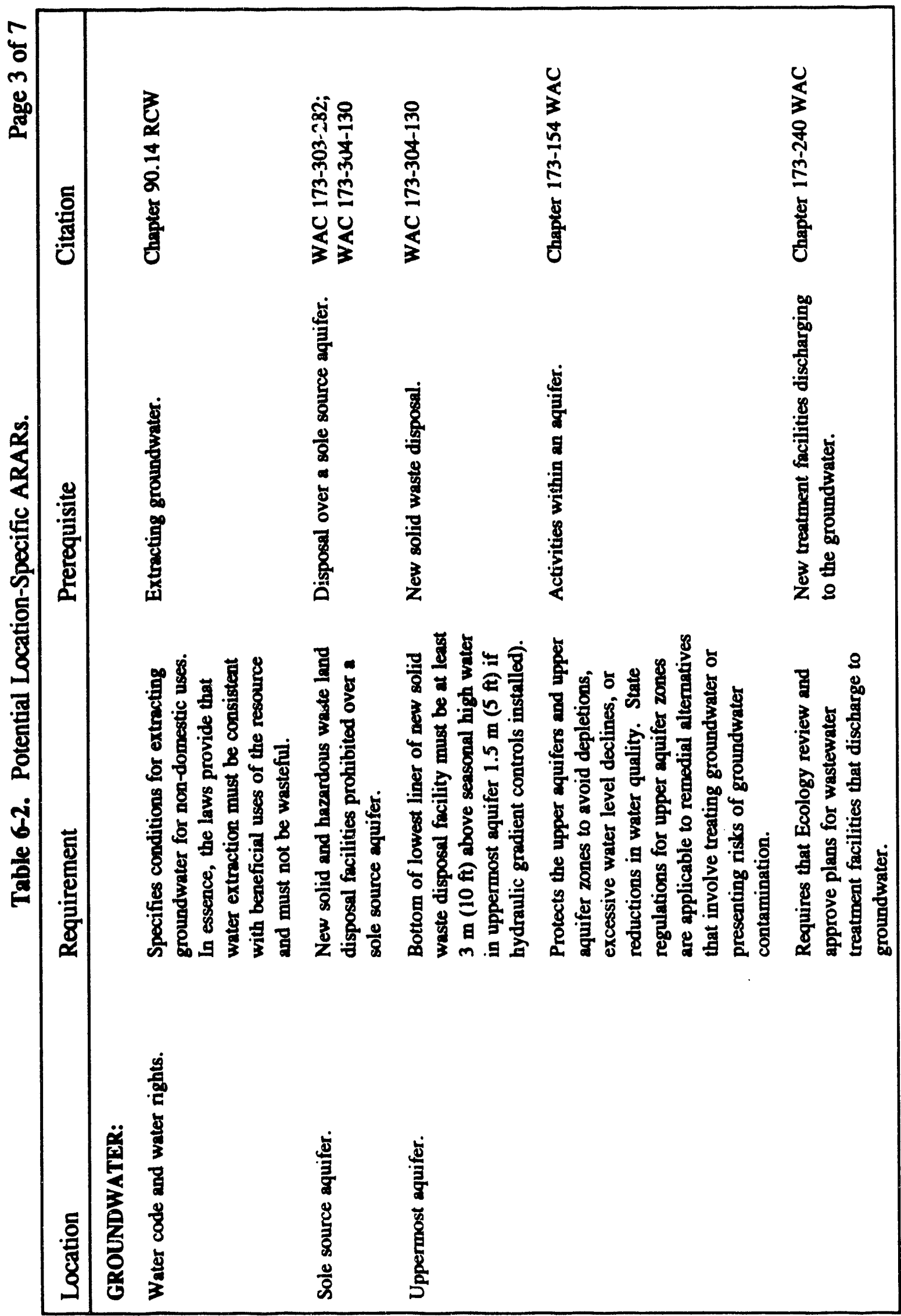


DOE/RL-92-17, Rev. 0

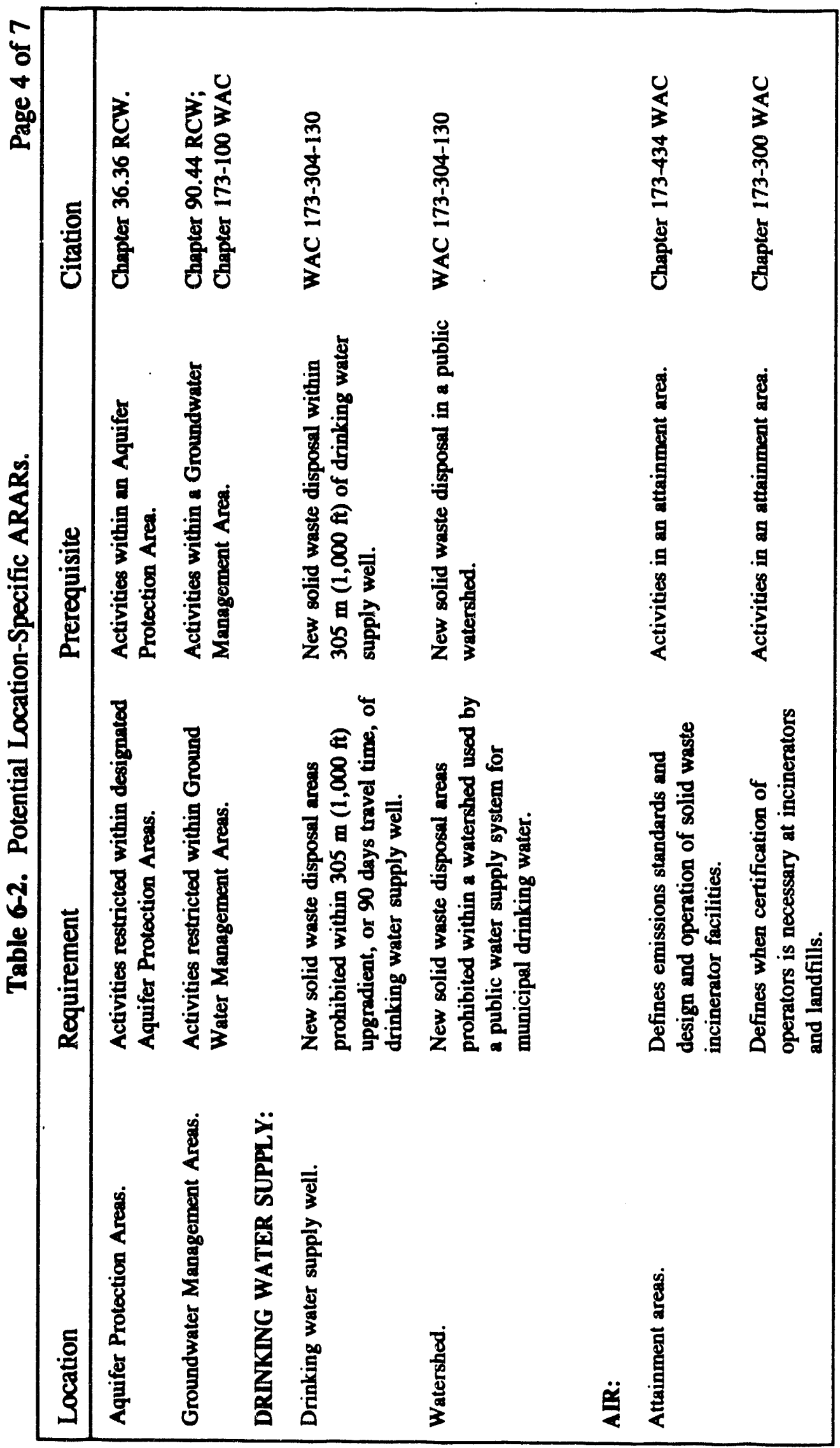


DOE/RL-92-17, Rev. 0

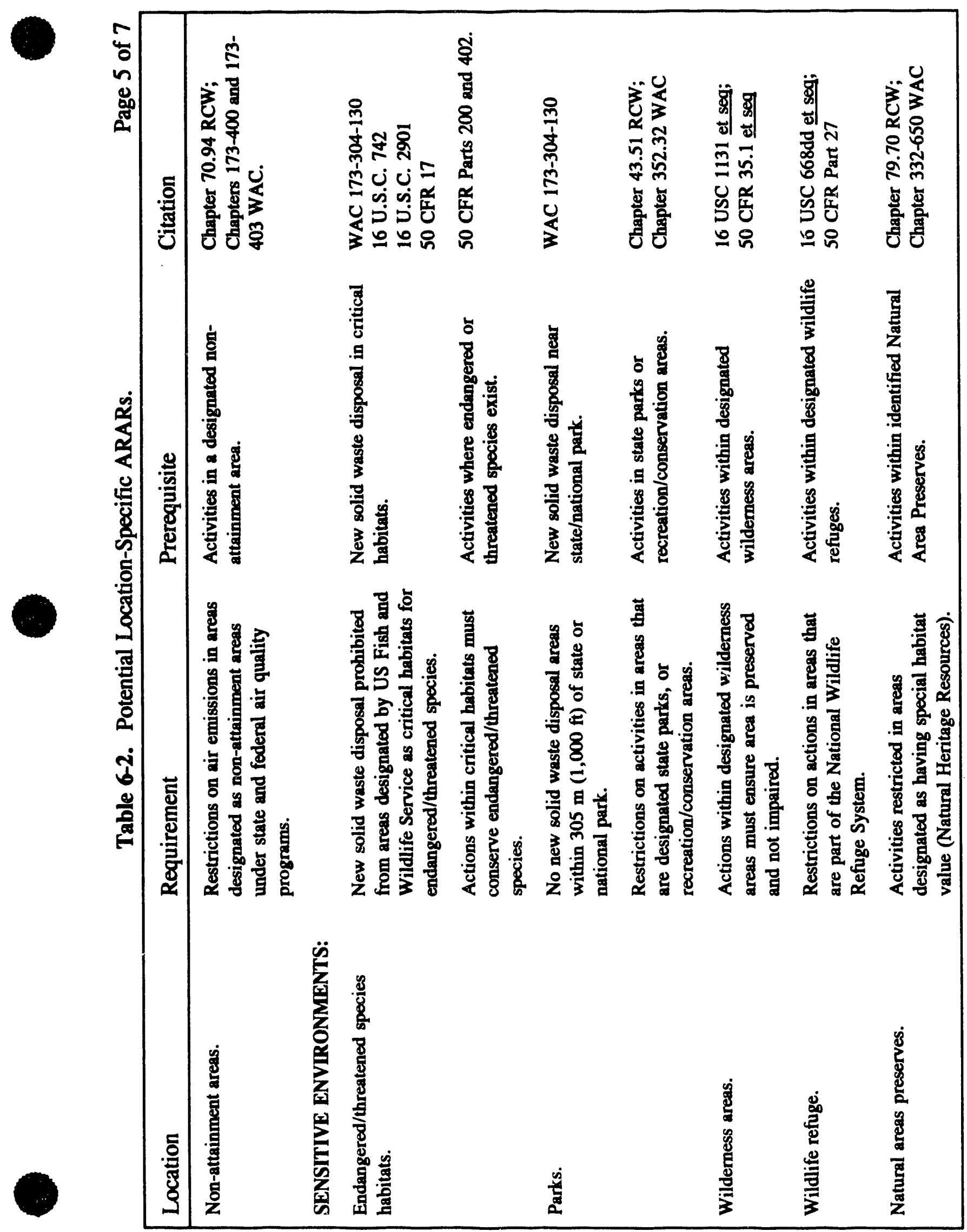


DOE/RL-92-17, Rev. 0

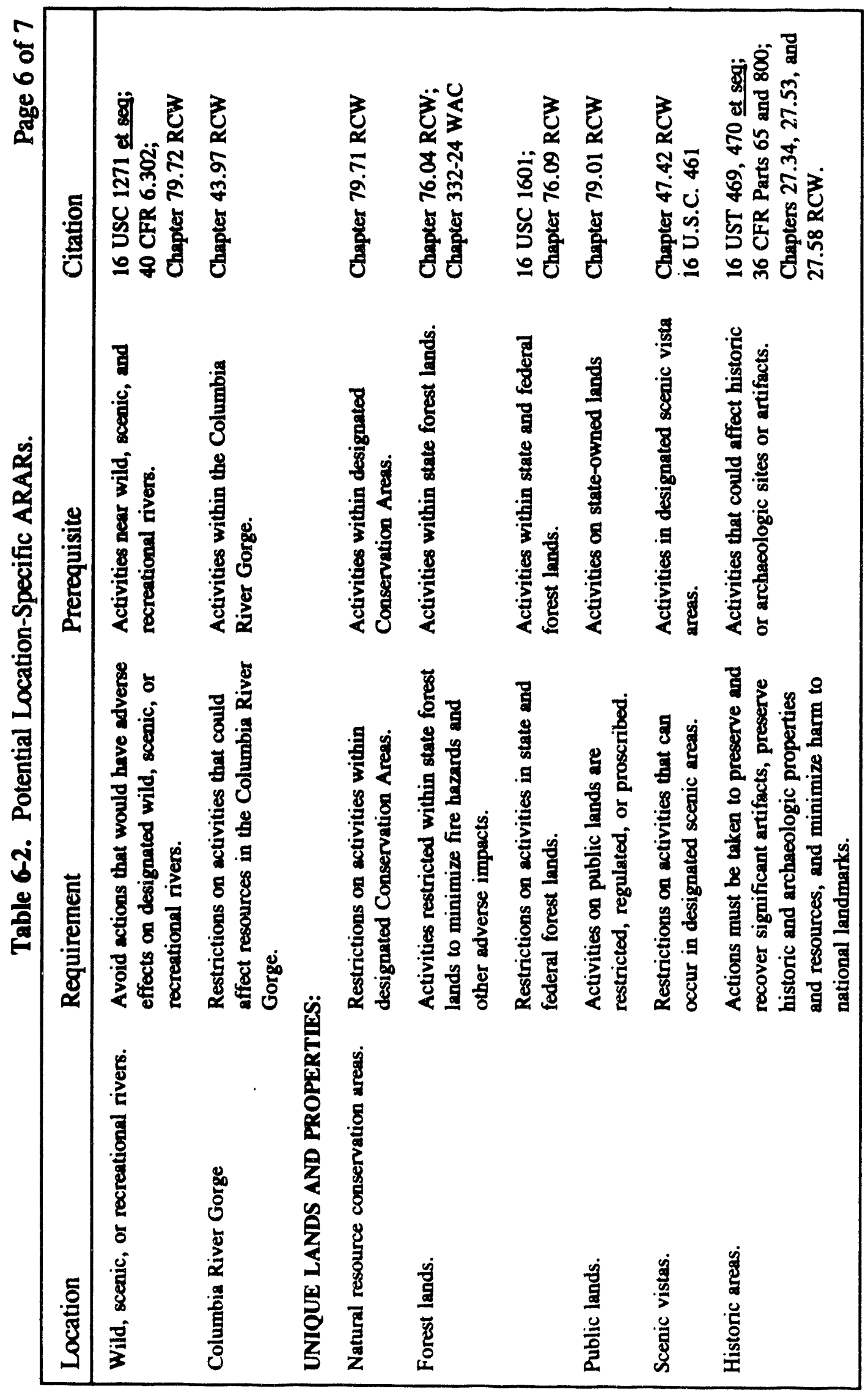


DOE/RL-92-17, Rev. 0

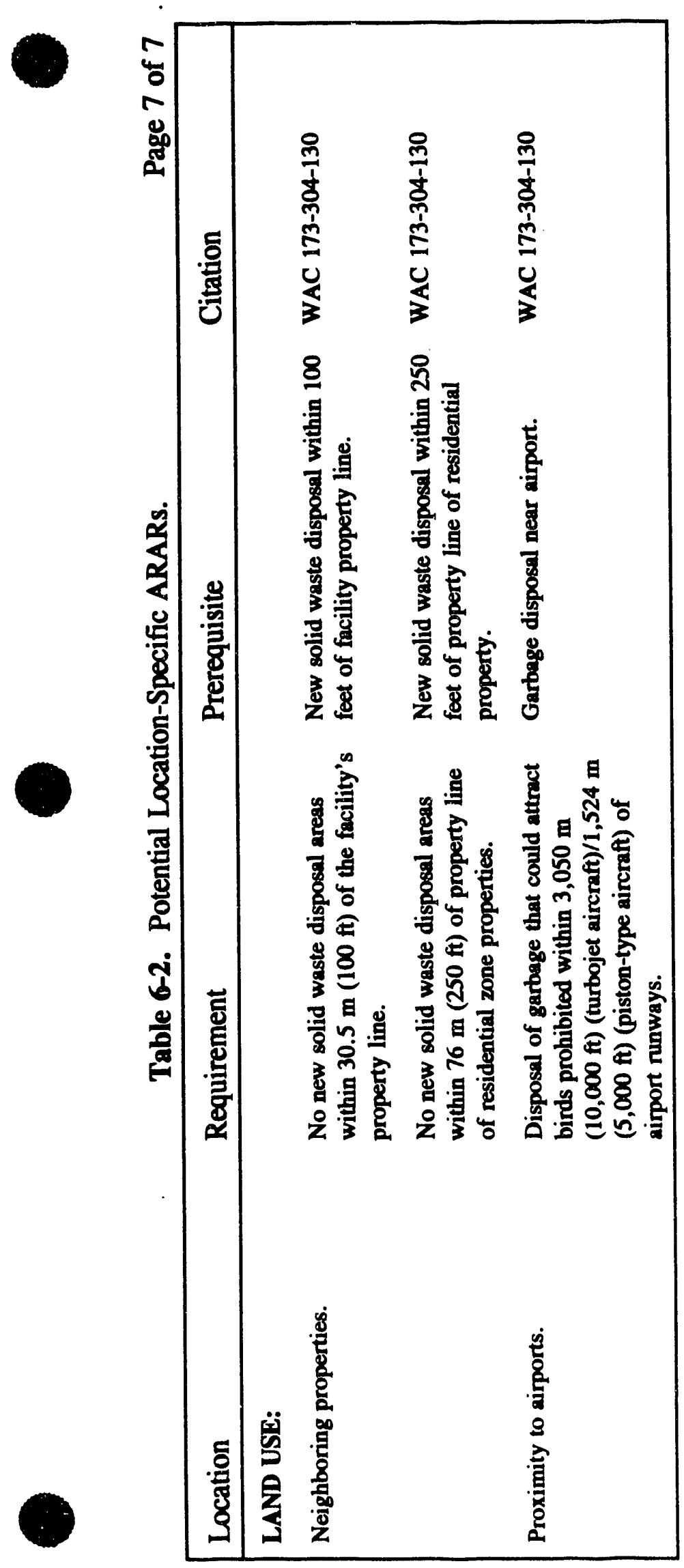




\subsection{PRELIMINARY REMEDIAL ACTION TECHNOLOGIES}

Previous sections identified contaminants of concern at the 200 North Aggregate Area, potential routes of exposure, and applicable or relevant and appropriate requirements (ARARs). Section 7.0 identifies preliminary remedial action objectives (RAOs) and develops preliminary remedial action alternatives consistent with reducing the potential hazards of this contamination and satisfying potential ARARs. The overall objective of this section is to identify viable and innovative remedial action alternatives for media of concern at the 200 North Aggregate Area.

The process of identifying viable remedial action alternatives consists of several steps. In Section 7.1, RAOs are first identified. Next, in Section 7.2, general response actions are determined along with specific treatment, resource recovery, and containment technologies within the general response categories. Specific process options belonging to each technology type are identified, and these process options are subsequently screened based on their effectiveness, implementability, and cost (Section 7.3). The combining cf process options into alternatives occurs in Section 7.4. Here the alternatives are described and diagrammed. Criteria are then identified in Section 7.5 for preliminary screening of alternatives that may be applicable to the waste management units and unplanned release sites identified in the 200 North Aggregate Area. Figure 7-1 is a matrix summarizing the development of the remedial action alternatives starting with media-specific RAOs.

Because of uncertainty regarding the nature and extent of contamination at the 200 North Aggregate Area waste management units, recommendations for remedial alternatives are general and cover a broad range of actions. Remedial action alternatives will be considered and more fully developed in future focused feasibility studies (FFSs). The Hanford Site Past-Practice Strategy (DOE/RL 1992a) is used to focus the range of remedial action alternatives that will be evaluated in focused studies. In general, the Hanford Site Past-Practice Strategy remedial investigation (RI)/feasibility study (FS) and the Resource Conservation and Recovery Act (RCRA) Facility Investigation (RFI)/Corrective Measures Studies (CMS) are defined as the combination of interim remedial measures (IRMs), limited field investigations (LFIs) for final remedy selection where interim actions are not clearly justified, and focused or aggregate area feasibility/treatability studies for further evaluation of treatment alternatives. After completion of an IRM, data will be evaluated including concurrent characterization and monitoring data to determine if a final remedy can be selected.

A secondary purpose of the evaluation of preliminary remedial action alternatives is the identification of acititional information needed to complete the evaluation. This information may include field data needs and treatability tests of selected technologies. Additional data will be developed for most sites or waste management units or waste groups during future data gathering activities (e.g., LFIs, characterization supporting IRMs, or treatability studies). These data may be used to refine and supplement the RAOs and proposed alternatives identified in this initial study. Data needs are defined in Section 8.0. 
Alternatives involving technologies that are not well-demonstrated under the conditions of interest are identified in Sections 7.3 and 7.5. These technologies may require bench-scale and pilot-scale treatability studies. The intent is to conduct treatability studies for promising technologies early in the RI/FS process. Conclusions regarding the feasibility of some individual technologies may change after new data become available.

The bias-for-action philosophy of addressing contamination at the Hanford Site requires an expedited process for implementing remedial actions. Implementation of general response actions may be accomplished using an observational approach in which the implementation is redirected as information is obtained. This observational approach is an iterative process of data acquisition and refinement of the conceptual model. Data needs are determined by the model, and data collected to fulfill these needs are used as additional input to the model. Use of the observational approach while conducting response actions in the 200 Areas will allow integrating these actions with longer range objectives of final remediation of similar areas and the entire 200 Areas. Site characterization and remediation data will be collected concurrently with the use of LFIs, IRMs, and treatability testing. The knowledge gained through these different activities will be applied to similar areas. The overall goal of this approach is convergence on an appropriate response action as early as possible while continuing to obtain valuable characterization information during remediation phases.

\subsection{PRELIMINARY REMEDIAL ACTION OBJECTIVES}

The RAOs are remediation goals for protection of human health and the environment that specify the contaminants and media of concern, exposure pathways, and allowable contaminant levels. The RAOs discussed in this section are considered to be preliminary and may change or be refined as new data are acquired and evaluated.

The fundamental objective of the corrective action process at the 200 North Aggregate Area is to protect environmental resources and/or human receptors from the potential threats that may exist because of known or suspected contamination. Specific interim and final RAOs will depend in part on current and reasonable potential future land use in the 200 North Aggregate Area and the 200 Areas. The RAOs also take into account the preference under the Comprehensive Environmental Response, Compensation, and Liability Act (CERCLA) for isolation and permanent or significant reduction of volume, toxicity, or mobility of hazardous substances. 
To focus remedial actions with a bias for action through implementing IRMs, preliminary RAOs are identified for the 200 Areas and 200 North Aggregate Area. The overall objective for the 200 Areas is as follows:

Reduce the risk of harmful effects to the environment and human users of the area by isolating and permanently reducing the toxicity, mobility, or volume of contaminants from the source areas to meet ARARs or risk-based levels that will allow industrial use of the area (this is a potential final RAO, and an interim action objective based on current use of the 200 Areas).

The RAOs are further developed in Table 7-1 for media of concern and applicable exposure pathways (see Sections 4.1 and 4.2) for the 200 North Aggregate Area. The media of concern for the 200 North Aggregate Area include the following:

- Radionuclide-contaminated and chemically contaminated soils that could result in direct exposure or inhalation of soil particles

- Contaminated soils that are or could contribute to groundwater contamination

- Vadose zone vapors that could cause ambient air impacts or contribute to the lateral and vertical migration of contaminants in the soil and to the groundwater

- Biota that could mobilize radionuclides or chemical contaminants and could thereby degrade the integrity of other controls, such as caps.

Groundwater as an exposure medium is not addressed in this source aggregate area management study report (AAMSR) but will be addressed in the 200 East Groundwater AAMSR.

\subsection{PRELIMINARY GENERAL RESPONSE ACTIONS}

General response actions represent broad classes of remedial measures that may be appropriate to achieve both interim and final RAOs at the 200 North Aggregate Area, and are presented in Table 7-2. The following are the general response actions for the 200 North Aggregate Area followed by a brief description:

- No action (applicable to specific facilities)

- Institutional controls

- Waste removal and treatment or disposal

- Waste containment 
- In situ waste treatment

- Combinations of the above actions.

These general response actions are intended to cover the range of options from no action to complete remediation. Included are options that satisfy the CERCLA preference for isolation and permanent or significant reduction in volume, mobility, and toxicity of hazardous substances. No action is included for evaluations as required by the National Environmental Policy Act and National Contingency Plan (NCP) [40 CFR 300.68 (f)(l)(v)] to provide a baseline for comparison with other response actions. The no action alternative may be appropriate foi some facilities and sources of contamination if risk assessments determine acceptable natural resource or human health risks posed by those sources or facilities and contaminant-specific ARARs are not exceeded.

Institutional controls involve the use of physical barriers or access restrictions to reduce or eliminate public exposure to contamination. Many access and land use restrictions are currently in place at the Hanford Site and will remain in place during implementation of remedial actions. Because the 200 Areas are already committed to waste management for the long term, institutional controls will also be important for final remedial measures alternatives.

Waste removal and treatment or disposal involves excavation of contamination sources for eventual treatment and/or disposal either on a small- or large-scale basis. One approach being considered for large-scale waste removal is macro-engineering, which is based on high volume excavation using conventional surface mining technologies. Waste removal on a macro-engineering scale would be used over large areas such as groups of waste management units, operable units, or operational areas as a final remedial action. Waste removal on a small scale would be conducted for individual waste management units on a selective basis. Small-scale waste removal could be conducted as either an interim or final remedial action.

The alternatives for disposal of the excavated waste would depend on the volume of soil and the nature of the contaminants:

- Soil that contained low levels of radionuclides but no hazardous chemical waste could be disposed of into existing disposal sites at Hanford, or it could be shipped to licensed offsite disposal sites.

- Soil that contained chemical contaminants but no radionuclides could be disposed of at existing offsite RCRA-approved landfills, or disposed of onsite in a Hanford RCRA-approved landrill.

- Soil that was designated as "mixed waste" with both low-level radionuclides and hazardous chemical contaminants would have to be disposed of at Hanford. 
- There are currently no facilities at Hanford or offsite for permanent geologic disposal of transuranic (TRU) waste. If such soil was excavated, it would have to be temporarily stored at Hanford until a geologic repository disposal site was licensed and constructed or another disposal option is identified.

One potential problem with offsite disposal of radioactive waste is the lack of an alternate disposal location that will decrease the potential human exposure over the long time required for many of the contaminants. Waste removal actions may not be needed, or only be required on a small scale, to protect human health or the environment for industrial uses of the 200 Areas.

Waste treatment involves the use of biological, thermal, physical, or chemical technologies. Typical treatment options include biological land farming, thermal processing, soil washing, and fixation/solidification/stabilization. As described in Section 7.3, some of the technologies that have been used at industrial sites may not be feasible at Hanford. Some treatment technologies must be pilot tested before they could be implemented. Waste treatment could be conducted either as an interim or final action and may be appropriate in meeting RAOs for all potential future land uses.

Waste containment includes the use of capping technologies (i.e., capping and grouting) to minimize the driving force for downward or lateral migration of contaminants. Vertical barriers can also be used to minimize lateral migration and to prevent biota from penetrating into contaminated areas. Containment also provides a radiation exposure barrier and barrier to direct exposure. In addition, these barriers provide long-term stability with relatively low maintenance requirements. Containment actions may be appropriate for either interim or final remedial actions.

In situ waste treatment includes thermal, chemical, physical, and biological technology types, of which there are several specific process options including in situ vitrification, in situ grouting or stabilization, soil flushing, and in situ biotreatment. The distinguishing feature of in situ treatment technologies is the ability to attain RAOs without removing the wastes. The final waste form generally remains in place. This feature is advantageous when exposure during excavation would be significant or when excavation is technically impractical. In situ treatment can be difficult because the process conditions may not be easily controlled.

In the next section, specific process options within these technology groups are evaluated. 


\subsection{TECHNOLOGY SCREENING}

In this section, potentially applicable technology types and process options are identified. These process options are then screened using effectiveness, implementability, and relative cost as criteria to eliminate those process options that would not be feasible at the site. The remaining applicable processes are then grouped into remedial alternatives in Sections 7.4.

The effectiveness criteria focuses on: (1) the potential effectiveness of process options in handling the areas or volumes of media and meeting the RAOs; (2) the potential impacts to human health and the environment during the construction and implementation phase; and (3) how proven and reliable the process is with respect to the contaminants and conditions at the site. This criteria also concentrates on the ability of a process option to treat a contaminant type (organics, inorganics, metals, radionuclides, etc.) rather than a specific contaminant (nitrate, cyanide, chromium, plutonium, etc.).

The implementability criteria places greater emphasis on the institutional aspects of implementability, such as the ability to obtain necessary permits for offsite actions, the availability of treatment, storage, and disposal services, and the availability of necessary equipment and skilled workers to implement the technology. It also focuses on the process option's developmental status, whether it is an experimental or established technology.

The relative cost criteria is an estimate of the overall cost of a process, including capital and operating costs. At this stage in the process, the cost analysis is made on the basis of engineering judgement, and each process is evaluated as to whether costs are high, medium, or low relative to other process options.

A process option is rated effective if it can handle the amount of area or media required, if it does not impact human health or the environment during the construction and implementation phases, and if it is a proven or reliable process with respect to the contaminants and conditions at the site. Also a process option is considered more effective if it treats a wide range of contaminants rather than a specific contaminant. An example of a very effective process option would be vitrification because it treats inorganics, metals, and radionuclides. On the other hand, chemical reduction may only treat chromium (VI), making it a less useful option.

An easily implemented process option is one that is an established technology, uses readily available equipment and skilled workers, uses treatment, storage, and disposal services that are readily available, and has few regulatory constraints. Preference is given to technologies that are easily implemented.

Preference is given to lower cost options, but cost is not an exclusionary criteria. A process option is not eliminated based on cost alone. 
Results of the screening process are shown in Table 7-3. Brief descriptions are given of the process options, followed by comments regarding the evaluation criteria. The last column of the table indicates whether the process option is rejected or carried forward for possible alternative formation. The table first lists technologies that address soil RAOs. Next, technologies pertaining to biota RAOs are presented. All the biota-specific technologies happen to be technologies that were listed for soil RAOs. Air RAOs are dealt with as soil remediation issues because the air contamination is a result of the contaminants in the soil: addressing and remediating the air pathways would be unnecessary and ineffective as long as there is soil contamination. If the soil is remediated, the source of the air contamination would be removed.

The conclusions column of Table 7-3 indicates that no action, monitoring, 3 institutional process options, and 16 other process options are retained for further development of alternatives. These options are carried forward into the development of preliminary alternatives.

\subsection{PRELIMINARY REMEDIAL ACTION ALTERNATIVES}

This section develops and describes several remedial alternatives considered applicable to disposal sites that contain hazardous chemicals, radionuclides, and volatile and semivolatile organic compounds (VOCs). These alternatives are not intended as recommended actions for any individual waste management units, but are intended only to provide potential options applicable to most units where multiple contaminants are present. Selection of actual remedial alternatives that should be applied to the individual units would be partly based on future expedited or interim actions and LFIs, as recommended in Section 9.0 of this report. Selection of proper alternatives would be conducted within the framework of the Hanford Site Past-Practice Strategy (DOE/RL 1992a) and the strategy outlined in Section 9.4. The selection process would also be based on a preference for isolation and permanent treatment.

The remedial alternatives are developed in Section 7.4.1. Then, in Section 7.4.2 through Section 7.4.7, the remedial action alternatives are described. Detailed evaluations and costs are not provided because site-specific conditions must be further investigated before meaningful evaluations could be conducted.

\subsubsection{Development of Remedial Alternatives}

Potentially feasible remedial technologies were described and evaluated in Section 7.3. Some of those technologies have been proven to be effective at industrial waste management units, while other technologies are in the developmental stages. The EPA guidance (EPA 1988b) on FSs for uncontrolled waste management units recommends that a limited number of candidate technologies be grouped into "Remedial Alternatives." For this study, 
technologies were combined to develop remedial alternatives and provide at least one alternative for each of the following general strategies:

- No action

- Institutional controls

- Removal, above-ground treatment, and disposal

- Containment

- In situ treatment.

The alternatives are intended to treat all or a major component of the 200 North Aggregate Area contaminated waste management units or unplanned releases. Consistent with the development of RAOs and technologies, alternatives were developed based on treating classes of compounds (radionuclides, heavy metals, inorganics, and organics) rather than specific contaminants. At a minimum, the alternative must be a complete package. For example, disposal of radionuclide-contaminated soil must be combined with excavation and backfilling of the excavated unit.

One important factor in the development of the preliminary remedial action alternatives is the fact that radionuclides, heavy metals, and some inorganic compounds cannot be destroyed. Rather, these compounds must be physically immobilized, contained, isolated, or chemically converted to less mobile forms to satisfy RAOs. Organic compounds can be destroyed, but may represent a smaller portion of the overall contamination at the 200 North Aggregate Area. Both no action and institutional controls are required as part of the Comprehensive Environmental Response, Compensation and Liability Act (CERCLA) RI/FS guidance. The purpose of including both of these alternatives is to provide decision makers with information on the entire range of available remedial actions.

For the containment alternative, an engineered multimedia cover, with or without vertical barriers (depending on the specifics of the remediation) was selected. Two alternatives were selected to represent the excavation and treatment strategy. One of these deals with disposal of TRU contaminated soils. Finally, three in-situ alternatives were identified. One deals with vapor extraction for VOCs, one with stabilization of soils and the other with vitrification of soils. 
It is ra - gnized that this does not represent an exhaustive list of all applicable alternatives. However, these do provide a reasonable range of remedial actions that are likely to be evaluated in future FSs. The remedial action altematives are summarized as follows:

- No action

- Institutional controls

- $\quad$ Fngineered multimedia cover with $\mathrm{c} r$ without vertical barriers (containment). Feasible vertical barriers include slurry walls and grout curtains

- In-situ grouting or stabilization of soil (in-situ treatment)

- Excavation abc ve-ground treatment, and disposal of soil (removal, treatment and disposal); easille technologies for organic compounds include thermal processing and siabilization; Feasible technologies for radionuclides include soil washing, vitrification, and stabilization

- In-situ vitrification of soil (in-situ treatment)

- Excavation, treatment, and geologic disposal of soil with TRU radionuclides (removal, treatment and disposal)

- In-situ soil vapor extraction of VOCs (in-situ treatment).

These alterratives, with the exception of no action and inst utional controls, were develuped because they satisfy a number of RAOs simultaneously and use technologies that are appropriate for a wide range of contaminant types. For example, constructing an engineered multimedia cover can effectively contain radionuclides, heavy metals, inorganic compounds, a id organic compounds simultaneously. It satisfies the RAOs of protecting human healt'، and the environment from exposures from contaminated soil, bio-mobilization, and aithme contaminants. In-situ soil vapor extraction is more specific than the other alternatives, but it addresses a contaminant class (VOCs) that is not readily treated using the other options, such as in-situ stabilization. It is possible that some waste management units may require a combination of the identified alternatives to completely address all contaminants.

The use of contaminant-specific remedial technologies was avoided because there appear to be few, if any, waste management units where a single contaminant has been is ntified. It is possible to construct alternatives that include several contaminant-specific technologies, but the number of combinations of technologies would result in an unmanageable number of alternatives. Moreover, the possible presence of unidentified contaminants may render specific alternatives unusable. Alternatives may be refined as more 
contamination data are acquired. For now, the alternatives will be directed at remediating the major classes of compour,ds (radionuclides, heavy metals, inorganics, and organics).

In all alternatives except the no-action alternative, it is assumed that monitoring and institutional controls are required, although they may be temporary. These features are not explicitly mentioned, and details are purposely omitted until a more detailed evaluation may be performed in subsequent studies. Also, treatability studies may accompany many of the alternatives during implementation.

In the next sections, the preliminary remedial action alternatives are described in more detail, with the exception of the no-action and institutional control options.

\subsubsection{Alternai:ve 1-Engineered Multimedia Cover with or without Vertical Barriers}

Alternative 1 consists of an engineered multimedia cover. Vertical barriers such as grout curtains or slurry walls may be used in conjunction with the cover. Figure 7-2 shows a schematic diagram of an engineered multimedia cover without the vertical barriers. If the affected area includes either a naturally occurring or engineered depression, then imported backfill would be placed to control runoff and run-on water. The engineered cover itself may consist of fine-grained soil, gravel, sand, asphalt, topsoil, and/or geo-synthetic liners. A liquid collection layer could also be included. The specific design of the cover and vertical barriers would be the subject of a focused feasibility study (FFS) which may be supported by treatability studies and performance testing. The barrier would be designed to minimize infiltration of surface water and to minimize biological intrusion (e.g. deep-rooting plants and burrowing animals). The covered area may be fenced, and warning signs may be posted.

Alternative 1 would provide a permanent cover over the affected area. The cover would accomplish the following: minimize the migration of precipitation into the affected soil; reduce the migration of windblown dust that originated from contaminated surface soils; reduce the potential for direct exposure to contamination and reduce the volatilization of VOCs and tritium to the atmosphere. If vertical barriers are included, they would limit the amount of lateral migration of contaminants.

This alternative would not reduce the volume or toxicity of the contaminants, and periodic inspections and maintenance would be required for an indefinite period.

\subsubsection{Alternative 2-In-Situ Grouting or Stabilization of Soil}

Radioactive and hazardous soil would be grouted in this alternative using in situ injection methods to significantly reduce the leachability of hazardous contaminants, radionuclides and/or VOCs from the affected soil. This technology has not been proven to 
be effective for VOCs, so it is not recommended as the sole remedial action for VOC affected areas. Grouting may also be used to fill voids, such as in cribs, thereby reducing subsidence. Another variation of this alternative would be to stabilize the soil using in-situ mixing of soil with stabilizing compounds such as pozzolanics or fly ash.

There are two common methods of in-situ grout injection that have been used at industrial sites. In the first method (Figure 7-3), grout injection wells are installed at prescribed lateral spacing (based on pilot tests) and screened through the affected vertical zones. Specially formulated grout is then injected at high pressure to provide overlapping zones of influence and allowed to cure. This first method can theoretically be used to stabilize soil deep below the ground surface. In the second method, a patented large diameter auger/mixer is used to mechanically agitate and blend grout mixtures that are injected into the soil through ports in the auger. This method has commonly been used to grout large areas of soil down to a depth of about $4.6 \mathrm{~m} \mathrm{(15} \mathrm{ft).}$

Alternative 2 would provide a combination of immobilization and containment of heavy metal, radionuclide, inorganic, and semi-volatile organic contamination. Thus, this alternative would reduce migration of precipitation into the affected soil; reduce the migration of windblown dust that originated from contaminated surface soils; reduce the potential for direct exposure to contaminated soils; and reduce the volatilization of VOCs.

In-situ grouting has been demonstrated to be effective for stabilization of metals and semivolatile organic compounds at several CERCLA sites. However, this is considered to be a developing technology and has not yet been fully proven. Therefore, it is expected that treatability tests would be required. Because this alternative would not remove the contaminants from the soil, it is likely that institutional controls would be required.

\subsubsection{Alternative 3-Excavation, Soil Treatment, and Disposal}

Under Alternative 3, radioactive and hazardous soil would be excavated using conventional techniques, with special precautions to minimize fugitive dust generation. Depending on the configuration of the area to be excavated, shoring might be required to comply with safety requirements and to reduce the quantity of excavated soil. The soil excavated would be treated above ground. Several treatment options could be selected from the excavated physical, chemical, and thermal treatment process options screened in Section 7.3. For example, thermal desorption with off- gas treatment could be used if organic compounds are present; soil washing could be used to remove contaminated silts and sands or specific compounds; and stabilization could be used to immobilize radionuclides and heavy metals. The specific treatment method would depend on site-specific conditions. Treatability tests would be performed to determine the specific soil treatment protocols methodology. The treated soil would be backfilled into the original excavation or landfilled. Soil treatment by-products may require additional processing or treatment. Figure 7-4 shows a schematic diagram of this alternative. 
Alternative 3 would be effective in treating a full range of contamination, depending on the type of treatment processes selected. Attainment of soil RAOs would depend on the depth to which the soil was excavated. If near surface soil was treated, airborne contamination, direct exposure to contaminated soil, and bio-mobilization of contamination would be minimized. Because of practical limits on deep excavation, deep contamination may not be removed and would be subject to migration into groundwater. Alternative 3 could be used in conjunction with Alternative 1 (multimedia cap) to reduce this possibility.

A combination of laboratory treatability tests and pilot-scale field tests might be required to develop the optimum methods for above-ground treatment of the excavated soil. The specification of the required treatability iests would depend on the nature of the contaminants at each of the remediation sites.

\subsubsection{Alternative 4-In-Situ Vitrification of Soil}

In this alternative, the contaminated soil in a subject site would be immobilized by insitu vitrification. Treatability tests would be performed initially to determine site-specific operating conditions. Figure 7-5 shows a schematic diagram of the alternative. Import fill would initially be placed over the affected area to reduce exposures to the remediation workers from surface contamination. High power electrodes would be used to vitrify the contaminated soil under the site to a depth below where contamination is present. A large fume hood would be constructed over the site before the start of the vitrification process to collect and treat emissions. After completion of the vitrification, the site would be built back to original grade with imported backfill. Fences and warning signs may be placed around the vitrified monolith to minimize disturbance and potential exposure.

In-situ vitrification would be effective in treating radionuclides, heavy metals, and inorganic contamination and may also destroy organic contaminants. This would reduce the potential for exposures by leaching to groundwater, windblown dust and direct dermal contact. However, this alternative would not reduce the mass or toxicity of the radionuclides present onsite. Also, in-situ vitrification has not been tested below about $30 \mathrm{~m}(100 \mathrm{ft})$ and may not be adequate to immobilize deep contamination.

If organic compounds are present in the affected area, they could migrate laterally and vertically during the vitrification process, as a result of the soil heating process. Therefore, this technology must include provisions for collection and treating organic vapors. This could be done using a combination of soil venting wells and an above-ground capture hood.

It should be noted that in-situ vitrification is a relatively new technology which is experiencing some "growing pains" and has not been used for a large-scale cleanup at an industrial site. Tests to date have not exceeded depths fo $6 \mathrm{~m}(20 \mathrm{ft})$. Therefore, using this technology at the Hanford Site will likely require extensive pilot testing. 


\subsubsection{Alternative 5-Excavation, Above-Ground Treatment, and Geologic Disposal of Soil with TRU Radionuclides}

Some of the waste management units in the 200 North Aggregate Area may contain isolated zones where the concentrations of TRU radionuclides exceeds $100 \mathrm{nCi} / \mathrm{g}$. For Alternative 5, the soil from those isolated zones would be excavated, stabilized or treated, and shipped to an offsite geologic disposal site. Such a disposal facility has not yet been licensed, so interim storage of the stabilized soil may be required until a final geologic repository is constructed.

Figure 7-6 shows a schematic diagram of Alternative 5. Depending on the configuration of the affected area, shoring may be required during excavation to comply with worker safety regulations and to minimize the amount of excavated soil. Special excavation procedures would have to be used to minimize fugitive dust. The excavated soil would be sorted according to TRU concentration. Soil with TRU radionuclides exceeding $100 \mathrm{nCi} / \mathrm{g}$ would be either vitrified or stabilized using an above-ground treatment plant, then stored until a geologic disposal facility was available.

Some of the excavated soil could contain TRU radionuclides at concentrations less than $100 \mathrm{nCi} / \mathrm{g}$, and could be treated using a combination of the technologies described in Section 7.3. After the non-TRU soil was treated to achieve appropriate cleanup standards, it could be backfilled into the original excavation. Alternatively, the non-TRU soil could be disposed of at an appropriate landfill. Imported fill material would be used to restore the site to its original grade. If the residual unexcavated soil or the treated soil used for backfill contained contaminants at concentrations exceeding the RAOs, then a combination of an engineered cover and vertical barriers (Alternative 1) might have to be installed at the site to prevent direct exposure or groundwater impacts.

This alternative would utilize many excavation and treatment technologies that have been only partly demonstrated at industrial sites. Extensive treatability testing would be required for the TRU-containing soil to develop optimum methods for treating or stabilizing the TRU radionuclides. Additional treatability studies might be required to support the above-ground treatment of the non-TRU soil.

For Alternative 5, soil containing TRU radionuclides at concentrations exceeding $100 \mathrm{nCi} / \mathrm{g}$ would be excavated, treated, and disposed. Thus, potential exposure to and migration of TRU-wastes would be minimized. Potential exposure to other contaminants would be determined by other remedial alternatives implemented. At sites containing TRU and non-TRU wastes, the use of Alternative 5 alone may not satisfy all RAOs.

\subsubsection{Alternative 6-In-Situ Soil Vapor Extraction for VOCs}

Figure 7-7 shows a schematic diagram of a representative soil vapor extraction system. Soil vapor is vented from wells that are screened in permeable soil zones that contain high 
organic vapor concentrations. The vented air would be treated to remove water vapor, the organic vapor of concern, particulate radionuclides that might be entrained in the air stream, and volatile radionuclides. Figure 7-7 shows one common combination of offgas treatment technologies; other technologies can also be used depending on the nature of the vapors that are extracted. Water vapor must be removed (usually by condensation) to protect the vacuum pumps. If the condensed water contains organic contamination or radionuclides, then it would have to be treated and/or disposal of in an appropriate manner. Particulate radionuclides that were entrained in the air stream can be effectively removed using banks of conventional High Efficiency Particulate Air (HEPA) filters. The organic vapors would have to be treated to satisfy Best Available Control Technology in accordance with air toxics regulations. If the disposal site is considered a RCRA facility, then the offgas treatment system must also satisfy RCRA emission control standards. Destruction efficiencies exceeding $98 \%$ have often been achieved for soil vapor extraction systems at industrial sites.

A pilot-scale test would probably have to be performed to determine the required venting well spacing and the required vacuum pump design. Analysis of the vented gas during the pilot test would be done to assess what types of offgas emission controls would be required.

Some of the waste management units at the 200 North Aggregate Area contain VOCs along with other non-volatile contaminants. Alternative 6 utilizes proven technologies to remove the volatilized vapors from the vadose zone soil. In-situ soil vapor extraction is a proven technology for removal of VOC from the vadose zone soils although some pilot-scale testing may be needed at specific units. Soil vapor extraction would reduce downward migration of the VOC vapors through the vadose zone, and thereby minimize potential cross-media migration into the groundwater. Soil vapor extraction would reduce upward migration of VOC through the soil column into the atmosphere and thereby, minimize inhalation exposures to the contaminants. In some cases radionuclides were discharged to the disposal sites with VOCs (e.g., MIBK). Removal of the VOC by implementing soil vapor extraction could reduce the mobility of the radionuclides and, thereby, reduce the potential for downward migration of the radionuclides. Finally, soil vapor extraction would enhance partitioning of the VOC off of the soil and into the vented air stream resulting in the permanent removal and destruction of the VOC. Alternative 6 may be used in conjunction with other alternatives if contaminants other than VOCs are present. However, because of the limited number of 200 North Aggregate Area units that contain VOCs, the use of soil vapor extraction will not be extensive. 


\subsection{PRELIMINARY REMEDIAL ACTION ALTERNATIVES APPLICABLE TO WASTE MANAGEMENT UNITS AND UNPLANNED RELEASE SITES}

The purpose of this section is to discuss which preliminary remedial action alternatives could be used to remediate each 200 North Aggregate Area waste management unit or unplanned release site. The criteria used for deciding this are as follows:

- Installing an engineered multimedia cover with or without vertical barriers (Alternative 1) could be used on any site where contaminants may be leached or mobilized by surface water infiltration or if surface/near-surface contamination exists.

- In-situ grouting or stabilization (Alternative 2) could be used on any waste management unit or unplanned release site that contain heavy metals, radionuclides, and/or other inorganic compounds. In-situ grouting could also be effective in filling voids for subsidence control.

- Excavation and soil treatment (Alternative 3) could be used at most waste management units or unplanned release sites that contain radionuclides, heavy metals, other inorganics compounds, semi-volatile organic compounds, and VOCs.

- In-situ vitrification (Alternative 4) could be used at most waste management units or unplanned release sites, although vapor extraction may be needed when VOCs are present. Waste management units or unplanned release sites where in-situ vitrification may not be effective include sites where the contamination is present in a very narrow geometry. In-situ vitrification is also not considered for surface-only contamination sites.

- Excavation, treatment, and gevilogic disposal of TRU-containing soils (Alternative 5) could be used only on those waste management units and unplanned release sites that contain TRU radionuclides. Since a geologic repository is likely to accept only TRU radioactive soils, non-TRU radioactive soils will not be remediated using this alternative.

- In-situ soil vapor extraction (Alternative 6) could be used on any waste management unit or unplanned release sites that contain volatile organic compounds. Such sites could exist in the 200 North Aggregate Area.

Using these criteria, Table 7-4 was created showing possible preliminary remedial action alternatives that could be used to remediate each of the waste management units and unplanned release sites. Note that a single alternative may not be sufficient to remediate all contamination at a single site. For example, soil vapor extraction to remove organic contaminants could precede in-situ vitrification. Also, different combinations of technologies are possible besides those presented in these preliminary alternatives. 
Each waste management unit or unplanned release site may require just one alternative or a combination of many alternatives. Furthermore, similar units or releases may be remediated simultaneously. Also more specific waste treatment alternatives could be identified and evaluated as more information is obtained.

Technology development studies will be needed for the in-situ vitrification process, and treatability studies will be needed for the in-situ grouting or stabilization process, and for soil treatment processes to make sure that they will effectively remediate the contaminants. Specifically, organic waste mobility may be a problem for in-situ vitrification; grouting agents and the resulting reduction of contaminant leachability will need to be determined before in-situ grouting can be performed; and appropriate treatment protocols and systems will need to be identified before soil washing can be used. Capping, soil vapor extraction, and disposal options are all proven processes but may require site-specific performance assessment (treatability) studies.

Focused feasibility studies (FFSs) will be required to evaluate alternative designs for all of the alternatives evaluated, as they relate to the specific waste management unit being remediated. A site-by-site economic evaluation is also required before making a decision. This evaluation will require site-specific information obtained in LFIs and FFSs. 
DOE/RL-92-17, Rev. 0

Figure 7-1. Development of Candidate Remedial Alternatives for 200 North Aggregate Area.

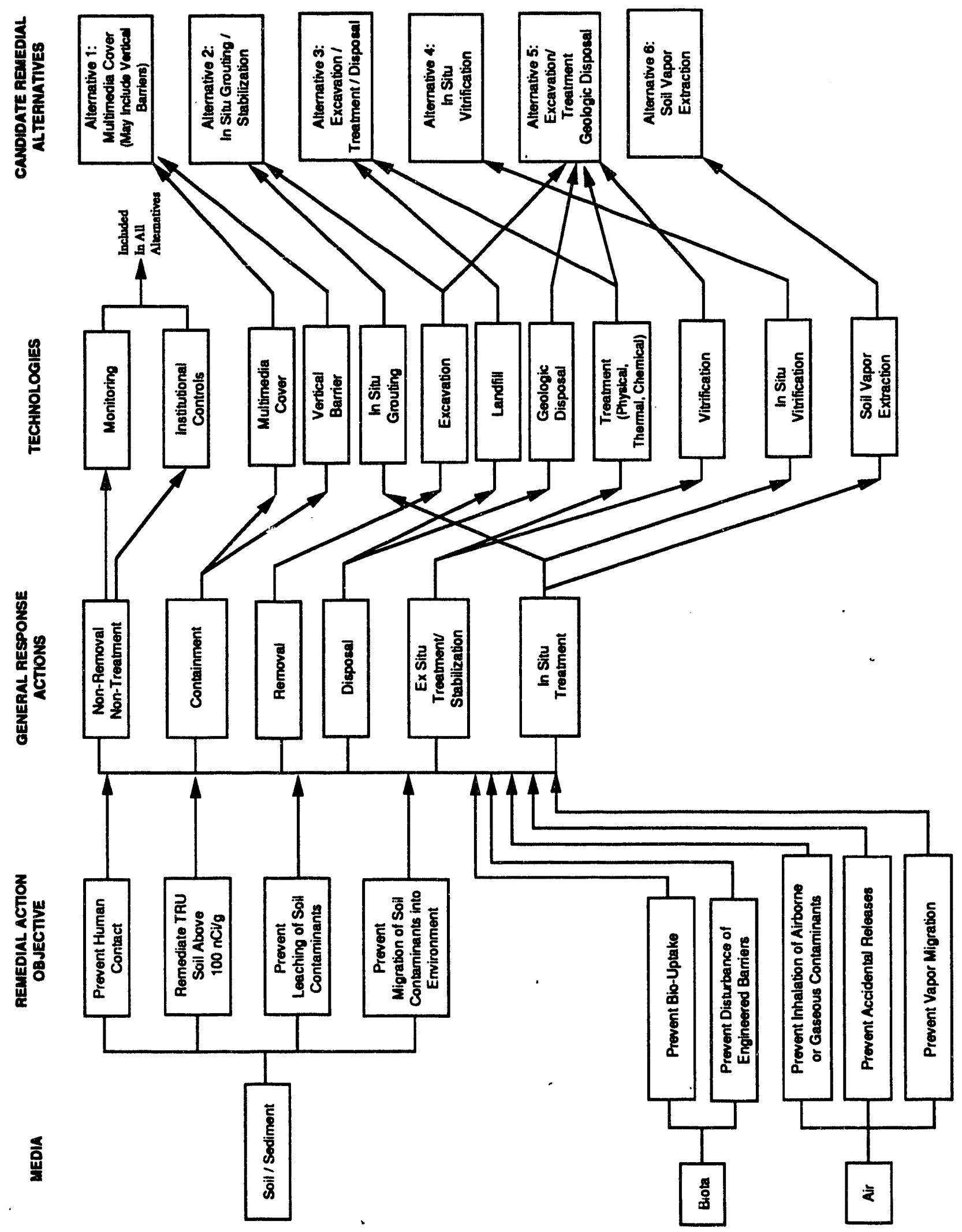


DOE/RL-92-17, Rev. 0

Figure 7-2. Alternative 1: Multimedia Cover.

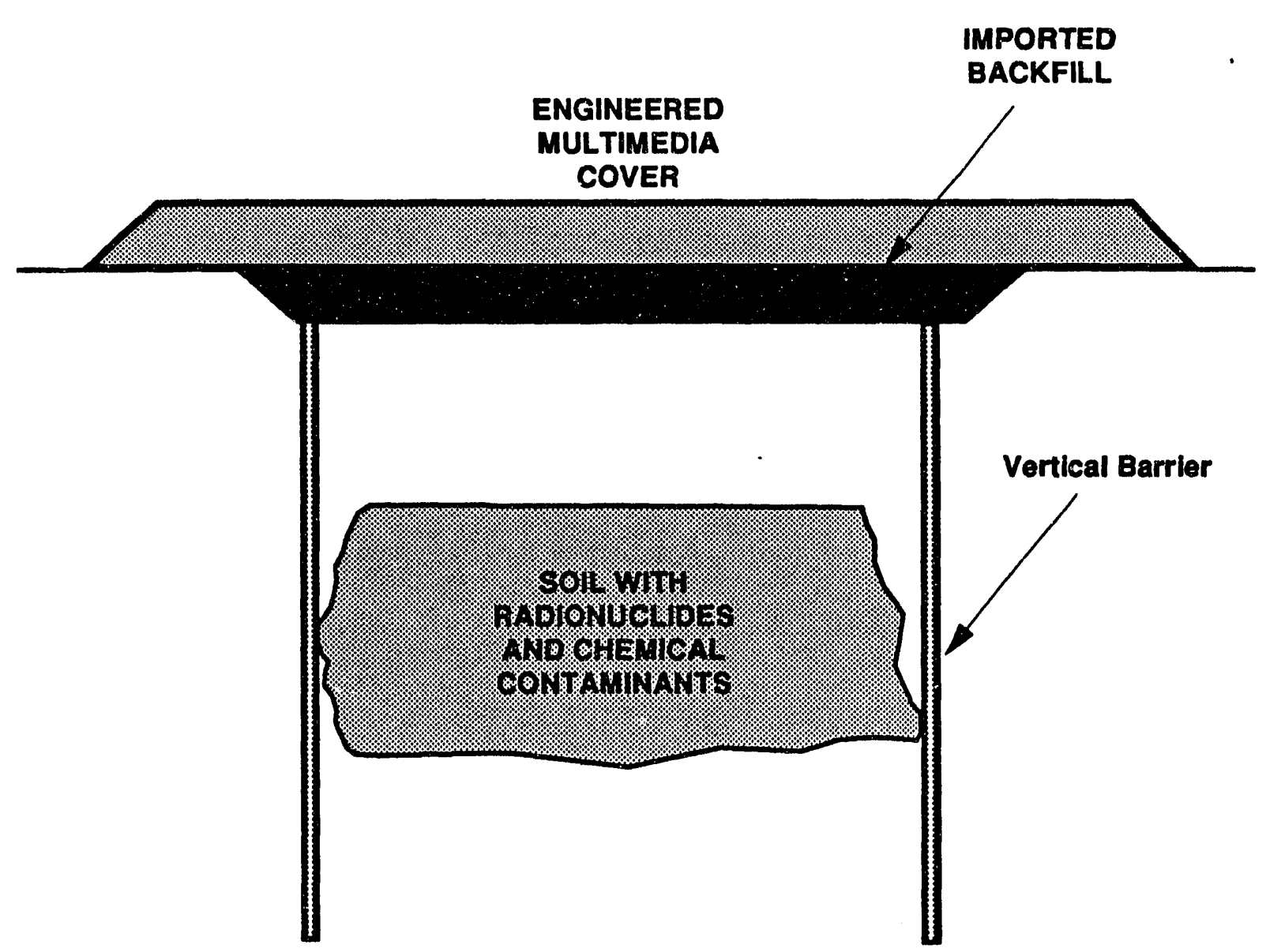


DOE/RL-92-17, Rev. 0

Figure 7-3. Alternative 2: In Situ Grouting of Soil.

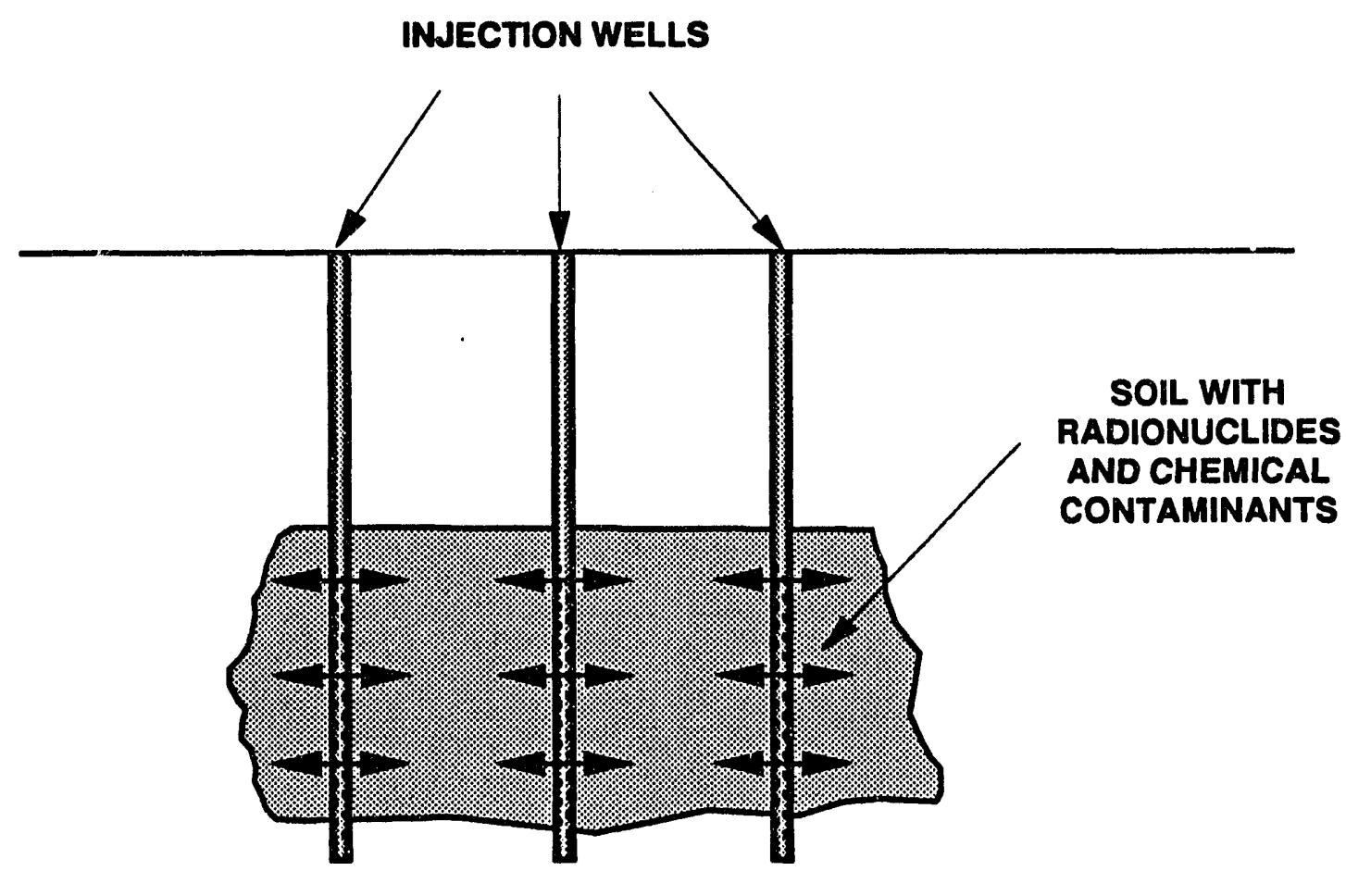


DOE/RL-92-17, Rev. 0

Figure 7-4. Alternative 3: Excavation, Treatment and Disposal.

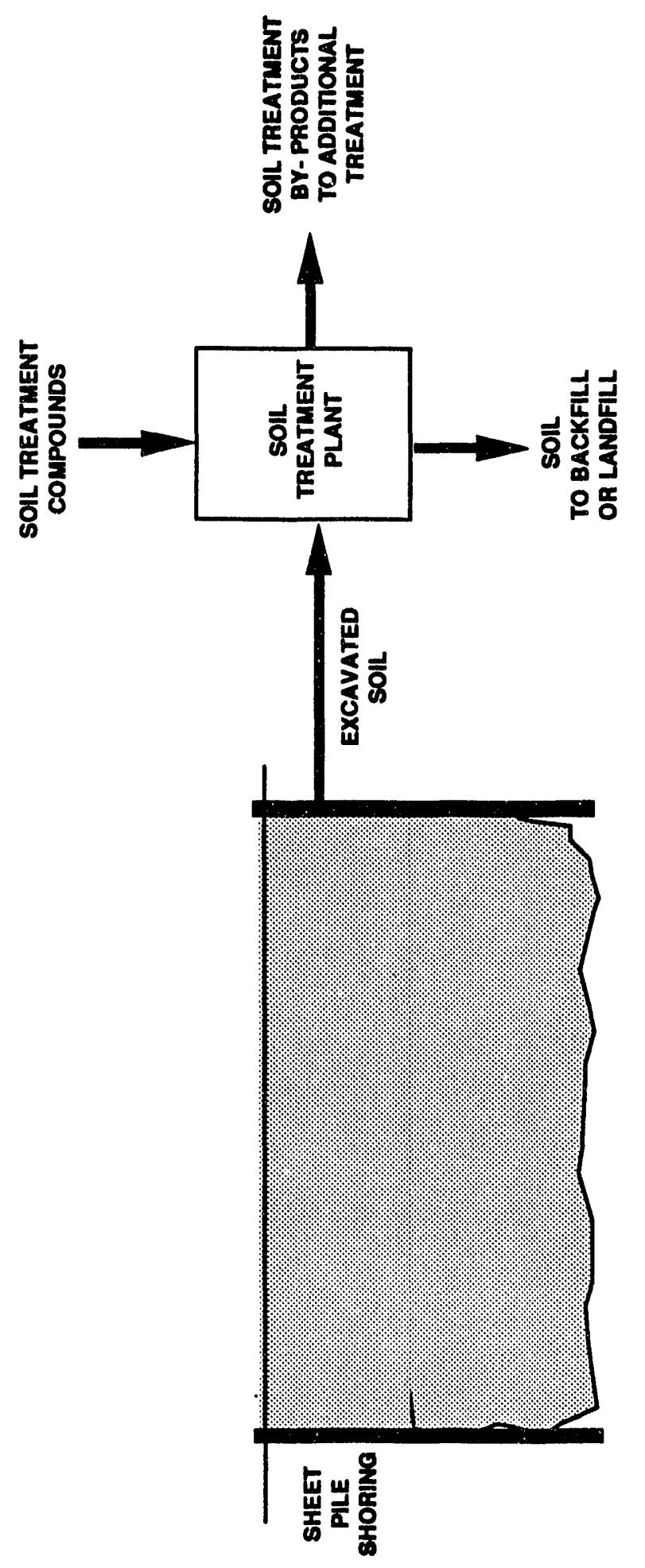


DOE/RL-92-17, Rev. 0

Figure 7-5. Alternative 4: In Situ Vitrification of Soil.

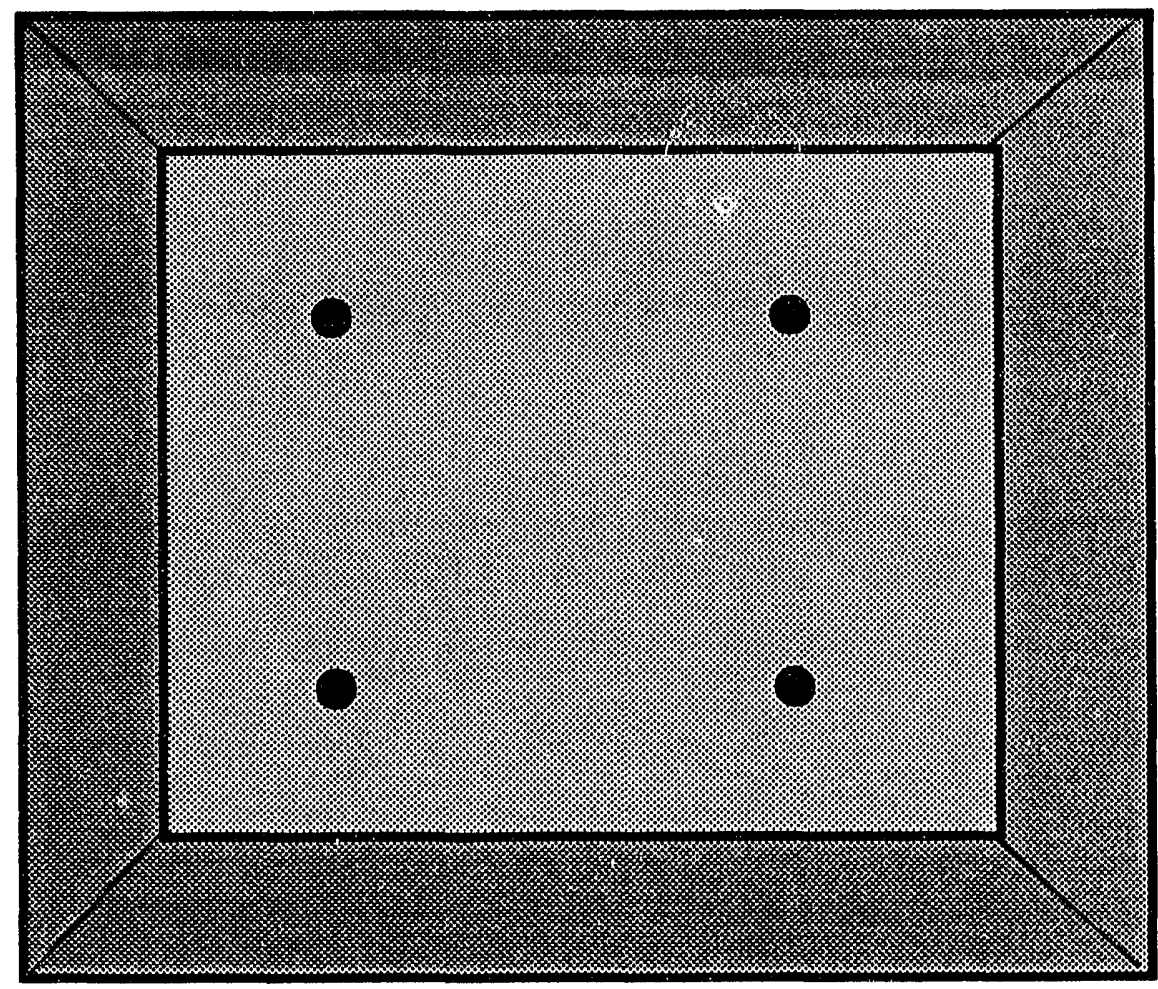

\section{PLAN VIEW OF ELECTRODES NOT TO SCALE}
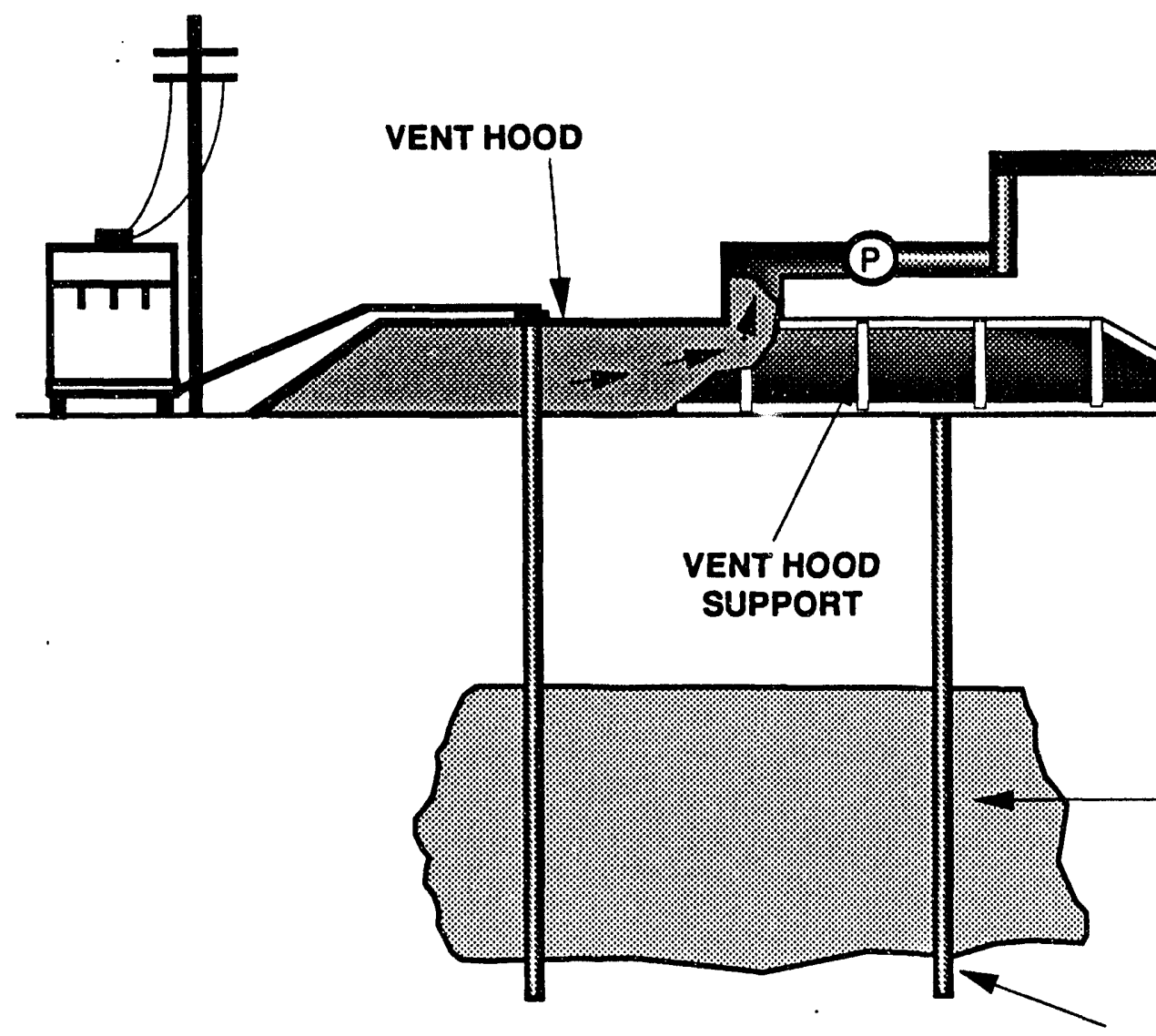

ELECTRODES 
Figure 7-6. Alternative 5: Excavation, Vitrification, and Geologic Disposal of Soil with TRU Radionuclides.

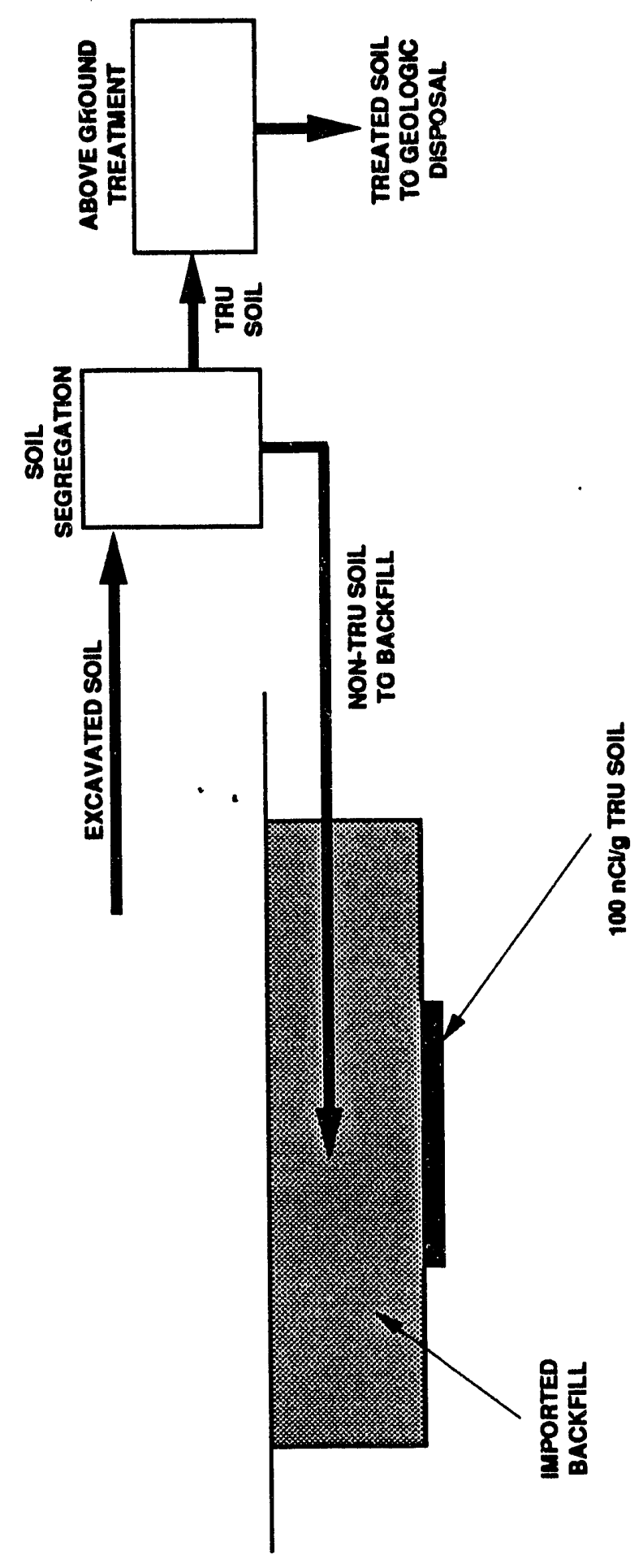


DOE/RL-92-17, Rev. 0

Figure 7-7. Alternative 6: Soil Vapor Extraction for VL_.

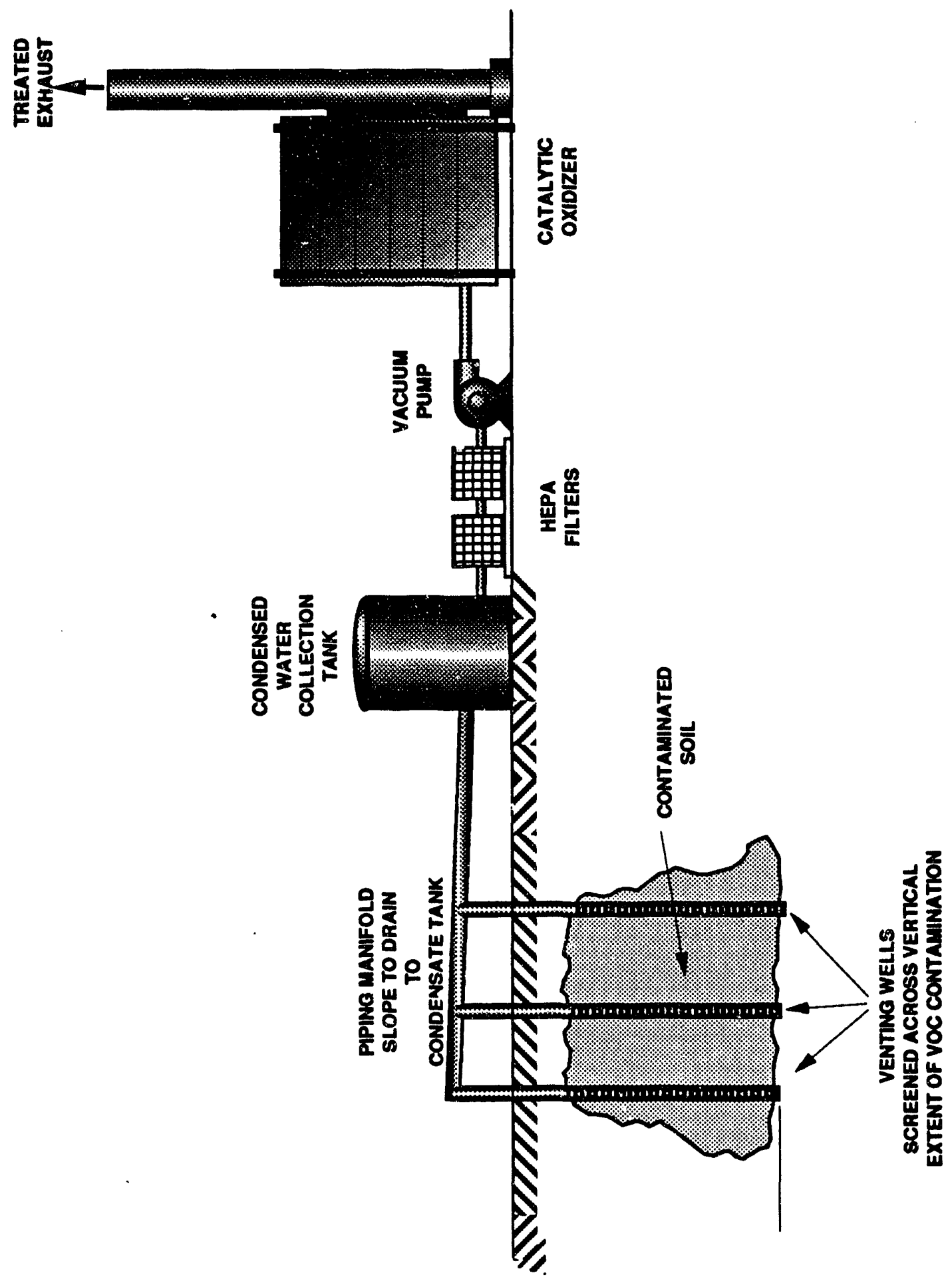


DOE/RL-92-17, Rev. 0

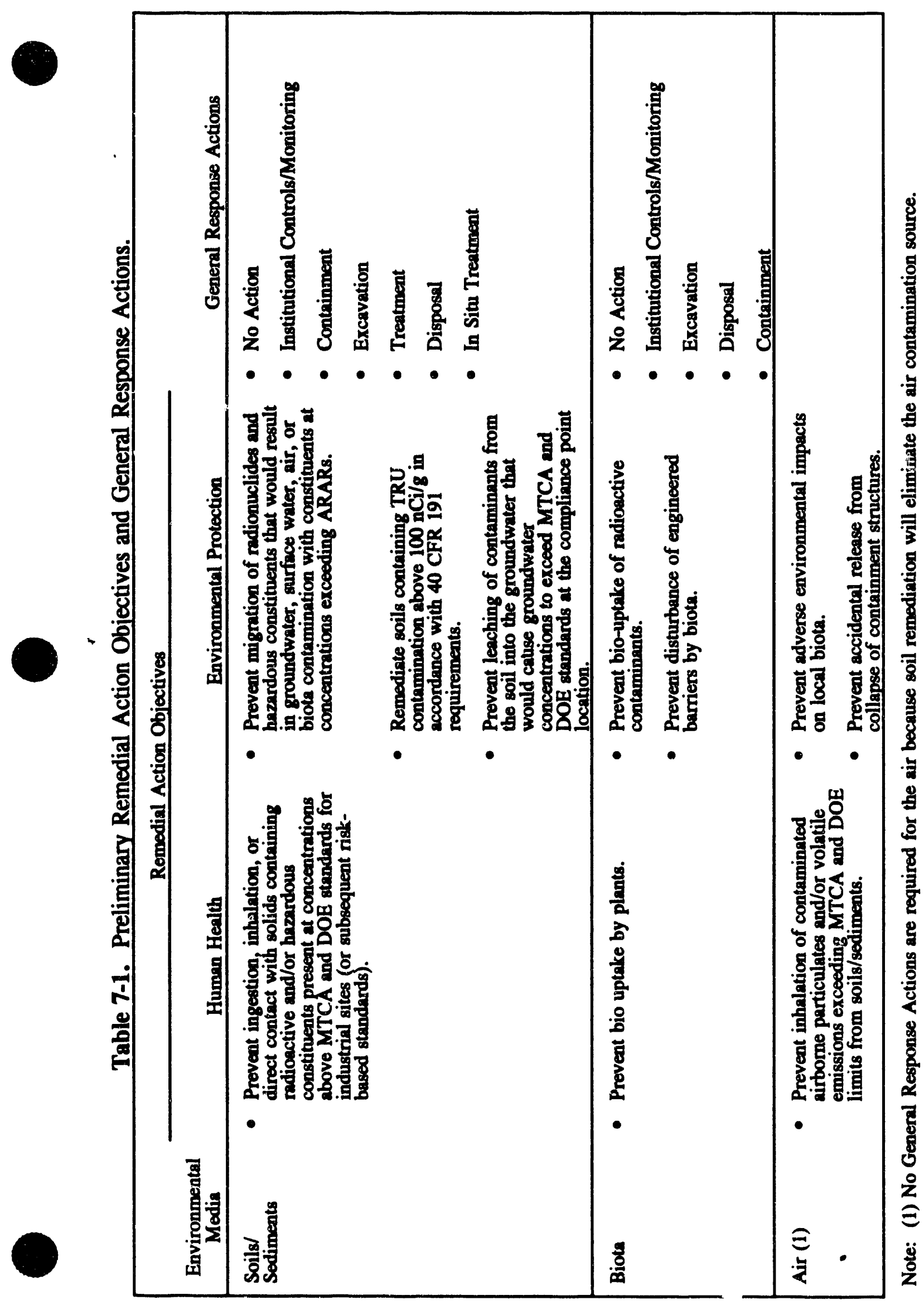


DOE/RL-92-17, Rev. 0

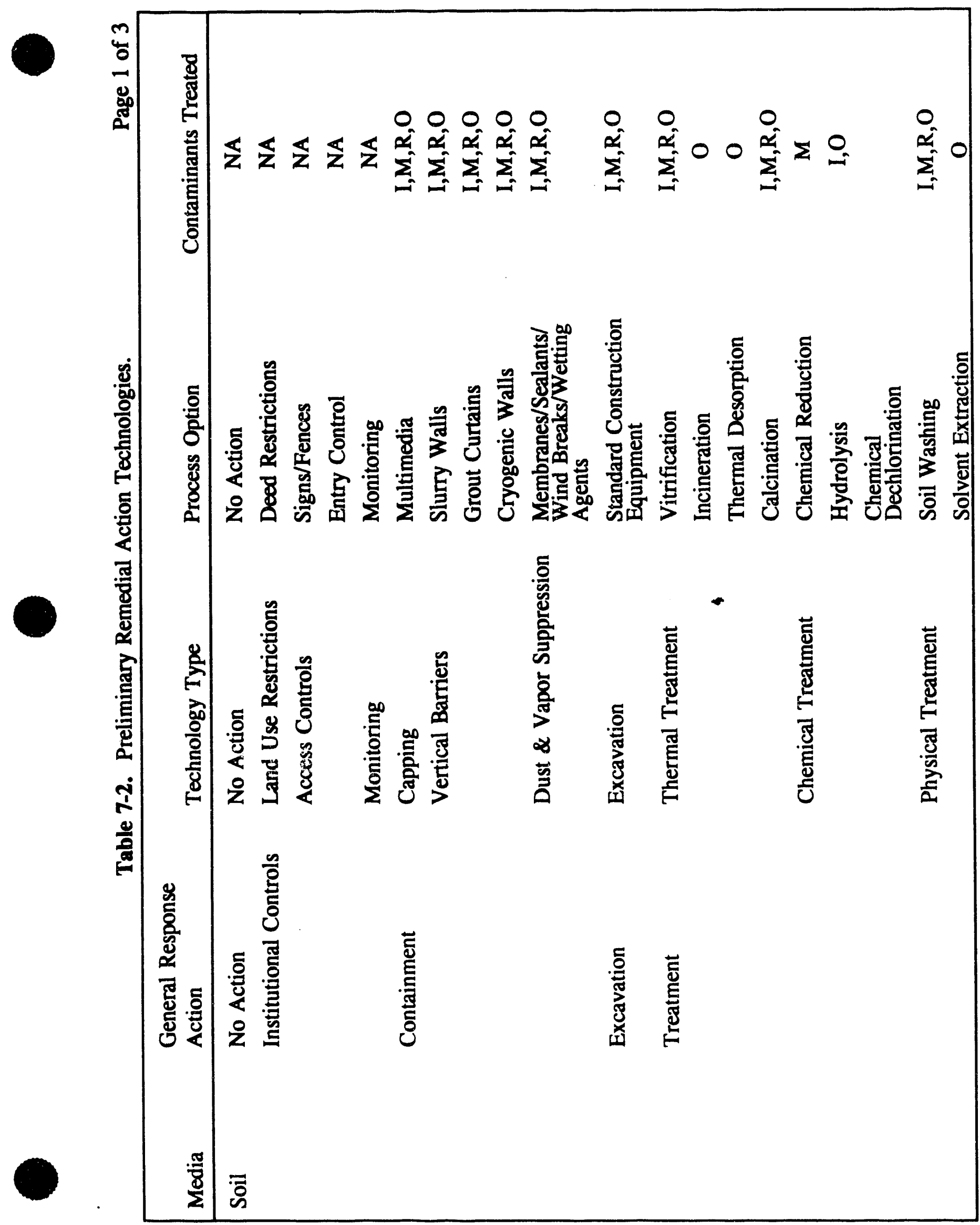


DOE/RL-92-17, Rev. 0

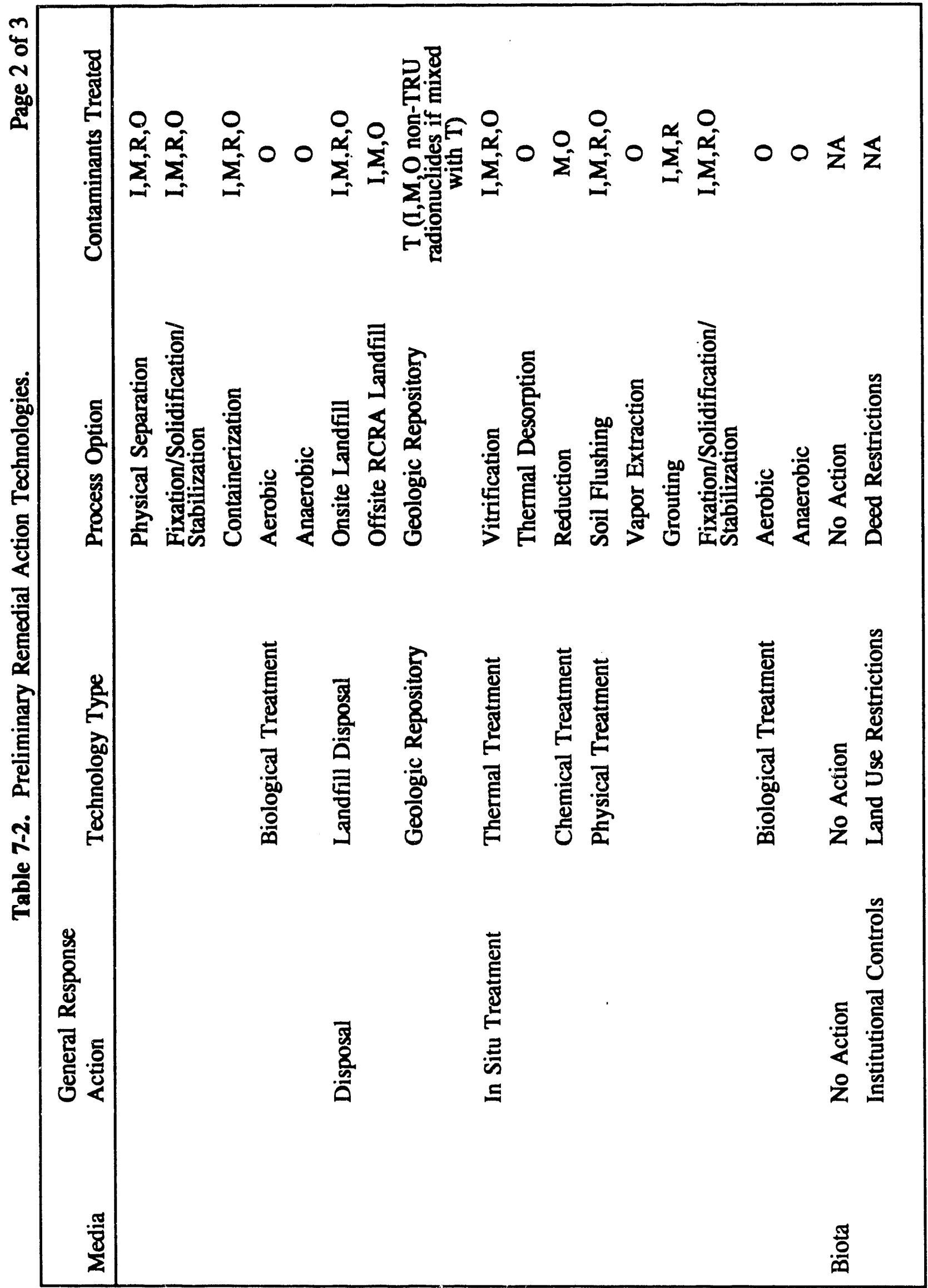


DOE/RL-92-17, Rev. 0

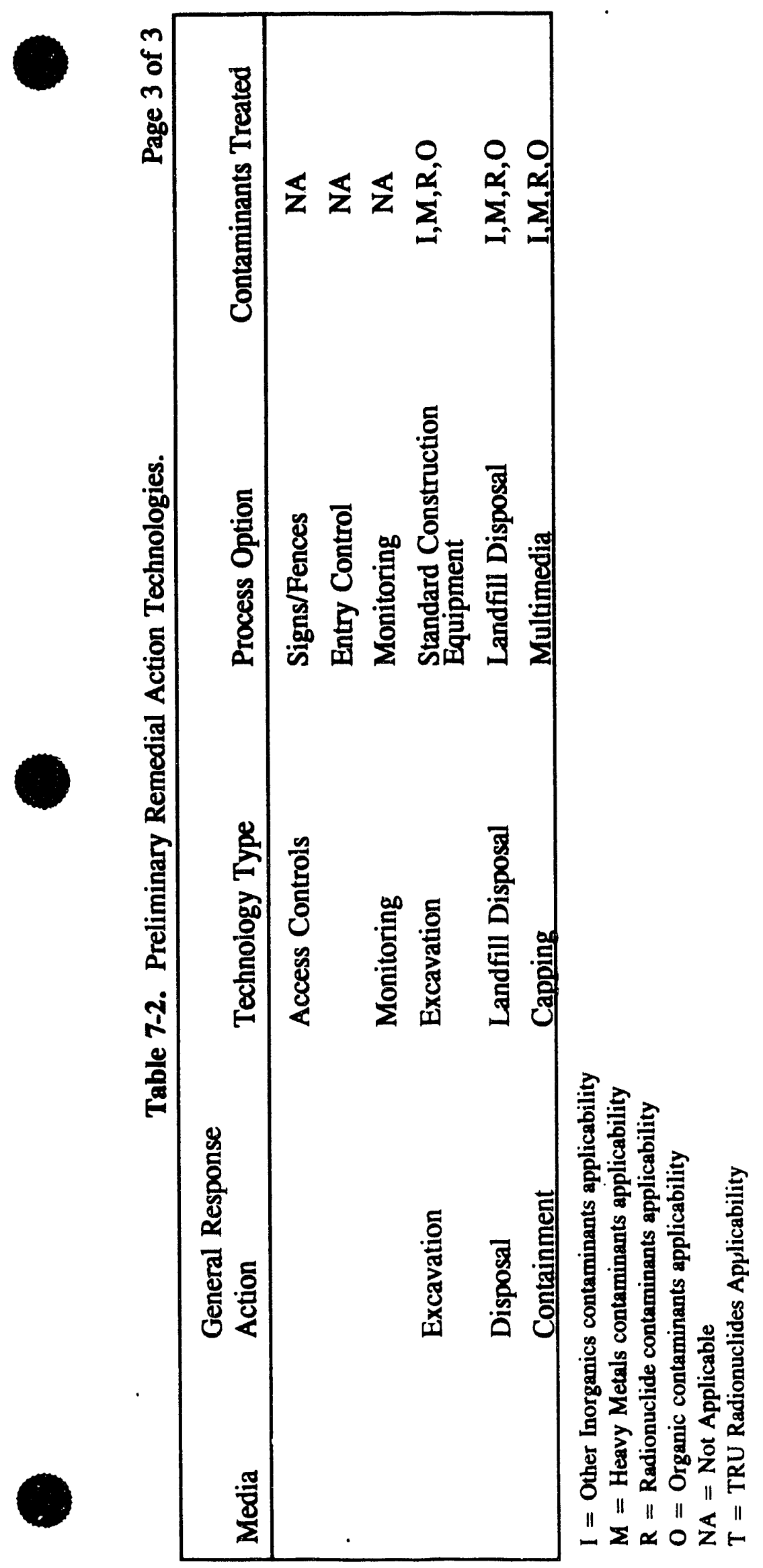


DOE/RL-92-17, Rev. 0

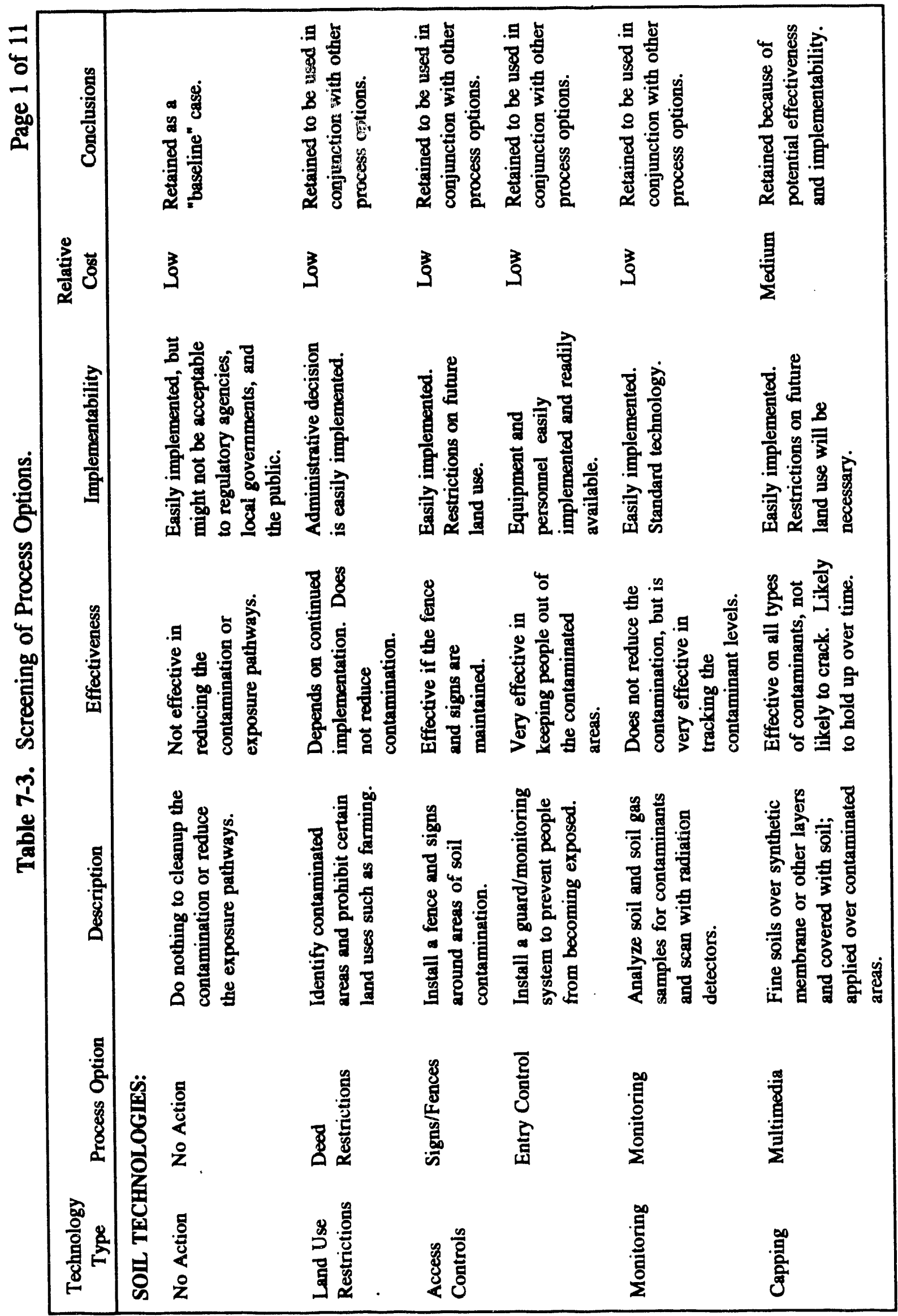


DOE/RL-92-17, Rev. 0

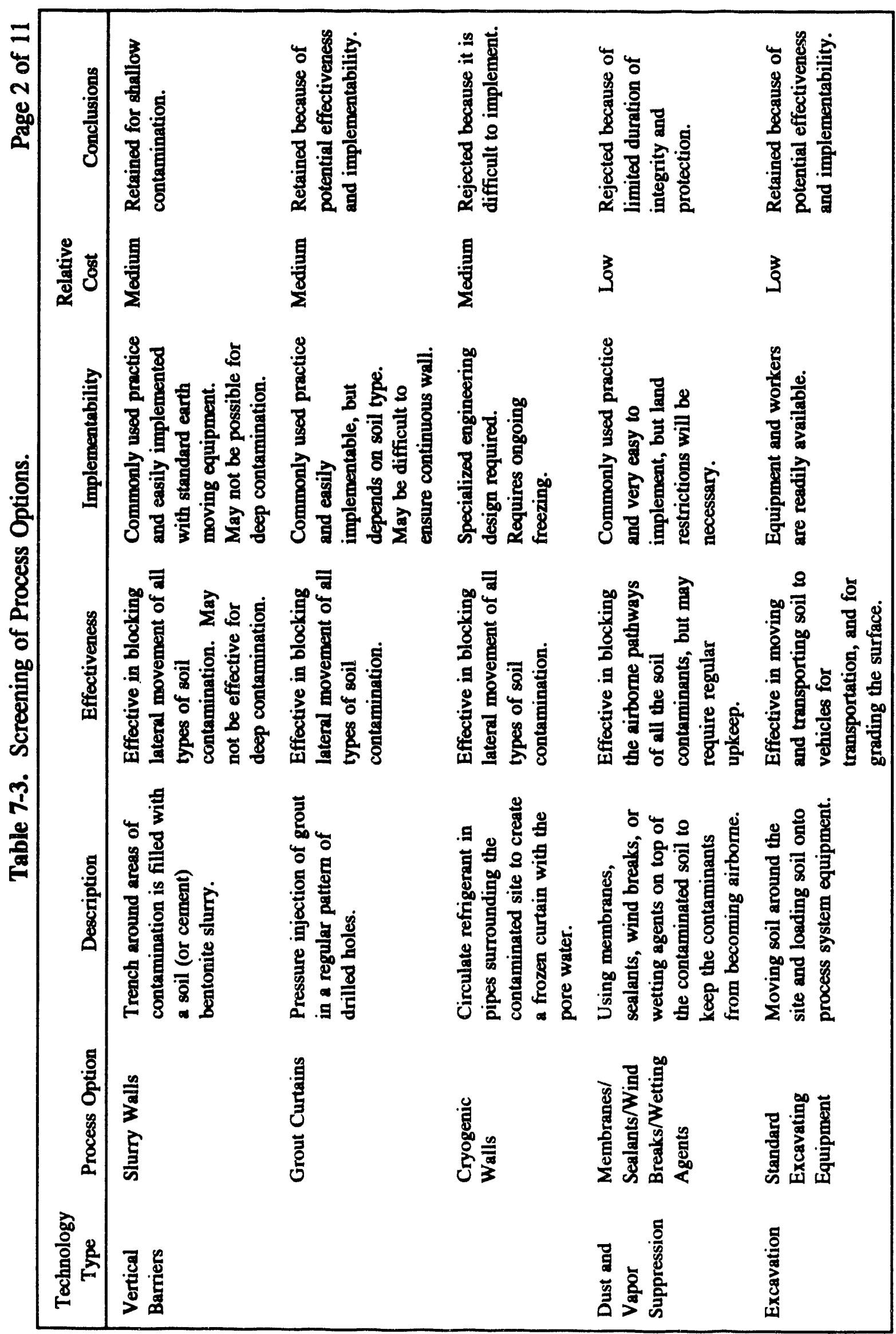


DOE/RL-92-17, Rev. 0

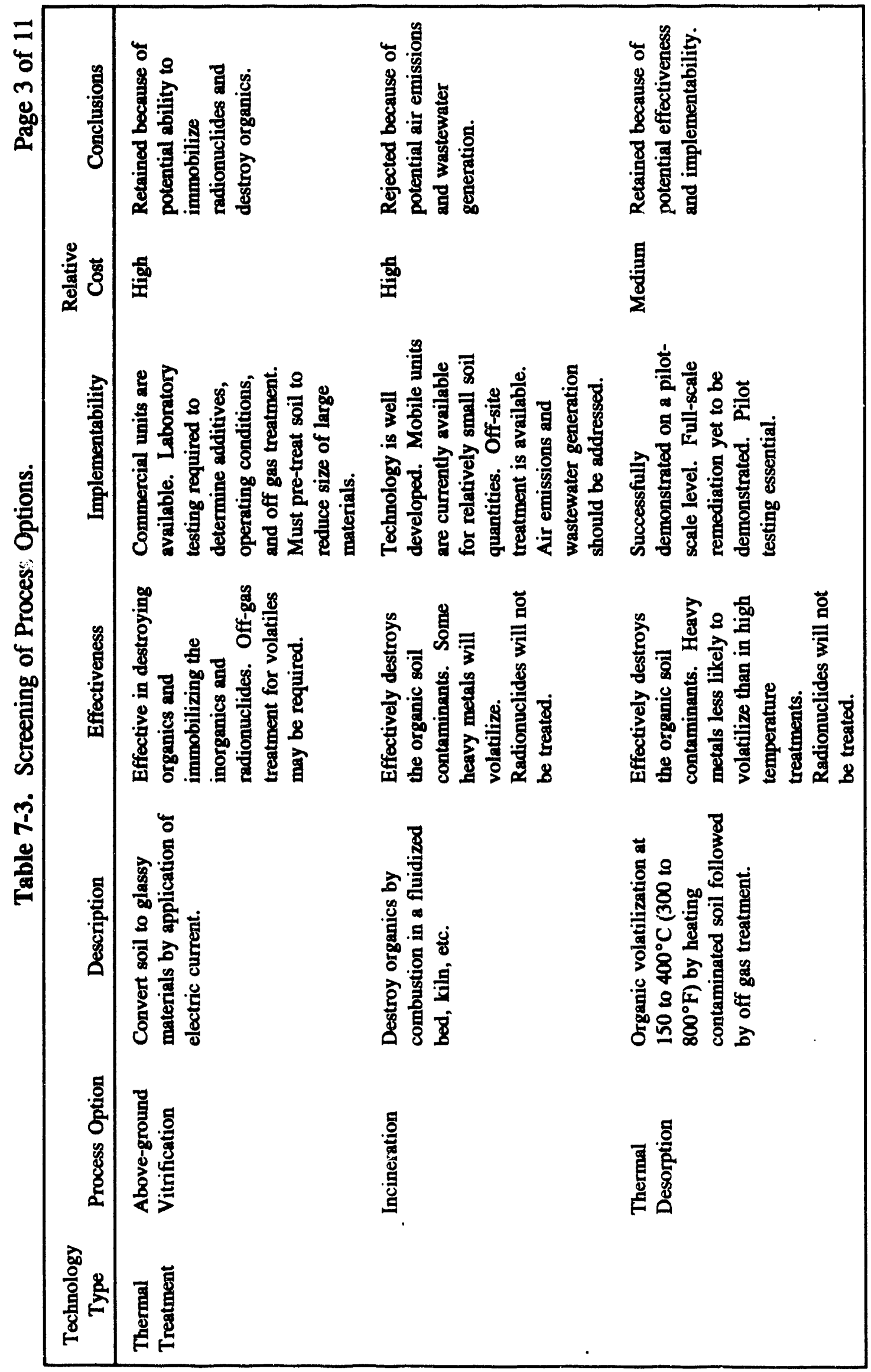


DOE/RL-92-17, Rev. 0

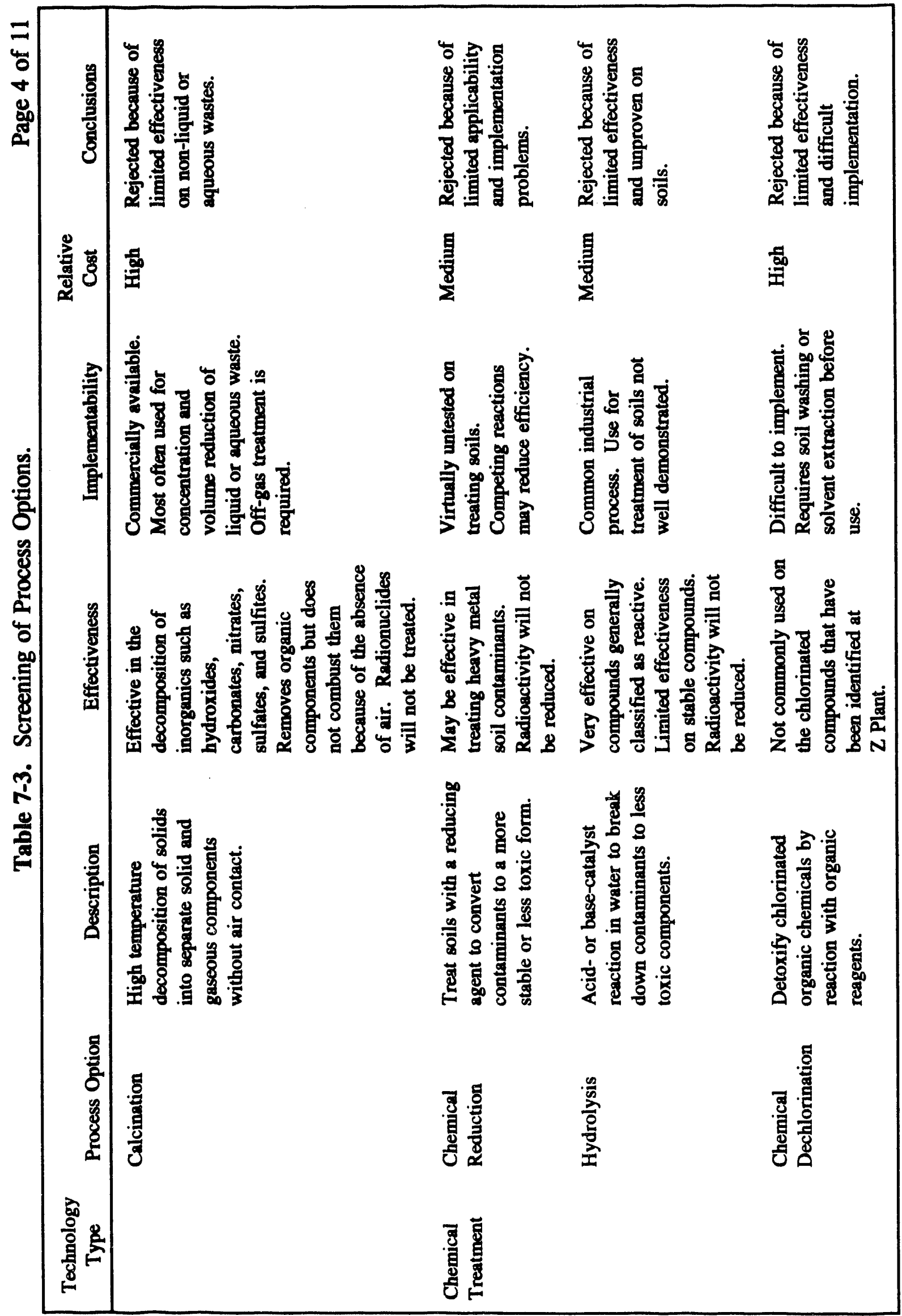


DOE/RL-92-17, Rev. 0

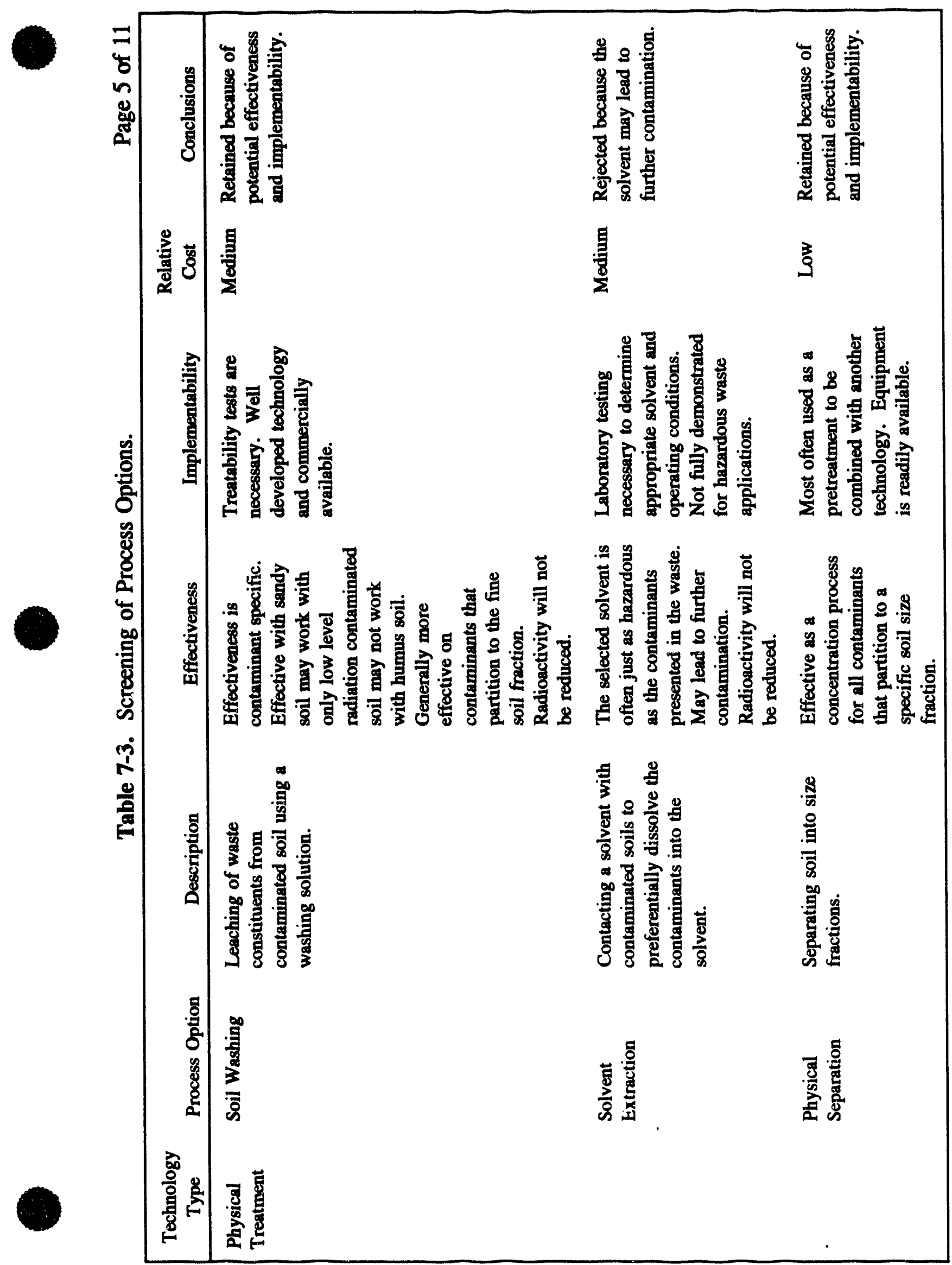


DOE/RL-92-17, Rev. 0

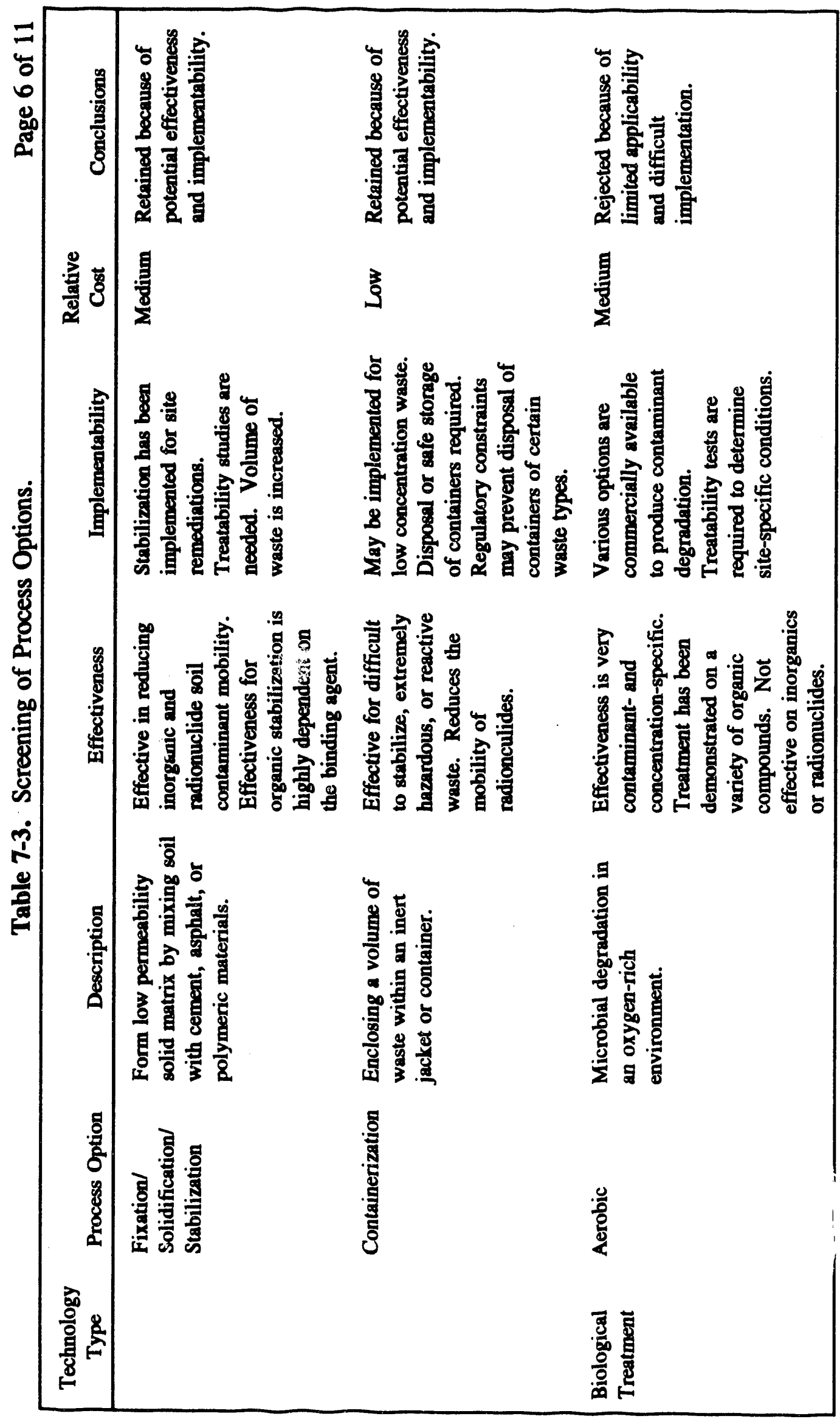


DOE/RL-92-17, Rev. 0

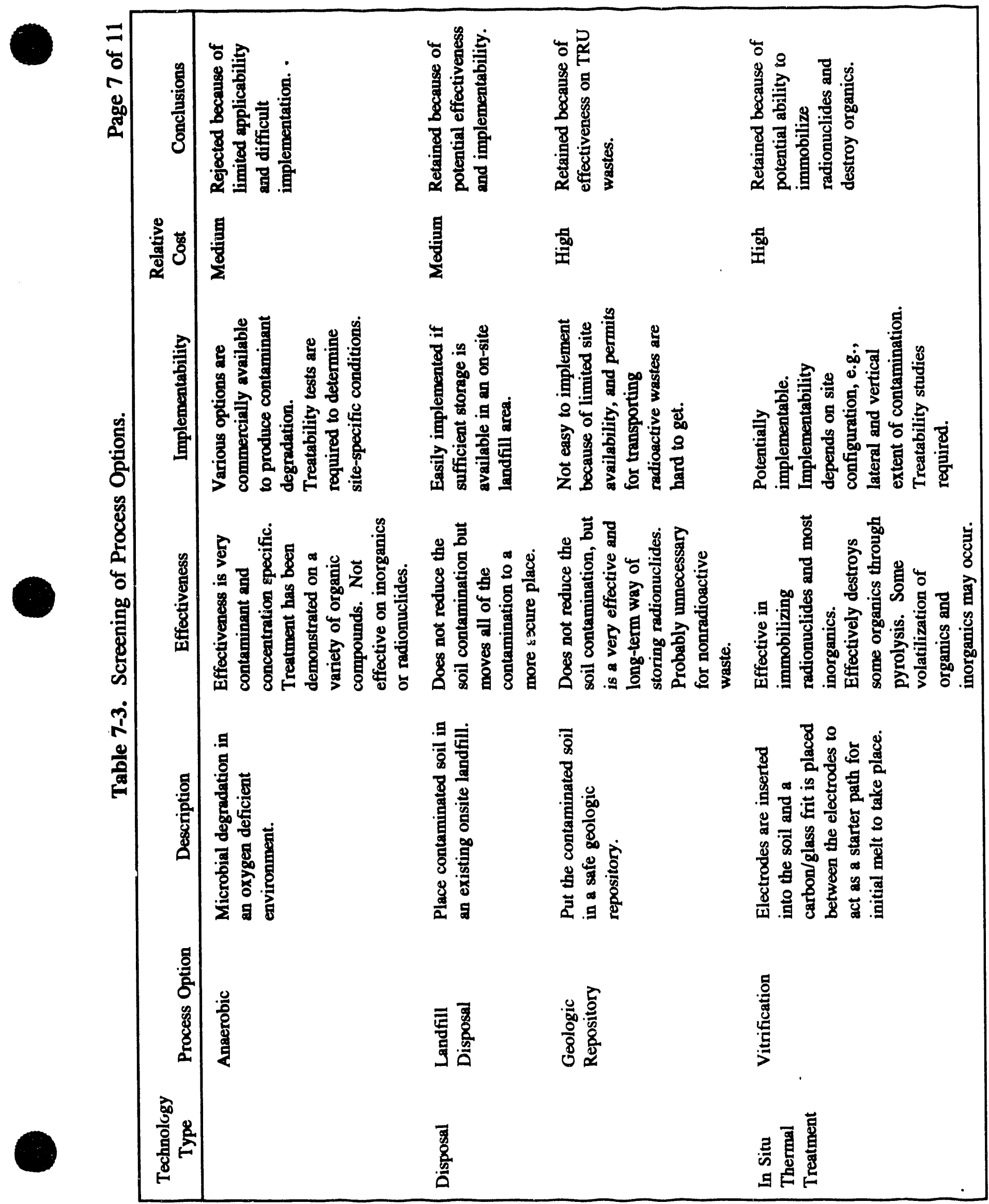


DOE/RL-92-17, Rev. 0

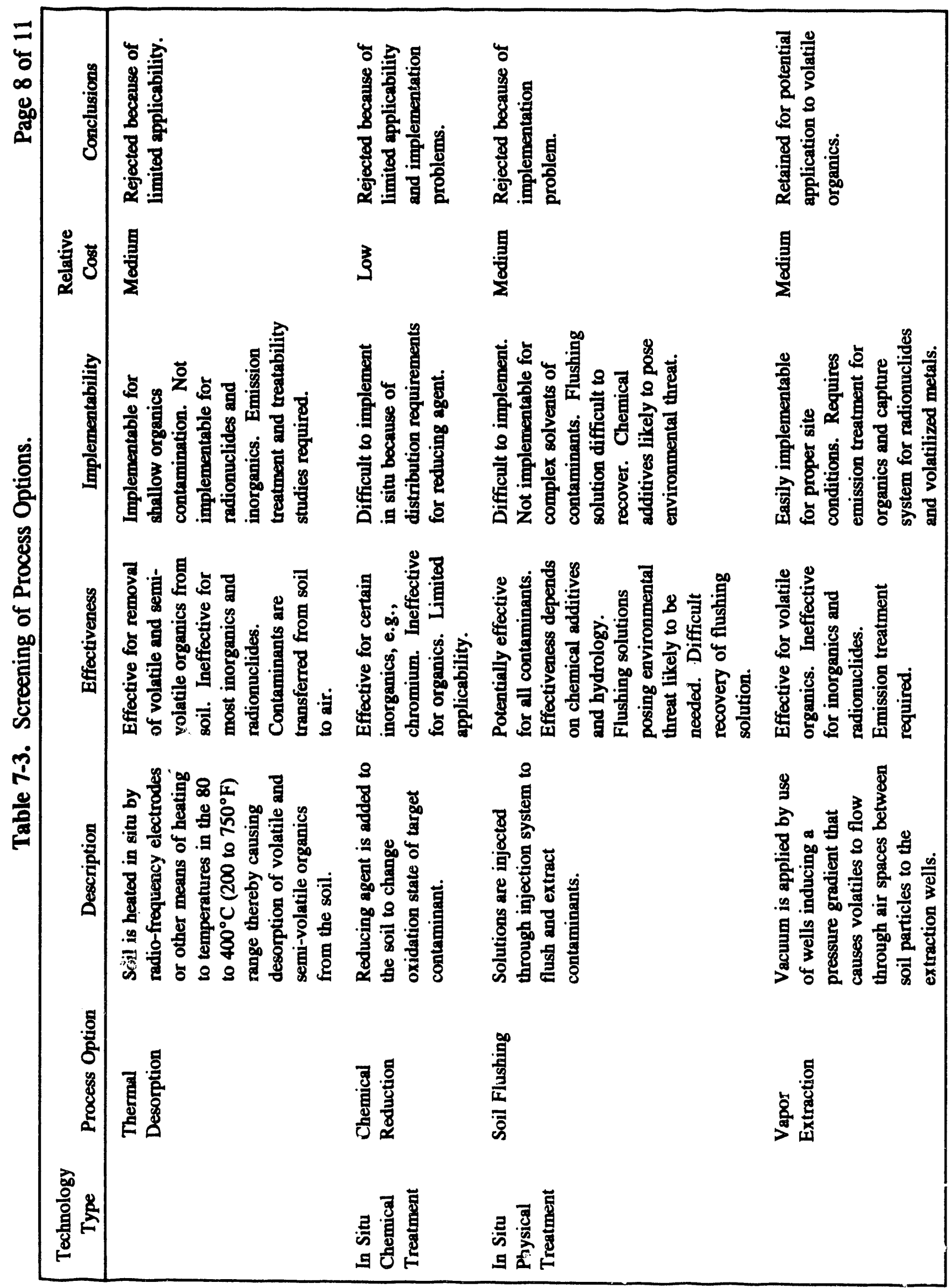


DOE/RL-92-17, Rev. 0

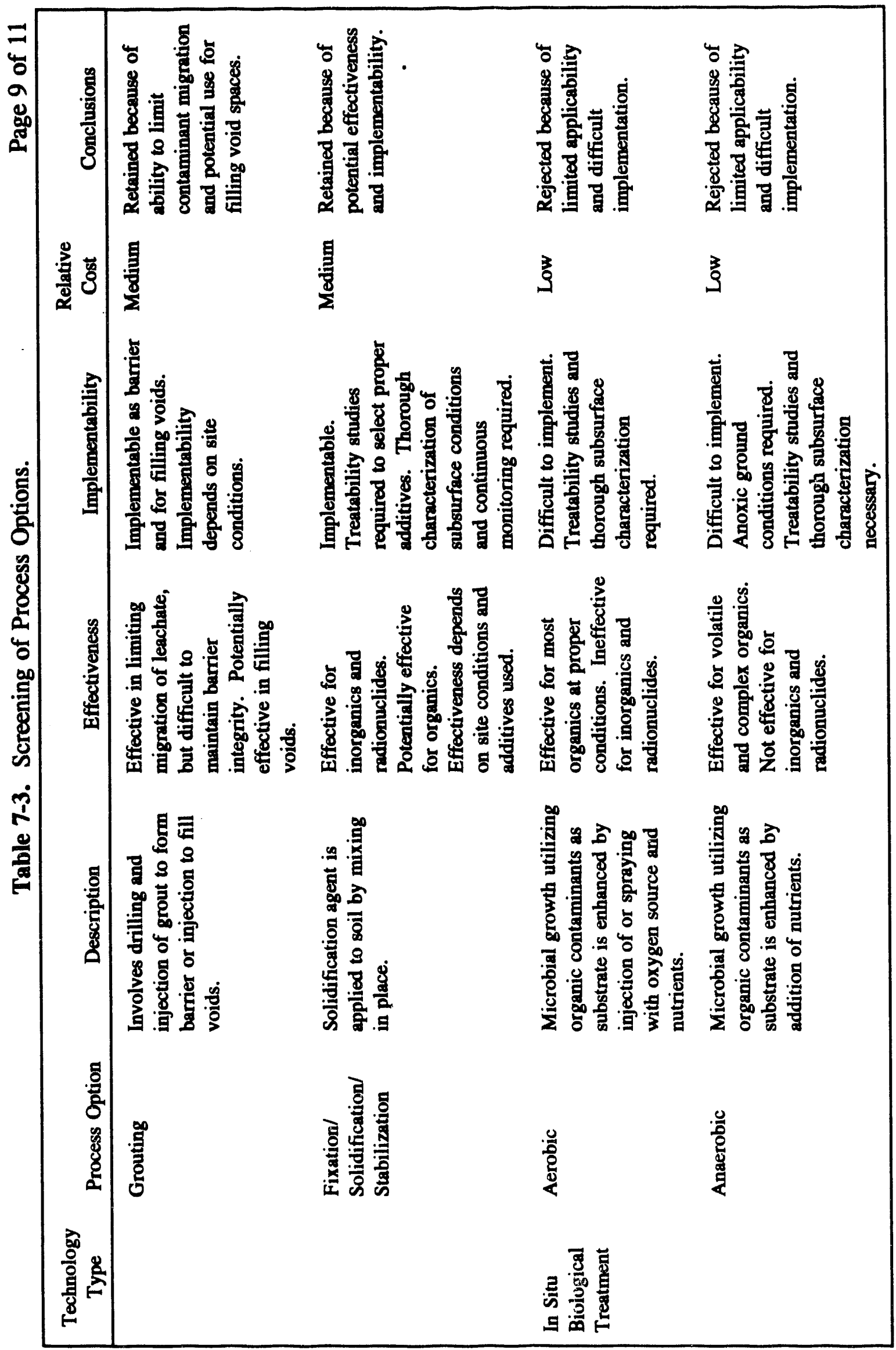


DOE/RL-92-17, Rev. 0

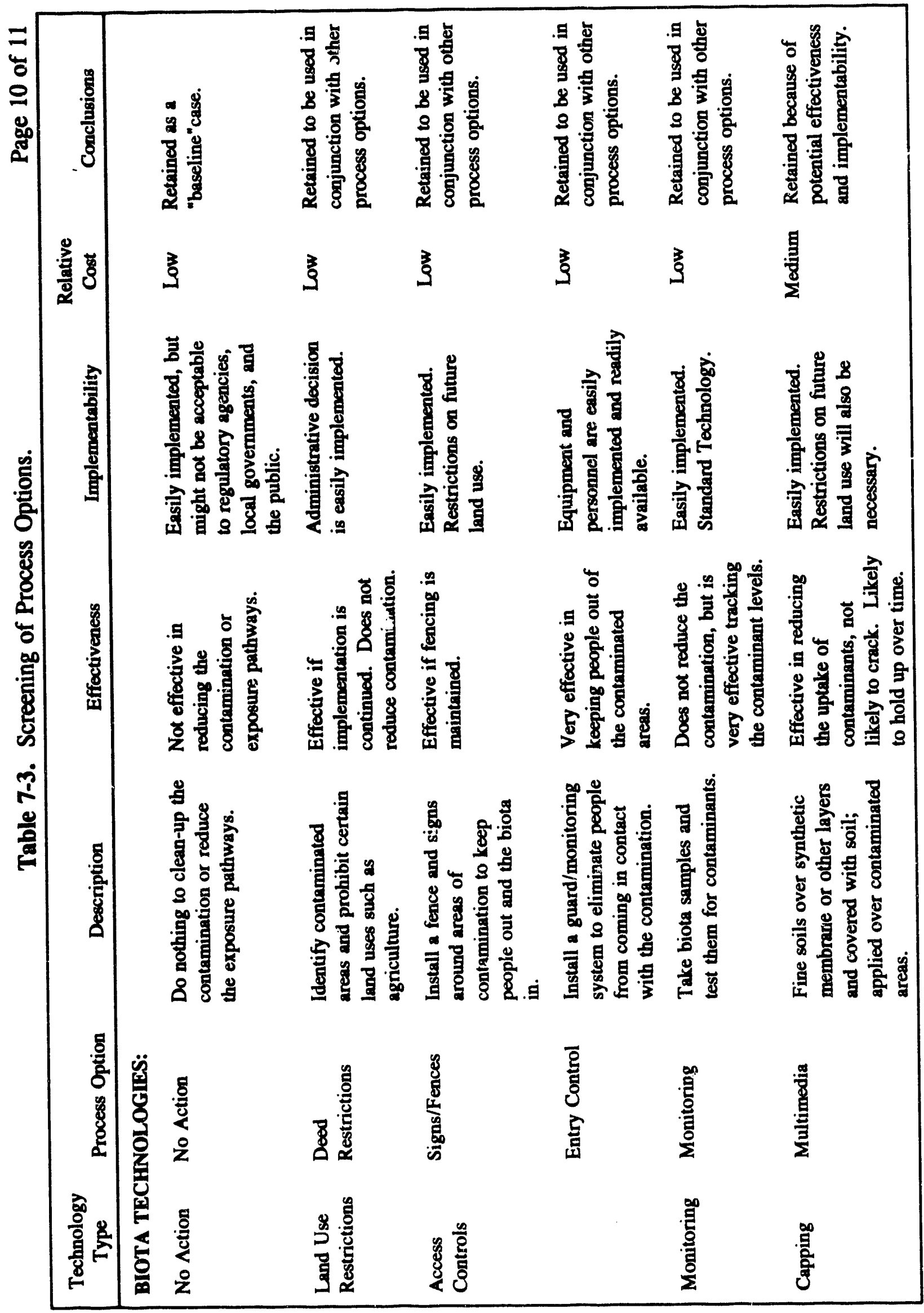


DOE/RL-92-17, Rev. 0

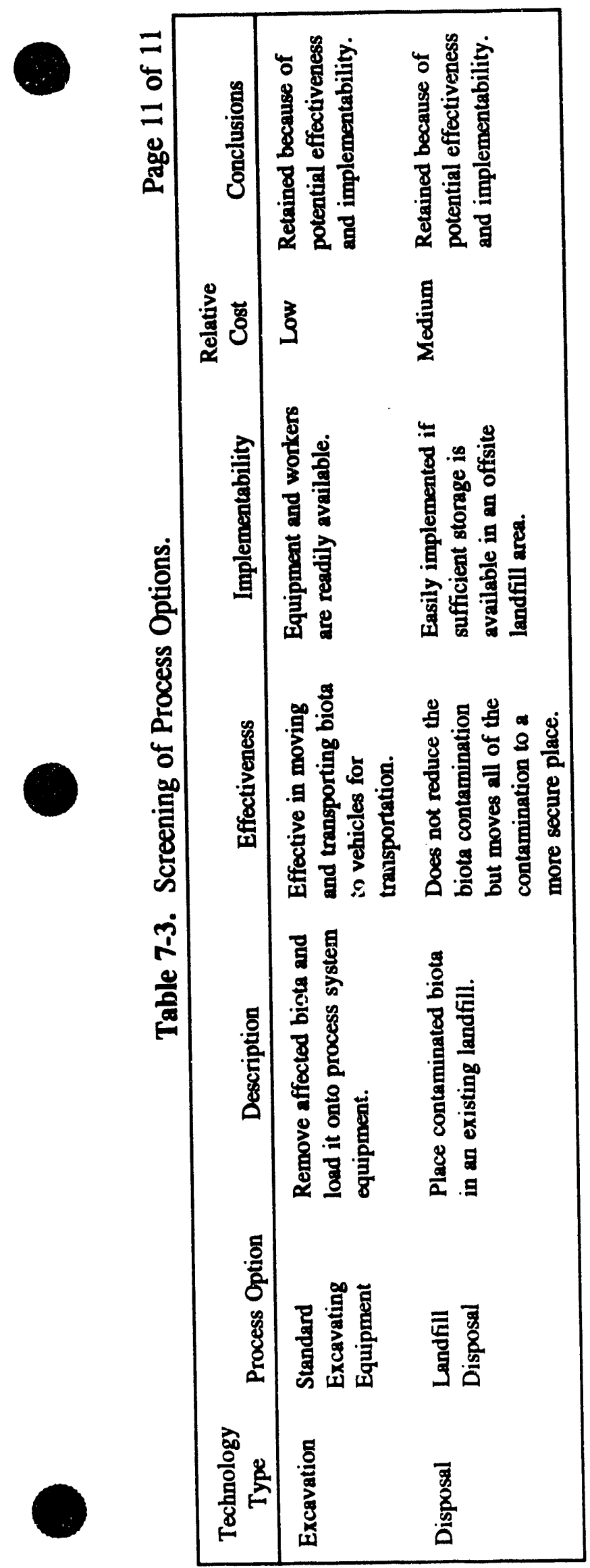


DOE/RL-92-17, Rev. 0

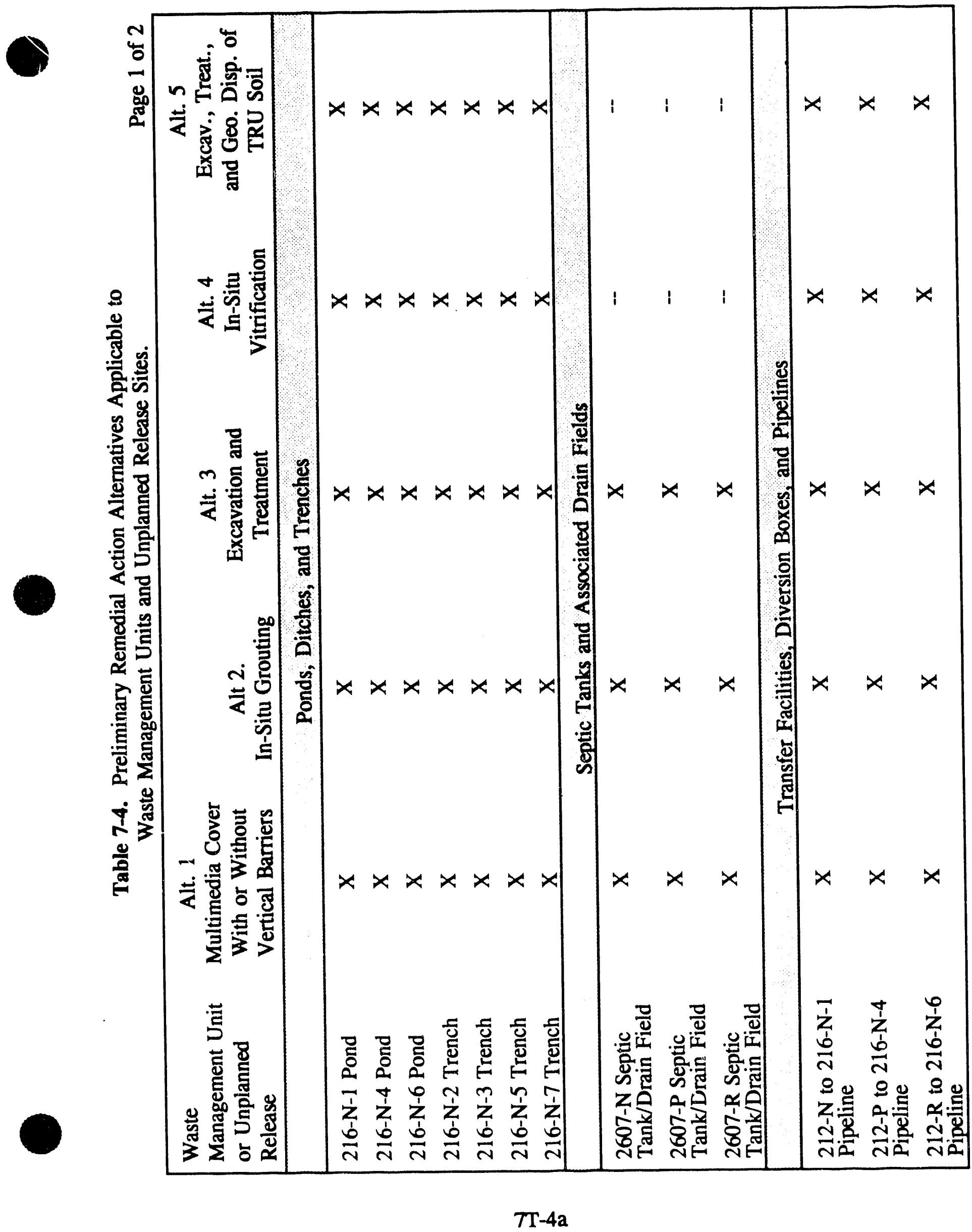


DOE/RL-92-17, Rev. 0

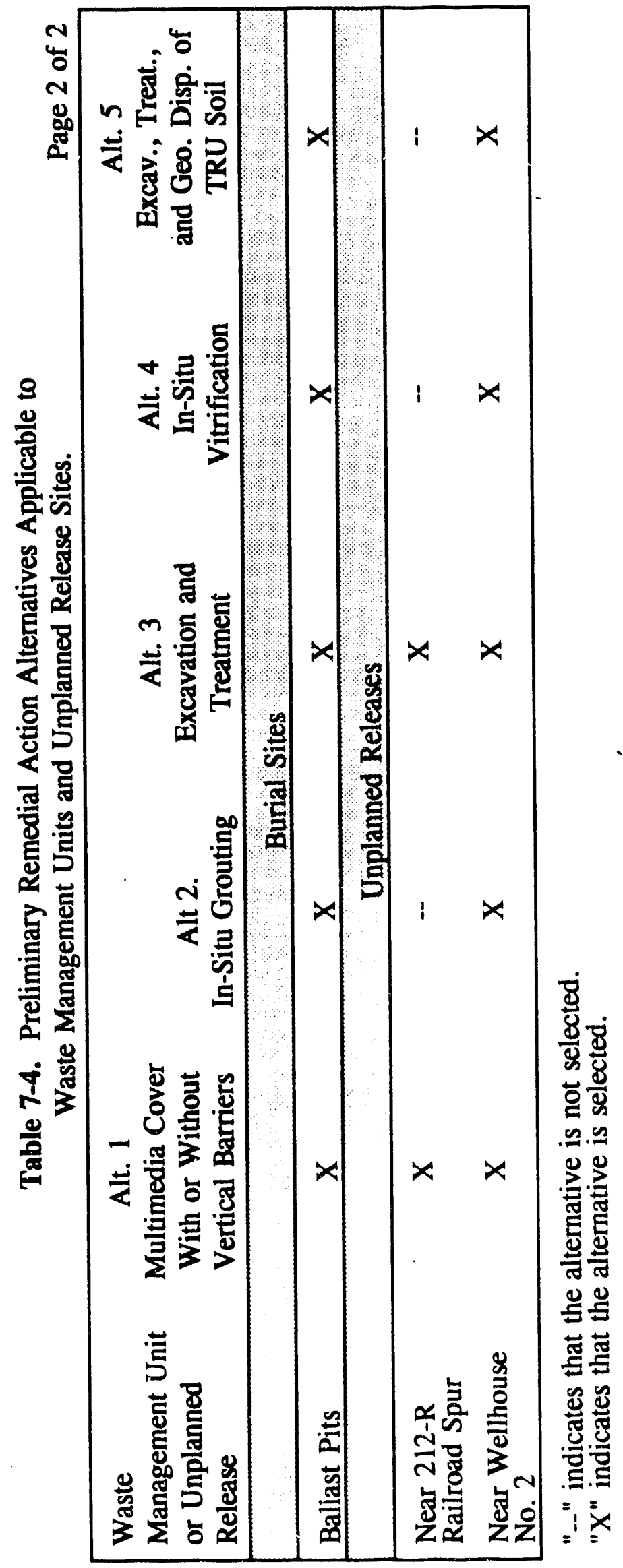




\subsection{DATA QUALITY OBJECTIVES}

As described in Section 1.2.2, this aggregate area management study (AAMS) process, as part of the Hanford Site Past-Practice Strategy (DOE/RL 1992a), is designed to focus the remedial investigation (RI)/feasibility study (FS) process toward comprehensive cleanup or closure of all contaminated areas at the earliest possible date and in the most effective manner. The fundamental principle of the Hanford Site Past-Practice Strategy is a "bias for action" which emphasizes the maximum use of existing data to expedite the RI/FS process as vell as allow decisions about work that can be done at the site early in the process, such as expedited response actions (ERAs), interim rernedial measures (IRMs), limited field investigations (LFIs), and focused feasibility studies (FFS). The data have already been described in previous sections $(2.0,3.0$, and 4.0). Remediation alternatives are described in Section 7.0. However, data, whether existing or newly acquired, can only be used for these purposes if it meets the requirements of data quality as defined by the data quality objective (DQO) process developed by the U.S. Environmental Protection Agency (EPA) for use at Comprehensive Environmental Response, Compensation, and Liability Act (CERCLA) sites (EPA 1987). This section implements the DQO process for this, the scoping phase in the 200 North Aggregate Area.

In the guidance document for DQO development (EPA 1987), the process is described as involving three stages which have been used in the organization of the following sections:

- $\quad$ Stage 1--Identify decision types (Section 8.1)

- $\quad$ Stage 2--Identify data uses and needs (Section 8.2)

- $\quad$ Stage 3--Design a data collection program (Section 8.3).

\subsection{DECISION TYPES (STAGE 1 OF THE DQO PROCESS)}

Stage 1 of the DQO process is undertaken to identify:

- The decision makers (thus, data users) relying on the data to be developed (Section 8.1.1)

- The data available to make these decisions (Section 8.1.2)

- The quality of these available data (Section 8.1.3)

- The conceptual model into which these data must be incorporated (Section 8.1.4)

- The objectives and decisions that must evolve from the data (Section 8.1.5). 
These issues serve to define, from various sides, the types of decisions that will be made on the basis of the 200 North AAMS.

\subsubsection{Data Users}

The data users for the 200 North AAMS and subsequent investigations such as LFIs, RI/FSs, and Resource Conservation and Recovery Act (RCRA) Facility Investigations (RFIs)/Corrective Measures Studies (CMS) are the following:

- The decision makers for policies and strategies on remedial action at the Hanford Site. These are the signatories of the Hanford Federal Facility Agreement and Consent Order (Tri-Party Agreement) (Ecology et al. 1990) including the Washington State Department of Ecology (Ecology) EPA, and the

U.S. Department of Energy (DOE).

Nominally these responsibilities are assigned to the managers of these agencies (the Director of Ecology, the Administrator of EPA, and the Secretary of Energy for DOE), although the political process requires that more local policy-makers (such as the Regional Administrator of EPA and the head of the U.S. Department of Energy, Richland Operations Office (DOE/RL) and, to a great extent, technical and policy-assessment staff of these agencies will have a major say in the decisions to be evolved through this process.

- Unit managers of Westinghouse Hanford and potentially other Hanford Site contractors who will be tasked with implementing remedial activities at the 200 North Aggregate Area. Staff of these contractors will have to make the lower level (tactical) decisions about appropriate scheduling of activities and allocation of resources (funding, personnel, and equipment) to accomplish the recommendations of the AAMS.

- Concerned members of the wide community involved with the Hanford Site. These may include:

- Other state (Washington, Oregon, and other states) and federal agencies

- Affected Indian tribes

- Special interest groups

- The general public.

These groups will be involved in the decision process through the implementation of the Community Relations Plan (Ecology et al. 1989), and will apply their concerns through the "primary" data users, the signatories of the Tri-Party Agreement. 
The needs of these users will have a pivotal role in issues of data quality. Some of this influence is already imposed by the guidance of the Tri-Party Agreement.

\subsubsection{Available Information}

The Hanford Site Past-Practice Strategy specifies a "bias for action" which intends to make the maximal use of existing data on an initial basis for decisions about remediation. This emphasis can only be implemented if the existing data are adequate for the purpose.

Available data for the 200 North Aggregate Area are presented in Sections 2.0, 3.0, and 4.0 and in Topical Reports prepared for this study. As described in Section 1.2.2, these data should address several issues:

- Issue 1: Facility and process descriptions and operational histories for waste sources (Sections 2.2, 2.3, and 2.4)

- Issue 2: Waste disposal records defining dates of disposal, waste types and waste quantities (Section 2.3)

- Issue 3: Sampling events of waste effluents and affected media (Section 4.1)

- Issue 4: Site conditions including the site physiography, topography, geology, hydrology, meteorology, ecology, demography, and archaeology (Section 3.0)

- Issue 5: Environmental monitoring data for affected media including air, surface water, sediment, soil, groundwater and biota (Section 4.1, except that groundwater data is presented in the separate 200 East Groundwater Aggregate Area Management Study Report, AAMSR).

A major requirement for adequate characterization of many of these issues is identification of chemical and radiological constituents associated with the sites, with a view to determine the contaminants of concern there and the extent of their distribution in the soils beneath each of the waste management units in the 200 North Aggregate Area. There was found to be a limited amount of data in this regard The environmental surveillance program conducted in the 200 East and 200 West areas did not include sampling locations in the 200 North Aggregate Area until 1990. The data reported for the various waste management units in the 200 North Aggregate Area (see Section 4.1 and Tables 4-1, 4-2, and 4-5) have been found to describe:

- Inventory: generally estimated from chemical process data and emphasizing radionuclides (Issues 1 and 2). These data are especially limited regarding reconstruction of early operations activities, and even the most recent data are based on very few sampling events, possibly non-representative of the long-term activity of the waste management units. 
- Surface radiological surveys: undifferentiated radiation levels, without identification of radionuclides present, presented in terms of extent of radiation and maximal levels (Issue 5). These historical data are extremely difficult to relate to the present-day distribution and nature of the radioactive contamination they purport to measure because of the lack of radionuclide identification and the likelihood that changes have occurred (at least to surface soils) since the time of the surveys. In addition, surface radiological surveys have been conducted at only a few locations in the 200 North Aggregate Area.

- External radiation monitoring: similar to the surface radiological surveys but provide even less information because with a fixed-point thermoluminescent dosimeter (TLD) no spatial distribution is provided. The TLD data do not dilferentiate radionuclide species. External radiation monitoring data do not exist for the 200 North Aggregate Area. The nearest TLD monitoring location is approximately $2 \mathrm{~km}$ ( 1 mile) away on the western shore of West Lake. Data from this location are provided in Tables 4-3 and 4-4.

- Waste, soil, or sediment sampling: Surface soil sainpling has been conducted in the 200 North Aggregate Area since 1990 as a part of the environmental surveillance program (Schmidt et al. 1991). Two sampling locations of the environmental surveillance program are within the aggregate area at the 216-N-1 and 216-N-6 Ponds. The quality of these data is apparently good. However, the limited extent of this sampling and the limited time period prevents it from being used for a determination of the present-day distribution of contamination.

Additional sampling is needed to confirm the initial results and to characterize the areas that are not included in the sampling program.

- Biota sampling: at the 216-N-1 Pond site. These data could assist assessment of bio-uptake and transfer pathways from this unit (Issue 5).

- Borehole geophysics--these data do not exist for the 200 North Aggregate Area (Chamness et al. 1992a). This information is used to characterize those units which discharged liquid waste to the soil column. Its purpose is to detect the presence of radionuclides (by their gamma-ray radiation) in the subsurface and to indicate whether these materials are migrating vertically (Issue 5). These data are limited by the method's inability to identify specific radionuclides and, thus, to differentiate naturally occurring radioactive materials from possible releases. Variation in quality control further limit their comparability and possible use for estimation of concentrations.

Besides these historic data, additional borehole geophysical data will be available through the Radionuclide Logging System (RLS), being carried out at the time of this report and in support of the AAMS process. Like the previous (gross gamma) logging conducted at waste management units in the other aggregate areas, the RLS depends on gamma rays and cannot detect some species of 
radionuclides. However, unlike the gross gamma surveys, the RLS is designed to identify individual radionuclide species through their characteristic gamma ray photon energy levels. It should thus be able to differentiate naturally-occurring radionuclides from those resulting from releases. It will also (like gross gamma logging) determine the vertical extent of the presence of the radionuclides. This program will not provide data that will be directly applicable to the 200 North Aggregate Area. However, it will provide data for similar waste management units in other Aggregate Areas that will provide some guidance in understanding the likely patterns for contamination movements in the 200 North Aggregate Area.

Based on the above summary, the data are considered to be quite limited and of varying quality. These data have not been validated, a process generally required for risk assessment or final Record of Decision (ROD) purposes. Most of the data are based on field methods, which are generally applicable only for screening purposes and can be used to focus future activities (e.g., sampling and analysis plans).

They are considered to be deficient in one or more of the following ways:

- The quantity of data are lacking. The 200 North Aggregate Area has not been included in programs that have provided data for other aggregate areas.

- Methods which have been used in the past are unable to differentiate the various radionuclides which may have been present at the time of the survey.

- The release locations have been changed (especially by remediation activities) since the time of the survey or sampling, and it is likely that contaminant distributions have changed.

- The survey or sampling has been done at a location different from the waste management unit or release, and so would not be representative of the concentrations in the zone of release. This deficiency applies to horizontal and vertical differences in location: the borehole geophysics data may be at the correct depths, but the distance of the borehole from the waste management unit can severely attenuate the gamma-radiation that is used to indicate contamination; surface sampling and surveys similarly cannot establish subsurface contaminant concentrations or even disprove the possible presence of some radioactive constituents (particularly alpha-emitting transuranic elements).

- There has been virtually no measurement of non-radioactive hazardous constituents in the sampling and analysis of media in the 200 North Aggregate Area. 
As a result of these deficiencies, the data are not considered to be usable for input to a quantitative risk assessment or for comparison to ARARs. Further discussion of the data qualities is provided in Section 8.1.3.

In addition to these data, there are also data regarding site conditions (Issue 2) which do not directly relate to the presence of environmental releases but which will assist in the assessment of their potential migration if present. These data are generally summarized in the Topical Reports prepared for this AAMS. These include the following:

- Geologic Setting of the 200 East Area: An Update (Lindsey et al. 1992) includes descriptions of regional stratigraphy, structural geology, and local (200 North Area) stratigraphy, with revised structure and isopach maps of the various unconsolidated strata found beneath the 200 North Aggregate Area.

- 200 North Geologic and Geophysics Data Package for the 200 Aggregate Area Management Study (Chamness et al. 1992a) contains tables of wells in which borehole geophysics have been conducted, the types and dates of the tests, and a reference to indicate the physical location of the logs. The package also includes a list of the data available from the drilling of each well located in the 200 North Aggregate Area, such as the logs available (driller's or geologist's; indication of their physical location; grain size, carbonate, moisture, and chemical/radiological analyses; lists of depths, dates, elevation, and coordinates for all wells); and copies of the boring logs and well completion (as-built) summaries for a selection of wells in the 200 North Aggregate Area.

The data in these topical report and others was obtained for the AAMS study based on a review of driller's and geologist's logs for wells drilled in the 200 Areas. A selection of those logs was made which best represented the geologic structures below the 200 North Aggregate Area and are presented in Chamness et al. (1992a). Lindsey et al. (1992) then used these wells (and others from other aggregate areas) to develop cross-sections, structure maps, and isopach maps, which were in turn adapted to the specific needs of this report and presented in Section 3.0. Only existing logs were used; no new wells were drilled as part of this study. The quality of the data varies among the logs according to the time they were drilled and the scope of the study they were supporting, but the data are sufficient for the general geological characterization of the site. Issues involving the potential of contaminant migration at specific sites, based on stratigraphic concerns, may not be fully addressed through any existing borings or wells because appropriate borings may not be located in close proximity; these issues should be addressed during subsequent field investigations at locations where contaminant migration is considered likely.

Another class of data which was gathered in the general area of the 200 West Area, and is potentially appropriate to the 200 North Aggregate Area, is the result of a set of studies which were performed for the Basalt Wrisste Isolation Project (BWIP) (DOE 1988b), in the attempt to site a high-level radioactive waste geologic repository in the basalt beneath and in the vicinity of the. Hanford Site. The proposed Reference Repository Site included the 
200 West Area and some distance beyond it, mainly to the west. For this siting project, a number of geologic techniques were used, and some of the data generated by the drilling program has been used for the stratigraphic interpretation presented in Section 3.4 (all the wells denoted with an alias "BH-.." were drilled for the BWIP project) and a number of the figures used in this and other sections of Section 3.0. The program also included a number of geophysical studies, using the following techniques:

- Gravity

- Magnetics

- Seisınic reflection

- Seismic refraction

- Magnetotellurics.

These data, as presented in Section 1.3.2.2.3 of DOE (1988b), were reviewed for their relevance to the present 200 North (source area) AAMS. The limitations of these studies include the following aspects:

- Most of the studies covered a regional scale with lines or coverages that may have crossed the 200 North Aggregate Area only in passing.

- Many of the techniques are more sensitive to the basalt than to the suprabasalt sediments of specific interest in the AAMS program, and even less sensitive to the features which are closer to the surface, as is applicable to the source area AAMS. Basalt is by nature much denser than the unconsolidated sediments (and thus also has a characteristic seismic signature) and has more consistent magnetic properties. In addition, the analysis of the data emphasized the basalt features which were apparent in the data. All this is appropriate to a study of the basalt, but does not make the studies applicable to the current study.

- Even when features potentially caused by shallow sediments are identified, they are interpreted either very generally (e.g., "erosional features in the Hanford and (or) Ringold Formations") or as complications (e.g., "shallow sediment velocity variations causing stacking velocity correction errors"). There are only a very few features (and none in the 200 North Aggregate Area) which are interpreted as descriptive of the structure of the suprabasalt sediments.

- Lastly, some of the anomalies which are interpreted in terms of a sedimentary stratigraphic cause (e.g., "erosion of Middle Ringold") do not bear up under the more detailed stratigraphic interpretation carried out under the Topical Reports for the AAMS (Lindsey et al. 1992; Chamness et al. 1992). 
However, these data will be reviewed in more detail for the purposes of the 200 East Groundwater AAMSR, since deeper features (including those in the basalt) are of more concern for that study.

Other data presented in Sections 2.0, 3.0, and 4.0 are broad-scale rather than sitespecific, such as contaminant concentrations. These include topography, meteorology, surface hydrology, environmental resources, human resources, and contaminant characteristics. These data are generally of acceptable quality for the purposes of planning remedial actions in the 200 North Aggregate Area.

\subsubsection{Evaluation of Available Data}

The EPA (1987) has specified indicators of data quality, the five "PARCC" parameters (precision, accuracy, representativeness, completeness, and comparability), which can be used to evaluate the existing data and to specify requirements for future data collection.

- Precision: the reproducibility of the data

- Accuracy: the lack of a bias in the data.

Much of the existing data are of limited precision and accuracy due to the analytical methods which have been used historically. The gross gamma borehole geophysical logging in particular is limited by methodological problems although reproducibility has been generally observed in the data. Conditions that have contributed to lack of precision and/or accuracy include: improvements in analytical instrumentation and methodology making older data incompatible; effects of background levels (particularly regarding radioactivity and inorganics); and lack of quality control on data acquisition.

The limitations in precision and accuracy in existing data are mainly due to the progress of analytical methodologies and quality assurance (QA) procedures since the time they were collected. The Hanford Site Past-Practice Strategy (DOE/RL 1992a) recommends that existing data be used to the maximum extent possible, at two levels: first to formulate the conceptual model, conduct a qualitative risk assessment, and prepare work plans, but also as an initial data set which can be the basis for a fully-qualified data set through a process of review, evaluation, and confirmation.

- Representativeness: the degree to which the appropriate environmental parameters or media have been sampled.

This parameter highlights a shortcoming of most of the historical data. Some discussion of representativeness limitations is presented in Section 8.1.2. Limitations include the observation only of gross gamma radiation rather than 
differentiating it by radionuclide (e.g., through spectral surveying methods as are being used by the RLS program), the analysis of samples only for radionuclides rather than for chemicals and radionuclides, and the failure to sample (especially in the subsurface) for the full potential extent of contaminant migration.

The data are incomplete primarily because of the lack of subsurface sampling for the extent of contamination. This is because no subsurface investigation has been initiated on the waste management units in the 200 North Aggregate Area yet. The lack of these data is also caused by concerns to limit the potential exposure to radioactivity of workers who would have to drill in contaminated areas and the possible release or spread of contamination through these intrusive procedures. The result of this data gap is that none of the sites can be demonstrated to have contamination either above or below levels of regulatory concern, and a full quantitative risk assessment carınot be conducted.

In addition, in many cases it has been necessary to use general data (i.e., from the 200 East Area, from the 200 West Area, or even from the 600 Area) rather than data specific to a particular waste management unit. For most purposes of characterization for transport mechanisms, this procedure is acceptable given the screening level of the present study. For example, while it is appropriate to use a limited number of boring logs to characterize the stratigraphy in the Aggregate Area (Chamness et al. 1992 \& 1992a, Lindsey et al. 1992), the later, waste management unit specific, field sampling plans will require detailed consideration of more of the logs of boreholes drilled in the immediate vicinity, whatever their quality, as a starting point to conceptually model the geology specifically beneath that unit.

- Completeness: the fraction of samples which are considered "valid."

None of the data that have been previously gathered in the 200 North Aggregate Area has been "validated" in the EPA Contract Laboratory Program (CLP) sense, although varying levels of quality control have been applied to the sampling and analysis procedures. The data are generally adequate for characterization purposes, but may not be suitable for use in a formal risk assessment. The best indication of the validity of the data is the reproducibility of the results, at least as far as precision is concerned (accuracy requires proof of a lack of bias). This indicates that validity (completeness) is one of the less significant problems with the data.

- Comparability: the confidence that can be placed in the comparison to two data sets (e.g., separate samplings).

With varying levels of quality control and varying procedures for sample acquisition and analysis, this parameter is also generally poorly met. Much of this is due to the more recent development of QA procedures. 
While these limitations cannot in most cases be quantified (and some such as representativiness are specifically only qualitative), most of the data gathered in the 200 North A.ggregate Area can be cited as failing one or more of the PARCC parameters. As discussed in Section 8.1.2, the data are considered to be mainly deficient in completeness (the appropriate media, constituents, or locations were never sampled or analyzed). These data should, however, be used to the maximum extent in the development of work plans for site field investigations, prioritization of the various units, and to determine, to the extent possible, where contamination is or is not present.

In addition to these site-specific data, there are also a limited number of non sitespecific sampling events that are being developed to determine background levels of naturally occurring constituents (Hoover and LeGore 1991). These data can be used to differentiate the effect of the environmental releases from naturally occurring background levels.

\subsubsection{Conceptual Model}

The initial conceptual model of the waste management units in the 200 North Aggregate Area is presented and described in Section 4.2 (Figure 4-3). The model is based on best estimates of where contaminants were discharged and their potential for migration from release points. The conceptual model is designed to be conservatively inclusive in the face of a lack of data. This means that a migration pathway was included if there is any possibility of contamination travelling on it, historically or at present. In most cases there may not be a significant flux of such contamination migration for many of the pathways shown on the figure.

The pathways from the trenches and ponds leading to adsorption of transuranic elements on vadose-zone soils are significant. Specifically, the 216-N-2, 216-N-3, 216-N-5, and 216-N-7 trenches and the 216-N-1,216-N-4, and 216-N-6 ponds are of particular concern. These waste management units exceeded their specific retention capacity by a large amount. These and other pathways can be traced on the conceptual model. All are possible; only a few are likely because of the conservatism inherent in including all conceivable pathways. More importantly, even if a pathway carries significant levels of a contaminant, it still may not have carried contamination to the ultimate receptors, human or ecological. This can only be assessed by sampling at the exposure point on this pathway, or sampling at some other point and extrapolation to the exposure point, to indicate the dosage to the receptors.

There are significant uncertainties in the contaminant levels in the contaminant migration pathways shown on the conceptual model, yet none of these pathways has been sampled to determine whether any contamination still exists in any of the locations implicated from the conceptual model, and if so which constituents, how much, and to what extent. 


\subsubsection{Aggregate Area Management Study Objectives and Decisions}

The specific objectives of the 200 North AAMS are listed in Section 1.3. They include the following:

- $\quad$ Assemble site data (as described in Section 8.1.2)

- Describe site conditions (see Section 3.0)

- Conduct limited new site characterization work (see separate topical reports)

- $\quad$ Develop a preliminary site conceptual model (see Section 8.1.4)

- Identify contaminants of concern and their distribution (Section 4.0)

- Identify potential ARARs (Section 6.0)

- Define preliminary remedial action objectives and screen potential remedial technologies to prepare preliminary remedial action alternatives (Section 7.0), and provide recommendations for FFS (Section 9.4.1) and treatability studies (Section 9.5)

- Define data needs, establish general DQOs, and set priorities

- $\quad$ Recommend ERA, IRM, LFI, or other actions (Section 9.0)

- Redefine and prioritize, as data allow, operable units, their boundaries, and work plan activities with emphasis on supporting early cleanup actions and records of decision (Sections 8.3 and 9.0).

The decisions that will have to be made on the basis of this AAMS can best be described according to the Hanford Site Past-Practice Strategy (DOE/RL 1992a) flow chart (Figure 1-2 in Section 1.0) that must be conducted on a site-by-site basis. Decisions are shown on the flow chart as diamond-shaped boxes, and include the following:

- Is an ERA justified?

- Is less than six months response needed (is the ERA time critical)?

- Are data sufficient to formulate the conceptual model and perform a qualitative risk assessment?

- Is an IRM justified?

- Can the remedy be selected? 
- Can additional required data be obtained by LFI?

- Are data (from field investigations) sufficient to perform risk assessment?

- Can an Operable Unit/Aggregate Area ROD be issued?

(The last two questions will only be asked after additional data are obtained through field investigations, and so are DQO issues only in assessing scoping for those investigations.)

Most of these decisions are actually a complicated mixture of many smaller questions, and will be addressed in Section 9.0 in a more detailed flowchart for assessing the need for remediation or investigation.

Similarly, the tasks that will need to be performed after the AAMS that drive the data needs for the study are found in the rectangular boxes on the flow chart. These include the following:

- ERA (if justified)

- Definition of threshold contamination levels, and formulation of conceptual model, performance of qualitative risk assessment and FS screening (IRM preliminaries)

- FFS for IRM selection

- Determination of minimum data requirements for IRM path

- Negotiation of Scope of Work, relative priority, and incorporation into integrated schedule, performance of LFI

- Determination of minimum data needs for risk assessment and final Remedy Selection (preparation of RI/FS pathway).

These stages of the investigation must be considered in assessing data needs (Section 8.2.2). 


\subsection{DATA USES AND NEEDS (STAGE 2 OF THE DQO PROCESS)}

Stage 2 of the DQO development process (EPA 1987) defines data uses and specifies the types of data needed to meet the project objectives. These data uses and needs are based on the Stage 1 results, but must be more specific. The elements of this stage of the DQO process include:

- Identifying data uses (Section 8.2.1)

- Identifying data types (Section 8.2.2.1)

- Identifying data quality needs (Section 8.2 .2 .2 )

- Identifying data quantity needs (Section 8.2.2.3)

- $\quad$ Evaluating sampling/analysis options (Section 8.2.2.4)

- $\quad$ Reviewing data quality parameters (Section 8.2.2.5)

- $\quad$ Summarizing data gaps (Section 8.2.3).

Stage 2 is developed on the basis of the conceptual model and the project objectives. These following sections discuss these issues in greater detail.

\subsubsection{Data Uses}

For the purposes of the remediation in the 200 North Aggregate Area, most data uses fall into one or more of four general categories:

- $\quad$ Site characterization

- Public health evaluation and human health and ecological risk assessments

- Evaluation of remedial action alternatives

- Worker health and safety.

Site characterization refers to a process that includes determination and evaluation of the physical and chemical properties of any wastes and contaminated media present at a site, and an evaluation of the nature and extent of contamination. This process normally involves the collection of basic geologic, hydrologic, and meteorologic data but more importantly for the 200 North Aggregate Area waste management units, data on specific contaminants and sources that can be incorporated into the conceptual model to indicate the relative significance of the various pathways. Site characterization is not an end in itself, as stressed 
in the Hanford Site Past-Practice Straiegy (DOE/RL 1992a), but rather the data must work toward the ultimate objectives of assessing the need for remediation (according to risk assessment methods, either qualitative or quantitative, or compliance with ARARs) and providing appropriate means of remediation (through an FFS, FS, or CMS). The understanding of the site characterization, based on existing data, is presented in Sections 2.0,3.0, and 4.0, and summarized in the conceptual model (Section 4.2).

Data required to conduct a public health evaluation, and human health and ecological risk assessments at the sites in the 200 North Aggregate Area include the following: input parameters for various performance assessment models (e.g., the Multimedia Environmental Pollutant Assessment System); site characteristics; and contaminant data required to evaluate the threat to public and environmental health and welfare through exposure to the various media. These needs usually overlap with site characterization needs. An extensive discussion of risk assessment data uses and needs, for both human health and ecological evaluations, is presented in the Risk Assessment Guidance for Superfund, Volumes 1 and 2 (EPA 1989a). The EPA Region 10 has also developed its preferred methodology for these assessment activities (EPA 1989a, 1991a). The ecological and human health risk assessments will follow the guidance outlined in the approved M-29-03 milestone document, Hanford Site Baseline Risk Assessment Methodology (DOE/RL 1992b). The data requirements for an ecological risk assessment include (1) identification of critical species, (2) identification of habitat within and surrounding the Hanford Site, (3) feeding relationships among species of concern, and (4) contaminant concentrations in environmental media and species of concern. The main deficiency in the data available for waste management units in the 200 North Aggregate Area is that a quantitative assessment of contaminant concentrations for the purposes of risk assessment can be performed. The present understanding of site risks is presented in the selection of constituents of concern (Section 4.0). The data needs for quantitative risk assessments will be considered in developing site-specific sampling and analysis plans according to the Hanford Site Past. Practice Strategy.

Data collected to support evaluation of remedial action alternatives for ERAs, IRMs, FFSs, or the full RI/FS, include site screening of alternatives, feasibility-level design, and preliminary cost estimates. Once an alternative is selected for implementation, much of the data collected during site investigations (LFI or RI) can also be used for the final engineering design. Generally, collection of information during the investigations specifically for use in the final design is not cost effective because many issues must be decided about appropriate technologies before effective data gathering can be undertaken. It is preferable to gather such specific information during a separate predesign investigation or at the time of remediation (i.e., the "observational approach" of the Hanford Site Past-Practice Strategy [DOE/RL 1992a]). Based on the existing data, broad remedial action technologies and objectives have been identified in Section 7.0.

The worker health and safety category includes data collected to establish the required level of protection for workers during various investigation activities. These data are used to determine if there is concern for the personnel working in the vicinity of the aggregate area. 
The results of these assessments are also used in the development of the various safety documents required for field work (see Health and Safety Plan, Appendix B).

It should be noted that each of these data use categories (site characterization, risk assessment needs, remedial actions, and health and safety) will be required at each decision point on the Hanford Site Past-Practice Strategy (DOE/RL 1992a) flow chart, as discussed at the end of Section 8.1.5. To the extent possible, however, not all sites will be investigated to the same degree but only those with the highest priority. These results will then be extended to the other, analogous sites which have similar geology and disposal histories (see Section 9.2.3).

The existing data can presently be used for two main purposes:

- Development of site-specific sampling plans (site characterization use)

- Screening for health and safety (worker health and safety use)

Table 8-1 presents a summary of the availability of existing data for these two uses.

For the purposes of developing sampling plans, existing information is available for:

- The location of waste management units and unplanned releases: many of the units or releases have surface expressions, markers, or have been surveyed in the past. The septic tanks in particular are lacking in this information.

- Possible contamination found at the waste management units: these data are derivable from the inventories for the units.

- The likely depth of contaminants-- $r_{1}$ J information is available

Two types of information are available for the purposes of worker health and safety, and will be used for the development of health and safety documents:

- Levels of surface radiation: derived from the on-going periodic radiological surveys done under the Environmental Surveillance program (Schmidt et al. 1991). Table 8-1 shows where surveys have been performed that can be used to determine levels of surface radiation. No additional survey is required for these areas before surface activities can be conducted.

- Expected maximum contaminant levels: these data can be based mainly on the results of subsurface soil sampling. Sampling of this type has not been conducted for 200 North Aggregate Area waste management units. 
Table 8-1 also presents a first expression of the data needs for the individual waste management units in the 200 North Aggregate Area, which must be addressed for remediation approaches to be developed, by defining areas where existing data is not adequate.

\subsubsection{Data Needs}

The data needs for the 200 North Aggregate Area are discussed in the following sections according to the categories of types of data (Section 8.2.2.1), quality (8.2.2.2), quantity (8.2.2.3), options for acquiring the data (8.2.2.4), and appropriate DQO (PARCC) parameters (8.2.2.5). These considerations are summarized for each category of waste management unit site in the 200 North Aggregate Area (Section 8.2.3).

8.2.2.1 Data Types. Data use categories described in Section 8.2.1 define the general purpose of collecting additional data. Based on the intended uses, a concise statement regarding the data types needed can be developed. Data types specified at this stage should not be limited to chemical parameters, but should also include necessary physical parameters such as bulk density, moisture, and hydraulic conductivity. Precipitation recharge and chemical distribution coefficients and organic complexation data appears adequate, but may require additional study based on the results of future evaluations. Since environmental media and source materials are interrelated, data types used to evaluate one media may also be useful to characterize another media.

Identifying data types by media indicates that there are overlapping data needs. Data objectives proposed for collection in the site investigations in the 200 North Aggregate Area are discussed in Section 8.3 to provide focus to investigatory methods that may be employed. The data type requirements for the preliminary remedial action alternatives developed in Section 7.4 are summarized in Table 8-2.

8.2.2.2 Data Quality Needs. The various tasks and phases of a CERCLA investigation may require different levels of data quality. Important factors in defining data quality include selecting appropriate analytical levels and validation and identifying contaminant levels of concern as described below. The Westinghouse Hanford document, $A$ Proposed Data Quality Strategy for Hanford Site Characterization, will be used to help define these levels (McCain and Johnson 1990). The DQOs will also be developed and defined on an operable unit basis in the work plans and, specifically, in the Quality Assurance Project Plans (QAPjPs) which will guide investigation activities.

Chemical and radionuclide laboratory analysis will be one of the most important data types, and is required at virtually all the sites in the 200 North Aggregate Area. In general, increasing accuracy, precision, and lower detection limits are obtained with increasing cost and time. Therefore, the analytical level used to obtain data should be commensurate with the intended use. Table 8-3 defines five analytical levels associated with different types of characterization efforts. While the bulk of the analysis during LFIs/RIs will be screening 
level (DQO Level I or II), these data will require confirmation sampling and analysis to allow final remedial decisions through quantitative risk assessment methods. Individual DQO analytical PARCC parameters for Level III or IV analytical data associated with each contaminant anticipated in the 200 North Aggregate Area (as developed in Section 5) are given in Table 8-4 (Note: Table 8-4 is developed by applying Section 5 criteria to Table 4-13). These parameters will be used for the development of site-specific sampling and analysis plans and quality assurance plans for investigations and remediations in the aggregate area.

Before laboratory or even field data can be used in the selection of the final remedial acuon, they must first be validated. Exceptions are made for initial evaluations of the sites using existing data, which may not be appropriate for validation but will be used on a screening basis based on the Hanford Site Past-Practice Strategy (DOE/RL 1992a). Other screening data (e.g., estimates of contaminant concentration inferred from field analyses) may also be excepted. Validation involves determining the usability and quality of the data. Once data are validated, they can be used to successfully complete the remedial action selection process. Activities involved in the data validation process include the following:

- Verification of chain-of-custody and sample holding times

- Confirmation that laboratory data meet Quality Assurance/Quality Control (QA/QC) criteria

- Confirmation of the usability and quality of field data, which includes geological logs, hydrologic data, and geophysical surveys

- Proper documentation and management of data so that they are usable.

Validation may be performed by qualified Westinghouse Hanford personnel from the Office of Sample Management (OSM), other Westinghouse Hanford organizations, or a qualified independent participant subcontractor. Data validation of laboratory analyses will be performed in accordance with A Proposed Data Quality Strategy for Hanford Site Characterization (McCain and Johnson 1990) and standards set forth by Westinghouse Hanford.

To accomplish the second point, all laboratory data must meet the requirements of the specific QA/QC parameters as set up in the QAPjP for the project before it can be considered usable. The QA/QC parameters address laboratory precision and accuracy, method blanks, instrument calibration, and holding times.

The usability of field data must be assessed by a trained and qualified person. The project geohydrologist/geophysicists will review the geologic logs, hydrologic data, geophysical surveys, and results of physical testing, on a daily basis, and senior technical reviews will be conducted periodically throughout the project. 
Data management procedures are also necessary for the validation. Data management includes proper documentation of field activities, sample management and tracking, and document and inventory control. Specific consistent procedures are discussed in the Information Management Overview (Appendix D).

8.2.2.3 Data Quantity Needs. The number of samples that need to be collected during an investigation can be determined by using several approaches. In instances where data are lacking or are limited (such as for contamination in the vadose zone soils), a phased sampling approach will be appropriate. In the absence of any available data, an approach or rationale will need to be developed to justify the sampling locations and the numbers of samples selected. This will be accomplished and documented in the production of work plans and field sampling plans for each agłregate area, under the guidance and review of the Tri-Party Agreement participants. Specific locations and numbers of samples will be determined based on data collected during screening activities. For example, the number and location of beta/gamma spectrometer probe locations can be based on results of surface geophysical and radiation surveys. These may help locate some subsurface features which may not be adequately documented. Details of any higher DQO level subsurface soil sampling scheme will depend on results of screening investigations such as geophysics surveys, surface radiation surveys, field chemical screening, and beta/gamma spectrometer probe surveys. In situations where and when available data are more complete, statistical techniques may be useful in determining the additional data required.

8.2.2.4 Sampling and Analysis Options. Data collection activities are structured to obtain the needed data in a cost-effective manner. Developing a sampling and analysis approach that ensures that appropriate data quality and quantity are obtained with the resources available may be accomplished by using field screening techniques and focusing the higher DQO level analyses on a limited set of samples at each site. The investigations on waste management units in the 200 North Aggregate Area should take advantage of this approach for a comprehensive characterization of the site in a cost-effective manner.

A combination of lower level (Levels I and II), and higher level analytical data (Levels III and IV), and special analytical data (Level V) should be collected. This approach would provide the certainty necessary to determine contaminants present near the sources. Samples collected from the other media (i.e., subsurface soils, sediments) will be analyzed by Test Methods for Evaluating Solid Wastes, (EPA 1986), CLP (EPA 1991c, EPA 1991d), Methods for Chemical Analysis of Water and Wastes (EPA 1983), or Prescribed Procedures for Measurement of Radioactivity in Drinking Water (EPA 1980).

8.2.2.5 Data Quality Parameters. The PARCC parameters are indicators of data quality. Ideally, the end use of the data collected should define the necessary PARCC parameters. Once the PARCC requirements have been identified, then appropriate analytical methods can be chosen to meet established goals and requirements. Definitions of the PARCC parameters are presented in Section 8.1.3. 
In general the precision and accuracy objectives are governed by the capabilities of the available methodologies and in most cases these are more than adequate for the needs of the investigations. Chemical analyses can usually attain parts per billion detection range in soils and water, and this level is adequate to the needs of the risk assessment for most analytes. Radiological analyses reach similar levels. Table 8-4 shows detection levels, generally obtained from the method description such as the document Test Methods for Evaluation Solid Wastes (EPA 1986) or from experience with laboratory analysis. Some constituents (e.g., arsenic) would require analysis to much lower levels, but this is impossible because of the limitations of analytical methods and the effects of natural background levels. For example, EPA Method 200.62-C-CLP can analyze to detection levels of $500 \mu \mathrm{g} / \mathrm{kg}$ in soils, while the Model Toxics Control Act (MTCA) Method C Industrial soils cleanup level is $50 \mu \mathrm{g} / \mathrm{kg}$. In some cases, special analytical methods can be developed to obtain lower detection levels. In addition, risk assessment is conventionally computed only to a single digit of precision and uses conservative assumptions, which reduce the impact of measurements with lower accuracy.

For other measurements, such as physical parameters, the precision and accuracy capabilities of existing measurement technologies are sufficient for the evaluation methods used to produce characterization data, so the objectives are based on the limitations of the analysis methodologies.

Representativeness is maintained by fitting the sampling program to the governing aspects of the sources and transport processes of the site, as demonstrated in the site conceptual model (Section 4.2). Initial sampling should concentrate on sources, which are fairly well-understood, and on representative locations of anticipated transport mechanisms. If necessary, following activities can focus on aspects or locations that were not anticipated but were demonstrated by the more general results.

Completeness is generally attained by specifying redundancy on critical samples and maintaining quality control on their acquisition and analysis. As with representativeness, the initial sampling program may lead to modifications of which samples should be considered critical during subsequent sampling activities.

Comparability will be met through the use of Westinghouse Hanford standard procedures generally incorporated into the Environmental Investigation and Site Characterization Manual (WHC 1988c).

\subsubsection{Data Gaps}

Considering the data needs developed in Section 8.2.2, and the data available to meet these needs as presented in Section 8.1.2, it is apparent that a number of data gaps can be identified. These are summarized, on a waste management unit category basis, in Table 8-5, and should be the focus of LFIs on a waste management unit category basis, using the analogue sites approach. The contaminant concentration data are the highest priority because 
of the need to assess the need for remediation (through quantative risk assessment and evaluation of compliance with ARARs) and appropriate remedial actions for each site.

In addition to these data needs specifically addressing contamination problems at sites included for consideration in this aggregate area, there are general data needs which will be required for characterization of the possible transport pathways, as presented in the conceptual model, at locations away from the individual units. These general, non-site specific needs include characterization of the fc'lowing:

- Geologic stratigraphy, particularly for possible perched water zones

- Transport through the vadose zone (mobilization through natural or artificial recharge or drainage)

- Air transport of contamination

- Ecological impacts and transport mechanisms (bio-uptake, bio-concentration, secondary receptors through predation)

- Potential releases from process effluent lines between facilities and to waste disposal sites.

All of these needs will have to be addressed in the data collection program (Section 8.3). In addition, data gaps that impact groundwater are also addressed in the 200 East and West Groundwater AAMSRs.

\subsection{DATA COLLECTION PROGRAM (STAGE 3 OF THE DQO PROCESS)}

The data collection program is Stage 3 of the process to develop DQOs. Conducting an investigation with a mixture of screening and higher-level data is a common method for optimizing the quantity and quality of the data collected. It would be very inefficient and overly expensive to specify beforehand all the types of samples and analyses that will yield the most complete and accurate understanding of the contamination and physical behavior of the site. Data adequate to achieve all the goals and objectives for remedial action decisions are obtained at a lower cost by using the information obtained in the field to focus the ongoing investigation and remediation process.

Initial sampling should collect new data believed necessary to confirm and refine the conceptual model particularly at priority sites. Sampling may then be extended to further reduce uncertainty, to fill in remaining data gaps, to collect more detailed information for certain points where such information is required, or to conduct any needed treatability studies or otherwise support the data needs of the remedial action selection process. An alternative of extrapolating the data from a limited number of sites to other analogous ones will also he used. The need for subsequent investigation phases will be assessed throughout 
the investigation and remediation activities as data become available. Assessing completeness of the investigation data through a formal statistical procedure is not possible, given the complexity and uncertainty of the parameters required to describe the site and the time to make decisions. Rather, the use of engineering judgement is considered sufficient to the decision process.

\subsubsection{General Rationale}

The general rationale for the investigation of sites in the 200 North Aggregate Area is to collect needed data that are not available. Because of the lack of data a large amount of new information will be required such as the specific radionuclides and chemicals present, their spatial distribution and form, and the presence of special migration pathways (such as perched groundwater systems).

The following work plan approach will be used for LFIs and RI/FS in the 200 North Aggregate Area. The results are described in Sections 8.3.2 and 8.3.3 in a general form.

- Existing data as described in Sections 2.0, 3.0, and 4.0 should be used to the maximum extent possible. Although existing data are not validated fully, the data are still useful in developing a preliminary conceptual model (Section 4.2) and in helping to focus and guide the planning of investigations, expedited actions, and interim measures.

- Additional data at validated and screening levels should be collected to obtain the maximum amount of useful information for the amount of time and resources invested in the investigation.

- Data should be collected to support the intended data uses identified in Section 8.2.1.

- Nonintrusive sampling (e.g., geophysical surveys, surface radiation surveys, soil gas, and spectral gamma probe surveys), and surficial and source sampling should be conducted early in any investigation effort to identify necessary interim response actions (i.e., additional ERAs or IRMs).

- Data collected from initial investigation activities should be used to confirm and refine the conceptual model (Section 4.2), refine the analyte constituents of concern, and provide information to conduct interim response actions or risk assessment activities.

- Additional investigation activities are proposed to support (if needed) quantitative baseline risk assessments for final cleanup actions and further refine the conceptual model. 
- Field investigation techniques should be used to minimize the amount of hazardous or mixed waste generated. Any waste generated will be in accordance with EII 4.2, "Interim Control of Unknown Suspected Hazardous and Mixed Waste" (WHC 1988c).

\subsubsection{General Strategy}

The overall objective of any field investigation (LFI, IRM, or RI) of the sites in the 200 North Aggregate Area will be to gather additional information to support risk assessment and remedial action selection according to the Hanford Site Past-Practice Strategy (DOE/RL 1992a) flow chart discussed in Section 8.1.5. The general approach or strategy for obtaining this additional information is presented below.

- Analytical parameter selection should be based on verifying overall conditions and then narrowed to specific constituents of concern, in consideration with regulaiory requirements and site conditions. Periodic analyses of this list of parameters should be conducted to verify that the list of constituents of concern has not changed, either because new constituents are identified or some of those considered as a potential concern do not appear to be significant.

- Similarly, investigations should work from a screening level (DQO Levels I or II, e.g., surface radiation surveys) to successively more specific sampling and analysis methodologies (e.g., beta/gamma spectral probes, then DQO Level III or IV soil sampling and analysis), without time consuming remobilizations.

- Dangerous and radioactive wastes may be generated during the field investigation. While efforts should be made to minimize these wastes, any waste generated will be handled in accordance with EII 4.2, "Interim Control of Unknown Suspected Hazardous and Mixed Waste" (WHC 1988c). The analyses of samples for constituents of concern analytes will allow wastes generated to be adequately identified.

\subsubsection{Investigation Methodology}

Initial field investigations (mainly LFIs, but also associated with IRMs at appropriate sites and possibly some RIs) may include some or all of the following integrated methodologies:

- $\quad$ Source Investigation (Section 8.3.3.1)

- $\quad$ Geological Investigation (Section 8.3.3.2)

- $\quad$ Soil Investigation (Section 8.3.3.3) 
- $\quad$ Air Investigation (Section 8.3.3.4)

- Ecological Investigation (Section 8.3.3.5)

- Geophysical Stratigraphic Survey (Section 8.3.3.6)

- $\quad$ Process Effluent Pipeline Integrity Assessment (Section 8.3.3.7)

- Geodetic Survey (Section 8.3.3.8)

- Cultural Resource Investigation (Section 8.3.3.9).

Each investigation methodology is briefly outlined in the following sections. Sperific survey methods (such as electromagnetics or ground-penetrating radar) have not been recommended to allow flexibility in the development of field sampling plans which can be sensitive to very local conditions. A summary of the applicable methods for each waste management unit is presented in Table 8-6. In addition, some of the ditia needs must be addressed on an area-wide basis (e.g., stratigraphy interpretation). More detailed descriptions and specific methods and instrumentation will be included in site-specific work plans, sampling and analysis plans, and field sampling plans for LFIs/IRMs at waste management units that require these investigations.

These investigations are presented in the approximate priority of their need, with the source investigation first because of its importance to the decisions about remedial action on a site-by-site basis. The other investigations are of lower priority, and should be conducted according to the need to determine whether contamination has been transported beyond the immediate vicinity of the waste management units. To some extent this need will depend on the results of the source investigation.

8.3.3.1 Source Investigation. The purpose of source investigation activities in the 200 North Aggregate Area is to characterize the waste management units and unplanned releases that exist in the area and that may contribute to contamination of surface soil, vadose zone, air, and biota. The completeness of the characterization effort will be assessed according to the needs of risk assessment, ARARs compliance, and remedial action selection, which will also determine what levels of the various constituents of concern comprise "contamination."

Source sampling should be conducted at waste management units or unplanned release locations where the available data indicate that dangerous, mixed, or radioactive wastes may be present. Activities which are proposed to be performed during the source investigations include the following:

- Compile and evaluate additional existing data for the purpose of: verifying locations, specifications of engineered facilities, and pipelines, and waste stream characteristics; assessment of the construction and condition of boreholes/wells 
that exist in the operable unit and their suitability for use for investigation activities, QA/QC information, and raw data regarding radiological and hazardous substances monitoring; and integrating any additional environmental modeling data into the conceptual model. This has been done (on an aggregate area basis) in this report; the process will be extended to site-specific planning and on-going assessments of the investigation/remediation as it is carried out.

Conduct surface radiological survey of suspected or known source areas to verify locations and nature of surface and subsurface radiological contamination. Conditions at specific sources within a waste management unit should also be noted in order to plan sampling/remediation activities and worker health and safety.

Conduct nonintrusive surface geophysical surveys at specific waste management units such as the septic tanks and unplanned release locations to verify locations and physical characteristics of source locations. Data generated from these activities can be used in planning intrusive source sampling activities.

Conduct beta/gamma spectrometer probe survey to screen for near-surface contamination and to confirm the absence or presence of some specific radionuclides, which may be of particular concern. New boreholes may be needed at many locations (to be decided based on screening results). Logging will be done both by $\mathrm{NaI}$ detectors or $\mu \mathrm{R}$ meters for rapid screening as well as the RLS high purity germanium logging system. Westinghouse Hanford will develop an EII Procedure for the beta/gamma spectrometer probe survey. The beta/gamma spectrometer probe survey serves two purposes depending on the source conditions: to confirm absence of contamination in the near-surface soils, and to serve as a screening tool to choose locations and quantities of vadose zone soil borings. The RLS procedure could demonstrate "assay quality" data for radionuclide concentrations, but will probably continue to require supporting Level III or IV soil analysis data to allow a risk assessment before final remedial decisions. The need to conduct this survey will be based (at least in part) on the screening results of the surface survey and on information about site burial.

- Soil gas surveys may be conducted at waste management units where volatile organic compounds are suspected, as a screening method to identify compounds such as solvents that may have been used in processes. A soil gas survey should not be considered conclusive that volatile organic compounds at lower concentrations may not be present. Data from the soil gas survey can be used to help locate surface and near-surface samples and vadose zone borings.

- Collect surface and near-surface samples of contaminated scils and/or waste materials at selected locations. Specific sampling sites will be chosen to assess particular facilities or releases. Additional sampling sites may be specified based on results from nonintrusive investigations. 
8.3.3.2 Geologic Investigation. A geologic investigation should be performed to better characterize the vadose zone and the nature of unsaturated soils that make up this system. The geologic investigation will include the following tasks:

- Borings may be advanced into zones where an accurate interpolation of the subsurface stratigraphy is important to understanding migration pathways in the vadose zone.

- Geologic data collected during the ongoing vadose zone soil (Section 8.3.3.4) and other (deeper) investigations (e.g., geologic and geophysical logs from groundwater well installations for groundwater AAMSs) will be compared, compiled, and evaluated.

8.3.3.3 Soil Investigation. The purpose of soil investigations is to determine physical and chemical properties of the soil and to determine the nature, type, and extent of soil contamination associated with waste management units and unplanned releases to allow initiation of interim remedial actions and to assess the quantitative risk at other sites. Sampling will include:

- Samples of vadose zone soil will be collected and analyzed for constituents of concern when wells are drilled for other studies (i.e., groundwater investigations) in the vicinity of a waste management unit or unplanned release with reported liquid disposals or spills. Organic vapor (at sites with suspected volatiles and radiation sampling should also be performed with samples selected by onsite screening.

- Data collected during this investigation will be evaluated to further understand the contribution of contaminants to the vadose zone from specific waste management units and/or unplanned releases and to better define the hydrology and water quality in the vadose zone system through moisture content profiles, tracking of specific contaminants, and soil hydraulic characteristics. However, the issue of contaminant transport through the vadose zone is more appropriate to studies conducted under the direction of the Groundwater AAMSRs.

8.3.3.4 Air Investigation. Air investigations (on an aggregate area scale) should consist of onsite particle sampling as part of the health and safety program. In addition, high-volume air samplers should be placed in appropriate locations on-site based on evaluation of existing meteorological data. The purpose of these samplers will be to determine if any migration of airborne contaminants occurs.

8.3.3.5 Ecological Investigation. Ecological investigation activities, on a site-wide scale, should include a literature search and data review, and a site walkthrough. Data collected during the soils characterization activities are expected to be sufficient to evaluate both remediation technologies. These activities are intended to identify potential biota concerns which need to be addressed in the site investigation. Particular emphasis should be given to 
identifying potential exposure pathways to biota that migrate offsite or that introduce contaminants into the food web. Data obtained in this survey will be used to both refine the conceptual model as well as to conduct the ecological risk assessment.

8.3.3.6 Geophysical Stratigraphic Survey. Additional information needs to be gathered to better define the depth and lateral extent of any perched water zones, or caliche (an important aquitard) in the Plio-Pleistocene unit. This information may be obtained using a number of subsurface characterization techniques such as magnetic and seismic surveys and borehole logging.

8.3.3.7 Process Effluent Pipeline Integrity Assessment. An assessment of process effluent pipeline integrity should be conducted early in site investigation activities to look for potential leaks and therefore possible areas of contamination. Initially, as part of this effort, drawings of the process lines and encasements within the aggregate area (Section 2.3.7) should be reviewed and their construction, installation, and operation evaluated. Specific lines will then be selected for integrity assessment with emphasis on lines serving the waste management units that have received large volumes of liquid (e.g., ponds). Investigation of operating high level waste transfer lines will be deferred to their respective programs. Results of the integrity assessments will be evaluated and additional sampling activities may be recommended for subsequent studies.

8.3.3.8 Geodetic Survey. Geodetic surveys will be conducted after the installation and completion of each investigation activity. The survey will be to locate the horizontal locations of surface and near-surface soil samples and comers of geophysics, soil gas, and beta/gamma probe surveys. Horizontal and vertical locations of all vadose zone soil borings and perched zone wells will be surveyed. The geodetic survey should be conducted by a professional surveyor licensed in the state of Washington and should be referenced to both historic (e.g., Hanford coordinates) and current coordinate datums (e.g., North American Datum of 1983 - NAD-83), both vertical and horizontal.

8.3.3.9 Cultural Resource Investigation. A cultural resource investigation should be conducted for investigation locations outside the 200 North Aggregate Area to verify the locations of known archaeological sites by reviewing existing data. The focus of the investigation will be to confirm that no archaeological resources are present at proposed drilling sites.

\subsubsection{Data Evaluation and Decision Making}

Data will be evaluated as soon as results (e.g., soil gas, radiation screening, drilling results) become available for use in restructuring and focusing the investigation activities. Data reports will be developed that summarize and interpret new data. This includes groundwater sampling and RLS borehole logging as part of the AAMS. Data will be used to refine the conceptual model, further assess potential contaminant-specific ARARs, develop the quantitative risk assessment, and assess remedial action alternatives. 
The objectives of data evaluation are:

- To reduce and integrate data to ensure that data gaps are identified and that the goals and objectives of the 200 North AAMS are met

- To confirm that data are representative of the media sampled and that QA/QC criteria have been met. 
Table 8-1. Uses of Existing Data for 200 North Aggregate Area Waste Management Units.

\begin{tabular}{|c|c|c|c|c|c|c|}
\hline \multirow[b]{2}{*}{$\begin{array}{l}\text { Waste } \\
\text { Management Unit }\end{array}$} & \multirow[b]{2}{*}{$\begin{array}{l}\text { Type of } \\
\text { Unit }\end{array}$} & \multicolumn{3}{|c|}{ Development of Sampline Plans } & \multirow{2}{*}{$\begin{array}{c}\text { Health and } \\
\text { Safety } \\
\text { Surface } \\
\text { Radiation }\end{array}$} & \multirow[b]{2}{*}{$\begin{array}{l}\text { Expected } \\
\text { Max. Level }\end{array}$} \\
\hline & & Location & $\begin{array}{c}\text { Possible } \\
\text { Contamination }\end{array}$ & $\begin{array}{c}\text { Depth of } \\
\text { Contamination }\end{array}$ & & \\
\hline \multicolumn{7}{|c|}{ 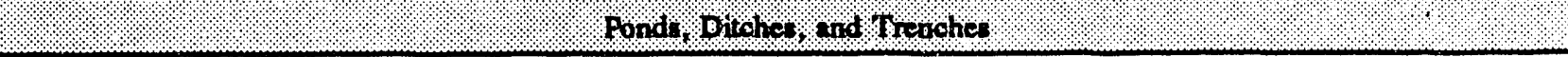 } \\
\hline $216-N-1$ & Pond & Yes & Yes & Yes & Yes & No \\
\hline $216-\mathrm{N}-4$ & Pond & Yes & Yes & Yes & Yes & No \\
\hline $216-N-6$ & Pond & Yes & Yes & Yes & Yes & No \\
\hline $216-N-2$ & Trench & Yes & Yes & Yes & Yes & No \\
\hline $216-N-3$ & Trench & Yes & Yes & Yes & Yes & No \\
\hline $216-N-5$ & Trench & Yes & Yes & Yes & Yes & No \\
\hline $216-N-7$ & Trench & Yes & Yes & Yes & Yes & No \\
\hline \multicolumn{7}{|c|}{ 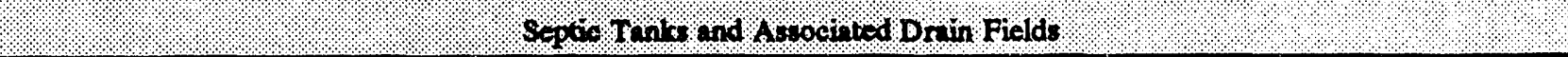 } \\
\hline $2607-N$ & $\begin{array}{l}\text { Septic Tankf } \\
\text { Drain Field }\end{array}$ & Yes & No & No & No & No \\
\hline 2607-P & $\begin{array}{l}\text { Septic Tankl } \\
\text { Drain Field }\end{array}$ & Yes & No & No & No & No \\
\hline 2607-R & $\begin{array}{l}\text { Septic Tankf } \\
\text { Drain Field }\end{array}$ & Yes & No & No & No & No \\
\hline \multicolumn{7}{|c|}{ Tranifor Ficilitias, Diversion Boxes, and Pipelines } \\
\hline $212-\mathrm{N}$ to $216-\mathrm{N}-1$ & Pipeline & Yes & Yes & No & No & No \\
\hline $212-\mathrm{P}$ to $216-\mathrm{N}-4$ & Pipeline & Yes & Yea & No & No & No \\
\hline $212-\mathrm{R}$ to $216-\mathrm{N}-6$ & Pipeline & Yea & Yes & No & No & No \\
\hline \multicolumn{7}{|c|}{ Burial Siten } \\
\hline Ballast Pits & Burial Site & Yes & No & No & No & No \\
\hline \multicolumn{7}{|c|}{ Unplanned Release } \\
\hline $\begin{array}{l}\text { Unplanned Release } \\
\text { Railroad Spur }\end{array}$ & lear 212-R & Yes & Yes & No & No & No \\
\hline $\begin{array}{l}\text { Unplanned Release } \\
\text { House No. } 2\end{array}$ & Tear Well & Yea & Yea & No & No & No \\
\hline
\end{tabular}

Note: A positive response indicates that the data can be used to determine the indicated properties. A negative response indicates that the data cannot be used to determine the indicated properties. 
Table 8-2. Data Needs for Preliminary Remedial Action Alternatives 200 North Aggregate Area.

\begin{tabular}{|c|c|c|}
\hline Alternative & Physical Attribute & $\begin{array}{c}\text { Chemical/Radiochemical } \\
\text { Attribute }\end{array}$ \\
\hline $\begin{array}{l}\text { 1. Multimedia Cover } \\
\text { (plus possible vertical } \\
\text { barriers) }\end{array}$ & $\begin{array}{l}\text { - areal extent } \\
\text { - depth of contamination } \\
\text { structural integrity } \\
\text { (collapse potential) } \\
\text { - run-off/run-on potential } \\
\text { - cover properties (permeability) }\end{array}$ & $\begin{array}{ll}\text { - } & \text { surface radiation } \\
\text { - biologic transport potential }\end{array}$ \\
\hline $\begin{array}{l}\text { 2. In Situ Grouting/ } \\
\text { Stabilization }\end{array}$ & $\begin{array}{l}\text { - areal extent } \\
\text { - depth } \\
\text { - particle size } \\
\text { - hydraulic properties } \\
\text { (permeability/porosity) } \\
\text { stratigraphy } \\
\text { - borehole spacing } \\
\text { - grout/additive mix parameters }\end{array}$ & $\begin{array}{ll}\text { - } & \text { solubility } \\
\text { - } & \text { reactivity } \\
\text { leachability from grout medium }\end{array}$ \\
\hline $\begin{array}{l}\text { 3. Excavation, Soil } \\
\text { Treatment, and } \\
\text { Disposal }\end{array}$ & $\begin{array}{l}\text { - } \text { areal extent" } \\
\text { - depth" } \\
\text { - particle size } \\
\text { - } \text { silt-size (dust) content } \\
\text { - excsvation stability }\end{array}$ & $\begin{array}{l}\text { - toxicity/radioactivity } \\
\text { - levels of contaminants } \\
\text { - solubility/reactivity } \\
\text { - } \text { soil chemistry (relative affinity) } \\
\text { - concentrations in PM-10 fraction } \\
\text { - } \text { spent solvent treatment/disposal } \\
\text { options }\end{array}$ \\
\hline 4. In Situ vitrification & $\begin{array}{l}\text { - areal extent } \\
\text { - depth } \\
\text { - soil/waste conductivity } \\
\text { - thermal properties } \\
\text { - moisture contact } \\
\text { - voids }\end{array}$ & $\begin{array}{l}\text { - } \text { volatility } \\
\text { - } \quad \text { leactivity } \\
\text { - } \text { off-gas treatment waste disposal } \\
\text { options }\end{array}$ \\
\hline $\begin{array}{l}\text { 5. Excavation, Above } \\
\text { Ground Treatment, } \\
\text { and Geologic } \\
\text { Disposal }\end{array}$ & $\begin{array}{l}\text { - areal extent" } \\
\text { - depth" } \\
\text { - mineralogy of soil/waste } \\
\text { - particle size } \\
\text { - silt-size (dust) content } \\
\text { - excavation stability } \\
\text { - treatment parameters }\end{array}$ & $\begin{array}{l}\text { - } \quad \text { concentrations of TRU } \\
\text { - } \text { lexicity/radioactivity } \\
\text { - concentrations in PM-10 fraction } \\
\text { - reactivity } \\
\text { - leachability/integrity of final waste } \\
\text { form }\end{array}$ \\
\hline $\begin{array}{l}\text { 6. In Situ Soil Vapor } \\
\text { Extraction }\end{array}$ & $\begin{array}{l}\text { - areal extent } \\
\text { - depth } \\
\text { - locations/depth of highest } \\
\text { concentrations (vapors, } \\
\text { adsorbed) } \\
\text { - stratigraphy } \\
\text { - soil permeability/porosity } \\
\text { - voids }\end{array}$ & $\begin{array}{ll}\text { - } & \text { volatility of constituents (Henry's Law } \\
\text { Constant) } \\
\text { - non-volatile organics } \\
\text { - levels } \\
\text { - volatile radionuclides (Radon) } \\
\text { - treatability (catalytic oxidization) }\end{array}$ \\
\hline
\end{tabular}

- May be obtained during remediation using the observational approach recommended by the Hanford Site Past-Practice Strategy (DOE/RL 1992a) 
Table 8-3. Analytical Levels for the 200 North Aggregate Area.

\begin{tabular}{|cl|}
\hline Level & \multicolumn{1}{c|}{ Description } \\
\hline LEVEL I & $\begin{array}{l}\text { Field screening. This level is characterized by the use of portable } \\
\text { instruments which can provide real-time data to assist in the optimization } \\
\text { of sampling point locations and for health and safety support. Data can } \\
\text { be generated regarding the presence or absence of certain contaminants } \\
\text { (especially volatiles) at sampling locations. }\end{array}$ \\
LEVEL II & $\begin{array}{l}\text { Field analysis. This level is characterized by the use of portable } \\
\text { analytical instruments which can be used onsite, or in mobile } \\
\text { laboratories stationed near a site (close-support laboratories). Depending } \\
\text { on the types of contaminants, sample matrix, and personnel skill, } \\
\text { qualitative and quantitative data can be obtained. }\end{array}$ \\
LEVEL III & $\begin{array}{l}\text { Laboratory analysis using methods other than the Contract Laboratory } \\
\text { Program (CLP) Routine Analytical Services (RAS). This level is used } \\
\text { primarily in support of engineering studies using standard EPA-approved } \\
\text { procedures. Some procedures may be equivalent to CLP RAS without } \\
\text { the CLP requirements for documentation. } \\
\text { Contract Laboratory Program (CLP) Routine Analytical Services (RAS). } \\
\text { This level is characterized by rigorous QA/QC protocols and } \\
\text { documentation and provides qualitative and quantitative analytical data. } \\
\text { Some regions have obtained similar support via their own regional } \\
\text { laboratories, university laboratories, or other commercial laboratories. } \\
\text { Nonstandard methods. Analyses which may require method modification } \\
\text { and/or development are considered Level V by CLP Special Analytical } \\
\text { Services (SAS). }\end{array}$ \\
\hline
\end{tabular}




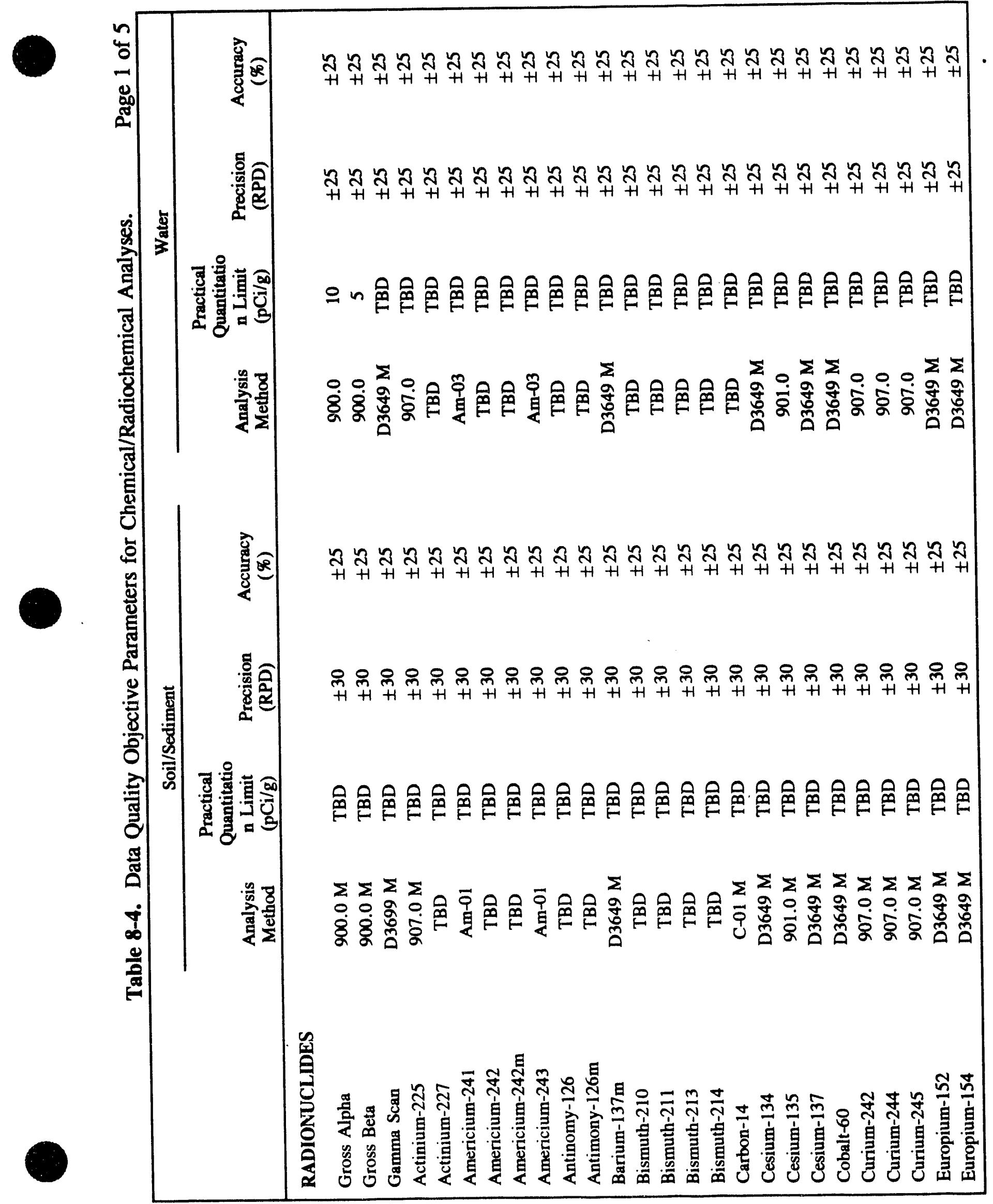


DOE/RL-92-17, Rev. 0

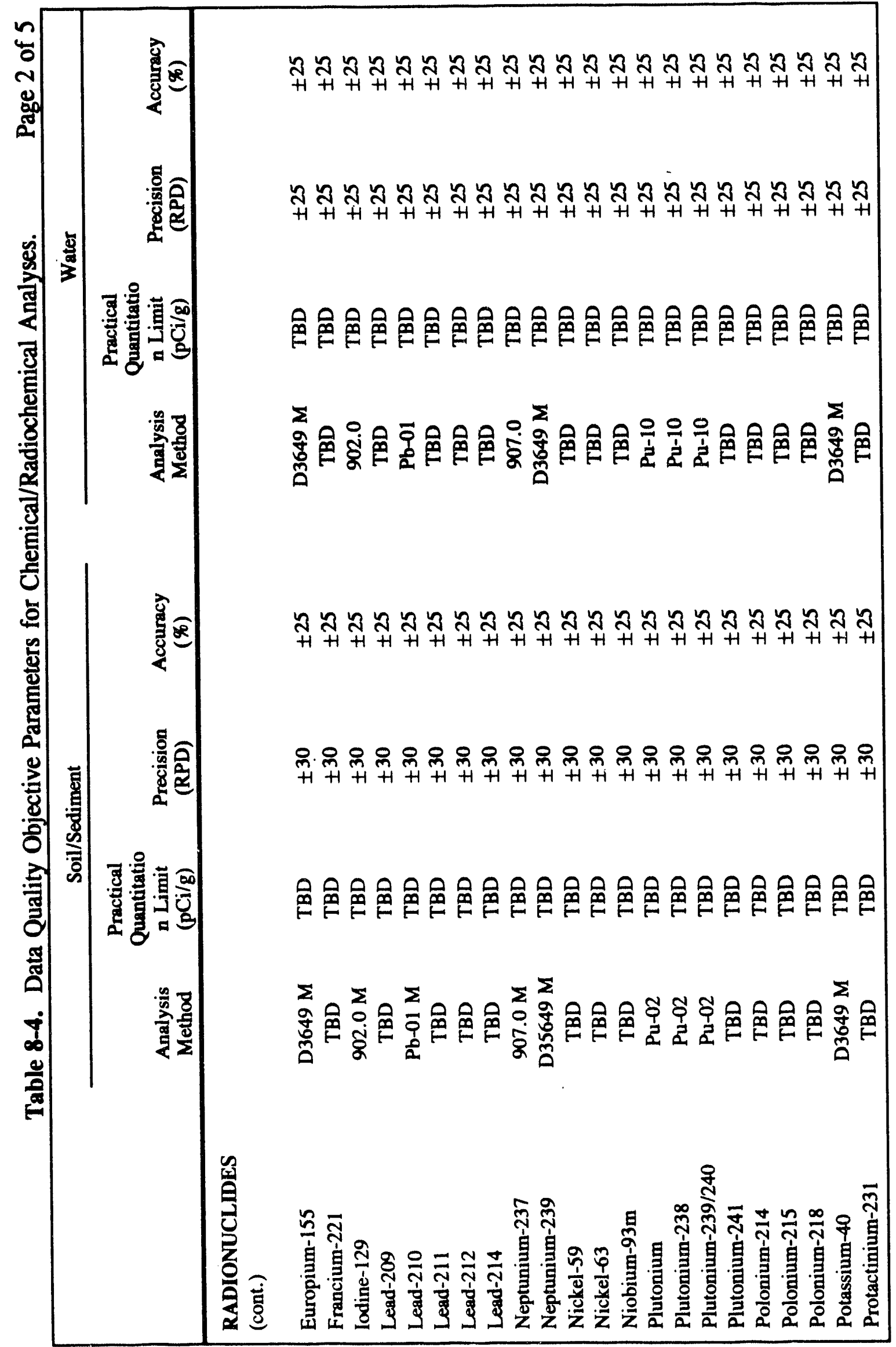


DOE/RL-92-17, Rev. 0

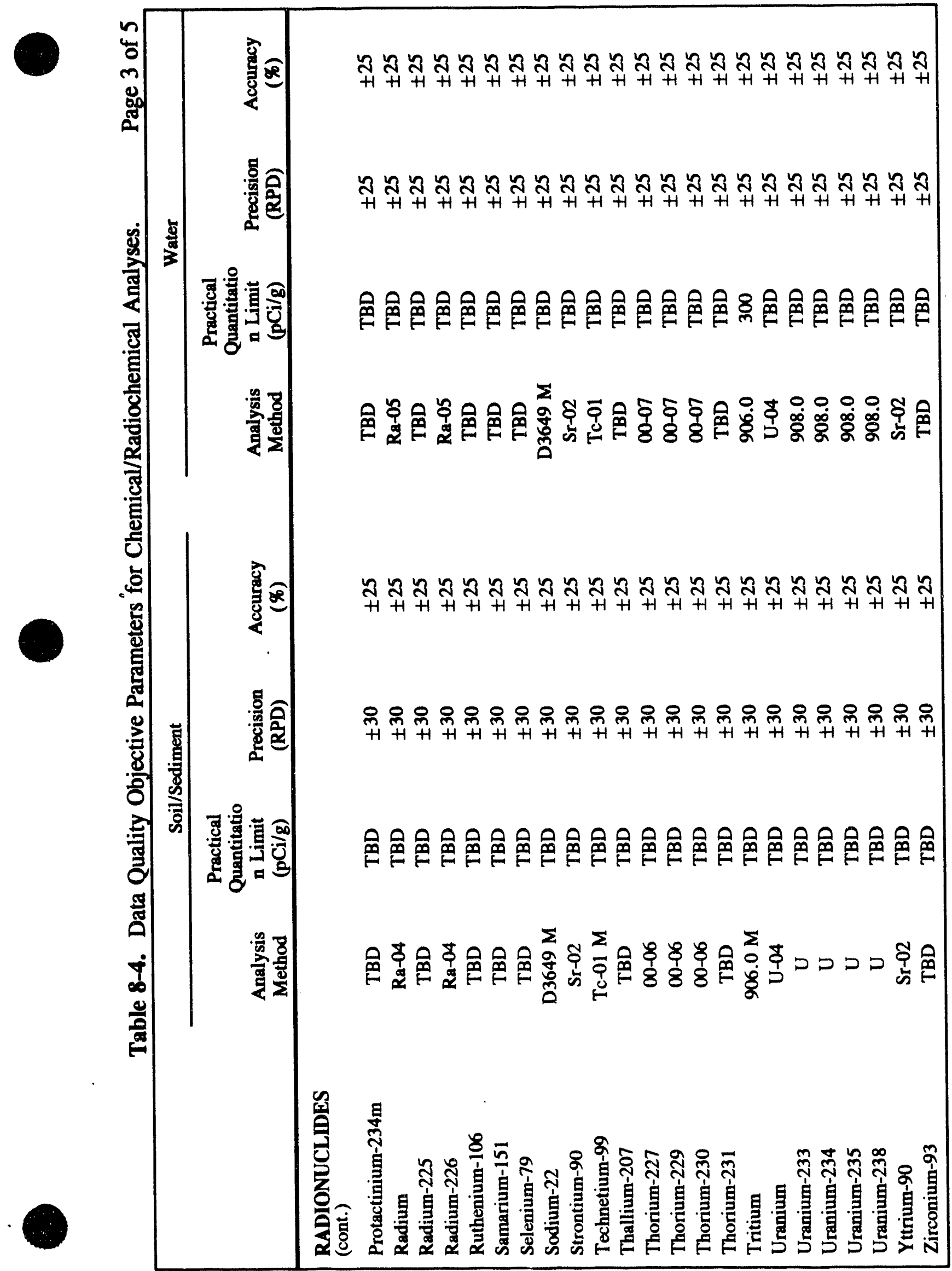


DOE/RL-92-17, Rev. 0

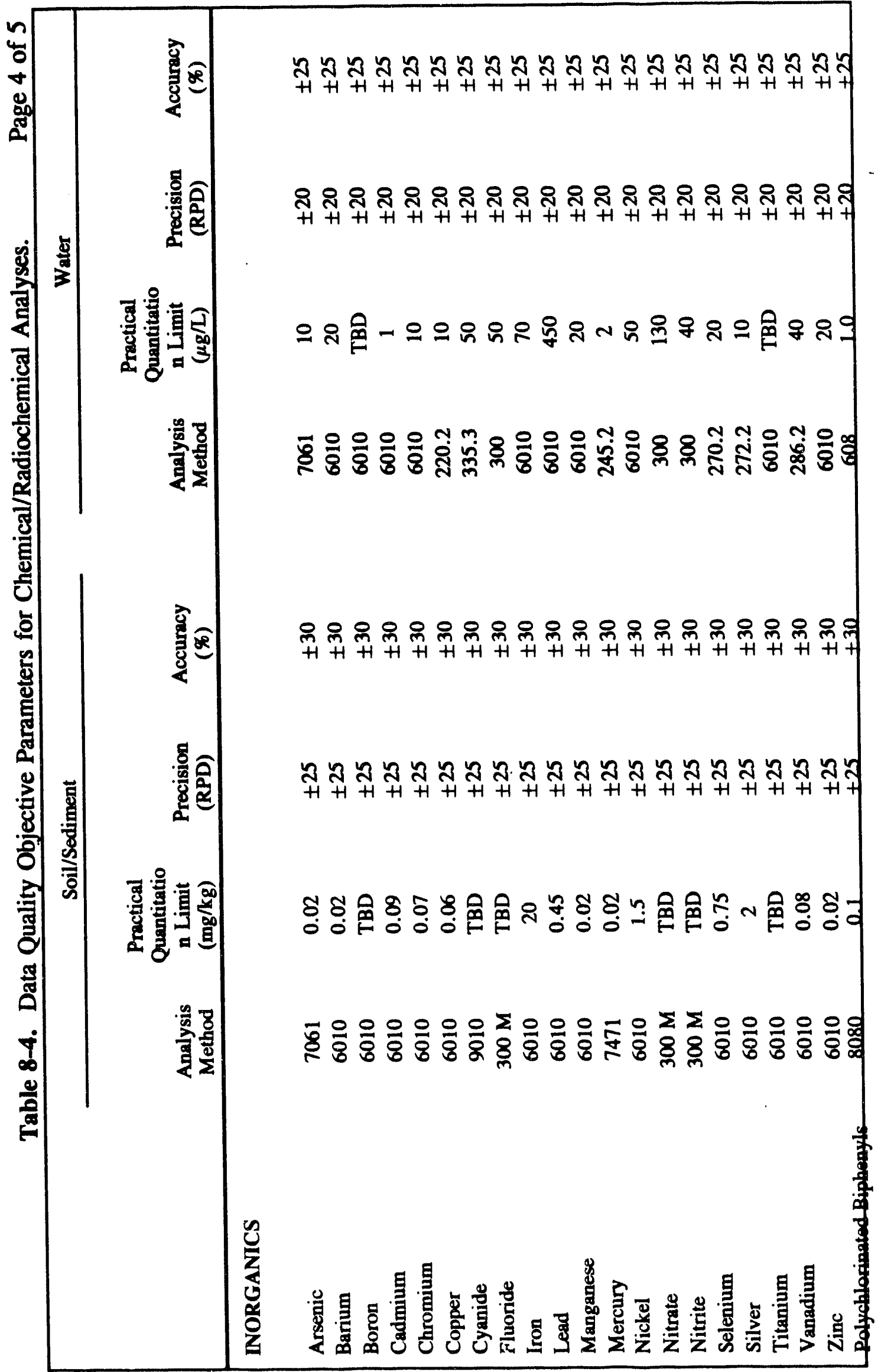


DOE/RL-92-17, Rev. 0

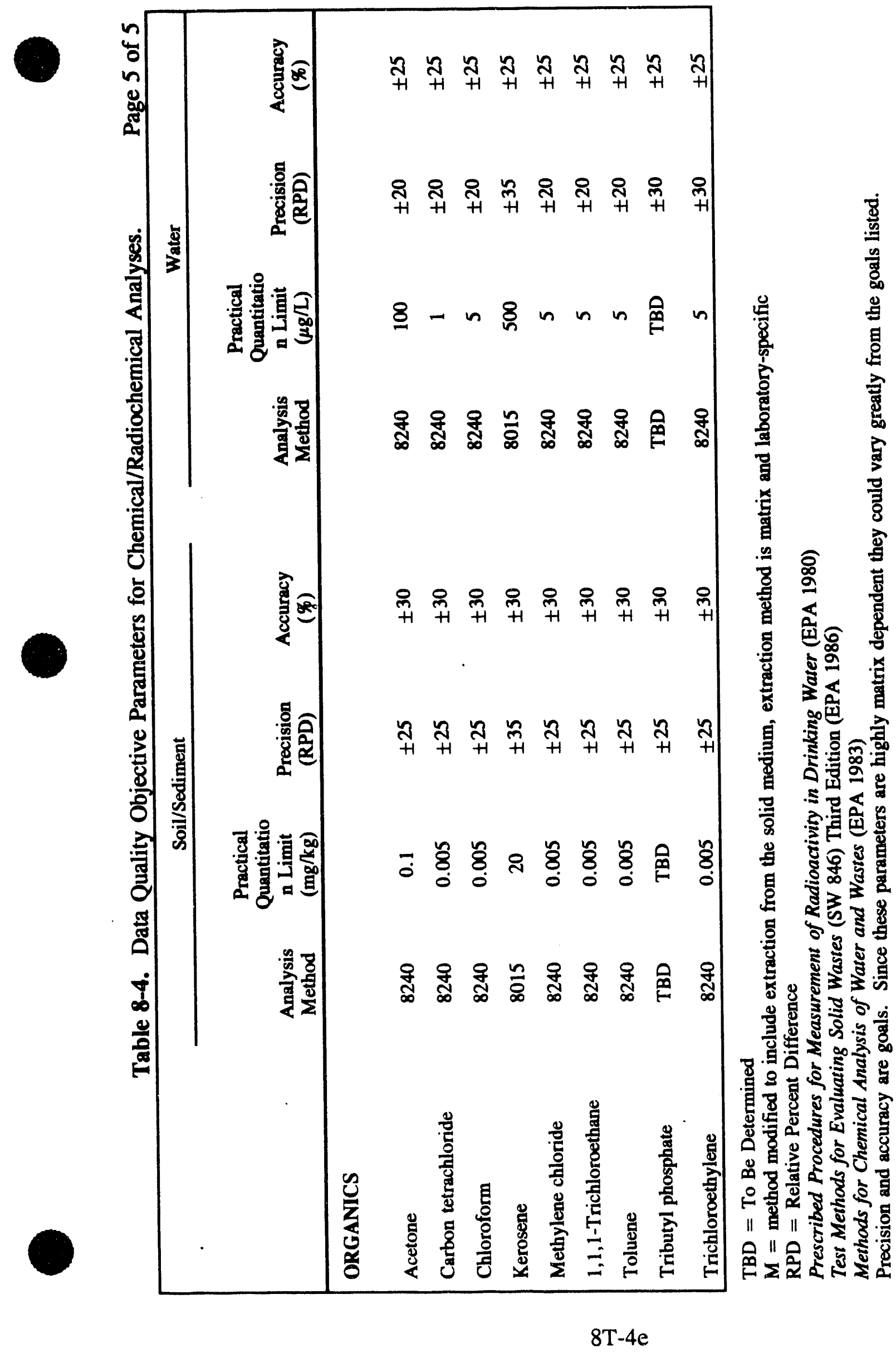


DOE/RL-92-17, Rev. 0

Table 8-5. Data Gaps by Site Category.

\begin{tabular}{|ll|}
\hline Site Category & Identified Data Gaps \\
\hline Tanks and Vaults & - Contaminant concentrations \\
& - Distribution of contaminants in subsurface soils \\
& - Coleased in leaks \\
& contamination concentrations in related surface \\
Ponds, Ditches, and Trenches & - Distribution/extent of subsurface contamination \\
& - Buried contaminant concentrations in stabilized \\
& - Ertions/units \\
Septic Tanks and Associated & - Actual discharge levels \\
Drain Fields & - Possible discharge and presence/level of \\
& non-sanitary wastes (e.g., laboratory drains) \\
Transfer Facilities, Diversion & - Contamination constituents and concentrations \\
Boxes, and Pipelines & - Direct radiation levels in facilities \\
& - Constituents/concentrations in related surface \\
& - Integrity of transfer lines \\
Burial Sites & - Identify subsurface location of burial sites \\
& - Distribution/extent of subsurface contamination \\
Unplanned Releases & - Surface soil constituents and concentrations \\
& - Buried contamination constituents and \\
& concentrations
\end{tabular}


DOE/RL-92-17, Rev. 0

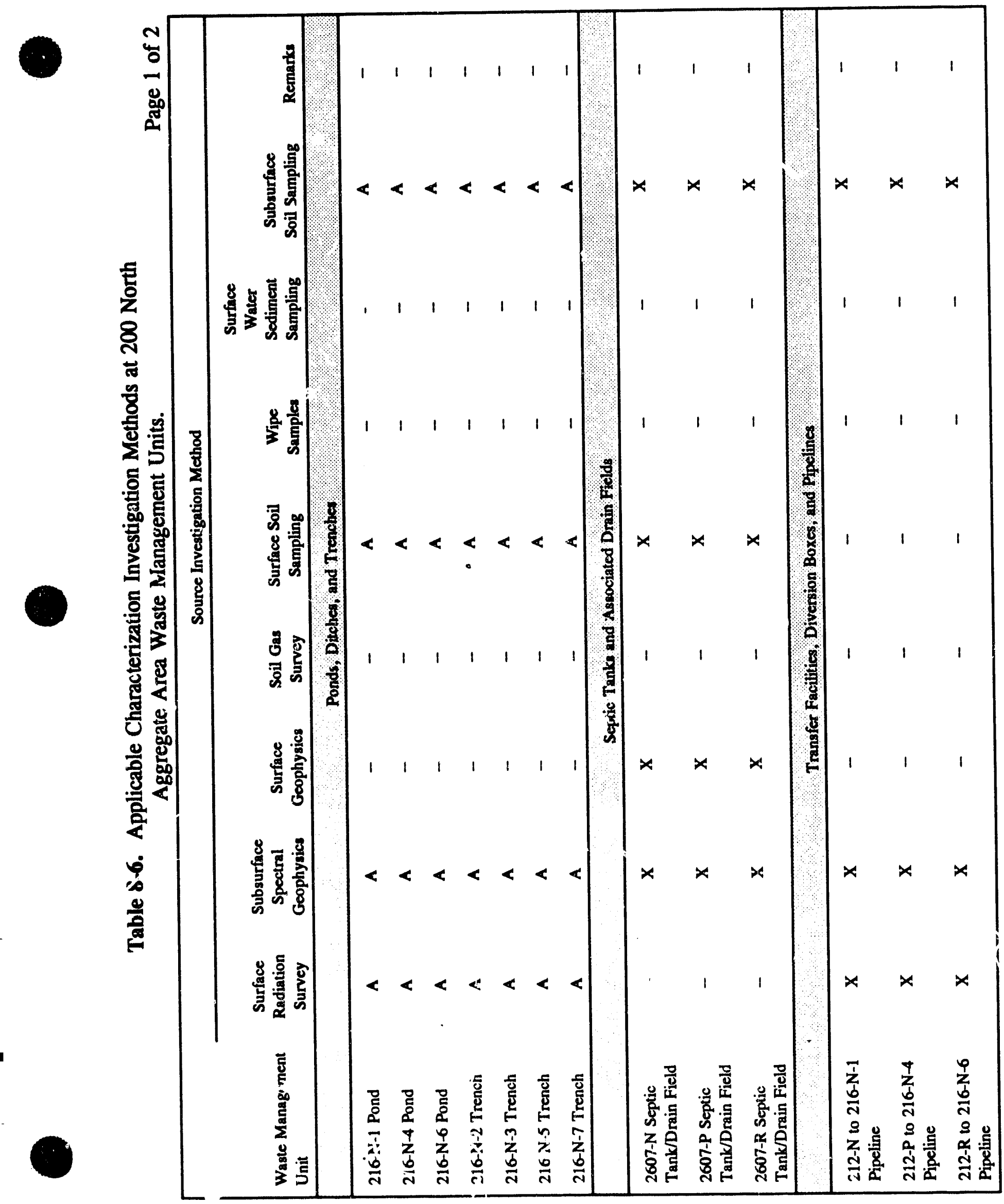


DOE/RL-92-17. Rev. 0

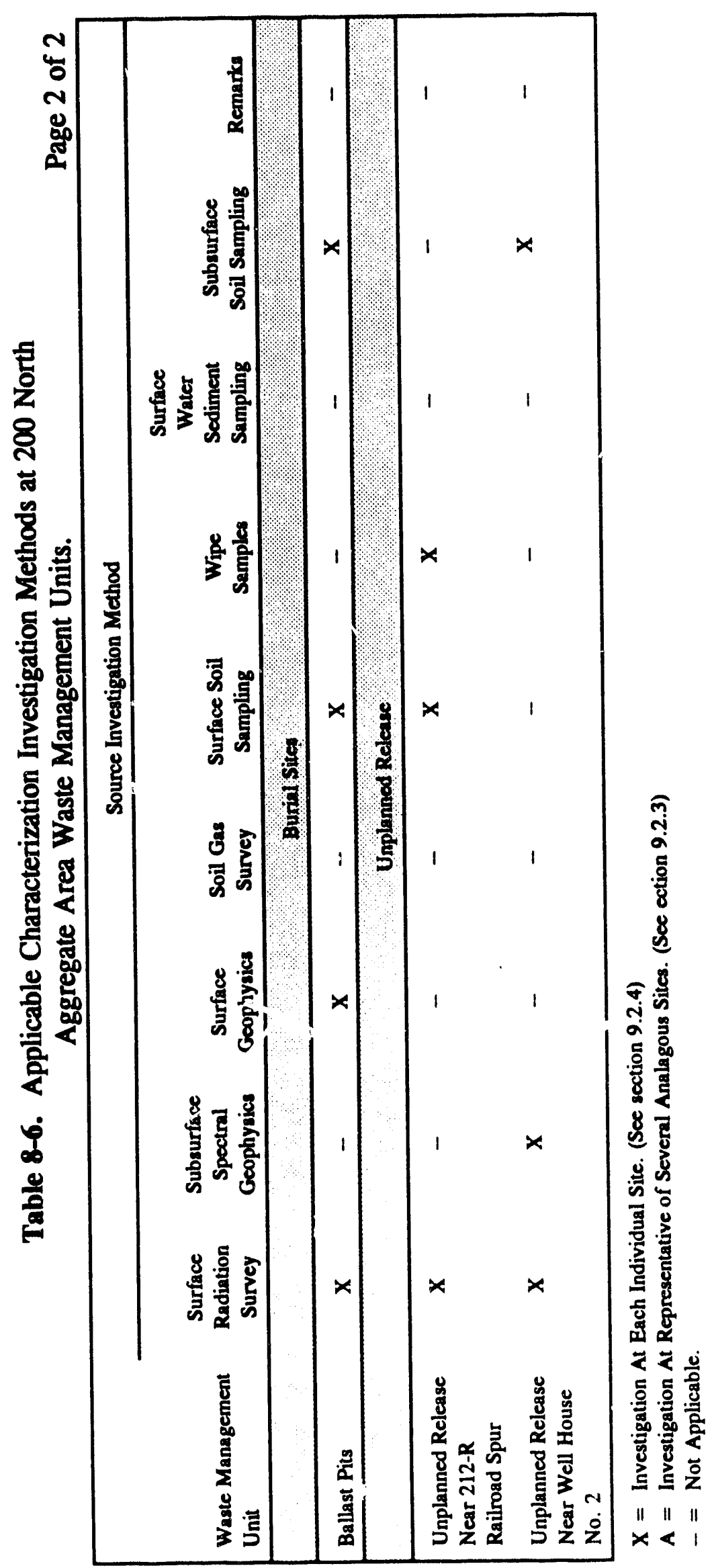




\subsection{RECOMMENDATIONS}

The purpose of the aggregate area management study (AAMS) is to compile and evaluate the existing body of knowledge to support the Hanford Site Past-Practice Strategy (DOE/RL 1992a) decision making process. A primary task in achieving this purpose is to assess each waste management unit and unplanned release within the aggregate area to determine the most expeditious path for remediation within the statutory requirements of the Comprehensive Environmental Response, Compensation and Liability Act (CERCLA) and Resource Conservation and Recovery Act (RCRA). The existing body of pertinent knowledge regarding the 200 North Aggregate Area waste management units and unplanned releases has been summarized and evaluated in the previous sections of this study. A data evaluation process has been established that uses the existing data to develop preliminary recommendations on the appropriate remediation path for each waste management unit. This data evaluation process is a refinement of the Hanford Site Past-Practice Strategy (Figure 1-2) and establishes criteria for selecting appropriate Hanford Site Past-Practice Strategy paths (expedited response action, ERA; interim remedial measures, IRM; limited field investigation, LFI; and final remedy selection) for individual waste management units and unplanned releases within the 200 Areas. A discussion of the criteria for path selection and the results of the data evaluation process are provided in Sections 9.1. and 9.2, respectively. Figure 9-1 provides a flowchart of the data evaluation process that will be discussed. Table 9-1 provides a summary of the results of data evaluation assessment of each unit. Table 9-2 provides the decisional matrix patterns each unit followed.

This section presents recommended assessment paths for the waste management units and unplanned releases at the 200 North Aggregate Area. These recommendations are only proposed at this time and are subject to adjustmerit and change. Factors that may affect development of final recommendations include, but are not limited to, comments and advice from the Washington State Department of Ecology (Ecology), U.S. Environmental Protection Agency (EPA), or U.S. Department of Energy (DOE); identification and development of new information; and modification of the criteria used in the assessment path decision making process. The data evaluation process depicted in Figure 9-1 and discussed in Section 9.1 was developed to facilitate only the technical data evaluation step shown on the Hanford Site Past-Practice Strategy (Box A, Figure 1-2). Procedural and administrative requirements for implementation of the recommendations provided in this AAMS will be performed in accordance with the Hanford Federal Facility Agreement and Consent Order (Tri-Party Agreement) (Ecology et al. 1990) and the Hanford Site Past-Practice Strategy. Changes in recommendations will be addressed, and more detail on recommended assessment paths for waste management units and unplanned releases will be included in work plans as they are developed for the actual investigation and remediation activities.

A majority of waste management units and unplanned releases do not have information regarding the nature and extent of contamination necessary for quantitative or qualitative risk assessment, especially with regard to hazardous constituents, and were recommended for additional investigation (e.g., LFI). Several units and releases assessed within the ERA path 
were recommended for actions that fall within the scope of existing operational programs. Sites with elevated levels of surface radionuclide contamination are addressed by the Radiation Area Remedial Action (RARA) Program.

Waste management units and unplanned releases which are addressed entirely by other programs were not subjected to the data evaluation process. This includes units and unplanned releases that are the responsibility of the Office of Support Services. Table 9-3 provides a list of the units not included in the evaluation.

A discussion of the four decision-making paths shown on Figure 9-1: ERA, IRM, LFI, and final remedy selection, is provided in Section 9.1. Section 9.2 provides a discussion of the waste management units grouped under each of these paths. A discussion of regrouping and prioritization of the waste management units is provided in Section 9.3.

Recommendations for redefining operable unit boundaries and prioritizing operable units for work plan development are also provided in Section 9.3. No additional aggregate area-based field characterization activities are recommended to be undertaken as a continuation of the AAMS. All recommendation for future characterization needs (see Section 8.0) will be more fully developed and implemented through work plans. Plan development and submittal will be accomplished in accordance with requirements of the Hanford Site Past-Practice Strategy and the Tri-Party Agreement and could include remedial investigation / feasibility study (RI/FS); RCRA Facility Investigation/Corrective Measures Study (RFI/CMS) or LFI work plans. Sections 9.4 and 9.5 provide recommendations for focused feasibility and treatability studies, respectively.

\subsection{DECISION MAKING CRITERIA}

The criteria used to assess the most expeditious remediation process path are based primarily on urgency for action and whether site data are adequate to proceed along a given path (Figure 9-1). All units and unplanned releases that are not completely addressed under other Hanford Site programs are assessed in the data evaluation process. All of the units and releases that are addressed in the data evaluation process are initially evaluated as candidates for an ERA. Sites where a release has occurred or is imminent are considered candidates for ERAs. Conditions that might trigger an ERA are the determination of an unacceptable health or environmental risk or a short time-frame available to mitigate the problem (DOE/RL 1992a). As a result, candidate ERA units were evaluated against a set of criteria to determine whether potential for exposure to unacceptable health or environmental risks exist. Units and unplanned releases that are recommended for ERAs will undergo a formal evaluation following the selection process outlined in WHC (1991c).

Waste management units and unplanned releases that are not recummended for consideration as an ERA continue through the data evaluation frocess. Sites continuing through the process that potentially pose a high risk (refer to Siction 5.0), become candidates for consideration as an IRM. The criteria used to determine a potential for high risk, thereby indicating a high priority site, were the Hazard Ranking System (HRS) score used 
for nominating waste management units for CERCLA cleanup (40 CFR 300), the modified Hazard Ranking System (mHRS) scores, surface radiation survey data, and rankings by the Environmental Protection Program. Units and unplanned releases with HRS or mHRS scores greater than 28.5 (the CERCLA cleanup criterion) were designated as candidate sites for IRM consideration. Units and unplanned releases that did not have an HRS score were compared to similar sites to establish an estimated HRS score. Sites with surface contamination greater than $2 \mathrm{mR} / \mathrm{h}$ exposure rate, $100 \mathrm{ct} / \mathrm{min}$ beta/gamma above background or alpha greater than $20 \mathrm{dis} / \mathrm{min}$ were also designated as candidate IRM sites. The radiation and surface contamination criteria are based on the Westinghouse Hanford Radiation Protection Manual (WHC-CM-4-10) posting requirements. In addition, surface contamination sites that had an Environmental Protection Program ranking of greater than 7 were also designated as candidate IRM sites. A value of 7 was chosen because it represents the approximate midpoint of the scoring range. The candidate IRM sites are listed in Table 5-1, which summarizes the high priority sites. The four risk indicators are based on limited data (refer to Section 8.0) and, therefore, may not adequately represent the actual risk posed by the site. Technical judgment, including assessment of similarities in site operational histories, was used to include sites not ranked as high priority in the list of sites under consideration for an IRM. Candidate IRM sites were then further evaluated to determine if an IRM is appropriate for the site. Candidate IRM sites that did not meet the IRM criteria were placed into the final remedy selection path. As future data become available the list of units recommended for consideration as IRM sites may be altered.

For certain units and unplanned releases, it was recognized that remedial actions could be undertaken under an existing operational or other Hanford Site program (e.g., Single-Shell Tank Closure, RARA, or Surplus Facility programs). As a result, recommendations were made that remedial actions be undertaken (partially or completely) outside the 200 AAMS past practice program. Units or unplanned releases that could be addressed only in part by another program (e.g., surface contamination cleanup under the RARA program) remained in the 200 AAMS data evaluation process for further consideration. If it cannot be demonstrated that these sites will be addressed under the operational program within a time frame compatible with the past practice program, they will be readdressed by the 200 AAMS process. Tracking of waste management units included in operational programs will be discussed in the work plans developed for each operable unit/aggregate area.

Units and unplanned releases recommended for complete disposition under another program (e.g., the waste staging area and transformer oil tank operated by the Office of Support Services) were not considered in the 200 AAMS data evaluation process.

Specific criteria used to develop initial recommendation for ERA, LFI, and IRM for units and unplanned releases within the 200 North Aggregate Area are provided in Sections 9.1.1 and 9.1.2. Units and unplanned releases not initially addressed as an ERA, LFI or IRM will be evaluated under the final remedy selection path discussed in Section 9.1.3. 


\subsubsection{Expedited Response Action Path}

Candidate ERA sites are evaluated to determine if they pose an unacceptable health or environmental risk and a short time-frame to mitigate the problem exists. All units and unplanned releases other than those recommended for complete disposition under another Hanford program are assessed against the ERA criteria. The Hanford Site Past-Practice Strategy describes conditions that might trigger abatement actions for a candidate waste management unit or unplanned release under an ERA. Generally, these conditions would rely on a determination of, or suspected, existing or future unacceptable health or environmental risk, and a short time-frame available to mitigate the problem. Conditions include, but are not limited to:

- Actual or potential exposure to nearby human populations, biota, or the food chain from hazardous substances and radioactive or mixed waste contaminants

- Actual or potential contamination of drinking water supplies or sensitive ecosystems

- Threats of release of hazardous substances and radioactive or mixed waste contaminants

- High levels of hazardous substances and radioactive or mixed waste contaminants in soils that pose or may pose a threat to human health or the environment, or have the potential for migration

- Weather conditions that may increase potential for release or migration of hazardous substances and radioactive or mixed waste contaminants

- The availability of other appropriate federal or state response mechanisms to respond to the release

- $\quad$ Time required to develop and implement a final remedy

- Further degradation of the medium which may occur if a response action is not expeditiously initiated

- Risks of fire or explosion or potential for exposure as a result of an accident or failure of a container or handling system

- Other situations or factors that may pose threats to human health or welfare or the environment.

These conditions were used as the initial screening criteria to identify candidate waste management units and unplanned releases for an ERA. Candidate waste management units and releases that did not meet these conditions were not assessed through the ERA evaluation 
path. Additional criteria for further, detailed screening of ERA candidates were developed based on the conditions outlined in the Hanford Site Past-Practice Strategy. Quantification of the criteria for further screening were developed. These additional screening criteria are shown in Figure 9-1 and are described below.

The next decision point on Figure 9-1 used to assess each ERA candidate is whether a driving force to an exposure pathway exists or is likely to exist. Units or unplanned releases with contamination that is migrating or is likely to significantly migrate to a medium that can result in exposure and harm to humans required additional assessment under the ERA process. Units or unplanned releases where contamination could migrate and, therefore, potentially require significantly more extensive remedial action if left unabated were also assessed in the ERA path.

Waste management units and unplanned releases with a driving force were assessed to determine if an unacceptable health or environmental risk and a short time-frame to mitigate the problem exists from the release. The criteria used to determine unacceptable risks are based on the quantity and concentration of the release. If the release or imminent release is greater than 100 times the CERCLA reportable quantity for any constituent, the unit or unplanned release will remain in consideration for an ERA. If the release or imminent release contains hazardous constituents at concentrations that are 100 times the most applicable standard, the unit or unplanned release continues to be considered for an ERA. Application of the criterion of 100 times applicable standards is for quantification of the strategy criterion which addresses "high levels of hazardous substances and radioactive or mixed waste contaminants..." The factor of 100 is based on best engineering judgment of what constitutes a high level of contamination warranting expedited action. In some cases, engineering judgment was used to estimate the quantity and concentration of a postulated release. Standards applied include Model Toxics Control Act (MTCA) standards for industrial sites and DOE and Westinghouse Hanford radiation criteria (refer to Section 6.0). The application of these standards does not signify they are recognized as ARARs.

The ERA screening criteria, in addition to those presented in the Hanford Site PastPractice Strategy were applied to provide a consistent quantitative basis for making recommendations in the AAMS. The decision to implement the recommendations developed in AAMS will be made collectively between DOE, EPA, and Ecology based only on the criteria established in the Hanford Site Past-Practice Strategy.

If a release is unacceptable with respect to health or environmental risk, a technology must be readily available to control the release for a unit or unplanned release to be considered for an ERA. An example that would require substantial technology development before implementation of cleanup would be a tritium release since no established treatment technology is available to separate low concentrations of tritium from water.

The next step in the ERA evaluation path involves determining whether implementation of the available technology would have adverse consequences that would offset the benefits of an ERA. Examples of adverse consequences include: (1) use of technologies that result in 
risks to cleanup personnel that are much greater than the risks of the release; (2) the ERA would foreclose future remedial actions; and (3) the ERA would prevent or greatly hinder future data collection activities. If adverse consequences are not expected, the site remains in consideration for an ERA.

The final criterion is to determine if the candidate ERA is within the scope of an operational program. Maintenance and operation of active waste management facilities are within the scope of activities administered by the Defense Waste Management Program. Active facilities include certain transfer lines, diversion boxes, and catch tanks. Generally, active waste management units will not be included in past practice investigations unless operation is discontinued prior to initiation of the investigation. The Decomissioning and RCRA Closure programs are responsible for safe and cost-effective surveillance, maintenance, and decommissioning of surplus facilities and RCRA closures at the Hanford Site. The Decomissioning and RCRA Closure program is also responsible for RARA activities that include surveillance, maintenance, decontamination, and/or stabilization of inactive burial grounds, cribs, ponds, trenches, and unplanned release sites.

If the proposed ERA will not address all the contamination present, the unit or unplanned release continues through the process to be evaluated under a second path. For example, surface contamination cleanup under the RARA program may not address subsurface contamination and, therefore, additional investigation may be needed.

Final decisions regarding whether ERAs are justified in the aggregate area will be made among Ecology, EPA, and DOE based, at least in part, on the recommendations provided in this section, and results of the final selection process outlined in WHC (1991c).

\subsubsection{Limited Field Investigation and Interim Remedial Measure Path}

High priority waste management units and unplanned release sites were evaluated to determine if sufficient need and information exists such that an IRM could be pursued. An IRM is desired for high priority units and unplanned releases where extensive characterization is not necessary to reach defensible cleanup decisions. Implementation of IRMs at waste management units and unplanned releases with minimal characterization is expected to rely on observational data acquired during remedial activities. Successful execution of this strategy is expected to reduce both time and cost for cleanup of waste management units and unplanned releases without impacting the effectiveness of the implemented action.

The initial step in the IRM evaluation path is to categorize the units. The exposure pathways of interest are similar for each site in a category; therefore, it is effective to evaluate candidate waste management units as a group. The groupings used in Section 2.3 (e.g., ponds and trenches) will continue to be used to group the waste management units for IRM assessment. This grouping approach is especially effective in reducing characterization requirements. As done in the 100 Areas using the observational approach, the LFIs can be 
used to characterize a representative unit or units in detail to develop a remedial alternative for the group of waste management units. Observational data obtained during implementation of the remedial alternative could be used to meet unit specific needs. Similarities of waste management units may make it possible to remediate them using the observational approach after first characterizing only a few units. It is expected, therefore, that a LFI would provide sufficient information to proceed with an IRM for groups of similar high priority waste management units.

Data adequacy is assessed in the next step. The existing data are evaluated to determine if: (1) existing data were sufficient to develop a conceptual model and qualitative risk assessment; (2) the IRM will work for this pathway; (3) implementing the IRM will have adverse impacts on the environment, future remediation activities or data collection efforts; (4) the benefits of implementing the IRM are greater than the costs. If data are not aclequate an assessment was made to determine if an LFI might provide enough data to determine if an IRM is justified, and also to perform an IRM. If an LFI would not collect sufficient data, the unit was addressed in the final remedy selection path.

The final step in the IRM evaluation process is to assess if the IRM will work without significant adverse consequences. This includes: will the IRM be successful? will it create significant adverse environmental impacts (e.g., environmental releases)? will the costs outweigh the benefits? will it preclude future cleanup or data collection efforts? and will the risks of the cleanup be greater than the risks of no action? Units where remediation is considered to be possible without adverse consequences outweighing the benefits of the remediation are recommended for IRMs. Low priority unplanned release at candidate IRM units will be included in the IRM evaluations of the candidate units.

Final decisions will be made between DOE, EPA, and Ecology on whether particular IRMs are justified based, at least in part, on the recommendation provided in this AAMSR, and the results of a supporting LFI.

\subsubsection{Final Remedy Selection Path}

Sites recommended for initial consideration in the final remedy selection path are those not recommended for IRMs, LFIs, or ERAs and those considered to be low priority sites. It is recognized that all units and unplanned releases within the operable unit or aggregate area will eventually be addressed collectively under the final remedy path to support a final aggregate area Record of Decision (ROD).

The initial step in the final remedy selection process path is to assess whether the combined data from the AAMS, and any completed ERAs, IRMs, and LFIs are adequate for performing a risk assessment (RA) and selecting a final remedy. Whereas the scope of an ERA, IRM, and LFI is limited to individual waste management units or groups of similar waste management units, the final remedy selection path will likely address an entire operable unit or aggregate area. 
If the data are collectively sufficient, an operable unit or aggregate area RA will be performed. If sufficient data are not available, additional needs will be identified and collected.

\subsection{PATH RECOMMENDATIONS}

Initial recommendations for ERA, IRM, and LFI are discussed in Section 9.2.1 through 9.2.3, respectively. Waste management units and unplanned releases proposed for initial consideration under the final remedy selection path are discussed in Section 9.2.4. Table 9-1 provides a summary of the data evaluation process path assessment. A summary of the responses to the decision points on the flowchart that led to the recommendations is provided in Table 9-2. A listing of sites that will be addressed by other operational programs is presented in Table 9-3. Following approval by Ecology, EPA, and DOE these recommendations will be further developed and implemented in work plans.

\subsubsection{Proposed Sites for Expedited Response Actions}

None of the 18 waste management units and unplanned releases evaluated along the ERA path met all of the criteria for an ERA prior to determining whether the proposed action was within the scope of an operational program.

The primary reason most waste management units were not recommended for ERAs was because of the lack of driving force to an exposure pathway. Inactive ponds and trenches are no longer receiving waste and, therefore, no longer have artificial recharge as a driving force to move subsurface contaminants. Natural recharge from local precipitation was not considered a significant short-term driving force. Surface contamination has not been found on the waste management units which are routinely surveyed which eliminates the exposure pathway via wind or biota.

Other waste management units did not meet the ERA criteria because they either had not released contaminants to the environment or had not released contaminants in a sufficiently large quantity to meet the ERA criteria. There is one site with surface contamination, the unplanned release near the 212- $R$ railroad spur. Based on engineering judgement, it was concluded that it is unlikely that the releases of radionuclides and potential radiation exposure levels at this site would be greater than 100 times the reportable quantities and quality standards. As stated earlier, an ERA at this site is not planned. Specifics for each waste management unit or unplanned release are provided in Table 9-2. 


\subsubsection{Proposed Sites for Interim Remedial Measures}

Eight of the 18 waste management units addressed in the 200 North Aggregate Area data evaluation process were identified as high priority waste management units (refer to Section 5.0) and were assessed as candidates for IRMs. Six of the units were designated as high priority waste management units because of high HRS and mHRS scores. A seventh, the 216-N-1 Pond, was added because its operational history was similar to other included units. The eighth unit, the unplanned release near Well House No. 2, was ranked as a high priority site due to the potential for migration.

All of the eight candidate IRM waste management units met the criteria for IRM designation with the exception of having adequate data. It was determined that an LFI could gather sufficient data for an IRM, therefore all of the sites remain IRM candidates. A discussion of the LFIs is provided in Section 9.2.3.

\subsubsection{Proposed Sites for Limited Field Investigation Activities}

Eight waste management units are recommended to undergo LFIs. The initial decision point in the IRM path is assess whether data are adequate to conduct an IRM. for each of the eight units, only inventory estimates are available. No data are avialable describing the nature and extent of contamination, so LFIs are required before IRMs may be implemented. The rationale for IRM and LFI will be more completely developed in work plans, however, the following addresses possible considerations during work plan development.

Possible LFI objectives would be to:

- Evaluate the potential for releases from the waste management unit to impact underlying groundwater quality.

- Determine if contamination exists in the soil beneath the waste management unit and, if so, assess the extent.

- Assess the nature and extent of contaminant migration from the units in support of focused feasibility studies.

Each waste management unit that is recommended for an LFI will be studied as part of an analogous group. The analogous site concept is presented in the Hanford Site PastPractice Strategy.

This concept emphasizes that characterization activities can be reduced by identifying select sites (analogue sites) for characterization that are representative of a group of sites (analogous groups). This concept is particularly applicable to operable units which contain a number of waste management units that are similar in design, disposal history, and geology. Appropriate confirmatory characterization, as necessary to support remedial action, can then 
be performed at the sites within each analogous group during remediation. Collection of confirmatory data can again be reduced during remediation activities by emphasizing in work plans the use of the observational approach discussed in the Hanford Site Past-Practice Strategy.

To facilitate the implementaion of these strategies in work plans, individual LFIs are assembled into analogous groups for study. Three primary analogous groups have been identified in the 200 North Aggregate Area: (1) all three ponds (216-N-1, 216-N-4, and 216-N-6), (2) all four trenches (216-N-2, 216-N-3, 216-N-5, and 216-N-7), and (3) the unplanned release near Well House No. 2. Specific waste management units are then identified that were considered to be representative of the analogous groups. Considerations used to select an analogue site for an analogous group include, but are not limited to, the following:

- Disposal history (including type and quantity of waste received)

- Physical and chemical setting.

Generally the selection process favored as analogue sites those units that received the most waste and were considered conservative examples in terms of release mechanisms, media of concern, exposure routes, and receptors.

9.2.3.1 Ponds. The three ponds have been recommended for LFIs as an analogous group. These ponds are:

- 216-N-1 Pond

- 216-N-4 Pond

- 216-N-6 Pond.

The three ponds are proposed as an analogous group due to their similar operational history (operated during the irradiated fuel storage period for 212-N, 212-P, and 212-R), waste stream received (low activity storage basin overflow water), similar physical configuration and size.

The physical and chemical setting for releases from these waste management units is also similar:

- Similar, large volumes of storage basin overflow water $(946,000,000 \mathrm{~L}$ $[250,000,000$ gal] $)$ were released at the three ponds likely affecting near-surface and deeper vadose zone soils.

- The units all have similar depths to goundwater. 
- The stratigraphy beneath these waste management units in the 200 North Aggregate Area is generally uniform (Section 3.0).

- The wastewater received by the three ponds originated from an identical process at each of the three storage facilities and was likely to contain similar contamination levels.

Because of their similar operational histories and settings it is expected that contaminants will be similarly distributed in the vadose zone. It is concluded that the ponds will, therefore, have similar release mechanisms, exposure routes, and receptors.

The 216-N-6 Pond is proposed as an analogue site for these waste management units. This pond potentially contains the highest levels of contamination based on excavation tests conducted in 1973 and its operating time period is identical to the other ponds. Therefore, the 216-N-6 Pond would be a conservative choice for an analogue for the other units in this analogous group.

9.2.3.2 Trenches. The four trenches have been recommended for LFIs as an analogous group. These trenches are:

\section{- $\quad 216-\mathrm{N}-2$}

- $\quad 216-\mathrm{N}-3$

- $\quad 216-\mathrm{N}-5$

- $\quad 216-\mathrm{N}-7$.

The four trenches are proposed as an analogous group due to their similar operational history (all operated for time intervals of a few weeks and three were operational in June 1952), waste stream received (storage basin cleanout water and sludge), similar physical configuration and size.

The physical and chemical setting for releases from these waste management units is also similar:

- Similar volumes of storage basin cleanout waste (approximately 7,500,000 L $[1,980,000$ gal $]$ ) were released at the four trenches likely affecting near-surface and deeper vadose zone soils.

- The units all have similar depths to goundwater.

- The stratigraphy beneath the these waste management units in the 200 North Aggregate Area is generally uniform (Section 3). 
- The wastewater received by the four trenches originated from a similar cleanout procedure at each of the three storage facilities and was likely to contain similar contamination levels.

Because of their similar operational histories and settings it is expected that contaminants will be similarly distributed in the vadose zone. It is concluded that the trenches will, therefore, have similar release mechanisms, exposure routes, and receptors.

The 216-N-5 Trench is proposed as an analogue site for these waste management units. This trench received a similar quantity and type of waste as the other trenches, has a similar waste inventory, is located midway between the other trenches, and is physically the largest in size.

9.2.3.3 Unplanned Release. The unplanned release near Well House No. 2 is proposed for an LFI based on the limited survey and inventory data available for this site. This site was considered to be high priority based on its potential for migration and lacked sufficient information to conduct an IRM.

\subsubsection{Proposed Sites for Final Remedy Selection}

One unplanned release, the burial site, the three pipelines, and the three septic tank/ drain fields have been proposed for the final remedy selection path. However, no sites have been proposed for inclusion in the final remedy selection risk assessment. Direct inclusion in the final remedy selection RI is recommended for the nine sites mentioned above due to the lack of information to perform RAs and select final remedies. These sites are discussed in Section 9.2.4.1.

9.2.4.1 Proposed Sites for Remedial Investigation. An RI has been recommended for the 200 North Aggregate Area which includes two groups of waste management units and unplanned releases. The first group contains three septic tanks and the bailast pit burial site. These units were assessed in the IRM path but did not meet the high priority criteria. The three septic tanks and drain fields and the ballast pit burial ground require confirmatory sampling to verify that they do not contain hazardous or radioactive substances. The second group includes the unplanned release near the 212-R railroad spur, and the three pipelines. These units were assessed in the IRM path but did not meet high priority criteria. The unplanned release on the 212- $R$ railroad spur and the transfer pipelines are known to contain radioactive substances and the extent and quantity of these needs to be determined.

9.2.4.1.1 Septic Tanks and Burial Ground. This group contains waste management units that were not intended to dispose of hazardous or radioactive waste. Confirmatory sampling should be performed to determine the presence or absence of these wastes. The septic tanks were all used to dispose of sanitary waste and are considered unlikely to have chemical or radiological contamination present. The ballast pit may have been used as a burial ground but this cannot be confirmed from existing documentation. 
There are no sampling or inventory data for any of the sites and so a RA cannot be performed. The, purpose of a limited sampling program is to confirm that no contamination exists in the tanks and drain fields. If no contamination were to be found, then no further action would likely be recommended. The sites in this group include:

- 2607-N Septic Tank and Drain Field

- 2607-P Septic Tank and Drain Field

- 2607-R Señic Tank and Drain Field

- Ballast Pit Burial Ground.

9.2.4.1.2 Pipelines. This group includes the pipelines used to convey the wastewater from the storage basins in the siorage facility buildings to the ponds and the unplanned release near the 212-R railroad spur. All of the pipelines potentially contain underground radioactive materials. The unjplanned release contain is surface contamination. Insufficient data exists at these sites to conduct a RA. A RI is recommended that would include each of these sites to rovic 2 nature and extent of contanination information to perform a risk assessment for final $\mathrm{rt}$ medy selection. The sites in this group include:

- $212-\mathrm{N}$ to $2,16-\mathrm{N}-1$ Pipeline

- 212-F to 216-N-4 Pipeline

- 212-R to 216-N-6 Pipeline

- Unplanned Release near 212-R railroad spur.

\subsection{SOURCE OPERABLE UNIT REDEFINITION AND PRIORITIZATION}

The investigation process can be made more efficient if waste management units with similar histories and waste constituents are studied together. The data needs and remedial actions required for similar waste management units are generally the same. It is much easier to ensure a consistent level of effort and investigation methodology if like waste management units are grouped together. Economies of scale also make the investigation process more cost effective if similar waste management units are studied together. 


\subsubsection{Units Addressed by Other Aggregate Areas or Programs}

The investigation of sev rral sites in the 200 North Aggregate Area will be addressed by the Office of Support Services. Table 9-3 lists the units that are within the scope of this office. No waste management units within the 200 North Aggregate Area are recommended for deferral to another aggregate area.

\subsubsection{North Aggregate Area Operable Unit Redefinition}

Redefinition of the 200 North Aggregate Area operable unit is suggested based on the data evaluation in this report. General redefinition is recommended as follows:

- Investigation of groundwater has been removed from the scope and included in a 200 East Aggregate Area Groundwater operable unit. Groundwater beneath the 200 North Aggregate Area operable unit interacts with all surrounding operable units since it is not confined by the geographic boundaries. Contamination from nearby operable units can migrate beneath the 200 North Aggregate Area operable unit. Similarly, the contamination originating from the operable unit may migrate outride the boundaries of the operable unit. These interactions with other operable units will necessitate the integration of groundwater response actions throughout the 200 East Area. This integration will be discussed in the 200 East Groundwater AAMS.

- There are 2 waste management units fully addressed by another program (Office of Support Services) which should not be included in the aggregate area investigations are listed in Table 9-3.

\subsubsection{Investigation Prioritization}

Very little data exist to rank the waste management units and unplanned releases within the 200 North Aggregate Area on a risk-related basis. The HRS and surface contamination data that were used to sort the waste management units and unplanned releases into either high or low priority are indicators of potential risk but are not suitable to develop a riskrelated ranking. The most useful data for indicating potential risk are probably the waste inventories and facility construction or operation information.

The four trenches, which contain nearly equivalent radionuclide inventories, should be investigated first. The sludges placed in these trenches were similar to sludges that were removed from storage basins in the 100 Areas that were found to contain high levels of contamination. The storage basins would have acted as settling basins that would have accumulated suspended particulate contamination as sediments in the bottom of the basins. These sediments would have contained the most concentrated radionuclides. The basins were cleaned out when the facilities were shut down and the sediments were placed into the 
trenches. The concentration effect of the sedimentation process would make it likely that the radionuclide inventory in the trenches is higher than that in the ponds. The three ponds each received approximately the same inventories and should be investigated second. The unplanned release near Well House No. 2 should be investigated next because of the possibility of injection of wastes into groundwater. The recommended groundwater operable unit should be assigned an investigation priority similar to the LFI/IRM investigation.

The remaining source units should be investigated after completion of the IRM and LFI investigations. The three pipelines rank fourth in prioritization. The pipelines carried contaminated basin water to the ponds and may still contain contaminated sludges. In addition, they may have leaked contaminants into the soil surrounding the pipeline. The unplanned release near the $212-\mathrm{R}$ railroad spur should be investigated fifth. It is likely that the radiological contamination level is low based on typical decontamination practices that were carried out at this site. However, the soils in this site may be contaminated with nonradioactive contamination as a result of sand blasting activities or spilled decontamination solvent. The three septic tanks/drain fields and the ballast pits rank sixth. These units likely handled nonhazardous waste.

\subsubsection{RCRA Facility Interface}

There are no RCRA waste management units operating within the 200 North Aggregate Area.

\subsection{FEASIBLITY STUDY}

Two types of the FS will be conducted to support remediation in the 200 Areas including focused and the final FS. The FFSs are studies in which a limited number of units or remedial alternatives are considered. Final FS will be prepared to provide the data necessary to support the preparation of final ROD. Insufficient data exists to prepare either a focused or final FS for any units or group of units within the 200 North Aggregate Area. Sufficient data are considered available to prepare a FFS on selected remedial alternatives.

\subsubsection{Focused Feasibility Study}

Both LFIs and IRMs are planned for the 200 North Aggregate Area for individual waste management units or waste management unit groups. The IRMs will be implemented as they are approved, and the FFSs will be prepared to support their implementation. The FFSs applied in this manner is intended to examine a limited number of alternatives for a specific unit or groups of units. The FFSs supporting IRMs will be based on the technology screening process applied in Section 7.0, engineering judgement, and/or new characterization data such as that generated by an LFI. 
Recommendations for the FFSs in support of IRMs are not provided in this report because the of limited data availability. In most cases, LFIs will be conducted at sites initially identified for IRMs. The information gathered is considered necessary prior to making a final determination whether an IRM is actually necessary or whether a remedy can be selected.

Rather than being driven by an IRM, the FFSs will also be prepared to evaluate and select remedial alternatives. In this case the FFSs focus on technologies or alternatives that are considered to be viable based on their implementability, cost, and effectiveness and have broad application to a variety of units. The following recommendations are made for FFSs that focus on a particular technology or alternative:

- $\quad$ Capping

- Ex-situ treatment of contaminated soils

- In-situ stabilization.

These recommendations reflect select technologies developed in Section 7.0 of this report.

The FFS is intended to provide a detailed analysis of select remedial alternatives. The results of the detailed analysis provide the basis for identifying preferred alternatives. The detailed analysis for alternatives consists of the following components:

- Further definition of each alternative, if appropriate, with respect to the volumes or areas of contaminated environmental media to be addressed, the technologies to be used, and any performance requirements associated with those technologies. Remedial investigations and treatability studies, if conducted, will also be used to further define applicable alternatives.

- An assessment and summary of each alternative against evaluation criteria specified in EPA's Guidance for Conducting Remedial Investigations and Feasibility Studies under CERCLA (EPA 1988b).

- A comparative analysis of the alternatives that will facilitate the selection of a remedial action.

\subsubsection{Final Feasibility Study}

To complete the remediation process for an aggregate area, a final or summary FS will be prepared. This study will address those sites not previously evaluated and will summarize the results of preceding evaluations. The overall study and evaluation process for an aggregate area will consist of a number of FFSs, field investigations, and interim RODs. All of this study information will be summarized in one final FS to provide the data necessary 
for the final ROD. The summary FS will likely be conducted on an aggregate area basis; however, future considerations may indicate that a larger scope is appropriate.

\subsection{TREATABILITY STUDIES}

A range of technologies which are likely to be considered for remediation of sites within the 200 North Aggregate Area were discussed in Section 7.3. The range of technologies included:

- Engineered multimedia cover

- In-situ grouting

- Excavation and soil treatment

- In-situ vitrification

- Excavation, treatment, and disposal of transuranic (TRU) radionuclides

- In-situ soil vapor extraction of volatile organic compounds (VOCs)

Treatability testing will be required to conduct a detailed analysis for most of the technologies. Relevant EPA guidance will be relied upon to conduct these future treatability studies. A summary of existing programs and treatability testing needs is as follows:

- Engineered multimedia cover--A number of cover design efforts have taken place in support of Hanford Site waste management, permitting, RARA and RCRA closure activities. Although performance testing is lacking, a number of conceptual cover designs have been developed for various types of waste management units. The feasibility/treatability process can be accelerated by utilizing existing cover design information. Long term performance and maintenance objectives, and design criteria should be established for various categories of waste management units based on the degree of protection required. The adequacy of existing conceptual designs should be evaluated against these design criteria and modified appropriately. Hydrologic performance and constructibility data needs can then be assessed by pilot-scale testing of preliminary cover designs.

- In-situ grouting--Field pilot tests would be required to assess the required injection well spacing and the optimum grout injection methods; bench-scale and pilot-scale tests would be required to demonstrate the effectiveness for stabilizing the contaminants. 
- Excavation and soil treatment--Testing will likely be required for several components of an excavation and treatment system. It is anticipated that the waste management units would be excavated with conventional mining and construction equipment. However, some equipment modifications may be required to ensure worker protection. If available, remote excavation equipment could be utilized to protect workers at waste management units containing high exposure potential. Testing of measures to control fugitive dust during retrieval activities will be required.

The testing required for the treatment process will depend on the type of treatment considered and the site-specific conditions. It is anticipated that most of the treatability information required could be obtained by a combination of literature research, laboratory screening, and bench-scale studies. However, pilot-scale testing may be required for certain treatment processes.

Physical separation (i.e., soil washing) pilot-scale treatability testing within the 300-FF-1 Operable Unit is being planned which will be applicable for the 200 Areas. The soils of the Hanford Site are well suited for treatment with a physical separations process. The soils are predominantly coarse sand and gravel, with iess than $10 \%$ silts and clay. It is expected that contaminants will be found largely adsorbed on the smaller soil particles and as coatings on larger particles. The physical soil washing process should provide removal of the precipitate coatings from the large particles and separation of large from small particles. This would result in a large volume reduction by separating and concentrating the contaminants.

The physical separations test in the 300-FF-1 Operable Unit will be conducted in three phases. In Phase I, soils will be characterized to assess physical, chemical, and radioactive properties. Phase II testing will establish baseline operations and capabilities of a system utilizing water as the washing solution. In Phase III, performance of the system will be optimized. Phase III may consist of two parts, processing with water only, and processing using selected nonhazardous and environmentally acceptable chemical extractants, if necessary to optimize the system. Laboratory bench tests may be performed to determine the primary and secondary chemical extractants to be considered for use in Phase III testing. However, it is anticipated that in the 300 Area, physical separation resulting in a large volume reduction of contaminated soil may be achieved with water only. Chemical extracts maybe required for soil washing to be successful in other areas of the Hanford Site (i.e., 200 and 100 Areas). This will depend to a large extent on the type of contaminant at the adsorption coefficient.

If the pilot-scale test is successful in the 300 Area, then the application of this process to the 200 Area should be tested. 
In-situ vitrification--In-situ vitrification has been tested and field demonstrated on soil sites contaminated with radionuclides, heavy metals, and organic wastes. As a result of this testing and demonstration program, established capabilities and limitations of the in-situ vitrification technology have been identified, along with technical issues that need to be resolved for successful implementation. The InSitu Vitrification Integrated Program was created by DOE's office of Technology Development to help resolve these issues and promote deployment of the technology in the field. The In-Situ Vitrification Integrated Program is currently working to resolve the following key issues for implementation at contaminated soil sites:

- Develop methods that accurately predict, measure, and achieve significantly greater melt depth and control of the melt shape. Presently, the in-situ vitrification process has been demonstrated to a depth of $5 \mathrm{~m}(16 \mathrm{ft})$.

- Improve the understanding of and verify VOC contaminant transport behavior.

- Determine the potential for transient gas release events while vitrifying contaminated soils under varying conditions. Better define operating parameters and limits to ensure containment and treatment of offgases during processing.

- Resolve secondary waste generation and handling concerns as they relate to the volatilization of ${ }^{137} \mathrm{Cs}$ from highly concentrated soils.

Other DOE in-situ vitrification related activities include evaluating the cost of insitu vitrification against other technologies (report to be released before fiscal year end) and a field demonstration at the Idaho National Engineering Laboratory (INEL) during fiscal year 1993. Additional field demonstrations will be required before all issues surrounding implementation of in-situ vitrification to contaminated soil sites can be resolved.

There is a large uncertainty whether the In-Situ Vitrification Integrated Program will obtain the funding required to resolve these issues. Without resolution of these issues in-situ vitrification will have very limited application to remediation at the Hanford Site.

- Excavation, treatment and disposal of transuranic radionuclides--Development and testing of methods to characterize, retrieve, treat, and package waste from TRU contaminated waste management units will be required. The DOE Office of Technology Development has established the Buried Waste Integrated Demonstration (BWID) at INEL to resolve these issues. The BWID is focused on sites containing buried waste; however, it is expected that many of the original containers at INEL 
degraded significantly, resulting in contamination of the immediately surrounding soil. As a result, the BWID will also be resolving some of the issues surrounding retrieval and treatment of TRU contaminated soil.

A major concern for retrieval of TRU contaminated materials will be control of fugitive dust. Testing of various types of foams and fixants, that will not interfere with treatment and disposal, will be required. In addition, development of foams and fixants for dust control will be important for non-TRU contaminated waste management units. The use of containment structures (e.g. buildings) to contain fugitive dust during remediation is very expensive and cumbersome (creating problems for both equipment and workers). A significant cost savings could be realized if foams and fixants are used in place of containment structures.

- In-situ soil vapor extraction of volatile organic compounds--Development and testing of methods to characterize, retrieve, and treat waste from VOC contaminated soil will be required. The DOE has established the VOC-Arid Integration Demonstration to resolve these issues. The Z Plant Aggregate Area is currently the initial host site for the demonstration and is associated with an active ERA to remove carbon tetrachloride from the vadose zone using vapor extraction. These activities are expected to resolve numerous design and treatability issues associated with in-situ soil vapor extraction. However, additional treatability testing may be required to resolve site specific data needs.

As treatability testing of the various alternatives progresses, other parameters are likely to be identified which require further development. 
DOE/RL-92-17, Rev. 0

Figure 9-1. 200 Aggregate Area Management Studies Decision-Making Flowchart.

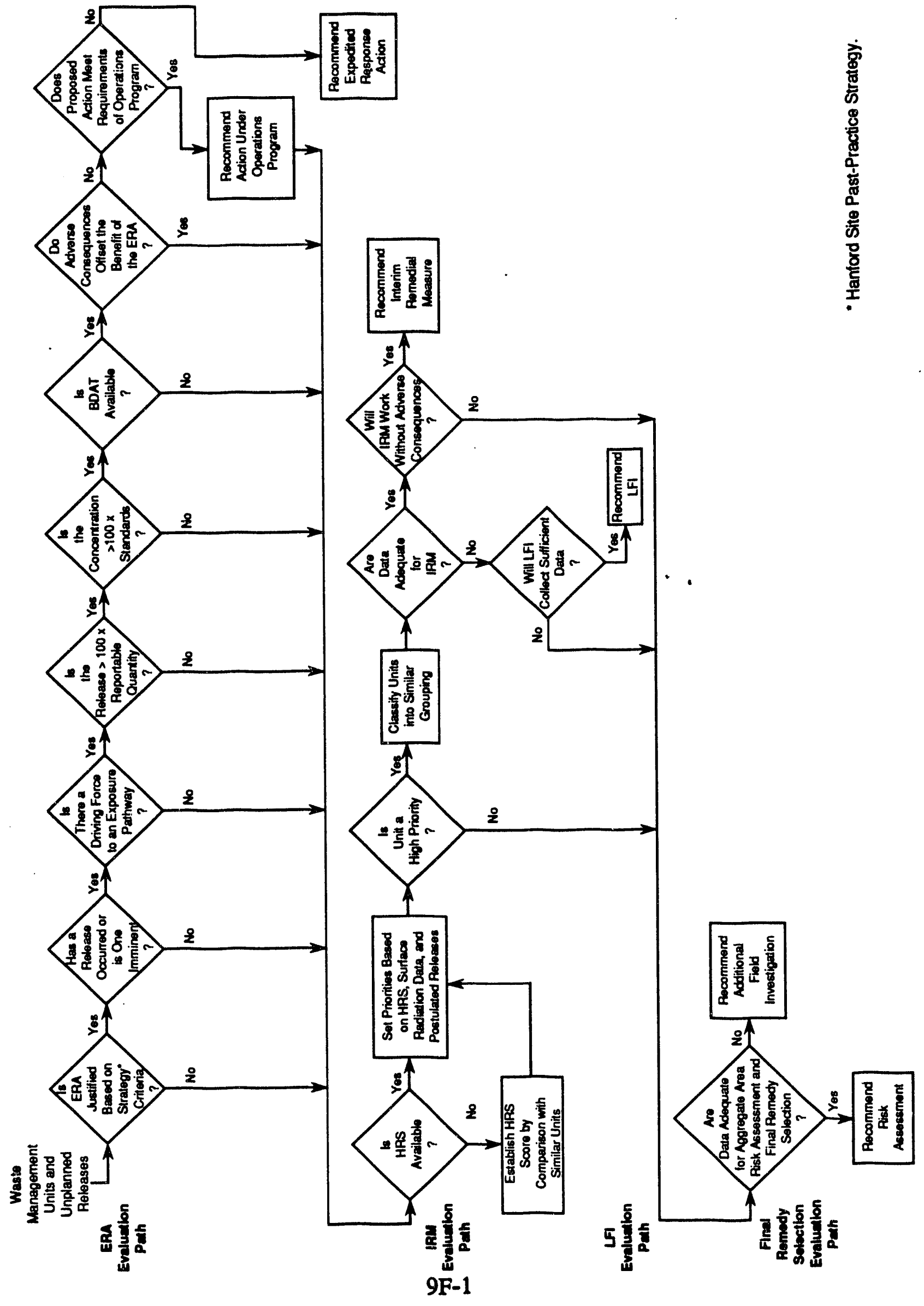


DOE/RL-92-17, Rev. 0

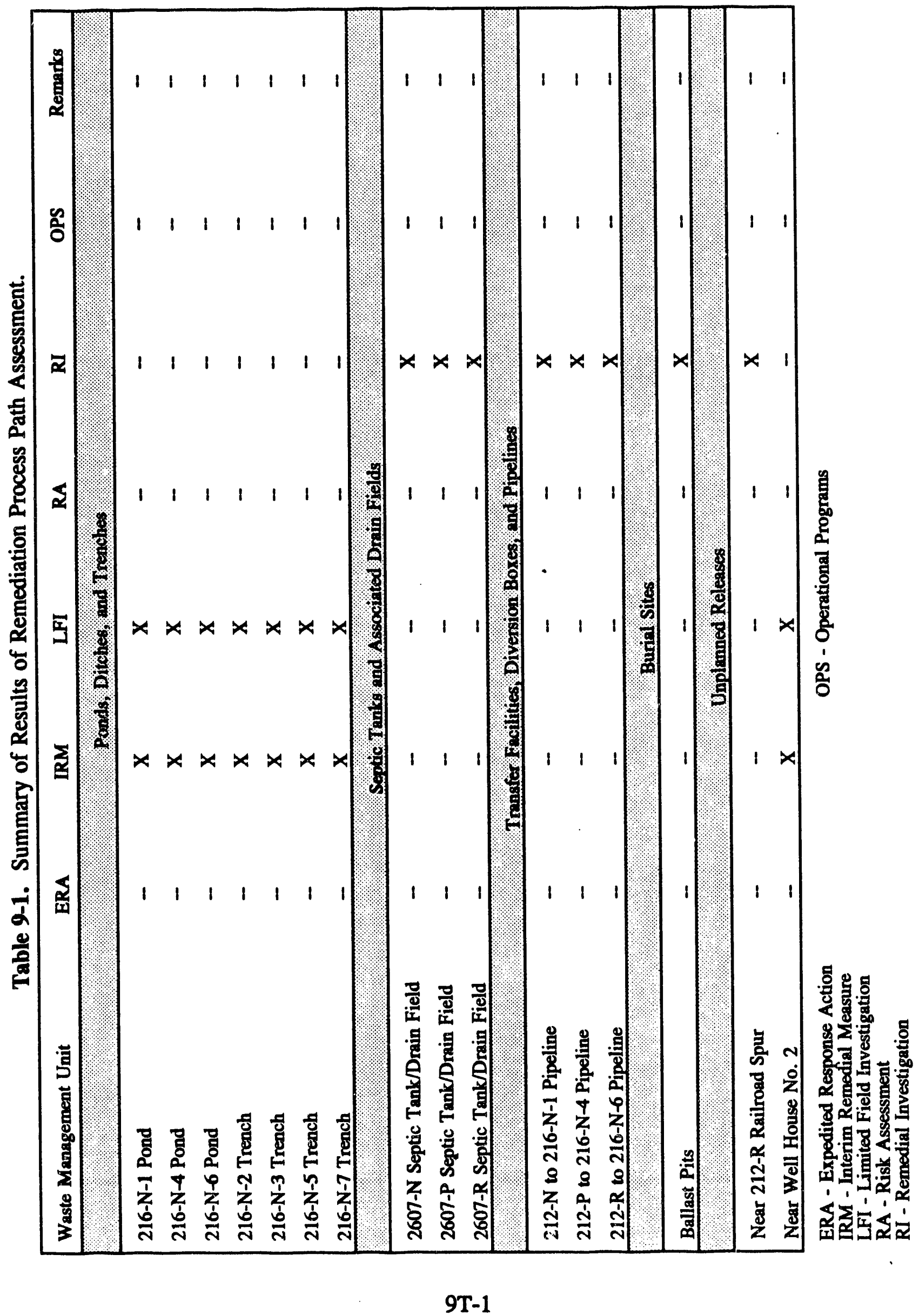


DOE/RL-92-17, Rev. 0

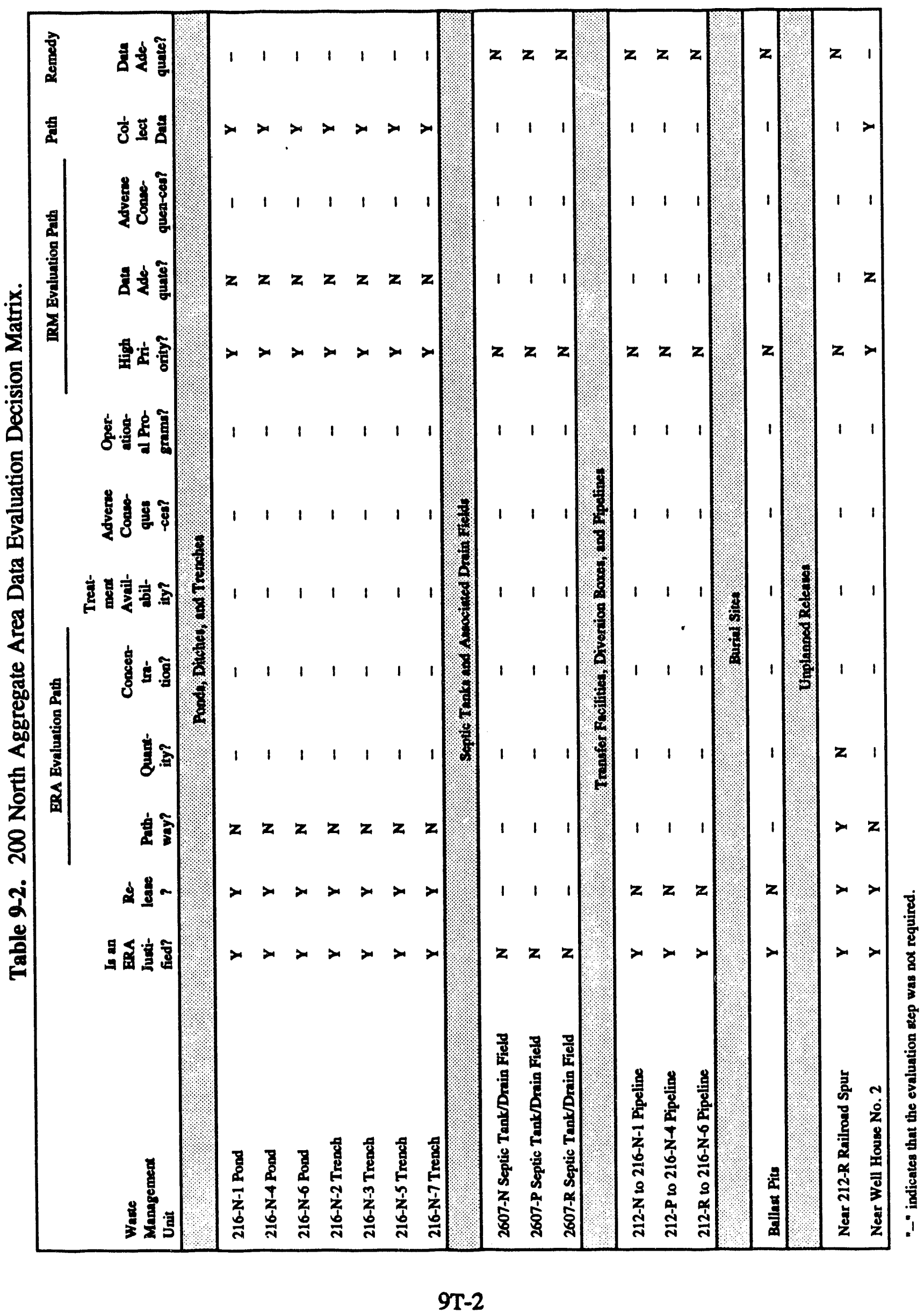


Table 9-3. Waste Management Units and Unplanned Releases to be Addressed by Other Programs.

\begin{tabular}{|c|c|c|c|c|}
\hline $\begin{array}{c}\text { Waste } \\
\text { Management } \\
\text { Unit }\end{array}$ & $\begin{array}{l}\text { Site } \\
\text { Type }\end{array}$ & Program & $\begin{array}{l}\text { Acitve/ } \\
\text { Inactive }\end{array}$ & $\begin{array}{c}\text { Operable } \\
\text { Unit }\end{array}$ \\
\hline \multicolumn{5}{|c|}{ Plants, Buildings, and Storrge Areas } \\
\hline 212-P HWSA & Hazardous Waste Staging Area & OsS & $\mathbf{A}$ & 200-NO-1 \\
\hline \multicolumn{5}{|c|}{ Tanks and Vaults } \\
\hline 212-P Transformer & Tank & OSS & $\mathbf{A}$ & 200-NO-1 \\
\hline
\end{tabular}

OSS - Office of Support Services 


\subsection{REFERENCES}

Ault, T.D., 1981, Subsurface Geology of the Cold Creek Syncline, RHO-BWI-ST-14, Appendix D - Geophysical Investigations of the Gable Mountain-Gable Butte Area, in Myers, C.W., Price, S.M., eds., Rockwell Hanford Operations, Richland, Washington.

Baker, V.R., B.N. Bjornstad, A.J. Busacca, K.R. Fecht, E.P. Kiver, V.A. Moody, J.G. Rigby, D.F. Stradling, and A.N. Tallman, 1991, "Quaternary Stratigraphy of the Pasco Basin, South-Central Washington," in Quaternary Nonglacial Geology, Westinghouse Hanford Company, Richland, Washington.

Baldridge, K.F., 1959, Unconfined Underground Radioactive Waste and Contamination in the 200 Areas, HW-60807, Hanford Laboratories Operation, Richland, Washington.

Ballinger, M.Y. and R.B. Hall, 1989, A History of Major Hanford Operations Involving Radioactive Material, PNL-6964, Pacific Northwest Laboratory, Richland, Washington.

Bjornstad, B.N., 1984, Suprabasalt Stratigraphy Within and Adjacent to the Reference Repository Location, SD-BWI-DP-039, Rockwell Hanford Operations, Richland, Washington.

Bjornstad, B.N., 1990, Geohydrology of the 218-W-5 Burial Ground, 200-West Area, Hanford Site, PNL-7336, Pacific Northwest Laboratory, Richland, Washington.

Black, R.F., 1980, Clastic Dikes of the Pasco Basin, Southwestern Washington, RHO-BWI-C-64, Rockwell Hanford Operations, Richland, Washington.

Brownell, L.E., J.G. Backer, R.E. Isaacson, and D.J. Brown, 1975, Soil Moisture Transport in Arid Site Vadose Zones, ARH-ST-123, Atlantic Richfield Hanford Company, Richland, Washington.

Buckmaster, M.A. and A.M. Kaczor, 1992, Drilling and Sampling Highly Radioactive Contaminated Soil at the 200-BP-1 Operable Unit, Hanford Site, Richland, Washington, WHC-SA-1460-FP, Westinghouse Hanford Company, Richland, Washington.

Chamness, M.A., S.S. Teel, A.W. Pearson, K.R.O. Barton, R.W. Fruland, and R.E. Lewis, 1992, PUREX Plant Geologic and Geophysics Data Package for the 200 Aggregate Area Management Study, Westinghouse Hanford Company, Richland, Washington. 
Chamness, M.A., D. L. McAlister, J. P. McDonal, A. W. Pearson, and R. E. Lewis, 1992a, 200 North Geologic and Geophysics Data Package for the 200 Aggregate Area Management Study, WHC-SD-EN-DP-027, Rev. 0, Westinghouse Hanford Company, Richland, Washington.

Connelly, M.P., K.A. Lindsey, L. Borghese, and B.H. Ford, 1992, Hydrogeologic Model for 200 West Groundwater Aggregate Area, WHC-SD-EN-TI-014, Rev. 0, Westinghouse Hanford Company, Richland, Washington.

Delaney, C.D., K.A. Lindsey, and S.P. Reidel, 1991, Geology and Hydrology of the Hanford Site: A Standardized Text for Use in Westinghouse Hanford Company Documents and Reports, WHC-SD-ER-TI-0003, Westinghouse Hanford Company, Richland, Washington.

DeFord, D.H., 1992, 200 North Aggregate Area Management Study Technical Baseline Report, Westinghouse Hanford Company, Richland, Washington.

DOE, 1986, Hanford Inactive Site Survey (HISS) Database, Phase I - Installation Assessment of Inactive Waste Disposal Sites.

DOE, 1988a Radioactive Waste Management, DOE Order 5820.2A, U.S. Department of Energy, Office of Civilian Radioactive Waste Management, Washington, D.C.

DOE, 1988b, Consultation Draft Site Characterization Plan, DOE/RW-0164, Vols. 1-9, Office of Civilian Radioactive Waste Management, U.S. Department of Energy, Washington, D.C.

DOE, 1991, Quality Assurance, DOE Order 5700.6C, U.S. Department of Energy, Washington, D.C.

DOE/RL, 1988, Preliminary Assessment/Site Inspection Activities on Inactive Waste Sites at Hanford, Draft, U.S. Department of Energy, Richland Field Office, Richland, Washington.

DOE/RL, 1991a, Annual Report for RCRA Groundwater Monitoring Projects at Hanford Site Facilities in 1990, DOE-RL-91-03, U.S. Department of Energy, Richland Field Office, Richland, Washington.

DOE/RL, 1991b, Hanford Site Waste Management Units Report, DOE-RL-88-30, U.S. Department of Energy, Richland Field Office, Richland, Washington.

DOE/RL, 1992a, Hanford Site Past-Practice Investigation Strategy; Draft A, DOE/RL-91-40, U.S. Department of Energy, Richland, Washington. 
DOE/RL, 1992b, Hanford Site Baseline Risk Assessment Methodology, DOE/RL-91-45, U.S. Department of E. Tergy, Richland Field Office, Richland, Washington.

Eberhardt, L.E., L.L. Caldwell, K.R. Price, and D.W. Carlile, 1989, Trends in Kadionuclide Concentration for Selected Wildlife and Food Products near the Hanford Ste From 1971 through 1988, PNL-6992, Pacific Northwest Laboratory, Richland, Washington.

Ecology, 1991, The Model Toxics Control Act Cleanup Regulation, Chapter 173-340 WAC, Washington State Department of Ecology.

Ecology, EPA, and DOF/RL, 1991, Hanford Federal Facility Agreement and Consent Order Change Puckages, Washirgton State Department of Ecology, Olympia, Washington, U.S. Envirn. mental Protection Agency, Region X, Seattle, Washington, and U.S. Department of Energy, Richland Operations Office, Richland, Washington.

Ecology, EPA, and DOF', 1990, Hanford Federal Facility Agreement and Consent Order (First Amendment), 89-10 Rev. 1, Olympia, Washington.

Ecology, EPA, and DOE, 1989, Community Relations Plan for the Hanford Federal Facility Agreement and Consent Order, Olympia; Washington.

E'Jer, R.E., A.W. Conklin, D.D. Brekke, G.W. Egert, and W.L. Osborne, 1986, Rockwell Hanford Operations Environmental Surveillance Annual Report - Calendar Year 1985, RHO-HS-SR-85-13P, Rockwell Hanford Operations, Richland, Washington.

Elder, R.E., G.W. Egert, A.R. Johnson, and W.L. Osborne, 1987, Rockwell Hanford Operations Environmental Surveillance Ainual Report - Caiendar Year 1986, RHr,-HS-SR-86-13P, Rockwell Hanford Operations, Richland, Washington.

Elder, R.E., G.W. Egert, A.R. Johnson, and W.L. Osborne, 1988, Westinghouse Hanford Company Environmental Surveillance Report - Calendar Year 1987, WHC-EP-C145, Westinghouse Hanford Company, Richland, Washington.

Elder, R.E., S.M. McKinney, and W.L. Osborne 1989, Westinghouse Hanford Company Environmental Surveillance Annual Report - 200/600 Areas, Calendar Year 1988, WHC-EP-0145-1, Westinghouse Hanford Company, Richland, Washington.

EPA, 1980, Prescribed Procedures for Measurement of Radioactivity in Drinking Water, In-House Repurt EPA-600/4-80-032, Environmental Monitoring and Support Lab, Cincinnati, Ohio.

EPA, 1983, Methods for Chemical Analysis of Water and Wastes, EPA-600/14-79-020, U.S. Environmental Protection Agency, EMSL, Cincinnati, Ohio. 
EPA, 1986, Test Methous for Evaluating Solid Wastes, SW-846, Third Edition, U.S. Environmental Protection Agency/Office of Solid Waste and Emergency Response, Washington, D.C.

EPA, 1987, Data Quality Objectives for Remedial Response Activities - Development Process, EPA/540/G-87/003, OSWER Directive 9335.3-01, U.S. Environmental Protection Agency, Washington D.C.

EPA, 1988b, Guidance for Conducting Remedial Investigations and Feasibility Studies under CERCLA, Interim Final, EPA 540/G-89-004, U.S. Environmental Protection Agency, Washington, D.C.

EPA, 1989a, Risk Assessment Guidance for Superfund, Vol. I: Human Health Evaluation Manual, EPA/540/1-89/002, Office of Emergency and Remedial Response, U.S. Environmental Protection Agency, Washington, D.C.

EPA, 1989c, Risk Assessment Guidance for Superfund, Vol. 2, EPA/540/1-89/002, Office of Emergency and Remedial Response, U.S. nvironemntal Protection Agency, Washington, D.C.

EPA, 1991a, EPA Region 10 Supplemental Risk Assessment Guidance for Superfund, U.S. Environmental Protection Agency.

EPA, 1991b, Integrated Risk Information System (IRIS), Toxnet online database.

EPA, 1991c, USEPA Contract Laboratory Program Statement of Work for Organic Analysis: Multi-Media Multi-Concentration, Sample Management Office, U.S. Environmental Protection Agency, Washington D.C.

EPA, 1991d, USEPA Contract Laboratory Program Statement of Work for Inorganic Analysis: Multi-Media Multi-Concentration, Sample Management Office, U.S. Environmental Protection Agency, Washington, D.C.

Fecht, K.R., 1978, Geology of the Gable Mountain - Gable Butte Area, RHO-BWI-LD-5, Rockwell Hanford Operations, Richland, Washington.

Fecht, K.R., S.P. Reidel, and A.M. Tallman, 1987, "Paleodrainage of the Columbia River System on the Columbia Plateau of Washington State--a Summary," in Selected Papers on the Geology of Washington, Division of Geology and Earth Resources, Bulletin 77, p. 219-248, edited by J.E. Schuster.

Fitzner, R.E. and W.H. Rickard, 1975, Avifauna of Waste Ponds ERDA Hanford Reservation, Benton County, Washington, BNWL-1885, Atlantic Richfield Hanford Company, Richland, Washington. 
Gee, G.W., and P.R. Heller, 1985, Unsaturated Water Flow at the Hanford Site: A Review of Literature and Annotated Bibliography, PNL-5428, Pacific Northwest Laboratory, Richland, Washington.

Gee, G.W., 1987, Recharge at the Hanford Site: Status Report, PNL-6403, Pacific Northwest Laboratory, Richland, Washington.

General Electric, 1956, Hanford Technical Manual Section C, HW-10475, General Electric, Richland Washington.

Goodwin, S.M., 1990, Borehole Completion Data Package for the 216-U-12 Crib, WHC-MR-0208, Westinghouse Hanford Company, Richland, Washington.

Graham, M.J., M.D. Hall, S.R. Strait, and W.R. Brown, 1981, Hydrology of the Separations Area, RHO-ST-42, Rockwell Hanford Operations, Richland, Washington.

Graham, M.J., G.V. Last, and K.R. Fecht, 1984, An Assessment of Aquifer Intercommunication in the B Pond-Gable Mountain Pond Area of the Hanford Site, RHO-RE-ST-12 P, Rockwell Hanford Operations, Richland, Washington.

Gustafson, F.W., 1991, Site Selection Process for Expedited Response Actions at the Hanford Site, WHC-MR-0290, Westinghouse Hanford Company, Richland, Washington.

Hillel, D., 1971, Soil and Water, Physical Principles and Process, Academic Press, Inc., New York, New York.

Hoover, J.D. and T. LeGore, 1991, Characterization and Use of Soil and Groundwater Background for the Hanford Site, WHC-MR-0246, Westinghouse Hanford Company, Richland, Washington.

Huckfeldt, C.R., 1991, Quarterly Environmental Radiological Survey Summary Second Quarter 1991 - 100, 200, 300, and 600 Areas, WHC-SP-0665-1, Westinghouse Hanford Company, Richland, Washington.

Huckfeldt, C.R., 1991b, Quarterly Environmental Radiological Survey Summary Third Quarter 1991 - 100, 200, 300, and 600 Areas, WHC-SP-0665-2, Westinghouse Hanford Company, Richland, Washington.

Hughes, M.C., R.K. Wahlen, and R.H. Winship, 1990, Hanford Surplus Facilities Program Plan, WHC-EP-0231-3, Westinghouse Hanford Company, Richland, Washington.

Kasper, R.B., 1981, Field Study of Plutonium Transport in the Vadose Zone, RHO-SA-224, Rockwell Hanford Operations, Richland, Washington. 
Kasza, G.L., S.F. Harris, and M.J. Hartman, 1990, Ground Water Maps of the Hanford Site, WHC-EP-0394-1, Westinghouse Hanford Company.

Landeen, D.S., A.R. Johnson, and R.M. Mitchell, 1991, Status of Birds at the Hanford Site in Southeastern Washington, WHC-EP-0402, Westinghouse Hanford Company, Richland, Washington.

Last, G.V. and D.W. Duncan, 1980, Radionuclide Distributions in Soils of the U-Pond Disposal System, Rockwell Hanford Operations, Richland, Washington.

Last, G.V., B.N. Bjornstad, M.P. Bergeron, D.W. Wallace, D.R. Newcomer, J.A. Schramke, M.A. Chamness, C.S. Cline, S.P. Airhart, and J.S. Wilbur, 1989, Hydrogeology of the 200 Areas Low-Level Burial Grounds - An Interim Report, PNL-6820, Westinghouse Hanford Company.

Lindsey, K.A., and D.R. Gaylord, 1989, Sedimentology and Stratigraphy of the Miocene-Pliocene Ringold Formation, Hanford Site, South-Central Washington, WHC-SA-0740-FP, Westinghouse Hanford Company, Richland, Washington.

Lindsey, K.A., B.N. Bjomstad, and M.P. Connelly, 1991, Geologic Setting of the 200 West Area: An Update, WHC-SD-EN-TI-008, Rev. 0, Westinghouse Hanford Company, Richland, Washington.

Lindsey, K.A., B.N. Bjornstad, J. Lindberg, and K. Hoffman, 1992, Geologic Setting of the 200 East Area: An Update, WHC-SD-EN-TI-02, Rev. 0, Westinghouse Hanford Company, Richland, Washington.

McCain, R.G. and W.L. Johnson, 1990, A Proposal Data Quality Strategy for Hanford Site Characterization, WHC-SD-EN-AP-023, Westinghouse Hanford Company, Richland, Washington.

McCullugh, R.W. and J.R. Cartnell, 1968, Chronological Record of Significant Events :n Chemical Separations Operations, ARH-780, Atlantic Richfield Hanford Comfany, Richland, Washington.

McGhan, V.L., 1989, Hanford Wells, PNL-6907, Pacific Northwest Laboratory, Richland, Washington.

Meinhardt, C.C. and J.C. Frostenson, 1979, Current Status of 200 Area Ponds, RHO-CD-798, Rockwell Hanford Operations, Richland, Washington. 
Myers, C.W., S.M. Price, and J.A. Caggiano, M.P: Cochran, W.J. Czimer, N.J. Davidson, R.C. Edwards, K.R. Fecht, G.E. Holmes, M.G. Jones, J.R. Kunk, R.D. Landon, R.K. Ledgerwood, J.T. Lillie, P.E. Long, T.H. Mitchell, E.H. Price, S.P. Reidel, and A.M. Tallman, 1979, Geological Studies of The Columbia Plateau: A Status Report, RHO-BWI-ST-4, Rockwell Hanford Operations, Richland, Washington.

Natural Heritage Program, 1990, Endangered, Threatened, and Sensitive Vascular Plant Species of Washington, Department of Natural Resources, Olympia, Washington.

Newcomb, R.C., 1958, "Ringold Formation of the Pleistocene Age in the Type Locality, the White Bluffs, Washington," American Journal of Science, Vol. 33, No. 1, p. 328-340.

Newcomb, R.C. and S.G. Brown, 1961, Evaluation of Bank Storage Along the Columbia River Between Richland and China Bar, Washington, Water-supply Paper 1539-I, U.S. Geological Survey, Washington, D.C.

PNL, 1989, Hanford Site Environmental Report for Calendar Year 1988, PNL-6825, Pacific Northwest Laboratory, Richland, Washington.

PNL, 1990, Hanford Site Environmental Report for Calendar Year 1989, PNL-7346, Pacific Northwest Laboratory, Richland, Washington.

Price, S.M., R.B. Kasper, M.K. Addition, R.M. Smith, and G.V. Last, 1979, Distribution of Plutonium and Americium beneath the 216-Z-1A rib: A Status Report, RHO-ST-17, Rockwell Hanford Operations, Richland, Washington.

PSPL, 1982, Skagit/Hanford Nuclear Project, Preliminary Safety Analysis Report, Vol. 4, App. 20, Amendment 23, Puget Sound Power and Light Company, Bellevue, Washington.

Reidel, S.P., 1984, "The Saddle Mountains: the Evolution of an Anticline in The Yakima Fold Belt," American Journal of Science, Vol. 284, p. 942-978.

Reidel, S.P., and K.R. Fecht, 1981, "Wanapum and Saddle Mountains Basalt in the Cold Creek Syncline Area" in Subsurface Geology of the Cold Creek Syncline, RHO-BWI-ST-14, Rockwell Hanford Operations, Richland, Washington.

Reidel, S.P., K.R. Fecht, M.C. Hagood, and T.L. Tolan, 1989a, "The Geologic Evolution of the Central Columbia Plateau," in Vilcanism and Tectonism in the Columbia River Flood-Basalt Province, Special Paper 239, edited by S.P. Reidel and P.R. Hooper, Geological Society of America, Boulder, Colorado, p. 247-264. 
Reidel, S.P., T.L. Tolan, P.R. Hooper, M.H. Beeson, K.R. Fecht, R.D. Bentley, J.L. Anderson, 1989b, "The Grande Ronde Basalt, Columbia River Basalt Group: Stratigraphic Descriptions and Correlations in Washington, Oregon, and Idaho," in Volcanism and Tectonism in the Columbia River Flood-Basalt Province, Special Paper 239, edited by S.P. Reidel and P.R. Hooper, Geological Society of America, Boulder, Colorado, p. 21-53.

Reiman, R.T. and T.S. Dahlstrom, 1988, An Aerial Radiological Survey of the Hanford Site and Surrounding Area, Richland, Washington, EGG-10617-1062, Performed by EGG/EM for the U.S. Department of Energy under Contract DE AC08-88NV-10617.

Rockhold, M.L., M.J. Fayer, and G.W. Gee, 1988, Characterization of Unsaturated Hydraulic Conductivity at the Hanford Site, PNL-6488, Pacific Northwest Laboratory, Richland, Washington.

Rockhold, M.L., M.J. Fayer, G.W. Gee, and M.J. Kanyid, 1990, Natural Groundwater Recharge and Water Balance at the Hanford Site, PNL-7215, Pacific Northwest Laboratory, Richland, Washington.

Rogers, L.E. and W.H. Rickard, 1977, Ecology of the 200 Area Plateau Waste Management Environs: A Status Report, PNL-2253, Pacific Northwest Laboratory, Richland, Washington.

Routson, R.C., and V.G. Johnson, 1990, "Recharge Estimates for the Hanford Site 200 Areas Plateau," Northwest Science, Vol. 64, No. 3.

Schmidt J.W., C.R. Huckfeldt, A.R. Johnson, and S.M. McKinney, 1990, Westinghouse Hanford Company Environmental Surveillance Report-200-600 Areas, Calendar Year 1989, WHC-EP-0145-2, Westinghouse Hanford Company, Richland, Washington.

Schmidt J.W., C.R. Webb, A.R. Johnson, and S.M. McKinney, 1991, Westinghouse Hanford Company Environmental Surveillance Report--200-600 Areas, Calendar Year 1990, WHC-EP-0145-4, Westinghouse Hanford Company, Richland, Washington.

Schmidt, J.W., C.R. Webb, A.R. Johnson, and S.M. McKinney, 1992, Westinghouse Company Environmental Surveillance Report--200-600 Areas, Calendar Year 1991, WHC-EP-0573, Westinghouse Hanford Company, Richland, Washington.

Serne, R.J. and M.I. Wood, 1990, Hanford Waste-Form Release and Sediment Interaction, A Status Report with Rationale and Recommendations for Additional Studies, PNL-7297, Pacific Northwest Laboratory.

Smith, A.E., 1973, Nuclear Reactivity Evaluations of 216-Z-9 Enclosed Trench, ARH-2915, Atlantic Richfield Hanford Company, Richland, Washington. 
Smith, G.A., B.N. Bjornstad, and K.R. Fecht, 1989, "Neogene Terrestrial Sedimentation on and Adjacent to the Columbia Plateau; Washington, Oregon, and Idaho," in Volcanism and Tectonism in the Columbia River Flood-Basalt Province, Special Paper 239, edited by S.P. Reidel and P.R. Hooper, Geological Society of America, Boulder, Colorado, p. 187-198.

Smoot, J.L., J.E. Szecsody, B. Sagar, G.W. Gee, and C.T. Kincaid, 1989, Simulations of Infiltration of Meteoric Water and Contaminant Plume Movement in the Vadose Zone at Single-Shell Tank 241-T-106 at the Hanford Site, WHC-EP-0332, Westinghouse Hanford Company, Richland, Washington.

Stone, W.A., J.M. Thorp, O.P. Gifford, and D.J. Hoitink, 1983, Climatological Summary for the Hanford Area, PNL-4622, Pacific Northwest Laboratory, Richland, Washington.

Strenge, D.L. and S.R. Peterson, 1989, Chemical Data Bases for the Multimedia Environmental Pollutant Assessment System (MEPAS): Version 1, PNL-7145, Pacific Northwest Laboratory.

Swanson, D.A., T.L. Wright, P.R. Hooper, and R.D. Bentley, 1979, Revisions in Stratigraphic Nomenclature of the Columbia River Basalt Group, Bulletin 1457-G, U.S. Geological Survey, Washington, D.C.

Swanson, L.C., A.R. Johnson, D.S. Landeen, S.P. Luttrell, R.M. Mitchell, R.C. Roos, D.C. Weekes, 1988, Grout Treatment Facility Environmental Baseline and Site Characterization Report, WHC-EP-0150, Westinghouse Hanford Company, Richland, Washington.

Tallman, A.M., K.R. Fecht, M.C. Maratt, and G.V. Last, 1979, Geology of the Separations Areas, Hanford Site, South-central Washington, RHO-ST-23, Rockwell hanford Operations, Richland, Washington.

Tallman, A.M., J.T. Lillie, and K.R. Fecht, 1981, "Suprabasalt Sediments of the Cold Creek Syncline Area," in Subsurface Geology of the Cold Creek Syncline, RHO-BWI-ST-14, edited by C.W. Myers and S.M. Price, Rockwell Hanford Operations, Richland, Washington.

Tolan, T.L. and S.P. Reidel, 1989, "Structure Map of a Portion of the Columbia River Flood-Basalt Province," in Volcanism and Tectonism in the Columbia River Flood-Basalt Province, Special Paper 239, edited by S.P. Reidel and P.R. Hooper, Geological Society of America, Boulder, Colorado, plate 1. 
Van Genuchten, M.P., F.J. Lij, and S.R. Yates, 1991, "The RETC Code for Quantifying the Hydraulic Functions of Unsaturated Soils," Robt. S. Kerr Environmental Research Laboratory, Office of Research and Development, United States Environmental Protection Agency, Ada, Oklahoma.

WHC, 1988a, Quality Assurance Manual, WHC-CM-4-2, Westinghouse Hanford Company, Richland, Washington.

WHC, 1988b, Radiation Protection, WHC-CM-4-10, Westinghouse Hanford Company, Richland, Washington.

WHC, 1988c, Environmental Investigation and Site Characterization Manual, Westinghouse Hanford Company, Richland, Washington.

WHC, 1990, Environmental Engineering, Technology, and Permitting Function Quality Assurance Program Plan, WHC-EP-0383, Westinghouse Hanford Company, Richland, Washington.

WHC, 1991a, Waste Information Data System, (WIDS), Westinghouse Hanford Company, Richland, Washington.

WHC, 1991b, Management Requirements and Procedures, WHC-CM-1-3, Westinghouse Hanford Company, Richland, Washington.

WHC, 1991c, Prioritizing Sites for Expedited Response Actions at the Hanford Site, WHC-MR-0244, Westinghouse Hanford Company, Richland, Washington.

WHC, 1992a, Environmental Compliance, WHC-CM-7-5, Westinghouse Hanford Company, Richland, Washington.

WHC, 1992b, Radiation Protection - Safery, Quality Assurance and Security, WHC-CM-4-10 Westinghouse Hanford Company, Richland, Washington.

Zimmerman, D.A., A.E. Reisaneuer, G.D. Black, M.A. Young, 1986, Hanford Site Water Table Changes 1950 through 1980, Data Observations and Evaluation, PNL-5506, Pacific Northwest Laboratory, Richland, Washington. 


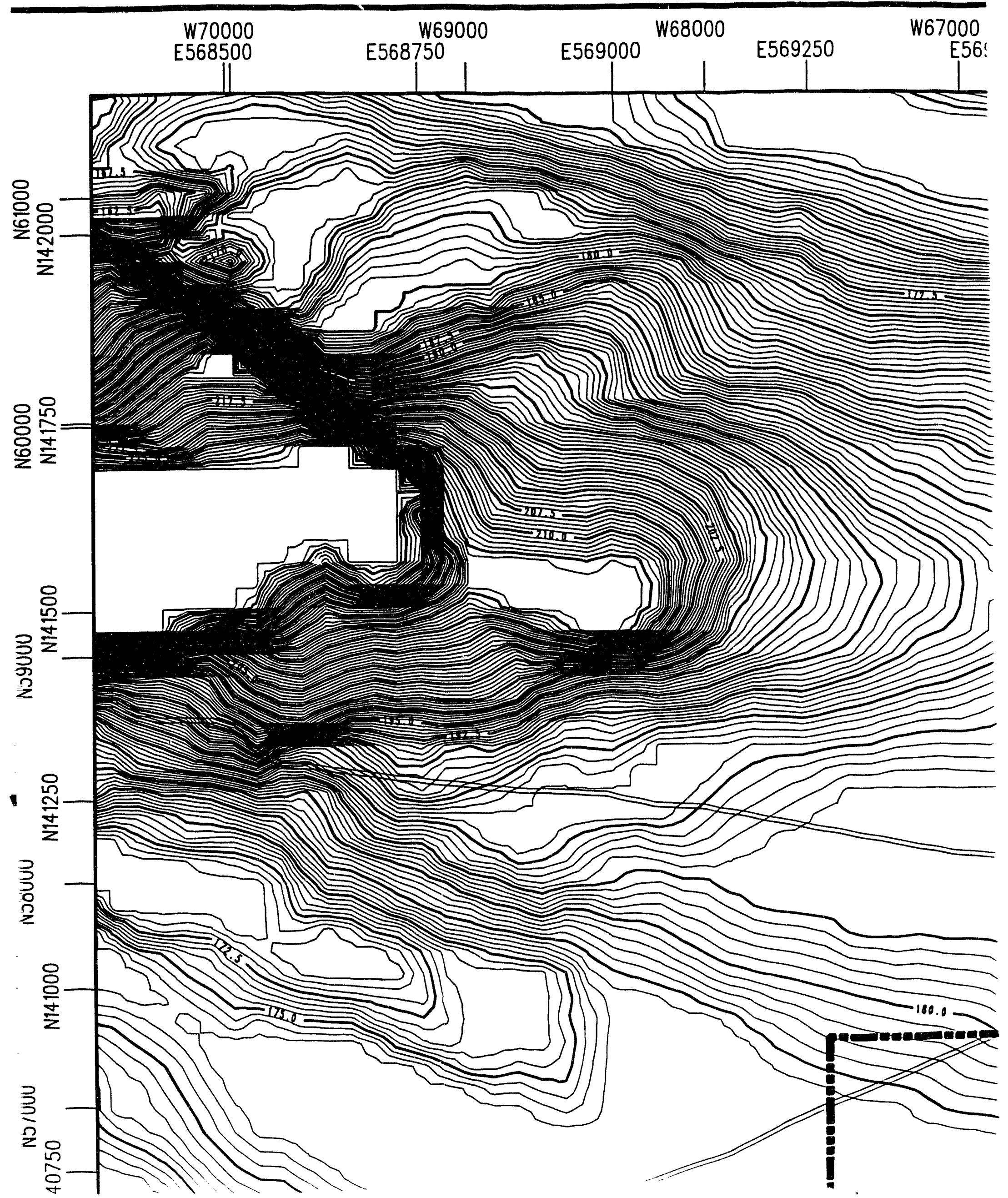




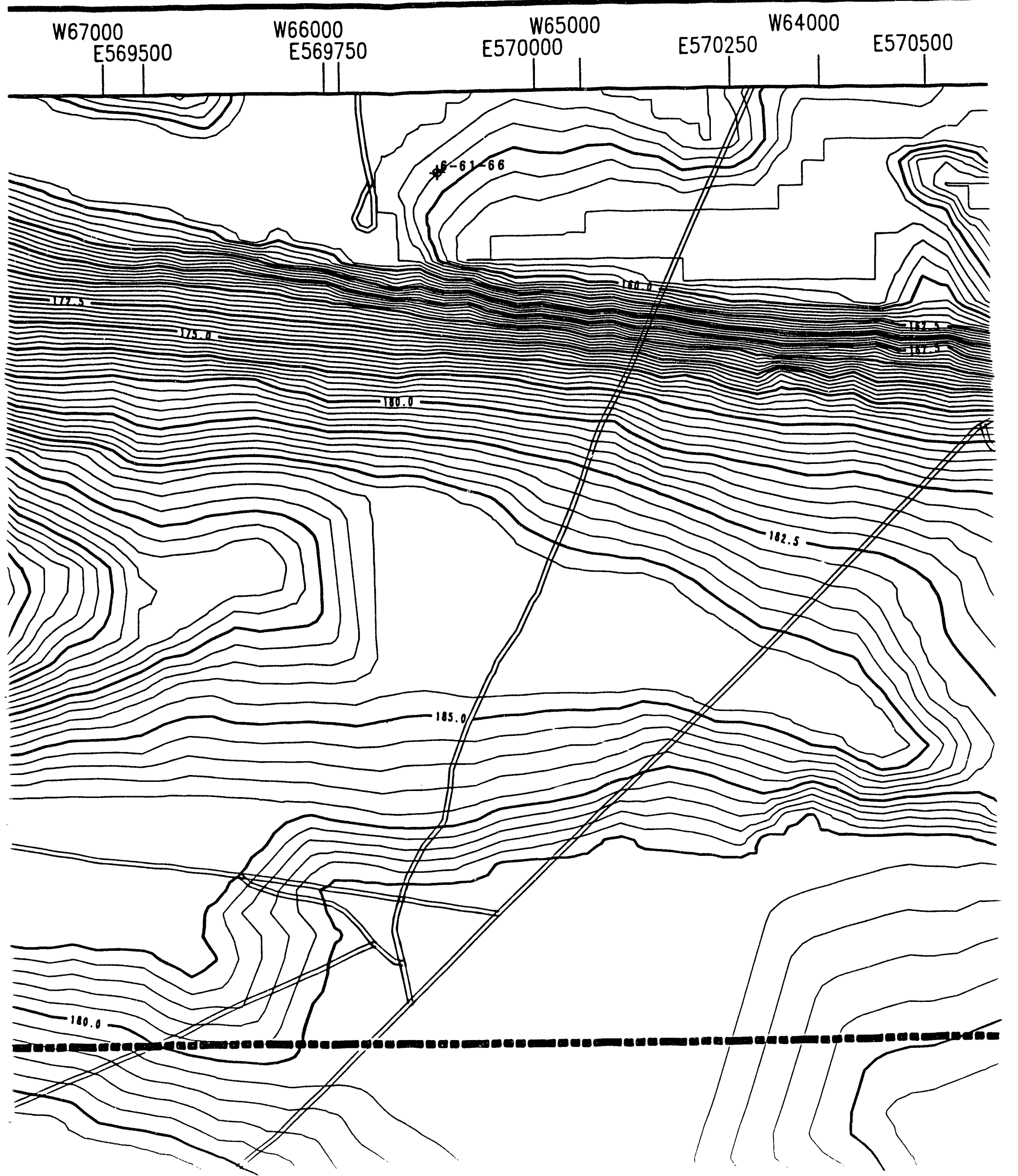




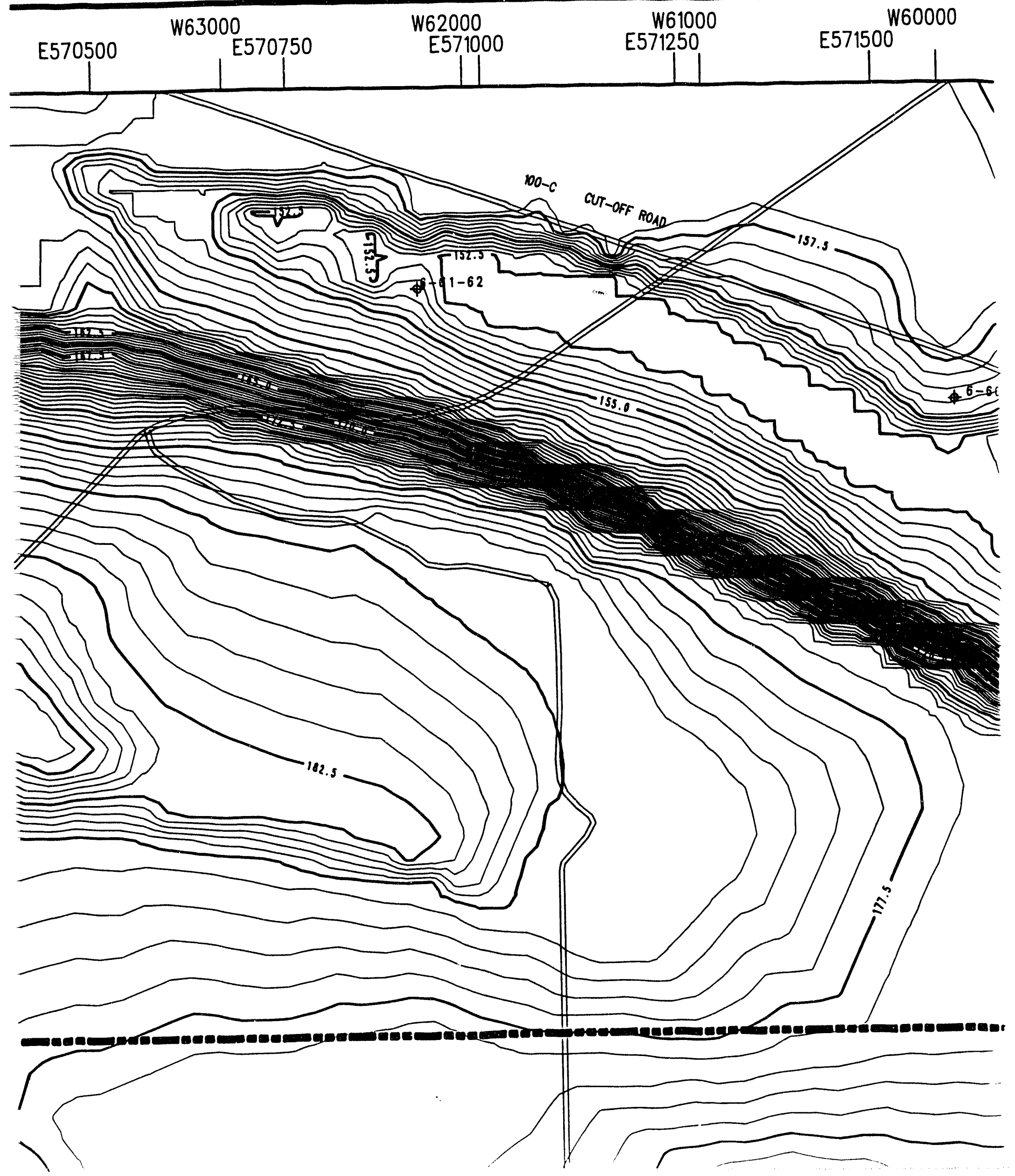




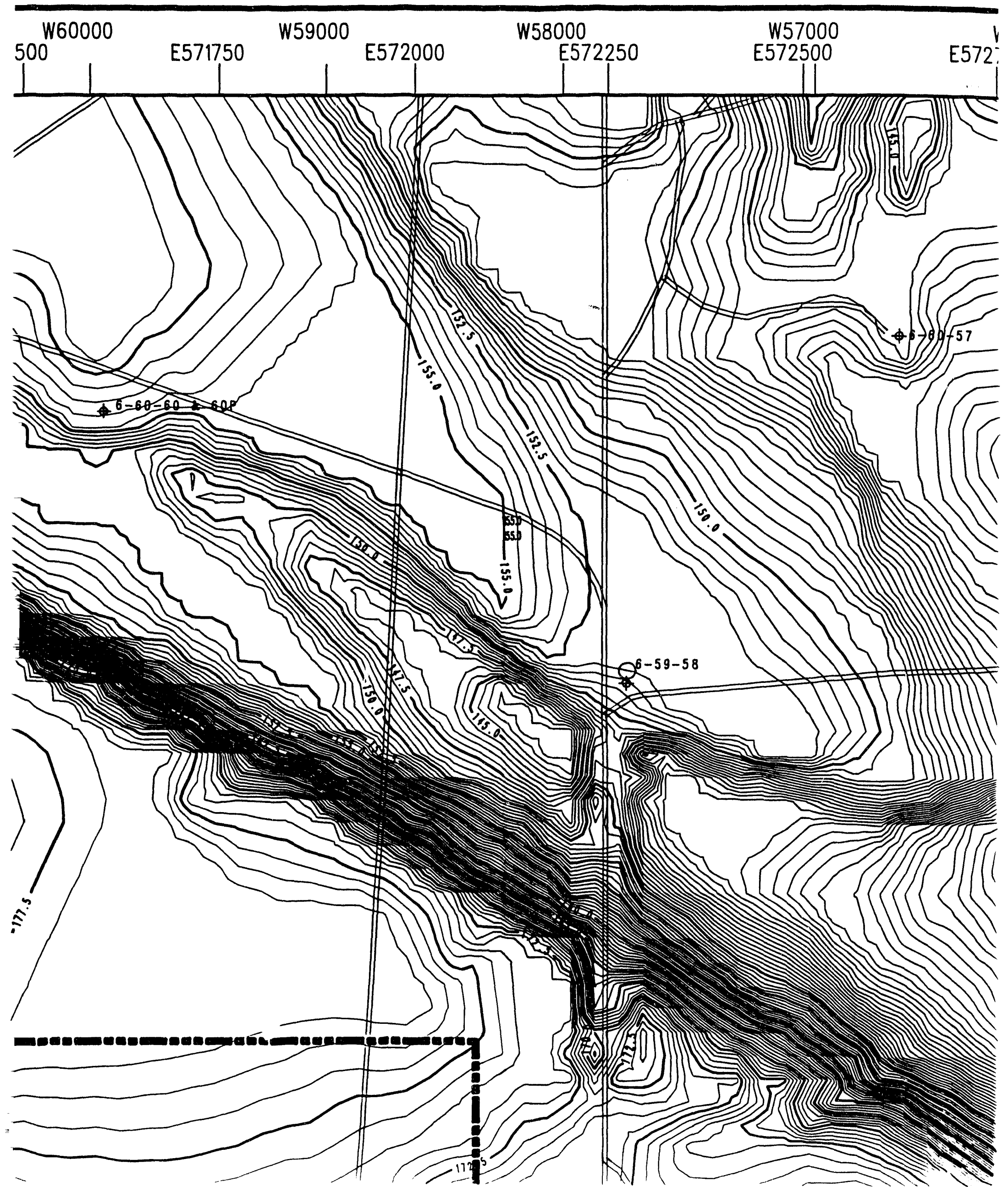


Westinghouse Hanford Company Aggregate Area Management Studies

200 NORTH AGGREGATE AREA PLATE 1 - Facilities, Sites, Unplanned Releases, Topography, \& Monitor Wells 

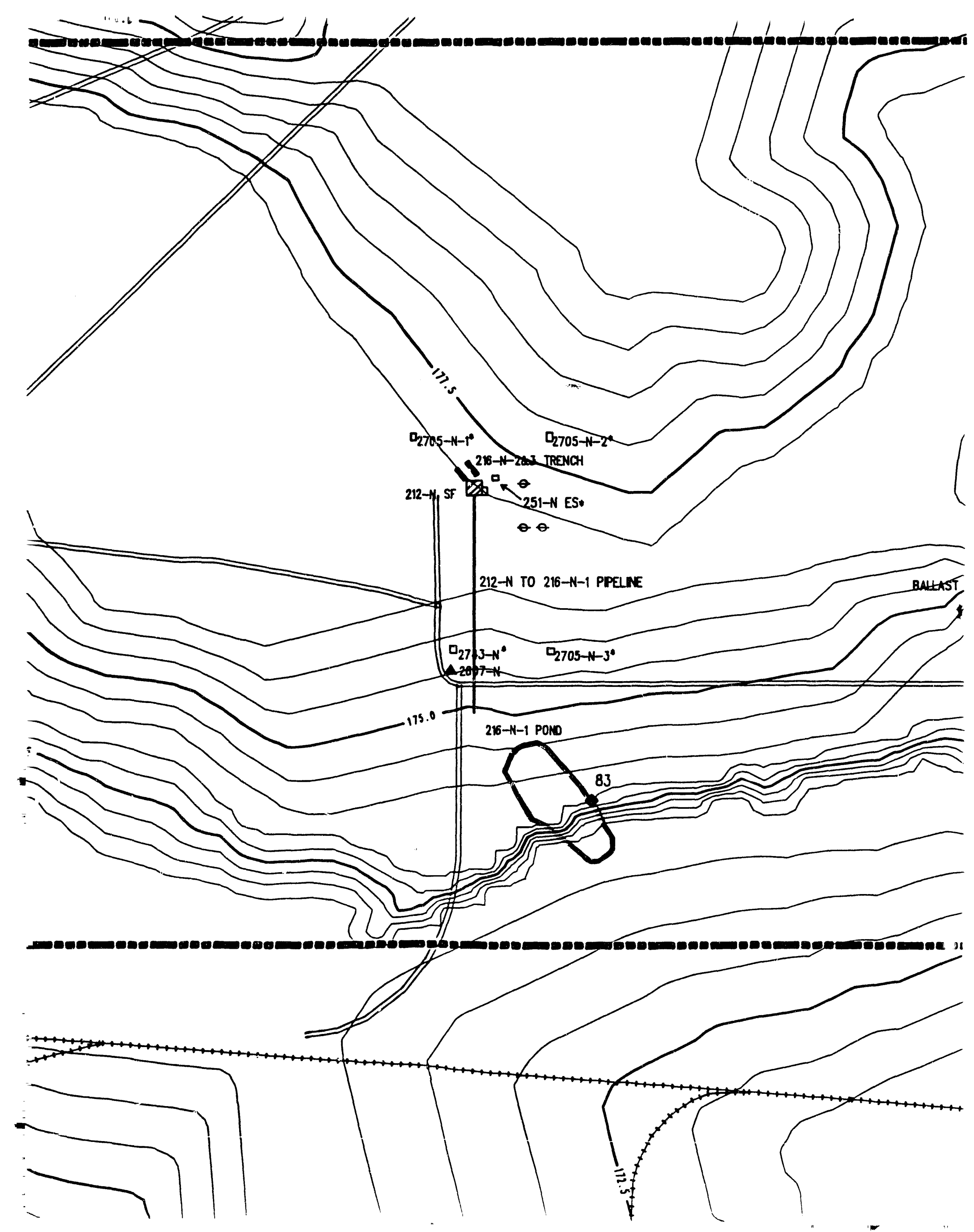


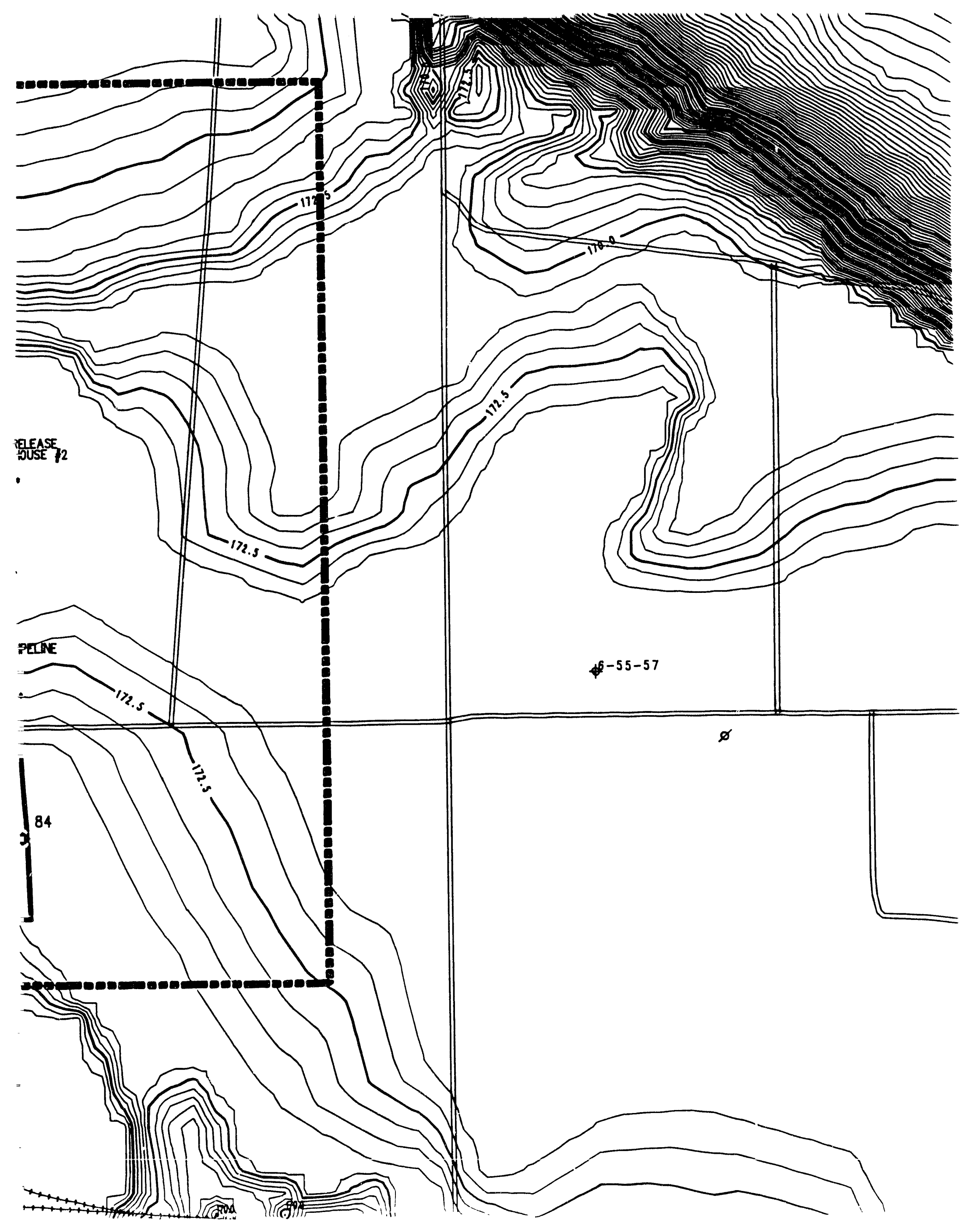




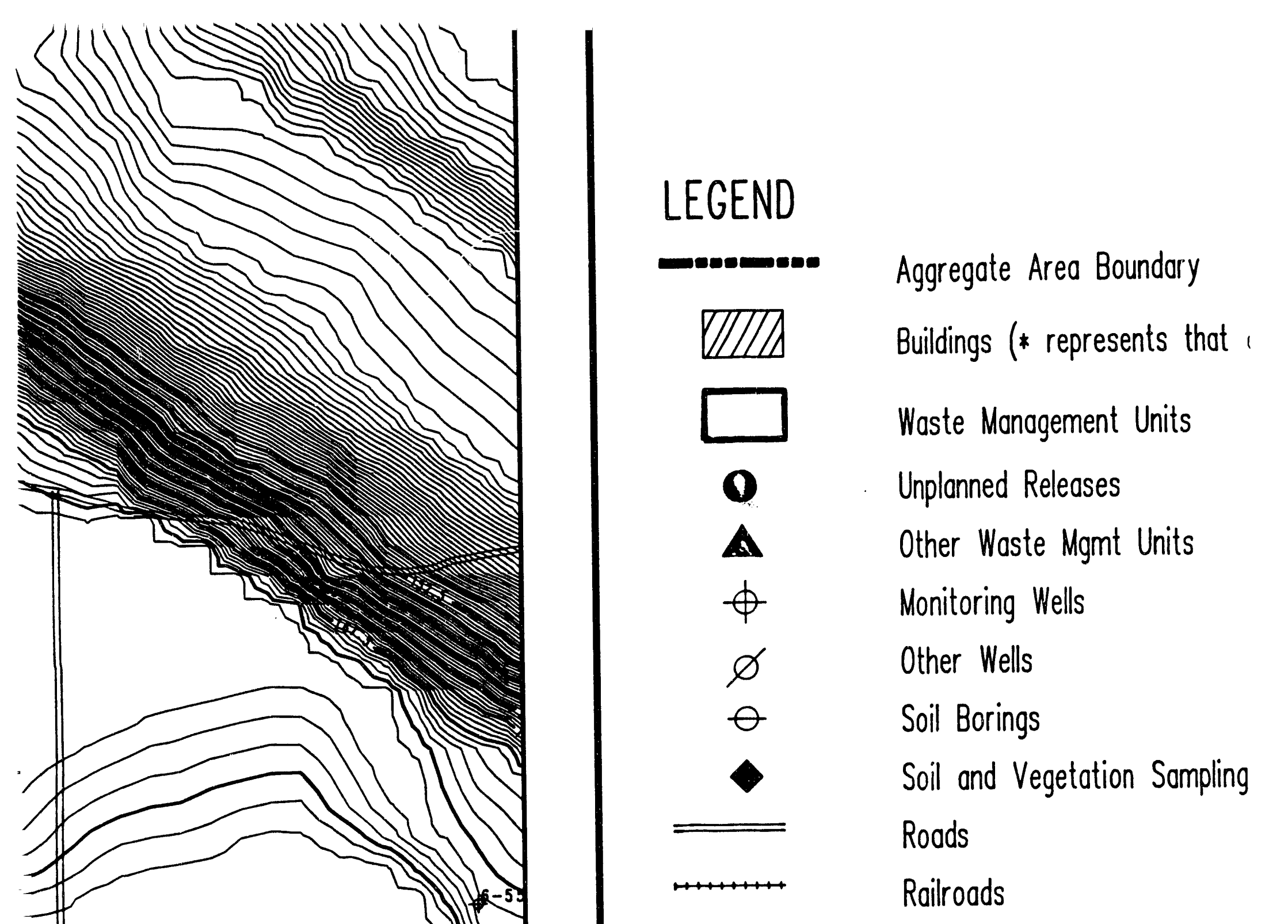




\section{LEGEND}

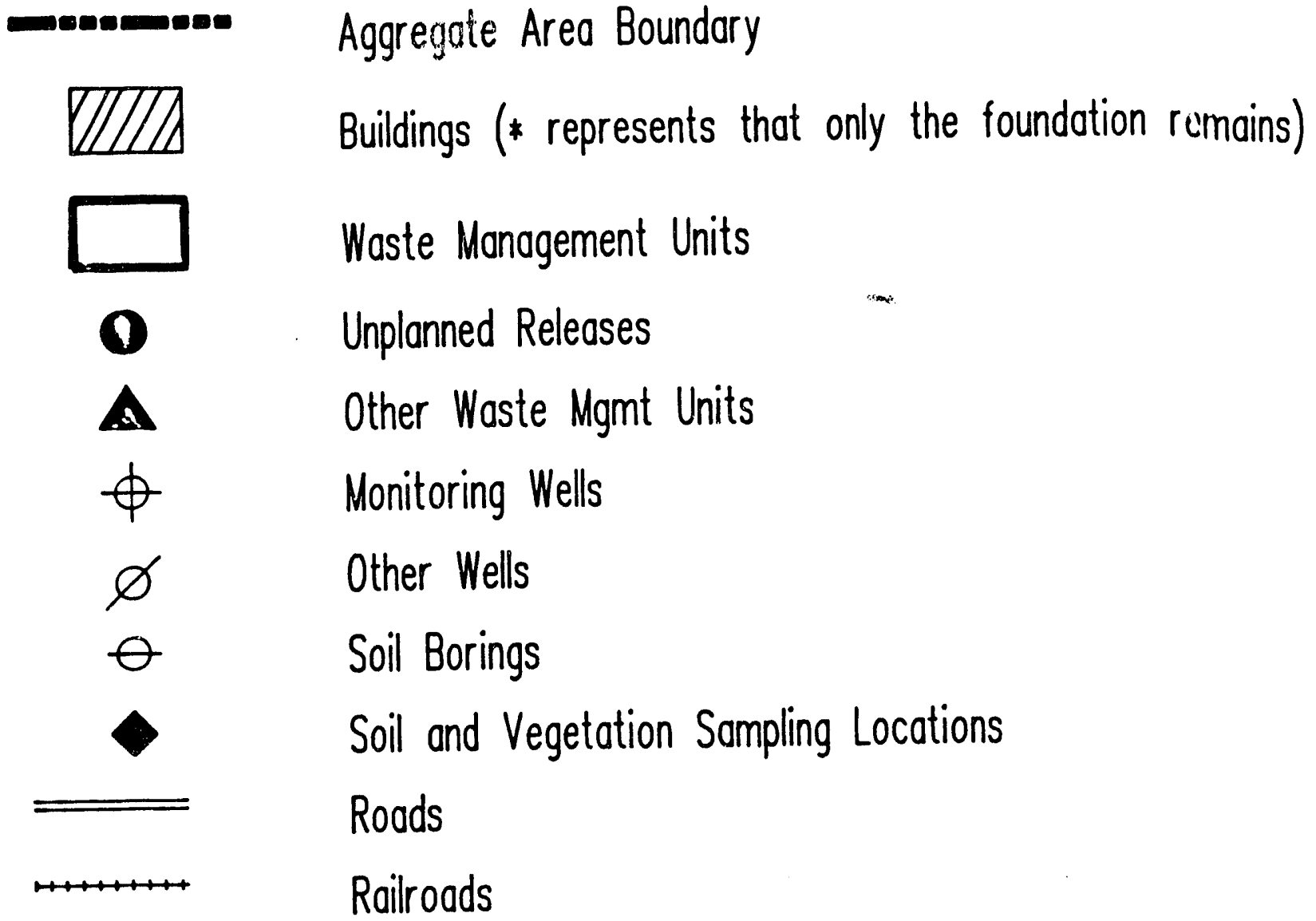

*Only the structure foundation remains

Contour Interval .5 Meter (Interpolated from 10 Foot Contours) 


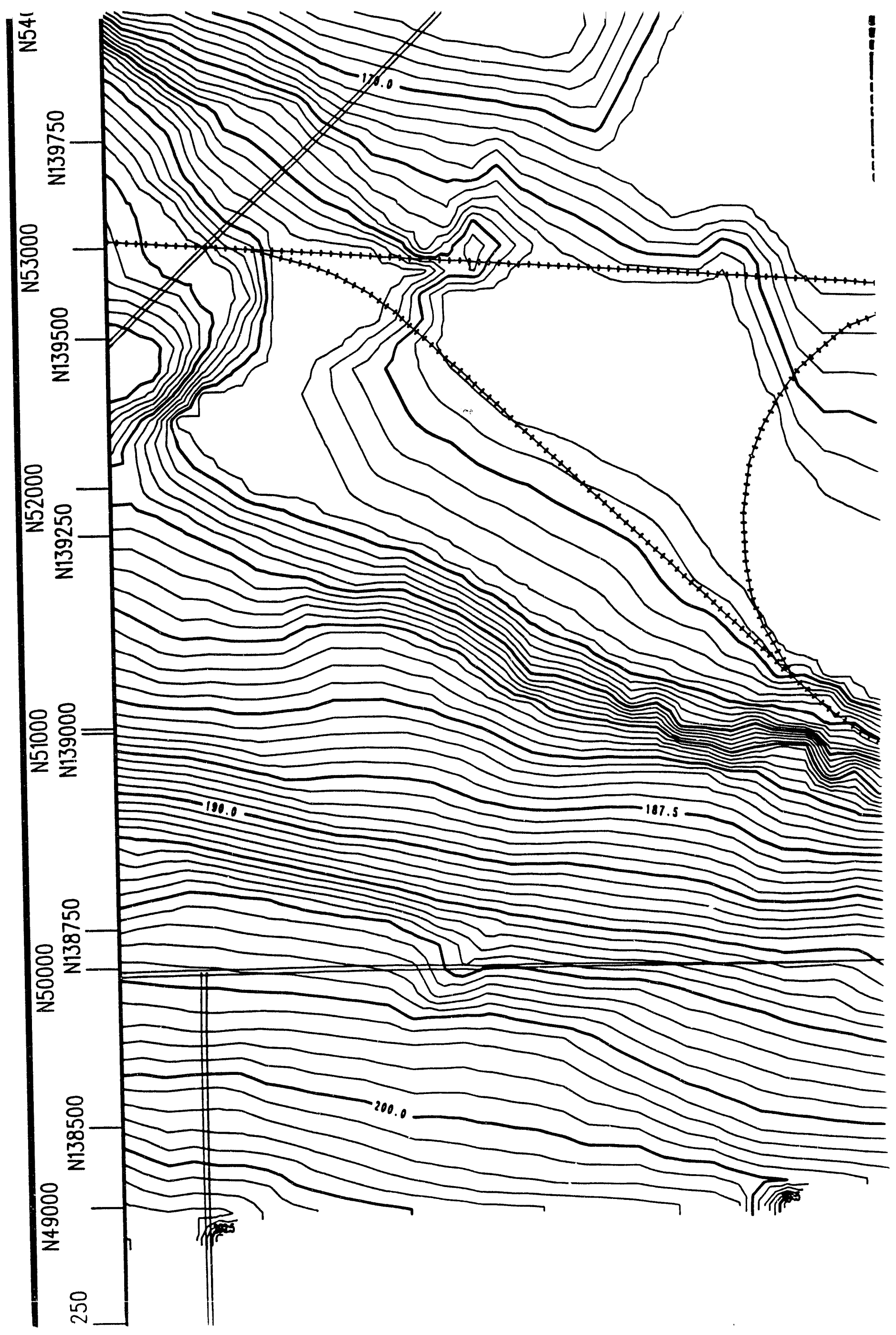




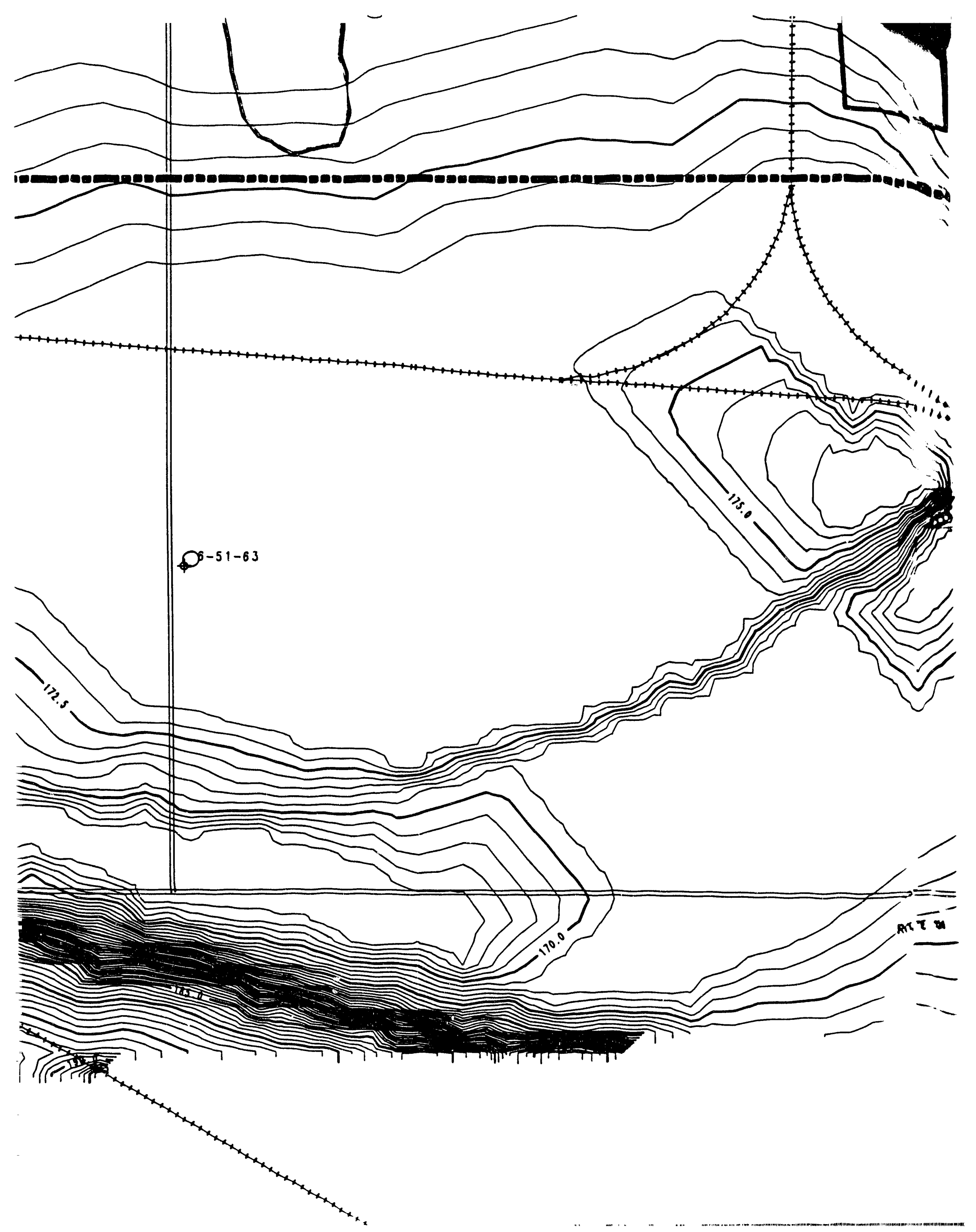




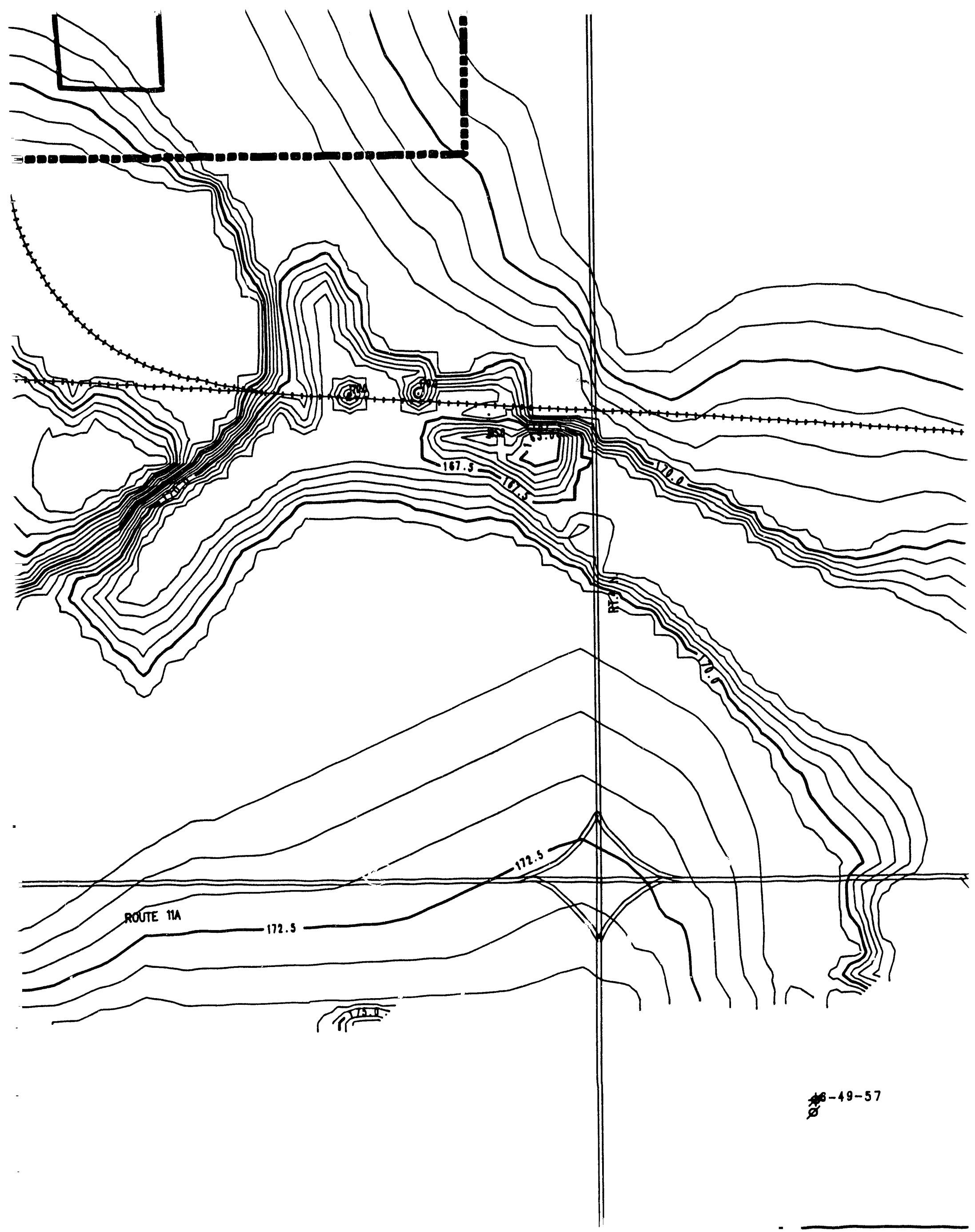


1

Scale in Feet

Scale in Meters




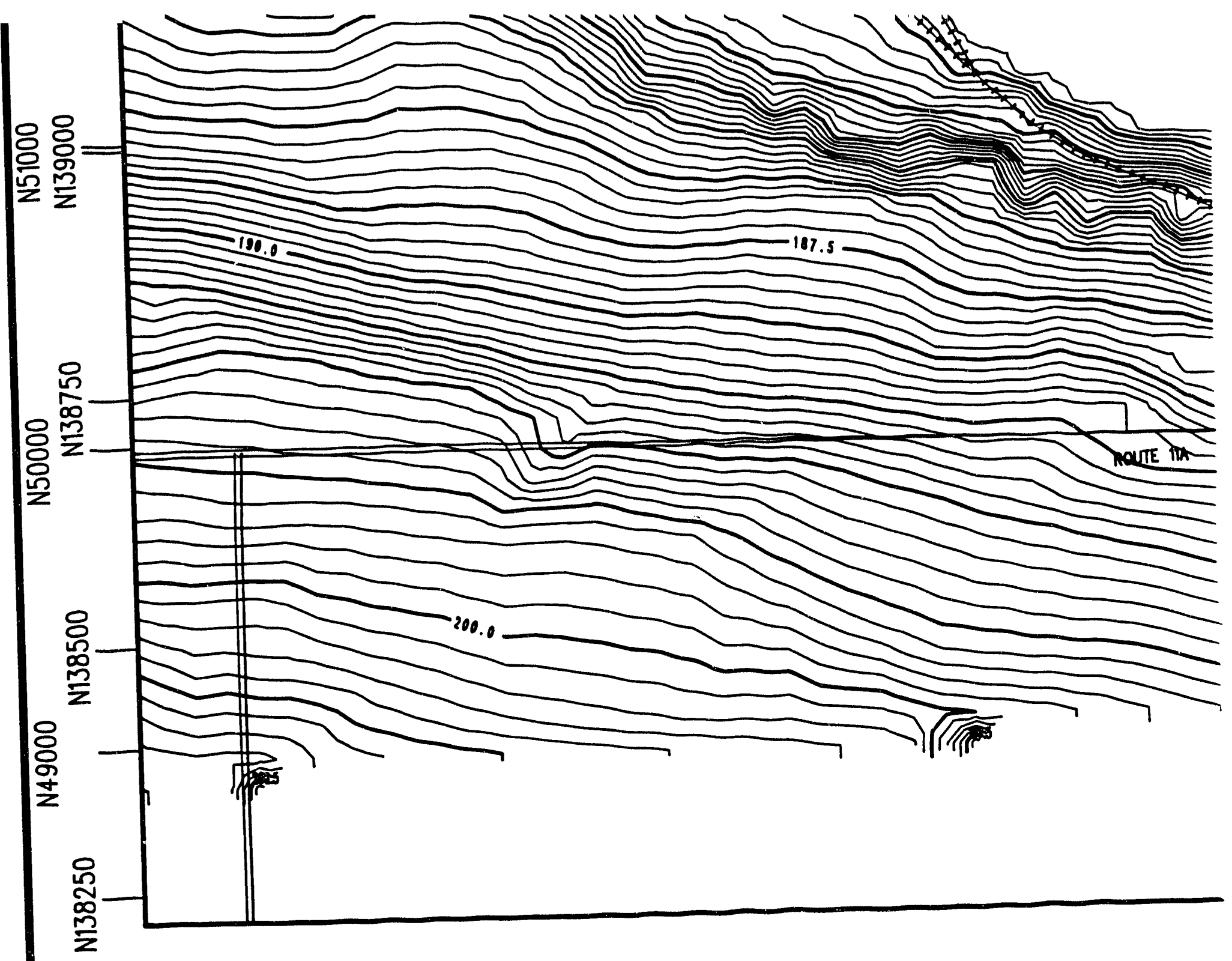




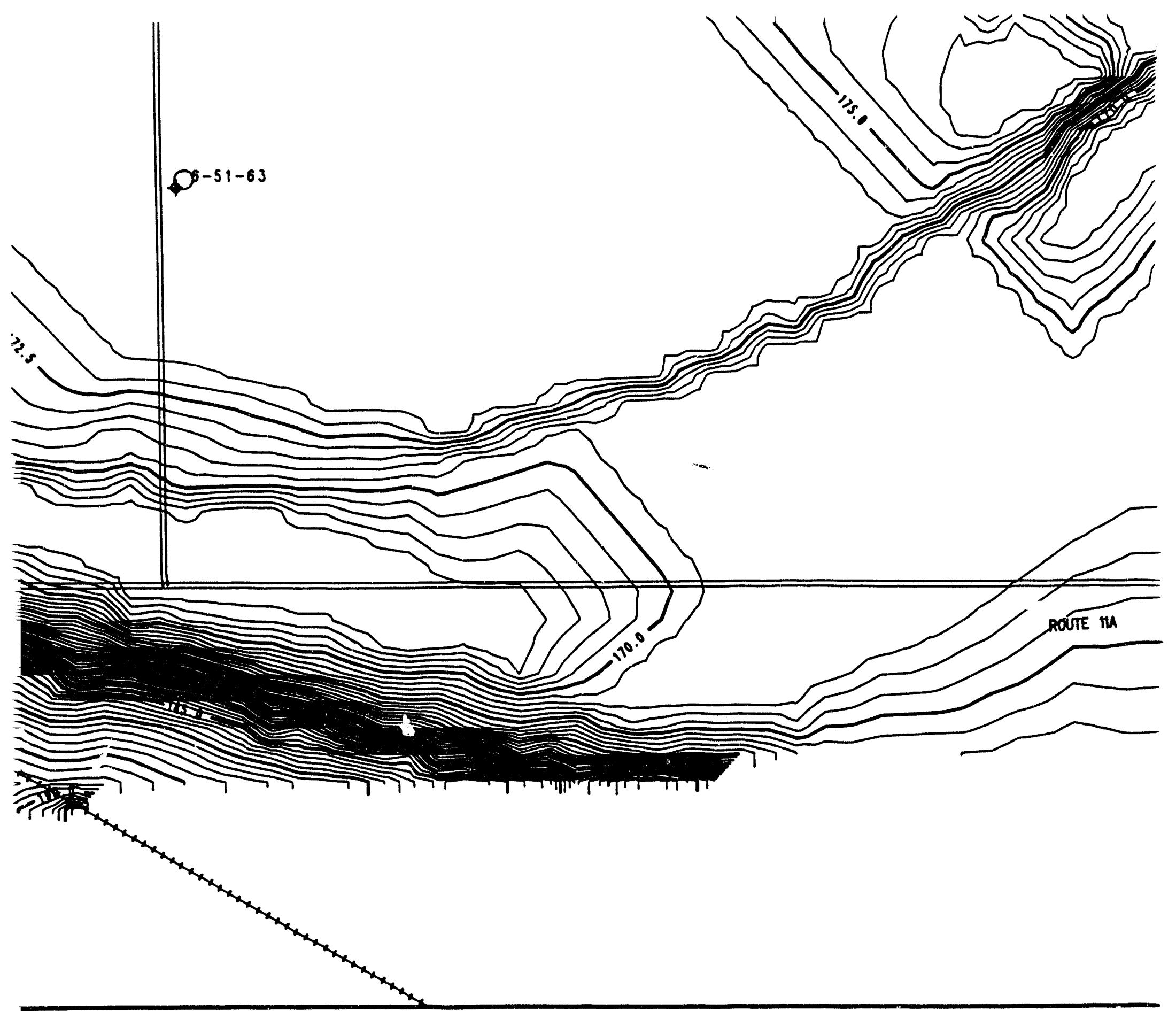




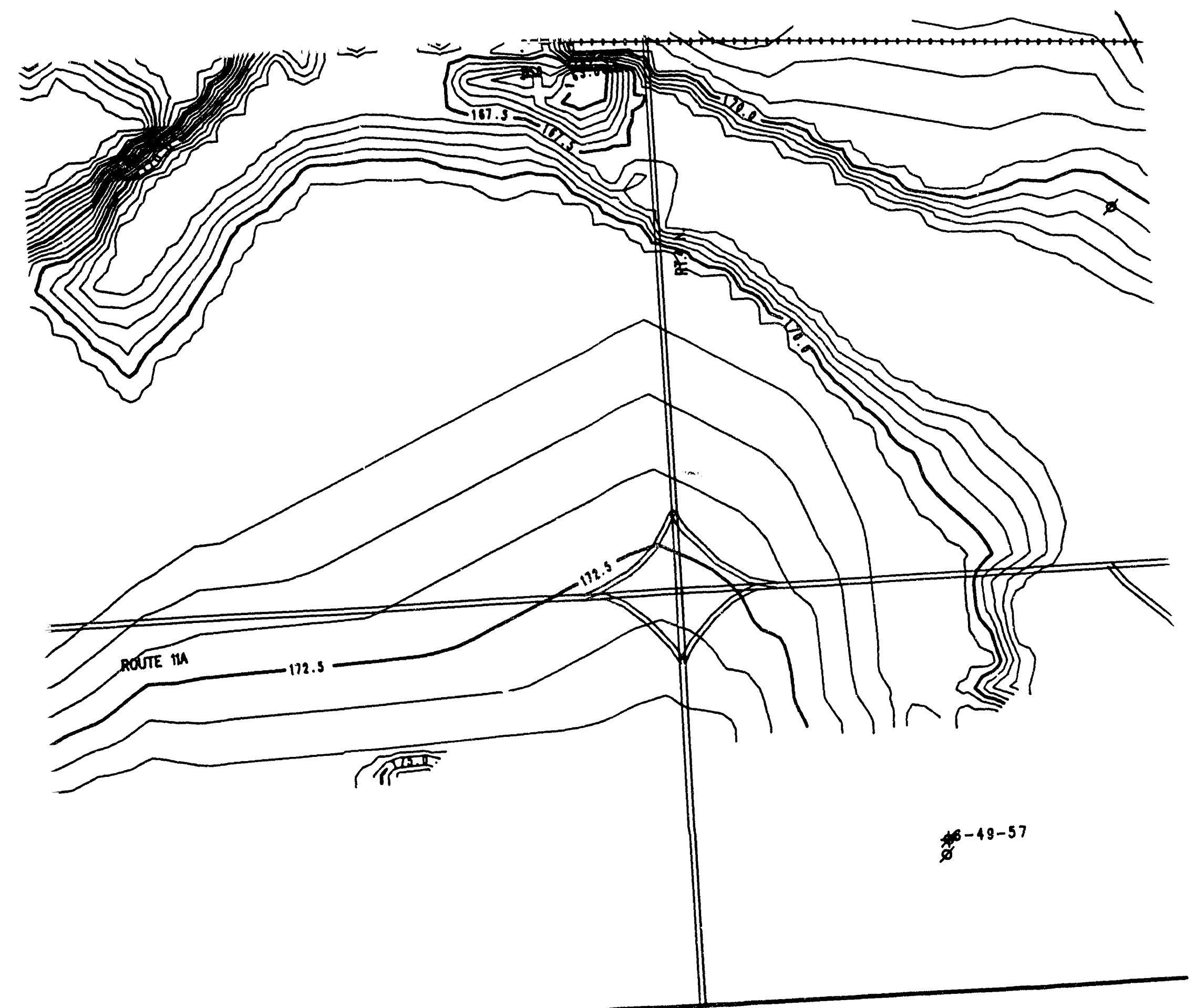




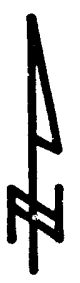

Scale in Feet

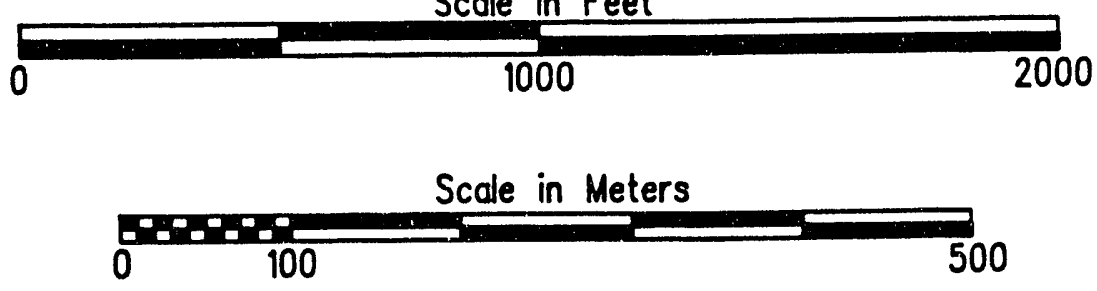


DOE/RL-92-17, Rev. 0

APPENDIX A

SAMPLE DATA 
DOE/RL-92-17, Rev. 0

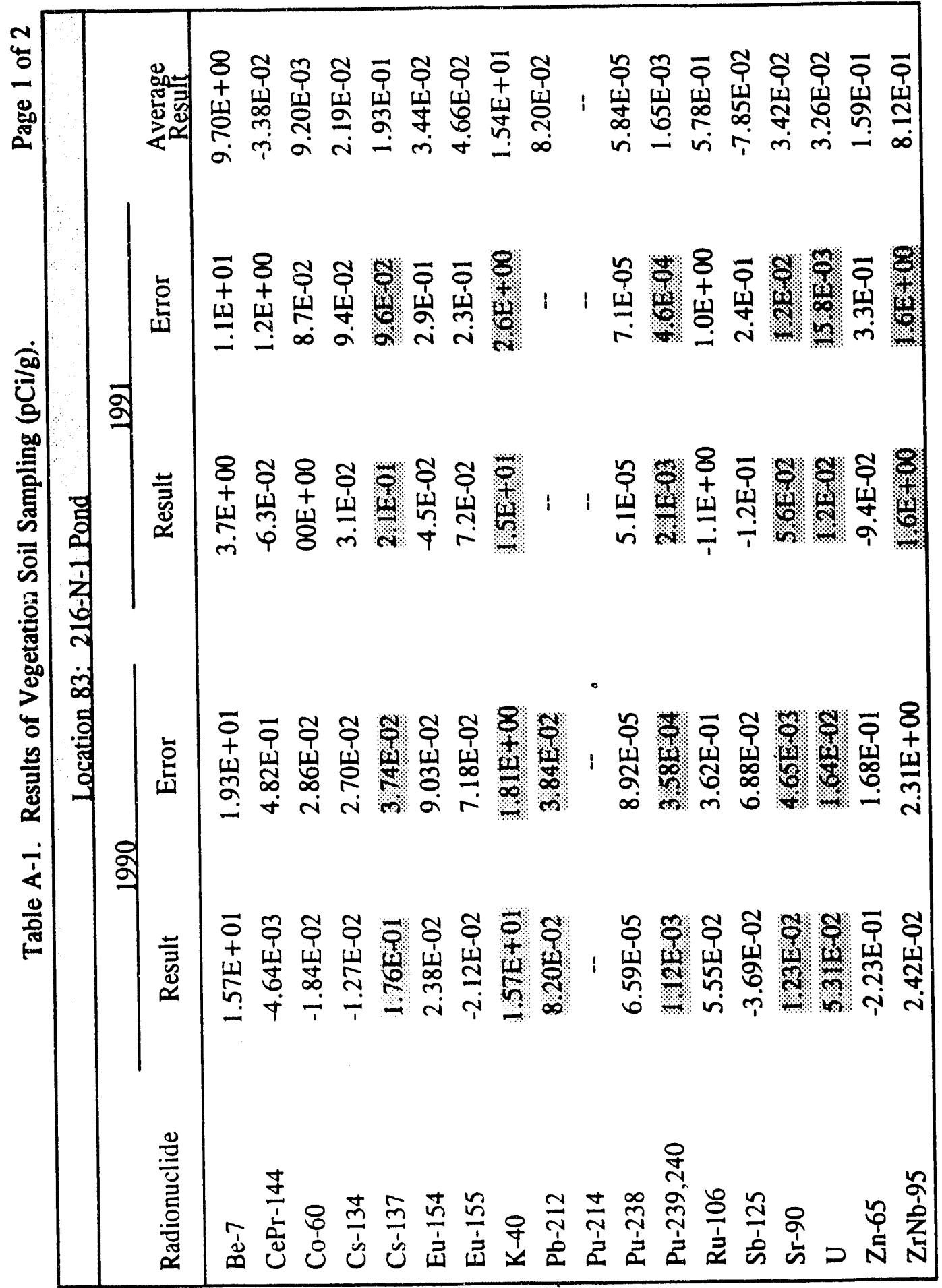


DOE/RL-92-17, Rev. 0

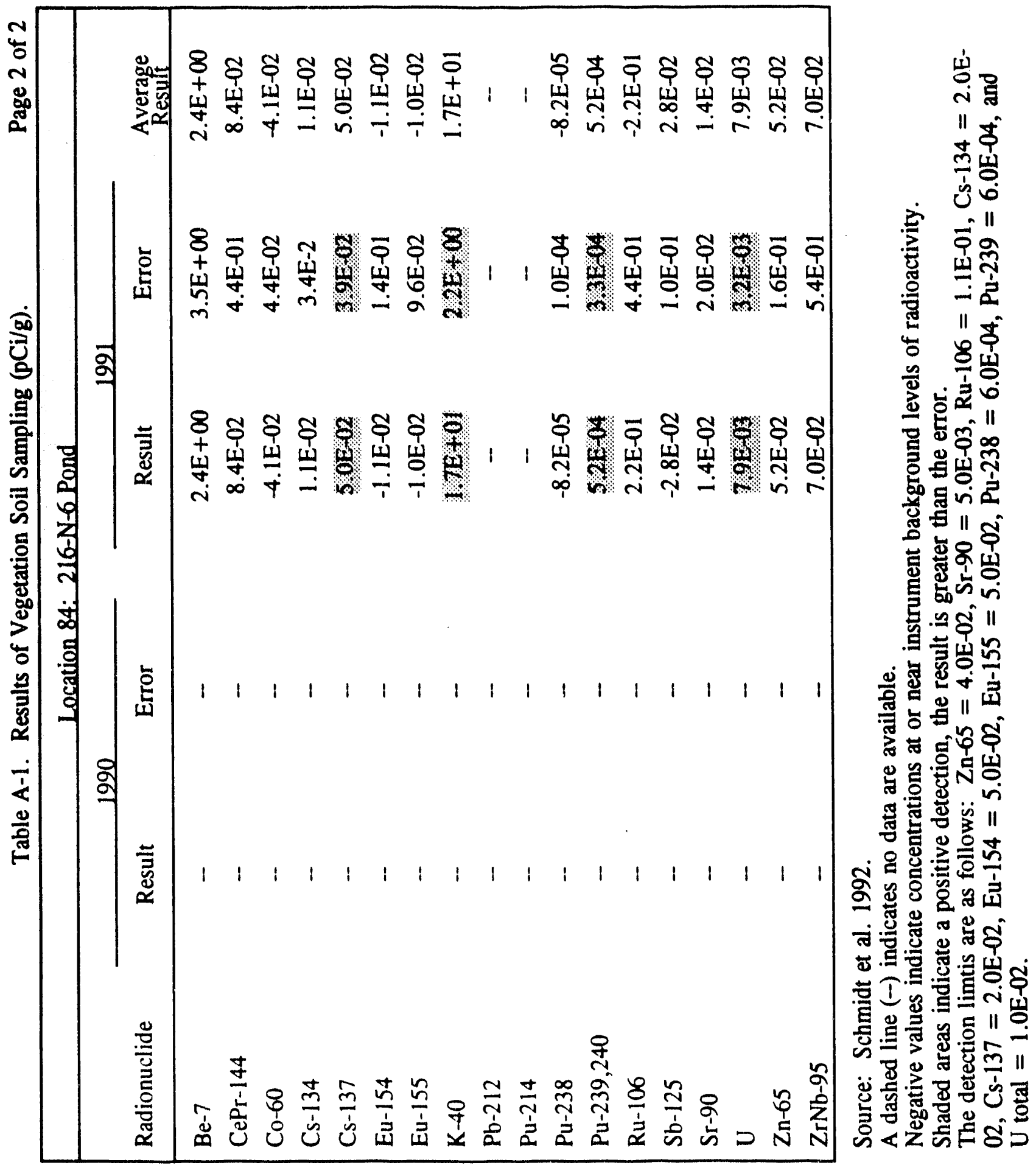


DOE/RL-92-17, Rev. 0

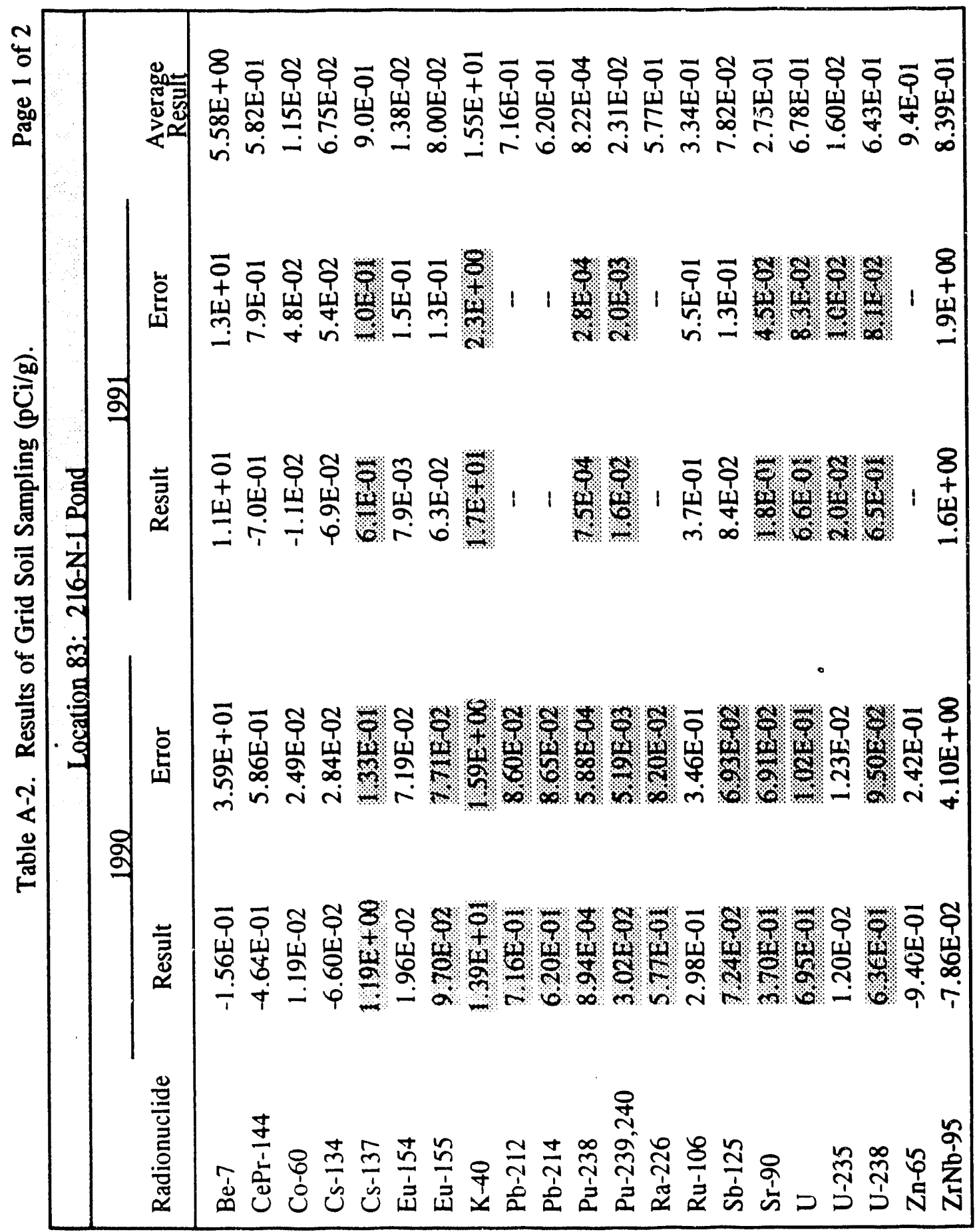


DOE/RL-92-17, Rev. 0

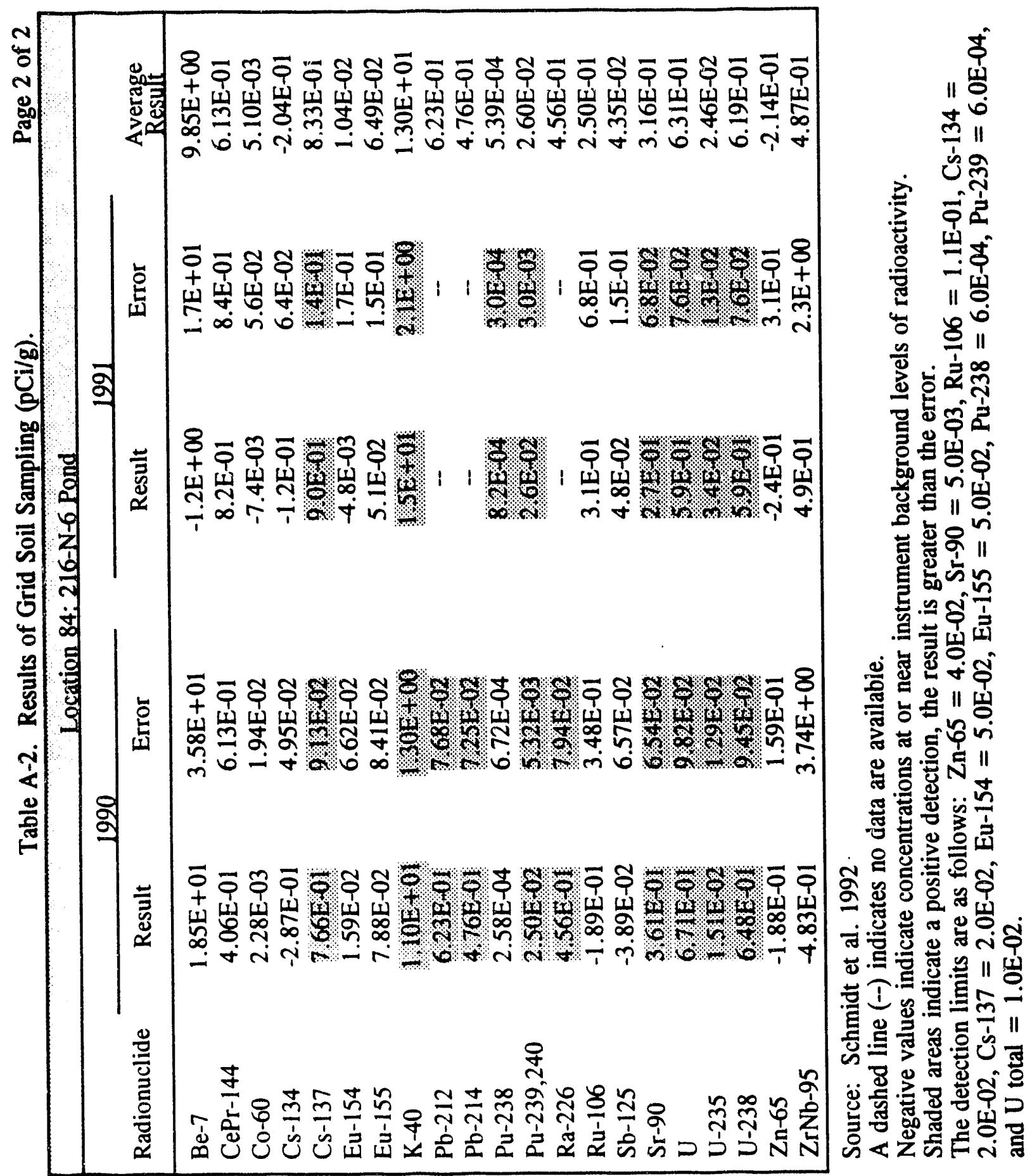


DOE/RL-92-17, Rev. 0

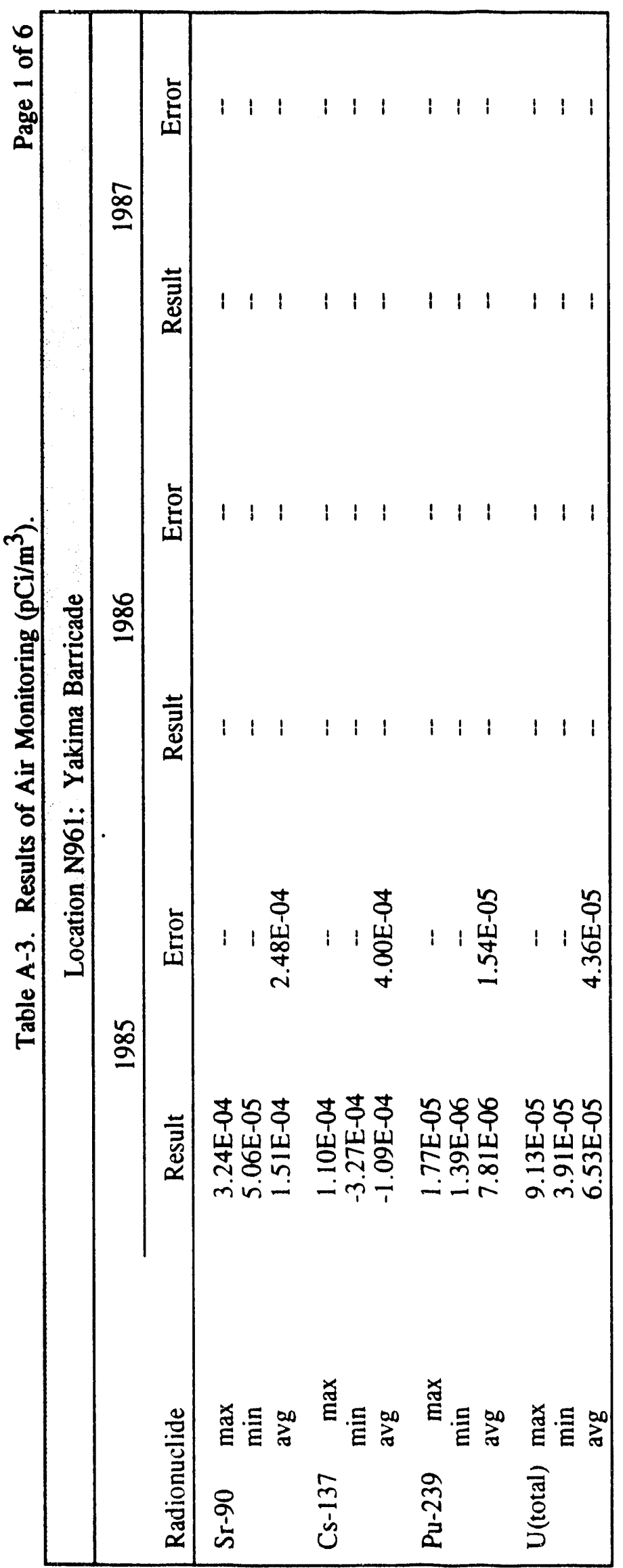


DOE/RL-92-17, Rev. 0

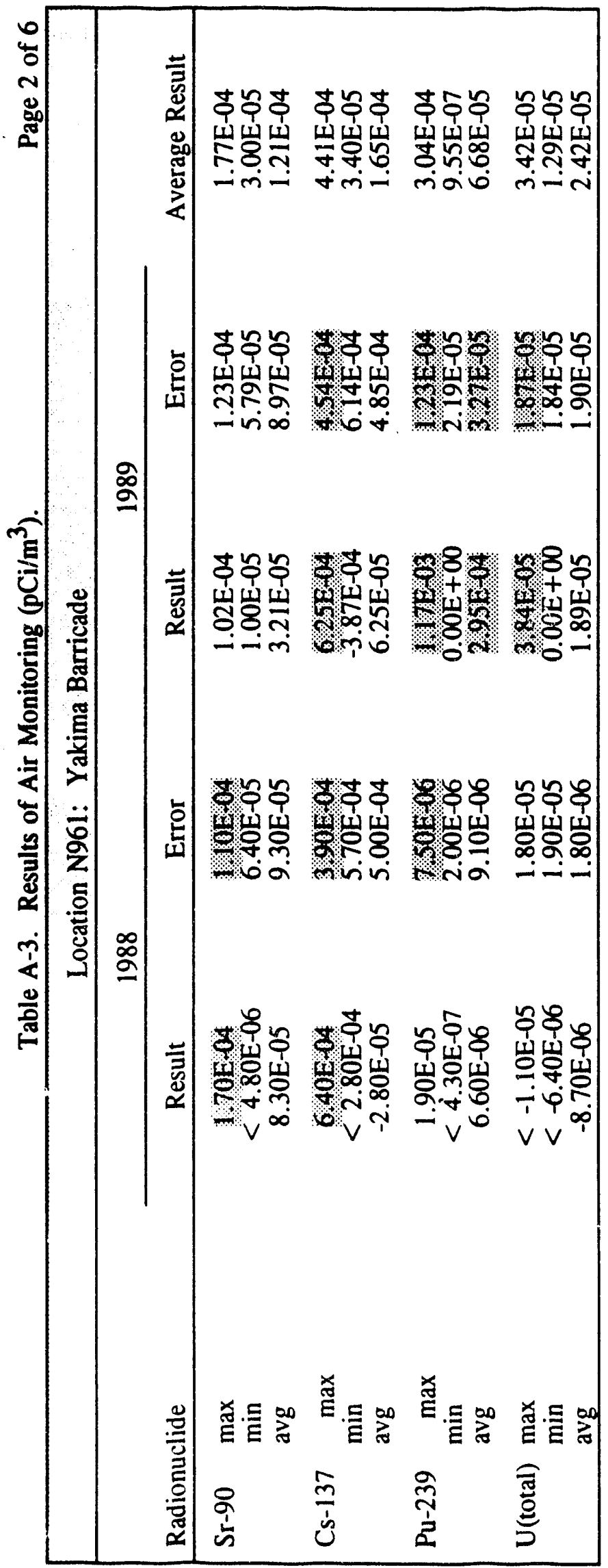


DOE/RL-92-17, Rev. 0

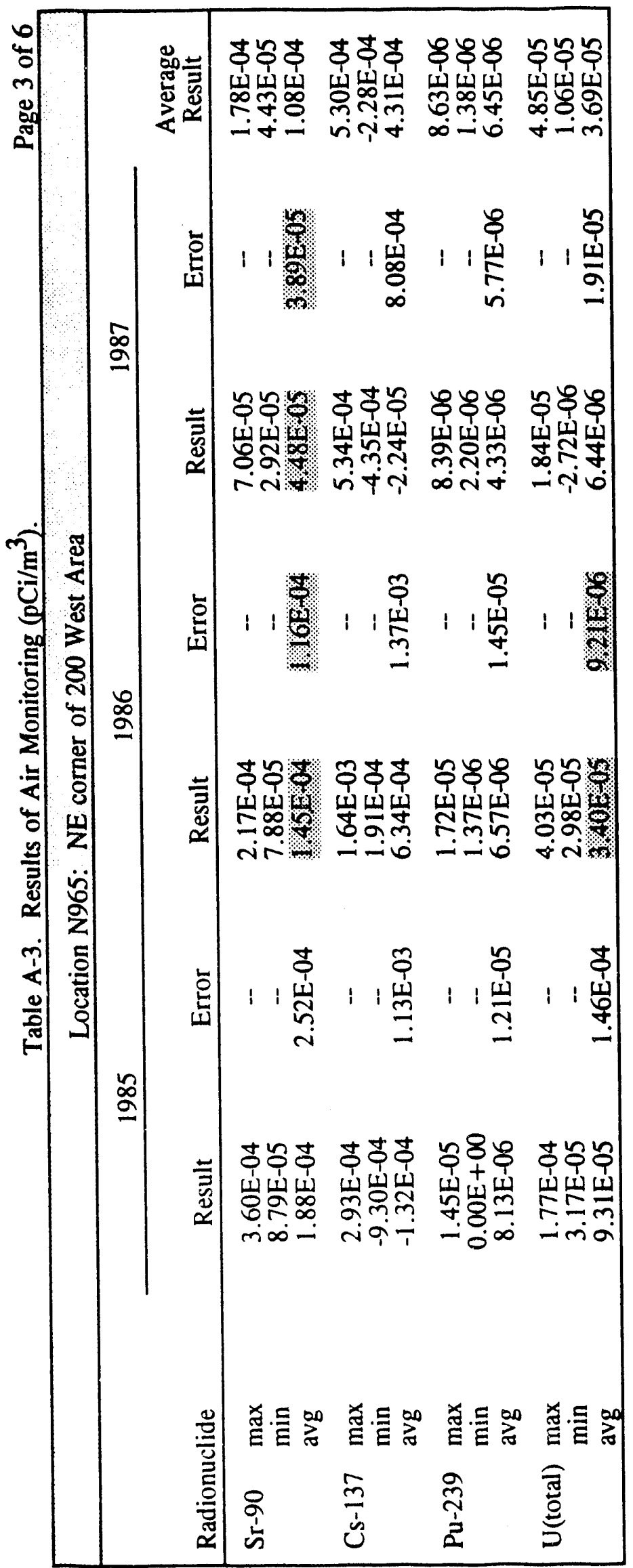

AT-3c 
DOE/RL-92-17, Rev. 0

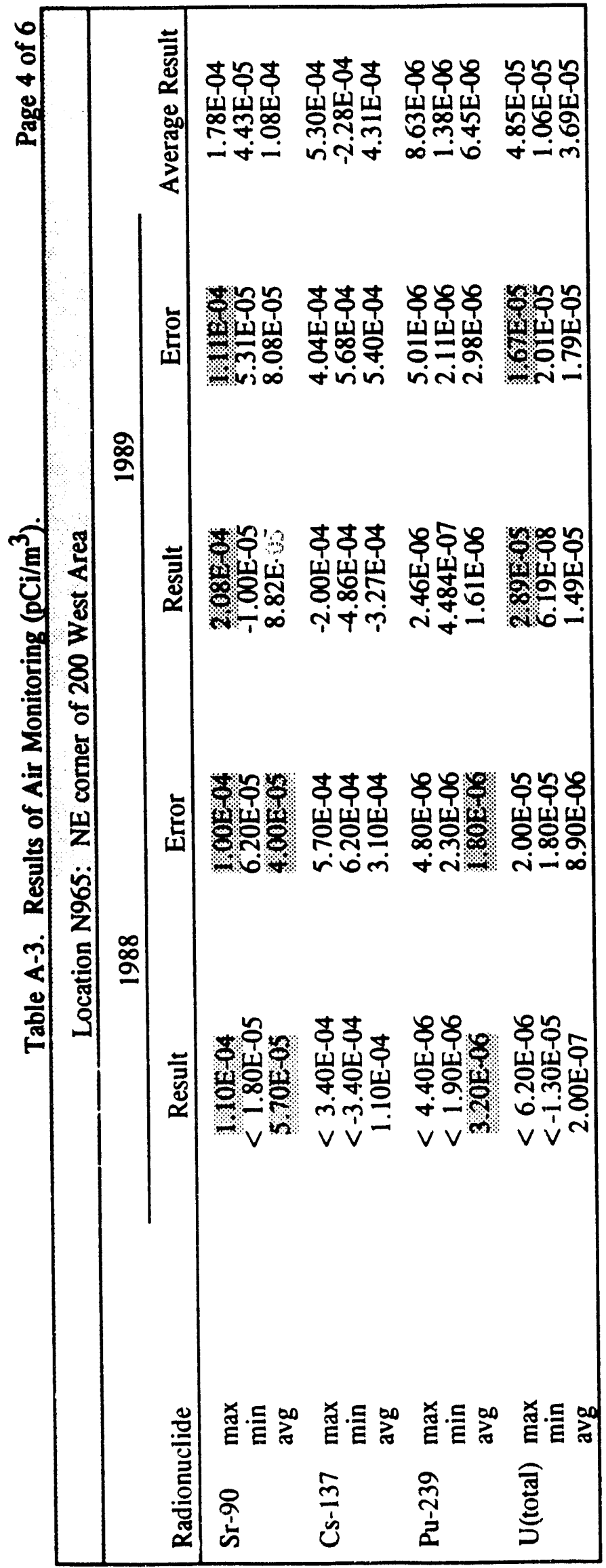


DOE/RL-92-17, Rev. 0

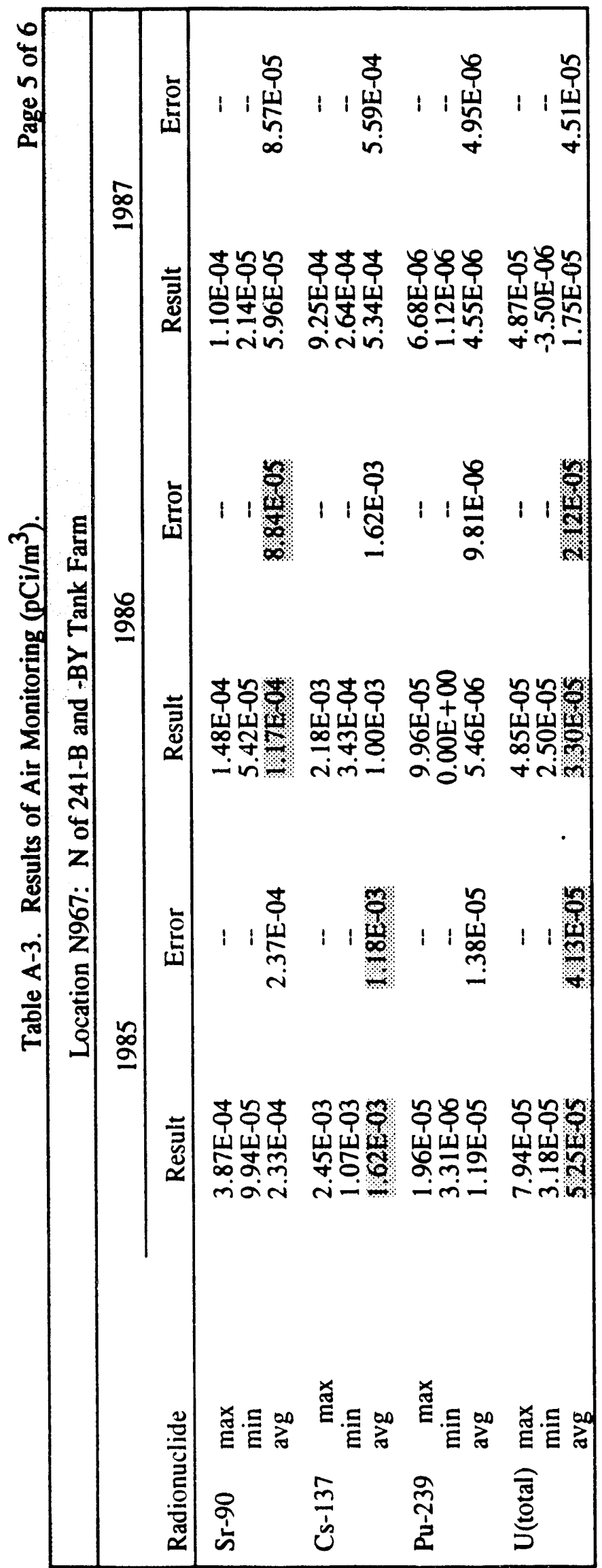


DOE/RL-92-17, Rev. 0

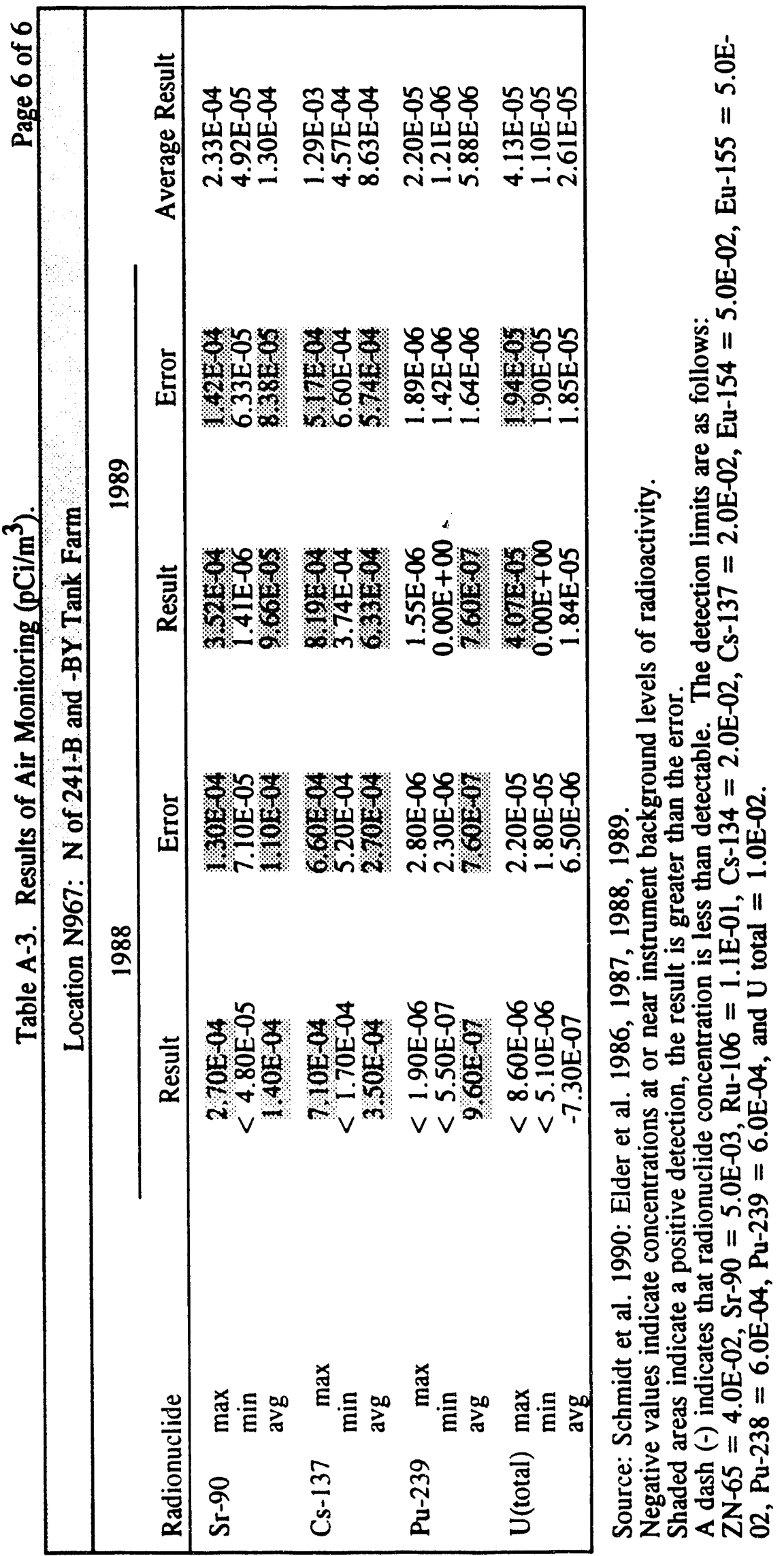


DOE/RL-92-17, Rev. 0

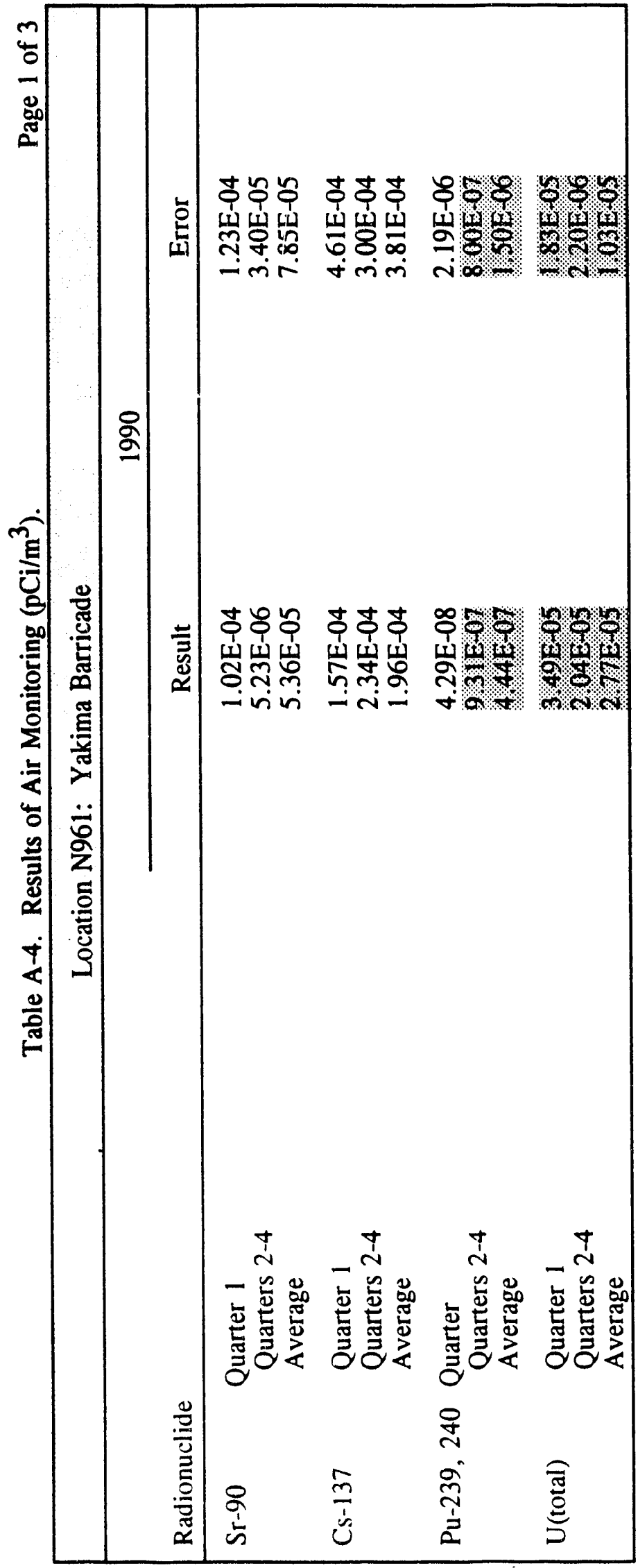


DOE/RL-92-17, Rev. 0

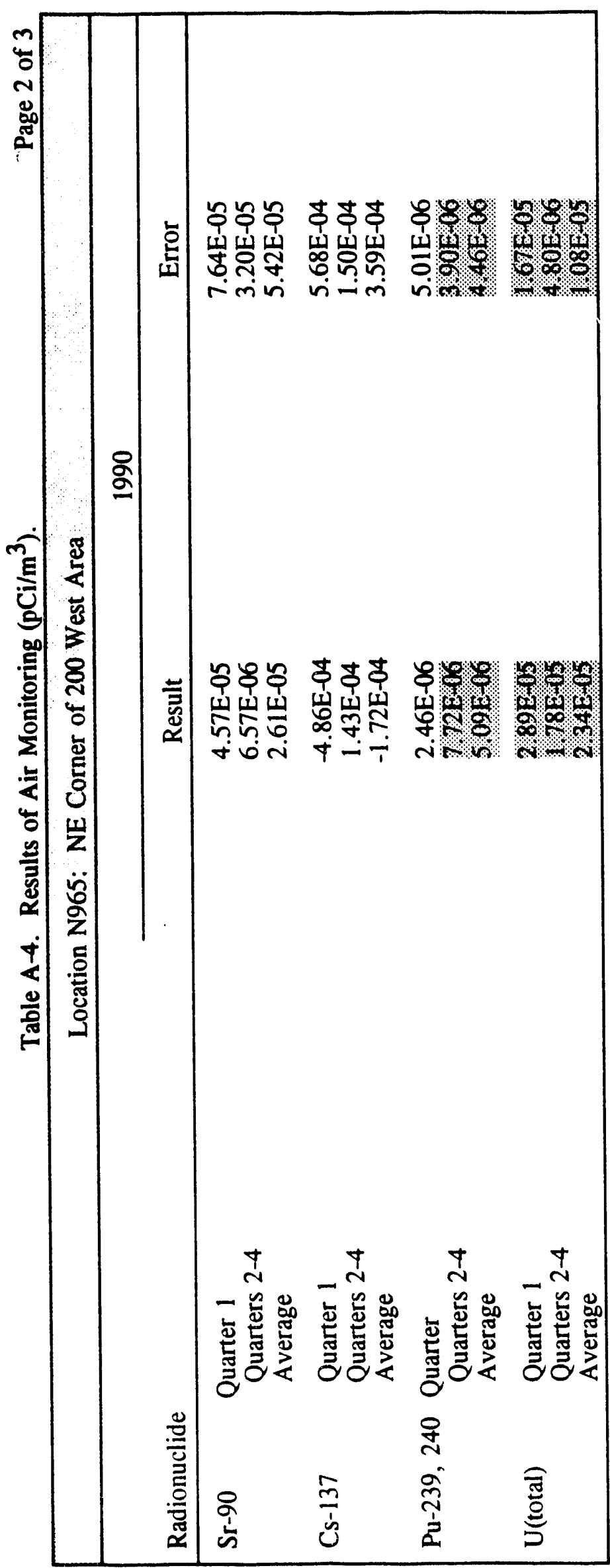

AT-4b 
DOE/RL-92-17, Rev. 0

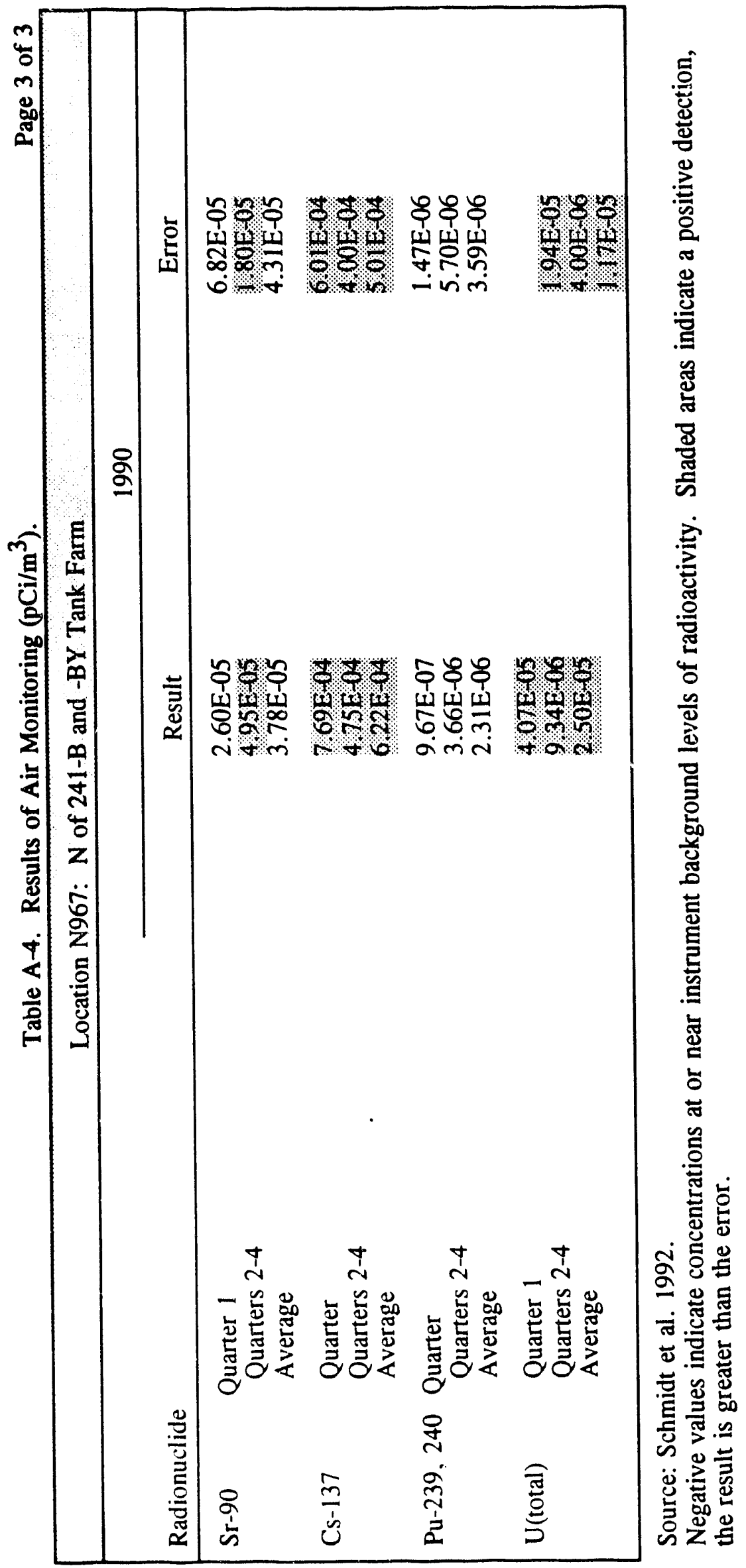

AT-4c 
DOE/RL-92-17, Rev. 0

\section{APPENDIX B}

\section{HEALTH AND SAFETY PLAN}


1.0 GENERAL CONSIDERATIONS AND REQUIREMENTS $\ldots \ldots \ldots \ldots \ldots$. . . .

1.1 INTRODUCTION $\ldots \ldots \ldots \ldots \ldots \ldots \ldots \ldots \ldots$ B-1

1.2 DESIGNATED SAFETY PERSONNEL $\ldots \ldots \ldots \ldots \ldots \ldots \ldots$ B-1

1.3 MEDICAL SURVEILLANCE $\ldots \ldots \ldots \ldots \ldots \ldots \ldots \ldots$ B-3

1.4 TRAINING $\ldots \ldots \ldots \ldots \ldots \ldots \ldots \ldots \ldots \ldots$ B-3

1.5 TRAINING FOR VISITORS $\ldots \ldots \ldots \ldots \ldots \ldots \ldots \ldots$ B-3

1.6 RADIATION DOSIMETRY . . . . . . . . . . . . . . . . . B-4

1.7 REQUIREMENTS FOR THE USE OF RESPIRATORY PROTECTION . . . B-4

2.0 GENERAL PROCEDURES $\ldots \ldots \ldots \ldots \ldots \ldots \ldots \ldots \ldots$ B-4

2.1 GENERAL WORK SAFETY PRACTICES $\ldots \ldots \ldots \ldots \ldots \ldots$. . .

2.1.1 Work Practices $\ldots \ldots \ldots \ldots \ldots \ldots \ldots \ldots \ldots$ B-5

2.1.2 Personal Protective Equipment $\ldots \ldots \ldots \ldots \ldots \ldots \ldots$ B-6

2.1.3 Personal Decontamination . . . . . . . . . . . . . B-7

2.1.4 Emergency Preparation . . . . . . . . . . . . B-7

2.2 CONFINED SPACE/TEST PIT ENTRY PROCEDURES $\ldots \ldots \ldots \ldots \ldots$ B-8

3.0 SITE BACKGROUND $\ldots \ldots \ldots \ldots \ldots \ldots \ldots \ldots \ldots$ B-9 . . . . . . . . .

4.0 SCOPE OF WORK AND POTENTIAL HAZARDS $\ldots \ldots \ldots \ldots \ldots \ldots \ldots$. . . . B-9

4.1 WORK TASKS $\ldots \ldots \ldots \ldots \ldots \ldots \ldots \ldots \ldots$ B-9

4.2 POTENTIAL HAZARDS . . . . . . . . . . . . . . . . . . . B-9

4.3 ASSESSMENT AND MITIGATION OF POTENTIAL HAZARDS . . . . . B-10

5.0 ENVIRONMENTAL AND PERSONAL MONITORING . . . . . . . . . . B-11

5.1 AIRBORNE RADIOACTIVE AND RADIATION MONITORING $\ldots \ldots$. B-12

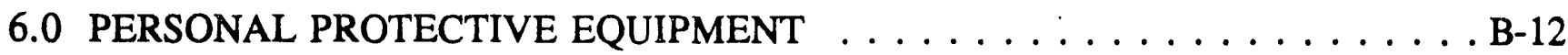

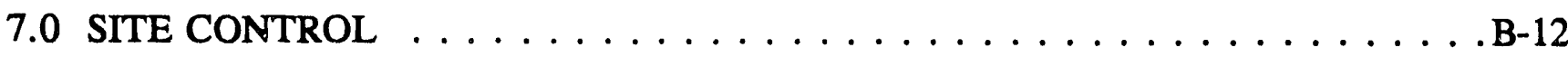

8.0 DECONTAMINATION PROCEDURES $\ldots \ldots \ldots \ldots \ldots \ldots \ldots$. . . . . . . . . .

9.0 CONTINGENCY AND EMERGENCY RESPONSE PLANS $\ldots \ldots \ldots \ldots \ldots$. . . . . . .

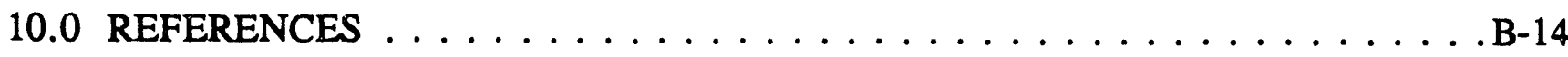




\subsection{GENERAL CONSIDERATIONS AND REQUIREMENTS}

\subsection{INTRODUCTION}

The purpose of this Health and Safety Plan (HSP) is to outline standard health and safety procedures fo: Westinghouse Hanford employees and contractors engaged in investigation acivities for the 200 North Aggregate Area Management Study (AAMS). These activities will include surface investigation, drilling and sampling boreholes, and environmental sampling in areas of known chemical and radiological contamination. Appropriate site-specific safety documents (e.g., Hazardous Waste Operations Permit [HWOP] or Job Safety Analysis [JSA]) will be written for each task or group of tasks. A more complete discussion of Westinghouse Hanford environmental safety procedures is presented in the Westinghouse Hanford manual Health and Safety for Hazardous Waste Field Operations, WHC-CM-4-3 Vol. 4 (WHC 1992).

All employees of Westinghouse Hanford or any other contractors who are participating in onsite activities for the 200 North AAMS shall read the site-specific safety document and attend a pre-job safety or tailgate meeting to review and discuss the task.

\subsection{DESIGNATED SAFETY PERSONNEL}

The field team leader and site safety officer are responsible for site safety and health. Specific individuals will be assigned on a task-by-task basis by project management, snd their names will be properly recorded before the task is initiated.

All activities onsite must be cleared through the field team leader. The field team leader has responsibility for the following:

- Allocating and administering resources to successfully comply with all technical and health and safety requirements

- Verifying that all permits, supporting documentation, and clearances are in place (e.g., electrical outage requests, welding permits, excavation permits, HWOP or JSA, sampling plan, radiation work permits [RWPs], and onsite/offsite radiation shipping records)

- $\quad$ Providing technical advice during routine operations and emergencies

- Informing the appropriate site management and safety personnel of the activities to be performed each day

- Coordinating resolution of any conflicts that may arise between RWPs and the implementation of the HWOP or JSA with health physics 
- Handling emergency response situations as may be required

- Conducting pre-job and daily tailgate safety meetings

- Interacting with adjacent building occupants and/or inquisitive public.

The site safety officer is responsible for implementing the HWOP at the site. The site safety officer shall do the following:

- Monitor chemical, physical, and (in conjunction with the health physics technician) radiation hazards to assess the degree of hazard present; monitoring shall specifically include organic vapor detection, radiation screening, and confined space evaluation where appropriate.

- Determine protection levels, clothing, and equipment needed to ensure the safety of personnel in conjunction with the health physics department.

- Monitor the performance of all personnel to ensure that the required safety procedures are followed.

- Halt operations immediately, if necessary, due to safety or health concerns.

- Conduct safety briefings as necessary.

- Assist the field team leader in conducting safety briefings as necessary.

The health physics technician is responsible for ensuring that all radiological monitoring and protection procedures are being followed as specified in the Radiation Protection Manual and in the appropriate RWP. Westinghouse Hanford Industrial Safety and Fire Protection personnel will provide safety overview during drilling operations consistent with Westinghouse Hanford policy and, as requested, will provide technical advice. Also, downwind sampling for hazardous materials and radiological contaminants and other analyses may be requested from appropriate contractor personnel as required.

The ultimate responsibility and authority for employee's health and safety lies with the employee and the employee's colleagues. Each employee is responsible for exercising the utmost care and good judgment in protecting his or her personal health and safety and that of fellow employees. Should any employee observe a potentially unsafe condition or situation, it is the responsibility of that employee to immediately bring the observed condition to the attention of the appropriate health and safety personnel, as designated previously. In the event of an immediately dangerous or life-threatening situation, the employee automatically has temporary "stop work" authority and the responsibility to immediately notify the field team leader or site safety officer. When work is temporarily halted because of a safety or health concern, personnel will exit the exclusion zone and meet at a predetermined place in the support zone. The field team leader, site safety officer, and health physics technician will determine the next course of action. 


\subsection{MEDICAL SURVEILLANCE}

All field team members engaged in operable unit activities at sites governed by an HWOP must have baseline physical examinations and be participants in Westinghouse Hanford (or an equivalent) hazardous waste worker medical surveillance program.

Medical examinations will be designed to identify any pre-existing conditions that may place an employee at high risk, and will verify that each worker is physically able to perform the work required by this plan without undue risk to personal health. The physician shall determine the existence of conditions that may reduce the effectiveness or prevent the employee's use of respiratory protection. The physician shall also determine the presence of coriditions that may pose undue risk to the employee while performing the physical tasks of this work plan using level B personal protection equipment. This would include any condition that increases the employee's susceptibility to heat stress.

The examining physician's report will not include any nonoccupational diagnoses unless directly applicable to the employee's fitness for the work required.

\subsection{TRAINING}

Before engaging in any onsite activities, each team member is required to have received $\mathbf{4 0}$ hours of health and safety training related to hazardous waste site operations and at least 8 hours of refresher training each year thereafter as specified in 29 Code of Federal Regulations (CFR) 1910.120. In addition, each inexperienced employee (never having performed site characterization) will be directly supervised by a trained/experienced person for a minimum of 24 hours of field experience.

The field team leader and the site safety officer shall receive an additional 8 hours of training (in addition to the refresher training previously discussed).

\subsection{TRAINING FOR VISITORS}

For the purposes of this plan, a visitor is defined as any person visiting the Hanford Site, who is not a Westinghouse Hanford employee or a Westinghouse Hanford contractor directly involved in the Resource Conservation and Recovery Act (RCRA)/Comprehensive Environmental Response, Compensation and Liability Act of 1980 (CERCLA) facility investigation activities, including but not limited to those engaged in surveillance, inspection, or observation activities.

Visitors who must, for whatever reason, enter a controlled (either contamination reduction or exclusion) zone, shall be subject to all of the applicable training, respirator fit testing, and medical surveillance requirements discussed in Westinghouse Hanford Environmental Investigations Instructions (EII) 1.1 and Appendix B to EII 1.1 (WHC 1991). 
All visitors shall be informed of potential hazards and emergency procedures by their escorts and shall conform to EII 1.1 (WHC 1991).

\subsection{RADIATION DOSIMETRY}

All personnel engaged in onsite activities shall be assigned dosimeters according to the requirements of the RWP applicable to that activity. All visitors shall be assigned basic dosimeters, as a minimum, that will be exchanged annually.

\subsection{REQUIREMENTS FOR THE USE OF RESPIRATORY PROTECTION}

All employees of Westinghouse Hanford and subcontractors who may be required to use air-purifying or air-supplied respirators must be included in the medical surveillance program and be approved for the use of respiratory protection by the Hanford Environmental Health Foundation (HEHF) or other licensed physician. Each team member must be trained in the selection, limitations, and proper use and maintenance of respiratory protection (existing respiratory protection training may be applicable towards the 40-hour training requirement).

Before using a negative pressure respirator, each employee must have been fit-tested (within the previous year) for the specific make, model, and size according to Westinghouse Hanford fit-testing procedures. Beards (including a few days' growth), large sideburns, or moustaches that may interfere with a proper respirator seal are not permitted.

Subcontractors must provide evidence to Westinghouse Hanford that personnel are participants in a medical surveillance and respiratory protection program that complies with 29 CFR 1910.120 and 29 CFR 1910.134, respectively.

\subsection{GENERAL PROCEDURES}

The following personal hygiene and work practice guidelines are intended to prevent injuries and adverse health effects. A hazardous waste site poses a multitude of health and safety concerns because of the variety and number of hazardous substances present. These guidelines represent the minimum standard procedures for reducing potential risks associated with this project and are to be followed by all job-site employees at all times. 


\subsection{GENERAL WORK SAFETY PRACTICES}

\subsubsection{Work Practices}

The following work practices must be observed:

- Eating, drinking, smoking, taking certain medications, chewing gum, and similar actions are prohibited within the exclusion zone. All sanitation facilities shall be located outside the exclusion zone; decontamination is required before using such facilities.

- Personnel shall avoid direct contact with contaminated materials unless necessary for sample collecting or required observation. Remote handling of such things as casings and auger flights will be practiced whenever practical.

- While operating in the controlled zone, personnel shall use the "buddy system" where appropriate, or be in visual contact with someone outside of the controlled zone.

- The buddy system will be used where appropriate for manual lifting.

- Requirements of Westinghouse Hanford radiation protection and RWP manuals shall be followed for all work involving radioactive materials or conducted within a radiologically controlled area.

- Onsite work operations shall only be carried out during daylight hours, unless the entire control zone is adequately illuminated with artificial lighting. A new tour (shift) will operate the drilling rig after completion of each shift.

- Do not handle soil, waste samples, or any other potentially contaminated items unless wearing the protective equipment specified in the HWOP or JSA.

- Whenever possible, stand upwind of excavations, boreholes, well casings, drilling spoils, and the like, as indicated by an onsite windsock.

- Stand clear of trenches during excavation. Always approach an excavation from upwind.

- Be alert to potentially changing exposure conditions as evidenced by such indications as perceptible odors, unusual appearance of excavated soils, or oily sheen on water.

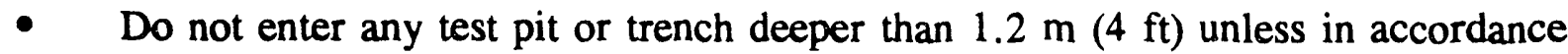
with procedures specified in the HWOP. 
- Do not under any circumstances enter or ride in or on any backhoe bucket, materials hoist, or any other similar device not specifically designed for carrying passengers.

- All drilling team members must make a conscientious effort to remain aware of their own and others' positions in regards to rotating equipment, cat heads, or ujoints. Drilling operations members must be extremely careful when assembling, lifting, and carrying flights or pipe to avoid pinch-point injuries and collisions.

- Tools and equipment will be kept off the ground whenever possible to avoid tripping hazards and the spread of contamination.

- Personnel not involved in operation of the drill rig or monitoring activities shall remain a safe distance from the rig as indicated by the field team leader.

- Follow all provisions of each site-specific hazardous work permit as addressed in the HWOP, including cutting and welding, confined space entry, and excavation.

- Catalytic converters on the underside of vehicles are sufficiently hot to ignite dry prairie grass. Team members should not drive over dry grass that is higher than the ground clearance of the vehicle and should be aware of the potential fire hazard posed by catalytic converters at all times. Never allow a running or hot vehicle to sit in a stationary location over dry grass or other combustible materials.

- Follow all provisions of each site-specific RWP.

- Team members will attempt to minimize truck tire disturbance of all stabilized sites.

\subsubsection{Personal Protective Equipment}

- Personal protective equipment will be selected specifically for the hazards identified in the HWOP. The site safety officer in conjunction with Westinghouse Hanford Health Physics and Industrial Hygiene and Safety is responsible for choosing the appropriate type and level of protection required for different activities at the job site.

- Levels of protection shall be appropriate to the hazard to avoid either excessive exposure or additional hazards imposed by excessive levels of protection. The HWOP will contain provisions for adjusting the level of protection as necessary. These personal protective equipment specifications must be followed at all times, as directed by the field team leader, health physics technician, and site safety officer. 
- Each employee must have a hard hat, safety glasses, and substantial protective foctwear available to wear as specified in the HWOP or JSA.

- The exclusion zone around drilling or other noisy operations will be posted "Hearing Protection Required" and team members will have had noise control training.

- Personnel should maintain a high level of awareness of the limitations in mobility, dexterity, and visual impairment inherent in the use of level B and level $\mathbf{C}$ personal protective equipment.

- Personnel should be alert to the symptoms of fatigue, heat stress, and cold stress and their effects on the normal caution and judgment of personnel.

- Rescue equipment as required by Occupational Safety and Health Administrationi (OSHA), Washington Industrial Safety and Health Act (WISHA), or standards for working over water will be available and used.

\subsubsection{Personal Decontamination}

- The HWOP will describe in detail methods of personnel decontamination, including the use of contamination control corridors and step-off pads when appropriate.

- Thoroughly wash hands and face before eating or putting anything in the mouth to avoid hand-to-mouth contarnination.

- At the end of each work day or each job, disposable clothing shall be removed and placed in (chemical contamination) drums, plastic-lined boxes or other containers as appropriate. Clothing that can be cleaned may be sent to the Hanford Site laundry.

- Individuals are expected to thorougilly shower before leaving the work site or Hanford Site if directed to do so by the health physics technician, site safety officer, or field team leader.

\subsubsection{Emergency Preparation}

- A multipurpose dry chemical fire extinguisher, a fire shovel, a complete field first-aid kit, and a portable pressurized spray wash unit shall be available at every site where there is potential for personnel contamination. 
- Prearranged hand signals or other means of emergency communication will be established when respiratory protection equipment is to be worn, because this equipment seriously impairs speech.

- The Hanford Fire Department shall be initially notified before the start of the site investigation project. This notification shall include the location and nature of the various types of field work activities as described in the work plan. A site location map shall be included in this notification.

\subsection{CONFINED SPACE/TEST PIT ENTRY PROCEDURES}

The following procedures apply to the entry of any confined space, which for the purpose of this document shall be defined as any space having limited egress (access to an exit) and the potential for the presence or accumulation of a toxic or explosive atmosphere. This includes manholes, certain trenches (particularly those through waste disposal areas), and all test pits greater than $1 \mathrm{~m}(3 \mathrm{ft})$ deep. If confined spaces are to be entered as part of the work operations, a hazardous work permit (filled out for confined space entry) must be obtained from Industrial Safety and Fire Protection.

The identified remedial investigation activities on the 200 North AAMS should not require confined space entry. Nevertheless, the hazards associated with confined spaces are of such severity that all employees should be familiar with the safe work discussed in the following paragraphs.

No employee shall enter any test pit or trench deeper than $1 \mathrm{~m}(3 \mathrm{ft})$ unless the sides are shored or laid back to a stable slope as specified in OSHA 29 CFR 1926.652 or equivalent state occupational health and safety regulations.

When an employee is required to enter a pit or trench $1 \mathrm{~m}(3 \mathrm{ft})$ deep or more, an adequate means of access and egress, such as a slope of at least 2:1 to the bottom of the pit or a secure ladder or steps shall be provided.

Before entering any confined space, including any test pit, the atmosphere will :e tested for flammable gases, oxygen deficiency, and organic vapors. If other specific contamination, such as radioactive materials or other gases and vapors may be present, additional testing for thuse substances shall be conducted. Depending on the situation, the space may require ventilation and retesting before entry.

An employee entering a confined or partially confined space must be equipped with an appropriate level of respiratory protection in keeping with the monitoring procedures discussed previously and the action levels for airborne contaminants (see "Warnings and Action Levels" in HWOP).

No employee shall enter any test pit requiring the use of level B protection, unless a backup person also equipped with a pressure-demand self-contained breathing apparatus 
(SCBA) is present. No backup person shall attempt any emergency rescue unless a second backup person equipped with an SCBA is present, or the appropriate emergency response authorities have been notified and additional help is on the way.

\subsection{SITE BACKGROUND}

Specific details on the 200 North AAMS background and known and suspected contamination are described in Sections 2.0 through 10.0 of the plan. The 200 North Aggregate Area is situated within the 200 North Area of the U.S. Department of Energy's (DOE) Hanford Site, in the south-central portion of the state of Washington. The 200 East Area is located in Benton County in the central portion of the Hanford Site. It is adjacent to the 200 West Area, located roughly $5 \mathrm{~km}(3 \mathrm{mi})$ to the east.

The 200 North Aggregate Area at the Hanford Site was used by the U.S. Government as a chemical separations area in the process to produce plutonium for nuclear weapons. These operations resulted in the release of chemical and radioactive wastes into the soil, air, and water of the area. Each waste site in the aggregate area is described separately in this document. Close relationships between waste units, such as overflow from one to another, are also discussed.

\subsection{SCOPE OF WORK AND POTENTIAL HAZARDS}

While the information presented in Sections 2.0 through 10.0 of the plan are believed to be representative of the constituents and quantities of wastes at the time of discharge, the present chemical nature, location, extent, and ultimate fate of these wastes in and around the liquid disposal facilities are largely unknown. The emphasis of the investigation in the 200 North AAMS will be to characterize the nature and extent of contamination in the vadose (unsaturated subsurface soil) zone.

\subsection{WORK TASKS}

Work tasks are described in Section 5.0 of the plan.

\subsection{POTENTIAL HAZARDS}

Onsite tasks will involve noninvasive surface sampling procedures and invasive soil sampling either directly in or immediately adjacent to areas known or suspected to contain potentially hazardous chemical substances, toxic metals, and radioactive materials. 
Surface radiological contamination and fugitive dust will be the potential hazards of primary concern during noninvasive mapping and sampling activities.

Existing data indicate that hazardous substances may be encountered during invasive sampling; these include radionuclides, heavy metals, and corrosives. In addition, volatile organics may also be associated with certain facilities such as the solvent storage buildings or underground storage tanks.

Potential hazards include the following:

- External radiation (gamma and to a lesser extract, beta) from radioactive materials in the soil

- Internal radiation resulting from radionuclides present in contaminated soil entering the body by ingestion or through open cuts and scratches

- Internal radiation resulting from inhalation of particulate (dust) contaminated with radioactive materials

- Inhalation of toxic vapors or gases such as volatile organics or ammonia

- Inhalation or ingestion of particulate (dust) contaminated with inorganic or organic chemicals, and toxic metals

- Dermal exposure to soil or groundwater contaminated with radionuclides

- Dermal exposure to soil or groundwater contaminated with inorganic or organic chemicals, and toxic metals

- Physical hazards such as noise, heat stress, and cold stress

- Slips, trips, falls, bumps, cuts, pinch points, falling objects, other overhead hazards, crushing injuries, and other hazards typical of a construction-related job site

- Unknown or unexpected underground utilities

- Biological hazards; snakes, spiders, etc.

\subsection{ASSESSMENT AND MITIGATION OF POTENTIAL HAZARDS}

The likelihood of significant exposure $(100 \mathrm{mR} / \mathrm{h}$ or greater) to external radiation is remote and can be readily monitored and controlled by limiting exposure time, increasing distance, and employing shielding as required. 
Internal radiation by inhalation or inadvertent ingestion of contaminated dust is a realistic concern and must be continuously evaluated by the health physics technician. Appropriate respiratory protection, protective clothing, and decontamination procedures will be implemented as necessary to reduce potential inhalation, ingestion, and dermal exposure to acceptable levels.

Dermal exposure to toxic chemical substances is not expected to pose a significant problem for the identified tasks given the use of the designated protective clothing. The appropriate level of personal protective clothing and respiratory protection will vary from work site to work site.

\subsection{ENVIRONMENTAL AND PERSONAL MONITORING}

The site safety officer or authorized delegate shall be present at all times during work activities which require an HWOP, and shall be in charge of all environmental/personal monitoring equipment. Industrial Hygiene and Safety shall review all activities involving or potentially involving radiological exposure or contamination control and shall prescribe the appropriate level of technical support and/or monitoring requirements. Other equipment deemed necessary by the site safety officer or Industrial Hygiene and Safety shall be obtained at their direction; work will be initiated or continued until such equipment is in place. These instruments are to be used only by persons who are trained in their usage and who understand their limitations. No work shall be done unless instrumentation is available and in proper working order.

Air sampling may be required downwind of the referenced waste sites to monitor particulates and vapors before job startup. Siting of such sampling devices will be determined by Health Physics, the site safety officer, and HEHF, if appropriate. Any time personnel exposure monitoring, other than radiological, is required to determine exposure levels, it must be done by HEHF. Discrete sampling of ambient air within the work zone and breathing zones will be conducted using a direct-reading instrument, as specified in the site-specific safety document, and other methods as deemed appropriate (e.g., pumps with tubes, $\mathrm{O}_{2}$ meters). The following standards will be used in determining critical levels:

- "Radionuclide Concentrations in Air," in Chapter XI, DOE Order 5480.1B (DOE 1986)

- $\quad$ "Air Contaminants - Permissible Exposure Limits," in 29 CFR 1910.1000

- Threshold Limit Values and Biological Exposure Indices for 1990-1991 (ACGIH 1991)

- Occupational Safety and Health Standards, 29 CFR 1910.1000 
- $\quad$ Pocket Guide to Chemical Hazards (NIOSH 1991), which provides National Institute for Occupational Safety and Health (NIOSH)-recommended exposure limits for substances that do not have either a threshold limit value or a permissible exposure limit.

\subsection{AIRBORNE RADIOACTIVE AND RADIATION MONITORING}

An onsite health physics technician will monitor airborne radioactive contamination levels and external radiation levels. Action levels will be consistent with derived air concentrations and applicable guidelines as specified in the radiation protection manual WHC-CM-4-10 (WHC 1988).

Appropriate respiratory protection shall be required when conditions are such that the airborne contamination levels may exceed an 8-hour derived air concentration (e.g., the presence of high levels of uncontained, loose contamination on exposed surfaces or operations that may raise excessive levels of dust contaminated with airborne radioactive materials, such as excavation or drilling under extremely dry conditions).

Specific conditions requiring the use of respiratory protection because of radioactive materials in air will be incorporated into the RWP. If, in the judgment of the health physics technician, any of these conditions arise, work shall cease until appropriate respiratory protection is provided.

\subsection{PERSONAL PROTECTIVE EQUIPMENT}

The level of personal protective equipment required initially at a site will be specified in the site-specific safety document for each task or group of tasks. Personal protective clothing and respiratory protection shall be selected to limit exposure to anticipated chemical and radiological hazards. Work practices and engineering controls may be used to control exposure.

\subsection{SITE CONTROL}

The field team leader, site safety officer, and health physics technician are designated to coordinate access control and security on the site. Special site control measures will be necessary to restrict public access. The zones will be clearly marked with rope and/or appropriate signs. The size and shape of the control zone will be dictated by the types of hazards expected, the climatic conditions, and specific operations required. 
Control zone boundaries may be increased or decreased based on results of field monitoring, environmental changes, or work technique changes. The site RWP and the contractor's standard operating procedures for radiation protection may also dictate the boundary size and shape. All team members must be surveyed for radioactive contamination when leaving the controlled zone if in a radiation zone.

The onsite command post and staging area will be established near the upwind side of the control zone as determined by an onsite windsock. Exact location for the command post is to be determined just before start of work. Vehicle access, availability of utilities (power and telephone), wind direction, and proximity to sample locations should be considered in establishing a command post location.

\subsection{DECONTAMINATION PROCEDURES}

Remedial investigation activities will require entry into areas of known chemical and radiological contamination. Consequently, it is possible that personnel and equipment could be contaminated with hazardous chemical and radiological substances.

During site activities, potential sources of contamination may include airborne vapors, gases, dust, mists, and aerosols; splashes and spills; walking through contaminated areas; and handling contaminated equipment. Personnel who enter the exclusion zone will be required to go through the appropriate decontamination procedures on leaving the zone.

Decontamination procedures shall be consistent with EII 5.4, "Field Decontamination of Drilling, Well Development, and Sampling Equipment," and EII 5.5, "Decontamination of Equipment for RCRA/CERCLA Sampling" (WHC 1991), or other approved decontamination procedures.

\subsection{CONTINGENCY AND EMERGENCY RESPONSE PLANS}

As a general rule, in the event of an unanticipated, potentially hazardous situation indicated by instrument readings, visible contamination, unusual or excessive odors, or other indications, team members shall temporarily cease operations and move upwind to a predesignated safe area as specified in the site-specific safety documentation. 


\subsection{REFERENCES}

ACGIH, 1991, Threshold Limit Values and Biological Exposure Indices for 1990-1991, American Conference of Governmental Industrial Hygienists, Cincinnati, Ohio.

DOE, 1986, Environment, Safety \& Health Program for DOE Operations, DOE Order 5480.1B, U.S. Department of Energy, Washington, D.C.

NIOSH, 1991, Pocket Guide to Chemical Hazards, National Institute for Occupational Safety and Health, U.S. Department of Health and Human Services, Public Health Service, Centers for Disease Control, Washington, D.C.

WHC, 1988, Radiation Protection, WHC-CM-4-10, Westinghouse Hanford Company, Richland, Washington.

WHC, 1991, Environmental Investigations and Site Characterization Manual, WHC-CM-7-7, Westinghouse Hanford Company, Richland, Washington.

WHC, 1992, Health and Safety for Hazardous Waste Field Operations, WHC-CM-4-3 Vol. 4, Westinghouse Hanford Company, Richland, Washington. 
DOE/RL-92-17, Rev. 0

\section{APPENDIX C}

PROJECT MANAGEMENT PLAN 
1.0 INTRODUCTION $\ldots \ldots \ldots \ldots \ldots \ldots \ldots \ldots \ldots \ldots \ldots$ C- 1

2.0 PROJECT ORGANIZATION AND RESPONSIBILITIES . . . . . . . . C

2.1 INTERFACE OF REGULATORY AUTHORITIES AND

THE U.S. DEPARTMENT OF ENERGY . . . . . . . . . . . . C-1

2.2 PROJECT ORGANIZATION AND RESPONSIBILITIES $\ldots \ldots \ldots \ldots$ C-1

2.2 .1 Project Managers $\ldots \ldots \ldots \ldots \ldots \ldots \ldots \ldots \ldots \ldots$ C-1

2.2.2 Unit Managers . . . . . . . . . . . . . . . C-2

2.2 .3 Quality Assurance Lead . . . . . . . . . . . . . . C-2

2.2.4 Health and Safety Officer (Environmental Division/Environmental Field Services) $\ldots \ldots \ldots \ldots \ldots \ldots$ C-2

2.2 .5 Technical Lead . . . . . . . . . . . . . . . . . . C-3

2.2.6 Remedial Investigation/Feasibility Study Coordinators .................... C-3

2.2.7 Resource Conservation and Recovery Act Facility Investigation/ Corrective Measures Study Contractors . . . . . . . . C C-3

2.2.8 Hanford Site Technical Resources . . . . . . . . . . . C-3

3.0 DOCUMENTATION AND RECORDS $\ldots \ldots \ldots \ldots \ldots \ldots$ C-4

4.0 FINANCIAL AND PROJECT TRACKING REQUIREMENTS $\ldots \ldots \ldots \ldots$ C-4

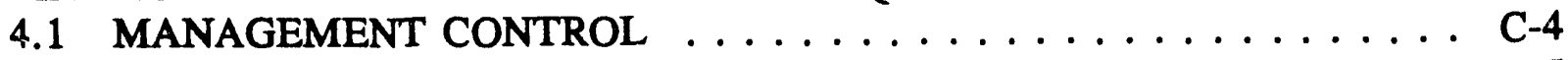

4.2 MEETINGS AND PROGRESS REPORTS $\ldots \ldots \ldots \ldots \ldots \ldots$ C-5

5.0 REFERENCES $\ldots \ldots \ldots \ldots \ldots \ldots \ldots \ldots \ldots$ C 6 . 
CONTENTS (cont.)

FIGURES:

C-1 Project Organization for the 200 North Aggregate

C-2 Example Project Organization for the 200 North Aggregate Area $\ldots \ldots \ldots \ldots \ldots \ldots \ldots \ldots \ldots \ldots$ CF-2

C-3 The Hanford Site Soil Sampling Team . . . . . . . . . . . . . CF-3

C-4 The Hanford Site Biological Sampling Team . . . . . . . . . . . . . CF-4

C-5 The Hanford Site Physical and Geophysical Survey Team . . . . . . . CF-5

C-6 Drilling, Sampling, and Well-Development Team . . . . . . . . C CF-6

TABLE:

C-1 Hanford Site RI/FS Technical Resources . . . . . . . . . . . C CT-1 


\subsection{INTRODUCTION}

This Project Management Plan (PMP) defines the administrative and institutional tasks necessary to support the 200 North Aggregate Area investigations at the Hanford Site. Also, this PMP defines the responsibilities of the various participants, the organizational structure, and the project tracking and reporting procedures. This PMP is in accordance with the provisions of the Hanford Federal Facility Agreement and Consent Order (Tri-Party Agreement) dated August 1990 (Ecology et al. 1990). Any revisions to the Tri-Party Agreement that would result in changes to the project mariagement requirements would supersede the provisions of this chapter.

\subsection{PROJECT ORGANIZATION AND RESPONSIBILITIES}

\subsection{INTERFACE OF REGULATORY AUTHORITIES AND THE U.S. DEPARTMENT OF ENERGY}

The 200 North Aggregate Area consists of active and inactive waste management units to be remedied under either the Resource Conservation and Recovery Act (RCRA) or the Comprehensive Environmental Response, Compensation, and Liability Act of 1980 (CERCLA). The U.S. Department of Ecology (Ecology) has been designated as the lead regulatory agency, as defined in the Tri-Party Agreement. Accordingly, Ecology is responsible for overseeing remedial action activity at this aggregate area and ensuring that the applicable authorities of both the U.S. Environmental Protection Agency (EPA) and the U.S. Department of Energy (DOE) are applied. The specific responsibilities of EPA, Ecology, and DOE are detailed in the Tri-Party Agreement.

\subsection{PROJECT ORGANIZATION AND RESPONSIBILITIES}

The project organization for implementing remedial activities at the 200 North Aggregate Area is shown in Figure C-1. The following sections describe the responsibilities of the individuals shown in Figure C-1.

\subsubsection{Project Managers}

The EPA, DOE, and Ecology have each designated one individual as project manager for remedial activities at the Hanford Site. These project managers will serve as the primary point of contact for all activities to be carried out under the Tri-Party Agreement. The responsibilities of the project managers are given in Section 4.1 of the Tri-Party Agreement. 


\subsubsection{Unit Managers}

As shown in Figure C-1, EPA, DOE, and Ecology will each designate an individual as a unit manager for the 200 North Aggregate Area.

The unit manager from Ecology will serve as the lead unit manager. The Ecology unit manager will be responsible for regulatory oversight of all activities required for the 200 North Aggregate Area.

The unit manager from EPA will be responsible for making decisions related to issues for which the supporting regulatory agency maintains authority. All such decisions will be made in consideration of recommendations made by the Ecology unit manager.

The unit manager from DOE will be responsible for maintaining and controlling the schedule and budget and keeping the EPA and Ecology unit managers informed as to the status of the activities at the 200 North Aggregate Area, particularly the status of agreements and commitments.

\subsubsection{Quality Assurance Lead}

The quality assurance lead will be a designated person within the Westinghouse Hanford Quality Assurance Organization. This designated person will be responsible for monitoring overall environmental restoration activities for this project. The designated personnel shall have the necessary organizational independence and authority to identify conditions adverse to quality and to systematically seek corrective action.

This individual is responsible for the preplanned survellance and audit activities for this project. A quality assurance report shall be provided to the technical lead, annually as a minimum, for inclusion in the project final report generated by the technical organization. The quality assurance report shall summarize the surveillance and audit activities as well as associated corrective actions that may have been taken during the interval.

\subsubsection{Health and Safety Officer (Environmental Division/Environmental Field Services)}

The health and safety officer is responsible for monitoring all potential health and safety hazards, including those associated with radioactive, volatile, and/or toxic compounds during sample handling and sampling decontamination activities. The health and safety officer has the responsibility and authority to halt field activities resulting from unacceptable health and safety hazards.

\subsubsection{Technical Lead}


The technical lead will be a designated person within the Westinghouse Hanford Environmental Engineering Group. The responsibilities of the technical lead will be to plan, authorize, and control work so that it can be completed on schedule and within budget, and to ensure that all planning and work performance activities are technically sound.

\subsubsection{Remedial Investigation/Feasibility Study Coordinators}

The remedial investigation (RI) and feasibility study (FS) coordinators will be responsible for coordinating all activities related to the RI and FS, respectively, including data collection, analysis, and reporting. The RI and FS coordinators will be responsible for keeping the technical lead informed as to the RI and FS work status and any problems that may arise.

\subsubsection{Resource Conservation and Recovery Act Facility Investigation/Corrective Measures Study Contractor}

Figure C-1 shows the organizational relationship of an offsite contractor. Assuming a contractor is used to perform the RI/FS for the 200 North Aggregate Area, the contractor would assume responsibilities of the RI and FS coordinators, as described above. In this instance, the contractor will be directly responsible for planning data collection activities and for analyzing and reporting the results of the data-gathering in the RI and FS reports. However, the Westinghouse Hanford coordinator would retain the responsibility for securing and managing the field sampling efforts of the Hanford Site technical resource teams, described below. Figure C-2 shows a sample organizational structure for an RI/FS contractor team.

\subsubsection{Hanford Site Technical Resources}

The various technical resources available on the Hanford Site for performing the field studies are shown in Table C-1. These resources will be responsible for performing data collection activities and analyses, and for reporting the results of specific technical activities. Figures C-3 through C-6 show the detailed organizational structure of specific technical teams. Internal and external work orders and subcontractor task orders will be written by the Westinghouse Hanford technical lead to use these technical resources, which are under the control of the technical lead. Statements of work will be provided to the technical teams and will include a discussion of authority and responsibility, a schedule with clearly defined milestones, and a task description including specific requirements. Each technical team will keep the coordinator informed of the work status performed by that group and any problems that may arise. 


\subsection{DOCUMENTATION AND RECORDS}

All plans and reports will be categorized as either primary or secondary documents as described by Section 9.1 of the Tri-Party Agreement. The process for document review and comment will be as described in Section 9.2 of the Tri-Party Afseament. Revisions, should they become necessary after finalization of any document, wili be in accordance with Section 9.3 of the Tri-Party Agreement. Changes in the work scheriule, as well as minor field changes, can be made without having to process a formal revision. The process for making these changes will be as stated in Section 12.0 of the Tri-liarty Agreement. Administrative records, which must be maintained to support the Hanford Site activities, will be in accordance with Section 9.4 of the Tri-Party Agreement.

\subsection{FINANCIAL AND PROJECT TRACKING REQUIREMENTS}

\subsection{MANAGEMFNT CONTROL}

Westinghouse Hanford will have the overall responsibility for planning and controlling the investigation activities, and providing effective technical, cost, and schedule baseline management. If a contractor is used, the contractor will assume the direct ddy-to-day responsibilities for these management functions. The management control system used for this project must mest the requirements of DOE Order 4700. and DOE Order 2250.1C, Cost and Schedule Control Systems Criteria. The Westinghuuse Hanford Management Control Sy:tem (MCS) meets these requirements. The primary goals of the Westinghouse Hanford MCS are to provide methods for planning, authorizing, and controlling v.ork so that it can be completed on schedule and within budget, and to ensure that all planning and work performance activities are technically sound and in conformance with management and quality requirements.

The schedule developed for the 200 North Aggregate Area will be updated at least annually, to expand the new current fiscal year and the follow-on year. In addition, any approved schedule changes (see Section 12.0 of the Tri-Party Agreement for the formal change control system) would be incorporated at this time, if not previously incorporated. This update will be performed in the fourth quarter of the previous fiscal year (e.g., July to September) for the upcoming current fiscal year. The work schedule can be revised at any time during the year if the neid arises, but the changes would be restricted to major changes that would not be suitable for the change controi process. 


\subsection{MEETINGS AND PROGRESS REPORTS}

Both project and unit managers must meet periodically to discuss progress, review plans, and address any issues that have arisen. The project managers' meeting will take place at least quarterly, and is discussed in Section 8.1 of the Tri-Party Agreement.

Unit managers shall meet monthly to discuss progress, address issues, and review nearterm plans pertaining to their respective operable units and/or treatment, storage, and disposal groups/units. The meetings shall be technical in nature, with emphasis on technical issues and work progress. The assigned DOE unit managar for the 200 North Aggregate Area will be responsible for preparing revisions to the aggregate area schedule prior to the meeting. The schedule shall address all ongoing activities associated with the 200 North Aggregate Area, including actions on specific source units (e.g., sampling). This schedule will be provided to all parties and reviewed at the meeting. Any agreements and commitments (within the unit manager's level of authority) resulting from the meeting will be prepared and signed by all parties as soon as possible after the meeting. Meeting minutes will be issued by the DOE unit manager and will summarize the discussion at the meeting, with information copies given to the project managers. The minutes will be issued within five working days following the meeting. The minutes will include, at a minimum, the following information:

- Status of previous agreements and commitments

- Any new agreements and commitments

- $\quad$ Schedules (with current status noted)

- Any approved changes signed off at the meeting in accordance with Section 12.1 of the Tri-Party Agreement.

Projer، coordinators for each operable unit also will meet on a monthly basis to share information and to discuss progress and problems.

The DOE shall issue a quarterly progress report for the Hanford Site within $\mathbf{4 5}$ days following the end of each quarter. Quarters end on March 31, June 30, September 30, and December 31 . The quarterly progress reports will be placed in the public information repositories as i iscussed in Section 10.2 of the Tri-Party Agreement. The report shall include the following:

- Highlights of significant progress and problems.

- Technical progress with supporting information, as appropriate.

- Problem areas with recommended solutions. This will include any anticipated delays $n$ meeting schedules, the reason(s) for the potential delay, and actions to prevent or minimize the delay. 
DOE/RL-92-17, Rev. 0

- Significant activities planned for the next quarter.

- Work schedules (with current status noted).

\subsection{REFERENCES}

Ecology, EPA, and DOE, 1990, Hanford Federal Facility Agreement and Consent Order, (First Amendment), 89-10, Rev.1, Olympia, Washington. 
Figure C-1. Project Organization for the 200 North Aggregate Area Project.

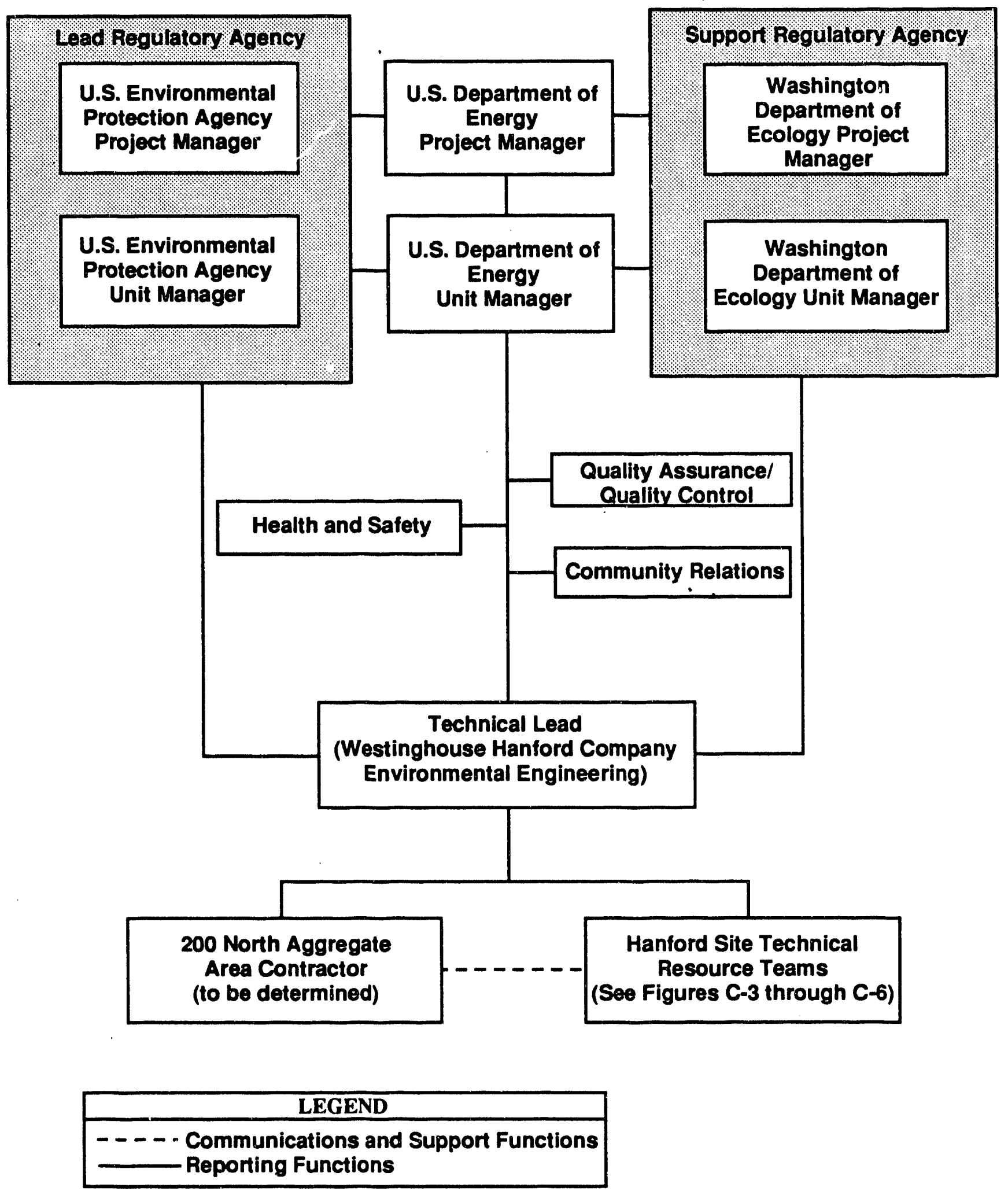


DOE/RL-92-17, Rev. 0

Figure C-2. Example Project Organization for the 200 North Aggregate Area.

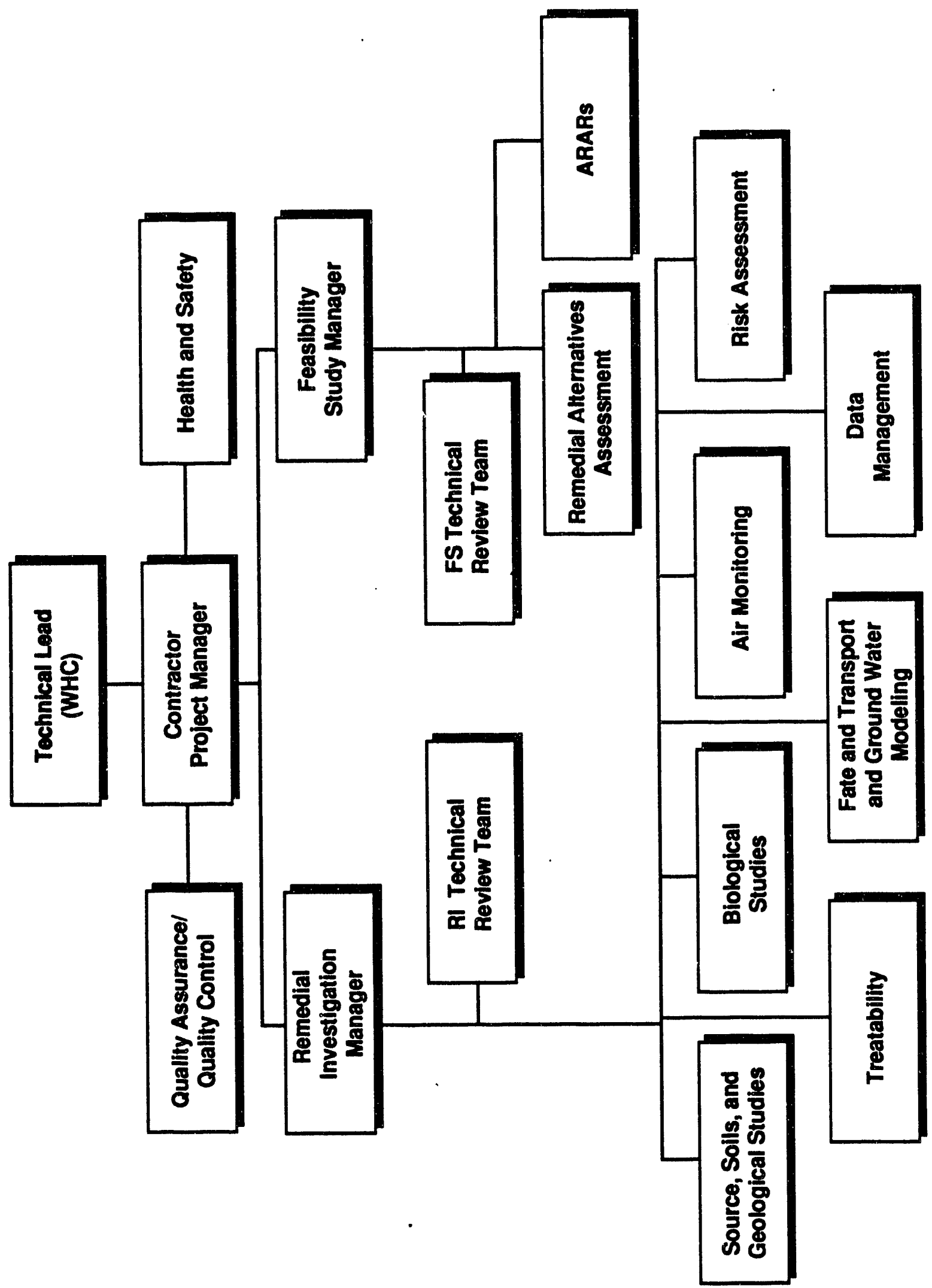


DOE/RL-92-17, Rev. 0

Figure C-3. The Hanford Site Soil Sampling Team.
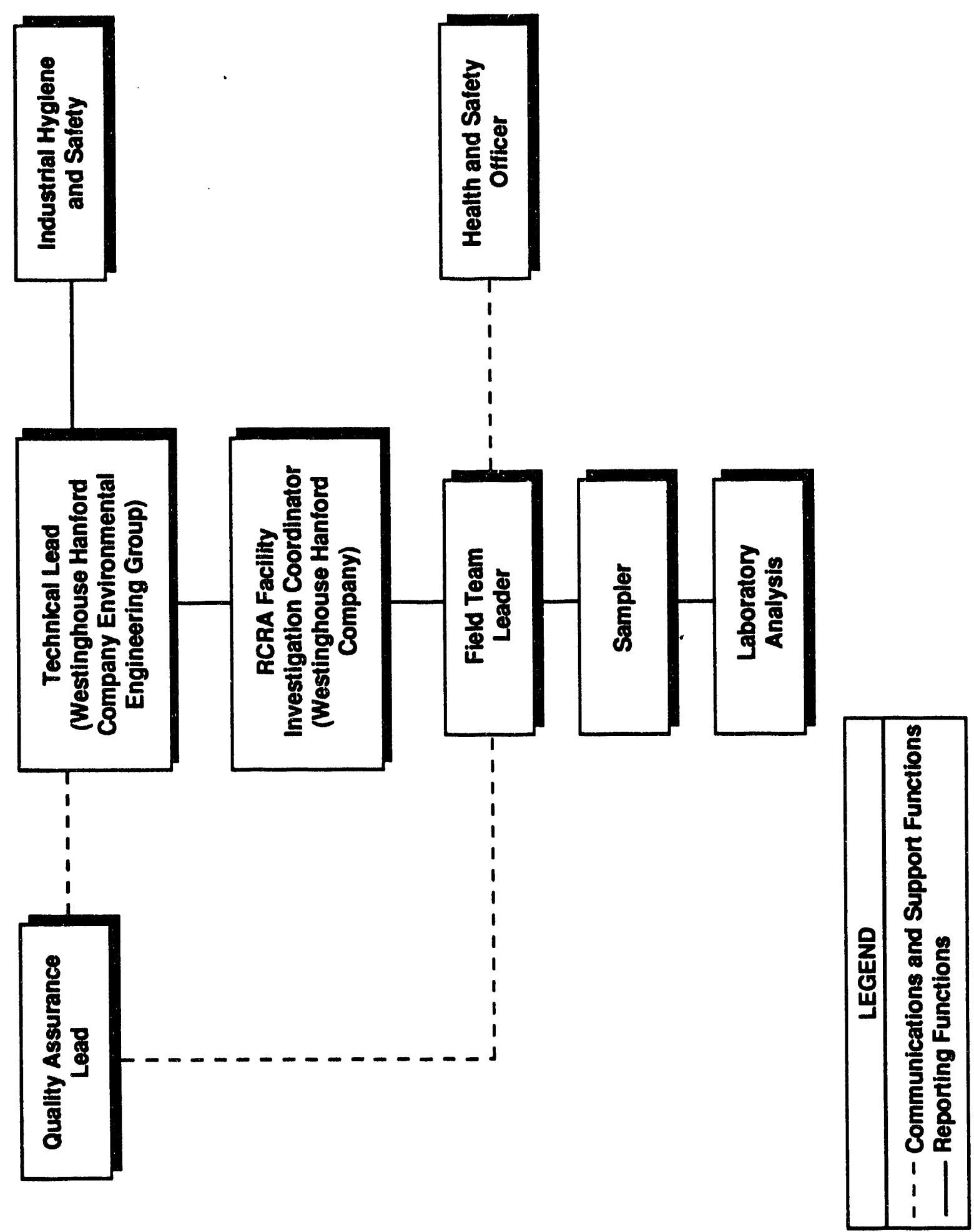
DOE/RL-92-17; Rev. 0

Figure C-4. The Hanford Site Biological Sampling Team.

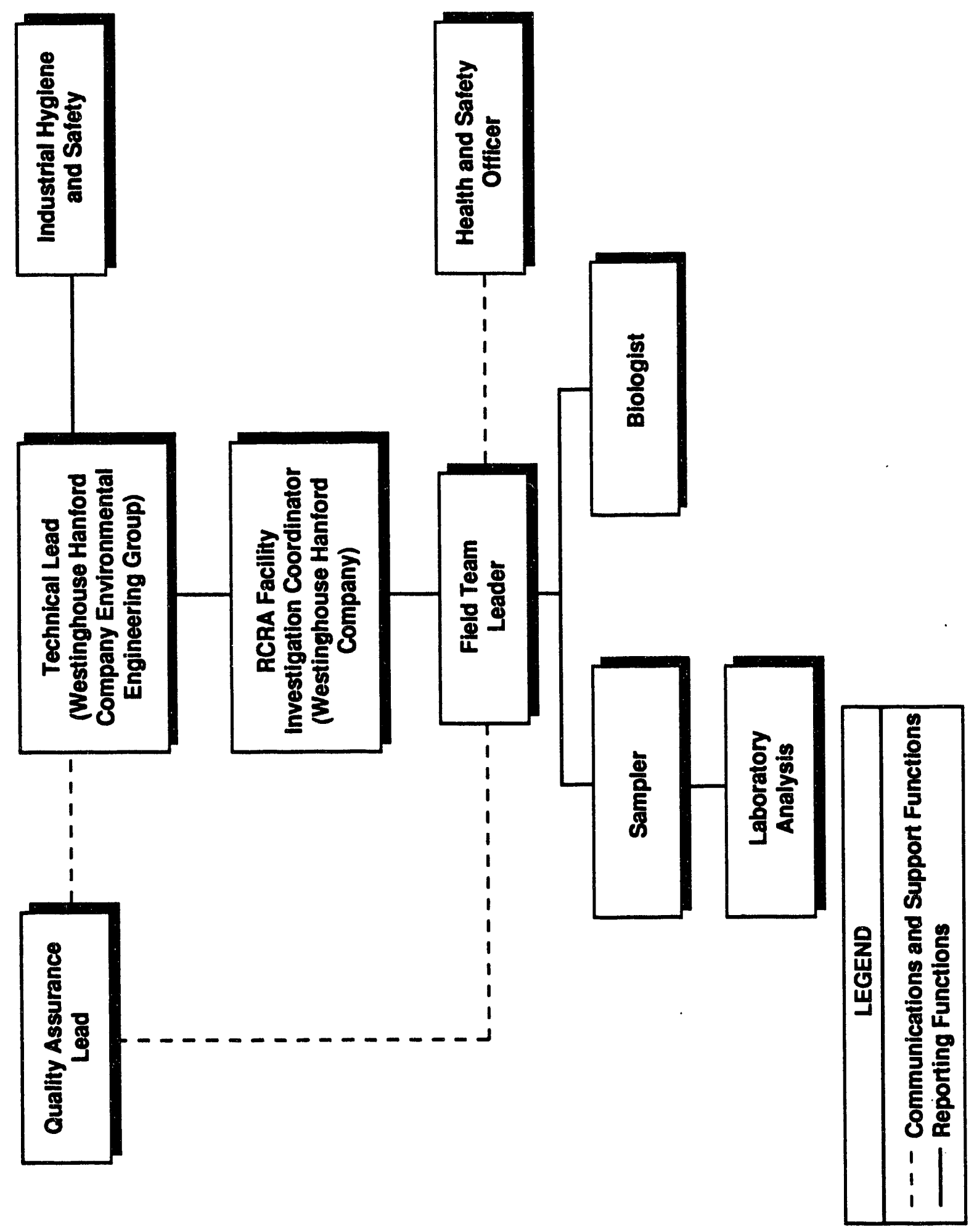


Figure C-5. The Hanford Site Physical and Geophysical Survey Team.
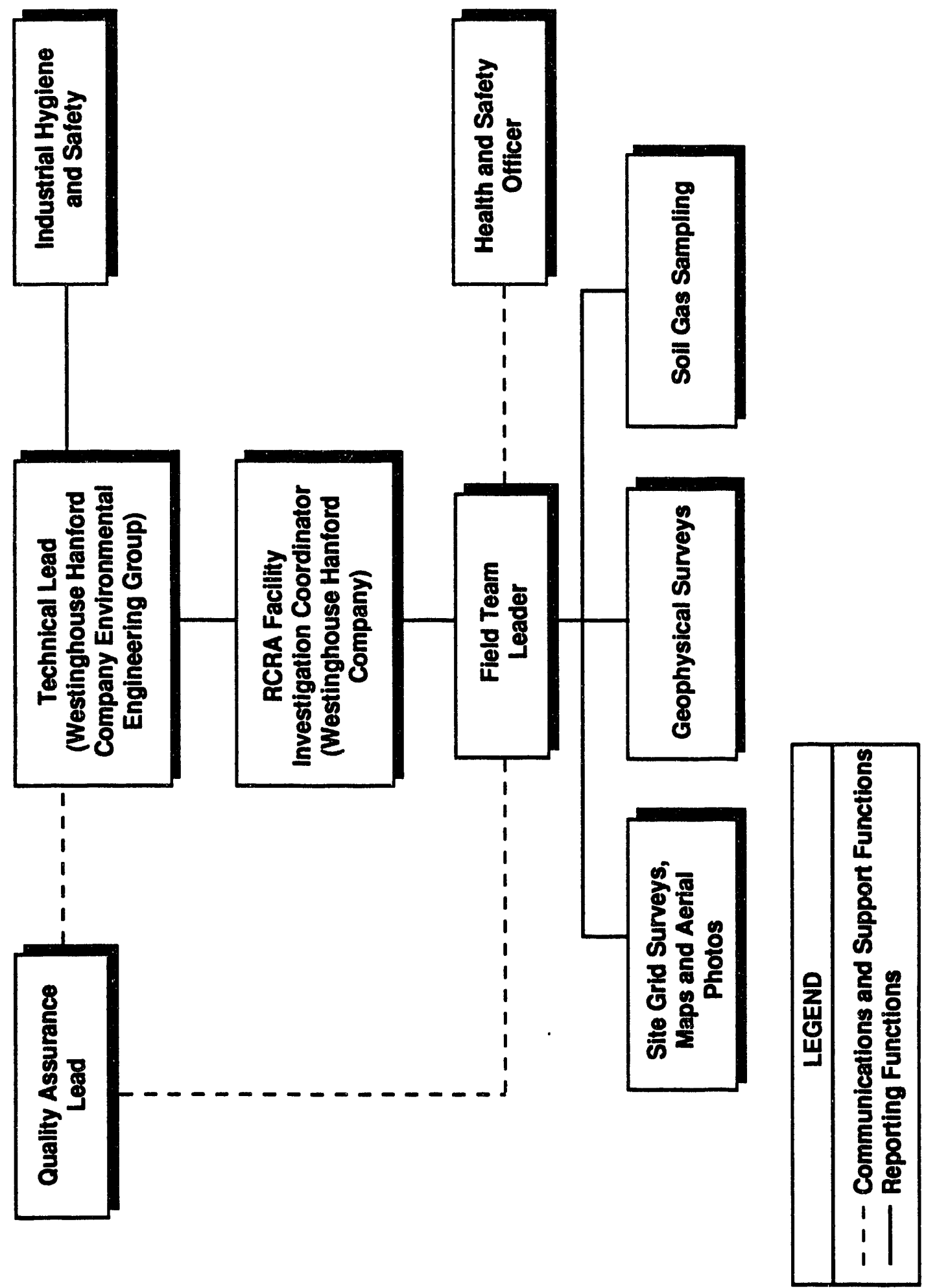
DOE/RL-92-17, Rev. 0

Figure C-6. Drilling, Sampling, and Well-Development Team.

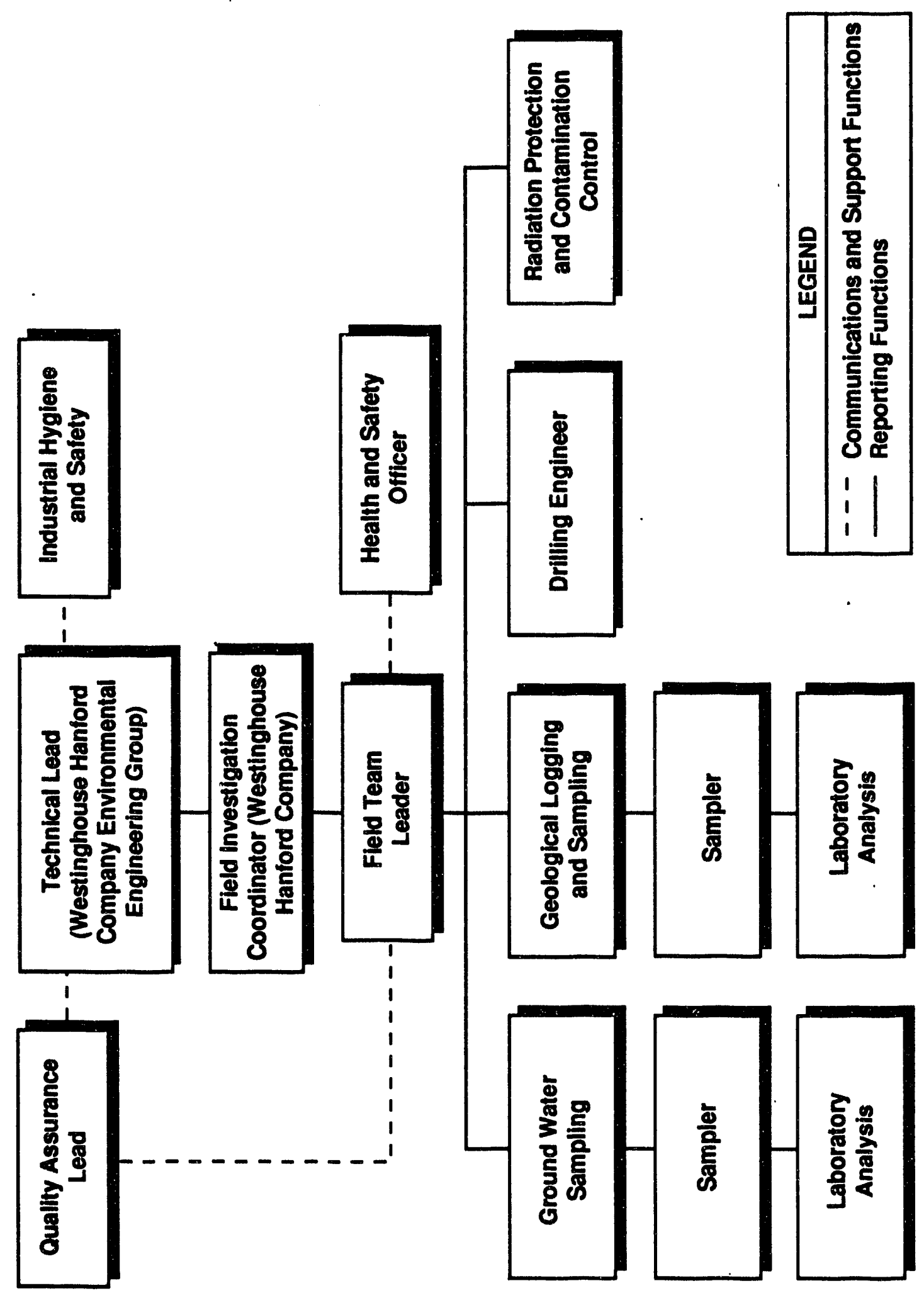


DOE/RL-92-17, Rev. 0

Table C-1. Hanford Site RI/FS Technical Resources.

Page 1 of 2

\begin{tabular}{|c|c|c|}
\hline \multirow[b]{2}{*}{ Subject/Activity } & \multicolumn{2}{|c|}{ Technical Resources } \\
\hline & $\mathrm{RI}$ & FS \\
\hline Hydrology and geology & $\begin{array}{l}\text { Westinghouse } \\
\text { Hanford/Geosciences } \\
\text { PNL/Earth and } \\
\text { Environmental Sciences } \\
\text { Center }\end{array}$ & $\begin{array}{l}\text { Westinghouse } \\
\text { Hanford/Geosciences }\end{array}$ \\
\hline $\begin{array}{l}\text { Toxicology and } \\
\text { risk/endangerment } \\
\text { assessment }\end{array}$ & $\begin{array}{l}\text { Westinghouse } \\
\text { Hanford/Environmental } \\
\text { Technology } \\
\text { PNL/Earth and } \\
\text { Environmental Sciences } \\
\text { Center } \\
\text { PNL/Life Sciences Center }\end{array}$ & $\begin{array}{l}\text { Westinghouse Hanford/ } \\
\text { Environmental Technology }\end{array}$ \\
\hline Environmental chemistry & $\begin{array}{l}\text { Westinghouse } \\
\text { Hanford/Geosciences } \\
\text { PNL/Earth and } \\
\text { Environmental Sciences } \\
\text { Center }\end{array}$ & $\begin{array}{l}\text { Westinghouse } \\
\text { Hanford/Geosciences }\end{array}$ \\
\hline $\begin{array}{l}\text { Geotechnical and civil } \\
\text { engineering }\end{array}$ & $\begin{array}{l}\text { Westinghouse } \\
\text { Hanford/Geosciences } \\
\text { (Planning) } \\
\text { Environmental Field } \\
\text { Services }\end{array}$ & NA \\
\hline $\begin{array}{l}\text { Geotechnical and civil } \\
\text { engineering }\end{array}$ & NA & $\begin{array}{l}\text { Westinghouse Hanford/ } \\
\text { Environmental Engineering } \\
\text { PNL/Waste Technology } \\
\text { Center }\end{array}$ \\
\hline $\begin{array}{l}\text { Groundwater treatment } \\
\text { engineering }\end{array}$ & NA & $\begin{array}{l}\text { Westinghouse Hanford/ } \\
\text { Environmental Engineering } \\
\text { PNL/Waste Technology } \\
\text { Center }\end{array}$ \\
\hline $\begin{array}{l}\text { Waste stabilization and } \\
\text { treatment }\end{array}$ & NA & $\begin{array}{l}\text { Westinghouse Hanford/ } \\
\text { Environmental Engineering } \\
\text { PNL/Waste Technology } \\
\text { Center }\end{array}$ \\
\hline Surveying & Kaiser Engineers Hanford & NA \\
\hline
\end{tabular}


DOE/RL-92-17, Rev. 0

Table C-1. Hanford Site RI/FS Technical Resources.

Page 2 of 2

Technical Resources

\begin{tabular}{|c|c|c|}
\hline \multirow[b]{2}{*}{ Subject/Activity } & \multicolumn{2}{|c|}{ Technical Resources } \\
\hline & RI & FS \\
\hline $\begin{array}{l}\text { Soil and water sampling and } \\
\text { analysis }\end{array}$ & $\begin{array}{l}\text { Westinghouse } \\
\text { Hanford/Environmental } \\
\text { Engineering } \\
\text { Westinghouse Office of } \\
\text { Sampling Management } \\
\text { PNL/Earth and } \\
\text { Environmental Sciences } \\
\text { Center } \\
\text { PNL/Materials and } \\
\text { Chemical Sciences Center }\end{array}$ & NA \\
\hline Drilling and well installation & $\begin{array}{l}\text { Westinghouse } \\
\text { Hanford/Geosciences } \\
\text { Environmental Field } \\
\text { Services } \\
\text { Kaiser Engineers }\end{array}$ & NA \\
\hline Radiation monitoring & $\begin{array}{l}\text { Westinghouse } \\
\text { Hanford/Operational Health } \\
\text { Physics }\end{array}$ & NA \\
\hline
\end{tabular}

NA $=$ Not applicable. 
DOE/RL-92-17, Rev. 0

\section{APPENDIX D}

INFORMATION MANAGEMENT OVERVIEW 


\section{CONTENTS}

Page

1.0 INTRODUCTION AND OBIECTIVES $\ldots \ldots \ldots \ldots \ldots \ldots \ldots$ D-1

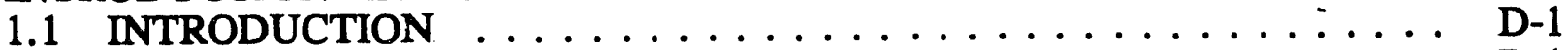

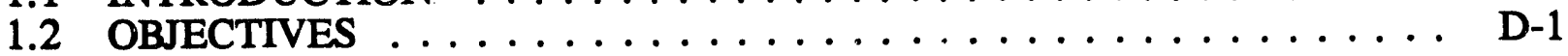

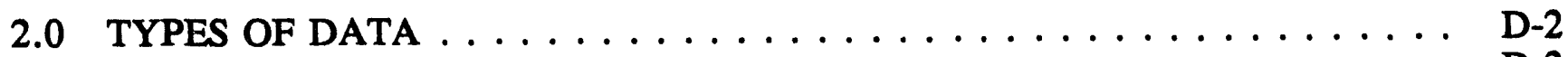

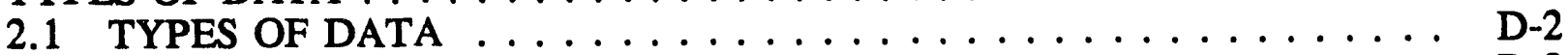

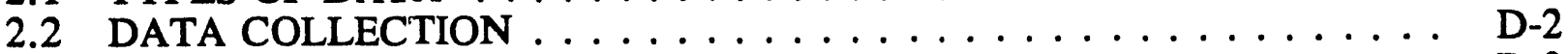

2.3 DATA STORAGE AND ACCESS $\ldots \ldots \ldots \ldots \ldots \ldots \ldots$ D-3

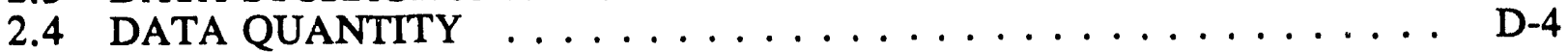

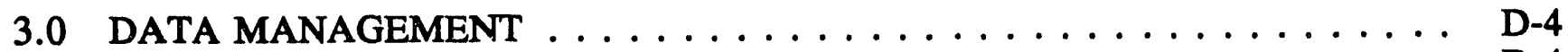

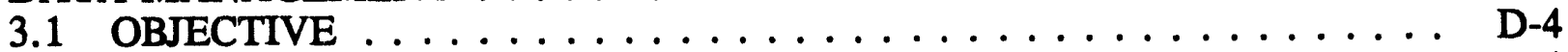

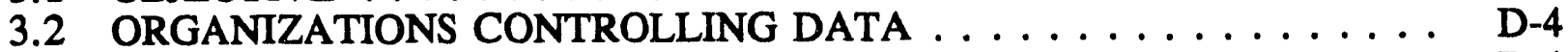

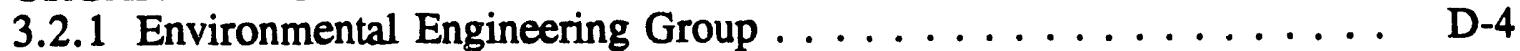

3.2.2 Office of Sample Management $\ldots \ldots \ldots \ldots \ldots \ldots$ D-4

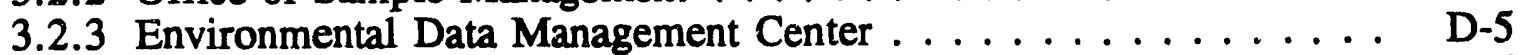

3.2.4 Information Resource Management . . . . . . . . . D-5

3.2.5 Hanford Environmental Health Foundation .......... D-5

3.2.6 Environmental Health and Pesticide Services Section $\ldots \ldots \ldots$ D-5

3.2.7 Technical Training Records and Scheduling Section ........ D-6

3.2.8 Pacific Northwest Laboratory $\ldots \ldots \ldots \ldots \ldots \ldots \ldots \ldots$ D-6

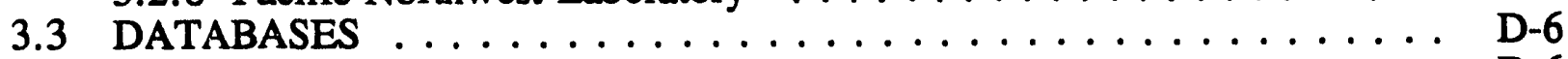

3.3.1 Meteorological Data ................ D-6

3.3.2 Nonradiological Exposure and Medical Records ......... D-6

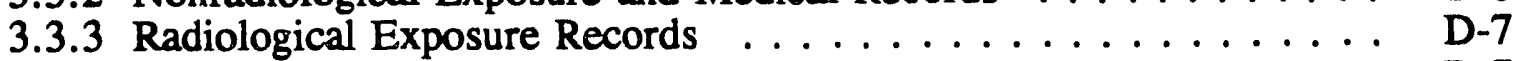

3.3.4 Training Records $\ldots \ldots \ldots \ldots \ldots \ldots \ldots \ldots$ D-7

3.3.5 Environmental Information/Administrative Record . . . . . . . D-7

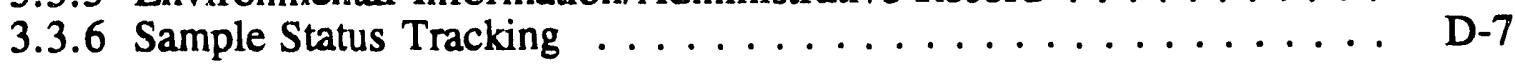

4.0 ENVIRONMENTAL INFORMATION AND RECORDS

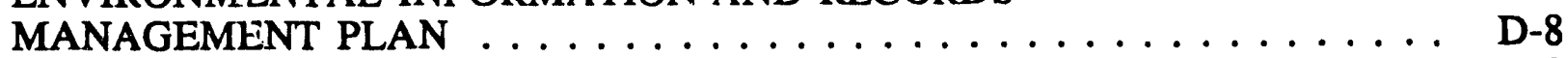

4.1 ENVIRONMENTAL INFORMATION MANAGEMENT PLAN ...... D-8

4.2 ENVIRONMENTAL RESTORATION REMEDIAL ACTION PROGRAM RECORDS MANAGEMENT PLAN $\ldots \ldots \ldots \ldots \ldots \ldots$ D-9

5.0 HANFORD ENVIRONMENTAL INFORMATION SYSTEM $\ldots \ldots \ldots \ldots$ D-10

5.1 OBJECTIVE . . . . . . . . . . . . . . . . . . . D-10

5.2 STATUS OF THE HANFORD ENVIRONMENTAL INFORMATION

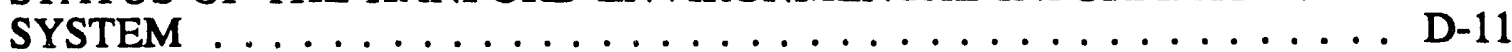

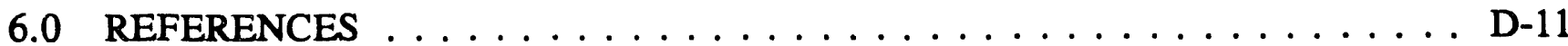


DOE/RL-92-17, Rev. 0

CONTENTS (cont.)

Page

\section{-FIGURE:}

D-1 Environmental Engineering, Technology, and Permitting Data Management Model . . . . . . . . . . . . . . . . DF-1

TABLE:

D-1 Types of Related Administrative Data $\ldots \ldots \ldots \ldots \ldots \ldots \ldots$ DT-1 
DOE/RL-92-17, Rev. 0

\section{DEFINITIONS OF TERMS}

Action Plan. Action plan for implementation of the Hanford Federal Facility Agreement and Consent Order (Ecology et al. 1990). A negotiation between the U.S. Environmental Protection (EPA), the U.S. Department of Energy (DOE), and the State of Washington Department of Ecology (Ecology). The Action Plan defines the methods and precesses by which hazardous waste permits will be obtained, and by which closure and rost-closure actions under the Resource Conservation and Recovery Act of 1976 (RCRA) and by which remedial actions under the Comprehensive Environriental Response, Compensition, and Liability Act of 1980 (CERCLA) will be conducted on the Hanford Site.

Administrative Record (AR). In CERCLA, the official file that contains all information that was considered or relied on by the regulatory agency in arriving at a final remedial action decision, as well as all documentation of public participation throughout the process. In RCRA, the official file that contains all documents to support a final RCRA permit determination.

Administrati Record File. The assemblage of documents compiled and maintained by an agency pertaining to a proposed project of administrative action and designated as AR or that ari: candidates for inclusion in the AR once a record of decision (ROD) is attained.

Data Management. The planning and control of activities affecting data.

Data Quality. The totality of features and characteristics of data that bears on its ability to satisfy a given purpose. The charasteristics of major importance are accuracy, precision, completeness, representativeness, and comparability.

Data Validation. The process whereby lata are accepted or rejected based on a set of criteria. This aspect of quality assurance involves establishing specified criteria for data vaiidation. The quality assurance project plan (QAPP) must indicate the specified criteria that wili be used for data validation.

ENCORE. The name given to the combination of hardware, software, and administrative subsystems that serve to integrate the management of the Hanford Site environmental data.

Environmental Data Management Center (EDMC). The central facility and services that provide a files management system fcr processing environmental information.

Environmental Information. Data related to the protection or improvement of the Hanford Site environment, including data required to satisfy environmental statutes, applicable DOE orders, or the Tri Party Agreement. 
Field File Custodian. $\mathbf{A n}_{\mathrm{n}}$ individual who is responsible for receipt, validation, storage, maintenance, con rol, and disposition of information or other records generated in support of Enviroumental Division activities.

Hanford Environmental Information System (HEIS). A computer-based information system under development as a resource for the storage, analysis, and display of investigative data collected for use in site characterization and remediation activities. Subject areas currently being developed include geophysics/soil gas, vadose zone soil (geologic), atmospherics, and biota.

Information System. Collection of components relate to the management of data and reporting of information. Information systems typically include computer hardware, computer software, operating systems, utilities, procedures, and data.

Lead Agency. The regulatory agency (EPA or Ecology) that is assigned the primary administrative and technical responsibility with respect to actions at a particular operable unit.

Nonrecord Material. Copies of material that are maintained for information, reference, and operating convenience and for which another office has primary responsibility.

Operable Unit. An operable unit at the Hanford Site is a group of land disposal and groundwater sites placed together for the purposes of doing a cemedial investigation/ feasibility study. The primary criteria for placement of a site into an operable unit are geographic proximity, similarity of waste characteristics and site types, and the possibility for economies of scale.

Primary Document. A document that contains information on which key decisions are made with respect to the remedial action or permitting process. Primary documents are subject to dispute resolution and are part of the administrative record file.

Project Manager. The individual responsible for implementing the terms and conditions of the Action Plan on behalf of his respective party. The EPA, DOE, and Ecology will each designate one project manager.

Quality Affecting Record. Information contained on any media, including but not limited to, hard copy, sample material, photo copy, and electronic systems, that is complete in terms of appropriate content and that furnishes evidence of the quality of items and/or activities affecting quality.

Quality Assurance. The systematic actions necessary to provide adequate confidence that a material, component, system, process, or facility performs satisfactorily or as planned in service. 
Quality Assured Data. Data developed under an integrated program for assurance of the reliability of data.

Raw Data, Unprocessed or unanalyzed information.

Record Validation. A review to determine that records are complete, legible, and meet records requirements. Documents are considered valid records only after the validation process has been completed.

Retention Period. The length of time records must be held before they can be disposed of. The time is usually expressed in years from the date of the record, but may also be expressed as contingent on the occurrence of an event.

Secondary Dacument. A document providing information that does not, in itself, reflect or support key decisions. A secondary document is subject to review by the regulatory agencies and may be part of the administrative record field. It is not subject to dispute resolution.

Validated Data. Data that meet criteria contained in an approved company procedure.

Verified Data. Data that have been checked for accuracy and consistency following a transfer action (e.g., from manual $\log$ to computer, or from distributed database to centralized data repository). 


\subsection{INTRODUCTION AND OBJECTIVES}

\subsection{INTRODUCTION}

An extensive amount of data will be generated over the next several years in connection with the activities planned for the $\mathbf{2 0 0}$ North Aggregate Area. The quality of these data are extremely important to the full remediation of the aggregate area as agreed on by the U.S. Department of Energy (DOE), the U.S. Environmental Protection Agency (EPA) the Washington Department of Ecology (Ecology), and interested parties.

The Information Management Overview (IMO) provides an overview of the data management activities at the operable unit level. It identifies the type and quantity of data to be collected and references the procedures which control the collection and handling of data. It provides guidance for the data collector, aggregate area investigator, project manager, and reviewer to fulfill their respective roles.

This IMO addresses handling of data generated from activities associated with the aggregate area activities. All data collected will be in accordance with the Environmental Investigations Instructions (EII) contained in the Westinghouse Hanford Company's (Westinghouse Hanford) Environmental Investigations and Site Characterization Manual (WHC 1991a).

Development of a comprehensive plan for the management of all environmental data generated at the Hanford Site is under way. The Environmental Information Management Plan (EIMP) (Steward et al. 1989), released in March 1989, described activities in the Environmental Data Management Center (EDMC) and long-range goals for management of scientific and technical data. The scientific and technical data part of the EIMP was reviewed, revised, and expanded in fiscal year 1990 (Michael et al. 1990). An Environmental Restoration Remedial Action Program Records Management Plan (WHC 1991b) issued in July 1991, enables the program office to identify, control, and maintain the quality assurance (QA), decisional, or regulatory prescribed records generated and used in support of the Environmental Restoration Remedial Action (ERRA) Program.

\subsection{OBJECTIVES}

This IMO describes the process for the collection and control procedures for validated data, records, documents, correspondence, and other information associated with this aggregate area. This IMO addresses the following:

- Types of data to be collected

- $\quad$ Plans for managing data

- Organizations controlling data

- Databases used to store the data 
$\begin{array}{ll}\text { - } & \text { EIMP } \\ \text { Hanford Environmental Information System (HEIS). }\end{array}$

\subsection{TYPES OF DATA}

\subsection{TYPES OF DATA}

The general types of technical data to be collected and the associated controlling procedures are as follows:

\section{Type of data}

Historical reports

Aerial photos

Chart recordings

Technical memos

Validated samples analyses

Reports

Logbooks

Chain-of-custody forms

Sample quality assurance/

quality control (QA/QC)

\section{Procedure}

EII 1.6

EII 1.6

EII 1.6

EII 1.6

EII 1.6

EII 1.6

EII 1.5

EII 5.1

Office of Sample

Management (OSM)

All such data are submitted to the EDMC for entry into the administrative record (AR).

General types of related administrative data is shown in Table D-1, which is organized in terms of general types of personnel and compliance/regulatory data. Table D-1 references the appropriate procedures and the record custodians. Data associated with aggregate area investigations will be submitted to the EDMC for entry into the AR, as appropriate.

\subsection{DATA COLLECTION}

Data will be collected according to the aggregate area sampling and analysis plans and the Quality Assurance Project Plan (QAPP). Section 2.1 listed the controlling procedures for data collection and handling before turnover to the organization responsible for data storage. All procedures for data collection shall be approved in compliance with the Westinghouse Hanford Environmental Investigations and Site Characterization Manual (WHC 1991a). 


\subsection{DATA STORAGE AND ACCESS}

Data will be handled and stored according to procedures approved in compliance with applicable Westinghouse Hanford procedures (WHC 1988). The EDMC is the central files manager and process facility. All data entering the EDMC will be indexed, recorded, and placed into safe and secure storage. Data designated for placement into the AR will be copied, placed into the Hanford Site AR file, and distributed by the EDMC to the user community. The hard copy files are the primary sources of information; the various electronic data bases are secondary sources.

Normal access to data is through EDMC which is responsible for the AR. The Administrative Record Public Access Room is located in the 345 Hills Street Facility in Richland, Washington. This facility includes AR file documents (including identified guidance documents and technical literature).

Project participants may access data that are not in the AR by requesting it at the monthly unit managers' meeting for the operable unit of concern. As the project moves to completion, it is expected that all of the relevant data will be contained in the AR and the need to access data will be minimal. EDMC:

The following types of data will be accessed from and reside in locations other than the

\section{Data Type}

- QA/QC laboratory data

- Sample status

- Archived samples

- Training records

- Meteorological data

- Health and safety records

- Personal protective fitting

- Radiological exposure
Data location

OSM (Westinghouse Hanford)

OSM (Westinghouse Hanford)

Laboratory performing analyses

Technical Training Support Section (Westinghouse Hanford)

Hanford Meteorological Station (HMS) (Pacific Northwest Laboratory [PNL])

Hanford Environmental Health Foundation (HEHF)

Environmental Health and Pesticide Services Section (Westinghouse Hanford)

Pacific Northwest Laboratory. 


\subsection{DATA QUANTITY}

Data quantities for the investigative activities will be estimated based on the sampling and analysis plans developed for investigation of sites within the aggregate area.

\subsection{DATA MANAGEMENT}

\subsection{OBJECTIVE}

A considerable amount of data will be generated through the implementation of the aggregate area sampling and analysis plans. The QAPP will provide the specific procedural direction and control for obtaining and analyzing samples in conformance with requirements to ensure quality data resuits. The sampling and analysis plans will provide the basis for selecting the location, depth, frequency of collection, etc., of media to be sampled and methods to be employed to obtain samples of selected media for cataloging, shipment, and analysis. Figure D-1 displays the general data management model for data generated through work plan activities.

\subsection{ORGANIZATIONS CONTROLLING DATA}

This section addresses the organizations that will receive data generated from aggregate area activities.

\subsubsection{Environmental Engineering Group}

The Westinghouse Hanford Environmental Engineering Group provides the operable unit technical coordinator. The technical coordinator is responsible for maintaining and transmitting data to the designated storage facility.

\subsubsection{Office of Sample Management}

The Westinghouse Hanford OSM will validate all analytical data packages received from the laboratory. Validated summary data (sample results and copies of chain-of-custody forms) will be forwarded to the technical coordinator. Nonvalidated data will be forwarded to the technical coordinator on request. Preliminary data will be clearly labeled as such. The OSM will maintain raw sample data, QA/QC laboratory data, and the archived sample index. 


\subsubsection{Environmental Data Management Center}

The EDMC is the Westinghouse Hanford Environmental Division's central facility and service that provides a file management system for processing environmental information. The EDMC manages and controls the AR and Administrative Record Public Access Room at the Hanford Site. Part 1 of the EIMP (Michael et al. 1990) describes the central file system and services provided by the EDMC. The following procedures address data transmittal to the EDMC:

- $\quad$ Ell 1.6, Records Management (WHC 1991a)

- $\quad$ EII 1.11, Technical Data Management (WHC 1991a)

- TPA-MP-02, Information Transmittals and Receipt Controls (DOE/RL 1990)

- TPA-MP-07, Administrative Record Collection and Management (DOE/RL 1990)

\subsubsection{Information Resource Management}

Information Resource Management is the designated records custodian (permanent storage) for Westinghouse Hanford. The procedural link from the EDMC to the Information Resource Management is currently under development.

\subsubsection{Hanford Environmental Health Foundation}

The HEHF performs the analyses on the nonradiological health and exposure data (Section 3.3.2) and forwards summary reports to the Fire and Protection Group and the Environmental Health and Pesticide Services Section within the Westinghouse Hanford Environmental Division. Nonradiological and health exposure data are maintained also for other Hanford Site contractors (PNL and Kaiser Engineers Hanford [KEH]) associated with aggregate area activities. The HEHF provides summary data to the appropriate site contractor. EII 2.1, Preparation of Hazardous Waste Operations Permits, and EII 2.2, Occupational Health Monitoring (WHC 1991a) address the preparation of health and safety plans and occupational health monitoring, respectively.

\subsubsection{Environmental Health and Pesticide Services Section}

The Westinghouse Hanford Environmental Health and Pesticide Services Section maintains personal protective equipment fitting records and maintains nonradiological health field exposure and exposure summary reports provided by HEHF for Westinghouse Hanford Environmental Division and subcontractor personnel. 
DOE/RL-92-17, Rev. 0

\subsubsection{Technical Training Records and Scheduling Section}

The Westinghouse Hanford Technical Training Records and Scheduling Section provides training and maintains training records (Section 3.3.4).

\subsubsection{Pacinic Northwest Laboratory}

The PNL operates the HMS and collects and maintains meteorological data (Section 3.3.1). Data management is discussed in Andrews (1988).

The PNL collects and maintains radiation exposure data (Section 3.3.3).

\subsection{DATABASES}

This section addresses databases that will receive data generated from the aggregate area activities. These and other databases are described in the EIMP (Michael et al. 1990). All of these databases exist independently of this aggregate area and serve other site functions. Data pertinent to the operable unit, housed in these databases, will be submitted to the AR.

\subsubsection{Meteorological Data}

The HMS collects and maintains meteorological data. Their database contains meteorological data from 1943 to the present, and Andrews (1988) is the document containing meteorological data management information.

\subsubsection{Nonradiological Exposure and Medical Records}

The HEHF collects and maintains data for all nonradiological exposure records and medical records.

\subsubsection{Radiological Exposure Records}

The PNL collects and maintains data on occupational radiation exposure. This database contains respiratory personal protective equipment fitting records, work restrictions, and radiation exposure information. 


\subsubsection{Training Records}

Training records for Westinghouse Hanford and subcontractor personnel are managed by the Westinghouse Hanford Technical Training Support Section. Other Hanford Site contractors (PNL and $\mathrm{KEH}$ ) maintain their own personnel training records. Training records for non-Westinghouse personnel are entered into the Westinghouse (soft reporting) database to document compliance.

Training records include:

- Initial 40-h hazardous waste worker training

- Annual 8-h hazardous waste worker training update

- Hazardous waste generator training

- Hazardous waste site specific training

- Radiation safety training

- Cardiopulmonary resuscitation

- Scott air pack

- Fire extinguisher

- Noise control

- $\quad$ Mask fit.

\subsubsection{Environmental Information/Administrative Record}

Environmental information and the AR are managed by Westinghouse Hanford EDMC personnel. They provide an index and key information on all data transmitted to the EDMC. This database is used to assist in data retrieval and to produce index lists as required.

\subsubsection{Sample Status Tracking}

The OSM maintains the sample status tracking database. This database contains information about each sample. Information maintained includes sample number, ship date, receipt date, and laboratory identification.

\subsection{ENVIRONMENTAL INFORMATION AND RECORDS MANAGEMENT PLAN}

This section briefly discusses the EIMP (Michael et al. 1990) that was developed to provide an overview of an integrated approach to managing Hanford Site environmental data, and the Environmental Restoration Remedial Action Program Records Management Plan (WHC 1991b). 


\subsection{ENVIRONMENTAL INFORMATION MANAGEMENT PLAN}

The EMMP provides an overview of how information is managed throughout the lifetime of Hanford Site environmental programs.

The Environmental Division of Westinghouse Hanford is responsible for the protection and improvement of the Hanford Site environment. To fulfill responsibility, the Environmental Division has assumed a management role with respect to Hanford Site environmental information. This management role includes (1) establishing standards for how data are validated and controlled, (2) developing and maintaining a supporting computer-based environment, and (3) sustaining a centralized file management system.

Hanford Site environmental information is defined as data related to the protection or improvement of the Hanford Site environment, including data required to satisfy environmental statutes, applicable DOE orders, or the Hanford Federal Facility Agreement and Consent Order (Ecology et al. 1990), (Tri-Party Agreement).

Environmental information falls into several overlapping categories, such as administrative versus technical and electronic versus manual or hard copy. A considerable amount of data are recorded in documents, which are governed by company-wide document and records control practices. Other data are collected or generated by computer and, therefore, exist in electronic form. The name ENCORE has been given to the combination of administrative, hardware, and software systems that serve to integrate the management of this electronic data.

Administrative information (e.g., budgets and schedules) is subject to accounting and other standard business practices. Scientific and technical data are subject to a different set of legal, classification, release, and engineering requirements.

Superimposed over these categories is the files management system for environmental information. This management system, has been developed to meet a number of Environmental Division needs, including requirements for compilation of AR files. The AR files are compilations of all material related to environmental restoration and remedial action records of decision (ROD) for each operable unit and treatment, storage, and disposal (TSD) group described in the Tri-Party Agreement.

Data in electronic form flows from information systems in the ENCORE realm to both scientific/technical and administrative documents. Environmental documents distributed within the Hanford Site and from regulatory agencies are received by the EDMC for storage and future processing.

Part I of the EIMP describes the overall Westinghouse Hanford systems that are generally applied to documents and records. Part I also describes, in greater detail, the files management system developed to manage the AR file information. The EDMC compiles the AR files and provides controlled distribution of specified information to the AR files held by 
DOE, Ecology, and the EPA. The EDMC also provides controlled distribution of specified community relations information to regional information repositories.

Part II addresses computer-based information, with an emphasis on scientific and technical data. The long-term nature of environmental programs and the complex interrelationships of environmental data require that the data be preserved, retrievable, traceable, and sufficient for future use. To ensure data availability for response to regulatory and agency requirements, the plan is directed toward optimizing the use of automated techniques for managing data. The current processing environment and the proposed ENCORE realm are described, and the plans for implementation of ENCORE are addressed.

\subsection{ENVIRONMENTAL RESTORATION REMEDIAL ACTION PROGRAM RECORDS MANAGEMENT PLAN}

The ERRA Program records management plan was developed to fulfill the requirements of the U.S. Department of Energy, Richland Operations Office (DOE/RL) Environmental Restoration Field Office Management Plan (FOMP) (DOE/RL 1989). The FOMP describes the plans, organization, and control systems to be used for management of the Hanford Site ERRA Program. The Westinghouse Hanford ERRA Program Office has developed this ERRA Program records management plan to fulfill the requirements of the FOMP. This records management plan will enable the program office to identify, control, and maintain the quality assurance, decisional, or regulatory prescribed records generated and used in support of the ERRA Program.

The ERRA Program records management plan describes how the applicable records management requirements will be impiemented for the ERRA Program. The plan also develops the criteria for identifying the appropriate requirements for each individual piece of information related to ERRA work activities.

This records management plan applies to all ERRA Program records and documents generated, used, or maintained in support of ERRA-funded work activities on the Hanford Site. The terms, information, documents, nonrecord material, records, record material, and QA records used throughout the ERRA records management plan are interpreted as ERRA information, ERRA documents, ERRA nonrecord material, ERRA records, ERRA record material, and ERRA QA records. 


\subsection{HANFORD ENVIRONMENTAL INFORMATION SYSTEM}

\subsection{OBJECTIVE}

The Hanford Environmental Information System (HEIS) has been developed by PNL for Westinghouse Hanford as a primary resource for computerized storage, retrieval, and analysis of quality-assured technical data associated with Comprehensive Environmental Response, Compensation and Liability Act of 1980 (CERCLA) remedial investigation/ feasibility study (RI/FS) activities and RCRA Facility Investigation/Corrective Measures Study (RFI/CMS) activities being undertaken at the Hanford Site. The HEIS will provide a means of interactive access to data sets extracted from other databases relevant to implementation of the Tri-Party Agreement (Ecology et al. 1990). The HEIS will support graphics analysis, including a geographic information system. Implementation of HEIS will serve to ensure that data consistency, quality, traceability, and security are achieved through incorporation of all environmental data within a single controlled database.

The following is a list of data subjects proposed to be entered into HEIS:

- Geologic

- Geophysics

- Atmospheric

- Biotic

- Site characterization

- Soil gas

- Waste site information

- Surface monitoring

- Groundwater.

\subsection{STATUS OF THE HANFORD ENVIRONMENTAL INFORMATION SYSTEM}

The HEIS, a computerized database containing technical data and information used to support the Hanford environmental restoration (ER) activities, is operational. The data for the Hanford groundwater wells and groundwater samples is currently accessible via the Hanford Local Area Network (HLAN) to local users and to offsite users via a modem link to the HEIS database computer. Additional data, including geologic, biota, and other pertinent environmental sample results, are being entered into the HEIS database.

The Hanford Environmental Information System (HEIS) User's Manual (WHC 1990) was issued in October 1990. An operator manual is being prepared and is expected to be issued in 1992. 
The HEIS geographic information system (GIS) will display detailed maps for the Hanford restoration sites including data from the HEIS database. Such spatially related data will be used to support analysis of waste site technical issues and restoration options. The combination of the HEIS for data and the GIS spatial displays offers some powerful tools for many users to analyze and collectively evaluate the environmental data from the ER and site-wide monitoring programs.

\subsection{REFERENCES}

Andrews, G. L., 1988, The Hanford Meteorological Data Collection System and Data Base, PNL-6509, Pacific Northwest Laboratory, Richland, Washington.

DOE/RL, 1989, Environmental Restoration Field Office Management Plan, DOE/RL-89-29, U.S. Department of Energy, Richland Operations Office, Richland, Washington.

DOE/RL, 1990, Hanford Federal Facility Agreement and Consent Order (Tri-Party Agreement) Handbook, RL-TPA-90-0001, U.S. Department of Energy, Richland Operations Office, Richland, Washington.

Ecology, EPA, and DOE/RL, 1990, Hanford Federal Facility Agreement and Consent Order, First amendment, Two Volumes, 89-10 Revision 1, Washington Department of Ecology, Olympia, Washington, U.S. Environmental Protection Agency, Region X, Seattle, Washington, and U.S. Department of Energy, Richland Operations Office, Richland, Washington.

Michael, L. E., G. C. Main, and E. J. See, 1990, Environmental Information Management Plan, WHC-EP-0219, Revision 1, Westinghouse Hanford Company, Richland, Washington.

Steward, J. C., G. C. Main, and E. J. See, 1989, Environmental Information Management Plan, WHC-EP-0219, Westinghouse Hanford Company, Richland, Washington.

WHC, 1988, Quality Assurance Manual, WHC-CM-4-2, Westinghouse Hanford Company, Richland, Washington.

WHC, 1991a, Environmental Investigations and Site Characterization Manual, WHC-CM-7-7, Westinghouse Hanford Company, Richland, Washington.

WHC, 1991b, Environmental Restoration Remedial Action Program Records Arrangement Plan, WHC-EP-0430, Westinghouse Hanford Company, Richland, Washington. 
DOE/RL-92-17, Rev. 0

Figure D-1. Environmental Engineering, Technology, and Permitting Data Management Model.

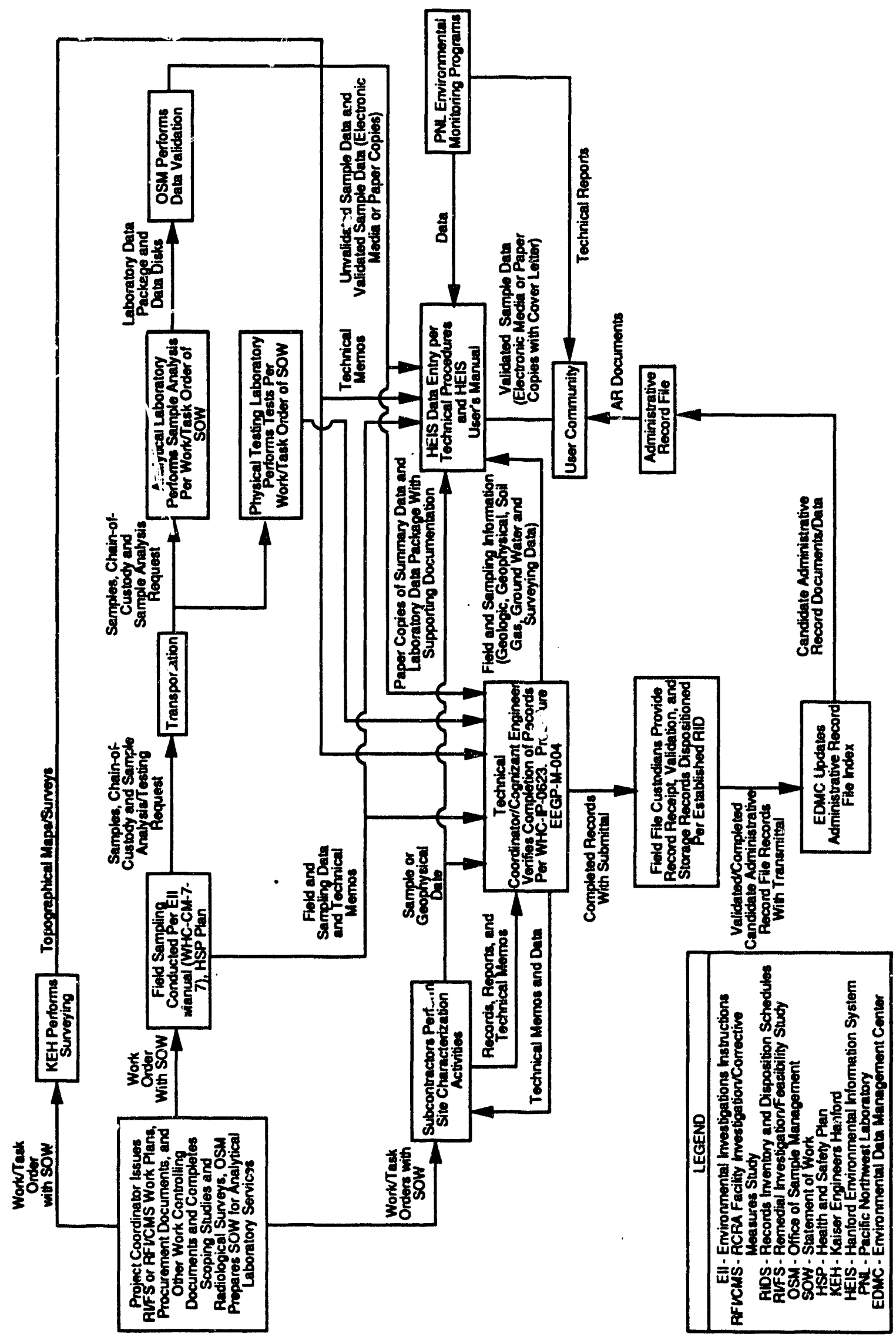

$\overline{D F}-\mathbf{i}$ 
DOE/RL-92-17, Rev. 0

Table D-1. Types of Related Administrative Data.

\begin{tabular}{|c|c|c|c|c|c|c|}
\hline \multirow[b]{2}{*}{ Type of Data } & \multirow[b]{2}{*}{$\begin{array}{l}\text { Cortrolling } \\
\text { document/procedure }\end{array}$} & \multicolumn{5}{|c|}{ Record Custodians } \\
\hline & & TR & HEHF & PNL & EDMC & EHPSS \\
\hline \multicolumn{7}{|l|}{ Personnel } \\
\hline $\begin{array}{l}\text { Personnel training and } \\
\text { qualifications }\end{array}$ & EII $1.7^{2}$ & $\mathbf{x}$ & & & & \\
\hline $\begin{array}{l}\text { Occupational exposure } \\
\text { records (nonradiological) }\end{array}$ & EII $2.2^{\mathrm{N}}$ & & $\mathbf{x}$ & & & $\mathbf{x}$ \\
\hline Radiological exposure records & & & & $\mathbf{x}$ & & \\
\hline Respiratory protection fitting & & & & & & $\mathbf{x}$ \\
\hline $\begin{array}{l}\text { Personnel health and safety } \\
\text { records }\end{array}$ & EII 2.1 & & $\mathbf{x}$ & & & $\mathbf{x}$ \\
\hline Compliance/resulatory & & & & & & \\
\hline $\begin{array}{l}\text { Action-spocific } \\
\text { requirements/screening levels }\end{array}$ & EII $1.6^{2}$ & & & & $\mathbf{x}$ & \\
\hline Guidance document tracking & EII 1.6" & & & & $\mathbf{x}$ & \\
\hline Compliance issues & EII $1.6^{\mathrm{N}}$ & & & & $\mathbf{x}$ & \\
\hline Problem resolution & EII $1.6^{\mathrm{a}}$ & & & & $\mathbf{x}$ & \\
\hline Administrative record & TPA-MP-11 ${ }^{\mathrm{b}}$ & & & & $\mathbf{x}$ & \\
\hline
\end{tabular}

2 WHC 1991a, Environmental Investigations and Site Characterization Manual.

b DOE/RL 1990, Hanford Federal Facility Agreement and Consent Order (Tri-Party Agreement) Handbook.

EDMC = Environmental Data Management Center (Westinghouse Hanford Company).

EHPSS = Environmental Health and Pesticide Services Section (Westinghouse Hanford Company).

EII = Environmental Investigations Instructions.

HEHF = Hanford Environmental Health Foundation.

TR = training records (Westinghouse Hanford Company, Pacific Northwest Laboratory [PNL], Kaiser Engineers Hanford [KEH]). 
DOE/RL-92-17, Rev. 0

\section{DISTRIBUTION}

Number of Copies

Onsite

31

U.S. Department of Energy, Richland Field Office

J. K. Erickson (30)

A5-19

Public Reading Room

A1-65

1

Pacific Northwest Laboratory

Hanford Technical Library

P8-55

48

Westinghouse Hanford Company

L. D. Arnold

B2-35

EDMC (7)

H6-08

ERC (G. Fitzgibbon)

H6-07

ERE (F. Stone) (2)

ERE Project File

H6-01

ER Program Office (2)

116-03

IRA (3)

H6-27

Resource Center

H4-17

M. A. Wasemiller (30)

N3-05

H6-03 

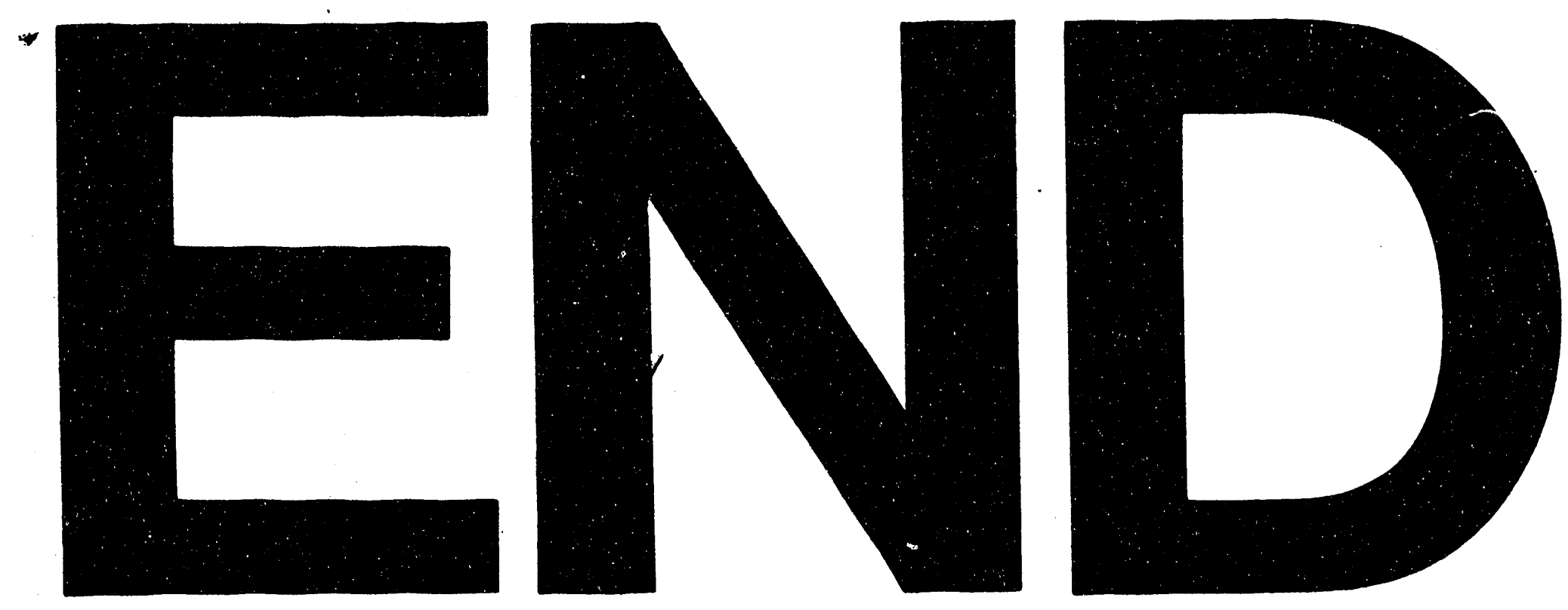

1
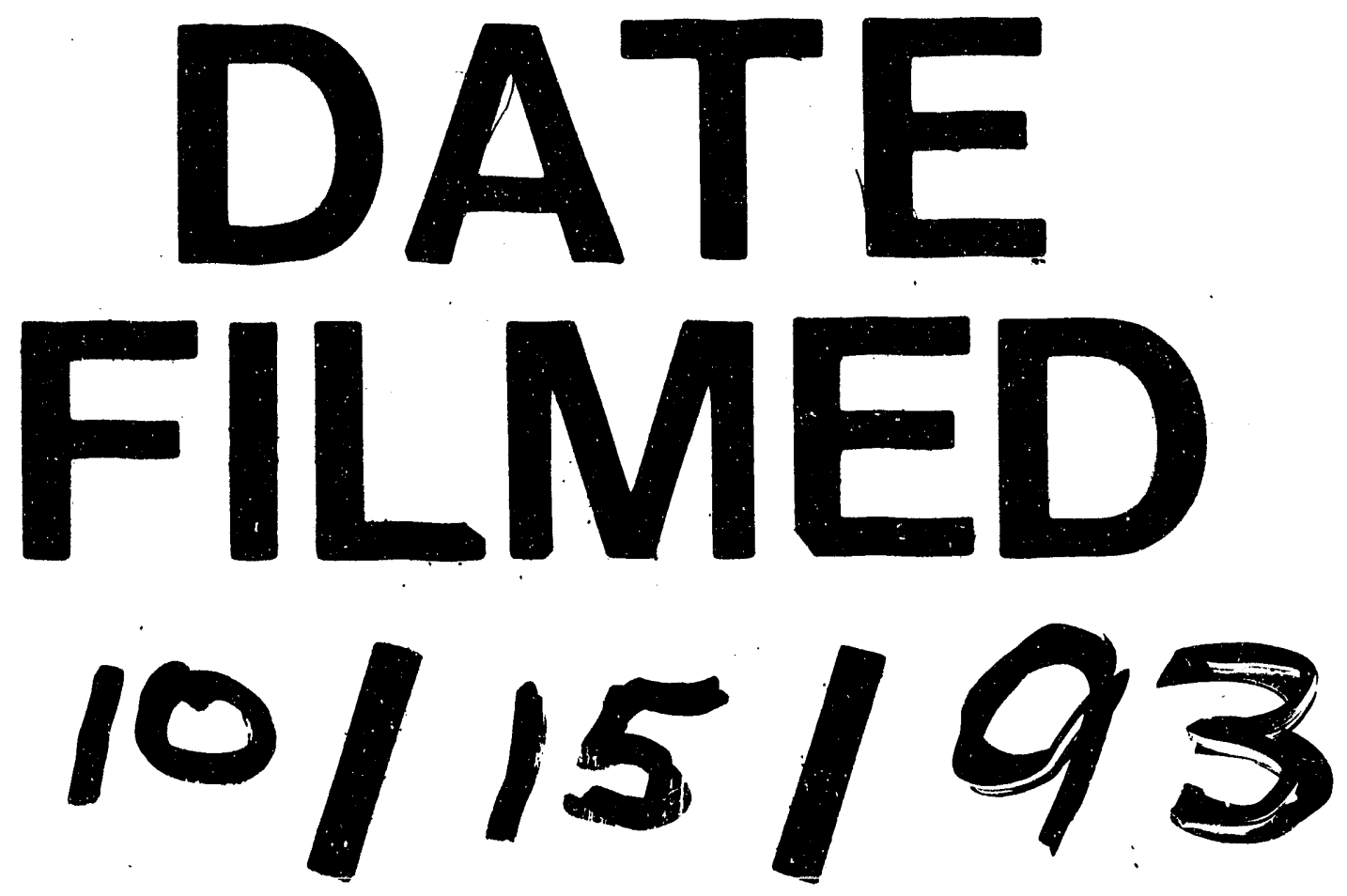
